UNIVERSIDADE DE SÃO PAULO - USP

FACULDADE DE EDUCAÇÃO

PROGRAMA DE PÓS-GRADUAÇÃO EM EDUCAÇÃO

NEILA PEDROTTI DRABACH

O “desvio de rota" nas políticas de Educação Profissional: uma análise do processo de construção e da oferta pública e privada do Pronatec 
NEILA PEDROTTI DRABACH

\title{
O "desvio de rota" nas políticas de Educação Profissional: uma análise do processo de construção e da oferta pública e privada do Pronatec
}

\author{
Versão Revisada
}

Tese apresentada à Faculdade de Educação da Universidade de São Paulo como requisito parcial para obtenção do título de Doutora em Educação.

Área de Concentração: Estado, Sociedade e Educação

Orientadora: Profa. Dra. Carmen Sylvia Vidigal Moraes

SÃO PAULO - SP 
AUTORIZO A REPRODUÇÃO E DIVULGAÇÃO TOTAL OU PARCIAL DESTE TRABALHO, POR QUALQUER MEIO CONVENCIONAL OU ELETRÔNICO, PARA FINS DE ESTUDO E PESQUISA, DESDE QUE CITADA A FONTE.

Catalogação na Publicação

Serviço de Biblioteca e Documentação

Faculdade de Educação da Universidade de São Paulo

373.7 Drabach, Neila Pedrotti

D756d O "desvio de rota" nas políticas de Educação Profissional: uma análise do processo de construção e da oferta pública e privada do Pronatec / Neila Pedrotti Drabach; orientação Carmen Sylvia Vidigal Moraes. São Paulo: s.n., 2018 .

$308 \mathrm{p}$.

Tese (Doutorado - Programa de Pós-Graduação em Educação. Área de Concentração: Estado, Sociedade e Educação) - - Faculdade de Educação da Universidade de São Paulo.

1. Pronatec 2. Educação Profissional 3. Relação Público-Privada I. Moraes, Carmen Sylvia Vidigal, orient.

Elaborado por Nicolly Leite - CRB-8/8204 
DRABACH, Neila Pedrotti. O “desvio de rota" nas políticas de Educação Profissional: uma análise do processo de construção e da oferta pública e privada do Pronatec. Tese apresentada à Faculdade de Educação da Universidade de São Paulo como requisito parcial para obtenção do título de Doutora em Educação.

Aprovada em:

Banca Examinadora

Profa. Dra. Carmen Sylvia Vidigal Moraes (Orientadora)

Julgamento:

Profa. Dra. Aparecida Neri de Souza

Julgamento:

Prof. Dr. Jorge Alberto Rosa Ribeiro

Julgamento:

Prof. Dr. Marcelo Lima

Julgamento:

Profa. Dra. Marise Nogueira Ramos

Julgamento:
Faculdade de Educação da Universidade de São Paulo - USP

Assinatura:

Faculdade de Educação da Universidade Estadual de Campinas - UNICAMP

Assinatura:

Faculdade de Educação da Universidade Federal do Rio Grande do Sul - UFRGS Assinatura:

Centro de Educação da Universidade Federal do Espírito Santo - UFES

Assinatura:

Faculdade de Educação da Universidade Estadual do Rio de Janeiro - UERJ e EPSJV Assinatura: 


\section{AgRadecimentos}

Finalmente escrevo o último texto dessa Tese, o qual, imagino, será o primeiro a ser lido por você, leitor. Digo isso, pois é a parte que primeiro leio em todos os trabalhos acadêmicos. Gosto de conhecer a "pessoa" que está "por trás" do texto, sua experiência na trajetória da produção da pesquisa, os temas que lhe ecoam mais alto, sua maneira de se relacionar com outras vidas, ou seja, de produzir-se a si mesma.

Confesso que não foi fácil percorrer essa jornada em tempos de Golpe! Acontecimentos novos a cada dia, a cada hora, interrompiam a concentração nos estudos. Quando racionalmente optava por me desconectar da realidade, na volta tinha a sensação de que o tempo tinha andado na velocidade da luz, tamanho era o acúmulo de acontecimentos, que giravam em torno de idas e vindas e traziam, na verdade, a sensação de volta ao passado! E, de fato, retrocedemos... O Golpe parlamentar de 2016 empurrou "para trás o processo histórico" (SINGER, 2018, p. 32).

Em meio a esse cenário tornaram-se cada vez mais importantes os espaços de solidariedade na Universidade, entre amigos e família, os quais foram fundamentais nessa trajetória. Assim, gostaria de agradecer a acolhida generosa da minha orientadora, Profa. Carmen Sylvia Vidigal Moraes, no Programa de Pós-Graduação em Educação da FEUSP e no Grupo de Estudos e Pesquisas em Trabalho e Educação, e todos os aprendizados e momentos de trocas que daí decorreram. Além da orientação e confiança depositada no meu trabalho de pesquisa, sou grata pelo exemplo de pesquisadora e professora comprometida com a produção do conhecimento com e para a classe trabalhadora.

À Banca de qualificação da pesquisa, Profa. Aparecida Neri de Souza e Prof. Gaudêncio Frigotto, pelas importantes contribuições, e à Banca de Defesa de Tese pela disponibilidade ao diálogo e sugestões que contribuíram para qualificar este texto.

Aos colegas e amigos do Grupo de Pesquisa em Trabalho e Educação, pelas profícuas leituras e debates que muito contribuíram para o desenvolvimento desta pesquisa e pelo companheirismo em momentos de descontração e de luta. Foi/é um privilégio fazer parte desse coletivo!

À professora Prisca Kergoat, pela acolhida na Université Toulouse, Jean Jaurès, pelos conhecimentos compartilhados e pela oportunidade de tantos aprendizados no período de Doutorado Sanduíche.

Às amigas da República "Maneúchas", pela acolhida em São Paulo e momentos compartilhados. Com vocês compartilhei não apenas um lar, mas a vida! 
Aos amigos e amigas que fiz ao longo do Doutorado: Angélica, Luciene, Sandra Glória, Fernanda, Letícia, Érika, Janaina, Lígia, Abelardo, Iracema, Daniel, Zéh Neto, Leandro e tantas outras pessoas especiais com quem pude trocar ideias e sorrisos. Foi um privilégio ter convivido com vocês e desejo profundamente que nossos caminhos nos reservem muitos outros encontros.

Aos professores com quem tive a honra de aprender e conviver durante esse período, em especial Vitor Paro, Celso de Rui Beisiegel (em memória) e Antonio Carlos Mazzeo, vocês foram muito importantes na construção da minha personalidade humano-histórica.

Aos amigos de perto e de longe que vibraram com as conquistas desse período e compreenderam os momentos de ausência da vida social. Cada palavra de incentivo foi muito importante. Em especial às queridas amigas Bete, Natália e Dani Faccin: gratidão pela escuta, pelos momentos de descontração e por cultivarmos esse sentimento tão profundo que é a nossa amizade; à querida Laura, pelos generosos diálogos sobre a tese e preciosas dicas de bibliografia; e aos amigos Marcos e Dani pela convivência e por nos presentearem com a existência da nossa amada Nina!

À querida Marlene, por tornar o aprendizado do francês tão prazeroso e por ter sido muito mais que uma professora, uma grande incentivadora e amiga.

À querida Sandra Bronzate pela indispensável ajuda no depósito da tese junto ao Programa de Pós-Graduação.

À Aurèline, Helöise, Leslie, Sophie, Marie, Doriane e Natália pela acolhida, diálogo e convivência na Maison de la Recherche e nas "manifs”, que muito contribuíram para os bons momentos e aprendizados do período de Doutorado Sanduíche.

Ao grupo "Les filles", amigas que (re)conheci em Toulouse e que foram fonte de afeto e autoconhecimento. Seguimos juntas por esse mundo!

Aos colegas e amig@s da Pró-Reitoria de Ensino do Instituto Federal Farroupilha, pelo apoio e compreensão no período de meu afastamento para a realização dos estudos de Doutorado. Na verdade, continuamos juntos, apenas ocupando, temporariamente, diferentes espaços na mesma "trincheira" de defesa e luta por uma educação profissional, científica e tecnológica pública, gratuita e de qualidade! Espero retribuir com os aprendizados construídos nesse percurso, pois o conhecimento só faz sentido quando compartilhado. Agradecimento especial à Janete, pelo apoio e incentivo que trouxe tranquilidade em meio ao compromisso com o trabalho e o desejo de continuar os estudos.

Aos meus pais, Pedro e Nair, pelo incentivo aos estudos e pela liberdade e confiança nas escolhas que eu fiz. Aos meus irmãos, Nadia, Edenei e Lucas, por serem o elo com a minha essência; em especial à Nadia, por partilharmos das alegrias e desafios da pós-graduação e por 
ter me instruído no uso do SPSS. À minha sobrinha Júlia, que, com sua chegada, trouxe um pouco de leveza para os últimos dias de escrita desta Tese.

À CAPES pela concessão de bolsa de Doutorado Sanduíche.

Às instituições e sujeitos que partilharam suas experiências, fundamentais para o desenvolvimento desta pesquisa.

À escola e à universidade pública que me permitiram chegar até aqui e ao povo brasileiro que sustenta essas instituições.

Aos funcionários da Secretaria do Programa de Pós-Graduação da FEUSP pela disponibilidade, cordialidade e atenção no atendimento a todas as demandas que se fizeram necessárias. Minha admiração e respeito por todos vocês!

E, por fim, aos melhores companheiros que eu poderia ter nessa jornada, meu marido Everton e nossa "filina" Jolie, por juntos construirmos um ambiente de muito amor, compreensão e apoio, fundamental para superar os desafios e chegar até aqui.

Em tempo, gratidão à vida do nosso gurizinho Inácio, que se revelou no período de defesa e revisão da Tese, renovando a esperança e a força para a continuidade da luta por uma educação e mundo melhor! 
A divisão fundamental da escola em clássica e profissional era um esquema racional: a escola profissional destinava-se às classes instrumentais, enquanto a clássica destinava-se às classes dominantes e aos intelectuais.

A tendência atual é a de abolir qualquer tipo de escola "desinteressada" (não imediatamente interessada) e "formativa", ou de conservar apenas um seu reduzido exemplar, destinado a uma pequena elite de senhores e de mulheres que não devem pensar em preparar-se para um futuro profissional, bem como a de difundir cada vez mais as escolas profissionais especializadas, nas quais o destino do aluno e sua futura atividade são predeterminados. A crise terá uma solução que, racionalmente, deveria seguir esta linha: escola única inicial de cultura geral, humanista, formativa, que equilibre de modo justo o desenvolvimento da capacidade de trabalhar manualmente (tecnicamente, industrialmente) e o desenvolvimento das capacidades de trabalho intelectual. Antonio Gramsci (Cadernos do Cárcere, 2014, p. 33)

A palavra de ordem 'pessimismo da inteligência, otimismo da vontade' deve ser a palavra de ordem de todo comunista consciente dos esforços e dos sacrificios que são exigidos a quem voluntariamente assumiu um posto de militante nas fileiras da classe operária. Antonio Gramsci (L’Ordini Nuovo, 1920) 


\section{RESUMO}

DRABACH, Neila Pedrotti. O "desvio de rota" nas políticas de Educação Profissional: uma análise do processo de construção e da oferta pública e privada do Pronatec. 2018. 308 f. Tese (Doutorado em Educação), Programa de Pós-Graduação em Educação, Faculdade de Educação, Universidade de São Paulo, 2018.

O objetivo principal da tese consiste em identificar e analisar o processo de construção e de desenvolvimento do Pronatec, utilizado aqui como sinônimo da iniciativa Bolsa Formação, no âmbito de instituição pública (integrante da Rede Federal de EPCT) e privada (integrante do Sistema S) situadas no Estado do Rio Grande do Sul, de modo a apreender as relações entre trabalho e educação, formação profissional e desenvolvimento econômico que informam essa política, e a identificar e examinar os impactos dessa nova forma de oferta no âmbito das políticas públicas de educação profissional já em andamento. A partir de um referencial analítico que situa a educação profissional como espaço de disputas na realização de distintos projetos formativos, e apreende as políticas educacionais como materialização de interesses de classe, buscou-se evidenciar as correlações de forças presentes na construção e no desenvolvimento do Pronatec no âmbito do Estado, compreendido na perspectiva gramsciana como conjunto da sociedade política e sociedade civil, apreendendo-o como parte e produto de uma totalidade social e histórica situada no campo das contradições, das mediações e das relações entre o particular e o geral, o singular e o universal. A pesquisa fez uso das abordagens qualitativa e quantitativa. Foram realizadas entrevistas com gestores em âmbito nacional, e com gestores, coordenadores e professores das instituições de ensino investigadas; aplicados questionários dirigidos ao conjunto de professores e de estudantes dos cursos ofertados nas unidades de ensino selecionadas. Procedeu-se, também, à análise dos projetos pedagógicos de curso que orientaram as ofertas, ao levantamento e análise de fontes primárias sobre o Pronatec e de indicadores quantitativos de orçamento e de matrículas do conjunto de iniciativas do Programa. Com base na interpretação das informações coletadas, pode-se indicar que o Pronatec representou uma disputa política sobre a concepção de formação da classe trabalhadora e pela apropriação dos fundos públicos da educação profissional, que resultou em desvio de rota nas políticas de educação profissional, construídas a partir das propostas dos movimentos sociais e de coletivos de educadores democráticos ligados à classe trabalhadora, durante a primeira década dos anos 2000, e produziu efeitos regressivos no âmbito de Programas, como Proeja e Mulheres Mil, e nas políticas de educação profissional do campo. É possível afirmar que a nova forma de indução da educação profissional, por meio da oferta de vagas gratuitas em instituições públicas e privadas, a partir do Pronatec Bolsa Formação, é parte das medidas desenvolvidas pelo governo federal que, com base nas premissas gramscianas, pode ser caracterizado como expressão de uma "revolução passiva à brasileira": parte "conservação" e parte "inovação". Apesar de incorporar elementos das lutas dos trabalhadores, como a reunião das políticas de formação profissional no âmbito do Ministério da Educação e a continuidade das políticas do período anterior, o protagonismo das instituições privadas e a fragilidade dos mecanismos para identificação das reais demandas formativas conduziu ao desenvolvimento de formas de oferta desintegradas da educação básica e à recuperação da hegemonia do projeto educacional da burguesia na socialização da classe trabalhadora no novo espírito do capitalismo.

Palavras-chave: Pronatec. Estado. Educação Profissional. Socialização da Classe Trabalhadora. Relação Público-Privada. 


\begin{abstract}
DRABACH, Neila Pedrotti. The "route detour" in Professional Education Politics: an analysis on the construction process and the public and private offer of Pronatec. 2018. $308 \mathrm{f}$. Thesis (Doctorate in Education), Postgraduate studies Program in Education, School of Education, University of São Paulo, 2018.

The thesis' main goal consists in identify and analyze the construction and development process of Pronatec, used here as synonymous of Bolsa Formação initiative, in the public institution (Rede Federal of EPCT member) and private (Sistema S member) scope situated in Rio Grande do Sul, in order to capture the relations between work and education, professional formation and economic development, that inform this politics, and to examine the impacts of this new offering way in the professional education public politics scope already on going. From an analytical referential that places the professional education as a space of dispute in distinct constitutive projects, and captures the educational politics as class interests materialization, it was sought to show the interconnection force present in Pronatec's construction and development in the State scope, understood under the gramscian perspective as a political and social society aggregation, capturing it as part and product of a social and historical totality situated in the contradiction field, in mediations and relations between the private and the general, the singular and the universal. The research used qualitative and quantitative approaches. Interviews with managers in national range were held, and with managers, coordinators and teachers from the investigated institutions; questionnaires were applied to the group of teachers and students from the offered courses at the selected teaching units. There was, also, the analysis on the course pedagogic projects that guided the offer, the collecting and analysis on primary sources about Pronatec and quantitative budget and enrollment indicators of the Program's initiative group. Based on the collected information interpretation, it can be seen that Pronatec represented a political dispute about the working class formation conception and the professional education's public funds appropriation, which resulted in route detour in professional education politics, built from social movements proposals and democratic educators groups linked to the working class, during the first 2000s decade, and produced regressive effects on the Programs extent, such as Proeja and Mulheres Mil, and on the field professional education politics. It's possible to claim that the new professional education induction way, through free spots offer in public and private institutions, from the Pronatec Bolsa Formação, is part of the measures developed by the federal government that, based on gramscian premisses, can be characterized as an expression of a "Brazilian passive revolution": part "conservation" and part "innovation". Despite embodying workers' struggle elements, such as the gathering of professional formation in the Education Ministry scope and the continuity of previous politics, the private institutions' protagonism and the mechanisms' fragility for identification of real formative demands lead to the development of offering ways detached from basic education and to the bourgeoisie hegemony retrieval educational project on the working class socialization in the new spirit of capitalism.
\end{abstract}

Keywords: Pronatec. State. Professional Education. Working Class Socialization. PrivatePublic Relation. 


\section{LISTA DE FIGURAS}

Figura 1 - Mapa das Instituições e unidades de pesquisa situadas no RS ......... 41

Figura 2 - Baú Pronatec Empreendedor ........................................................... 111

Figura 3 - Fluxo do Mapa de Demandas Específicas e pactuação da oferta de cursos no Pronatec Bolsa Formação .................................................................. 122

Figura 4 - Agentes do Pronatec Bolsa Formação ............................................. 123

Figura 5 - Histórico das alterações nas Resoluções do FNDE no âmbito da Bolsa Formação ........................................................................................ 126

Figura 6 - Mapa das unidades do IF Farroupilha .......................................... 147

Figura 7 - Kit de material escolar entregue aos estudantes de curso Pronatec

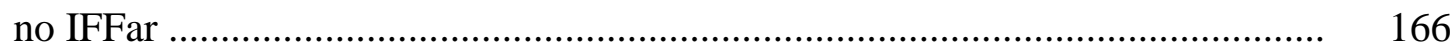




\section{LISTA DE GRÁFICOS}

Gráfico 1 - Matrículas públicas e privadas em cursos técnicos no período de 2003 a 2016

Gráfico 2 - Matrículas Bolsa Formação Nacional - por tipo de curso e ano (2011 a 2016)

Gráfico 3 - Bolsa Formação Nacional - Matrículas por tipo de curso e

Instituição Ofertante (2011-2016)

Gráfico 4 - Matrículas no Pronatec Bolsa Formação Nacional por natureza da Instituição Ofertante (2011-2016)

Gráfico 5 - Matrículas no Brasil Profissionalizado e total de matrículas em cursos técnicos integrados nas redes estaduais (2011 a 2016)

Gráfico 6 - Vagas ofertadas pela Rede e-Tec no Instituto Federal Farroupilha 2009 a 2017

Gráfico 7 - Matrículas Pronatec - Rede e-Tec Brasil (2011-2016)

Gráfico 8 - Matrículas Expansão da Rede Federal (2011-2016)

Gráfico 9 - Matrículas no Acordo de Gratuidade no SENAC e SENAI (2011-

2016)

Gráfico 10 - Total de Matrículas nas Iniciativas do Pronatec (2011-2016)

Gráfico 11 - Orçamento destinado às Iniciativas do Pronatec (2011-2014)

Gráfico 12 - Matrículas nos cursos regulares do IFFar no ano de 2017

Gráfico 13 - Matrículas Bolsa Formação por sexo e tipo de curso no IFFar 2011-2016

Gráfico 14 - Matrículas por Sexo e Tipo de Curso - Pronatec Bolsa Formação 


\section{LISTA DE QUADROS}

Quadro 1 - Valores referência para pagamento de profissionais da Rede e-Tec

Quadro 2 - Remuneração dos Profissionais do Pronatec Bolsa Formação IFFar - Reitoria

Quadro 3 - Remuneração dos Profissionais do Pronatec Bolsa Formação IFFar

- Campus

Quadro 4 - Remuneração dos Profissionais do Pronatec Bolsa Formação IFFar

- Centro de Referência

Quadro 5 - Currículo do curso de Operador de Máquinas e Implementos

Agrícolas - Campus IFFar

Quadro 6 - Estrutura remuneratória do corpo docente na instituição SNA

Quadro 7 - Componente curricular de Psicologia Organizacional - Curso

Balconista de Farmácia (SNA) 


\section{LISTA DE TABELAS}

Tabela 1 - Matrículas do Pronatec Bolsa Formação no RS - realizadas no período de 2011 a outubro de 2015

Tabela 2 - Matrículas Pronatec Bolsa Formação por unidade de ensino (2011 a 2015) - IFFar

Tabela 3 - Entrevistas realizadas e questionários aplicados no IFFar no âmbito da pesquisa de campo

Tabela 4 - Entrevistas realizadas e questionários aplicados no SNA no âmbito da pesquisa de campo

Tabela 5 - Entrevistas realizadas com gestores nacionais no âmbito da pesquisa de campo

Tabela 6 - Matrículas Proeja em âmbito nacional - 2007 a 2016

Tabela 7 - Recursos transferidos e matrículas realizadas por IEs privadas no Pronatec - 2013 a 2016

Tabela 8 - Relação de demandantes e modalidades de demanda do Pronatec Bolsa Formação

Tabela 9 - Matrículas x Pactuações no Pronatec Copa

Tabela 10 - Diferença entre valor pago e valor praticado pelo mercado - Cursos FIC e Técnico

Tabela 11 - Recursos do Pronatec Bolsa Formação por Instituição Ofertantes 2011 a 2016

Tabela 12 - Recursos do Pronatec Bolsa Formação por Instituição do Sistema S -2011 a 2016

Tabela 13 - Matrículas do Pronatec Bolsa Formação por Eixo Tecnológico e Instituição Ofertante - 2011 a 2016

Tabela 14 - Orçamento destinado ao Programa Brasil Profissionalizado - 2011 a 2016

Tabela 15 - Orçamento destinado ao Programa Rede e-Tec Brasil - 2011 a 2016 Tabela 16 - Execução orçamentária e financeira da Expansão da Rede Federal, 2011 a 2014 (em milhões)

Tabela 17 - Matrículas por ano Pronatec Bolsa Formação - IFFar

Tabela 18 - Matrículas Programa Mulheres Mil em nível nacional e do IFFar 2011 a 2017

Tabela 19 - Matrículas em cursos Proeja no IFFar - 2012 a 2017

Tabela 20 - Cursos e matrículas do Pronatec Bolsa Formação no IFFar - 2011 a 2016

Tabela 21 - Matrículas por Eixo Tecnológico e tipo de curso Pronatec Bolsa Formação IFFar - 2011 a 2016 
Tabela 22 - Matrículas Pronatec Bolsa Formação por Sexo e Eixo Tecnológico no IFFar - 2011 a 2016

Tabela 23 - Matrículas Pronatec Bolsa Formação por Escolaridade e por Sexo no IFFar-2011 a 2016

Tabela 24 - Matrículas Pronatec Bolsa Formação por faixa etária e sexo - IFFar 2011 a 2016

Tabela 25 - Matrículas Pronatec Bolsa Formação por faixa etária e Eixo Tecnológico - IFFar 2011 a 2016

Tabela 26 - Matrículas Pronatec Bolsa Formação por sexo e cor da pele - IFFar 2011 a 2016

Tabela 27 - População economicamente ativa por grupos de ocupação Município Centro de Referência IFFar 182

Tabela 28 - Cursos Pronatec Bolsa Formação ofertados no CR do IFFar

Tabela 29 - Instituição Ofertante x Tipo de Curso no município do CR do IFFar

Tabela 30 - Eixo Tecnológico x Instituição Ofertante - Pronatec no Município do CR do IFFar

Tabela 31 - Corpo Docente do CR IFFar - Carga horária e atividade além do Pronatec

Tabela 32 - Cursos Pronatec Bolsa Formação do CR IFFar - atraso e percentual de concluintes

Tabela 33 - População economicamente ativa por grupos de ocupação Município Campus do IFFar

Tabela 34 - Cursos e locais de oferta do Pronatec Bolsa Formação desenvolvidos pelo Campus do IFFar

Tabela 35 - Eixos Tecnológicos atendidos pelo Sistema $\mathrm{S}$ nos municípios atendidos pelo Campus do IFFar

Tabela 36 - Matrículas regulares e Matrículas Pronatec - Campus IFFar (2012 a 2016)

Tabela 37 - Cursos da modalidade Pronatec Campo desenvolvidos pelo Campus do IFFar

Tabela 38 - Cursos ofertados na modalidade Pronatec Campo no RS - 2013 a 2015

Tabela 39 - Índice de conclusão dos cursos Pronatec Bolsa Formação no Campus do IFFar

Tabela 40 - Matrículas no Pronatec Bolsa Formação - SNA (2011-2016)

Tabela 41 - Número de colaboradores no SNA - 2012 a 2017 234

Tabela 42 - Cursos ofertados pelo SNA no Pronatec Bolsa Formação - 2011 a 2016

Tabela 43 - Matrículas por Eixo Tecnológico e Tipo de Curso - Pronatec Bolsa Formação SNA - (2011 a 2016)

Tabela 44 - Matrículas por Eixo Tecnológico e Sexo - Pronatec Bolsa Formação SNA - (2011 a 2016)

Tabela 45 - Matrículas por Escolaridade e Sexo - Pronatec Bolsa Formação SNA $-(2011$ a 2016) 
Tabela 46 - Matrículas por Sexo e Cor da Pele - Pronatec Bolsa Formação SNA - (2011 a 2016)

Tabela 47 - IE Ofertante x Eixo Tecnológico Matrículas Pronatec Bolsa Formação em Porto Alegre (2011 a 2016)

Tabela 48 - Matrículas Pronatec Bolsa Formação realizadas pela Escola A do SNA (2011 a 2015)

Tabela 49 - Matrículas em cursos de Mercado - Escola A SNA (2011 a 2016) .. 261

Tabela 50 - Status de Matrícula dos Cursos Pronatec Bolsa Formação - Escola

A SNA 262

Tabela 51 - Índice de conclusão dos cursos por turno de oferta - Escola A SNA 263

Tabela 52 - População economicamente ativa por grupos de ocupação Município de Uruguaiana Escola B SNA 266

Tabela 53 - Cursos Pronatec Bolsa Formação por Instituição Ofertante Município de Uruguaiana (2011 a 2016)

Tabela 54 - Cursos Pronatec Bolsa Formação por Eixo Tecnológico - Município de Uruguaiana (2011 a 2016)

Tabela 55 - Turno dos cursos Ofertados pela Escola B do SNA pelo Pronatec Bolsa Formação (2011 a 2016)

Tabela 56 - Status de Matrícula dos Cursos Pronatec Bolsa Formação - Escola B SNA

Tabela 57 - Índice de conclusão dos cursos por turno de oferta - Escola A SNA

Tabela 58 - Percentual de conclusão dos cursos nas unidades de ensino pesquisadas 


\section{LISTA DE SIGLAS}

ACCC - Association of Canadian Community Colleges

ANPED - Associação Nacional de Pós-Graduação e Pesquisa em Educação

BIRD - Banco Mundial

BNDES - Banco Nacional do Desenvolvimento Econômico e Social

CEFET - Centros Federais de Educação Tecnológica

CMEP - Centro Municipal de Educação Profissional

CNC - Confederação Nacional do Comércio

CNE - Conselho Nacional de Educação

CNI - Confederação Nacional da Indústria

CNTE - Confederação Nacional dos Trabalhadores em Educação

CONSUP - Conselho Superior do IFFar

CONTAG - Confederação Nacional dos Trabalhadores na Agricultura

CR - Centro de Referência

EAD - Educação a Distância

EJA - Educação de Jovens e Adultos

EMATER - Associação Riograndense de Empreendimentos de Assistência Técnica e

Extensão Rural

ENEM - Exame Nacional do Ensino Médio

EPT - Educação Profissional e Tecnológica

E-SIC - Sistema Eletrônico do Serviço de Informação ao Cidadão

FASE - Fundação de Atendimento Socioeducativo do RS

FAT - Fundo de Amparo ao Trabalhador

FDE - Fórum dos Dirigentes de Ensino da Rede Federal de Educação Profissional e

Tecnológica

FEE - Fundação de Economia e Estatística do Estado do RS

FHC - Fernando Henrique Cardoso

FIC - Formação Inicial ou Continuada

FIES - Fundo de Financiamento ao Estudante do Ensino Superior

FIESP - Federação das Indústrias do Estado de São Paulo

FNDE - Fundo Nacional de Desenvolvimento da Educação

FONEC - Fórum Nacional de Educação do Campo

FUNDETEC - Fundação Educacional e Tecnológica 
FUNTEP - Fundo Nacional de Formação Técnica e Profissional

IBGE - Instituto Brasileiro de Geografia e Estatística

IDH - Índice de Desenvolvimento Humano

IDORT - Instituto de Organização Racional do Trabalho

IES - Instituições de Ensino Superior

IFFar - Instituto Federal de Educação, Ciência e Tecnologia Farroupilha

INCRA - Instituto Nacional de Colonização e Reforma Agrária

INEP - Instituto Nacional de Estudos e Pesquisas Educacionais Anísio Teixeira

IPEA - Instituto de Pesquisa Econômica Aplicada

LDB - Lei de Diretrizes e Bases da Educação Nacional

MDA - Ministério do Desenvolvimento Agrário

MDB - Movimento Democrático Brasileiro

MDS - Ministério do Desenvolvimento Social

MEC - Ministério da Educação

MMil - Programa Nacional Mulheres Mil

MTE - Ministério do Trabalho e Emprego

NEP - Núcleo de Educação Profissional

PAC - Programa de Aceleração do Crescimento

PDT - Partido Democrático Trabalhista

PIB - Produto Interno Bruto

PIPMO - Programa Intensivo de Preparação de Mão de Obra

PIPMOI - Programa Intensivo de Preparação de Mão de Obra Industrial

PLANFOR - Plano Nacional de Qualificação do Trabalhador

PMDB - Partido do Movimento Democrático Brasileiro

PNQ - Plano Nacional de Qualificação

PPC - Projeto Político Pedagógico

PROEJA - Programa Nacional de Integração da Educação Profissional com a Educação

Básica na Modalidade de Educação de Jovens e Adultos

PROEN - Pró-Reitoria de Ensino do IFFar

PROEP - Programa de Expansão da Educação Profissional

PROEX - Pró-Reitoria de Extensão do IFFar

PROJOVEM - Programa Nacional de Inclusão de Jovens

PRONACAMPO - Política Nacional de Educação do Campo

PRONATEC - Programa Nacional de Acesso ao Ensino Técnico e Emprego 
PRONERA - Programa Nacional de Educação na Reforma Agrária

PROUNI - Programa Universidade para Todos

PSDB - Partido da Social Democracia Brasileira

PT - Partido dos Trabalhadores

PUC - Pontifícia Universidade Católica

REDE CERTIFIC - Rede Nacional de Certificação Profissional e Formação inicial e

Continuada

Rede Federal de EPCT - Rede Federal de Educação Profissional, Científica e Tecnológica

SEBRAE - Serviço Brasileiro de Apoio às Micro e Pequenas Empresas

SENAC - Serviço Nacional de Aprendizagem Comercial

SENAI - Serviço Nacional de Aprendizagem Industrial

SENAR - Serviço Nacional de Aprendizagem Rural

SENAT - Serviço Nacional de Aprendizagem do Transporte

SESC - Serviço Social do Comércio

SESCOOP - Serviço Nacional de Aprendizagem do Cooperativismo

SESI - Serviço Social da Indústria

SEST - Serviço Social de Transporte

SETEC - Secretaria de Educação Profissional e Tecnológica do MEC

SIMEC - Sistema Integrado de Monitoramento Execução e Controle do MEC

SISTEC - Sistema Nacional de Informações da Educação Profissional e Tecnológica

SISUTEC - Sistema de Seleção Unificada da Educação Profissional e Tecnológica

TAE - Técnico Administrativo em Educação

TCU - Tribunal de Contas da União

UFSM - Universidade Federal de Santa Maria

UNIPAMPA - Universidade Federal do Pampa

UNITRA - Universidade do Trabalho

USAID - United States Agency International for Development 


\section{SUMÁRIO}

INTRODUÇÃ

CAPÍTULO I - GÊNESE DO PRONATEC: “O DESVIO DE ROTA" ......... 46

1.1 A "rota" da educação profissional no Brasil: bases econômico-sociais da "formação" da classe trabalhadora

1.1.1 A educação como formação de "capital humano" .......................................

1.1.2 A formação para a "empregabilidade" a partir do desenvolvimento de "competências".

1.2 Os governos do Partido dos Trabalhadores: ensaio de uma nova "rota" para a educação profissional

CAPÍTULO II - A CONSTRUÇÃO DO PRONATEC BOLSA FORMAÇÃO E SUAS IMPLICAÇÕES NO CONJUNTO DAS POLÍTIÇAS DE EDUCAÇÃO PROFISSIONAL

2.1 O Pronatec como expressão da coalizão com a burguesia industrial no governo Dilma e da disputa privada pelos fundos públicos

2.1.1 A tradução do "Prouni do ensino técnico" no âmbito da SETEC

2.1.2 O Pronatec Empreendedor: a socialização da classe trabalhadora no "novo espírito do capitalismo"

2.2 O modus operandi do Pronatec Bolsa Formação

$2.3 \mathrm{O}$ andamento das demais iniciativas que compõe o Pronatec no período de 2011 a 2016

CAPÍTULO III - O DESENVOLVIMENTO DO PRONATEC BOLSA FORMAÇÃO EM UM INSTITUTO FEDERAL DE EDUCAÇÃO,

3.1 Perfil da Instituição e do desenvolvimento do Pronatec Bolsa Formação

3.2.1 A Resistência em relação à concepção do Pronatec Bolsa Formação ...........

3.2.2 A expansão provisória a partir de Centros de Referência .............................

3.2.3 O corpo docente e a dualidade institucional

3.2.4 O desenvolvimento pedagógico e o currículo dos cursos: normativas didático-pedagógicas institucionais x normativas do Programa

3.2.5 O Programa Mulheres Mil e sua (des)caracterização no âmbito do Pronatec Bolsa Formação

3.2.6 O processo de pactuação e o perfil dos cursos e do público atendido pelo IFFar no âmbito do Pronatec Bolsa Formação

3.3 Unidade de desenvolvimento dos Cursos do Pronatec Bolsa Formação I - Centro de Referência do IFFar

3.3.1 - A instabilidade nas condições de infraestrutura e manutenção do Centro de Referência - a disputa de projetos e a (in)suficiência do Pacto Federativo ..... 3.3.2 O desenvolvimento pedagógico dos cursos dos cursos Pronatec Bolsa Formação no CR do IFFar - (im)possibilidades frente ao atraso dos recursos ..... 3.3.3 "Aprendemos melhor a história do Brasil do que na escola": índices de evasão e aproveitamento nos cursos 
3.4 Unidade de desenvolvimento dos Cursos do Pronatec Bolsa Formação II - Campus do IFFar

3.4.1 O desenvolvimento pedagógico dos cursos Pronatec Bolsa Formação no Campus do IFFar....

3.4.2 Pronatec Campo: entre o desenvolvimento da agricultura familiar e a formação de mão de obra para as grandes propriedades

3.4.3 Pronatec Sistema Prisional: "agora posso dizer que sou um Pintor profissional"

CAPÍTULO IV - O DESENVOLVIMENTO DO PRONATEC BOLSA FORMAÇÃO EM UMA INSTITUIÇÃO DO SISTEMA $S$

4.1 Perfil da Instituição e do desenvolvimento do Pronatec Bolsa Formação

4.1.1 O desenvolvimento pedagógico e o currículo dos cursos: ênfase no empreendedorismo e na psicologia organizacional

4.1.2 O processo de pactuação e o perfil dos cursos e do público atendido pelo SNA no âmbito do Pronatec Bolsa Formação

4.2 Desenvolvimento do Pronatec Bolsa Formação na Escola A do SNA .... 
O Pronatec (Programa Nacional de Acesso ao Ensino Técnico e Emprego) foi anunciado pelo governo Dilma como a maior reforma na educação profissional nos últimos tempos (AGÊNCIA BRASIL, 2011). Concebido à luz das experiências consideradas exitosas no ensino superior, como o Prouni (Programa Universidade para Todos) e o Fies (Fundo de Financiamento ao Estudante do Ensino Superior), o Programa reúne as políticas de educação profissional já existentes e cria a "Bolsa Formação", que consiste no repasse de recursos públicos para a oferta de cursos em instituições públicas e privadas, e o Fies Técnico, o que permitiria uma rápida expansão das matrículas de educação profissional com vistas a atender a demanda de formação de mão de obra do período, muitas vezes anunciada como "apagão de mão de obra", conforme destacou o Ministro da Educação, Fernando Haddad, no ato de seu lançamento (BLOG DO PLANALTO, 2011).

A proposta do Programa foi recebida com elogios pelos empresários e ao mesmo tempo provocou críticas de alguns setores do meio acadêmico e sindical. Cinco dias antes do lançamento oficial do Programa, o Jornal O Globo publicou uma notícia, sob o título "Contra o apagão de mão de obra", destacando o Pronatec como "a primeira ação concreta de seu governo [governo Dilma] para tentar solucionar o problema da falta de mão de obra qualificada no país, agravada com o crescimento da economia e da demanda por obras e serviços" (O GLOBO, 2011). No mesmo sentido, o Presidente da Confederação Nacional da Indústria (CNI), Robson Braga de Andrade, em notícia publicada no site da Confederação no dia do lançamento do Programa, afirmou que "com esse projeto, garantimos que não haverá falta de mão de obra, porque vamos construir escolas e fazer parcerias com as escolas públicas. Esperamos alcançar 4 milhões de matrículas ao ano até 2014, praticamente o dobro das 2,3 milhões de matrículas que o SENAI teve em 2010" (CNI, 2011).

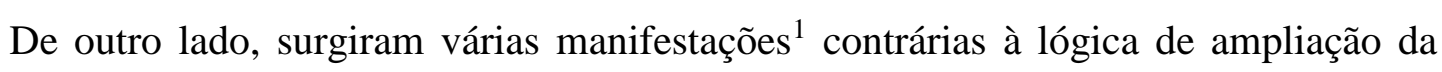
educação profissional utilizada pelo Programa, não apenas no momento de sua aprovação, mas no decorrer de seu desenvolvimento, entre as quais destacamos ${ }^{2}$ as duas primeiras, em ordem

\footnotetext{
1 Além das manifestações citadas neste texto, há outros documentos elaborados com esse propósito, como: Manifesto do Fórum De EJA de SC e do Fórum de EJA de Florianópolis, de 01 de junho de 2012; Manifesto do Fórum de Educação de Jovens e Adultos do Espírito Santo em defesa do Proeja, de 11 de junho de 2013; Carta de Natal, 09 de agosto de 2013, assinada pelos participantes do II Colóquio Nacional A Produção do Conhecimento em Educação Profissional e encaminhada ao Ministério da Educação; e a Moção sobre o PRONATEC: apoio à Carta de Natal 2013 (apresentada pelos GTs 9 e 18 da ANPED), 03 de outubro de 2013.

${ }^{2} \mathrm{Na}$ introdução desta Tese optamos por escrever na primeira pessoa do plural. No restante do texto, o leitor irá observar que será utilizada a terceira pessoa do singular.
} 
cronológica. Ainda durante o processo de aprovação do Projeto de Lei do Pronatec ${ }^{3}$ pelo Congresso Nacional, a Diretoria Executiva da Confederação Nacional dos Trabalhadores em Educação (CNTE) publicou, no dia 01 de setembro de 2011, um documento intitulado "Os riscos do Pronatec para a educação técnica profissional" apontando seis aspectos que ameaçariam o conceito e os pressupostos da educação técnica profissional de nível médio construídos ao longo dos últimos oito anos, dos governos Lula. Entre as críticas constavam: a flexibilização do papel do Estado na oferta da educação profissional e estímulo à criação de um mercado educacional, por meio da oferta de financiamento e bolsa de estudos na rede privada; a inibição da expansão das instituições públicas de educação profissional, ao repassar recursos públicos para instituições privadas; promoção do reducionismo curricular da formação para o trabalho ao privilegiar a oferta de cursos de curta duração e cursos técnicos desvinculados do ensino médio, com vistas a atender os interesses dos agentes produtivos, entre outros (CNTE, 2011).

No mesmo sentido, durante a $34^{\mathrm{a}}$ Reunião Científica Anual da Associação Nacional de Pós-Graduação e Pesquisa em Educação (ANPED), ocorrida nos dias 02 a 05 de outubro de 2011, os Grupos de Trabalho ligados às temáticas Trabalho e Educação, Estado e Políticas Educacionais, Educação de Jovens e Adultos e Políticas de Educação Superior aprovaram uma Moção em que apresentam suas preocupações em relação ao Projeto de Lei do Pronatec. Dentre as críticas encontravam-se: o abandono do Ensino Médio integrado como prioridade; a transferência de recursos públicos para a oferta privada de Educação Profissional; a precarização do trabalho dos profissionais da rede pública, a partir de jornada extra de trabalho e remuneração; a subordinação da educação profissional a uma lógica privatista (ANPED, 2011).

Durante o processo de tramitação na Câmara - no período de 29 de abril a 31 de agosto de 2011 -, o texto encaminhado pelo Governo Federal teve a incorporação de algumas emendas parlamentares, possibilitando, por exemplo, a atuação das escolas técnicas privadas de educação profissional na iniciativa Bolsa Formação, o que ampliou a participação da esfera privada no Programa (CNTE, 2011). Quando o Projeto de Lei chegou ao Senado, algumas das críticas emanadas dos setores organizados da sociedade civil foram apresentadas na forma de emendas ${ }^{4}$, como a retirada do Sistema S (Sistema Nacional de Aprendizagem) e das instituições privadas,

\footnotetext{
${ }^{3}$ Na câmara Federal o Projeto de Lei tramitou sob o n. 1.209/2011 e no Senado Federal tramitou como Projeto de Lei da Câmara (PLC) n. 78/2011. A aprovação do Pronatec no Congresso Nacional seguiu regime de urgência, a pedido do Executivo.

${ }^{4}$ Tais emendas foram apresentadas pelos Senadores do Psol Randolfe Rodrigues (Psol/AP) e Marinor Brito (Psol/PA)
} 
porém, foram rejeitadas e o texto foi aprovado sem alterações no dia 19 de outubro de 2011 (EPSJV, 2011). Poucos dias depois, o texto foi sancionado pela Presidenta da República, transformando-se na Lei n. 12.513, de 26 de outubro de 2011.

Assim, desde o seu nascedouro, o Pronatec evidenciava a existência de disputas na orientação da política de educação profissional no Governo Dilma. As críticas oriundas de organismos da sociedade civil denunciavam uma mudança de orientação no projeto de educação profissional do Governo, em comparação às ações desenvolvidas nos governos anteriores, liderados pelo mesmo Partido político (Governos Lula 2003-2006 e 2007-2010). Tal situação nos colocou, inicialmente, algumas questões que motivaram a realização deste estudo: Quais forças políticas, econômicas e sociais estavam em disputa no processo de construção e aprovação do Pronatec? As preocupações apontadas pelas entidades educacionais e sindicais se confirmaram como tais? Quais as mudanças que o Pronatec forjou na política de educação profissional construída ao longo dos governos Lula?

Conforme o texto da Lei aprovada, o objetivo principal do Pronatec constitui-se em “expandir, interiorizar e democratizar a oferta de cursos de educação profissional técnica de nível médio presencial e a distância e de cursos e programas de formação inicial e continuada ou qualificação profissional" (Art. $1^{\text {o }}$, BRASIL, 2011). Tendo como pressuposto a necessidade de formação de mão de obra no país, o Pronatec se apresenta como "política estruturante da educação Profissional Brasileira" (MEC, 2012). Proposto como um Programa "guarda-chuva" das políticas de educação profissional, o Pronatec abarca as ações já em andamento e cria duas novas, quais sejam: Bolsa Formação, que atua no repasse de recursos para instituições públicas ou privadas ofertarem matrículas gratuitas em cursos técnicos ou de formação inicial e continuada, e amplia o Fundo de Financiamento Estudantil incluindo os cursos Técnicos. No entanto, o FIES Técnico não foi implementado enquanto tal $^{5}$, pois acabou sendo absorvido pela Bolsa Formação em virtude do ingresso das instituições privadas como instituições ofertantes.

As ações já em andamento que passaram a integrar o Programa referem-se: ao Fortalecimento e Expansão da Rede Federal de Educação Profissional e Tecnológica (iniciado em 2003), por meio da criação e consolidação de unidades dos Institutos Federais de Educação, Ciência e Tecnologia; à Rede e-Tec Brasil (criada em 20116 , pelo Decreto n. 7.589), que oferta

\footnotetext{
5 A Lei do Pronatec altera a Lei do FIES (Lei n. 10.260/2001), passando sua denominação de Fundo de Financiamento ao Estudante do Ensino Superior para Fundo de Financiamento Estudantil, com vistas a estender o financiamento para cursos técnicos. No entanto, apesar de o FIES Técnico ter sido normatizado por meio da Portaria n. 161, de 06 de março de 2013, essa ação não foi executada.

${ }^{6}$ A Rede e-Tec é originária do Sistema Escola Técnica Aberta do Brasil, criado em 2007, pelo Decreto n. 6.031, que incluía apenas as instituições públicas. Com a instituição da Rede e-Tec as instituições do Sistema $S$ também passaram a fazer parte.
} 
cursos técnicos na modalidade de ensino a distância; ao Programa Brasil Profissionalizado, que atua no repasse de recursos para a expansão das redes públicas estaduais para a oferta de ensino médio integrado à educação profissional; e ao Acordo de Gratuidade do Sistema S (instituído em 2008, por meio dos Decretos n. 6.633 - referente ao SENAC - e n. 6.635 referente ao SENAI), que definiu, de forma progressiva até 2014, a aplicação do percentual de $66,67 \%$ dos recursos recebidos da contribuição compulsória das empresas na oferta gratuita de cursos de formação profissional.

Tendo em vista que a Bolsa Formação foi a única ação criada pela Lei do Pronatec, passou a ser chamada como sinônimo de Pronatec e é sobre ela que recaem as críticas ao Programa. A Bolsa Formação atua no repasse de recursos públicos para instituições públicas e privadas para a oferta de matrículas gratuitas em cursos técnicos ou de qualificação profissional, conforme a demanda local. Os cursos técnicos de nível médio seriam destinados para o público que está cursando ou concluiu recentemente o ensino médio, na forma concomitante ou subsequente $^{7}$, e para o público trabalhador são ofertados cursos de formação inicial ou continuada (FIC) - também denominados cursos de qualificação profissional -, os quais exigem níveis mais baixos de escolaridade.

Desde a sua criação, o Pronatec vem sofrendo alterações em sua configuração inicial em virtude de demandas da sociedade civil, defendidas tanto por organismos educacionais, quanto empresariais, evidenciando que as disputas observadas no momento da sua aprovação continuaram atuando no seu desenvolvimento. A partir de reivindicações de movimentos sociais da área de educação de jovens e adultos, o Programa incorporou a oferta de cursos técnicos ou de formação inicial e continuada articulada à Educação de Jovens e Adultos, em nível de educação básica, a partir das diretrizes do Proeja (Programa Nacional de Integração da Educação Profissional com a Educação Básica na Modalidade de Educação de Jovens e Adultos), instituindo-se o Pronatec EJA por meio da Portaria MEC n 168 , de 07 de março de 2013. Essa demanda tinha como duplo propósito assegurar a continuidade e expansão da oferta de cursos Proeja, por meio dos recursos viabilizados pelo Pronatec, uma vez que ela vinha perdendo espaço nas instituições, e disputar os rumos do programa a partir da concepção de

\footnotetext{
${ }^{7}$ Os egressos do Ensino Médio passaram a ser público alvo do Pronatec Bolsa Formação apenas com o ingresso das instituições privadas na oferta da Bolsa Formação, as quais não estavam presentes no Projeto original do Pronatec. Assim, o objetivo de melhoria do Ensino Médio através da oferta de cursos técnicos concomitantes no âmbito da Bolsa Formação acabou ficando em segundo plano, uma vez que essas instituições ofertaram a maior parte dos cursos técnicos, sendo esses realizados na forma subsequente ao ensino médio.
} 
educação profissional enquanto política de formação integral dos trabalhadores, associando a elevação da escolaridade à profissionalização, a qual orienta o Proeja ${ }^{8}$.

De outra parte, fruto das reivindicações empresariais, a partir da Medida Provisória n. 593, de dezembro de $2012^{9}$, ampliou-se a participação do setor educacional privado no Pronatec. Foram incluídas, também, as instituições privadas de Ensino Superior e as Fundações Públicas de direito privado dedicadas à educação profissional, as quais passaram a receber recursos do Pronatec Bolsa Formação para ofertar cursos técnicos nas suas áreas de atuação. Tendo em vista que não há a exigência de tradição na oferta de Educação Profissional pelas instituições de ensino superior, muitas IES privadas identificaram essa oportunidade como um novo "nicho de mercado", de captação de recursos públicos a partir da criação e oferta de cursos técnicos.

A partir do Golpe parlamentar de 2016 (SINGER, 2018), o então governo em exercício criou uma nova ação dentro do Pronatec chamada MedioTec, que tem como foco a oferta de cursos técnicos na forma concomitante, por meio de instituições públicas e privadas, para estudantes de escolas públicas de ensino médio, inclusive na modalidade a distância. Essa mudança de foco tem sido apontada por vários pesquisadores (ARELARO, 2017; MOTTA, FRIGOTTO, 2017) como uma forma de antecipação da Reforma do Ensino Médio, aprovada pela Lei 13.415 de 15 de fevereiro de 2017, que reduz a base formativa comum nessa etapa de ensino e insere itinerários formativos de "escolha" dos estudantes, entre eles a formação técnica, permitindo o estabelecimento de parcerias público-privadas, como é o caso do MedioTec.

Observando-se os dados referentes à oferta de cursos no período de 2011 até o final de 2016, têm-se como características marcantes do Pronatec Bolsa Formação a oferta privada da grande maioria das matrículas de educação profissional e a predominância de cursos de formação rápida, desvinculados da elevação da escolaridade. Nesse período, foram realizadas mais de 4,6 milhões de matrículas (SISTEC Nacional, 2017) e destinados mais de 13,3 bilhões de reais no desenvolvimento do Pronatec Bolsa Formação (e-SIC, 2017). Do total de matrículas, $77,3 \%$ foram realizadas em cursos FICs, que se caracterizam por serem cursos rápidos, entre 160 e 400 horas $^{10}$, e por exigirem baixa escolaridade como pré-requisito, e 78,8\% foram

\footnotetext{
${ }^{8} \mathrm{O}$ ingresso do Proeja no âmbito do Pronatec, que resultou na elaboração do "Documento Referência Pronatec EJA" com vistas a assegurar os princípios político-pedagógicos e curriculares do Proeja, entre eles o trabalho como princípio educativo, não foi consenso nos Fóruns de EJA no país. O documento "Manifesto do Fórum de Educação de Jovens e Adultos do Espírito Santo em defesa do Proeja" apresentou posicionamento contrário, apontando que a inserção do Proeja no Pronatec implicará em sua descaracterização "em função de sua incompatibilidade teóricometodológica em seus pressupostos e princípios que são antagônicos” (FORUM EJA/ES, 2013).

${ }^{9}$ Essa medida foi convertida na Lei 12.816, de 05 de junho de 2013, a qual alterou a Lei de criação do Pronatec.

${ }^{10}$ Para regulamentar a oferta de cursos de Formação Inicial e Continuada, o Ministério da Educação publicou o Guia Pronatec de cursos FIC, através da Portaria MEC n 899, de 20 de setembro de 2013. Esse Guia discrimina
} 
desenvolvidas por instituições privadas, sendo que $66,7 \%$, exclusivamente, por instituições dos Serviços Nacionais de Aprendizagem, o chamado Sistema S $^{11}$ (SISTEC Nacional, 2017).

Em nível nacional, 78\% dos recursos investidos em todas as iniciativas que compõem o Pronatec, no período de 2011 a 2014 ${ }^{12}$, correspondem à Bolsa Formação, sendo que a grande maioria foi destinada às instituições do Sistema $\mathrm{S}$ e Instituições privadas de ensino superior e de ensino técnico. Embora todas as matrículas realizadas pelo programa sejam gratuitas, esses dados apontam para uma forma de privatização da educação profissional, na qual a oferta é gratuita, mas o conteúdo e o seu desenvolvimento são orientados pelos interesses privados.

O Pronatec Bolsa Formação foi criado em um contexto histórico de grandes investimentos na educação profissional pública, que vinham ocorrendo desde o primeiro mandato do Governo do PT (2003-2006), orientados pela concepção de educação profissional como direito à educação, integrando a formação profissional à educação básica, a partir da mudança político-pedagógica nessa área promovida pelo Decreto 5.154/2004. Como exemplo, podemos citar a ampliação e a criação de novas instituições de Educação Profissional, como os Institutos Federais de Educação, Ciência e Tecnologia ${ }^{13}$, e o desenvolvimento de Programas centrados na integração entre a educação básica e a educação profissional, como o Proeja ${ }^{14}$, o Brasil Profissionalizado e a política de ensino dos próprios Instituto Federais, que devem destinar $50 \%$ de suas vagas para cursos técnicos, preferencialmente, integrados ao ensino médio, conforme artigo $8^{\circ}$ da Lei 11.892/2008 que cria os Institutos Federais, entre outros. Essas ações foram construídas a partir de demandas das organizações da classe trabalhadora.

A partir de 2007, ocorreu um crescimento das matrículas públicas em virtude da expansão da Rede Federal de Educação Profissional e do investimento nas redes estaduais, por meio do Brasil Profissionalizado. Com isso, pela primeira vez as instituições públicas haviam suplantado a oferta privada de matrículas nessa modalidade de ensino. Já no período de vigência

\footnotetext{
a escolaridade exigida, a carga horária e o perfil profissional de cada curso, estando organizado por meio dos Eixos Tecnológicos que orientam a oferta de Educação Profissional e Tecnológica. Essa normatização representou um avanço, pois até então cursos com carga horária bem inferior, como 10h ou 20h, eram considerados formação inicial ou continuada.

${ }^{11}$ Serviço Nacional de Aprendizagem Industrial (SENAI): 35,70\%; Serviço Nacional de Aprendizagem Comercial (SENAC): 25,53\%; Serviço Nacional de Aprendizagem Rural (SENAR): 3,23\% e Serviço Nacional de Aprendizagem do Transporte (SENAT): 4,25\%.

12 Não foi possível identificar o montante de recursos destinados a todas as iniciativas do Programa até 2016.

${ }^{13}$ Durante os dois mandatos do Governo Lula a Rede Federal de Educação Profissional e Tecnológica, que inclui os CEFETs, Escolas Técnicas Federais, a Universidade Tecnológica Federal do Paraná, o Colégio Pedro II e os Institutos Federais, passou de 140 unidades, em 2002, para 354 unidades, em 2010.

${ }^{14}$ Programa Nacional de Integração da Educação Profissional com a Educação Básica na modalidade de educação de jovens e adultos, criado por meio do Decreto $n^{\circ} 5.478$, de 24 de junho de 2005, substituído em seguida pelo Decreto $\mathrm{n}^{\circ} 5.840$, de 13 de julho de 2006, que amplia a abrangência do primeiro a partir da inclusão da oferta de cursos Proeja para o público do ensino fundamental da EJA e da ampliação das instituições ofertantes.
} 
do Pronatec Bolsa Formação, as matrículas em instituições privadas ultrapassaram novamente as matrículas públicas, atingindo um crescimento vertical nos anos de 2013 e 2014, que podem ser inferidos ao ingresso, a partir de 2013, das instituições privadas, e à concentração da maior oferta de recursos financeiros em 2014, ano em que o Programa teve a maior oferta de vagas. Com a diminuição dos recursos destinados a essa política, observa-se, em 2015, uma forte queda nas matrículas privadas, ao passo que as matrículas públicas continuaram crescendo, evidenciando que o investimento nessas instituições aparenta produzir efeitos mais duradouros. No Gráfico 01, que apresenta as matrículas em cursos técnicos nas formas concomitante, subsequente e integrada, essa última a partir de 2005, pode-se visualizar o crescimento da oferta nas redes públicas (federal, estadual e municipal) e privada, no período de 2003 a 2016.

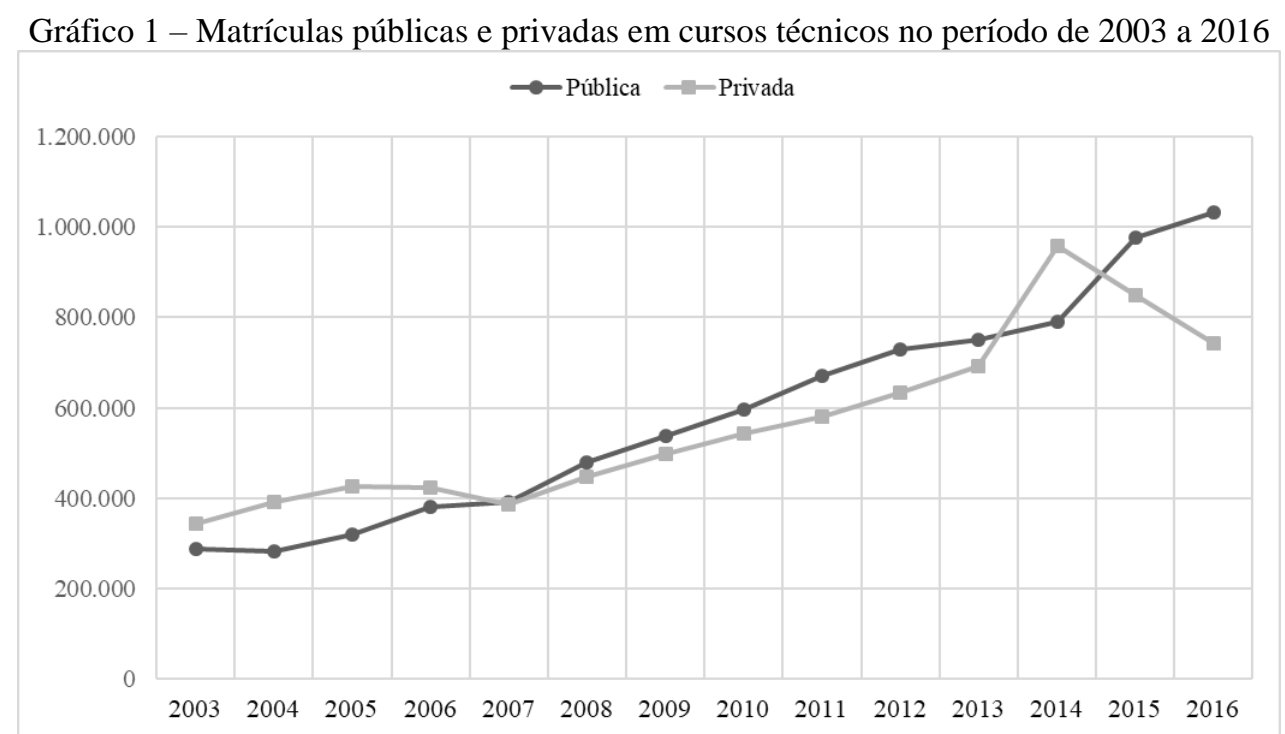

Fonte: elaborado pela autora com base nos dados do Censo Escolar - INEP

Esses dados evidenciam que as políticas de educação profissional nesse período expressam uma disputa de projetos educativos e pelo acesso aos fundos públicos destinados à formação da classe trabalhadora, à medida em que cresce a oferta e o orçamento público destinado a essa modalidade de ensino. A criação do Pronatec, apesar de incluir as políticas do período anterior, incorpora outros elementos, como o financiamento público para instituições privadas e retoma a centralidade da formação profissional desvinculada da educação básica, voltada ao atendimento das demandas do mercado de trabalho. Nesse sentido, traz à tona as disputas de concepção em torno de projetos para a educação profissional e intensifica o projeto do empresariado brasileiro na formação de trabalhadores, uma vez que a maioria das matrículas foram realizadas em cursos de rápida formação, e desarticulados da educação básica, e 2/3 (dois terços) das matrículas no âmbito do Programa foram desenvolvidas por instituições do 
Serviço Nacional de Aprendizagem (Sistema S) ligadas às suas organizações de classe, retomando as marcas históricas da educação profissional no país.

Diferentemente do processo de construção das políticas de educação profissional no Governo Lula, marcado pelo debate público envolvendo entidades educacionais, instituições públicas de educação profissional e organizações da sociedade civil, a construção do Pronatec não contou um forte debate público, tendo sido anunciado pouco mais de um mês após o início do mandato da Presidenta Dilma Roussef ${ }^{15}$ e tramitado no Congresso Nacional em regime de urgência. $\mathrm{O}$ que evidencia uma mudança na correlação de forças na construção das políticas públicas nessa área, privilegiando espaços em que as organizações dos trabalhadores têm pouca ou quase nenhuma força, como o Congresso Nacional.

Sob a alegação de democratizar o acesso à educação profissional, o Pronatec Bolsa Formação pulveriza a oferta fragmentada e aligeirada de formação profissional em instituições de diferentes naturezas e condições de qualidade, em uma lógica similar ao apontado por Gramsci (2014, p. 50), “a multiplicação de tipos de escolas profissional, portanto, tende a eternizar as diferenças tradicionais; mas, dado que tende, nestas diferenças, a criar estratificações internas, faz nascer a impressão de ter uma tendência democrática”.

Na avaliação de Frigotto (2013), o Pronatec reedita o PIPMO - Programa Intensivo de Formação de mão de obra, desenvolvido nos anos 60 -, porém com um volume ainda maior de recursos, resguardadas as diferenças de conjuntura em que foram constituídos. E conforme destaca Moraes (2013a, p. 997), "sustentado nas concepções economicistas da Teoria do Capital Humano e baseado em um suposto 'apagão' de mão de obra, o Pronatec é hoje política emblemática do protagonismo atribuído, pelo governo federal, às instituições privadas na oferta dos cursos de educação profissional e tecnológica".

Em que pese a construção e desenvolvimento de políticas e programas que produziram uma disputa de hegemonia no âmbito da educação profissional, indicamos nesta tese que os enfrentamentos políticos e pedagógicos que marcaram todo o período dos governos Lula e Dilma caracterizaram-se pela forte presença dos interesses privatistas e sua concepção mercantil de educação, os quais influenciaram com maior ou menor intensidade a formulação das políticas públicas, de acordo com a correlação das forças sociais em disputa. Parte-se da hipótese, desenvolvida ao longo da tese, que a partir da adoção de uma política econômica

\footnotetext{
${ }^{15}$ No dia 10 de fevereiro, em pronunciamento à nação, por meio de rádio e televisão, a Presidenta Dilma anunciou que estava sendo planejado, para lançamento dentro de três meses, o Programa Nacional de Acesso à Escola Técnica (PALÁCIO DO PLANALTO, 2011). No entanto, o Programa foi lançado no dia 28 de abril como "Programa Nacional de Acesso ao Ensino Técnico e Emprego", indicando uma mudança em relação ao projeto inicial.
} 
voltada ao desenvolvimento industrial (CARVALHO, 2018; SINGER, 2018), que colocou em marcha várias demandas do setor, o governo Dilma sinaliza para o atendimento das demandas de formação de mão de obra apresentadas pelos empresários - anunciadas sob a ameaça do "apagão de mão de obra" - com a criação do Pronatec, o qual é perpassado pelos interesses privados no acesso aos recursos públicos, fazendo com que o projeto hegemônico de educação adquira força e que a política de educação profissional avançasse na direção da socialização da força de trabalho às demandas do setor produtivo, desvinculando-a da elevação da escolaridade.

De um cenário em que pela primeira vez o Sistema S passou a ter um mínimo de oferta gratuita de cursos, tendo em vista o caráter público de sua fonte de financiamento, viu-se o retorno do financiamento público para a esfera privada, por meio da Bolsa Formação, e consequentemente o financiamento do projeto educacional da burguesia pelo Estado. Essa mudança de perspectiva, teria configurado um "desvio de rota" 16 no âmbito do projeto de formação da classe trabalhadora construído nos governos Lula, conforme apontavam as críticas ao Programa.

Tendo o Estado como o principal articulador da Educação Profissional, enquanto política pública, parte-se do entendimento de que essas diferentes concepções se encontram ligadas a diferentes interesses de classes sociais e frações de classes que disputam o Estado e, por consequência, as políticas públicas. Com base na concepção de Estado Ampliado desenvolvido por Gramsci (2007), as políticas públicas, entre elas as educacionais, podem ser compreendidas como expressão da disputa de hegemonia das classes na sociedade civil e na sociedade política. Por sua importância estratégica na construção e manutenção da hegemonia de classe, a educação é espaço de disputa de diferentes projetos político-pedagógicos. As políticas educacionais traduzem os diferentes interesses emanados da sociedade civil e sociedade política, ora avançando para uma concepção democrática de educação, ora retrocedendo e/ou convivendo com iniciativas socialmente excludentes, sendo resultado da atuação do Estado na manutenção das relações de produção capitalista a partir da mediação entre as demandas da classe trabalhadora e as necessidades da reprodução do capital (OFFE, 1984).

\footnotetext{
16 Essa expressão é oriunda da pesquisa de campo, a partir de entrevista com o ex-Secretário de Educação Profissional Eliezer Pacheco. É utilizada no âmbito desta Tese para expressar, de forma metafórica, uma mudança de perspectiva no âmbito das políticas de educação profissional no Governo Dilma. Compreende-se que a/as rota/as de educação profissional, identificadas a partir de diferentes projetos formativos, não são lineares, mas disputam dialeticamente a condução político-ideológica da formação da classe trabalhadora. Assim, o "desvio de rota" não significa a substituição de uma rota por outra, mas uma mudança na disputa de hegemonia entre diferentes projetos formativos a partir da formulação e implementação de políticas públicas, nesse caso, o Pronatec.
} 
Para Gramsci, o Estado não está restrito ao aparelho estatal, ele é formado pelo conjunto sociedade política - identificada com o aparelho de Estado - e sociedade civil. Nas palavras de Gramsci "na noção geral de Estado entram elementos que devem ser remetidos à noção de sociedade civil (no sentido, seria possível dizer, que Estado = sociedade política + sociedade civil, isto é, hegemonia couraçada de coerção)" (GRAMSCI, 2007, p. 244) ou "no significado integral: ditadura + hegemonia" (GRAMSCI, 2007, p. 257). Nesse sentido, identificando que o Estado no capitalismo "é certamente concebido como organismo próprio de um grupo, destinado a criar as condições favoráveis à expansão máxima desse grupo" (GRAMSCI, 2007, p. 41), Gramsci caracteriza a sua atuação como o processo de formação de equilíbrios entre a incorporação das reivindicações e interesses dos grupos subalternos - que são subtraídas de sua própria lógica e enquadradas na ordem vigente - e as necessidades de reprodução da própria ordem vigente (BIANCHI, 2008). A formação de equilíbrios é realizada por meio do exercício da hegemonia do grupo dominante, através do consenso, obtido a partir da difusão da sua ideologia - modo de pensar e agir - ao conjunto da sociedade, através dos organismos privados de hegemonia - como a escola, a Igreja, os partidos políticos - e da coerção, que visa assegurar “'legalmente' a disciplina dos grupos que não 'consentem', nem ativa nem passivamente” (GRAMSCI, 2014, p. 21).

Com base nessa perspectiva, faz-se necessário examinar os fundamentos teóricos, políticos e econômicos que dão sustentação a esse programa, tendo como viés de análise as configurações da relação trabalho, educação e desenvolvimento econômico, a partir das disputas de diferentes interesses de grupos e classes sociais no âmbito do Estado, e como se materializam no processo de construção e desenvolvimento dessa política de educação profissional. Como lembra Frigotto, "a lei não é expressão da realidade, mas das forças que a produzem" (2012, p. 46).

Análises realizadas sobre o Pronatec apontam, em geral, a preocupação com o volume de transferência de recursos públicos para a iniciativa privada, a secundarização, ou quase anulação, da integração entre educação básica e formação profissional no âmbito da iniciativa Bolsa Formação e suas semelhanças com programas de formação profissional desenvolvidos no passado, como o PIPMO e o PLANFOR - Plano Nacional de Qualificação do Trabalhador, desenvolvido nos anos 1990 - (LIMA, 2011; 2012; MACHADO, GARCIA, 2013; MOURA, 2013; FRANZOI et al, 2013; SALDANHA, 2012). Por outro lado, são sinalizados alguns méritos do Programa, como a tentativa de superar a pulverização de iniciativas de formação profissional no âmbito dos ministérios, reunindo-as na esfera do Ministério da Educação, sem deixar de se integrar com as demais políticas sociais do governo, e o fato de concentrar a oferta 
de cursos pela Rede Federal de Educação Profissional e Tecnológica e pelo Sistema S, ao contrário de programas anteriores que mobilizavam um grande número de instituições de diversas naturezas, conforme aponta Castioni (2013).

No âmbito dos Programas de Pós-graduação em Educação e em Educação Profissional, conforme levantamento realizado no Banco de Teses e Dissertações da CAPES $^{17}$, as pesquisas já concluídas que tiveram como objeto central de investigação o Pronatec, concentraram-se, de um lado, na análise de indicadores financeiros e de matrículas, das normatizações jurídicas e de discursos produzidos sobre o Programa, cumprindo o importante papel de socializar os dados quantitativos da oferta e analisá-los criticamente (COSTA, 2015; RAMOS, 2014a; SILVA, 2015; SANTIAGO, 2015). De outro, na realização de estudos de caso em instituições que ofertam cursos pelo Programa, que revelam, por exemplo, elevada evasão nos cursos, em especial nos cursos técnicos concomitantes, em razão da dupla jornada dos estudantes ao frequentar duas instituições de ensino e conciliar, em muitos casos, também o trabalho, não se confirmando, assim, o objetivo de democratizar o acesso à educação profissional técnica de nível médio, conforme se propunha (SALDANHA, 2016), e a "inclusão excludente" dos estudantes de cursos Pronatec no âmbito de um Instituto Federal, em razão das condições diferenciadas de corpo docente e pedagógico-administrativas (RAMOS, 2014b). Ressalta-se a importância das investigações por meio de estudos de caso, pois a apreensão dos resultados de uma política tão ampla como o Pronatec requer a análise das diferentes situações e realidades em que se insere, de forma a constituir um panorama que nos permita, no conjunto, identificar os principais "efeitos” produzidos pelo Programa.

Algumas pesquisas dedicaram uma maior ênfase na compreensão do processo de constituição do Pronatec, como os estudos de Rodrigues (2017) e Reis (2017). Tendo como recorte a análise da relação público-privada estabelecida no âmbito do Programa, Rodrigues (2017) destaca, numa perspectiva não linear, a influência de recomendações dos organismos internacionais, entre eles a CEPAL (Comissão Econômica para a América Latina e o Caribe), a Unesco (Organização das Nações Unidas para a Educação, a Ciência e a Cultura) e a OCDE (Organização para a Cooperação e Desenvolvimento Econômico), na elaboração de políticas de educação profissional em países de capitalismo periférico, como o Brasil, e na adoção de parcerias público-privadas como estratégias para a efetivação dessas políticas, situadas no âmbito da lógica de atuação do Estado Brasileiro e das demandas oriundas da burguesia. Na

\footnotetext{
${ }^{17}$ Utilizamos como termo de busca a palavra "Pronatec" e restringimos a pesquisa no âmbito dos Programas de Pós-Graduação em Educação e em Educação Profissional. Foram localizadas 54 pesquisas que tiveram como objeto central de estudo o Pronatec, sendo 49 dissertações de mestrado e 05 teses de doutorado.
} 
análise de Reis (2017), observa-se uma maior valorização da influência dos organismos internacionais, em especial da CEPAL, ao afirmar que "o PRONATEC consiste em um processo de formação humana influenciado pelas diretrizes do CEPAL sob a égide da financeirização do capital" (p. 08).

No entanto, não identificamos entre as pesquisas já realizadas uma análise do processo de construção do Programa que considere de forma conjunta os fatores políticos e econômicos e o processo de correlação de forças entre os distintos projetos de formação da classe trabalhadora, apreendidos por meio da investigação nos espaços de formulação e regulamentação do desenvolvimento do Pronatec. Do ponto de vista do desenvolvimento do Programa no âmbito das instituições ofertantes, embora um grande número de pesquisas se dedique a apreender as condições de sua materialização em instituições de diferentes naturezas, não foram localizados estudos comparativos que permitam apreender se há diferenças na oferta e no conteúdo formativo, por exemplo, entre instituições públicas e privadas, e quais os fatores que concorrem para a grande diferença na oferta quantitativa. O estudo de Lima et al (2016), que apresenta uma análise da oferta quantitativa entre o SENAI e o Instituto Federal do Espírito Santo (IFES), no Estado do Espírito Santo, permite inferir que a capilaridade das instituições não pode ser tomada como único elemento explicativo para a preponderância do Sistema $\mathrm{S}$ no desenvolvimento do Programa. Naquele estado, o IFES possui o dobro de unidades de ensino em relação ao SENAI e, no entanto, a oferta de matrículas no âmbito do Pronatec Bolsa Formação não chegou à sexta parte do montante desenvolvido pela instituição do Sistema S.

Com base nos estudos já realizados, pretendeu-se avançar na compreensão do processo de construção e desenvolvimento do Pronatec, a partir da incorporação desses elementos na análise. Nesse sentido, os esforços analíticos aqui empreendidos se direcionaram para o aprofundamento da compreensão sobre o contexto de elaboração dessa política, à apreensão das mediações histórico-concretas na sua materialização a partir da análise do desenvolvimento do Pronatec Bolsa Formação em duas instituições de diferentes naturezas - uma integrante do Sistema S e outra integrante da Rede Federal de Educação Profissional - e à identificação e análise dos impactos dessa nova forma de oferta de cursos de formação profissional no âmbito das políticas públicas já em andamento.

Com essa perspectiva, a pesquisa foi orientada pelas seguintes questões: como se deu o processo de construção do Pronatec? Quais os sujeitos (individuais e/ou coletivos), instituições e fatores políticos, econômicos e sociais que atuaram na sua configuração? Que concepção de educação profissional orienta o Programa? Quais as características do desenvolvimento do Pronatec Bolsa Formação no âmbito de instituições públicas (federal) e privadas (Sistema S) 
situadas no Estado do Rio Grande do Sul? Quais os fatores que concorrem para a grande diferença da oferta quantitativa do Programa entre instituições públicas e privadas? Qual o conteúdo das formações desenvolvidas pelo Programa e a qual demanda do mercado de trabalho elas respondem? Qual o perfil dos alunos que realizam os cursos do Pronatec Bolsa Formação?

Ao investigar essas questões tínhamos como horizonte apreender as implicações do Pronatec Bolsa Formação na configuração da educação profissional no país. Em outras palavras, interessava compreender se o arranjo institucional e de cursos promovido pelo Pronatec Bolsa Formação teve impactos regressivos sobre o projeto de educação profissional voltado aos interesses da classe trabalhadora construído nos últimos anos, conforme apontavam as críticas iniciais ao Programa. Nessa direção, o objetivo mais amplo que orientou a pesquisa foi identificar e analisar o processo de construção do Pronatec e o desenvolvimento da iniciativa Bolsa Formação no âmbito de instituições públicas e privadas situadas no Estado do Rio Grande do Sul, com vistas a apreender as relações entre educação e trabalho, formação profissional e desenvolvimento econômico que informam essa política, assim como as suas implicações na conformação da Educação Profissional, enquanto modalidade de ensino, no contexto atual.

Esse objetivo geral, por sua vez, nos conduziu ao desenvolvimento de algumas questões fundamentais, as quais orientaram o desenvolvimento do processo de estudo, da pesquisa empírica e da sistematização dos resultados. São elas: a compreensão da emergência do Pronatec no atual momento histórico, no âmbito do processo de construção das políticas de educação profissional no Brasil, e de sua relação com as diferentes configurações da relação trabalho e educação, e o papel do Estado; a identificação dos fundamentos políticos e econômicos e os sujeitos/instituições que dão sustentação a essa política; as características do desenvolvimento do Pronatec Bolsa Formação em instituições públicas e privadas situadas no Estado do Rio Grande do Sul, e o perfil do público e dos cursos ofertados no âmbito do programa no espaço dessas instituições; a natureza das relações público-privadas que perpassam o Pronatec Bolsa Formação; e a apreensão dos possíveis efeitos do Programa no âmbito das políticas educacionais já em andamento.

Assim, a pesquisa que deu origem à tese foi desenvolvida a partir de três diferentes eixos de investigação que se entrelaçam: o processo que deu origem ao Pronatec; o desenvolvimento da iniciativa Bolsa Formação em instituições ofertantes de diferentes naturezas (federal e do Sistema S); e a análise sobre o andamento das políticas de educação profissional que foram inseridas no âmbito do Pronatec.

A fim de atingirmos o objetivo da pesquisa, a investigação foi realizada por meio de abordagens qualitativa e quantitativa, com vistas a compreender o processo de construção e 
desenvolvimento do Pronatec, enquanto política pública de educação profissional, no âmbito federal, analisando-se as mediações históricas, políticas, econômicas e sociais que o configuram. No intuito de apreender as formas de materialização do Programa, foram realizados estudos de caso em duas instituições - uma pública federal e outra privada, pertencente ao Sistema $\mathrm{S}$ - que ofertam cursos pelo Programa. Tanto em nível nacional, quanto no âmbito das instituições pesquisadas, buscou-se evidenciar se a emergência do Pronatec Bolsa Formação trouxe implicações para as demais iniciativas de educação profissional já em andamento.

Por situar-se em um campo de confluência de diversas áreas, como a sociologia da educação, a economia, a história e a sociologia do trabalho, a apreensão das relações entre trabalho e educação exige a integração de conhecimentos desenvolvidos nesses diferentes campos (MORAES, 2015). Assim, tivemos como perspectiva a análise interdisciplinar do objeto, transitando por conhecimentos produzidos acerca da configuração do mundo do trabalho capitalista, das configurações históricas da relação trabalho e educação, das especificidades da formação econômica e social do Brasil e dos elementos da conjuntura político-econômica e social (tanto no âmbito da sociedade política, quanto na sociedade civil) na qual emerge a política educacional em estudo. Assumimos, nesse sentido, a perspectiva histórico-dialética ao tomar o objeto de análise como parte e produto de uma totalidade social e histórica, compreendendo-o no campo das contradições, das mediações e das relações entre o particular e o geral, o singular e o universal (KOSIK, 1969).

Ao tomarmos como ponto de partida a "aparência" do fenômeno - concentração da oferta e do acesso aos fundos públicos por instituições privadas - buscou-se compreender, na essência, os fatores que concorreram para a constituição de sua "aparência fenomênica". Isso não significa, contudo, desconsiderar a importância da "aparência" na compreensão do objeto de estudo, uma vez que "sem o fenômeno, sem a sua manifestação, a essência seria inatingível" (KOSIK, 1969, p. 12). A aparência juntamente com a essência constituem a totalidade do fenômeno.

Nessa direção, a pesquisa foi constituída por três momentos desenvolvidos de forma integrada, que, na nossa visão, abrangeriam espaços importantes para a apreensão da materialidade do objeto de estudo. Um deles refere-se ao levantamento e análise da literatura acerca da temática (teses, dissertações, livros e artigos científicos), nas diferentes áreas de conhecimento que perpassam o objeto de estudo. $\mathrm{O}$ outro momento diz respeito ao levantamento e análise das fontes primárias: documentos produzidos sobre o Pronatec em âmbito nacional, como leis, portarias, resoluções, publicações realizadas pelos Ministérios e órgãos de controle do governo federal, indicadores de matrículas e de recursos sobre o conjunto das iniciativas do 
Pronatec; documentos produzidos por organismos da sociedade civil e pelas instituições pesquisadas, como projetos pedagógicos de curso, normatizações internas sobre o Programa, indicadores institucionais de matrícula, corpo docente, entre outros. E o terceiro momento foi dirigido à realização de entrevistas semiestruturadas, em âmbito nacional, com gestores envolvidos na construção e na gestão das ações do Pronatec, e no âmbito das instituições pesquisadas, com gestores, docentes e funcionários e à aplicação de questionário a estudantes e docentes que participaram de cursos do Pronatec Bolsa Formação.

As instituições participantes da pesquisa foram definidas, de acordo com alguns objetivos e critérios. Em primeiro lugar, procurou-se abranger tanto as instituições públicas como as instituições privadas participantes do Pronatec Bolsa Formação no Estado do Rio Grande do Sul, de modo a apreender as possíveis diferenças na condução do Programa e suas implicações para a formação profissional; e em segundo lugar buscou-se priorizar as instituições que tiveram a maior oferta de cursos, tanto FICs, quanto técnicos. Com base em dados obtidos por meio do SIMEC (Sistema Integrado de Monitoramento Execução e Controle do Ministério da Educação), no segundo semestre de 2015, identificou-se que no Estado do Rio Grande do Sul a Rede Estadual não se consolidou como ofertante do Programa - houve a oferta de apenas uma turma em escola estadual, com 22 matrículas. Assim, se encontravam como instituições ofertantes do Pronatec Bolsa Formação aquelas pertencentes à Rede Federal (três Institutos Federais e duas escolas técnicas), escolas técnicas e universidades privadas e instituições do Sistema S (SENAI, SENAC, SENAR e SENAT).

Tabela 1 - Matrículas do Pronatec Bolsa Formação no RS - realizadas no período de 2011 a outubro de 2015

\begin{tabular}{l|l}
\hline \hline Instituição Ofertante & Matrículas \\
\hline Escolas Técnicas privadas & 21.162 \\
Universidades privadas & 5.510 \\
Rede Estadual & 22 \\
Rede Federal & 33.124 \\
Sistema S & 270.445 \\
\hline Total Geral & 330.263 \\
\hline \hline
\end{tabular}

Fonte: elaborada pela autora com base em dados obtidos por meio de consulta ao SIMEC (2015).

Com base nesses dados, evidenciamos que a Rede Federal e o Sistema S se configuravam como instituições públicas e privadas, respectivamente, com maior oferta de matrículas no âmbito do Pronatec Bolsa Formação no RS. Assim, ao detalharmos as matrículas por instituição, a partir de consulta direta às instituições de ensino da Rede Federal e pelo próprio SIMEC, considerandose novamente o critério de maior oferta de matrículas, incluindo oferta expressiva tanto de cursos técnicos quanto FICs, chegamos ao Instituto Federal de Educação, Ciência e Tecnologia 
Farroupilha - IFFar, com suas unidades de ensino - Campus ou Centro de Referência - situadas na região central, norte e na fronteira oeste do Rio Grande do Sul, como instituição pública federal, e de uma das instituições do Sistema S, nomeada nesta Tese como "Instituição SNA" ou apenas "SNA"18, com escolas distribuídas em todas as regiões do Estado. Destaca-se que o IFFar foi a segunda instituição com maior oferta de matrículas no âmbito da Rede Federal no RS. Porém, foi o único que teve oferta expressiva tanto de cursos técnicos quanto FICs, o que, de acordo com os critérios da pesquisa, resultou na sua escolha.

Ambas as instituições acolheram, inicialmente, muito bem a proposta de pesquisa, disponibilizando informações e concedendo entrevistas por meio de seus gestores. A partir desse contato inicial, tendo em vista a característica multicampi dessas instituições, foi possível obter os dados de oferta do Programa em cada uma das unidades de ensino, a partir dos quais selecionamos, em cada uma delas, duas unidades de ensino, com base nos mesmos critérios utilizados na seleção das instituições.

O contato com o IFFar deu-se a partir do Gabinete da Reitoria, no segundo semestre de 2015, o qual nos encaminhou à Reitora a fim de apresentar a proposta e solicitar autorização para a investigação. Obtida a autorização, por meio de Termo de Consentimento assinado pela dirigente da Instituição ${ }^{19}$, realizou-se o levantamento das normatizações do Programa no âmbito da Instituição e das matrículas ofertadas em cada unidade de ensino a fim de nos direcionarmos aos sujeitos envolvidos diretamente com as ações do Pronatec e a seleção das unidades onde seria realizado o aprofundamento da análise.

Conforme Resolução Institucional que normatiza o Pronatec Bolsa Formação no âmbito do IFFar, a gestão do Pronatec é de responsabilidade da Pró-Reitoria de Extensão (PROEX), a partir de equipe composta pelos seguintes encargos: 1) Coordenador Geral da Bolsa Formação, no âmbito da Pró-Reitoria; 2) Coordenador Adjunto da Bolsa Formação, no âmbito da Pró-Reitoria e das unidades de oferta do Programa; 3) Orientador, no âmbito das unidades de oferta do Programa; 4) Supervisor de Curso, no âmbito dos cursos técnicos nas unidades de oferta do Programa; 5) Apoio às atividades acadêmico-administrativas, no âmbito da Pró-Reitoria e das unidades de oferta do Programa; e 6) Professor, no âmbito das unidades de oferta do Programa.

\footnotetext{
${ }^{18}$ Esse nome é utilizado em virtude da necessidade de preservação da identidade da instituição, de acordo com as condições firmadas no Termo de Consentimento da Instituição, no âmbito desta pesquisa.

${ }^{19}$ Por meio do Termo de Consentimento, obtivemos a autorização para utilizar o nome da instituição na pesquisa. Entretanto, optamos por não identificar as unidades de ensino pesquisadas, uma vez que, na nossa visão, essa informação não seria imprescindível para os objetivos da pesquisa.
} 
Com base nos dados da oferta do Programa por unidade de ensino, obtidos em fevereiro de 2016, definimos as duas unidades que seriam incluídas na pesquisa. Visando contemplar as diferentes condições de oferta, optamos por selecionar um Campus e um Centro de Referência, tendo como critério a maior oferta de cursos, tanto de formação inicial e continuada quanto de técnico. A escolha de um campus e de um centro de referência justifica-se pelo objetivo de apreender se haviam diferenças nas condições de oferta do Programa nesses espaços, considerando que o Centro de Referência oferta exclusivamente cursos Pronatec Bolsa Formação, criados no contexto da Expansão da Rede Federal durante a vigência do Pronatec, e no Campus são ofertados diferentes níveis (do ensino médio integrado à pós-graduação) e programas de ensino. Assim, foram selecionadas as seguintes unidades: Campus 5, situado na região central, e Centro de Referência 2, situado na região norte do Estado.

Tabela 2 - Matrículas Pronatec Bolsa Formação por unidade de ensino (2011 a 2015) - IFFar

\begin{tabular}{|c|c|c|c|}
\hline Unidades do IFFar & FIC & Técnico & Total \\
\hline Campus 1 & 324 & 32 & 356 \\
\hline Campus 2 & 127 & 31 & 158 \\
\hline Campus 3 & 763 & 77 & 840 \\
\hline Campus 4 & 397 & 123 & 520 \\
\hline Campus 5 & $\underline{1440}$ & $\underline{93}$ & $\underline{1533}$ \\
\hline Campus 6 & 1062 & 31 & 1093 \\
\hline Campus 7 & 407 & 0 & 407 \\
\hline Campus 8 & 163 & 0 & 163 \\
\hline Campus 9 & 1071 & 80 & 1151 \\
\hline Campus 10 & 513 & 57 & 570 \\
\hline Campus 11 & 268 & 0 & 268 \\
\hline Centro de Referência 1 & 0 & 52 & 52 \\
\hline Centro de Referência 2 & $\underline{119}$ & $\underline{125}$ & $\underline{244}$ \\
\hline Centro de Referência 3 & 47 & 41 & 88 \\
\hline Centro de Referência 4 & 98 & 71 & 169 \\
\hline Centro de Referência 5 & 92 & 71 & 163 \\
\hline Centro de Referência $6^{20}$ & 362 & 30 & 392 \\
\hline Centro de Referência 7 & 73 & 86 & 159 \\
\hline Centro de Referência 8 & 60 & 80 & 140 \\
\hline Centro de Referência 9 & 0 & 49 & 49 \\
\hline
\end{tabular}

Fonte: elaborada pela autora com base nos dados do SISTEC institucional (fev. 2016).

A partir dessa configuração de gestão do Pronatec Bolsa Formação e dos dados de oferta, foi possível definirmos os sujeitos participantes da pesquisa e os locais para coleta de informações. Assim, realizamos entrevista com Gestores da instituição, em nível de Reitoria, e com gestores das unidades de ensino selecionadas; aplicamos questionários online direcionados a estudantes e professores dos cursos realizados; realizamos entrevistas de aprofundamento com alguns professores que responderam ao questionário, de forma a abranger diferentes perfis de

\footnotetext{
${ }^{20}$ Esse Centro de Referência teve suas atividades suspensas no início de 2016.
} 
formação, gênero e vínculo com a instituição; além de análise de documentos como: resoluções que normatizam o desenvolvimento do Programa na Instituição, projetos pedagógicos dos cursos ofertados no âmbito do Programa e indicadores quantitativos da oferta do Pronatec Bolsa Formação. Na Tabela 3 é possível visualizar os sujeitos participantes da pesquisa no IFFar e sua forma de participação ${ }^{21}$.

Tabela 3 - Entrevistas realizadas e questionários aplicados no IFFar no âmbito da pesquisa de campo

\begin{tabular}{|c|c|c|c|}
\hline Unidade & Função & Quantidade & "Participação \\
\hline \multirow[t]{8}{*}{ Reitoria } & Reitora & 01 & Entrevista \\
\hline & Pró-Reitora de Extensão* & 01 & Entrevista \\
\hline & Pró-Reitor de Ensino** & 01 & Entrevista \\
\hline & $\begin{array}{l}\text { Coordenador Geral da Bolsa } \\
\text { Formacão }(\mathrm{CGBF})\end{array}$ & 02 & Entrevista \\
\hline & Coordenador Adjunto da Bolsa & 01 & Entrevista \\
\hline & Formação (CABF) & & \\
\hline & Diretor de Implantação de & 01 & Entrevista \\
\hline & Novas Unidades (DINU) & & \\
\hline \multirow{9}{*}{$\begin{array}{l}\text { Unidade de análise } 1 \text { - } \\
\text { Campus }\end{array}$} & Coordenador Adjunto do & 02 & Entrevista \\
\hline & Pronatec & & \\
\hline & Coordenador Adjunto & 01 & Entrevista \\
\hline & Pronatec Mulheres Mil & & \\
\hline & Supervisor de Curso*** & 01 & Entrevista \\
\hline & Técnico da Emater & 01 & Entrevista \\
\hline & Professor & 04 & Entrevista \\
\hline & Professor & 34 & Questionário \\
\hline & Estudante & 32 & Questionário \\
\hline \multirow{6}{*}{$\begin{array}{l}\text { Unidade de Análise } 2- \\
\text { Centro de Referência }\end{array}$} & Coordenador do Centro de & 02 & Entrevista \\
\hline & Referência (CCR) & & \\
\hline & $\begin{array}{l}\text { Apoio às atividades acadêmicas } \\
\text { e pedagógicas }\end{array}$ & 01 & Entrevista \\
\hline & Professor & 02 & Entrevista \\
\hline & Professor & 15 & Questionário \\
\hline & Estudante & 16 & Questionário \\
\hline
\end{tabular}

* A Pró-reitora de Extensão também atuou como Coordenadora Geral da Bolsa Formação.

** O Pró-reitor de Ensino também foi Coordenador do Fórum de Dirigentes de Ensino (FDE) no âmbito das instituições da Rede Federal de EPCT, no período de 2014 a 2016.

*** A supervisora de curso entrevistada também atuou como Coordenadora Adjunta da Bolsa Formação.

Fonte: elaborada pela autora com base nas entrevistas realizadas e questionários aplicados.

O contato com a instituição do Sistema S, ocorreu por e-mail, em fevereiro de 2016, a partir do qual agendou-se entrevista com o Gestor do Núcleo de Educação Profissional da instituição. A instituição autorizou, por meio de Termo de Consentimento, a realização da pesquisa, porém na condição de sigilo quanto à sua identidade.

\footnotetext{
${ }^{21}$ Foram realizadas 09 visitas para a pesquisa de campo nessa instituição, além da realização de algumas entrevistas com docentes via internet ou por meio de encontro fora do horário e local de trabalho, em virtude de suas disponibilidades. No âmbito da Reitoria, foram realizadas 5 visitas com vistas na realização das entrevistas com os gestores e coleta de documentos e relatórios de matrículas. Nas unidades de ensino, foram realizadas duas visitas para pesquisa, as quais foram complementadas por meio de troca de e-mails com vistas a esclarecer dúvidas ou solicitar novas informações.
} 
Diferentemente do IFFar, na instituição SNA não havia encargos criados exclusivamente para a gestão e desenvolvimento do Pronatec Bolsa Formação. As atividades do Programa foram incorporadas no âmbito das coordenações/funções já existentes. No âmbito estadual, as atividades do Pronatec foram desenvolvidas pela equipe do Núcleo de Educação Profissional (NEP) do Diretório Regional da instituição, e nas escolas os cursos ofertados por meio do Programa seguiam a mesma dinâmica dos demais. Assim, para compreender o desenvolvimento do Pronatec Bolsa Formação no âmbito dessa instituição e das escolas onde se realizou o aprofundamento do estudo - uma situada na Capital, Porto Alegre (Escola A) e outra situada na cidade de Uruguaiana, região da fronteira oeste do Estado (Escola B) ${ }^{22}$-, além da coleta de documentos, projetos pedagógicos de curso e indicadores de matrículas e perfil dos estudantes, realizou-se entrevista e questionários com os seguintes sujeitos ${ }^{23}$ :

\begin{tabular}{lllll} 
Tabela 4- Entrevistas realizadas e questionários aplicados no SNA no âmbito da pesquisa de campo \\
\hline \hline Unidade & Função & Quantidade & Participação \\
\hline Diretório Regional & Subgerente do Núcleo de & 01 & Entrevista \\
& Educação Profissional (Gestor & & \\
\hline NEP) & & & \\
\hline Unidade de análise 1 - & Diretor & 01 & Entrevista \\
Escola A & Pedagoga & 01 & Entrevista \\
& Professor & 02 & Entrevista \\
& Professor & 20 & Questionário \\
& Estudante & 31 & Questionário \\
\hline Unidade de Análise 2 - & Diretora & 01 & Entrevista \\
Escola B & Pedagoga & 01 & Entrevista \\
& Secretária Acadêmica & 01 & Entrevista \\
& Professor & 04 & Entrevista \\
& Professor & 06 & Questionário \\
& Estudante & 03 & Questionário \\
\hline
\end{tabular}

Fonte: elaborada pela autora com base nas entrevistas realizadas e questionários aplicados.

O acesso aos indicadores de conclusão dos cursos não foi possível via instituição. Apesar de ter se comprometido a enviar os relatórios finais do desenvolvimento dos cursos, a instituição não deu retorno. Por meio de relatório de matrículas do Pronatec Bolsa Formação em todo o país, obtido via e-SIC, foi possível obter grande parte dos indicadores de conclusão dos cursos

\footnotetext{
${ }^{22}$ Não serão apresentados aqui os dados da oferta nas unidades de ensino do SNA, como fizemos em relação ao IFFar, tendo em vista que a divulgação dessas informações comprometeria o sigilo quanto à identidade da instituição, conforme o acordado. Contudo, os critérios de seleção das unidades de ensino foram os mesmos adotados pela pesquisa no IFFar, analisados em um universo de 45 escolas que ofertaram matrículas pelo Programa.

${ }^{23}$ Foram realizadas 5 visitas para o desenvolvimento da pesquisa nessa instituição: uma ao Diretório Regional, em fevereiro de 2016; duas na Escola A, em outubro de 2016 e junho de 2017; e duas na Escola B, uma em novembro de 2016 e outra em julho de 2017. Não foi possível realizar entrevista com a Diretora da Escola B na ocasião da primeira vista, e quando retornei a Diretora à época do Pronatec havia sido demitida do cargo, não fazendo mais parte do quadro da instituição. Assim, a entrevista foi realizada com a nova Diretora, a qual, embora não tivesse atuado nessa escola no período do desenvolvimento do Pronatec, conhecia muito bem o Programa, em razão de que já atuava em outra escola da mesma instituição.
} 
ofertados pelas Escolas A e B. Alguns cursos, no entanto, constavam com o registro de matrículas "em curso", apesar de já terem sido concluídos, o que nos impeliu a desconsiderar essas matrículas no cálculo dos percentuais de conclusão.

Na Figura 1, pode-se visualizar a localização geográfica das instituições e unidades de ensino onde foi realizada parte da pesquisa.

Figura 1 - Mapa das Instituições e unidades de pesquisa situadas no RS

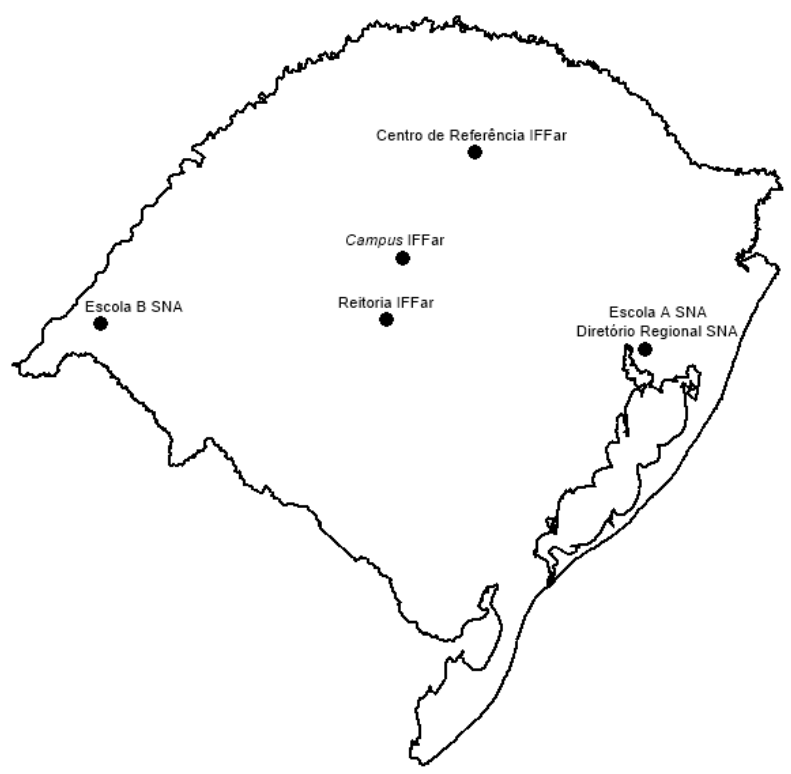

Fonte: elaborada pela autora.

Tendo em vista que a construção do projeto de Lei do Pronatec não se deu a partir de espaços abertos à participação pública, a compreensão do contexto de sua criação implica, necessariamente, a recomposição dos elementos do debate no espaço institucional, junto aos sujeitos participantes desse processo no MEC. Em razão das críticas da academia direcionadas a essa política, a pesquisa não teve boa recepção junto a alguns gestores da SETEC contatados. Um deles concedeu entrevista e depois de enviada a transcrição da gravação não assinou o Termo de Consentimento que autorizaria o seu uso na pesquisa; outro solicitou que as questões fossem respondidas por escrito, no entanto, o documento encaminhado se restringia a trechos da Lei e de relatórios de gestão, que já eram de acesso público, não aportando novos elementos para a pesquisa.

Assim, conseguimos realizar entrevista com dois ex-Secretários da SETEC, Eliezer Pacheco, que atuou no processo de elaboração do Pronatec, e Marcelo Feres, que apesar de ter sido Secretário apenas no período de execução do Programa, já fazia parte da equipe dessa Secretaria. Além desses, também realizamos entrevista com a Técnica em Assuntos 
Educacionais, Caetana Juracy Rezende da Silva, então Coordenadora Geral de Políticas de Educação Profissional e Tecnológica, que participou das primeiras formulações do Programa, e com uma Técnica que atua na SETEC, identificada pelo nome fictício de Flor, que acompanhou a execução da política ${ }^{24}$.

Considerando que o Pronatec reuniu no Ministério da Educação as políticas de qualificação profissional antes desenvolvidas pelo Ministério do Trabalho e Emprego, entrevistamos o ex-Diretor de Qualificação Profissional do MTE, Antonio Almerico Biondi Lima (no decorrer do texto usaremos apenas Almerico Lima), para levantar informações sobre a trajetória da qualificação profissional desenvolvida nos governos do PT. Enquanto atual gestor da Educação Profissional na rede pública estadual da Bahia, também acompanhou o processo de construção e desenvolvimento do Pronatec, tendo fornecido importantes elementos para a compreensão do Programa. As entrevistas com esses sujeitos, exceto com Eliezer Pacheco, que ocorreu de forma presencial, foram realizadas por meio de ferramentas de comunicação via internet, que foi a forma escolhida pelos entrevistados.

Tabela 5 - Entrevistas realizadas com gestores nacionais no âmbito da pesquisa de campo

\begin{tabular}{llll}
\hline \hline Unidade & Função & Participação & Identificação \\
\hline SETEC & Ex-Secretário & Entrevista & PACHECO, 2016 \\
SETEC & Ex-Secretário & Entrevista & FERES, 2018 \\
SETEC & Ex-Coordenadora de Políticas de EPT & Entrevista & SILVA, 2017 \\
SETEC & Servidora Técnica & Entrevista & FLOR, 2017 \\
MTE & Ex-Diretor de Qualificação Profissional & Entrevista & LIMA, 2017 \\
\hline \hline
\end{tabular}

Fonte: elaborada pela autora com base nas entrevistas realizadas.

Quanto ao terceiro eixo de análise desta pesquisa - o andamento das políticas de educação profissional que foram inseridas no âmbito do Pronatec - nos valemos especialmente dos indicadores de matrícula e de recursos destinados a essas iniciativas, quais sejam: Expansão da Rede Federal de EPT, Brasil Profissionalizado, Rede e-Tec Brasil e Acordo de Gratuidade. Analisamos também os efeitos do Pronatec no desenvolvimento de Programas como o Proeja e Mulheres Mil que passaram a ser financiados pelo Bolsa Formação, tanto no âmbito do Instituto Federal pesquisado, quanto em âmbito nacional, por meio dos indicadores de matrículas nesse período (2011 a 2016).

Na análise dos dados quantitativos coletados no âmbito dos diferentes eixos da pesquisa, nos utilizamos do software Statistical Package for the Social Sciences (SPSS), versão 24.0, que possibilitou a leitura dos relatórios obtidos, a realização de frequências e o cruzamento das

\footnotetext{
${ }^{24}$ Com exceção de Flor, os demais entrevistados autorizaram o uso de sua identidade na pesquisa, por isso seus nomes verdadeiros estão sendo utilizados.
} 
informações, de forma a identificar o perfil dos cursos, dos estudantes, dos percentuais de conclusão, entre outros.

Ressaltamos a grande dificuldade de acesso aos dados quantitativos no âmbito da pesquisa, uma vez que apenas em março de 2018 foi lançada a Plataforma Nilo Peçanha que permitiu, pela primeira vez, o acesso a dados de matrículas consolidados sobre a Rede Federal de Educação Profissional. O Sistema Nacional de Informações da Educação Profissional e Tecnológica (SISTEC), que registra as matrículas da Rede Federal, tem apresentado muitas inconsistências nas informações, resultado de seu caráter descentralizado de alimentação de dados, da ausência de tratamento das informações, e do fato de não ter sido originalmente projetado para a função que acabou tendo. Talvez por isso não apresente ferramentas de fácil extração de relatórios, uma vez que, para atender os diferentes programas de educação profissional desenvolvidos ao longo dos anos foram criadas diversas abas, o que dificulta a integração dos dados ${ }^{25}$. O censo da educação básica (Educacenso) e do ensino superior (Censup), que representam uma ferramenta consolidada quanto ao registro de informações desses níveis de ensino, quando aplicados no âmbito das instituições de educação profissional apresentam lacunas. O Educacenso, por exemplo, registra apenas os estudantes matriculados no momento da coleta, não dando conta dos cursos que iniciam e/ou que terminam após a data de registro das informações, como são os cursos de formação inicial e continuada. Enquanto o Censup, informa os estudantes do ano anterior, não sendo possível uma simples soma das duas bases de dados para se obter as informações sobre a educação profissional e tecnológica. A Plataforma Nilo Peçanha vem suprir, nesse sentido, as necessidades e particularidades da educação profissional ofertada na Rede Federal, com potencialidade de fornecer dados consolidados que permitirão maior confiabilidade às futuras pesquisas que se utilizem desses indicadores.

No entanto, informações referentes ao Acordo de Gratuidade não podem ser obtidas com essa plataforma, uma vez que apenas as instituições da Rede Federal são abarcadas. Os dados sobre essa iniciativa, disponíveis ao acesso público ${ }^{26}$, restringem-se ao número de matrículas e tipo de curso (técnico ou FIC) e, quando solicitamos à SETEC, via e-SIC, as

\footnotetext{
${ }^{25}$ Em sua tese de Doutorado em Educação, Gustavo Henrique Moraes, um dos idealizadores da Plataforma Nilo Peçanha, relata as inconsistências do SISTEC em relação à produção de indicadores sobre a oferta de EPT e as dificuldades de gestão financeira de políticas educacionais decorrentes disso. $\mathrm{O}$ leitor interessado em conhecer melhor essa situação, poderá consultar esse estudo: MORAES, Gustavo Henrique. Identidade de Escola Técnica vs. Vontade de Universidade: A Formação da Identidade dos Institutos Federais. Tese (Doutorado em Educação) Programa de Pós-Graduação em Educação da Faculdade de Educação da Universidade de Brasília (UnB). 388 f. Brasília, DF: 2016.

${ }^{26}$ Essas informações podem ser consultadas por meio do site http://painel.mec.gov.br/, selecionando o indicador 2577 (PRONATEC: Total de matrículas por iniciativa e tipo de curso).
} 
informações sobre os cursos ofertados e a situação da matrícula (indicador que permite verificar o percentual de concluintes), recebemos como resposta a impossibilidade do envio de tais informações, uma vez que não se encontram automatizadas nos sistemas informatizados do Ministério da Educação.

Em relação aos indicadores orçamentários destinado às iniciativas "Expansão da Rede Federal", "Brasil Profissionalizado" e "Rede e-Tec", que foram incluídas no âmbito do Pronatec, também nos deparamos com a falta de consistência das informações. As diversas consultas realizadas por meio do e-SIC, em diferentes anos, apresentaram informações distintas para o mesmo período e iniciativa. Assim, tivemos de realizar o cruzamento dessas informações com dados dos relatórios do TCU e/ou CGU, cujo objeto de análise era o Pronatec, de forma a chegar a resultados mais fidedignos. Contudo, não conseguimos suprir todas as inconsistências, as quais serão apontadas ao longo do texto.

Outra dificuldade com a qual nos deparamos ao longo da pesquisa de campo, que trouxe implicações para o alcance da compreensão do processo de pactuação de cursos por meio do Pronatec Bolsa Formação, e envolve instituições/órgãos demandantes e ofertantes, foi a mudança no governo do Estado do RS. Em âmbito estadual, haviam sido criados os Comitês Gestores do Pronatec (de cursos técnicos, de cursos FICs e do Pronatec Campo), os quais eram coordenados por Secretarias e órgãos do governo com participação das instituições ofertantes. No entanto, após as eleições de 2014, essas instâncias passaram por mudança de pessoal tendo diminuído o ritmo de atuação dos próprios Comitês. Desde que soubemos da existência desses espaços, fizemos contato com a pessoa responsável, a qual alegou dificuldade de agenda para concessão de entrevista, em virtude da sobrecarga de trabalho de seu setor. Continuamos as tratativas por mais de um ano, sem que tivéssemos obtido sucesso. Assim, a análise do processo de pactuação dos cursos ofertados pelas instituições pesquisadas se deu, de certa forma, apenas a partir do ponto de vista dessas instituições, restando como uma questão a ser explorada em pesquisas futuras.

A partir desse percurso, a sistematização dos resultados foi organizada em quatro capítulos, além desta Introdução e das Considerações Finais. No Capítulo I, apresentamos uma análise socio-histórica da trajetória da educação profissional no país, com vistas a apreender o contexto em que se insere o Pronatec. Partimos das críticas que situam o Pronatec como um "desvio de rota" nas políticas de educação profissional nos governos do Partido dos Trabalhadores com vistas a compreender qual(is) rota(s) a educação profissional percorreu historicamente, apreendendo-as como expressão das disputas em torno do projeto de formação da classe trabalhadora em determinada formação econômico-social. Identificamos as políticas desenvolvidas nos governos Lula como uma tentativa de construir uma "nova rota" para a 
educação profissional, que expressam a disputa de hegemonia com o projeto educacional da burguesia. Construídas sob a base de uma correlação de forças que conciliava as diferentes frações de classe no âmbito do governo, situamos os avanços representados por essas políticas e os limites que se apresentavam diante da ausência de reformas estruturais.

Com vistas na apreensão dos fatores que teriam levado à mudança de perspectiva na educação profissional, a partir do Pronatec, no segundo Capítulo, analisamos o processo de construção dessa política, com base no contexto político e econômico em que emerge e do discurso de gestores e técnicos da SETEC e do MTE. Com base na análise da correção de forças produzidas no âmbito do governo Dilma, a partir das mudanças no projeto de desenvolvimento econômico, situamos a disputa de projetos e dos fundos públicos destinados à formação profissional. Tendo como foco central da análise a iniciativa Bolsa Formação, analisamos a concepção pedagógica que a orienta, a partir da ação Pronatec Empreendedor, as formas de pactuação e oferta de cursos pelas diferentes instituições credenciadas, os indicadores de matrículas e de recursos, evidenciando o caráter das relações público-privadas desenvolvidas no âmbito do Programa. E por fim, com base nos indicadores de matrículas e de orçamento, analisamos o impacto do Pronatec Bolsa Formação nas demais ações de educação profissional já em andamento.

No terceiro e quarto Capítulos, apresentamos os resultados da investigação realizada no âmbito do Instituto Federal Farroupilha e da instituição do SNA, de forma a identificar as especificidades do desenvolvimento do Pronatec no âmbito de instituições de diferentes naturezas - pública e privada. Analisamos, por meio dos cursos ofertados, dos conteúdos da formação, do público atendido e dos percentuais de conclusão observados nos cursos, as disputas em relação ao projeto de formação dos trabalhadores jovens e adultos, as diferenças no uso dos recursos destinados ao Programa e as condições administrativo-pedagógicas do seu desenvolvimento que concorreram para a diferença na oferta quantitativa do programa no âmbito dessas instituições. No âmbito do Instituto Federal, analisamos também os impactos no desenvolvimento de Programas que foram inseridos no âmbito da iniciativa Bolsa Formação e das tensões geradas no âmbito institucional.

Nas considerações finais fazemos um retrospecto da pesquisa, sistematizando os principais resultados de acordo com o objetivo que orientou a investigação. Entrelaçamos a análise apresentada ao longo do texto de forma a sistematizar a tese que resultou dessa pesquisa e as questões que demandam maior aprofundamento na análise, apontando-se para a continuidade da investigação. 


\title{
CAPítulo I
}

\section{GÊNESE do PronATEC: "O DESVIO DE ROTA"}

\author{
"Enquanto não enxergarmos a dimensão histórica de um ser, \\ de um objeto, de um fenômeno, de um acontecimento, \\ não podemos aprofundar, de fato, a compreensão que temos deles. \\ É o movimento histórico que passa por todas as coisas e permanentemente \\ as modifica que as torna concretas" (Konder, 2001, p. 187).
}

As críticas oriundas de algumas entidades da sociedade civil na ocasião do lançamento do Pronatec, assim como em algumas entrevistas com gestores da educação profissional, situam o Programa como um "desvio de rota" no projeto de educação profissional em curso nos dois primeiros governos do PT (2003 a 2010). Nesse sentido, compreender a gênese dessa nova "rota" tomada pelo Pronatec implica em conhecer a "rota" deixada para trás, como também esclarecer as questões: a rota tomada pelo Pronatec é de fato uma nova rota? Que rota ou rotas a educação profissional percorreu historicamente? O que ela(s) pode(m) nos informar sobre o contexto atual?

Concorda-se com Frigotto (2006) que "as concepções, os projetos e as políticas de educação escolar e educação profissional em disputa hoje, no Brasil, ganham sentido como constituídos e constituintes da especificidade de projeto de sociedade em disputa pelo capital e pela classe trabalhadora” (p. 242). Nessa direção, tal como nos ensina Konder na epígrafe deste capítulo, para compreender as políticas de educação profissional em voga é necessário situá-las social e historicamente, apreendendo-as como expressão dos diferentes interesses políticos, econômicos e sociais em disputa no âmbito do Estado.

O Pronatec, como política de qualificação da força de trabalho, expressa um conjunto de concepções e práticas em torno da relação trabalho e educação que são possíveis de compreender apenas se forem consideradas suas dimensões históricas. Enquanto prática inserida na relação social entre capital e trabalho, ou seja, entre classes sociais, a formação profissional expressa as contradições e lutas que constituem a produção material das sociedades.

Neste capítulo, se propõe realizar uma leitura sócio-histórica da trajetória da formação profissional no Brasil, dos projetos formativos em disputa, a partir de sua contextualização no(s) projeto(s) de desenvolvimento econômico e social em curso no país, em especial a atuação do Estado, com vistas a apreender elementos históricos que auxiliem na compreensão da gênese do Pronatec. 


\subsection{A "rota" da educação profissional no Brasil: bases econômico-sociais da "formação" da classe trabalhadora}

É importante destacar, como nos lembra Luiz Pereira (1965), que quando se fala em “qualificação do trabalhador” não se trata apenas da dimensão técnica, mas de um processo mais amplo que é a "constituição do trabalhador num tipo de formação econômico-social" (p. 57). No Brasil, diferentemente dos países centrais em que a passagem do feudalismo para o capitalismo foi marcada por revoluções burguesas, o capitalismo se desenvolveu de forma muito particular.

Na análise de Marx (2012), a relação trabalho-capital pressupõe a existência de duas classes fundamentais: a dos trabalhadores e a da burguesia. No sistema de produção e circulação de mercadorias, a classe burguesa, de um lado, detém o capital e os meios de produção, e a classe trabalhadora, de outro, dispende da sua força de trabalho na transformação da matériaprima em mercadoria. Porém, a classe trabalhadora, enquanto grupo social de trabalhadores livres, é formada, no Brasil, apenas no final do século XIX com a abolição da escravatura e o avanço do capitalismo industrial.

Nos países capitalistas centrais, a classe trabalhadora emergiu a partir da liberação dos servos e dos artesãos expropriados de suas formas de produção. Esses sujeitos, ao serem separados - no caso dos artesãos, não sem violência - de seus espaços produtivos, tornaram-se mão de obra livre para a produção capitalista. No Brasil, no entanto, os colonizadores, após terem frustrado a expectativa de utilizarem os indígenas como mão de obra, valeram-se do tráfico de escravos. A concentração da produção de mercadorias no meio rural e o uso de mão de obra escrava no processo de trabalho constitui-se numa particularidade histórica do modo de produção capitalista no Brasil colonial, conforme aponta Mazzeo (2015).

Conforme lembra Martins, essa particularidade do processo de produção capitalista colonial "gerou uma estrutura social vigorosa, produziu instituições duradouras e engendrou mentalidades que persistem de algum modo até nossos dias" (MARTINS, 2006, p. 20). Uma dessas consequências é o desprezo pelo trabalho manual, considerado "coisa de escravo", e a própria relação de poder estabelecida entre os diferentes grupos econômico-sociais que se expressa historicamente na condução do Estado.

A sociedade urbano-industrial brasileira formou-se, portanto, sob as bases de uma sociedade agrário-exportadora que se caracterizava pelo latifúndio e trabalho escravo. Dessa forma, “o empresário industrial local não enfrentaria imediatamente a necessidade de destruir 
o trabalho qualificado existente, e sim o problema de formar e qualificar a força de trabalho para o desempenho das atividades fabris", conforme aponta Moraes (2013a, p. 892).

A emergência desse novo personagem histórico - o trabalhador assalariado - impeliu a classe dominante a articular novas formas de controle social, visto que o poder político e econômico exercido pelos senhores rurais sobre a sua força de trabalho não poderia ser personificado nos donos das fábricas, pois o assalariado, diferente do escravo, era um sujeito "livre". O Estado passa então, progressivamente, a ampliar suas funções, legitimando-se como agente mediador dos conflitos sociais inerentes às relações entre capital e trabalho e, enquanto aparelho dirigido pela classe dominante, atuando na criação e manutenção das condições favoráveis à reprodução do capital, num movimento histórico que é próprio do capitalismo.

Nesse contexto, as instituições educacionais passam a ser vistas como importantes espaços de socialização da classe trabalhadora às novas exigências do processo produtivo. É com este objetivo, conforme aponta o estudo de Moraes (2003), que a burguesia paulista passa a investir na criação de instituições educacionais particulares ainda no final do Império. Essa estratégia foi também utilizada pela burguesia gaúcha, tendo-se registros da criação de uma escola no espaço de uma fábrica de tecidos na cidade de Rio Grande no ano de 1882 (PESAVENTO, 1988).

Essas instituições, embora não se constituíssem naquele momento em espaços privilegiados de formação e qualificação para o trabalho, cumpriam um papel de disciplinar e socializar a força de trabalho, atingindo outras dimensões da vida operária para além do domínio da fábrica (MORAES, 2003). Além disso, construíam no imaginário social a representação do “'bom patrão', aquele que, como pai, decide, orienta e ampara seus subordinados, regulando as relações trabalho-capital" (PESAVENTO, 1988, p. 57). Com essas iniciativas, a burguesia foi construindo e difundido seu projeto pedagógico para a classe trabalhadora e atuando na construção de sua hegemonia enquanto classe ao difundir o conjunto de valores e normas necessários à reprodução do capital e da sociedade de classes.

É interessante observar que o projeto educacional para a classe trabalhadora era bem diferente daquele reservado aos filhos da burguesia. Com vistas a manter seus privilégios e prestígio de classe, a escolarização destinada aos filhos da classe trabalhadora restringia-se às primeiras letras, à disciplina e a cursos de preparação para o trabalho em determinadas áreas da indústria, visando torná-los úteis à nação, enquanto os filhos da elite tinham acesso ao conhecimento intelectual e a formações bacharelescas que os conduziam a ocupar funções prestigiadas na sociedade, como nas áreas de Direito, Engenharia e Medicina. 
Com o avanço do desenvolvimento industrial, crescia entre frações da classe dominante a importância da atuação do Estado frente à escassez de mão de obra, o que constituiria um entrave ao desenvolvimento econômico. Em São Paulo, a burguesia industrial, ligada ao grande capital cafeeiro - liberal "cientificista" - atuava no sentido de formar força de trabalho necessária à modernização industrial, urbanização e também à modernização do trabalho no campo. É nesse contexto que a burguesia paulista opta em primeiro lugar pela grande imigração subsidiada e a incorporação do imigrante no mercado livre de força de trabalho, e, depois, com os problemas recorrentes com os imigrantes, pela introdução da mão de obra dos nacionais dos brancos pobres e dos libertos - para os quais a escola profissional atuava como importante “instrumento de legitimação das novas relações sociais instauradas pelo movimento do capital”, conforme aponta o estudo de Moraes (2003, p. 328-329).

Embora algumas dessas instituições particulares de formação profissional contasse com o subsídio de governos provinciais, como no caso do Liceu de Artes e Ofícios da Província de São Paulo (MORAES, 2003), é somente na primeira década do século XX que se vê desabrochar uma iniciativa da União frente à educação profissional. No governo de Nilo Peçanha, dirigente identificado com o positivismo de Estado (CARVALHO, 2017), são criadas, em plano nacional, as Escolas de Aprendizes Artífices, por meio do Decreto 7.566 de 23 de setembro em 1909. O referido Decreto justificava a criação destas escolas em prol dos “desfavorecidos da fortuna”, visando torná-los úteis à Nação, mediante o preparo técnico e intelectual (AZEVEDO; SHIROMA; COAN, 2012). Foram instituídas 19 escolas de Aprendizes Artífices situadas nas capitais dos Estados, exceto no Rio Grande do Sul e no Distrito Federal ${ }^{27}$, dando origem ao sistema federal de educação profissional, que, a partir de suas transformações ao longo dos anos, estão na base dos atuais Instituto Federais de Educação, Ciência e Tecnologia ${ }^{28}$.

\footnotetext{
27 O Decreto informava que no Estado em que já existia um estabelecimento de ensino, de mesma natureza, custeado ou subvencionado pelo poder público, a união poderia contribuir com esse estabelecimento através de cota de instalação e custeio. Em Porto Alegre já funcionava o Instituto Técnico Profissional ligado à Escola de Engenharia de Porto Alegre, mais tarde denominado Instituto Parobé, que ofertava, gratuitamente, aos meninos pobres e filhos de operários uma formação técnica e profissional com vistas na formação de operários e contramestres. Mais tarde, com o Decreto n. 9.070/1911, definiu-se que o Instituto Parobé ficaria mantido como escola de Aprendizes Artífices do Rio Grande do Sul, enquanto não fosse estabelecida a escola da União, a qual nunca veio a existir (CUNHA, 2005).

${ }^{28}$ A rede de escolas de Aprendizes Artífices passou por várias mudanças na sua identidade institucional, ao longo dos anos: em 1937 essas escolas foram transformadas em Liceus Profissionais, ampliando a oferta do ensino profissional a todos os ramos e graus, por meio da Lei 378; em 1942 o Decreto 4.127 transforma essas instituições em Escolas Técnicas e Industriais, para oferta de ensino técnico em nível secundário; em 1959, as escolas são transformadas em autarquias federais, com autonomia didática e de gestão, e são chamadas Escolas Técnicas Federais; em 1978, através da Lei 6.545, três destas escolas (Paraná, Minas Gerais e Rio de Janeiro) são transformadas em Centros Federais de Educação Tecnológica (CEFET); em 1994, através da Lei 8.948, progressivamente, as Escolas Técnicas Federais e as Escolas Agrícolas - criadas em 1967 - são transformadas em
} 
Situada nesse contexto de passagem da mão de obra escrava para o trabalho assalariado, as Escolas de Aprendizes Artífices visavam, sobretudo, "a formação de força de trabalho qualificada para fazer frente às exigências do processo de industrialização" (CUNHA, 2005, p. 66), a partir da socialização de seus estudantes nos "hábitos de trabalho profícuo" por meio de oficinas para aprendizagem de ofícios, as quais deveriam ser definidas de acordo com as especialidades das indústrias locais. Nos termos do Decreto, os motivos para criação destas instituições consideravam:

\begin{abstract}
Que o aumento constante da população das cidades exige que se facilite às classes proletárias os meios de vencer as dificuldades sempre crescentes da luta pela existência; que para isso se torna necessário, não só habilitar os filhos dos desfavorecidos da fortuna com o indispensável preparo técnico e intelectual, como fazê-los adquirir hábitos de trabalho profícuo, que os afastará da ociosidade ignorante, escola do vício e do crime; que é um dos primeiros deveres do Governo da República formar cidadãos uteis à Nação (BRASIL, 1909).
\end{abstract}

Apesar dessa orientação, em virtude de o processo de industrialização ter se desenvolvido de forma concentrada, especialmente nas regiões centro-sul, ou porque no âmbito de alguns Estados ${ }^{29}$ as atividades manufatureiras não se localizavam na Capital - onde foram instaladas as escolas - as oficinas desenvolvidas voltavam-se às atividades de interesse local e poucas aos ofícios manufatureiros ou industriais, mostrando-se "inadequadas aos propósitos de incentivar a industrialização pela formação profissional sistemática da força de trabalho" (CUNHA, 2005, p. 71). Exceção a esse fato era a escola situada em São Paulo, que a exemplo de outros estabelecimentos de ensino profissional de iniciativa da burguesia industrial local, cumpria o papel de formação para os ofícios fabris, ao lado da formação voltada ao artesanato local, o que indica a diversidade de tempos históricos no espaço social brasileiro.

A despeito dos problemas enfrentados por essas escolas em relação ao atendimento de seus objetivos, não se pode negar que essa iniciativa expressa uma ação do Estado com vistas na formação do trabalhador livre, indispensável para o avanço do modo de produção industrial naquele período, atendendo assim aos interesses da burguesia industrial. Além disso, tão importante quanto à formação para o trabalho no interior das fábricas é a formação de hábitos e valores que são indispensáveis para a reprodução da força de trabalho na sociedade de classes.

\footnotetext{
CEFETs; e, por fim, em 2008, através da Lei 11.892, são criados 38 Institutos Federais de Educação, Ciência e Tecnologia a partir da transformação de Escolas Técnicas Federais, Escolas Agrícolas e CEFTEs. Algumas escolas técnicas ligadas a Universidades e dois CEFETs (o do Rio de Janeiro e o de Minas Gerais) optaram por permanecer na sua atual institucionalidade e um dos CEFETs, o do Paraná, transformou-se em Universidade Federal Tecnológica, em 2005 (MEC, 2009).

${ }^{29}$ Como nos casos de Minas Gerais e Santa Catarina, por exemplo (CUNHA, 2005).
} 
"É por isso que a luta contra o álcool, o mais perigoso agente de destruição das forças de trabalho, torna-se função do Estado", conforme reitera Gramsci (2007, p. 267).

É interessante observar que essas escolas estavam subordinadas ao Ministério da Agricultura, Indústria e Comércio enquanto a educação geral estava sob a jurisdição do Ministério da Justiça e Negócios Interiores. Essa dualidade revela a mentalidade da burguesia em relação ao projeto educacional destinado à classe trabalhadora. Conforme sintetiza Carvalho:

\begin{abstract}
A própria divisão da educação em dois ministérios confirmava a sua dualidade no regime republicano: de um lado, uma educação teórica e bacharelesca e desvinculada da realidade nacional destinada às famílias das classes mais elevadas; de outro, uma instrução mais elementar e prática na tentativa de inserir no mundo do trabalho formal uma parcela dos jovens das classes populares analfabetas e que viviam de trabalhos mais simples (CARVALHO, 2017, p. 152).
\end{abstract}

Com a criação do Ministério da Educação, em 1930, pela primeira vez a educação é organizada a partir de uma orientação nacional. O primeiro Ministro, Francisco Campos, emitiu vários Decretos que ficaram conhecidos como "Reforma Francisco Campos", entre eles estava a criação do Conselho Nacional de Educação e a organização do ensino secundário. Paralelamente ao ensino secundário, caracterizado pelo currículo enciclopédico e seriado, a Reforma instituiu, em nível profissionalizante, o ensino comercial, que conduzia à formação de contador de nível médio. Essa formação restringia o acesso ao ensino superior apenas à área de finanças, enquanto que o ensino secundário acadêmico possibilitava o ingresso em qualquer área. De acordo com Romanelli (2006, p. 139), essa talvez seja "uma das fortes razões que orientaram a demanda social da educação em direção ao ensino acadêmico, desprezando o ensino profissional".

A partir da Constituição de 1937, os ensinos industrial, agrícola e comercial são reunidos sob a expressão “ensino profissional”, o qual, juntamente com o "ensino pré-vocacional", era destinado às "classes menos favorecidas". Essa orientação institui em Lei a discriminação social, oriunda da divisão entre trabalho manual e intelectual, e, portanto, da divisão da sociedade de classes, conforme analisa Romanelli (2006).

Com o avanço do processo de industrialização nas primeiras décadas do século XX e a complexificação do processo de trabalho a partir da introdução das máquinas, cresce vertiginosamente a necessidade de mão de obra qualificada. Para os industriais, segundo Weinstein (2000), o objetivo "era garantir um número suficiente de operários especializados suficiente não apenas para atender à crescente demanda de trabalhadores em determinados 
setores, mas também para forçar para baixo os níveis salariais e limitar o poder de barganha desses mesmos operários" (WEINSTEIN, 2000, p. 104-105).

Nesse contexto, o governo do Estado Novo, com vistas a se aproximar das frações industriais da burguesia, descontentes com as leis trabalhistas implantadas pelo governo, responde com uma proposta de formação profissional para a indústria por meio do Decreto-Lei n. 1.238 de 02 de maio de 1939, que determinava que as empresas com mais de 500 empregados oferecessem "cursos de aperfeiçoamento profissional para menores e adultos". Embora descontentes com a proposta apresentada pelo governo, os industriais souberam aproveitar essa oportunidade para disseminar seu projeto pedagógico, com vistas a manter o controle sobre a formação profissional de seus operários. Conforme previa o Decreto, formou-se uma comissão designada pelos Ministérios do Trabalho e da Educação, a qual, composta inicialmente por técnicos desses ministérios, apresentou uma proposta de formação profissional aos industriais e seus órgãos representativos, como a FIESP (Federação da Indústria do Estado de São Paulo) e a CNI (Confederação Nacional da Indústria).

É nesse momento que a FIESP, por meio de seu Presidente, Roberto Simonsen, valendose das experiências formativas realizadas pelos industriais no estado de São Paulo, com base na organização racional do trabalho, dos estudos produzidos pelo IDORT (Instituto de Organização Racional do Trabalho) ${ }^{30}$ e do prestígio e influência de seus intelectuais, como Roberto Mange ${ }^{31}$, apresenta uma nova proposta, mais adequada aos seus interesses. Essa proposta deu origem à primeira organização que constitui o atual "Sistema $\mathrm{S}^{32}$ ": o SENAI (Serviço Nacional de Aprendizagem dos Industriários), por meio do Decreto-Lei $\mathrm{n}^{\circ} 4.048$, de

\footnotetext{
${ }^{30}$ O IDORT, criado em 1931 pelos empresários paulistas, tinha como objetivo disseminar a organização racional do trabalho, por meio de estudos, publicações e treinamentos de caráter científico, educativo e cultural. É no seio do IDORT, que intelectuais como Roberto Mange formulam projetos de educação profissional de acordo com a organização racional do trabalho, tendo se constituído, nesse sentido, como uma instituição educacional, conforme analisa BATISTA (2015).

${ }^{31}$ Engenheiro suíço que veio para o Brasil para lecionar mecânica na Escola Politécnia, em São Paulo. Era um defensor dos métodos científicos de treinamento para o trabalho, que deveria conjugar o conhecimento técnico aliado a alguma forma de instrução com vistas a moldar o caráter moral do trabalhador, de forma que ele se identificasse com o progresso industrial. O primeiro "laboratório" para as ideias de Mange foi o Liceu de Artes e Ofícios de São Paulo, onde colocou em prática o sistema de aprendizagem das "séries metódicas", que consistia na aprendizagem das tarefas mais simples às mais complexas juntamente com os princípios teóricos subjacentes a cada atividade, e onde também instituiu o Gabinete de Psicoténica, o qual, baseado nas inovações da psicologia aplicada, realizavam testes psicotécnicos a fim de encaminhar os estudantes para os cursos mais adequados ao seu perfil (WEINSTEIN, 2000).

32 É denominado como "Sistema S" o conjunto de organizações das entidades corporativas voltadas para o treinamento profissional, assistência social, consultoria, pesquisa e assistência técnica, que além de terem em comum a primeira letra do nome "S", têm raízes e características organizacionais similares. Compõem o sistema $\mathrm{S}$ as seguintes instituições: Serviço Nacional de Aprendizagem Industrial (Senai); Serviço Social do Comércio (Sesc); Serviço Social da Indústria (Sesi); Serviço Nacional de Aprendizagem do Comércio (Senac); Serviço Nacional de Aprendizagem Rural (Senar); Serviço Nacional de Aprendizagem do Cooperativismo (Sescoop); e Serviço Social de Transporte (Sest).
} 
22 de janeiro de1942. Com esse Decreto, o Estado institucionalizava o projeto educacional da burguesia industrial, que já vinha sendo desenvolvido no Estado de São Paulo (WEINSTEIN, 2000).

É interessante destacar, conforme análise de Weinstein, que no debate de propostas que culminou na criação do SENAI a "comissão dos patrões" defendia, com base no discurso da competência técnica, que a questão da formação profissional era "um assunto ligado à demanda da indústria e não a objetivos educacionais ou a direito dos trabalhadores" (WEINSTEIN, 2000, p. 119). Era nítido o interesse dos dirigentes da burguesia industrial paulista na liderança da formação profissional, porém, dependiam da ajuda do Estado para "disciplinar os membros da sua própria classe" (p.71), visto que seria difícil obter a contribuição voluntária dos industriais para o desenvolvimento desse projeto. Com a criação do SENAI, obteve-se a equação perfeita para esses objetivos: por força de um Decreto Federal os recursos viriam de contribuições mensais compulsórias das indústrias, de acordo com o número de empregados, e ao mesmo tempo conservava-se a autonomia da burguesia na condução da formação profissional, visto que o SENAI seria organizado e dirigido pela CNI (WEINSTEIN, 2000).

A formação profissional era vista como elemento chave para a implantação do projeto de modernização da indústria com base no modelo fordista e taylorista de organização racional do trabalho, que objetivava minimizar os conflitos de classe e contornar as perdas na produtividade em decorrência das novas leis trabalhistas, como a jornada de 8 horas diárias. Com vistas a minimizar os conflitos na relação entre trabalho e capital, a utilização de métodos racionais na capacitação e aprendizagem industrial conduziria à "formação de uma força de trabalho mais disciplinada e mais qualificada" (WEINSTEIN, 2000, p. 46). Ao mesmo tempo, os intelectuais da burguesia industrial viam nos métodos científicos um meio para "reorganizar não apenas a indústria, mas toda a sociedade brasileira" (p. 46).

A criação do SENAI constituiu uma das ações da reforma da educação conhecida como "Reforma Capanema" "33, que instituiu as Leis Orgânicas do Ensino, as quais adequavam o sistema educacional para o atendimento das demandas do capitalismo industrial. A partir dessa Reforma, inspirada na organização da educação profissional italiana no período fascista, a qual

\footnotetext{
${ }^{33}$ Apesar de ter sido inserido no âmbito da Reforma Capanema, vale destacar que o Ministro da Educação, Gustavo Capanema, era contrário ao projeto apresentado pelos industriais e defendia a supervisão direta do governo e que o "programa de formação deveria ser supervisionado pela Comissão Nacional de Educação Profissional, que era composta de educadores. e não de industriais" (WEINSTEIN, 2000, p. 118). No entanto, apoiados pelo Ministro do Trabalho e com a concordância de Vargas, o projeto da "comissão de patrões" foi aprovado em sua integralidade. A única crítica de Capanema incorporada foi em relação ao nome, que trazia uma ênfase maior no "aperfeiçoamento" que na educação, na visão do Ministro. Assim, a nomenclatura original, "Serviço Nacional de Seleção, Aperfeiçoamento e Formação de Industriários (SENAFI)", foi alterada para "Serviço Nacional de Educação Profissional dos Industriários (SENAI)” (WEINSTEIN, 2000).
} 
Gramsci criticava (MORAES, 2015), o ensino médio - ao contrário da proposta de Escola Pública Unitária, defendida por Anísio Teixeira, e presente no Manifesto dos Educadores ao Povo e ao Governo (MORAES, 2013a) - foi dividido em dois ciclos e cinco ramos de formação: um propedêutico, o Curso Colegial Secundário, e quatro profissionais, o Curso Normal, o Curso Técnico Industrial, o Curso Técnico Comercial e o Curso Técnico Agrícola. Essa organização legitimava a separação entre trabalho manual e intelectual e reforçava a dualidade educacional: o ensino secundário, propedêutico ao ensino superior, destinado à formação das elites dirigentes, e os ramos profissionais destinados às classes menos favorecidas, sem canais de comunicação entre si, constituindo-se em estruturas educacionais paralelas (MANFREDI, 2002; MORAES, 2013a).

Observa-se, assim, que a formação da classe trabalhadora no período inicial de industrialização no país foi orientada hegemonicamente pelo projeto de formação profissional da burguesia, tanto as iniciativas particulares quanto as próprias iniciativas públicas. Conforme destaca Weinstein, num contexto em que a presença do Estado nas relações industriais era cada vez mais crescente, era bastante incomum encontrar uma sociedade em que a "responsabilidade pela capacitação profissional (...) estivesse sendo delegada a organizações essencialmente privadas" (2000, p. 19), como no caso da criação do SENAI. Esse fato revela a importância do Estado brasileiro na objetivação dos interesses da classe dominante.

O período que sucede o Estado Novo, ao ser reestabelecida as condições formais da democracia, foi marcado pelas lutas em defesa da escola pública, tanto em relação à sua expansão como em relação à sua concepção e métodos de ensino. Como resultado dos embates entre as forças progressistas e conservadoras, a Lei de Diretrizes e Bases da Educação Nacional, aprovada no final de 1961, após 13 anos de tramitação no Congresso Nacional, não conseguiu expressar os ideais progressistas gestados naquele período. Em relação ao ensino médio e ao ensino profissional, a LDB trouxe um avanço ao estabelecer a equivalência entre esses segmentos, permitindo que os egressos pudessem se candidatar a qualquer curso superior, dando um caráter mais universal ao ensino técnico (RAMOS, 2011, p. 232), mantendo, porém, a lógica dual nesse nível de ensino.

Em relação ao projeto dos industriais, o sucesso do SENAI, que cresceria em estrutura física e matrículas nos anos que sucederam sua criação, ganhou cada vez mais espaço. Inspirados no êxito da indústria, a Confederação Nacional do Comércio (CNC), criada em 1945, com o apoio do Ministro do Trabalho, Indústria e Comércio, também constitui instituição destinada ao ensino comercial, com o mesmo estatuto jurídico do SENAI, por meio Decreto- 
Lei $\mathrm{n}^{\circ}$ 8.621, de janeiro de 1946, o chamado Serviço Nacional de Aprendizagem Industrial SENAC.

1.1.1 A educação como formação de "capital humano"

Com o advento dos "anos de ouro" do capitalismo (HOBSBAWM, 1995), o país, que vivia sob o regime da Ditadura civil-militar, iniciado em 1964, e guiado por uma política de desenvolvimento econômico baseado na abertura ao capital externo - "que integrou o país ao bloco histórico hegemônico do capitalismo global" (ALVES, 2014, p. 128) -, investiu na educação como forma de produção de "capital humano", visando atender à demanda de mão de obra, que crescia cada vez mais. Assim como no plano econômico, o campo educacional também passa a ter intervenção de organismos internacionais, a partir dos acordos MEC/USAID (Ministério da Educação e Cultura/United States Agency International for Development), alinhando a política educacional ao atendimento da política econômica. Pressupondo uma relação direta entre sistema educativo e sistema produtivo, essa concepção aponta a educação como a responsável pelo fator de produtividade e desenvolvimento econômico, conforme defendiam Schultz (1973) e Castro (1976).

A concepção de educação como formação de "capital humano" orientou não apenas a educação profissional, mas o conjunto da educação básica. Conforme destaca Frigotto, a visão da educação enquanto estratégia de formação de capital humano, em detrimento da concepção de educação enquanto direito social e subjetivo, reduz o processo educativo, seja ele escolar ou não, "à função de produzir um conjunto de habilidades intelectuais, desenvolvimento de determinadas atitudes, transmissão de um determinado volume de conhecimentos que funcionam como geradores de capacidade de trabalho e, consequentemente, de produção" (FRIGOTTO, 2010, p. 51). Assim, se do ponto de vista macroeconômico a superação do atraso econômico das sociedades passava pelo investimento no "fator humano", do ponto de vista microeconômico, "constituiu-se no fator explicativo das diferenças individuais de produtividade e renda e, consequentemente, de mobilidade social" (FRIGOTTO, 2010, p. 51), justificando pela perspectiva individual as desigualdades sociais.

Desse contexto resultou a Lei 5.692/71, que instituiu a profissionalização obrigatória no ensino secundário. Essa medida implicou na descaracterização e desqualificação do ensino médio ( $2^{\circ} \mathrm{Grau}$ ), uma vez que, como destaca Moraes (2013a, p. 989), “o empobrecimento dos currículos escolares com a retirada e o esvaziamento dos conteúdos de formação geral, imprescindíveis para a compreensão crítica da realidade social, e o fracasso na realização da 
pretendida formação técnica só vieram reforçar a dicotomia entre a educação para a 'elite' e a educação para o trabalhador". Assim, a escola pública de $2^{\circ}$ grau, não se constituiu em escola profissional e ao mesmo tempo deixou de ser também uma escola propedêutica, esvaziando-se de suas "atribuições sociais de socialização do conhecimento" (MORAES, 2013a, p. 989). Nesse sentido, a profissionalização obrigatória no ensino secundário acabou cumprindo apenas o seu objetivo velado: o de "conter a crescente demanda das classes médias pelo ensino superior, uma vez que esta era sua nova e única forma de ascensão social" (FRANZOI et al, 2008, p. 2-3).

De outro lado, as escolas de ensino técnico, estaduais ou federais, "continuaram a funcionar, adquirindo uma qualidade diferenciada, propiciada em parte pelo caráter seletivo de acesso dos alunos por meio do 'vestibulinho' e, em parte, pela relativa autonomia de sua gestão" (MORAES, 2013a, p. 989). Essa realidade configurou uma “dualidade no ensino invertida: a escola pública regular, propedêutica, consiste na modalidade de maior acesso à população pobre, ao passo que a escola técnica pública de nível médio se torna seletiva, destinada a menor número", conforme destaca Moraes (2013a, p. 989).

A par dessa política educacional, o governo do período ditatorial implementou um Programa concebido no governo João Goulart, em 1963, o PIPMOI (Programa Intensivo de Preparação de Mão de Obra Industrial), voltado ao treinamento dos trabalhadores, visando adequá-los "às novas tecnologias e às novas atitudes de trabalho, inerentes às novas relações de produção" (BARRADAS, 1986, p. 39). O programa que nasceu com a proposta de durar 20 meses, foi mantido por 19 anos, tendo o início de suas atividades em 1964 e o término em 1982. Em 1972, foi transformado em Programa Intensivo de Preparação de Mão de Obra (PIPMO), ampliando os cursos para outras áreas produtivas, além da indústria. O financiamento do PIPMO contava com recursos públicos, oriundos de fundos da educação e do trabalho, e tinha como principais responsáveis por sua execução as escolas técnicas do Sistema "S" e as próprias indústrias, que se beneficiavam da dedução de impostos como contrapartida para os cursos ofertados. As escolas técnicas federais também poderiam fazer convênio com o Programa, porém o formato dos cursos continuava sendo de conteúdo reduzido, de natureza prática e operacional, sem estabelecer relação com a elevação da escolaridade, na maioria dos casos (MACHADO; GARCIA, 2013).

O modelo pedagógico fomentado nesse período ficou conhecido como Pedagogia Tecnicista. Tributária da concepção de educação como fator de produtividade, essa teoria pedagógica se baseia nos padrões tayloristas-fordistas inseridos nas relações sociais de produção, incorporando-os ao planejamento, aos métodos e aos conteúdos educacionais, tais 
como: "planejamento e organização racional dos tempos, movimentos e espaços; disciplina rígida; fiel obediência a normas de execução do trabalho; e atendimento aos padrões convencionais de comportamento" (RAMOS, 2010, p. 191). Assim, observa-se que o projeto da burguesia de difusão da organização racional do trabalho e correspondente projeto educacional no seio da sociedade teve grande êxito.

\subsubsection{A formação para a "empregabilidade" a partir do desenvolvimento de "competências"}

Com o processo de redemocratização do país, na década de 1980, o debate sobre a educação profissional enquanto formação integral do ser humano, com base nos princípios da politecnia, ganha força, a partir das lutas de organizações educacionais, sindicais, movimentos populares e partidos políticos de esquerda gestados nesse período, buscando constituir-se enquanto princípio na nova Lei de Diretrizes e Bases. No plano acadêmico, a partir de pesquisas de base teórica marxista, procurava-se demonstrar que as relações entre educação e trabalho, entre instituições escolares e econômicas não são diretas, como proclama a teoria do Capital Humano, mas indiretas e mediatas (FRIGOTTO, 2010). A escola deveria ter como horizonte "proporcionar aos alunos o domínio dos fundamentos das técnicas diversificadas utilizadas na produção, e não o mero adestramento em técnicas produtivas" (RAMOS, 2011, p. 235), no sentido da politecnia ${ }^{34}$.

Estudos realizados no contexto francês também apontavam que as modalidades de formação profissional estreitamente dependentes do mercado de trabalho têm sucumbido às próprias mudanças impostas pela organização do trabalho, enquanto "aquelas que dispõem de maior autonomia têm tido a capacidade de traduzir as novas demandas em sua própria lógica, oferecendo-lhes respostas gerais, integradas em um projeto aberto de futuro" (TANGUY,1998, p. 209). Com vistas nisso, defendia-se que a educação profissional não deve se subordinar ao mercado de trabalho, mas pode e deve ir além do "treinamento" para o desempenho de determinada tarefa, isto é, promover uma formação ampla e consistente do trabalhador, articulando os conhecimentos básicos aos fundamentos científicos e sociais do trabalho.

Embora tenha sido considerada pelos economistas como a década perdida, em função da crise econômica vivida nesse período, no âmbito educacional a década de 1980 foi palco de muitas expectativas e proposições de mudança para a educação (ARELARO, 2000). Em contrapartida, a década de 1990, momento em que se encaminhava a construção e aprovação

\footnotetext{
${ }^{34}$ Tendo como base teórica o marxismo, a "politecnia diz respeito ao domínio dos fundamentos científicos das diferentes técnicas que caracterizam o processo de trabalho produtivo moderno" (SAVIANI, 2003, p. 40).
} 
da nova LDB, não pode ser considerada tão produtiva quanto à década de 1980 , no que se refere à continuidade e consolidação dos projetos educacionais gestados no período anterior.

Em resposta à crise financeira que se estabelecia em nível global, gestava-se no país um projeto de Reforma Estatal a partir de orientações neoliberais, que colocou em xeque os avanços democráticos. Ao lado do projeto de LDB da sociedade civil, novos projetos educacionais entraram em interlocução com o governo federal, gerando tensões e conflitos que resultaram em um processo de "contrarreforma" ao projeto democrático de educação e sociedade que a Constituição Federal de 1988 apontava. Sendo resultado de uma intensa disputa de projetos que durou 8 anos, a LDB aprovada consolidou a perspectiva do governo, claramente identificada com a perspectiva neoliberal (SAVIANI, 2004).

Conforme sintetiza Arelaro,

A década de 1990 inicia-se com dois movimentos aparentemente contraditórios e
fortes: de um lado, o desejo de implementação dos direitos sociais recém-conquistados
e a defesa de um novo projeto político-econômico para o Brasil, presente
especialmente nas propostas dos governos municipais progressistas, eleitos em 1989;
de outro, a assunção de Fernando Collor de Mello, na Presidência da República, com
um discurso demagógico de defensor dos "descamisados" (os pobres) contra os
"marajás" (os ricos) e um projeto de caráter neoliberal, traduzindo o "sentimento
nacional" de urgência de reformas do Estado para colocar o país na era da
modernidade (ARELARO, 2000, p. 96).

Na análise de Brasilio Sallum Jr. (2003), as eleições presidenciais de 1989, com a vitória de Fernando Collor de Mello - "político identificado com o neoliberalismo e pouco simpático aos experimentos participativos da democracia" - demarcaram a separação entre "dois momentos da transição política brasileira, quais sejam, o período em que predominou a democratização política e o que teve como seu impulso básico a liberalização econômica" (p. 42). Apesar de o projeto neoliberal ter sido, em partes, interrompido com a renúncia de Collor, sua retomada e intensificação ocorre pelas eleições de 1994, quando o Partido da Social Democracia Brasileira (PSDB) assume o governo por meio da eleição de Fernando Henrique Cardoso, que fora ministro do governo Itamar Franco, em 1993.

A reforma promovida na educação, na década de 1990, buscou desconstituir o projeto da sociedade civil organizada. Conforme destaca Moraes, as ações promovidas pelo governo Fernando Henrique Cardoso (FHC), moldadas, em geral, pelas orientações do Banco Mundial (BIRD), "propõem adequar o ensino às novas demandas econômicas, reformulam o ensino técnico, criam o sistema de Educação Profissional, e, dessa maneira, aprofundam o dualismo estrutural no ensino médio e reforçam o caráter compensatório e assistencialista atribuído à formação profissional continuada" (2013a, p. 995). 
Nesse período, o país vivia as consequências do fim dos "anos de ouro" do capitalismo. Na análise de Antunes (2005), após um longo período de expansão, o denominado pós-guerra, que se estendeu de 1945 até por volta de 1973, o tripé que sustenta o sistema capitalista Capital, Trabalho e Estado - começa a dar sinais de crise. O que se torna visível com esta crise, segundo Harvey (2008) é a incapacidade do regime de acumulação fordista e do Keynesianismo, enquanto modelo de Estado, em conter as contradições inerentes ao capitalismo. No entanto, a resposta à crise partiu de uma visão fenomênica que resultou em uma mudança no padrão produtivo (regime de acumulação) e na adoção do neoliberalismo como modo de regulação social e política desta nova fase do capitalismo (HARVEY, 2008).

Enquanto estratégia para sair da crise, o governo FHC adotou o receituário neoliberal, que tem como diagnóstico para a crise "o Estado", o qual deveria passar por Reforma. Alinhada ao receituário neoliberal do tipo Terceira Via (PERONI, 2003) a reforma processada em 1995 deslocou a função do Estado de provedor de políticas sociais para a função de regulador. Não sendo o responsável direto pelos serviços sociais, entre eles os educacionais, o Estado abre espaço para a atuação de organizações da sociedade civil e da intervenção da lógica de gestão do setor privado entendida como mais eficiente que a do setor público. Esta última forma de intervenção, constitui-se a partir das parcerias com o setor privado que se encarregam de empregar suas técnicas "neutras" de gestão a fim de aumentar a eficiência do setor público, constituindo o "quase-mercado" (DALE, 1994), no campo educacional.

Tendo em vista que a Educação Profissional foi regulamentada na LDB como um processo educacional específico, não articulado, necessariamente, às etapas da educação básica, tornou-se campo aberto para a implantação de diferentes práticas. No plano legal, o governo FHC instituiu o Decreto 2.208/1997, que proibia a formação integrada no ensino médio pretendida pelo projeto de LDB da sociedade civil e regulamentava formas "fragmentadas e aligeiradas de educação profissional em função das alegadas necessidades do mercado" (FRIGOTTO, CIAVATTA e RAMOS, 2005, p. 25), reduzindo o conhecimento e o ensino à formação de competências (RAMOS, 2008; 2011) ${ }^{35}$. Esta medida legal contribuiu para o aprofundamento da dualidade entre educação básica e educação profissional ao preconizar que

\footnotetext{
${ }^{35}$ Seguindo os preceitos dos organismos internacionais para a educação, disseminados nesse período, este Decreto, da mesma forma que os Parâmetros Curriculares Nacionais para a educação básica formulados neste mesmo governo, instituiu o modelo da pedagogia das competências na formação profissional, enquanto modelo educativo que visa adequar a formação às necessidades do mercado de trabalho baseado na acumulação flexível. Nas palavras de Ramos (2008, p. 304) “a 'pedagogia das competências' pretende preparar os indivíduos para a adaptação permanente ao meio social instável da contemporaneidade."
} 
“o ensino técnico-profissional possui organização curricular própria, independente do ensino médio, podendo ser oferecido de forma concomitante ou sequencial a este" (BRASIL, 1997).

Como importantes mecanismos de consolidação da reforma da educação profissional, levada a cabo por meio do referido Decreto e da parceira com o Banco Mundial, o governo FHC desenvolveu dois programas nessa área: o PROEP (Programa de Expansão da Educação Profissional) e o PLANFOR (Plano Nacional de Qualificação do Trabalhador). Enquanto o primeiro se voltava ao financiamento e reestruturação dos cursos e instituições de educação profissional (escolas técnicas e CEFETs), a partir de novas metodologias de gestão e de ensino que privilegiassem o atendimento às demandas do mercado de trabalho, na lógica da pedagogia das competências; o segundo, vinculado ao Ministério do Trabalho e Emprego, visava atender à população economicamente ativa, buscando qualificar a força de trabalho com vistas à sua empregabilidade ${ }^{36}$ no mercado de trabalho, tendo o Sistema S como o principal vetor dessa formação, a partir de cursos de curta duração. Assim, enquanto o primeiro visava à preparação de mão de obra adequada às demandas atuais do modelo de produção toyotista, ou acumulação flexível, o segundo visava requalificar a mão de obra existente, visando torná-la "empregável" ao mercado.

O PLANFOR, na análise de Santos (2003), tem suas origens no PIPMO, porém esses programas são desenvolvidos a partir de diferentes bases produtivas: enquanto o PIPMO preparava os trabalhadores para o emprego, no âmbito do modelo fordista/taylorista de produção, o PLANFOR visava preparar os trabalhadores para a empregabilidade, em um contexto marcado pela convivência de paradigmas produtivos - introdução do modelo produtivo toyotista e permanência de postos de trabalho tradicionais - e pelo aumento do desemprego, contribuindo para "naturalizar a associação entre a posse de uma ocupação e dispositivos de formação" (HIRATA, 1999, p. 13).

Gaudêncio Frigotto sintetiza muito bem esse período por meio da seguinte passagem:

Do ciclo de reformas educativas do golpe civil militar, centrado na ideologia do capital humano, transitamos para um ciclo de reformas sob a ditadura do capital. A travessia efetivou-se, perversamente, pela profunda regressão das relações sociais e com um aprofundamento da mercantilização da educação no seu plano institucional e no seu plano pedagógico [...]. No âmbito do pensamento pedagógico, o discurso em defesa da educação é dominantemente retórico ou colocado de forma inversa, tanto na ideologia do capital humano (conjuntura das décadas de 1960 a 1980), quanto nas teses, igualmente ideológicas, da sociedade do conhecimento, da pedagogia das

\footnotetext{
${ }^{36}$ O termo empregabilidade é utilizado nesse contexto, conforme destaca Oliveira (2008, p. 200), como a necessidade de "os indivíduos disporem de habilidades e conhecimentos adequados aos interesses da produção", justificando assim o desemprego pela falta de preparação dos mesmos para acompanharem as mudanças do mundo do trabalho.
} 
competências [...] e da empregabilidade (décadas de 1980 a 1990) (FRIGOTTO, 2007, p. 1137-1138).

Nesse contexto, tanto em nível nacional, quanto internacional, a educação/qualificação profissional ganha cada vez mais importância. Para além de seu papel na qualificação da mão de obra, a qualificação profissional torna-se um atributo da força de trabalho a ser "trocado" no mercado. Com a crise do emprego e a adoção do modelo de competências, tanto no trabalho quanto no processo formativo, cada indivíduo é impelido a buscar seus próprios meios de construir e atualizar constantemente suas competências, tendo na qualificação da sua força de trabalho um atrativo ao mercado. O mercado, de outro lado, se beneficia duplamente: ao empregar mão de obra qualificada e ao ter a seu dispor, ao mesmo tempo, um grande número de trabalhadores qualificados de reserva. A absolutização do mercado como o espaço para a produção da subsistência nas sociedades capitalistas faz com que os indivíduos se submetam a relações precárias de emprego e busquem incessantemente qualificar sua força de trabalho a fim de se manter nele, visto que a noção de "empregabilidade" passa a ser uma característica e responsabilidade de cada indivíduo.

É interessante observar, conforme analisa Silva (2003), como a noção de "empregabilidade" toma o lugar da noção de "informalidade" - "categoria em torno da qual se constituía um debate mais ou menos estruturado" (SILVA, 2003, p. 141) - e contribui para um esvaziamento desta categoria. Enquanto categoria de análise da relação trabalhador e mercado de trabalho - assalariado, diga-se de passagem -, a noção de informalidade, surgida na década de 1960, expressava “os problemas ligados à incorporação produtiva de crescentes contingentes de trabalhadores que se deslocavam para a cidade em todo o mundo subdesenvolvido" (SILVA, 2003, p. 145) e revelava, do ponto de vista marxista, que o trabalho informal, embora não fizesse parte das relações salariais típicas do mercado de trabalho, reafirmava a lógica da exploração capitalista, "já que mesmo relações não-capitalistas de trabalho, na medida em que reduziam o custo de reprodução dessa força produtiva, aumentando com isso a proporção de trabalho nãopago, estavam subordinadas ao capital e participavam da lógica de acumulação" (SILVA, 2003, p. 146). Ao reconhecer sua funcionalidade ao capital, as lutas sociais se estruturavam em torno da ampliação dos direitos desses trabalhadores na direção do trabalho assalariado, sob a “fórmula trabalho livre, mas protegido" (SILVA, 2003, p. 163).

A noção de empregabilidade, a par da noção de competência, rompe com o padrão de sociabilidade com base no trabalho assalariado, ao projetar a imagem do "novo trabalhador" como aquele disposto a substituir "a carreira em um emprego assalariado de longo prazo pelo desenvolvimento individual através da venda de sua força de trabalho em uma série de 
ocupações contingentes, obtidas através da demonstração pública de disposição e competência para atividades e condições de trabalho em constante mudança", ou seja, "como empresário de si mesmo" (SILVA, 2003, p. 166). Nesse sentido, a organização do mercado de trabalho flexível sob a noção de empregabilidade, na verdade, desloca grande parte dos trabalhadores para a informalidade, sujeitos a relações salariais precárias, ou relações não-assalariadas: o trabalhador "auto-empregado". Ou seja, a exceção passa a ser uma regra, e é apresentada sob a perspectiva da "autonomia" do trabalhador. Com isso, os princípios de solidariedade que organizavam a conduta e a ação coletiva diante dos conflitos da relação capital e trabalho não encontram mais espaço nesse novo quadro social caracterizado pela "heterogeneidade da experiência social" (SILVA, 2003, 165).

Nesse contexto, a noção de qualificação, enquanto relação social de forças entre capital e trabalho, que corresponde a uma relação, socialmente construída, entre "algumas operações técnicas e a estimativa de seu valor social" (NAVILLE, 2012, p. 156) - que deu origem a sistemas de classificação profissional, como no caso da França, oferecendo bases concretas para a organização e luta coletiva dos trabalhadores -, passa a ser substituída pela noção de “competências", que desloca para o nível das características individuais (competências, atitudes e valores) a avaliação, por parte do empregador, da correspondência entre posto de trabalho (desempenho esperado) e trabalhador (competências que levariam àquele desempenho). Conforme sintetiza Kergoat (2010), “enquanto a qualificação é negociada no âmbito dos setores profissionais pelos representantes dos empregadores e dos assalariados, a competência é fixada, avaliada e validada na empresa a partir de uma entrevista individual, de um face-à-face entre o assalariado e sua hierarquia” (KERGOAT, 2010, p. 91, tradução nossa). Assim, ao contrário da qualificação, medida pela obtenção do diploma, "título adquirido de uma vez por todas", as competências, como "conjunto de propriedades instáveis", são colocadas constantemente à prova (TANGUY, 1997, p. 193). Na prática, como aponta Dubar (1999, p. 98), “diante da ausência de 'super-regras' organizando as negociações coletivas, essas 'competências' tornamse rapidamente pretextos para a exclusão dos mais frágeis, dos mais velhos e dos menos diplomados".

Nessa direção, da mesma forma que as competências retiram a centralidade do diploma/qualificação na esfera do trabalho, na esfera educacional o currículo organizado por saberes/conhecimentos construídos historicamente dá lugar ao conjunto de competências requeridas pelo mercado de trabalho. Oriunda do mundo empresarial, "a ideia que se difunde quanto à apropriação da noção de competência pela escola é que ela seria capaz de promover o encontro entre formação e emprego" (RAMOS, 2011, p. 221). Nessa perspectiva, os 
conhecimentos a serem mobilizados devem ser apenas aqueles necessários ao desenvolvimento de tais competências. Esse conjunto de competências que passa a orientar a formação são oriundas e validadas no âmbito das empresas, o que as torna os verdadeiros agentes da formação ${ }^{37}$ (TANGUY, 1997).

No entanto, conforme analisa Dedeca (1998), enquanto nos países desenvolvidos o debate sobre a qualificação e competência era intrínseco às mudanças nos processos de trabalho, visto que nesses países a inserção do modelo de formação por competências se opunha, justamente, ao modelo de qualificação, no Brasil o debate das competências serviu muito mais como discurso e justificativa frente às políticas adotadas tanto no campo econômico quanto no educacional.

Observa-se que a mudança de nomenclaturas e o esvaziamento de conceitos que orientavam as lutas dos trabalhadores é operada de forma a parecer benéfica para o trabalhador: as competências parecem valorizar características individuais do trabalhador, "capturando a sua subjetividade", como se refere Alves (2011), enquanto a empregabilidade destacaria o protagonismo do trabalhador. Parafraseando a análise de Evelina Dagnino (2004), em relação ao projeto democrático e neoliberal ${ }^{38}$, esses deslocamentos realizam uma verdadeira "confluência perversa", pois, sob o signo do protagonismo e da valorização da subjetividade do trabalhador, conduzem, na verdade, a uma precarização das condições de trabalho e remuneração.

\subsection{Os governos do Partido dos Trabalhadores: ensaio de uma nova "rota" para a educação profisssional}

A impossibilidade da oferta do ensino médio integrado à educação profissional e a lógica da formação por competências instituídas pelo Decreto 2.208/97, geraram fortes críticas das entidades, organizações e atores do campo educacional, o que os conduziu a pressionar o próximo governo eleito a revogar o referido Decreto.

\footnotetext{
${ }^{37} \mathrm{O}$ leitor poderá visualizar um exemplo dessa relação por meio da análise do desenvolvimento do Pronatec no âmbito da instituição do Sistema S que fez parte dessa pesquisa, apresentada no Capítulo IV. O processo de elaboração do currículo nessa instituição é realizado a partir de "mesa redonda" com os empresários da área, que ditam as competências requeridas pelo mercado e a partir delas o grupo de professores seleciona os conhecimentos necessários, resultando no currículo do curso.

${ }^{38}$ Na década de 1990, Evelina Dagnino analisa a emergência de projetos democráticos de sociedade, em alguns países da América Latina que saiam de períodos ditatoriais, como o Brasil, e a instalação, ao mesmo tempo, do projeto neoliberal, o que gerou um processo de "confluência perversa". A confluência perversa ocorre, pois, "ambos os projetos requerem uma sociedade civil ativa e propositiva", no entanto, apontam "para direções opostas e até antagônicas" (DAGNINO, 2004, p. 142).
} 
Com a eleição do Presidente Luiz Inácio Lula da Silva, em 2002, ampliaram-se as expectativas dos setores progressistas em retomar o debate travado na década de $1980 \mathrm{em}$ relação à educação politécnica, tendo em vista que o Partido dos Trabalhadores (PT), gestado nesse período, era um dos principais defensores dessa proposta. Embora não tenha sido levado à cabo pelo governo nos anos 1990, essa concepção orientou várias experiências desenvolvidas a partir de organizações sindicais, que expressam resistência à política de educação profissional vigente, como o Programa Integrar, desenvolvido em sindicatos de base da CUT, do ramo metalúrgico, em diferentes regiões do país, que tinha como objetivo a integração do conhecimento técnico aos conhecimentos científicos da educação básica (LIMA, 2006).

Nessa direção, desde o início do governo foram realizados seminários nacionais ${ }^{39}$ para a construção da política de educação profissional, em substituição ao Decreto em vigor, os quais se mantiveram polêmicos e envolveram representantes da sociedade civil e de órgãos governamentais (FRIGOTTO, CIAVATTA e RAMOS, 2005). Fruto dessas discussões, que representavam disputas de interesses e concepções, é que se originou o Decreto n. 5.154/2004.

O novo Decreto representou um importante avanço ao retomar as bases jurídicas para a oferta da educação profissional integrada à educação básica. Contudo, como resultado de um conjunto de disputas ${ }^{40}$, expressa algumas contradições: reproduziu o modelo de Decreto, ao invés de Lei, o que seria mais democrático e legítimo enquanto instrumento legal; preservou a oferta de cursos dissociados da educação básica; e "caminhou” por 08 (oito) anos a par das Diretrizes Curriculares para a Educação Profissional Técnica de Nível Médio elaboradas com base no antigo Decreto ${ }^{41}$ (FRIGOTTO, CIAVATTA e RAMOS, 2005).

Na visão de Ramos (2011, p. 105), a operacionalização do novo Decreto com base nas diretrizes emanadas do antigo marco legal acabou dando "continuidade à política curricular do governo anterior, marcada pela ênfase no individualismo e na formação por competências

\footnotetext{
${ }^{39}$ São eles: "Ensino Médio: Construção Política", em maio de 2003, e "Educação Profissional: concepções, experiências, problemas e propostas", em junho de 2003.

${ }^{40}$ Gaudêncio Frigotto, Maria Ciavatta e Marise Ramos, relatam, enquanto participantes desse processo, a existência de pelo menos três propostas diferentes que atuaram nessa disputa: "uma primeira posição expressa em três documentos defendia a ideia ou tese de que cabe apenas revogar o Decreto n. 2.208/97 e pautar a elaboração da política de Ensino Médio e Educação Profissional, de uma parte pelo fato de a LDB em vigor (Lei n. 9.394/96) contemplar as mudanças que estão sedo propostas e, de outra, por se entender que tentar efetivar mudanças por decreto significa dar continuidade ao método impositivo do governo anterior. Uma segunda posição é expressa, mais diretamente, por um documento que se posiciona pela manutenção do atual Decreto n. 2.208/97 e outros documentos que indiretamente desejariam que as alterações fossem mínimas. Por fim, uma terceira posição, que consta de um número mais significativo de documentos, direta ou indiretamente partilha da ideia da revogação do Decreto n. 2.208/97 e da promulgação de um novo Decreto" (FRIGOTTO, CIAVATTA e RAMOS, 2005, p. 2324).

${ }^{41}$ Durante esse período as Diretrizes aprovadas em 1999, sob a Resolução CNE/CEB n. 04/99, foram atualizadas pela Resolução CEB 01/2005, que incluiu a possibilidade de oferta da forma Integrada entre ensino médio e curso técnico, aprovada pelo novo Decreto.
} 
voltadas para a empregabilidade". Apenas em 2012, também fruto de intensas disputas e debates, como se verá adiante, é que foram publicadas as Diretrizes Curriculares para a Educação Profissional Técnica de Nível Médio, tendo como base as normativas do Decreto 5.154/2004, a partir da Resolução CNE/CEB 06/2012.

Essa primeira experiência de tentativa de mudança na concepção e políticas de educação profissional em curso evidenciou, conforme analisam Frigotto, Ciavatta e Ramos, que o Governo não colocava em pauta mudanças estruturais, em razão de ser "expressão de um bloco heterogêneo dentro do campo da esquerda e com alianças cada vez mais conservadoras" (2005, p. 26). $\mathrm{O}$ uso de decreto, enquanto forma legal de mudança ${ }^{42}$, e as contradições que ele carrega, representou, nesse cenário, a forma possível - em face das forças conservadoras no Congresso Nacional e da ausência de forças políticas no próprio governo para sustentação de uma mudança estrutural na política da área - para instituir as bases para a "(re)construção de princípios e fundamentos da formação dos trabalhadores para uma concepção emancipatória dessa classe" (2005, p. 30).

Análises produzidas sobre os Governos Lula, no período de 2003 a 2010, apontam a existência de uma coalizão entre frações da burguesia e frações da classe trabalhadora. $\mathrm{Na}$ análise de Singer (2015, p. 58), ao longo dos dois mandatos do Governo Lula se estruturaram duas coalizões burguesas contrapostas, a "produtivista" e a "rentista": "a coalizão rentista unificaria o capital financeiro e a classe média tradicional, enquanto a produtivista seria composta pelos empresários industriais associados à fração organizada da classe trabalhadora." Tendo como suporte político de apoio o subproletariado ${ }^{43}$, especialmente no segundo mandato, o governo fazia uma constante arbitragem "de acordo com a correlação de forças, ora dando ganho de causa a uma, ora à concorrente". O programa de desenvolvimento econômico e social possível dentro desta coalizão de forças, ligadas ao capital e ao trabalho, resultou em um "programa de combate à desigualdade dentro da ordem" e a continuidade de algumas medidas

\footnotetext{
${ }^{42}$ Em 2008, a regulamentação da educação profissional conforme este Decreto foi incorporada à LDB, por meio da Lei n. 11.741/08, tornando-se um complemento da seção do Ensino Médio (Seção IV-A) e alterando a redação do capítulo específico da Educação Profissional (Capítulo III), saindo da situação frágil que é a normatização por Decreto. Esse fato representou um grande avanço, visto que imprimiu na LDB - a mais abrangente e superior norma jurídica da educação - a integração entre a educação básica e a educação profissional.

${ }^{43}$ Com base em estudo de Paul Singer (1982), o cientista político identifica o subproletariado como "aqueles que oferecem a sua força de trabalho no mercado sem encontrar quem esteja disposto a adquiri-la por um preço que assegure sua reprodução em condições normais. Estão nessa categoria empregados domésticos, assalariados de pequenos produtores diretos e trabalhadores destituídos das condições mínimas de participação na luta de classes" (2009, p. 98). Essa fração da classe trabalhadora, na sua análise, teria assegurado a reeleição de Lula, como resposta às políticas de redistribuição de renda do governo (como o Programa Bolsa Família e valorização do Salário Mínimo), em face do abandono de parcela da classe média, escandalizada com a corrupção do governo (processo do "mensalão"), e de parte da classe trabalhadora organizada, que estava descontente com o abandono das mudanças estruturais na pauta do governo.
} 
macroeconômicas ${ }^{44}$ do governo $\mathrm{FHC}$, como condição posta pela burguesia para "não haver 'guerra"”, conclui o cientista político $(2009$, p. 96).

$\mathrm{Na}$ análise de Oliveira (2010), o governo Lula teria desenvolvido o projeto do capital a partir da "direção moral" da classe trabalhadora, invertendo assim a equação da hegemonia grasmciana: "não são mais os dominados quem consentem na sua própria exploração; são os dominantes - os capitalistas e o capital, explicite-se - que consentem em ser politicamente conduzidos pelos dominados, à condição de que a 'direção moral' não questione a forma da exploração capitalista (OLIVEIRA, 2010, p. 27). A hegemonia seria às avessas, segundo o autor, pois as classes populares teriam passado a trabalhar em prol da hegemonia das elites conservadoras. Singer, por outro lado, afirma que esse governo realizou "um completo programa de classe", ao "construir uma substantiva política de promoção do mercado interno voltado aos menos favorecidos, [...] somada à manutenção da estabilidade" (2009, p. 98). Porém, não o programa da classe trabalhadora organizada, que tinha como bandeira as mudanças estruturais no modelo econômico, e sim o da fração da classe trabalhadora identificada como subproletariado, conclui o autor (2009).

É desse contexto que emerge o "Lulismo", caracterizado por Singer como "o encontro de uma liderança, a de Lula, com uma fração de classe, o subproletariado" (2012, p.15), por meio de um programa delineado nos primeiros anos de seu governo, cujos pontos principais eram: “combater a pobreza, (...), por meio da ativação do mercado interno, melhorando o padrão de consumo da metade mais pobre da sociedade, que se concentra no Norte e Nordeste do país, sem confrontar os interesses do capital", resultando em um "reformismo fraco" (SINGER, 2012, p. 15-16).

A análise de Boito Jr. (2012) assinala no interior do bloco de poder, nesse período, a configuração de uma "frente" 45 composta pela fração da burguesia identificada como "burguesia interna"46 e pelo "movimento operário e popular", com o apoio político dos "trabalhadores pauperizados e desorganizados", conquistados por meio dos programas de

\footnotetext{
${ }^{44}$ As medidas macroeconômicas que Singer aponta, tendo como base o estudo de Araújo (2006) se referem a três pilares: metas de inflação, câmbio flutuante e superávit primário nas contas públicas (SINGER, 2009, p. 96).

45 Boito Jr. chama atenção para o uso do termo "frente", destacando que se trata de forças e segmentos que se uniram em torno de interesses convergentes, mas não se fundiram (2012, p. 99). No interior da própria burguesia interna há contradições, aponta o autor, podendo-se identificar as diferenças entre a burguesia industrial e o sistema bancário nacional em relação à política de juros do Banco Central. Ao mesmo tempo, estes segmentos possuem em comum o interesse na proteção do Estado diante do capital estrangeiro, fator que as une na frente política.

${ }^{46}$ A burguesia interna é identificada por Boito Jr. como uma fração da classe burguesa - crítica em relação ao governo FHC na forma de condução da abertura ao capital internacional, que estimulou um processo de desindustrialização no país - interessada no protecionismo estatal como forma de "preservar e ampliar as posições que detém no sistema econômico e social nacional e no exterior", pois teme ser "engolida ou destruída pelos grandes grupos econômicos estrangeiros" (2012, p. 77).
} 
transferência de renda, e do movimento sindical, através da melhoria salarial do funcionalismo público, aumento do emprego e da recuperação do salário mínimo (BOITO JR. 2012, p. 72-73). Identificando como "força principal", o movimento operário e popular e como "força hegemônica" - aquela que define os objetivos da luta - a burguesia interna, esta frente política estaria unificada em torno do projeto "neodesenvolvimentista" - "projeto econômico que expressa essa relação de representação política entre os governos Lula e a grande burguesia interna" (BOITO JR. 2012, p. 68) -, porém, não sem conflitos e instabilidades, destaca o autor. A política econômica do governo possibilitou, dessa forma, alguns ganhos para a classe trabalhadora, preservando, ao mesmo tempo, os interesses estratégicos da burguesia interna ou lhe impondo "sacrifícios menores", o que se justifica pelo fato de o governo não ter desencadeado "nenhum processo amplo de regulamentação do mercado de trabalho", sinaliza Boito Jr. (2012, p. 73).

Boito Jr. define, de forma provisória, o neodesenvolvimentismo como o "desenvolvimentismo possível dentro do modelo capitalista neoliberal periférico" (2012, p. 69) e justifica três diferenças principais em relação ao desenvolvimentismo das décadas de 1930 a 1980, do qual o neodesenvolvimentismo é tributário, porém não equivalente. São elas: produção de menores índices de crescimento, em razão de estar limitado pela acumulação financeira do modelo capitalista neoliberal; aceitação da especialização regressiva, atuando no processamento de produtos de baixo valor agregado, em virtude do recuo imposto pelo modelo neoliberal aos países dependentes; e produção voltada para o mercado externo, ou seja, para a exportação (BOITO JR., 2012).

No âmbito desse projeto político econômico, segundo Boito Jr., não estaria incluída toda a burguesia brasileira. A fração da burguesia "integrada e subordinada ao capital estrangeiro" - ou a burguesia rentista, como define Singer (2009) -, para a qual melhor atenderia uma "política econômica neoliberal extremada", continuou pleiteando o retorno do PSDB ao governo federal (BOITO JR. 2012, p. 71). Nesse sentido é que, para "levar de vencida a grande burguesia compradora e o capital financeiro internacional", a burguesia interna "teve de aceitar integrar uma frente com o movimento sindical e popular", uma vez que "teme ser engolida ou destruída pelos grupos econômicos estrangeiros" e depende, assim, do protecionismo e intervenção do Estado a seu favor, conforme analisa Boito Jr. (2012, p. 71-77). Por não se tratar de uma "frente" ou "coalizão", para usar os termos de Boito Jr. e Singer, de natureza orgânica, o seu sucesso dependia da capacidade de arbitragem do governo ${ }^{47}$.

\footnotetext{
${ }^{47}$ Embora não se tenha o objetivo, aqui, de discorrer sobre o Golpe de 2016, cabe ressaltar os elementos desse contexto que teriam impacto nesse evento posterior. Na análise de Singer e Boito Jr (em que pese suas diferenças
} 
O sociólogo Giovani Alves, ao analisar o projeto político econômico desenvolvido pelo governo Lula, situa o neodesenvolvimentismo como um "novo projeto capitalista de desenvolvimento alternativo às políticas neoliberais da década de 1990" (ALVES, 2014, p. 129). Apoiado na parceria do Estado com o mercado, o Estado assume, com o projeto neodesenvolvimentista, o papel de "indutor da economia capitalista no Brasil", seja como "Estado financiador", "capaz de financiar e constituir grandes corporações de capital privado nacional com a capacidade competitiva no mercado mundial", como no caso da atuação do BNDES (Banco Nacional do Desenvolvimento Econômico e Social), seja como "Estado investidor", ao colocar "em marcha a construção de grandes obras de infraestrutura destinadas a atender as demandas exigidas pelo grande capital", que teve como grande expressão a política do PAC (Programa de Aceleração do Crescimento) (ALVES, 2014, p. 131, grifos do autor). No entanto, a legitimidade social e política desse "novo projeto burguês neodesenvolvimentista", foi alcançada nesse período, em grande medida, "pelo vasto programa de transferência de renda para a classe trabalhadora pobre", conclui Alves (2014, p. 132). Assim, embora situado nos limites da ordem sistêmica do capital ${ }^{48}$, o neodesenvolvimentismo no Brasil permitiu conjugar redistribuição de renda, ampliação do mercado de consumo e instauração de "suportes sociais mínimos de existência para a classe trabalhadora, aumentando o gasto social do Estado nos limites do orçamento público, comprometido com o pagamento da dívida pública" (ALVES, 2014, p. 136).

A partir de uma visão radical dos limites do neodesenvolvimentismo, Plínio de Arruda Sampaio Jr. aponta que o projeto neodesenvolvimentista é uma espécie de "farsa", uma vez que não visa romper com o caráter dependente do capitalismo no Brasil. Para esse autor, o neodesenvolvimentismo, tal como conduzido pelos governos do PT, procura conjugar os aspectos "positivos" do neoliberalismo - "compromisso incondicional com a estabilidade da

na nomeação e identificação das frações de classe que compunham a coalizão ou frente dos governos petistas), fruto da impossibilidade de arbitrar os interesses dessas diferentes frações da burguesia, em decorrência da crise capitalista internacional que inicia em 2008, é que resulta o Golpe de 2016. Medidas tomadas pela Presidenta Dilma, em resposta a demandas da fração da burguesia produtivista ou interna, como a baixa da taxa de juros e redução dos spreads bancários, com vistas a impulsionar o crescimento econômico interno, atingiram a fonte dos lucros da burguesia rentista, atrelada ao capital financeiro internacional, iniciando uma ofensiva política contra o governo, com o objetivo de restaurar a "hegemonia do neoliberalismo puro e duro" (BOITO JR. 2016, p. 28). O movimento do governo Dilma no sentido de deslocar "o lulismo para um pouco mais perto do reformismo forte" a partir do aprofundamento do projeto neodesenvolvimentista com vistas a reindustrializar o país, teria impulsionado a "construção de uma frente antidesenvolvimentista" que faria parte da explicação do impeachment, analisa Singer (2018, p. 26).

${ }^{48}$ Para Giovanni Alves, as Jornadas de Junho de 2013 expressam os limites do neodesenvolvimentismo: "quem ascendeu pelos méritos da política distributiva agora quer outros direitos que a frente política neodesenvolvimentista, tal como se constitui hoje, não pode mais lhe oferecer. Dez anos de Lula e Dilma liberaram forças sociais e demandas radicais que o lulismo, como engenharia política do reformismo fraco, não é mais capaz de conter" (2014, p. 145). 
moeda, austeridade fiscal, busca de competitividade internacional, ausência de qualquer tipo de discriminação contra o capital internacional" - com aqueles do velho desenvolvimentismo, quais sejam, "comprometimento com o crescimento econômico, industrialização, papel regulador do Estado, sensibilidade social" (SAMPAIO JR. 2012, p. 679). No entanto, ao não assumir a "crítica da ordem e a aposta na possibilidade de mudanças estruturais que criassem as condições objetivas e subjetivas para que se pudesse conciliar capitalismo, democracia e soberania nacional", tal como previa a economia política desenvolvimentista, o neodesenvolvimentismo torna-se uma "espécie de versão ultra light da estratégia de ajuste da economia brasileira aos imperativos do capital financeiro", alçando crescimento e distribuição de renda à condição de desenvolvimento (SAMPAIO JR. 2012, p. 680, grifos do autor).

Do ponto de vista da estrutura estatal, Alves (2014) aponta que o desenvolvimento de políticas pós-neoliberais ou neodesenvolvimentista nos governos do PT manteve intacta a “morfologia política e social do Estado neoliberal” (2014, p. 151), herdada da ditadura civilmilitar e aprofundada na década de acirramento do neoliberalismo, enquanto estrutura de Estado e desenvolvimento econômico (1990 - 2002). Nesse sentido, a cultura neoliberal, com seus valores de mercado e cultura do individualismo se mantiveram presentes tanto na sociedade civil, quanto na estrutura do Estado. Do ponto de vista do Estado, a política macroeconômica desenvolvida pelo Banco Central, com base no tripé "metas de inflação, câmbio flexível e superávit primário", representam um "traço orgânico do Estado neoliberal" nesse período (ALVES, 2014, p. 153). Do ponto de vista da sociedade civil, a não condução de um projeto de formação da opinião pública e de constituição de um polo protagonista na luta ideológica, deixou livre o espaço para o aprofundamento dos valores neoliberais por meio dos organismos privados da hegemonia neoliberal (ALVES, 2014), como a mídia televisiva e o grande aumento de igrejas disseminadoras do empreendedorismo enquanto modo de vida ${ }^{49}$ em que pese as disputas realizadas nas redes sociais e na internet.

Os esforços analíticos empreendidos por estes intelectuais brasileiros, oferecem elementos para identificar e compreender a natureza dos diferentes interesses que conviviam no governo desse período, os quais se expressam nas ações do Estado, que visavam equilibrar esse jogo de forças, oriundas das necessidades dos trabalhadores e da burguesia, por meio da realização de consensos, sem, no entanto, romper com o modelo econômico-ideológico

\footnotetext{
${ }^{49}$ Um interessante estudo sobre a relação entre organizações religiosas e empreendedorismo o leitor poderá encontrar em: SERAFIM, Maurício Custódio. Sobre esta Igreja edificarei minha empresa: organizações religiosas e empreendedorismo. (Tese de Doutorado) Programa de Pós-Graduação em Administração de Empresas, Fundação Getúlio Vargas. 257 f. São Paulo, 2008.
} 
vigente $^{50}$. Com exceção de Sampaio Jr., estes intelectuais reconhecem avanços dos governos Lula em relação à década anterior, uma vez que incluiu parcela das demandas dos trabalhadores nas políticas sociais promovidas e inseriu políticas redistributivas a par da atuação do Estado no desenvolvimento econômico. Na análise de Singer (2012), o "lulismo" pode ser compreendido, no sentido gramsciano, como um tipo de "Revolução Passiva", assim como para Alves (2014), o neodesenvolvimentismo conduzido pelo governo Lula também pode ser analisado do ponto de vista desta categoria, na medida em que se realizam a partir de processos de "restauração", quando não ocorrem mudanças radicais e efetivas, "de baixo para cima", e de "renovação", à medida em que parte das exigências vindas de baixo são assimiladas. Conforme sintetiza Coutinho:

\begin{abstract}
Ao contrário de uma revolução popular, "jacobina”, realizada a partir de baixo - e que, por isso, rompe radicalmente com a velha ordem política e social -, uma revolução passiva implica sempre a presença de dois momentos: o da "restauração" (trata-se sempre de uma reação conservadora à possibilidade de uma transformação efetiva e radical proveniente "de baixo") e da "renovação" (no qual algumas das demandas populares são satisfeitas "pelo alto", através de "concessões" das camadas dominantes) (COUTINHO, 2012, p. 118).
\end{abstract}

Tendo em vista que essa noção foi formulada por Gramsci para apreender as diferentes formas de desenvolvimento das sociedades capitalistas, é possível identificar diferentes modelos de Revolução Passiva. Gramsci caracteriza pelo menos três modelos em seus Cadernos do Cárcere, como a Revolução Passiva Francesa, Revolução Passiva Piemontesa (Risorgimento italiano) e Revolução Passiva Americana (americanismo e fordismo), que caracterizam diferentes processos de mudança/conservação no âmbito dessas sociedades. Na forma francesa a restauração é precedida de um processo de revolução que antecede a restauração, ou seja, "há um evento disruptivo na política que tem como resposta uma restauração que evidentemente não consegue reconstituir a velha ordem, mas constitui uma nova forma de organização política na qual o novo e o velho conciliam-se entre si” (BIANCHI, 2017, p. 31); na forma piemontesa, revolução passiva que conduz à constituição do Estado nacional italiano, não há um processo de revolução, como no caso francês, a unificação italiana ocorre por meio da liderança do Estado Piemontês, ou seja, por meio do aparato estatal, uma "revolução sem revolução"; e, por

\footnotetext{
${ }^{50}$ Essa afirmação não nos aproxima das análises que caracterizam o governo do PT como mera continuidade das políticas neoliberais do governo do PSDB, como aponta Filgueiras (2006), por exemplo. As políticas voltadas à redução da pobreza, a ampliação dos direitos humanos, a ampliação do acesso e qualidade da educação básica e ensino superior, acompanhadas de políticas afirmativas, a política de habitação, melhoria do salário mínimo e regulamentação de trabalhos precários, como o de empregada doméstica, entre outras, possibilitou uma melhoria substantiva na vida dos trabalhadores, possibilitando um rearranjo positivo na configuração da população nas classes econômicas, fato que não se vislumbrava no governo anterior.
} 
fim, no caso americano, a fórmula "inovação-conservação" ocorre no âmbito das forças produtivas e não no âmbito das forças políticas (BIANCHI, 2017).

Nesse sentido, alguns intelectuais brasileiros identificam, também, um modelo de "revolução passiva à brasileira", que caracterizaria o desenvolvimento de nossa sociedade. Conforme analisam Braga e Bianchi (2015), a "revolução passiva à brasileira" consistiria num "processo de atualização gradual do capitalismo por meio de reformas promovidas diretamente pelo Estado, o qual parecia se destacar de suas bases sociais para melhor realizar sua função" (2015, s./p.). Esse processo, no Brasil, se caracteriza por uma "via de modernização conservadora, plasmada pelos limites inerentes à semiperiferia capitalista, em que o avanço nutre-se permanentemente do atraso", conforme destaca Braga (2010, s./p.). A variante, no caso do Lulismo, segundo os autores, foi a participação dos movimentos sociais no interior do bloco hegemônico do governo que permitiu "por um lado, atender certas aspirações das classes subalternas e, por outro, ampliar a base social do Estado por meio da incorporação passiva destas ao arranjo político" (BRAGA, BIANCHI, 2015, s./p.). Nesse processo, as transformações nos planos sociais, econômicos e político que, de fato, ocorreram, transcorriam no "no interior dos mesmos quadros históricos e institucionais do capitalismo dependente e financeirizado" (BIANCHI, 2017, 30).

Nesse cenário, é possível compreender as contradições presentes nas políticas educacionais desenvolvidas nesse período e ao mesmo tempo mensurar a importância dos avanços obtidos nas políticas de educação profissional, os quais configuram importantes elementos de "inovação" nesse campo, identificados a partir da noção de Revolução Passiva. Além da alteração no ordenamento jurídico e pedagógico da oferta, alcançado por meio do Decreto n. 5.154/2004, fazia-se necessário também a expansão das instituições públicas de educação profissional - escolas técnicas federais e Centros Federais de Educação Tecnológica/CEFET -, entendidas como espaço privilegiado para a disputa e construção de um projeto educacional para a classe trabalhadora, as quais haviam sofrido um processo de sucateamento no governo anterior. A Lei que criou os CEFETs em 1994 - Lei n. 8.948 -, a partir da transformação de escolas técnicas federais, ao mesmo tempo, limitou a sua expansão. A criação de novas unidades de ensino pela união, conforme seu artigo $5^{\circ}$, foi condicionada à realização de parcerias com estados, municípios, distrito federal, setor produtivo ou instituições não governamentais, os quais serão, por conseguinte, os responsáveis pela manutenção e gestão destas instituições, o que representava uma estratégia da União para a diminuição dos gastos sociais de acordo com o ideário neoliberal e o entendimento de que a formação profissional deveria ficar a cargo do setor produtivo. 
A mudança nesse artigo foi realizada apenas em 2005, com a inserção da palavra "preferencialmente" por meio da Lei n. 11.195:

§ 5o A expansão da oferta de educação profissional, mediante a criação de novas unidades de ensino por parte da União, ocorrerá, preferencialmente, em parceria com Estados, Municípios, Distrito Federal, setor produtivo ou organizações não governamentais, que serão responsáveis pela manutenção e gestão dos novos estabelecimentos de ensino. (BRASIL, 2005, grifo nosso)

Conforme entrevista concedida à autora pelo Secretário da Educação Profissional e Tecnológica desse período, Eliezer Pacheco, é possível visualizar a dificuldade enfrentada pelo Ministério da Educação na aprovação dessa mudança e os limites que ela ainda representa:

(...) nós levamos quase um ano ainda, depois de 2004, para alterar essa Lei no Congresso Nacional, para poder retomar a expansão da Rede Federal. (...) com uma correlação de forças, que naquela época era mais desfavorável. (...) O que nós conseguimos foi colocar a palavra "preferencialmente". Então lá na Lei está que a expansão ainda é preferencialmente pelas redes estaduais e comunitárias. Claro, a palavra preferencialmente nos abriu espaço para nós não exercermos essa preferência. Mas tu vês que isso é uma espada que está na cabeça da Rede sempre, porque lá está escrito "preferencialmente", isso não se alterou. Isso foi o máximo que se conseguiu na época (PACHECO, 2016).

Essa "brecha" criada na lei foi o que permitiu ao governo ampliar as unidades de ensino dos CEFETs, criar a primeira Universidade Federal Tecnológica do país e mais tarde, em 2008, transformar a maioria dos CEFETs e Escolas Técnicas Federais em Institutos Federais de Educação, Ciência e Tecnologia, criando assim a Rede Federal de Educação Profissional Científica e Tecnológica (Rede Federal de EPCT). Essa ampliação representou um crescimento de mais de $250 \%$, no período de 8 anos, em relação ao número de instituições de educação profissional criadas pela União nos últimos 100 anos: de 140 unidades de ensino existentes em 2002, chegou-se ao final de 2010 com 356 instituições.

A Lei de criação dos Institutos Federais (Lei n. 11.892/2008) assegurou a oferta de pelo menos $50 \%$ das suas matrículas em cursos técnicos, preferencialmente, integrados ao ensino médio, com vistas a assegurar a integração entre educação básica e profissional. Como instituições de ensino superior, básico e profissional, os IFs tem competência para atuar na oferta de cursos de formação inicial e continuada, cursos técnicos de nível médio, nas formas integrada, concomitante ou subsequente ao ensino médio, cursos superiores de licenciatura, tecnologia e bacharelado e cursos de pós-graduação, nas modalidade de ensino presencial e a distância - no ensino técnico, através da Rede e-Tec Brasil e no ensino superior, por meio da solicitação de credenciamento ao Ministério da Educação - permitindo ao estudante, em uma 
mesma instituição, realizar desde a última etapa da educação básica até a pós-graduação. A expansão da rede federal de educação profissional e tecnológica representou o crescimento de $114 \%$ na oferta de cursos técnicos por meio dessas instituições, passando de 77.190 matrículas em 2002, para 165.335 ao final de 2010, sendo que 46\% correspondiam, nesse período, a cursos de ensino médio integrado ao ensino técnico (INEP, 2010).

A expansão das vagas e a adoção de ações afirmativas (cotas sociais e raciais) permitiram enfrentar a "dualidade invertida" no acesso às instituições federais de educação profissional, que era marcante, como se viu, desde a década de 1970. A partir de um movimento que começou nas universidades federais no início dos anos 2000, em 2012, ainda que sob intensa polêmica e controvérsias, tanto no âmbito da sociedade civil quanto na sociedade política, a Presidência da República sancionou a Lei n. 12.711 que reserva o mínimo de 50\% das vagas para estudantes oriundos de escola pública, assegurando percentual mínimo aos estudantes pretos, pardos, indígenas, pessoas com deficiência e estudantes de escola pública oriundos de famílias com renda igual ou inferior a 1,5 salário-mínimo per capita. Em 2017, conforme dados disponíveis na Plataforma Nilo Peçanha, entre as matrículas que informam a cor da pele e renda ${ }^{51}, 55 \%$ possuem renda per capita de até 01 (um) salário mínimo e 55\% se autodeclaram pardos $(45 \%)$ ou pretos $(10 \%)$, o que expressa os resultados desta política afirmativa no âmbito das instituições da Rede Federal de EPCT.

Aliado a esta expansão das instituições de educação profissional, também ocorreram importantes mudanças nas orientações político-pedagógicas da área, como a criação do Catálogo Nacional de Cursos Superiores de Tecnologia, em 2006, e do Catálogo Nacional de Cursos Técnicos de Nível Médio, em 2008. A elaboração desses catálogos, além de possibilitar uma unificação na nomenclatura dos cursos ofertados, promoveu a organização dos cursos por Eixos Tecnológicos, que se assentam na lógica do conhecimento e da inovação tecnológica, substituindo a antiga organização baseada nas áreas profissionais, identificadas com os setores da economia (MACHADO, 2010).

O Governo Lula promoveu avanços na educação profissional, também, ao articular a educação de jovens e adultos à oferta de ensino técnico e formação inicial e continuada, por meio do Decreto 5.478/2005 - substituído, posteriormente, pelo Decreto n. 5.840/2006, ampliando as instituições ofertantes - que instituiu o Programa Nacional de Integração da Educação Profissional com a Educação Básica na Modalidade de Educação de Jovens e Adultos, o PROEJA. Essa política, oriunda das experiências de resistência ao modelo neoliberal

\footnotetext{
${ }^{51}$ Conforme consulta realizada na Plataforma Nilo Peçanha (https://www.plataformanilopecanha.org/), em março de 2018, 58,5\% das matrículas possuem informações sobre cor/raça e 43,8\% informam a renda familiar per capita.
} 
implantado nos anos 1990, realizadas por movimentos populares, sindicais e por entidades educacionais ligadas à educação básica e à universidade ${ }^{52}$ (MORAES, 2013a), promoveu significativo avanço na área de educação de jovens e adultos, ao associar elevação de escolaridade, tanto de ensino fundamental quanto de ensino médio, à formação profissional a partir de um currículo integrado, representando uma conquista das lutas pelo direito à educação e de "resistência à lógica fragmentária, focalizada, compensatória e reducionista das ações de formação implementadas anteriormente" (RAMOS, 2011, p. 106). Somada a isso, a criação do Programa Brasil Profissionalizado, voltado para o financiamento das condições de oferta de ensino médio integrado nas redes estaduais de ensino, na forma regular e na modalidade de educação de jovens e adultos, fortaleceram a oferta de educação profissional integrada à educação básica para esse público.

Com o mesmo viés de integração entre educação básica e formação profissional, porém dirigido ao público jovem, teve início em 2005 o Programa Nacional de Inclusão de Jovens, o Projovem, regulamentado pelo Decreto $\mathrm{n}^{\circ}$ 5.557/2005. Inserido no contexto da Política Nacional da Juventude do Governo Lula, o Projovem visava o público entre 18 e 24 anos que não havia concluído o segundo ciclo do ensino fundamental, a partir da oferta integrada entre qualificação profissional e a conclusão dessa etapa da educação básica. Coordenado em nível nacional pela Secretaria Nacional da Juventude em pareceria com as secretarias municipais e estaduais de educação, a execução do Programa também permitia parceria com instituições privadas sem fins lucrativos, o que reiterava a manutenção das parcerias público-privadas que conduziram a oferta da educação profissional na década de 1990. A partir de 2008, esse Programa foi ampliado, a partir da emissão do Decreto, n. 6.629/2008, por meio de modalidades de oferta que reuniu iniciativas desenvolvidas por outras esferas do governo federal ${ }^{53}$ destinadas, igualmente, ao público jovem e estendeu o limite de idade entre 15 e 29 anos: Projovem Adolescente - Serviço Socioeducativo; Projovem Urbano; Projovem Campo Saberes da Terra; e Projovem Trabalhador.

\footnotetext{
52 Moraes cita como exemplo destas experiências o "Programa Integrar", da Confederação Nacional dos Metalúrgicos (CNM/CUT), e "Educação de trabalhadores por trabalhadores", realizado por sindicatos da CUT pela base de seis diferentes categorias, em seis cidades do Estado de São Paulo.

${ }_{53}$ De acordo com Grabowski (2010, p. 147), "a mudança promovida no PROJOVEM, entre muitas razões, foi motivada pela fragmentação excessiva de programas que dialogavam com a juventude em várias esferas do governo federal. O novo PROJOVEM - denominado Projovem Integrado, surgiu da união de outros seis programas voltados para a juventude: o próprio Projovem (...); Agente Jovem; Saberes da Terra e Escola de Fábrica; Juventude Cidadã e Consórcio Social da Juventude. O objetivo foi ampliar o atendimento a um número maior de jovens assegurando-lhes a reintegração à escola e a qualificação profissional, além de inseri-los em ações de cidadania, esporte, cultura e lazer."
} 
Embora pensando por meio de um currículo que integra a elevação da escolaridade à formação profissional, a baixa carga horária (2.000 horas para a conclusão da segunda etapa do ensino fundamental, incluída a qualificação profissional) e o desenvolvimento de qualificações profissionais destinadas ao "trabalho simples", foram pontos criticados por pesquisadores da área trabalho e educação. Na análise de Rummert e Gaspar (2017, p. 405), “a formação integral anunciada no PROJOVEM constitui mais uma proposta vazia, marcada pela ausência de articulação quanto aos objetivos finais, caracterizando-se como mais uma política sazonal, transitória e precária".

Como iniciativas de formação profissional voltadas aos trabalhadores, a SETEC promoveu também outros dois Programas: Mulheres Mil e Rede Certific. O Programa Mulheres Mil consiste na qualificação profissional de mulheres em situação de vulnerabilidade social, tendo como eixo de atuação “educação, cidadania e desenvolvimento sustentável”. Para além da qualificação profissional o Programa Mulheres Mil tem como proposta o desenvolvimento da cidadania destas mulheres, assim parte dos conteúdos dos cursos emerge das necessidades do próprio grupo em formação. Um dos métodos de ensino utilizados nos cursos é a construção do mapa da vida, por meio do qual elas refletem sobre sua trajetória de vida e projetam suas expectativas para o futuro.

Inspirado em experiência do contexto canadense, esse programa teve início em 2007, como um projeto piloto desenvolvido em 12 estados das regiões norte e nordeste, por meio de uma parceria com a Association of Canadian Community Colleges (ACCC) do Canadá ${ }^{54}$. Foi institucionalizado em 2011, através da Portaria MEC n. 1.015, tendo como executores, preferencialmente, as instituições públicas de educação profissional (federais, estaduais e municipais), por meio do desenvolvimento de cursos de formação inicial e continuada e/ou cursos técnicos, que poderão estar articulados à elevação da escolaridade, na forma de cursos PROEJA. A partir de 2013, este Programa foi incorporado ao Pronatec Bolsa Formação, constituindo um dos públicos a ser atendidos dentro do Programa Brasil sem Miséria.

A Rede Certific (Rede Nacional de Certificação Profissional e Formação inicial e Continuada), por sua vez, foi criada, em 2009, com vistas a estimular a atuação dos Institutos Federais como "instituições acreditadoras e certificadoras de competências profissionais", conforme normatiza sua Lei de Criação (art. $2^{\circ}, \S 2^{\circ}$, da Lei 11.892/2008). Por meio de práticas de avaliação para o reconhecimento de saberes adquiridos nos processos de trabalho, os

\footnotetext{
${ }^{54}$ Para conhecer melhor a trajetória desse Programa, sugere-se a leitura do Artigo: O Programa Mulheres Mil e o Cooperativismo no Brasil, de Liliane Bordignon, publicado na Revista Trabalho Necessário, ano 14, número 24, de 2016.
} 
Institutos Federais poderiam realizar a certificação profissional para fins de inserção profissional, ofertando também a possibilidade de complementação dessa formação e elevação de escolaridade, através da oferta de cursos e programas específicos. A não dissociação entre certificação profissional e elevação da escolaridade configurou um grande avanço em relação às propostas de certificação do governo anterior ${ }^{55}$, baseadas apenas na certificação de competências laborais.

Após mais de 60 anos da criação e de autonomia absoluta das instituições do Sistema S, como o SENAI e o SENAC, em 2008, o governo Lula regulamentou o uso dos recursos oriundos da contribuição compulsória destinada a estas instituições, por meio de Acordos de Gratuidade, o que representou um grande avanço. Apesar de serem destinados à formação dos trabalhadores, não havia uma regulamentação que atrelasse a oferta gratuita de matrículas em cursos de formação profissional a partir desses recursos. O que ocorria, é que essas instituições realizavam de forma gratuita apenas cursos de curta duração, destinados às empresas a que estão ligadas, e cobravam pelos cursos técnicos e de qualificação ofertados à sociedade. De acordo com matéria publicada pelo IPEA, à época "apenas $45 \%$ das vagas na área da indústria são de graça e, no caso do comércio, o máximo oferecido é de $20 \%$. Em alguns estados sequer há gratuidade" (IPEA, 2008).

A proposta inicial do governo era criar o Fundo Nacional de Formação Técnica e Profissional (Funtep), a partir do percentual destinado às instituições de aprendizagem (1\% sobre a folha de pagamento das empresas), o qual seria gerenciado de forma participativa com vistas a redistribuir o recurso entre os estados por meio de critérios a serem definidos em lei (IPEA, 2008). No entanto, essa proposta soou como "intervencionista" e "estatizante" para os empresários e Confederações da área, o que levou o governo a recuar, resultando em um acordo que atrela um percentual desses recursos a serem aplicados em matrículas gratuitas, em cursos FICs, técnicos ou de aprendizagem, os quais são definidos pelas instituições.

Cabe ressaltar, conforme analisa Pinto (2016), que embora o setor empresarial privado busque transparecer em seu discurso que os recursos do Sistema "S" seriam "bancados pelo próprio setor, trata-se de uma falácia, uma vez que são tributos arrecadados pela Receita Federal do Brasil (RFB) como os demais, tendo por base essencialmente a folha de pagamentos e, como tributos indiretos que são, têm seu valor repassado ao preço final dos produtos”, sendo que o

\footnotetext{
55 O governo FHC produziu, segundo Moraes e Neto (2005), três documentos referenciais sobre certificação: Sistema Nacional de Certificação Profissional baseada em Competências, em fevereiro de 2000; Subsistema de Avaliação e Certificação Profissional baseada em Competências - SAC, em outubro de 2000 e Organização de um Sistema Nacional de Certificação baseada em Competências - SNCPC, em novembro de 2002, porém não resultaram em medidas concretas.
} 
ônus recai sobre o consumidor e "não ao empresário que tão somente o recolhe" (PINTO, 2016, p. 137). Além disso, a forma de gestão desses tributos, diferentemente dos demais tributos que compõem o fundo público, pelas entidades patronais do Sistema $\mathrm{S}$, ocorre de "forma bastante descentralizada e pouco transparente em termos de prestação de contas” (PINTO, 2016, p. 137), sendo que o montante arrecadado via contribuição compulsória "é de cerca de $0,3 \%$ do PIB, valor muitas vezes superior ao que é gasto na rede federal de educação profissional e técnica" (EDUCAÇÃO e SOCIEDADE, 2013, p. 337).

Nessa direção, por meio do chamado “Acordo de Gratuidade", aprovado pelos Decretos n. 6.633 - referente ao SENAC - e n. 6.635 - referente ao SENAI, tanto o SENAI quanto o SENAC deveriam destinar 2/3 (dois terços, que equivale a 66,66\%) de sua receita oriunda da contribuição compulsória para oferta gratuita de cursos, de forma progressiva com vistas a atingir o teto em 2014. Já as instituições de serviço social ligadas à indústria e ao comércio (SESI e SESC), que recebem 1,5\% sobre a folha de pagamento, devem destinar 1/3 (um terço, que equivale a 33,33\%) desta receita para a área de educação. As demais instituições do Sistema S - SENAT, SEST, SENAR, SESCOOP e SEBRAE - não fizeram parte do acordo.

Por meio desse Acordo, foi também definido um parâmetro de carga horária mínima para os cursos de formação inicial e continuada. Do patamar, inicialmente proposto pelo governo, de 200 horas, chegou-se ao acordo de 160 horas. Essa carga horária mínima serviu como parâmetro para as demais políticas de qualificação profissional, e inclusive para o Pronatec, e representou um avanço diante da carga horária praticada pelas instituições de educação profissional, especialmente as privadas e do Sistema $S$, que ofereciam cursos de formação profissional a partir de 20 a 60 horas.

Em paralelo a essas e tantas outras ações, o governo Lula desenvolveu o Plano Nacional de Qualificação (PNQ), financiado pelo Ministério do Trabalho e Emprego através de recursos do Fundo de Amparo ao Trabalhador (FAT), em substituição ao PLANFOR, dando continuidade à política de qualificação voltada ao atendimento das demandas do mercado de trabalho, porém com um viés formativo voltado também para as necessidades do trabalhador. Buscando superar as críticas dirigidas ao PLANFOR, o PNQ definiu como carga horária mínima para os cursos de qualificação profissional 200 horas $^{56}$; estimulou a integração entre a formação profissional e a educação básica e a valorização dos conhecimentos prévios dos trabalhadores e privilegiou formas descentralizadas e participativas de gestão, através dos mecanismos: Plano Territorial de Qualificação - PlanTeQ, desenvolvidos pelos Estados e

\footnotetext{
${ }^{56}$ Com o Pronatec todos os cursos de qualificação profissional passaram a ter o mínimo de 160h, o que significou um retrocesso frente a essa conquista que data de 2003.
} 
municípios, e Projetos Especiais de Qualificação - ProEsQs (TOLEDO, RUMMERT, 2009). Em que pese seu caráter de inclusão social, na análise de Kuenzer (2006), os cursos ofertados pelo PNQ não possibilitaram condições para a formação básica integrada à qualificação profissional, seja porque as agências formadoras - entre elas as agências do Sistema "S" - "não consideram atrativo o investimento em cursos mais extensos e que integrem conhecimentos básicos, o que não tem feito parte de sua experiência", ou por falta de interesse do "públicoalvo que busca alternativas que viabilizem a inclusão a curto prazo", dificultando o fechamento de turmas (KUENZER, 2006, p. 890).

Assim, a Política de Educação Profissional desenvolvida no governo Lula permitia a convivência de distintas concepções e práticas, representando avanços e permanências em relação à política do governo anterior. No entanto, pela primeira vez o projeto educacional voltado estritamente ao atendimento das demandas do processo produtivo perdeu força no cenário das políticas públicas direcionadas à educação profissional, ao entrar na disputa pela hegemonia o projeto educacional voltado aos interesses da classe trabalhadora, defendido pelas organizações sindicais, civis e acadêmicas. A partir da participação dessas organizações da sociedade civil e da presença de seus representantes no aparelho estatal, a concepção de educação profissional enquanto direito à educação de qualidade e o fortalecimento das instituições públicas para a oferta dessa modalidade de ensino foram materializadas por meio de políticas e programas.

No entanto, como a disputa pela hegemonia é um processo permanente (GRAMSCI, 2007), e o fato de que as conquistas estabelecidas no campo político não foram acompanhadas de mudanças econômicas estruturais, esses avanços ficaram sujeitos às alterações na própria correlação de forças que os produziram. Como expressão das disputas entre capital e trabalho, o projeto de educação profissional levado à cabo nos anos 1990 permaneceu latente, conquistando cada vez mais apoio, especialmente à medida em que o crescimento no número de empregos e o aumento dos salários demandava formas de aumento da produtividade, por parte das empresas, em prol de sua competitividade no mercado mundial (FIESP, 2012).

\subsection{0 "desvio de rota" ou a retomada da rota original?}

No campo da educação profissional, no qual as relações entre educação e trabalho são postas em maior evidência que em outras etapas e modalidades da educação básica, as disputas entre capital e trabalho, ou seja, entre classes sociais, se tornam mais evidentes, expressandose nas diferentes concepções pedagógicas e na natureza das políticas educacionais. Pode-se 
identificar evidências da perda de espaço do projeto da classe trabalhadora no momento da construção e aprovação das Diretrizes Curriculares para a Educação Profissional Técnica de Nível Técnico (DCN EPTNM), ao final do governo Lula e início do governo Dilma. Conforme análise de Ciavatta e Ramos (2012), a proposta relatada pelo Conselheiro Francisco Cordão ${ }^{57}$ da Câmara de Educação Básica do Conselho Nacional de Educação, no primeiro semestre de 2010, ignorou as particularidades introduzidas pelo Decreto 5.154/2004 em relação à formação integrada, reiterando em seu conteúdo "os princípios que orientaram a reforma da educação profissional e do ensino médio dos anos 1990" (p. 21), como o currículo orientado por competências. Essa proposta mobilizou vários órgãos e entidades ligadas à área, como o Fórum de Dirigentes de Ensino da Rede Federal de EPT (FDE), o Conselho de Dirigentes das Instituições Federais de Educação Profissional, Cientifica e Tecnológica (CONIF), a ANPED e setores do próprio Ministério da Educação, em especial a SETEC, que se reuniram em Brasília, por meio do Seminário da Educação Profissional e Tecnológica, no mês de maio do mesmo ano, juntamente com integrantes do Conselho Nacional de Educação, para discutir as Diretrizes da EPTNM (CIAVATTA, 2014).

A partir desse encontro, em face da mobilização criada, a SETEC organizou um Grupo de Trabalho com a participação das secretarias do MEC que atuam na educação básica e contando com "a colaboração de pesquisadores da educação profissional e tecnológica, representantes de entidades e de movimentos sociais" (CIAVATTA, 2014, p. 201), o qual elaborou uma proposta alternativa apresentada por meio do Documento "Educação Profissional Técnica de Nível Médio em Debate”. Esse documento serviu como base para a apresentação de uma proposta também para as Diretrizes Curriculares do Ensino Médio (DCN EM), que estavam na pauta do CNE, com vistas a estabelecer a articulação entre as duas, assegurando o ensino médio integrado à educação profissional e a concepção de formação politécnica no ensino médio (CIAVATTA, 2014).

No entanto, o caminho adotado pelo CNE foi outro. Enquanto o Parecer sobre as DCN EM incorporou a fundamentação contida na proposta do GT, o novo Parecer sobre as DCN EPTNM foi reapresentado em uma versão híbrida, buscando incorporar elementos da proposta alternativa, mas sem alterar a essência do documento. Por meio de Carta ${ }^{58}$ encaminhada ao CNE, o GT solicitou a retirada do documento em votação, reiterando a defesa dos princípios da

\footnotetext{
${ }^{57}$ Não por acaso, Francisco Cordão, identificado como "quadro orgânico do SENAI" (CIAVATTA, 2014), foi também o relator do Parecer CNE/CEB n. 16/99 que deu origem à Resolução CNE/CEB n. 04/99 que normatizou o Decreto 2.208/97.

${ }^{58}$ CARTA ao CNE/CEB. Em defesa da Educação Profissional Técnica de Nível Médio. Brasília, $1^{\circ}$ de junho de 2011. (Publicada, posteriormente, em: Revista Brasileira de Educação, v.17, n.49, p.219-222, jan.-abr. 2012).
} 
formação integrada e da necessária coerência e unicidade com as Diretrizes do Ensino Médio, aprovadas pelo Parecer CNE/CEB n. 05/2011, que preconizam a formação integrada, a politecnia e a formação humana integral nesse nível de ensino - a qual representou uma grande conquista das forças progressistas.

Como resultado dessas disputas, que provocaram a emissão de seis novas versões de Parecer e Resolução pelo CNE (MOURA, 2013), o texto final aprovado por meio do Parecer CNE/CEB 11/2012 e da Resolução CNE/CEB n. 06/2012, embora apresente avanços em relação à proposta inicial, incorporou à versão inicial do CNE fragmentos do documento elaborado pelos educadores, abrigando contradições e ambiguidades ao inserir lado a lado termos como "competências", "politecnia", "pensamento crítico", "autonomia intelectual" e "espírito empreendedor", como "se todos fizessem parte de um todo orgânico e articulado" (MOURA, 2013, p. 177). Ao analisar os embates ocorridos ao longo dos dois anos do processo de aprovação, Moura aponta que

(...) o metabolismo do capital se mostrou muito forte, conseguindo, inclusive, por meio de seus intelectuais orgânicos, utilizar-se de conceitos e expressões construídos para dar sentido a uma perspectiva de formação humana autônoma e emancipada com o fim de distorcê-los completamente na direção que lhe interessa (2013, p. 177).

De acordo com entrevista concedida no âmbito desta pesquisa pelo ex-Diretor de Qualificação do Ministério do Trabalho e ex-Superintendente da Educação Profissional no Estado da Bahia, Antonio Almerico Biondi Lima, desde a Conferência Nacional de Educação, em 2010, a discussão sobre os caminhos da educação profissional foi conduzida por disputas intensas: "foi um embate muito forte das redes públicas com a rede privada, particularmente, com o Sistema S”, sobre que tipo de educação seria priorizado (Entrevista LIMA, 2017). Esse debate permeou a construção das políticas na área, resultando no hibridismo observado na Resolução das Diretrizes da Educação Profissional:

Se você pegar a Resolução 6, de 2012, do Conselho Nacional de Educação - eu participei do debate, ativo; inclusive estava lá no dia da votação, eu e uma pessoa para falar da rede federal, intervindo, e citando várias coisas, não é -, ela é o espelho do que significava essa luta nesse período, porque ela é, alguns diziam, um Frankenstein; porque tem elementos que é quase Sistema $S$, e elementos que são muito avançados. Os elementos avançados, você pode creditar às redes públicas, que estavam lá defendendo a manutenção. E claro que a rede privada, o Sistema $S$, estavam lá também presentes, fazendo o mesmo, travando, não é, legitimamente, defendendo, num estado capitalista, os seus interesses. Então, deu essa Resolução. Ela é, para mim, o espelho bastante significativo disso (Entrevista LIMA, 2017). 
Essa disputa entre público e privado também permeou o processo de aprovação da Meta 11 do PNE, que define a meta de matrículas na Educação Profissional Técnica no decênio 20142024. A proposta inicial, encaminhada pelo MEC ao Congresso Nacional, previa a duplicação das matrículas, considerando os indicadores do ano de 2010 como referência, sendo $50 \%$ dessa oferta realizada pelo segmento público. Ao ser apreciada pela Câmara essa meta foi ampliada, estimando-se a triplicação das matrículas e considerando 2013 como ano referência, o que representou um acréscimo de 76\% à meta inicial (FASOLO, CASTIONI, 2017). Durante a apreciação pelo Senado, foi alvo de emendas no que se refere à prioridade de expansão pelo segmento público, sendo indicado como prioridade apenas a gratuidade, o que asseguraria o financiamento público de vagas em instituições privadas, como vinha ocorrendo por meio do Pronatec Bolsa Formação. Embora essa proposta tenha sido rejeitada pela Comissão de Educação, Cultura e Esporte, do Senado, e a redação final tenha assegurado a oferta de pelo menos $50 \%$ das vagas pelo segmento público ${ }^{59}$, esse posicionamento indicava que "boa parte do Senado Federal priorizava a possibilidade de financiamento de vagas por instituições privadas, diferentemente do defendido pela sociedade civil nas Conferências Nacionais de Educação" (FASOLO, CASTIONI, 2017, p. 586). Conforme destaca Freitas (2016, p. 139), “é pelo Congresso que os chamados reformadores empresariais da educação, (...) agem criando leis e abrindo facilidades para que a política pública educacional avance nessa direção”.

Nesse contexto de crescente disputa de interesses, em que a lógica mercadológica de educação profissional ganha mais força, emerge o Pronatec. Diferentemente do processo de disputas que marcou a criação das políticas de educação profissional no governo Lula, como se viu, a aprovação do Pronatec deu-se por meio de um processo quase sem conflitos, seguindo os trâmites de regime de urgência no seu processo de aprovação no Congresso Nacional. Assim, desde o percurso de sua criação se expressa o caráter dessa proposta: mais conciliadora com os interesses da burguesia.

Essa mudança de perspectiva nas políticas de educação profissional durante os governos do PT, levou alguns pesquisadores a situar dois momentos nessa trajetória, que expressariam diferentes projetos de educação profissional. Maldaner (2016), em sua pesquisa sobre o papel da formação docente no âmbito das políticas de EPT no período de 2003 a 2015, situa o primeiro momento, localizado nas políticas desenvolvidas entre 2003 e 2009, como aquele orientado por

\footnotetext{
${ }^{59}$ A Meta 11, que se refere à Educação Profissional Técnica apresentou a seguinte redação na Lei no ${ }^{\circ}$ 13.005/2014, que aprova o PNE "Meta 11: triplicar as matrículas da educação profissional técnica de nível médio, assegurando a qualidade da oferta em pelo menos $50 \%$ (cinquenta por cento) da expansão no segmento público" (BRASIL, 2014). Uma análise mais detalhada do processo de aprovação da Meta 11 do PNE no Congresso pode ser encontrada em Fasolo e Castioni (2017).
} 
uma “concepção orgânica entre trabalho e educação" (p. 13), expressa por meio de políticas como o Proeja e o Ensino Médio Integrado. No segundo momento, iniciado a partir de 2009, as políticas nessa área passam a ser orientadas por uma "concepção que vê o trabalho como emprego" (p. 13), o que se expressa por meio do Pronatec. Para Lima (2012), o Pronatec demarca uma mudança de direção no projeto que se encontrava no caminho de consolidação do direito à educação profissional de qualidade social, para um processo de "mercantilização da educação", que ao mesmo tempo em que promove a formação para o mercado, cria "um mercado da formação" (LIMA, 2012; 2016).

$\mathrm{Na}$ interpretação realizada nesta Tese, o "desvio de rota" nas políticas de educação profissional a partir do Pronatec expressa a disputa desses diferentes projetos formativos no âmbito das políticas públicas promovidas por um mesmo governo. O projeto formativo concebido a partir das experiências e lutas da classe trabalhadora que orientou as políticas e programas nessa área no início dos anos 2000, tornando-se hegemônico no âmbito da formulação das ações governamentais, tem sua direção disputada pelo projeto formativo orientado pelo mercado, o qual ganha espaço a partir da política do Pronatec. Assim, não há, necessariamente, uma subsunção de um projeto formativo por outro, mas uma mudança de direção na disputa de hegemonia nesse campo, a qual será melhor explicitada ao longo do texto.

Com vistas na apreensão dos possíveis fatores que levaram a esta mudança de perspectiva na política de educação profissional, no próximo Capítulo, analisa-se o processo de construção do Pronatec, a partir do contexto político e econômico em que emerge esta política e do discurso de gestores e técnicos da SETEC. Tendo como foco central desta pesquisa a iniciativa Bolsa Formação, analisa-se a concepção pedagógica que a orienta, a partir da ação Pronatec Empreendedor, e as formas de pactuação e oferta de cursos pelas diferentes instituições ofertantes. E por fim, com base nos indicadores de matrículas e de orçamento, analisa-se o impacto do Pronatec Bolsa Formação nas demais ações de educação profissional já em andamento. 
Capítulo II

\section{A Construção do Pronatec Bolsa FormaÇão e suas IMPlicaÇões no} Conjunto das Políticas de Educação Profissional

Com o objetivo de identificar e analisar os fundamentos político-econômicos e os sujeitos/instituições que deram sustentação ao Pronatec Bolsa Formação, neste Capítulo, apresenta-se uma análise a partir de referências da área da economia e das ciências sociais sobre o contexto em que emerge essa política de educação profissional. A partir dos elementos desse contexto, sem perder de vista o histórico da educação profissional analisado no primeiro Capítulo, busca-se, na primeira parte deste Capítulo, situar as entrevistas realizadas com gestores e técnicos da SETEC e do MTE com vistas à apreensão das disputas que deram origem ao Programa. Levando-se em consideração a inflexão da política econômica para um projeto de reindustrialização do país a partir do governo Dilma e do crescimento do orçamento destinado à educação profissional, trabalha-se com a hipótese de que ao assumir a "Agenda Fiesp" (CARVALHO, 2018), o governo tenha aberto a brecha necessária para o aprofundamento da disputa pela hegemonia/direção do projeto de formação da classe trabalhadora em prol do projeto privatista que vinha orientando essa modalidade de ensino até o final dos anos 1990, que se traduziu no protagonismo do Sistema S na oferta, na transferências de recursos públicos e na orientação pedagógica do Pronatec Bolsa Formação.

Na segunda parte, tendo como foco central da análise a iniciativa Bolsa Formação do Pronatec, situa-se sua regulamentação normativa a partir da relação entre demandante e ofertante, os quais configuram diferentes modalidades de oferta, e as normas quanto ao repasse e utilização dos recursos, consolidadas ao longo do período analisado (2011 a 2016). Apresenta-se, também, uma caracterização do perfil de cursos e do público atendido pelas diferentes instituições no âmbito do Programa. Por fim, na terceira e última parte, considerando o caráter "guarda-chuva" representado pelo Pronatec, caracteriza-se, a partir de indicadores de matrículas e de orçamento, a forma como "caminharam" as demais iniciativas de oferta da educação profissional que se abrigam sob esse mesmo guarda-chuva.

\subsection{O Pronatec como expressão da coalizão com a burguesia industrial no governo Dilma e da disputa privada pelos fundos públicos}

O Pronatec surge em um período marcado pelo crescimento da economia e consequente diminuição das taxas de desemprego. Em 2010, o país havia atingido um crescimento de 7,5\% 
no PIB, o maior crescimento registrado desde os anos 1980, e o desemprego alcançava a menor taxa dos últimos 8 anos, 6,7\% em média, chegando a 5,3\% no mês de dezembro (IBGE, 2011). Após um período de crescimento ancorado no "boom de exportação de commodities" (de 2003 a 2005), motivado especialmente pelo crescimento da economia chinesa, a segunda metade dos anos 2000 - mais especificamente, o segundo Governo Lula -, foi marcada pelo crescimento do mercado interno, promovido pelas políticas redistributivas e investimentos públicos, o que não permite atribuir esse bom momento da economia brasileira apenas a um "momento de sorte" (CARVALHO, 2018). Nesse período, conforme análise da economista Laura Carvalho (2018, p. 10), o país obteve, juntamente com a elevação das taxas de crescimento, "uma redução das desigualdades sociais e regionais, o aumento sustentado dos salários, a elevação do nível de emprego formal, a melhoria das contas públicas e externas, tudo isso mantendo as taxas de inflação sob controle", resultado do bom momento da economia global aliado à política econômica do governo, o que teria configurado o "Milagrinho brasileiro", na visão de parte dos economistas.

O termo "Milagrinho" é utilizado por Carvalho (2018) em contraposição ao "Milagre econômico" ocorrido no período ditatorial, que teve taxas mais altas de crescimento. Outra diferença entre esses dois momentos é de que no período do "Milagrinho" o crescimento, embora menor, foi acompanhado de uma redução das desigualdades sociais, enquanto o primeiro representou a sua ampliação - conforme a linguagem da época: "o bolo cresceu, mas não podia ainda ser dividido" (CARVALHO, 2018, p. 22). Segundo a autora, isso ocorreu, conforme análise de Tavares e Serra (1972), porque o crescimento da economia no período do Milagre econômico se deu nos setores de bens industrializados mais sofisticados, que demandava mão de obra relativamente qualificada, com salários acima da remuneração média. Ou seja, não incluía os trabalhadores da base da pirâmide, o que ampliou as desigualdades salariais. Já em relação ao Milagrinho, "as transferências de renda via Bolsa Família, a valorização mais acelerada do salário mínimo e a inclusão no mercado de consumo ${ }^{60}$ de uma parte significativa da população brasileira levaram à expansão de setores cuja produção demandava uma mão de obra menos qualificada" - como no caso de "muitos setores de serviços e da construção civil, que cresceram de forma expressiva nesse período" (CARVALHO, 2018, p. 22). O que, por sua vez, promoveu a ampliação do número de trabalhadores da base da pirâmide salarial, a qual, junto à valorização do salário mínimo, contribuiu para diminuir a

\footnotetext{
${ }^{60}$ Aliado ao aumento da renda, as políticas de acesso ao crédito - sejam elas direcionadas, como as linhas de crédito destinadas à habitação e à agricultura, ou livres, como o crédito consignado -, também promoveram o estímulo ao consumo nos anos do Milagrinho, conforme analisa Carvalho (2018).
} 
diferença salarial entre a base e a remuneração média da pirâmide, impactando positivamente os indicadores de desigualdade social: o índice GINI, que mede a distribuição de renda, passou de 0,594, em 2001, para 0,527, em 2011, atingindo o menor nível de desigualdade de renda desde os anos 1960, quando foram realizados os primeiros registros nacionais, conforme aponta estudo do IPEA (2012).

Somado ao processo de transferência de renda, o crescimento econômico nos anos do Milagrinho foi impulsionado, especialmente, pelo investimento público, que cresceu em média 27,6\% entre 2006 e 2010, capitaneado, principalmente, em torno do PAC (Programa de Aceleração do Crescimento), lançado no início de 2007. O investimento público potencializou o crescimento à medida que "esses investimentos induzem outros investimentos e geram emprego e renda no conjunto da economia, estimulando também um maior consumo das famílias", aponta Carvalho (2018).

Assim, juntamente com a alta do preço e da exportação de commodities, a distribuição de renda, a expansão do crédito e os investimentos públicos, que compõem os "três pilares de crescimento" desse período, explicam o bom desempenho da economia, na análise de Carvalho. Na composição do PIB, o maior crescimento real foi observado em relação ao investimento e não ao consumo das famílias, ao contrário do que faziam crer as análises que indicavam um crescimento da economia apenas pelo consumo: “o consumo das famílias teve crescimento real médio anual de 5,8\% entre 2006 e 2010, ante 9,1\% de crescimento real anual do investimento no mesmo período" (CARVALHO, 2018, p. 33).

No entanto, esse crescimento guardava algumas contradições internas para a economia a longo prazo, como a baixa participação da indústria ${ }^{61}$, que vinha em decadência desde os anos 1980, aprofundada nos anos 1990 (CARVALHO, 2018), e a ausência de marcos regulatórios sobre a taxação da renda e do patrimônio, fruto da própria correlação de forças que o governo procurava $\operatorname{arbitrar}^{62}$. Do ponto de vista social, a diminuição das desigualdades de renda, foi acompanhada pelo crescimento de capital no topo da pirâmide, estimulado também pela política de crédito que transfere o pagamento dos juros para o setor financeiro e a manutenção das altas taxas de juros, que fazia crescer os ganhos com os títulos da dívida pública, concentrados nas mãos dos mais ricos ${ }^{63}$. Ao mesmo tempo, o meio da pirâmide apresentou os menores ganhos

\footnotetext{
${ }^{61}$ De acordo com os indicadores apresentados por Laura Carvalho (2018), a participação da indústria no PIB teve seu auge em 2004, com 24,3\%. Em 2010, a participação da indústria havia caído para 12,7\%, enquanto os serviços haviam aumentado de 54,9\%, em 2004, para 57,6\%, e o setor de construção de 4,2\%, para 5,3\%.

${ }^{62}$ Conforme as análises de Singer (2009; 2012; 2015; 2018) e Boito Jr (2012), como se viu no Capítulo I.

${ }^{63}$ Em 2010, o percentual do PIB investido no Programa Bolsa Família foi de 0,36\%, enquanto que o pagamento de juros com a dívida pública foi de 1,2\% do PIB. Embora a parcela de juros tenha sido reduzida durante os governos Lula, resultante da diminuição do saldo da dívida, que chegava a 5\% do PIB em 2005, a alta taxa de
} 
em relação à valorização salarial, sofrendo os impactos do aumento do valor dos serviços, promovido pela valorização salarial da base da pirâmide ${ }^{64}$. Assim, em que pese o crescimento da distribuição da renda, graças ao aumento acelerado dos rendimentos de trabalhadores da base da pirâmide, "a renda do capital cresceu ainda mais e se manteve altamente concentrada na mão dos mais ricos" (CARVALHO, 2018, p. 50), uma vez que a política adotada não implicou "na redistribuição de renda do topo da pirâmide para o meio ou para a base" (CARVALHO, 2018, p. 49-50), o que ajudou a manter a estabilidade do governo. Os setores médios, por sua vez, sofriam os efeitos econômicos e sociais da ascensão da classe trabalhadora, por meio do aumento no custo dos serviços e do rompimento de fronteiras em relação aos espaços considerados "de classe média" (como, por exemplo, ingresso em universidades, viagens de avião e ampliação dos espaços de lazer e consumo), descontentamento que viria a se expressar mais tarde na adesão desses segmentos às jornadas de junho, embora orientados mais pelo seu "preconceito de classe" (SOUZA, 2016) do que pela consciência da sua nova condição de renda em relação à base e ao topo da pirâmide.

Nessa direção, apresentava-se o desafio da obtenção de maior arrecadação tributária para que o pilar da distribuição de renda, que se apoiava na maior arrecadação a partir do crescimento da economia, não retrocedesse a partir da primeira crise, e da promoção do desenvolvimento de setores estratégicos da indústria e de serviços para que o dinamismo do mercado interno se sustentasse no longo prazo $^{65}$. As críticas em relação ao baixo desenvolvimento da indústria, realizada por economistas e pelo próprio setor, ganhou cada vez mais força, tendo conquistado o apoio de organizações da classe trabalhadora e da Presidente eleita em 2010, a economista Dilma Rousseff, "formada em economia em uma escola de tradição industrialista" (CARVALHO, 2018, p. 57), que passou a orientar a política econômica do seu governo a partir de medidas de intervenção estatal que proporcionassem condições para a reindustrialização do país, na expectativa de crescimento da economia e geração de empregos mais qualificados.

\footnotetext{
juros contribuía para que o Estado transferisse renda "para os detentores de riqueza financeira", representando 3 vezes mais que o percentual destinado às políticas de distribuição de renda (CARVALHO, 2018, p. 53).

${ }^{64}$ Com base no estudo de Morgan, que analisou a desigualdade de renda com base nos dados da Pesquisa Nacional por Amostra de Domicílios (PNAD) e informações de declarações de Imposto de Renda, obtidas via receita federal, Carvalho aponta que "enquanto os 50\% mais pobres aumentaram sua participação na renda total de $11 \%$ para $12 \%$ entre 2001 e 2015 , os $10 \%$ mais ricos subiram a sua parcela de $25 \%$ para $28 \%$ ", já "os $40 \%$ intermediários reduziram sua participação na renda de 34 para $32 \%$ naqueles anos" (2018, p. 50). Esse fenômeno foi chamado por Morgan (apud CARVALHO, 2018) de squeezed middle, ou "miolo espremido".

65 "Se o comércio cresce e a indústria não, é porque os produtos comprados estão sendo produzidos em outro lugar" (CARVALHO, 2018, p. 43). E, de fato, as importações haviam crescido 103,4\% em termos reais, no acumulado entre 2005 e 2010 , motivada pela valorização do real nesse período.
} 
Com isso, o Governo Dilma investiu no aprofundamento do "desenvolvimentismo 66 ", a partir de uma base de sustentação que apostava na "coalização entre os industriais e os trabalhadores" (SINGER, 2018, p. 39). Os sinais para essa aposta seriam confirmados no documento entregue ao governo, produzido a partir de seminário reunindo representantes de trabalhadores e empresários, ocorrido em maio de 2011, que demonstrava a preocupação frente à baixa participação da indústria de transformação no PIB e a importância do desenvolvimento de uma política industrial:

\begin{abstract}
A previsão de que em 30 ou 40 anos o Brasil será a quarta economia do mundo apenas se sustenta com o restabelecimento do papel da indústria e com o adensamento de suas cadeias produtivas. Não existem países cujos cidadãos gozem de alto padrão de vida e pleno acesso a bens e serviços que não contem com indústria sólida, diversificada e com alto grau de inserção em mercados internacionais. A possibilidade de estabelecimento de um diálogo contínuo entre a Federação das Indústrias do Estado de São Paulo (Fiesp), a Central Única dos Trabalhadores (CUT), a Força Sindical, o Sindicato dos Metalúrgicos do ABC e o Sindicato dos Metalúrgicos de São Paulo é algo inovador e reflete o compromisso de construir um Brasil forte e industrializado. Este é o momento para que os diferentes atores desse processo - trabalhadores, empresários e o governo - formem um grande consenso acerca da política industrial nos rumos da economia (SKAF, HENRIQUE e SILVA, 2011 ${ }^{67}$ ).
\end{abstract}

Alçado novamente à frente do Ministério da Fazenda, Guido Mantega - um dos quadros do governo Lula que mais se identificava com a linha desenvolvimentista - coordenou a "nova matriz econômica"68, que apresentava uma série de ações com vistas a estimular a economia interna, especialmente por meio da geração de condições, pelo Estado, que impulsionassem a produção industrial do país, sendo a maioria oriunda das reinvindicações do setor. Entre essas ações, Singer (2018, p. 43-46) destaca: redução dos juros - as taxas básicas de juros que eram de 12,5\% passaram para 7,5\% entre agosto de 2011 e abril de 2013; ampliação de crédito por meio do BNDES, destinando crédito subsidiado a empresas para fins de "produção, aquisição e exportação de bens de capital e inovação tecnológica"; criação do Programa Brasil Maior, que reunia 287 ações (entre elas redução do Imposto sobre Produtos Industrializados - IPI, com vistas a estimular o consumo de produtos nacionais), atendendo às reinvindicações da indústria,

\footnotetext{
${ }^{66}$ Singer, apesar de reconhecer os limites do uso do termo "desenvolvimentismo" em relação ao seu conteúdo original, diz preferir esta palavra para "ressaltar a marca de ativismo estatal da nova matriz. A vantagem em utilizála está em denotar o viés antiliberal da experiência dilmista." (SINGER, 2018, p. 42, grifos do autor). Ao mesmo tempo, aponta que sua interpretação estaria protegida pelo termo "ensaio", "que remete tanto ao caráter efêmero da experiência como ao seu contorno vago" (SINGER, 2018, p. 42).

${ }^{67}$ Publicado na Folha de São Paulo em 26 de maio de 2011, o documento, intitulado "Um acordo pela indústria brasileira", estava assinado pelos Dirigentes da Fiesp (Federação das Indústrias do Estado de São Paulo) e do Ciesp (Centro das Indústrias do Estado de São Paulo), Paulo Skaf, da Central Única dos Trabalhadores (CUT), Arthur Henrique e da Força Sindical, Paulo Pereira da Silva.

${ }^{68}$ Conforme o texto de Mantega: "O primeiro ano da nova matriz econômica" publicado em Valor Econômico, em 19 dez. 2012.
} 
via CNI, e estimulando o microempreendedorismo por meio da ampliação da política do MEI (Microempreendedor Individual); desoneração da folha de pagamento de quinze setores intensivos em mão de obra, que, em 2014, chegou a 56 setores (CARVALHO, 2018), com vistas a reduzir a "carga fiscal elevada" aos empresários; Programa de Investimentos em Logística (PIL), a partir de leilão de concessão de rodovias e ferrovias à empresas privadas que apresentassem as menores tarifas, com vistas a ampliar os investimentos privados em infraestrutura (a partir do final de 2012 o governo estendeu o PIL para portos e aeroportos); Reforma do Setor Elétrico, que reduziu em $20 \%$ o preço da eletricidade, atendendo à reivindicação da indústria como forma de reduzir seus custos e aumentar a competitividade ${ }^{69}$; desvalorização do real para favorecer os produtos da indústria nacional (passou de 1,65 real por dólar no final do governo Lula para 2,05 reais o dólar no início de 2012) e, associado a essa medida, o controle de capitais, por meio de ações como a ampliação do IOF (Imposto sobre Operações Financeiras) em transações internacionais, com o objetivo de limitar a entrada de dólares e, assim, evitar a valorização do real; e medidas de proteção ao produto nacional, via elevação de impostos sobre alguns produtos e veículos importados, e políticas de valorização da produção nacional, como a construção de navios-sondas pela Petrobrás com a exigência de que $55 \%$ a $65 \%$ de seu conteúdo fosse nacional.

$\mathrm{Na}$ análise de Carvalho, essa nova matriz econômica representava, na prática, a “Agenda Fiesp" ${ }^{\text {70 }}$. Quando o governo anunciou a redução no preço da energia elétrica, o Presidente da Fiesp, que havia liderado a campanha "Energia a Preço Justo" desde 2011, comemorou a medida no noticiário televisivo: "Com o apoio da presidente Dilma, da maioria dos deputados

\footnotetext{
${ }^{69}$ Realizada por meio de Medida Provisória (MP n. 579), em setembro de 2012, essa medida promoveu a antecipação do término de contratos com concessionárias de energia, com vistas na diminuição das tarifas. Um dos efeitos "colaterais" dessa medida foi o impacto no valor de mercado das empresas envolvidas, causando perda aos investidores. Conforme aponta Singer, um exemplo foi o que aconteceu com o Fundo norueguês Skagen que "tinha no começo de 2012 uma participação que valia 1,3 bilhão de reais na Eletrobrás; depois do pacote passou a valer 740 milhões de reais", com isso o Fundo reagiu "com a seguinte declaração bombástica ao Financial Times: 'Vemos isso como uma forma de nacionalização de propriedade então é mais ou menos o que vimos na Venezuela e Argentina" (SINGER, 2018, p. 45). Esses efeitos iriam repercutir, mais tarde, no movimento "antidesenvolvimentista", analisa Singer.

${ }^{70}$ Laura Carvalho questiona a tese de Singer de que a "nova matriz econômica" seria desenvolvimentista, ou um ensaio desenvolvimentista, pois o investimento público diminuiu muito nesse período - o investimento público chegou a 4,6\% do PIB em 2010, ante os 2,9\% verificados em 2006, diminuindo para 3,94\%, em 2014 - em especial no setor de infraestrutura. Nas suas palavras: "dificilmente se atribui a alcunha de 'desenvolvimentista' a um modelo em que os investimentos públicos em infraestrutura não são protagonistas" (CARVALHO, 2018, p. 85). Além disso, discorda que a política econômica do governo Dilma teria fracassado apenas em função da frente "antidesenvolvimentista" gerada a partir da intervenção do Estado nos interesses do capital financeiro, resultado das medidas de redução dos juros. Na sua análise, a "agenda Fiesp" não era "tão progressista quanto pode parecer à primeira vista" e "havia razões econômicas suficientes para que os empresários não realizassem maiores investimentos", uma vez que "não havia qualquer expectativa de aumentar as vendas" e grande partes das empresas estava comprometida com obrigações financeiras decorrentes de empréstimos contraídos para enfrentar a crise de 2008/2009 (CARVALHO, 2018, p. 77).
} 
e senadores e com o apoio de todos vocês, o sonho virou realidade" (CARVALHO, 2018, p. $68)$.

Sem entrar, neste momento, nos problemas políticos e econômicos decorrentes dessa nova matriz econômica, destaca-se a existência desse cenário, a partir de 2010, pois, na intepretação aqui realizada, a decisão política de atender às demandas dos industriais teria fortalecido o projeto educacional da burguesia para a formação profissional. O interesse e a preocupação do governo em estimular o desenvolvimento da indústria brasileira, que dependia da mobilização dos agentes privados, trouxe para o âmbito das políticas de educação profissional o protagonismo do Sistema $\mathrm{S}$ - instituição ligada às organizações patronais da indústria, comércio, infraestrutura e rural - que defende uma formação profissional alinhada com as necessidades das empresas da área, em detrimento da formação integral do trabalhador. Além disso, o crescimento da oferta de educação profissional em instituições públicas, tanto na Rede Federal quanto nas Redes Estaduais, somado ao Acordo de Gratuidade com as principais instituições de ensino do Sistema S, como se viu, limitou o uso e a expansão da receita dessas instituições. Diante do crescimento do orçamento público destinado à educação profissional, gerou-se uma disputa pelo acesso a esses fundos, como se observa historicamente na relação público-privada no campo educacional.

Pode-se citar duas medidas que reforçam esse raciocínio: a inclusão dos Serviços Nacionais de Aprendizagem (que são as instituições de ensino do Sistema S) no sistema federal de ensino, por meio do artigo 20 da Lei do Pronatec, conferindo-lhes autonomia para a criação de instituições e de cursos (antes, esses atos institucionais estavam subordinados à autorização dos Conselhos Estaduais de Educação), e o financiamento subsidiado via BNDES para a ampliação da infraestrutura do SENAI, no valor de 1,5 bilhões de reais, liberado em março de 2012. De acordo com notícia publicada no site da CNI, o empréstimo junto ao BNDES permitiria atender a demanda de formação da mão de obra necessária para o desenvolvimento da indústria:

A ampliação e a modernização das instalações aumentarão a capacidade do SENAI de oferecer cursos para formação profissional e soluções tecnológicas para as indústrias. O objetivo do SENAI, um dos principais parceiros do Programa Nacional de Acesso ao Ensino Técnico e Emprego (Pronatec), do governo federal, é dobrar em dois anos o número de matrículas de educação profissional. Em 2011, a instituição registrou 2,4 milhões de matrículas. A meta é alcançar 4 milhões de matrículas ao ano em 2014. "O SENAI funcionará como um trampolim para a competitividade da indústria brasileira, seja na capacitação da força de trabalho, seja na agenda de tecnologia e de inovação", explica o diretor-geral do SENAI, Rafael Lucchesi. Segundo ele, a qualificação de pessoas e a inovação são decisivas para a indústria agregar valor à produção e ganhar competitividade (CNI, 2012). 
A análise indica que a realização do projeto econômico foi acompanhada de um projeto determinado de formação profissional da classe trabalhadora. A formação da mão de obra no capitalismo tem um duplo propósito: aumentar a produtividade do trabalho e o montante de trabalhadores qualificados disponíveis, de forma que a relação entre a oferta de postos de trabalho e o número de trabalhadores faça diminuir o custo da mão de obra - a qual havia encarecido a partir do aumento do salário mínimo e do crescimento do emprego. O crescimento econômico experimentado na primeira década dos anos 2000 havia incorporado boa parte do subproletariado no mercado de trabalho, reduzindo, assim, "o exército industrial de reserva", como diria Marx. Frente a isso, crescia entre os empresários o discurso do "apagão de mão de obra", largamente noticiado pelos meios de comunicação ${ }^{71}$.

No entanto, estudos realizados por técnicos do IPEA (Instituto de Pesquisa Econômica Aplicada), nesse período, procuravam, empiricamente, demonstrar que não havia motivos para essa preocupação - pelo menos não de forma generalizada como os empresários faziam crer:

\begin{abstract}
O debate acerca de um eventual "apagão" de mão de obra qualificada no Brasil vem sendo recorrentemente colocado em pauta por setores empresariais, do governo e da imprensa do país nos últimos anos. O temor de que o crescimento econômico pudesse vir a ser limitado pela baixa disponibilidade de mão de obra qualificada se intensificou ao longo da década de 2000, arrefeceu um pouco durante a crise financeira internacional eclodida no último trimestre de 2008 e voltou a ganhar destaque diante do crescimento elevado do Produto Interno Bruto (PIB) em 2010. Mesmo com a deterioração das expectativas no decorrer de 2011, quando o cenário internacional volta a sinalizar um recrudescimento da crise global, o receio de um possível "apagão" dessa natureza permeia discussões sobre os desafios do Brasil na década de 20112020, particularmente em face dos investimentos em infraestrutura necessários para a Copa do Mundo, para as Olimpíadas e para a exploração de petróleo na camada do pré-sal. No centro desse problema estariam os profissionais de áreas técnicocientíficas - tais como engenheiros, tecnólogos e técnicos de nível médio empregados em atividades industriais e na construção civil. Vale notar, contudo, que as análises empíricas disponíveis não parecem corroborar essa percepção fundada no senso comum. A leitura desses trabalhos sugere que a escassez de mão de obra não seria um problema generalizado na economia brasileira, pelo menos não quando se tenha em mente as camadas mais qualificadas da força de trabalho, isto é, profissionais com formação em nível técnico ou superior (NASCIMENTO, 2011, p. 19).
\end{abstract}

Dois anos depois, nova análise do IPEA (2013) com base nos dados da Pesquisa Nacional por Amostra de Domicílios (PNAD/IBGE) indicava que na série histórica compreendida entre 1992 e 2012 o perfil da população desempregada se alterou inversamente

\footnotetext{
${ }^{71}$ Em uma rápida pesquisa sobre o tema na internet, pode-se encontrar várias páginas de notícias sobre o "apagão de mão de obra", que datam entre 2009 a 2012, tais como algumas manchetes de sites e jornais: "Especialistas alertam para apagão de mão de obra em alguns setores - Se o crescimento do Brasil continuar num ritmo forte há risco de faltar trabalhador", publicada pelo site do G1, em 18/02/2011; "Confira as 20 ocupações com maior apagão de mão de obra", publicada na coluna de Economia do site de notícias UOL, em 2012; "Falta de mão de obra qualificada é um entrave", na Folha de São Paulo, em 26 de dezembro de 2010.
} 
em relação aos anos de estudo: em 1992, 20\% da população desempregada possuía mais de 11 anos de estudo, chegando a mais de 50\% em 2012. Já entre aqueles com 0 a 7 anos de estudo, a proporção se tornou o inverso: em 1992 esse perfil compunha mais de 50\% da população desempregada, passando para menos de $20 \%$ em 2012. Nesse sentido, a análise dos dados indicava que havia

\begin{abstract}
fortes evidências contrárias à noção de que haveria uma escassez de mão de obra qualificada no país. De um lado, a oferta - tanto relativa quanto absoluta - de trabalho qualificado vem aumentando quase que continuamente, especialmente na última década. De outro, o preço relativo da mão de obra mais qualificada vem caindo também quase que continuamente. Mais ainda, os desempregados hoje são em sua maioria qualificados e não o contrário. Sendo assim, essas evidências sugerem que, se há escassez, é de mão de obra não-qualificada (IPEA, 2013, p. 19).
\end{abstract}

Nesse contexto, revela-se a inconsistência da teoria do capital humano, que aponta para uma relação direta entre formação profissional e inserção no mercado de trabalho, a qual, apesar das evidências empíricas, "alcança um imenso sucesso e uma ampla difusão", uma vez que oferece "uma justificativa econômica às despesas educativas, a única que tem valor hoje em dia aos olhos dos que tem poder de decisão" (LAVAL, 2004, p. 29 e 26). A análise do IPEA revela, ainda, os problemas da própria estrutura do mercado de trabalho no país, que expressa um sistema produtivo baseado em postos de trabalhos simples, para o qual a desigualdade educacional e econômica se constitui em um dos pilares em que se assenta o desenvolvimento do país (OLIVEIRA, 2013).

Contudo, o tema ocupou importante espaço nos debates e nas propostas das candidaturas à presidência, em 2010, e passou a pressionar o governo eleito a apresentar iniciativas para enfrentar o suposto "apagão de mão de obra". A continuidade do governo do Partido dos Trabalhadores, a partir da eleição da Presidente Dilma Roussef, fazia crer que a política nessa área fosse a continuidade e aprofundamento do ensino técnico integrado ao ensino médio e dos programas de qualificação profissional integrados à elevação da escolaridade, construídos nos últimos oito anos, conforme defendiam os movimentos sociais e entidades educacionais de esquerda. No entanto, junto da proposta de expansão das instituições públicas de EPT e da continuidade das políticas e programas em andamento, foi criada, por meio do Pronatec, essa nova iniciativa de fomento à oferta de educação profissional, a Bolsa Formação, que trilha um outro caminho, como seus indicadores demonstram. O "desvio de rota" conforme vem sendo apontado nesta Tese, se revela, nesse sentido, na disputa de hegemonia de dois diferentes projetos de formação profissional no interior das políticas de educação profissional lideradas por um mesmo governo. 
Desde o projeto de Lei, o Pronatec Bolsa Formação previa a participação das instituições formadoras do Sistema S. Tendo em vista o prestígio dessas instituições junto aos empresários, seria contraditório que, ao atender as demandas dos industriais, a política governamental desenvolvida na área de ensino profissional não incluísse suas principais instituições educativas. A participação dessas instituições faria parte, nesse sentido, do consenso com a burguesia industrial e a classe trabalhadora na formação de mão de obra para alavancar o setor industrial, o que, supostamente, permitiria melhores ofertas de empregos e condições de vida para toda a sociedade.

É importante destacar aqui alguma semelhança com a estratégia da burguesia no processo histórico de criação do Sistema S, como se viu na análise de Weinstein (2000) apresentada no Capítulo I. No contexto de criação do Pronatec, diante da suposta demanda de mão de obra, essa classe pressiona o governo para o fomento de políticas na área, mas busca assegurar que suas instituições de ensino sejam protagonistas e, sobretudo, tenham autonomia sobre o processo formativo. Novamente, o Pronatec Bolsa Formação se apresenta como uma equação perfeita: a partir de recursos públicos as instituições do Sistema $\mathrm{S}$ puderam desenvolver a oferta de acordo com sua proposta pedagógica e ainda obter uma receita que, para além de suprir os gastos com a oferta, também permitiu investimentos na sua infraestrutura, como se observou no estudo de caso realizado em uma dessas instituições.

Destaca-se que durante os governos Lula as instituições do Sistema S se mantiveram como parceiras na execução de políticas públicas de qualificação profissional, como o PNQ, por exemplo. No entanto, o fortalecimento das instituições públicas, federais e estaduais, e a concepção político-pedagógica voltada ao desenvolvimento de cursos e programas integrados à educação básica, oriunda das experiências e demandas das organizações da classe trabalhadora e de entidades educacionais progressistas, direcionou grande parte das políticas desenvolvidas nessa área, embora não sem conflitos e disputas, fazendo com que as matrículas públicas ultrapassassem a oferta privada, conforme se observou no Gráfico 01. A concepção de educação profissional que orientou as ações do MEC, nesse período, levou ao questionamento da baixa carga horária desenvolvida nos cursos de qualificação ofertados especialmente pelo Sistema S, ampliando-a para o mínimo de 160 horas, assim como a regulamentação da oferta gratuita de matrículas nessas instituições por meio do Acordo de Gratuidade, como se viu. Havia, portanto, uma disputa de projetos, na qual o projeto historicamente hegemônico havia perdido força, tanto na condução dessa modalidade de ensino quanto no acesso aos recursos públicos. 
Embora bem-sucedidas do ponto de vista social, a política de educação profissional centrada em sistemas de ensino públicos e integrada à educação básica é criticada pelos empresários, que julgam ser uma formação demorada e que não atenderia às necessidades e à celeridade das mudanças no mercado de trabalho. Essa crítica não é realizada apenas pelos empresários brasileiros, mas observada em vários países e tem como principais porta-vozes os organismos internacionais, especialmente o Banco Mundial, que insere seu projeto educacional, aliado aos interesses do capital, como contrapartida aos seus financiamentos - como o que ocorreu por meio do PLANFOR, no Brasil, nos anos 1990 (OLIVEIRA, 2003; 2006).

O avanço da lógica empresarial no desenvolvimento da formação profissional segue tendência capitalista mundial de desconstruir a forma escolar, sob a alegação de que as competências profissionais se desenvolvem melhor no contato direto com o sistema produtivo. Na França, por exemplo, o modelo escolar de formação profissional construído a partir do pós Segunda Guerra Mundial, como uma conquista do Estado de Bem-Estar Social, tem seu espaço cada vez mais ameaçado a partir do avanço da "formação por aprendizagem", que se realiza em alternância entre centros de formação de aprendizes (CAF) e o espaço das empresas, destinando-se à formação desde os níveis básicos, até à obtenção de diplomas de nível técnico ou superior, conforme relata Tanguy (2016). Nesse sentido, a “adoção de uma via de formação de trabalhadores qualificados e de cidadãos instruídos de seus direitos no quadro de um sistema educativo unificado" vai sendo substituída pela aprendizagem na empresa, a qual oferece uma formação centrada nas competências e valores requeridos pelo sistema produtivo (TANGUY, 2016, p. 87, tradução nossa).

No Brasil, o Sistema $\mathrm{S}$ constitui um espaço de aprendizagem destinado a atender às necessidades formativas do mercado de trabalho, nas suas diferentes áreas de atuação. Essas instituições atuam de forma orgânica às demandas do setor a que estão vinculadas e contribuem na disseminação dos valores oriundos das empresas, uma vez que os empresários participam diretamente da elaboração do currículo dos cursos, como se verá no Capítulo IV. Considerando que o Sistema S constitui a maior rede de educação profissional privada no país (embora sustentada com recursos públicos, como já se viu), o anúncio da Presidente Dilma em realizar o "Prouni do ensino técnico", em fevereiro de $2011^{72}$, trazia desde o início a ideia de parceria com o setor privado na expansão da oferta do ensino técnico.

\footnotetext{
${ }^{72}$ Conforme notícia publicada no site Uol, sob o título "Em seu primeiro pronunciamento, Dilma anuncia Prouni para o ensino técnico e fala em corrigir falhas do Enem", disponível em: https://noticias.uol.com.br/politica/ultimas-noticias/2011/02/10/em-seu-primeiro-pronunciamento-dilmaanuncia-prouni-para-o-ensino-tecnico-e-fala-em-corrigir-falhas-do-enem.htm
} 
Não por acaso, após o primeiro anúncio do governo em relação ao Pronatec, o candidato derrotado nas eleições de 2010, José Serra, do PSDB, parabeniza ironicamente o governo por estar desenvolvendo uma política que constava no seu programa de campanha: "Dei os parabéns ao governo pelo anúncio do Pronatec - o Prouni do ensino técnico - que propus na campanha. Bolsa para pagar anuidades do Ensino Técnico. O governo do PT copiou uma ideia nossa Protec - que na campanha eles atacavam" (O GLOBO, 2011).

Durante o pleito eleitoral, havia sido noticiada por vários meios de comunicação a diferença de programa dos principais candidatos em relação à Educação Profissional. Cita-se, por exemplo, a notícia da Folha de São Paulo, a qual tinha como título "Dilma e Serra têm concepções opostas sobre ensino técnico"73. Embora ambos os candidatos defendessem o ensino técnico, segundo o folhetim, as propostas diferenciavam-se quanto à concepção: enquanto Dilma Rousseff defendia o ensino técnico integrado ao ensino médio, representado pelas escolas federais, José Serra, por sua vez, defendia cursos técnicos independentes do ensino médio, o qual o aluno poderia já ter cursado ou estar cursando concomitantemente ao ensino técnico, a exemplo das escolas técnicas implantadas por governos do seu partido no estado de São Paulo. Em termos de expansão da educação profissional, a candidata petista tinha como meta a criação de escolas técnicas, enquanto o candidato tucano planejava a ampliação do número de vagas através de bolsas para estudo em escolas técnicas particulares.

Sem, contudo, deixar de expandir o número de instituições públicas, o Pronatec acabou promovendo também o projeto de formação profissional defendido pelo PSDB - o "moderno príncipe" ${ }^{, 74}$ da burguesia brasileira (GUIOT, 2006) -, partido à frente da Reforma da Educação Profissional promovida nos anos 1990, que conduziu à separação dessa modalidade de ensino da educação básica e estimulou a oferta por meio de instituições privadas. Além disso, o avanço da oferta de matrículas por meio do Pronatec Bolsa Formação trouxe implicações no desenvolvimento de algumas políticas já em andamento, como o Proeja, a Rede e-TEC e o Brasil Profissionalizado, como se verá ao longo deste Capítulo.

\footnotetext{
${ }^{73}$ WESTIN, Ricardo. Dilma e Serra têm concepções opostas sobre ensino técnico. Folha de São Paulo (online), São Paulo,11 out. 2010. Caderno Poder. Disponível em: http://www1.folha.uol.com.br/poder/2010/10/812788dilma-e-serra-tem-concepcoes-opostas-sobre-ensino-tecnico.shtml Acesso em 10/03/2014.

${ }^{74}$ Segundo Guiot, "o PSDB encarna a função do "moderno Príncipe" da burguesia brasileira na medida em que se imbui do desafio de unificar os diversos setores do capital. E o faz tanto por meio dos seus programas partidários quanto por sua atuação militante nos diversos organismos da sociedade civil ligados aos setores empresariais" (2006, p. 14).
} 


\subsubsection{A tradução do "Prouni do ensino técnico" no âmbito da SETEC}

No primeiro tópico deste capítulo buscou-se situar o contexto político-econômico em que emerge o Pronatec, como política de educação profissional. Identificou-se que o direcionamento da política econômica para o estímulo ao desenvolvimento da indústria brasileira trouxe para o âmbito do governo a demanda de formação de mão de obra e a valorização do Sistema S como o espaço desejável para essa formação, aliado à disputa pelo projeto pedagógico de formação da classe trabalhadora e ao interesse no acesso aos recursos públicos destinados às políticas nessa área. No entanto, a construção de uma política pública não resulta de uma única ideia ou direcionamento; ela é expressão de um conjunto de forças que estão em disputa. Conforme aponta Oliveira, as políticas públicas "apresentam-se como dirigidas por interesse universal, ainda que focalizadas a determinados públicos-alvo. Contudo, essas políticas são resultantes de disputas em que os grupos organizados tentam legitimar como universais, acima de particularismos, seus próprios interesses" (2010, p. 02). Nesse sentido, neste tópico, busca-se apreender como essa demanda foi traduzida no âmbito da SETEC, considerando seu histórico de atuação e a visão de alguns dos sujeitos que atuaram no momento inicial da formulação da política, e de que forma a correlação de forças produzida no processo construção e desenvolvimento do Programa atuou na conformação dos seus resultados.

Nessa direção, busca-se aportar novos elementos para a compreensão do processo de elaboração do Pronatec, de modo a problematizar as visões que destacam o protagonismo dos organismos internacionais, sem evidenciar a existência de disputas, como expressa a análise de Reis (2017, p. 183): “o Pronatec se firmou enquanto um dos projetos educacionais orientados pelos organismos internacionais, no caso a CEPAL, voltados para a formação da classe trabalhadora brasileira”. Na mesma direção apontam Silva Júnior, Lucena e Ferreira:

O Proeja, o Pronatec, as diretrizes e parâmetros curriculares atendem às recomendações de organismos internacionais, tal qual demonstrado através das recomendações da CEPAL, bem como às reivindicações empresariais da qualificação de trabalhadores para o exercício da função, em um cenário de constantes transformações tecnológicas na produção industrial. (SILVA JÚNIOR; LUCENA; FERREIRA, 2011, p. 854).

Assim, considera-se que as orientações dos organismos internacionais em relação ao projeto de educação profissional requerido pelo atual estágio de desenvolvimento do capitalismo, que reduzem "a função da educação a instrumento para o incremento da produtividade do trabalho e da competitividade do país e o investimento em capital humano, via capacitação permanente, como estratégia para manutenção da empregabilidade dos 
trabalhadores", como se observa no documento da CEPAL (RODRIGUES, 2017, p. 124), atuam não de forma direta, mas como elemento do discurso e proposições da burguesia no processo de correlação de forças com as demandas dos trabalhadores. Embora os resultados da política possam convergir com essas orientações, ela só pode ser compreendida por meio da apreensão das propostas e dos agentes em disputa.

A partir das entrevistas realizadas com gestores da SETEC, o Pronatec é situado como uma forma de dar continuidade à expansão da educação profissional e ao mesmo tempo reunir as iniciativas de qualificação profissional "pulverizadas" nas diferentes esferas do governo federal. Na visão de Marcelo Feres, Secretário de Educação Profissional no período de 2015 a maio de 2016, o crescimento da educação profissional durante os governos Lula colocou o tema no centro do debate eleitoral de 2010, o que levou o governo eleito a apresentar novas propostas nesse campo:

Na eleição, o projeto vitorioso foi o projeto da Dilma Rousseff, e ela tinha, então, um
compromisso de dar sequência à expansão da Educação Profissional Brasileira. O
Ministro, à época, o Fernando Haddad, que continuou na gestão por mais algum
tempo, foi um dos principais responsáveis pela gestão do Pronatec, junto com a equipe
do MEC, eu participei diretamente nesse período, que se vislumbrava fortalecer, mas
com metas objetivas. (...) Era preciso criar um programa que não iniciasse coisas
novas apenas, mas, sobretudo, que fortalecesse e integrasse as ações pré-existentes.
Então, o Pronatec, ele nasce com essa dupla missão: se, por um lado, ele deveria
continuar fortalecendo as iniciativas existentes e também criar novas iniciativas,
aperfeiçoar as existentes, para que se pudesse dar escala no atendimento em termos
de Educação Profissional. E aí o Pronatec nasce com um fator, que eu destaco na sua
legislação, criada no final de outubro de 2011 , que é justamente um artigo que
centraliza a oferta da Educação Profissional no Ministério da Educação. Esse foi um
marco em termos de política pública, porque, a partir daquele momento, os demais
Ministérios não poderiam demandar orçamento para formação profissional. Então,
esse é um fator de ineditismo na política, porque passou-se a criar um modelo
sistêmico. Então, todo Ministério que antes tinha recurso público para poder tocar
ações de capacitação profissional, a partir do Pronatec, ele perde essa prerrogativa,
com a mudança que teve na lei, na criação da Lei do Pronatec (Entrevista FERES,
2018).

Na mesma direção, Caetana Juracy Rezende da Silva, Coordenadora Geral de Políticas de Educação Profissional e Tecnológica em 2011, ao recuperar o histórico de como a demanda para a criação do que resultou no Pronatec chega para a SETEC, associa a necessidade de integração das políticas de qualificação profissional com um discurso da Presidenta Dilma, no início de 2011, que anunciava o interesse do governo de expandir a experiência do Prouni para a educação técnica. Nas suas palavras:

De longa data, vinha uma queixa dos Movimentos Sociais, principalmente, dos Sindicatos, e também do pessoal que fazia pesquisa na Área de Educação e Trabalho, que era a fragmentação das ações de qualificação profissional nos diversos órgãos do 
Governo. Então, você tinha qualificação profissional no Ministério do Trabalho, tinha qualificação profissional em outros órgãos; no Ministério da Saúde... E isso não tinha muita integração. Então, essa era uma questão que estava colocada, mas que no início não estava relacionada com o Pronatec. O Pronatec é muito interessante, porque ele surge de uma fala, na época, era a Presidente Dilma, em 2011, ela faz um discurso, e ela fala, ela muito empolgada com o que estava se alcançando com o Prouni, ela faz uma fala sobre um programa parecido, nos moldes do que seria o Prouni, mas para a Educação Técnica. Então, assim, tem essa fala que não era o Pronatec ainda, naquele momento. Era uma ideia de ser algo parecido com o Prouni. E, na época, quando ela coloca essa fala, o Paim era o Secretário-Executivo do Ministério, e ele chama o pessoal que estava dentro da Secretaria nessa época - particularmente a Coordenação que eu ocupava, que era a que trabalhava na formulação de políticas -, e pede para a gente pensar alguma coisa que fosse nessa direção. A gente colocou para ele a dificuldade que seria seguir os moldes do Prouni para os Cursos Técnicos, por conta que o Prouni tem todo um desenho muito específico. Nesse momento, a gente começou a propor algumas coisas, de forma que a gente conseguisse pensar uma oferta mais estruturada, que fizesse a articulação dessas políticas de qualificação profissional. E aí foi justamente no momento em que eu saí (Entrevista SILVA, 2017).

Na visão de Eliezer Pacheco, Secretário da Educação Profissional, no período de 2004 a fevereiro de 2012, o Pronatec foi pensando para que os Institutos Federais tivessem "um pé lá na periferia", e que as metas ambiciosas do Programa conduziram ao grande volume de recursos repassados ao Sistema S. Observa-se, assim, uma tentativa de traduzir a demanda de formação profissional, no âmbito do projeto de educação profissional em andamento, conforme apontam os argumentos de Eliezer Pacheco:

O Pronatec surgiu da nossa preocupação que os Institutos tivessem um pé lá na periferia. Nós tínhamos programas importantes, como o Proeja, que nós criamos, que é o EJA com formação profissional, era uma modalidade que não existia; o Mulheres Mil, um belo programa também, é uma tecnologia social canadense que a gente adaptou. A nossa preocupação sempre - porque a tentação no Brasil à elitização é muito forte sempre, a classe média toma conta de tudo - era criar um Programa em que o Instituto tivesse um pé lá na periferia, com formação profissional inicial. Claro que na nossa regulação, nós passamos também a definir o quê que nós reconhecemos como curso de formação inicial, porque o Sistema $\mathrm{S}$ tinha curso de 5 horas, 10 horas, ainda tem... Mas, no mínimo 160 horas. Com menos de 160 horas não é reconhecido para efeito de Pronatec e em nenhuma legislação federal. Bom, o que que aconteceu, de certa forma... Eu não acompanhei essa evolução, mas o governo federal, para atingir as metas, porque realmente são de milhões de vagas, colocou muito dinheiro, mais dinheiro ainda no Sistema S. (...) Hoje, até onde eu sei, a grande maioria da oferta é via Sistema S. Os institutos ofertam, mas num percentual menor. O serviço público ele é mais engessado, tem mais dificuldade. Isso que nós criamos uma remuneração muito atrativa para o professor. Nós abrimos uma exceção na Lei: o professor do Instituto Federal, que tem dedicação exclusiva, ele, para trabalhar no Pronatec, ganha, uma bolsa. É a título de bolsa, porque não pode pagar salário. O coordenador do Pronatec, ele tem a dedicação exclusiva no Instituto, mas para trabalhar no Pronatec ele ganha. Isso foi uma mudança na Lei que nós fizemos, porque não poderia. Mas, de qualquer forma, a expansão do Pronatec, pelo que eu sei se deu muito mais pelo Sistema S, do que pelos Institutos Federais (PACHECO, 2016).

A partir dessas falas pode-se visualizar que a proposta que dá origem ao Programa não parte do âmbito da SETEC. Ele surge como resposta ao suposto "apagão de mão de obra", 
visualizada a partir de experiências já desenvolvidas pelo Ministério da Educação, como o Prouni, um caminho para o atendimento rápido dessa demanda. Quando posta no âmbito da SETEC, soma-se a essa ideia inicial - o Prouni do Ensino Técnico - a demanda de organizar e centralizar as políticas de qualificação profissional no Ministério da Educação. Conforme aponta Feres, "se a gente fosse resumir o Pronatec: foi um programa, cujo objetivo era ampliar a formação profissional, por meio de parceiros públicos, parceiros governamentais, que tinham a demanda por formação profissional, e parceiros públicos e privados, cuja missão é fazer a formação profissional" (Entrevista FERES, 2017).

A crítica à pulverização dos programas de qualificação profissional nas diferentes esferas do governo, de fato, existia, motivada especialmente pela falta de unidade e integração entre essas iniciativas e o público a ser atendido, e da ausência de uma orientação pedagógica sobre o conteúdo e a qualidade dos cursos ofertados, muitos deles desenvolvidos em parceria com ONGs que não tinham experiência na área. O Programa Nacional de Qualificação Profissional (PNQ), realizado pelo Ministério do Trabalho e Emprego, se apresentou como uma resposta à parte dessas críticas, oriundas dos movimentos sociais e da própria base do Partido dos Trabalhadores, especialmente quanto à carga horária, conteúdo formativo e a participação dos trabalhadores na definição dos cursos e conteúdo da formação (LIMA, 2006). No entanto, continuaram sendo pulverizadas várias iniciativas de formação profissional em diferentes esferas do governo, conforme analisa Castioni (2013).

De acordo com Almerico Lima, que atuou como Diretor de Qualificação Profissional no Ministério do Trabalho, no primeiro governo Lula, o Pronatec apresentava-se, inicialmente, como uma estratégia positiva no sentido de "limpar da Esplanada todos os miríades de cursos, de recursos orçamentários que existiam para fazer qualificação e concentrar tudo no Ministério da Educação", pois "cada departamentozinho tinha lá um programa de qualificação, com as suas próprias regras, às vezes contratando as mesmas entidades, que ganhavam muito dinheiro, e não tinha nenhum saldo concreto, em termos de aumentar a escolaridade ou aumentar a qualificação da força de trabalho" (Entrevista LIMA, 2017). O Ministério do Trabalho e Emprego (MTE), no primeiro governo Lula, vinha se aproximando do Ministério da Educação no sentido de desenvolver políticas integradas na área da qualificação profissional, conforme relata Lima:

Então, eu me lembro, até parece uma anedota, mas é uma realidade, que quando eu entrei no MEC, em 2003, final de 2003, como membro do Ministério do Trabalho, para discutir certificação profissional - na verdade, a retirada da proposta de certificação do Governo anterior, Governo Fernando Henrique, do Conselho Nacional de Educação, porque ela era totalmente sem discussão com a sociedade, e não se 
pegava essa visão de educação integral - eu fui aplaudido, aplaudido! Eu não entendia muito bem porque que eu fui aplaudido. E me disseram que era a primeira vez, em, não sei quantos anos, 10, 15 anos, que um dirigente do Ministério do Trabalho veio ao MEC! Tu vês a separação que você tinha nesse período anterior, era uma divisão de tarefas: o MEC forma para a elevação de escolaridade e o Ministério do Trabalho forma os cursos de curta duração (Entrevista LIMA, 2017).

Havia, nesse sentido, um movimento de aproximação do MTE e MEC com vistas a associar qualificação profissional e educação básica, tendo em vista a baixa escolaridade de grande parte dos trabalhadores. Nessa direção, a política desenvolvida pelo MTE se orientava pela concepção de qualificação profissional como direito do trabalhador, a qual deveria permitir que o trabalhador "pudesse se assenhorar não apenas do ferramental técnico e tecnológico, mas também do instrumental social”, reconhecendo-se que a associação com a educação básica era fundamental, avalia Lima (2017). "Nessa concepção não tinha sentido o Ministério do Trabalho se envolver em elevação de escolaridade, ele deveria, gradativamente, abandonar a qualificação; a qualificação deveria ser algo vinculado à educação", concentrando esforços para "atuar muito mais numa lógica da regulação da qualificação, da relação entre patrões e empregados em relação à qualificação; no reconhecimento dos saberes, na certificação profissional, no acompanhamento das carreiras, dos processos de disputa em relação as carreiras", avalia Almerico (Entrevista LIMA, 2017).

Assim, a lógica de integração das ações de qualificação profissional no âmbito do Pronatec vinha ao encontro dessa perspectiva, presente tanto no Ministério do Trabalho, nesse período, quanto no Ministério da Educação. Conforme avalia Caetana, "em termos de formulação, ele [o Pronatec] consegue algo que há muito tempo vinha sendo solicitado, que era pensar em conjunto todas as qualificações, as ofertas de qualificação para trabalhador, principalmente, os cursos iniciais" (Entrevista SILVA, 2017).

A centralização da oferta da qualificação profissional no âmbito do MEC continuou, porém, reproduzindo a mesma lógica anterior, pois não conseguiu suplantar a concepção de qualificação orientada estritamente pelas demandas do mercado de trabalho, configurando um espaço de socialização dos trabalhadores na lógica do capital. O desenvolvimento do programa não foi acompanhado de um debate sobre a orientação pedagógico-curricular e mais de $60 \%$ das matrículas foram realizadas por meio de instituições que se orientam pela concepção pedagógica do capital. Soma-se a isso a parceria estabelecida entre o MEC e o SEBRAE (Serviço Brasileiro de Apoio às Micro e Pequenas Empresas), instituição integrante do Sistema S, por meio da ação "Pronatec Empreendedor", que introduziu a educação empreendedora como conteúdo de alguns cursos e da formação de professores, como se verá adiante. 
Ao questionar as razões para a expressiva participação do Sistema $S$ nesta política, Pacheco apontou a mudança que ocorreu no Ministério da Educação, no início de 2012, ano em que de fato o Pronatec começa a ser executado, o que configurou um "desvio de rota" nesta política de educação profissional:

É que aí vem a variável da política, digamos assim, porque logo depois disso muda o
Ministério da Educação, o [Fernando] Haddad sai para concorrer em SP, e assume o
[Aluísio] Mercadante. Eu não continuo, eu vou lá para o Ministério de Ciência e
Tecnologia, assumir a Secretaria de Tecnologias Sociais. (...) O Mercadante não tinha
a visão política do Haddad. É do PT também, mas o PT também é um partido
heterogêneo. Não que sejam radicalmente diferentes, mas tem nuances diferentes
entre eles. (...) Então, eu acho que esse desvio de rota, de certa forma, se dá porque,
tanto o Fernando Haddad, como eu, no caso, como a equipe do MEC naquela época,
eram quadros técnicos sim, acadêmicos, mas com uma opção política muito clara: nós
somos de esquerda. Todos nós éramos, lá. Eu acho que pra ti definir uma política
consequente, tu tens que ter um embasamento teórico, tu tens que ter uma concepção
ideológica que te orienta. Por que os Institutos, na verdade, o quê que é: os institutos
eles são orientados por uma concepção marxista da educação profissional, é isso.
Claro que o Marx nunca falou em Instituto Federal, óbvio, mas ele tinha uma visão da
educação, profissional, inclusive. Obviamente que os tempos são outros, mas,
digamos, a nossa inspiração é uma inspiração marxista. Tu não faz política nenhuma
sem ter uma base teórica: ou uma base liberal, ou uma base marxista. Tu partes de
uma base, mas não quer dizer que aquilo é um catecismo. Não é um catecismo, mas
tu tens uma base teórica. Não existe política neutra. Os Institutos Federais são a síntese
da concepção do governo Lula para a Educação Profissional no país (Entrevista
PACHECO, 2016, grifos nossos).

A partir dessa fala, indiretamente, Pacheco indica que houve uma mudança de concepção na orientação da política de educação profissional no Governo Dilma, que expressa as diferentes visões no interior do próprio Partido dos Trabalhadores. No entanto, pode-se apontar que, em que pese a intenção da SETEC de que o Pronatec tecesse uma unidade à política de qualificação profissional no governo e o estímulo à maior integração dos Institutos Federais com os contextos e sujeitos em vulnerabilidade social, esse "desvio de rota" ocorre desde o Projeto de Lei do Pronatec, uma vez que estabeleceu legalmente os canais para a participação da iniciativa privada, os quais foram aprofundados no decorrer do desenvolvimento da política.

Essa mudança de concepção na orientação da política de educação profissional é apontada também em documento elaborado pelo MOVATE - Movimento de Valorização dos Trabalhadores em Educação do Ministério da Educação, criado em 2005 -, com base no histórico das políticas desenvolvidas pela SETEC durante os dois primeiros governos do PT. Conforme registra o documento, em relação ao Pronatec:

Nesse programa é de se espantar, porém, que a dimensão integrada, que foi uma conquista histórica da sociedade brasileira, não tenha sido ao menos citada na Lei do Pronatec. Isso, em nosso ponto de vista, é um retrocesso aos tempos ainda do Decreto $n^{\circ}$ 2.208/97, instituído pelo Governo Fernando Henrique Cardoso. Enquanto 
o Decreto $\mathrm{n}^{\circ}$ 5.154/04 vinha na direção de contemplar as formas concomitante, subsequente e integrada, com o Pronatec a forma integrada é omitida. Por quê? Quais as razões que motivaram isso? A que tipo de interesse essa omissão atende? Por que há esse retrocesso no fomento à perspectiva da integração que historicamente vinha sendo construída? Retrocedemos? (MOVATE, 2012, p. 02, grifos no original)

Observa-se, a partir desse documento, que as críticas emanadas de organismos da sociedade civil também estavam presentes nos espaços da sociedade política, evidenciando que o desenvolvimento desse Programa passou por disputas nas duas esferas que compõe o Estado. Em entrevista concedida por uma servidora técnica integrante do MOVATE - identificada aqui com o nome fictício de Flor - que atua na SETEC desde o governo Lula, pode-se evidenciar melhor esses deslocamentos de concepção na condução da política pública na área:

Fazendo uma leitura do histórico: em 2004 a gente tem a implantação do Decreto 5.154, que substitui o 2208 de 97 e com essa abertura - que eu acho que foi muito positiva para a educação profissional, que foi a possibilidade de o integrado retornar - em 2004 se abre a possibilidade do Proeja. Em 2005 eu chego no MEC, final de 2005, e começo na SETEC. E aí quando a gente começou lá na SETEC, a gente começa a enxergar no Proeja não a solução, porque não existe uma solução assim, mas como um caminho possível de se pensar uma educação profissional integrada voltada para o público trabalhador que tivesse pelo menos uma perspectiva maior de emancipação, que fosse uma perspectiva não de aligeiramento ou de tratar aquele trabalhador como um apertador de botão. Uma perspectiva que pensasse a formação dele de uma forma integral como ser humano, cidadão, enfim..., isso que a gente fala muito. É um desafio, né? É um desafio, mas a gente acreditava que essa educação profissional era a que interessa e interessava para a classe trabalhadora. E aí começa o Proeja, várias ações... De 2005 a 2010 eu atuo no Proeja de forma, assim, intensa, de corpo e alma. Eu fazia parte de um coletivo bem integrado, que queria muito que as coisas acontecessem, embora tivessem todos os desafios que a gente sabe do Proeja. Enfim, era um programa né? A gente fez todo esse trabalho defendendo a integração. Em 2010 eu saio para o Mestrado. (...) Quando eu chego em 2012 no MEC, na SETEC eu me assustei quando eu li a lei do Pronatec e não tinha uma palavra de integração (Entrevista FLOR, 2017).

A mudança de concepção na condução da educação profissional no governo Dilma parece ter sido aprofundada com a mudança de gestores no âmbito do MEC e da SETEC, no início de 2012, conforme relata Flor:

(...) As pessoas que estavam lá [em 2012] na área de construção da política pública tinham mudado; a gente tinha o Sistema S pautando o Estado; a gente tinha na mesa do MEC o Sistema S com voz de, sei lá, de Secretário. E a integração? Se começou a ter uma certa aversão à integração. Como eu vivi um movimento forte do grupo de integração, das pessoas que defendiam a integração de forma intensa, né, ideológica, assim, como causa do trabalho, de superação do capital, enfim... E de repente nesse novo cenário, eu vejo um grupo, que é um grupo que diverge e que estava sendo acolhido pelo MEC de uma forma assim, eu acho, na minha leitura, desproporcional; não democrático, mas, desproporcional. Chegou ao ponto de uma audiência pública que teve inclusive no CNE, eu não lembro bem o teor da audiência pública, eu não vou me recordar, mas teve uma audiência e o pessoal do CEDES falou, da ANPED falou, uma audiência que foi muito rica, contra a construção que a SETEC estava fazendo, inclusive, acho que sobre a Resolução da Educação Profissional - eu não sei 
bem, não lembro o texto, os detalhes disso. E aí teve essa audiência e depois, na semana seguinte, a SETEC chamou um grupo privado para fazer um debate que diferia da maioria das opiniões da audiência. Ou seja, você faz uma audiência para levantar questões e, de repente, você, SETEC, chama um grupo privado que não representa o que a audiência disse e começa a fazer uma construção totalmente alheia à audiência. Nesse dia, eu lembro, eu pontuei na reunião, não sei como eu não fui expulsa da SETEC! Porque eu pontuei para as pessoas: espera aí, a gente faz uma audiência, depois chega aqui e um grupo vem... eu questionei o teor. Tinha até um colega da CNTE que me apoiou, eu lembro disso. Tinha umas pessoas... mas a gente via que o teor da reunião, era um teor para subscrever uma coisa contrária ao que a audiência, a maioria do grupo da audiência estava trazendo, enfim... Aí eu comecei a ver que os atores do cenário de construção da política pública ali estavam sendo hegemonicamente outros; poderiam ser outros, mas que defendiam uma lógica que não era a da integração (Entrevista FLOR, 2017).

$\mathrm{Na}$ mesma direção, alguns pesquisadores de organizações acadêmicas, que acompanharam o processo de construção e desenvolvimento de políticas progressistas no campo da educação profissional, durante os governo Lula, apontam para as dificuldades na sua materialização em virtude, principalmente, das “mudanças nas bases de sustentação política do governo que foi se endireitando e, em consequência, retomando seu metabolismo natural", como analisa Moura (2016, p. 03).

Esses apontamentos expressam uma mudança na correlação de forças nesse período. No governo Lula, apesar das disputas, a correlação de forças no campo da educação profissional esteve mais favorável ao desenvolvimento do projeto não hegemônico, enquanto a inserção do Sistema S como novo ator na oferta dessa política pública, a partir de 2010, motivado pela expansão da oferta, acabou favorecendo o projeto hegemônico. Essa aproximação gerou críticas das organizações das instituições públicas de ensino participantes do Programa, tanto em relação ao grande volume de recursos repassados às instituições privadas, como em relação à concepção que orientava o Programa - a não integração com a educação básica, resultando em algumas resistências das instituições públicas no desenvolvimento dessa política.

Ao analisar a grande participação do Sistema S na oferta do Programa, Caetana aponta como fatores que podem ter contribuído para esse cenário a sua capacidade enquanto rede de escolas, que o situava como importante parceiro para o atendimento das metas do Pronatec que no primeiro Governo Dilma era de oito milhões de matrículas até 2014 -, e sua representatividade social e política no próprio Congresso Nacional. Nas suas palavras:

Mas, especificamente, quanto ao Sistema S, é que, na verdade, assim, como eles são ofertantes muito importantes, eles têm um potencial, uma visibilidade muito alta, eu acho que, em determinado momento, eles passaram a dar as cartas, a falar como que eles queriam que fosse, o quê eles aceitavam e o que eles não aceitavam. Eles têm uma importância muito grande dentro do Congresso; eles têm representantes muito fortes dentro do Congresso. Coisa que a rede federal não tem - tem alguns, mas não tem tantos, não tem o mesmo peso. Então, no momento de negociação, em que uma 
das partes se encontra favorecida, não é, em termos de peso, de visibilidade, eles acabam conseguindo bons termos no acordo, diria nesses termos (Entrevista SILVA, 2017).

Na mesma direção, Almerico aponta para a aproximação da lógica do Sistema S no âmbito do Pronatec e a resistência a esse processo por parte das instituições públicas. Por outro lado, do ponto de vista do MEC isso ocorria pela disponibilidade do Sistema S em desenvolver o Programa, diferentemente das instituições públicas, que precisavam ser “mais abertas".

Eu me lembro que um dirigente do MEC, disse assim: "Poxa, vocês precisam ser um pouco mais abertos, o pessoal do Sistema S está se aproximando de nós”. Aí eu disse: "O navio também acha que a margem está se aproximando dele". Ou seja, na minha opinião, ele [Sistema S] estava inamovível, e era o MEC que estava se aproximando, $e$ não o contrário. As premissas eram as mesmas. Não que não tivesse coisas interessantes, não que eu não respeite... Não estou tirando a honestidade pessoal, a questão não é pessoal, a questão é pensando enquanto um artefato, instrumento institucional, de controle da mão de obra trabalhadora, e isso é o que ele é [o Pronatec]. Então, essa lógica, ela acabou permeando muitas ações do MEC, e começaram a ter alguns embates, inclusive, com o CONIF, que não concordava com isso; e com o próprio Fórum de Gestores Estaduais da Educação Profissional, a gente começou a ter esses embates (Entrevista LIMA, 2017, grifos nossos).

No processo de desenvolvimento do Programa, tendo em vista as metas a serem atingidas, as instituições que estavam contribuindo passaram a ser fortes interlocutores no âmbito do governo, o que pode ser compreendido como um fator de aproximação com o Sistema S, conforme aponta Flor:

Chega um momento que você começa a ser democrático e aí o grupo que é contra a política começa a incomodar, e aí como você faz como gestor? Você começa a tirar esse grupo que está lhe incomodando. E o pessoal do Sistema S estava somando com o governo, então ele é um grupo que vai fincando na construção da política pública. Porque os gestores dizem que o grupo é democrático, chama os institutos, mas dentro dos Institutos chama quem não incomoda, não é que vai incomodar, é quem vai se contrapor à política. Então, inicia colocando todo mundo na mesa e quando eles começam a perceber que aquela pessoa ali vai fazer um contraponto muito forte, vai tirando a pessoa, não vai chamando mais. E aí vai ficando só quem vai somando... E quem somava ao Pronatec era quem estava ganhando muito dinheiro com ele. Quem estava ganhando muito dinheiro, quem ganhou muito dinheiro com o Pronatec? O Sistema S. (...) A SETEC virou um verdadeiro balcão de negócios! (Entrevista FLOR, 2017).

A partir de reportagem do SENAC, pode-se identificar que essa instituição participou do Pronatec antes mesmo de a Lei ser aprovada, com vistas a testar os fluxos para sua oferta. Conforme destaca a Revista Correio do SENAC, "antes do início oficial das aulas no âmbito do Pronatec, três DRs do Senac executaram projetos-pilotos ou provas de conceito (...). A partir de solicitação do MEC, foram oferecidos cursos cujo objetivo era testar e avaliar processos e 
fluxos iniciais do programa" (SENAC, 2012, p. 09). A esse respeito, o Diretor Geral do SENAC enfatizava a "importância da Instituição para a educação profissional brasileira", apontando que a participação no Pronatec constitui-se em mais um capítulo na história da instituição "que será escrito por todo o Sistema Senac, que, desde os primeiros meses de 2011, ao ser convocado pelo Governo Federal para colaborar com as estratégias iniciais do programa, até o momento, não poupou esforços para seu êxito" (SENAC, 2012, p. 07). O conhecimento e execução prévia dos fluxos do Programa pode ter contribuído para aproximação do Programa à lógica destas instituições.

Em entrevista com um dos Coordenadores Gerais do Pronatec Bolsa Formação no âmbito do Instituto Federal Farroupilha que fez parte desta pesquisa, também foi apontada a atenção diferenciada destinada por parte do governo ao Sistema $S$, chegando a realizar reuniões separadas das demais instituições, e o grande interesse dessas instituições no acesso aos recursos públicos destinados ao Programa:

\begin{abstract}
Não tenho fundamentos, provas pra te dizer, mas o Pronatec ele foi feito para o Sistema S. O Pronatec foi concebido para o Sistema S. Foi uma ideia...foi uma visão política. Se tu olhares o Sistema S antes do Pronatec, era um sistema quebrado. Surgiram os institutos, uma série de coisas... era um sistema que estava à deriva. Eles se tornaram de novo "gente", vamos dizer assim, com o Pronatec. Tanto é que eles fazem um maior número [de matrículas], eles levam um maior recurso. As reuniões deles já foram separadas das nossas, no MEC, até isso acontece. Na realidade eles marcam um dia nós e marcam outro dia eles. Daí tem uns colegas que vão antes e vão lá e assistem. Até o dinheiro pra eles tem fluido melhor, em nome de gestão... Agora com a simpatia do Ministro [refere-se ao Ministro Aloísio Mercadante] que é voltado pra essa área do Sistema $\mathrm{S}$, então os institutos acabam ficando de lado... (...) $\mathrm{Na}$ realidade o que a gente sabe é que a toda hora o Sistema S quer o Pronatec pra ele. Eu também queria, qualquer um queria... É muito dinheiro, é muito dinheiro! (Entrevista, CGBF 2, IFFar)
\end{abstract}

Em 2013, com vistas a suprir as lacunas da falta de integração do Programa com a elevação da escolaridade, buscou-se inserir a oferta do Proeja no âmbito do Pronatec Bolsa Formação, a partir das demandas das organizações do campo da educação de jovens e adultos, visto que o Proeja estava perdendo espaço no âmbito das instituições em virtude do atendimento das demandas do Pronatec Bolsa Formação. No próprio espaço da SETEC as ações voltadas ao Proeja foram secundarizadas no primeiro ano de execução do Pronatec, conforme aponta Flor: o orçamento de mais de 30 milhões de reais destinado ao fomento do Proeja, naquele ano, não foi gasto, porque "a SETEC parou por causa desse Pronatec"; "chega o Pronatec e você não tem tempo para nada, você tem que rodar o Pronatec"; "não conseguimos publicar um edital [do Proeja] em 2012" (Entrevista FLOR, 2017). Conforme consta em relatório elaborado pela equipe técnica do Proeja, ao qual se obteve acesso no âmbito desta pesquisa: 


\begin{abstract}
Apesar desse esforço técnico, ao longo de todo o ano de 2012, a equipe Proeja deparase com várias negativas da gestão da SETEC frente às ações Proeja. Por motivos que nos fogem ao entendimento, a gestão da SETEC não viabiliza o encaminhamento das 20 ações, embora estas estivessem garantidas como ações orçamentárias do Plano Plurianual. Consequentemente, ao final do ano, temos o resultado de que, dos 36,7 milhões destinados ao Proeja, somente cerca de 2 milhões de reais são utilizados em 2012 (RELATÓRIO EQUIPE TÉCNICA PROEJA, 2013) ${ }^{75}$.
\end{abstract}

A partir de Seminário envolvendo as instituições ofertantes do Proeja e do Pronatec, em 2013, elaborou-se o documento Pronatec EJA, com o intuito de orientar a oferta a partir da elaboração conjunta, entre instituições de educação básica e de educação profissional, do projeto pedagógico de curso, de forma a assegurar a integração curricular e formativa. No entanto, em 2014, quando as instituições se organizaram para pactuar cursos no âmbito do Pronatec EJA, grande parte das propostas não foram homologadas em razão da diminuição dos recursos destinados ao Programa.

Foi desenhado um programa [o Pronatec EJA], nós, da Bahia, inclusive, fomos os maiores demandantes do programa, (...) mas não foi financiado, acabou não acontecendo, de fato, na prática, aquela proposta em relação a EJA. Então, os vários elementos que a gente tinha colocado como elementos, como é que eu diria, inovadores do Pronatec, integradores, eles começaram a se a se perder, pelo número, pelo tamanho, e, principalmente, porque, é óbvio, o Sistema $\mathrm{S}$ aderiu fortemente ao programa, ele só recebia depois de fazer o programa; então, não precisava de um investimento inicial do Governo Federal; enquanto que, as redes estaduais, com as suas dificuldades, cada uma com a sua dificuldade, fez o que pôde; e a rede federal, alguns fizeram e outros se recusaram a fazer. Então, quando você pegava os números lá, claro, que vários números eram do Sistema S. Então, assim, essa armadilha, eu acho que foi muito grande; e aí a partir desse número, acabavam acontecendo algumas coisas, que eram algumas concessões, não é; as lógicas passaram a ser mais próximas do Sistema S (Entrevista LIMA, 2017).

Em relação aos dados de matrícula em cursos técnicos integrados ao ensino médio na modalidade de educação de jovens e adultos, o crescimento observado a partir de 2008 sofre uma redução em 2011, o qual é retomado de forma mais lenta em 2013, possivelmente em razão da oferta do Pronatec EJA, e reduz novamente em 2015, conforme indicam os dados apresentados na Tabela 6. Nesse sentido, pode-se apontar que os esforços direcionados ao desenvolvimento do Pronatec Bolsa Formação, fez com que diminuísse a oferta do Proeja e seu público passou a ser atendido no âmbito dos cursos FIC, como se verá em relação à escolaridade dos estudantes que realizaram esses cursos.

\footnotetext{
${ }^{75}$ Esse documento encontra-se nos arquivos da pesquisa.
} 
Tabela 6 - Matrículas Proeja em âmbito nacional - 2007 a 2016

\begin{tabular}{llll}
\hline \hline Ano & Proeja Técnico & Proeja FIC & Total* \\
\hline 2007 & 9.747 & -- & 9.747 \\
2008 & 14.939 & 3.976 & 18.915 \\
2009 & 19.533 & 3.628 & 23.161 \\
2010 & 38.152 & 13.001 & 51.153 \\
2011 & 41.971 & 23.239 & 65.210 \\
2012 & 35.993 & 18.622 & 54.615 \\
2013 & 41.269 & 20.194 & 61.463 \\
2014 & 42.875 & 9.153 & 52.028 \\
2015 & 38.228 & 17.653 & 55.881 \\
2016 & 32.710 & 19.405 & 52.115 \\
\hline \hline
\end{tabular}

* Não foram somadas as matrículas do Projovem, pois foram incluídas no Censo Escolar apenas a partir de 2012. Fonte: Censo Escolar, INEP/MEC.

Por outro lado, o Programa Mulheres Mil, desenvolvido por meio de cursos de qualificação, que também foi incluído no âmbito da Bolsa Formação a partir da mesma Portaria que regulamentou o Pronatec EJA (Portaria n. 168, de 07 de março de 2013), teve uma grande oferta em 2014, passando de 7.032 matrículas, em 2013, para $35.896^{76}$. Assim, observa-se que os cursos não integrados à educação básica tinham um fluxo melhor no Programa, talvez porque, como aponta Flor, para "fazer o Proeja eu tenho que me articular com outra instituição e fazer um projeto unificado. Isso dá trabalho! (...) Você não vai fazer uma coisa de complexidade, se você pode fazer uma coisa simples e ganhar o mesmo valor..." (Entrevista FLOR, 2017).

No decorrer do desenvolvimento do Programa, as instituições privadas de ensino superior passaram a pressionar o governo para também atuarem na oferta de cursos do Pronatec Bolsa Formação. Essa demanda foi atendida por meio de Medida Provisória, n. 593, datada de dezembro de 2012, a qual foi incorporada à Lei do Pronatec apenas em junho de 2013, por meio da Lei 12.816. Na visão de Almerico, o grande interesse dessas instituições era o acesso ao recurso, uma vez que vinham perdendo espaço diante do crescimento das instituições públicas de ensino superior, tanto de universidades quanto de institutos federais. De outro lado, o Ministério da Educação teria visto essas instituições como oportunidade de ampliação do atendimento das metas do Programa. A incorporação destas instituições teria se dado por meio de um processo de muita pressão e acabou fragilizando, em alguns casos, as condições de infraestrutura das ofertas. Nas suas palavras:

Pressão pura. Pressão. Pressão. Queremos participar. Queremos participar. É o recurso, não é? Claro! A grande questão era o recurso, o financiamento. As escolas estavam perdendo muitos estudantes, estavam com a questão do Reuni, com a questão

\footnotetext{
${ }^{76}$ Dados obtidos por meio de consulta via e-SIC. A série histórica de matrículas nesse Programa pode ser
} visualizada na Tabela 18, no Capítulo III desta Tese. 
de todas as políticas de promoção, mais vagas e criação de novas unidades federais, as privadas estavam perdendo espaço, elas queriam, assim, uma compensação por isso. Então: nós estamos com espaço aqui ocioso, nós vamos oferecer isso ao Pronatec. O MEC viu nisso uma oportunidade, não estou dizendo que não deveria fazer, mas eu acho que o erro foi dar uma carta branca para eles, não é. Para você ter uma ideia, teve uma escola privada, e eu sinalizei isso, eu fui representante no Conselho Nacional do Pronatec, nos fóruns estaduais, assinalei, vi lá os casos da Bahia, em que escolas que eram aprovadas pelo Conselho Estadual, para ter 04 turmas, era o tamanho da escola, fechou com o Pronatec, 100 turmas. E qual a estrutura adequada para fazer isso? (Entrevista LIMA, 2017).

Conforme destaca Lima Filho (2015), diante do grande volume de recursos do Programa, a educação profissional passou a ser visualizada pelas empresas educacionais como um "mercado emergente", despertando a atenção de grandes corporações da área:

\begin{abstract}
as possibilidades abertas pela conversão da educação profissional em "mercado emergente" atraíram a atenção de grupos e corporações nacionais e internacionais e investidores em educação, a exemplo do Grupo Kroton, conforme revelado em matéria publicada na Revista Exame de 8 de agosto de 2.013, sob o título "Kroton cria unidade de negócios para ensino técnico" em que o Diretor Presidente da corporação, Rodrigo Galindo, anuncia a adesão ao Pronatec declara as expectativas positivas de oportunidades de crescimento no ramo: "Estamos entrando fortemente nessa indústria, num jogo que a gente sabe jogar [...]" (KROTON, 2013), concluiu o investidor (LIMA FILHO, 2015, p. 211-212).
\end{abstract}

De acordo com os censos da educação no Brasil, o período que congrega o maior número de estudantes em instituições privadas é o noturno, uma vez que normalmente são estudantes que precisam trabalhar durante o dia para pagar a mensalidade de seus cursos e contribuir na renda familiar. Assim, sem deixar de vender seus cursos para esse público, a oferta no âmbito da Bolsa Formação teve maior concentração nos turnos matutino e vespertino, ocupando a capacidade ociosa destas instituições, conforme aponta o "Comunicado ao Mercado" do grupo Kroton:

No total, a Kroton recebeu a autorização para preencher 22.992 vagas, sendo 13.464
para o período matutino, 6.760 para o período vespertino e 2.768 para o período
noturno, as quais serão oferecidas por meio de 41 diferentes cursos e em 30
Instituições de Ensino. Cabe lembrar, também, que essas vagas são referentes à
modalidade Bolsa Formação, a qual oferece bolsas de estudos totalmente subsidiadas
pelo Governo Federal. As vagas aqui anunciadas terão suas aulas iniciadas já neste
primeiro semestre de 2014 (KROTON, 2014, apud LIMA FILHO, 2015, p. 212).

Além do incremento da oferta de educação profissional em instituições já existentes, o "mercado da formação" constituído em torno do Pronatec Bolsa Formação também estimulou a criação de cursos técnicos em instituições que não tinham essa modalidade de ensino em seu 
"plano de negócios", com vistas a aproveitar o "bom momento" na área, conforme aponta o levantamento e análise realizada por Lima Filho:

\begin{abstract}
Em seminário realizado em Brasília, no início de 2014, sob o sugestivo título "Por que montar uma escola técnica", entidades de consultoria e grupos de investidores demonstram sua atenção ao "promissor" mercado da educação profissional, ressaltando que os programas governamentais de financiamento são a "bola da vez" dos investimentos em educação e enumerando vantagens comparativas dessa inversão, dentre as quais, destacam: evitam salas ociosas; otimizam custo fixo; melhoram fluxo de caixa; têm pouca inadimplência; divulgam e fortalecem a marca; crescimento rápido da escola; fidelização dos alunos para outros cursos (NEWEDUCATION, 2014, apud LIMA FILHO, 2015, p. 212).
\end{abstract}

Pode-se visualizar, na Tabela 7, em relação ao crescimento do número de instituições privadas que passaram a integrar o Programa e o, consequente, aumento do volume de recursos transferidos a estas instituições, que a pressão dessas instituições para o ingresso no âmbito do Pronatec tinha como mote a disputa pelos fundos públicos.

Tabela 7 - Recursos transferidos e matrículas realizadas por IEs privadas no Pronatec - 2013 a 2016

\begin{tabular}{llll}
\hline \hline Ano & Valor (em milhões) & Matrículas & Número de IEs \\
\hline 2013 & $51.681 .163,63$ & 147.275 & 105 \\
2014 & $644.920 .316,54$ & 367.302 & 512 \\
2015 & $931.691 .313,70$ & 45.788 & 518 \\
2016 & $485.096 .160,40$ & 13 & 562 \\
\hline Total & $2.113 .388 .954,27$ & 560.378 &
\end{tabular}

Fonte: elaborada pela autora com base nos dados obtidos via SIGEF/FNDE (2018) e SISTEC Nacional (2017).

A grande participação das instituições privadas, conduziu a uma mudança nas ações previstas pelo Programa, como o FIES Técnico, o qual não foi executado em virtude de que as vagas a serem financiadas eram as mesmas que passaram a ser ofertadas por meio do SISUTEC $^{77}$ (Sistema de Seleção Unificada da Educação Profissional e Tecnológica), conforme justificou a SETEC em informação obtida via email:

esclarecemos que o FIES Técnico, instituído pela Lei n 12.513 , de 2011, trata de uma ação que visa ampliar o acesso de beneficiários a cursos técnicos, por meio do financiamento escolar. No entanto, com o surgimento do Sistema de Seleção Unificada da Educação Profissional e Tecnológica - Sisutec, que garante o acesso gratuito do cidadão à mesma vaga, a ação FIES Técnico foi absorvida pela ação do Sisutec" (SETEC, 2016a).

\footnotetext{
77 O SISUTEC é utilizado como forma de seleção de estudantes para cursos técnicos subsequentes ofertados por meio da Bolsa Formação em instituições públicas, privadas e do Sistema S, tendo como critério a nota obtida no ENEM (Exame Nacional do Ensino Médio).
} 
Com o avanço da lógica privada no desenvolvimento do Pronatec, observa-se, como aponta Almerico, que "tudo o que era estratégico, que foi pensado originalmente para o Pronatec, ele se transformou, a partir de um pragmatismo, a partir de uma necessidade em demonstrar os resultados e os números" (Entrevista LIMA, 2017).

Ao mesmo tempo, é possível identificar os esforços da SETEC para pensar a oferta do ponto de vista pedagógico, como a inserção de itinerários formativos, com vistas a constituir uma formação mais ampla e sólida do trabalhador, que foi incorporada na Portaria n. 817/2015 e que estava presente nos debates sobre a qualificação profissional, assim como o aprofundamento da integração da oferta com a educação básica e a formação de jovens e adultos, conforme destacou Marcelo Feres, em entrevista. Do ponto de vista operacional, por meio dessa nova Portaria, que seria executada a partir de 2016, o repasse dos recursos estaria atrelado aos índices de conclusão, de forma a criar uma contrapartida das instituições ofertantes em relação aos seus resultados. No entanto, a crise política e econômica se aprofundou vertiginosamente após a eleição de 2014, culminando no impeachment da Presidenta Dilma, em agosto de 2016, o que comprometeu a tentativa de colocar em prática esses avanços.

Com isso, a lógica privada acabou preponderando no processo de construção e desenvolvimento do Pronatec, tanto do ponto de vista da oferta quanto do ponto de vista da concepção pedagógica, que foi estendida para o conjunto das instituições por meio da ação Pronatec Empreendedor. No próximo tópico será apresentada essa ação e seu funcionamento no âmbito do Programa.

2.1.2 O Pronatec Empreendedor: a socialização da classe trabalhadora no "novo espírito do capitalismo"

No primeiro período de atuação do Ministro da Educação Aluísio Mercadante (24 de janeiro de 2012 a 02 de fevereiro de 2014) no governo Dilma, o Ministério da Educação assinou um Acordo de Cooperação Técnica com o SEBRAE (Serviço Brasileiro de Apoio às micro e pequenas empresas) - instituição integrante do Sistema $\mathrm{S}$ - para implantar o Pronatec Empreendedor. Esse acordo tem por objetivo "difundir a cultura empreendedora em cursos técnicos de nível médio e cursos de formação inicial e continuada oferecidos por intermédio da Bolsa Formação" (MEC/SEBRAE, 2013) a partir de atividades de sensibilização e capacitação de alunos, professores e escolas e premiação das experiências consideradas exitosas. 
As atividades formativas envolvem a oferta de cursos online para professores que atuam nos cursos da Bolsa Formação, inclusive em nível de especialização ${ }^{78}$ e a inserção de conteúdos de empreendedorismo na proposta curricular de alguns cursos - com carga horária de mínima de 24 horas, podendo chegar até 52 horas, e material elaborado e distribuído pelo SEBRAE. Com vistas na sensibilização para o empreendedorismo, as instituições ofertantes receberam cartilhas e vídeos sobre a temática, destinados aos professores e estudantes, e um Baú (Figura 2), com o slogan "Aqui tem Empreendedorismo", portando publicações sobre empreendedorismo, guia com recomendações de sites e filmes que tratam do tema, banner, cartilha com apresentação do Pronatec Empreendedor, marcadores de livro, entre outros materiais, conforme Nota Informativa SETEC, n. 20/2013. A premiação ocorre a partir de inscrição pelas escolas e seleção pelo SEBRAE de experiências empreendedoras nas categorias “Pronatec Empreendedor" e "Objeto de Aprendizagem”. Os alunos e professores envolvidos nas experiências selecionadas recebem como prêmio tablets e viagens nacionais, custeados pelo SEBRAE.

A partir de reunião envolvendo gestores do MEC e do SEBRAE definiu-se uma lista de cursos que possuíam maior "aderência" à temática empreendedorismo. Em 2013, a lista contemplava 15 cursos ( 2 técnicos e 13 FICs) e em 2015 aumentou para 70 cursos ( 7 cursos técnicos e 63 FICs). Essas informações foram repassadas pela SETEC às instituições ofertantes por meio das Notas Informativas n. 20/2013 e n. 122/2015 ${ }^{79}$. De acordo com a Nota Informativa 20/2013, “as instituições ofertantes, a partir de setembro de 2013, deverão agregar o módulo 'Plano de Vida e Carreira', com carga horária de 24 horas, aos cursos que integrarão o Pronatec Empreendedor. Existem, ainda, os módulos 'Atitudes Empreendedoras', com 16 horas, e "Mundo do Trabalho, com 12 horas, que poderão, opcionalmente, integrar o currículo dos cursos".

No site do SEBRAE ${ }^{80}$ a ação do Pronatec Empreendedor é justificada pela necessidade de orientação aos estudantes para as diferentes possibilidades do mundo do trabalho, inclusive

\footnotetext{
${ }^{78}$ Foi ofertado, no ano de 2016, pelo Ensino à Distância da PUC/RJ o curso de Especialização Lato Sensu em Educação Empreendedora, para 200 profissionais com vínculo empregatício junto às instituições ofertantes do Pronatec Bolsa Formação: 81 vagas para os institutos federais; 27 para as secretarias estaduais de educação; 02 vagas para a SETEC e 90 vagas para os Sistemas Nacionais de Aprendizagem, conforme Nota Informativa SETEC n. 122/2015. Nota-se que, ao exigir que apenas os profissionais do quadro permanente das instituições realizem o curso, há o intuito de inserir a cultura do empreendedorismo no âmbito das instituições. Ressalta-se que o SEBRAE é o responsável pelo custo das matrículas no curso, incluindo passagens e diárias para os encontros presenciais, tendo sido alertado aos profissionais que a não integralização do curso, após efetivada a matrícula, implicará na devolução dos recursos investidos ao SEBRAE.

79 Disponíveis em: https://map.mec.gov.br/projects/parceiros-demandantes-e-ofertantes-da-bolsaformacao/wiki/Notas_Informativas

${ }^{80}$ No endereço: http://pronatecempreendedor.sebrae.com.br/
} 
na "perspectiva do auto emprego", destacando a importância do desenvolvimento de "competências empreendedoras" frente ao conceito de "trabalhabilidade 81 " presente "nos Referenciais Curriculares Nacionais da Educação Profissional de Nível Técnico (RCNEPT)". Embora seja possível identificar pelos próprios argumentos a filiação conceitual que expressa, o documento citado na justificativa é datado do ano 2000, tendo sido elaborado sob a égide do Decreto 2.208/97, no contexto da concepção de educação profissional orientada pela pedagogia das competências, o que expressa a retomada dos pressupostos que orientaram a educação profissional nos anos 1990 no âmbito do Pronatec.

Figura 2 - Baú Pronatec Empreendedor

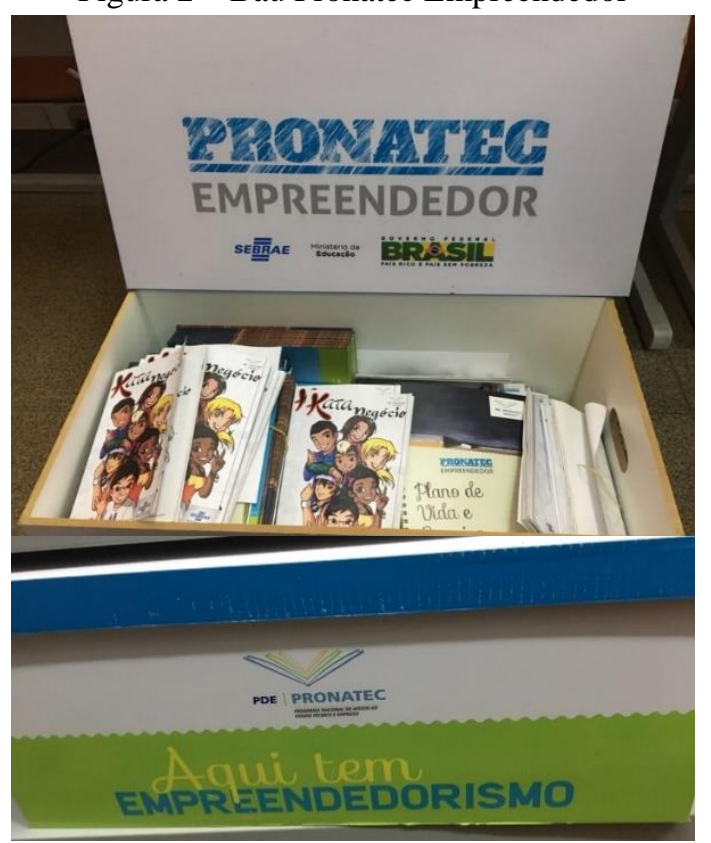

Fonte: Fotografia coletada pela pesquisadora durante a pesquisa de campo na instituição do SNA (2017).

Observa-se que os princípios duramente combatidos pelos educadores no momento da elaboração e aprovação das Diretrizes Curriculares da EPTNM, no período de 2010 a 2012, como apresentado no Capítulo I, são reiterados a partir do Pronatec Empreendedor. Revela ainda que a lógica privada no Pronatec não se resume à apropriação dos recursos públicos e à formação no âmbito das instituições privadas, mas busca influenciar inclusive a formação desenvolvida pelas instituições públicas, ao se inserir de forma totalizante no âmbito do Programa.

\footnotetext{
${ }^{81}$ Esse conceito é expresso no documento da seguinte forma: "A laborabilidade ou a trabalhabilidade, entendida como componente da dimensão produtiva da vida social e, portanto, da cidadania, é objetivo primordial da educação profissional. No núcleo dessa modalidade de educação está o processo de apropriação da condição ou do conjunto de condições para produzir benefícios - produtos e serviços - compartilhados socialmente e para o acesso ao usufruto desses benefícios, em situações permanentemente mutáveis e instáveis" (RCNEPT, 2000, p. 09).
} 
Essa ação do SEBRAE, enquanto instituição voltada para o desenvolvimento empresarial, com vistas no fomento à educação empreendedora no âmbito das instituições de ensino não se resume apenas no nível da educação profissional. A ação Pronatec Empreendedor faz parte de uma política maior desta instituição denominada "Programa Nacional de Educação Empreendedora - PNEE" que visa "ampliar, promover e disseminar nos currículos das instituições de ensino os conteúdos sobre empreendedorismo aos jovens", por meio de parecerias com instituições de ensino que atuam desde o ensino fundamental até o ensino superior. Conforme consta no site do SEBRAE, entre 2014 e 2016 "foram capacitados 2.408.032 estudantes e 51.919 professores de 2.942 instituições de ensino parceiras de todo o país". Para isso, a instituição dispõe de diferentes produtos, de acordo com o nível de ensino dos estudantes, como o "Jovens Empreendedores Primeiros Passos", destinado ao ensino fundamental; "Crescendo e Empreendendo", "Despertar", "Jovem Empreendedor no Campo" e "Formação de Jovens Empreendedores", voltados ao ensino médio; "Disciplina de Empreendedorismo", para a educação profissional; e palestras, plataformas digitais, disciplinas, simpósio de educação empreendedora e projetos, entre outros, que se destinam ao ensino superior (SITE SEBRAE).

Conforme destaca Lucie Tanguy (2016), a realização de parcerias com vistas a “aprender a empreender" constituem formas de introdução dos valores das empresas no âmbito das escolas. Sob a acusação de que as escolas são muito tradicionais e não despertam a criatividade e protagonismo nos estudantes - características valorizadas no atual mercado de trabalho - as instituições empresariais promovem formas de intervir no "seio das escolas para ensinarem, elas mesmas, o espírito das empresas" (TANGUY, 2016, p. 198).

A ação do Pronatec Empreendedor foi bem recebida no âmbito da SETEC, conforme aponta Marcelo Feres, uma vez que oportunizou a inserção de conteúdo do setor produtivo no âmbito da formação e representou, por outro lado, a colaboração, inclusive financeira, de uma instituição privada no âmbito do Programa. Observa-se, com isso, que o projeto pedagógico que representa essa ação, não é questionado pela SETEC, indicando que a "base ideológica marxista" que orientou a criação dos Institutos Federais e demais políticas da área durante os governos Lula, conforme situou Pacheco, havia perdido espaço no âmbito dessa Secretaria.

A ação Pronatec Empreendedor foi muita discussão com o SEBRAE, que levou o SEBRAE a colocar orçamento dele, preparar material didático, curso à distância, possibilitou que a gente pudesse capacitar muitos docentes. Alguns não se interessaram. Mas, enfim, é um processo que demora mais tempo também, e muitos docentes fizeram o processo de capacitação, incorporaram os materiais didáticos produzidos pelo SEBRAE. Eu acho que nós deveríamos ter mais isso. Isso também 
foi uma outra amostragem que nós poderíamos ter, por exemplo, de conteúdo do setor produtivo, que pudesse ser avaliado pelos docentes. Não é para você ficar subalterno, subordinado ao setor produtivo, é para você dialogar com ele. Eu acho que a ação, com o SEBRAE, em relação ao empreendedorismo, a ideia de microempreendedor individual, de microempresa, faz o nosso aluno sonhar mais. Então, ele conhecer, ele ter essa visão, também, que a Educação, ela tem que servir para ele dentro de uma perspectiva de projeto de vida. O objetivo do curso, ele começa com a ideia de projeto de vida: onde é que entra o estudar? Não é estudar por estudar. Nós ainda vivemos um modelo de que o estudante vai para a escola, porque o vizinho dele vai, porque o pai foi, porque todo mundo vai, ele não sabe porquê, ele não tem motivação. Então, ele não vê sentido no estudo, é um esforço que ele faz porque tem que fazer. Então, é preciso que a gente tenha outras vias, porque só a via da escola, muitas vezes não consegue. Colocar toda essa carga só para o professor, dentro do seu modelo didáticopedagógico não é suficiente. Ouvir de outras vias, eu acho importante também. Achei uma ação importantíssima. O SEBRAE poderia ter usado aquele recurso, não em instituições públicas, como fez, poderia ter usado instituições privadas. Então, tem gente que fala, às vezes, que o recurso público foi para o privado, você me faz lembrar de um recurso privado que veio para o público. Privado, que eu estou dizendo, é porque tipicamente ele vai para o privado (Entrevista FERES, 2018).

A educação empreendedora vem ao encontro da formação para o "novo espírito do capitalismo" (BOLTANSKI; CHIAPELLO, 2009, p. 126), ao estimular a criatividade, a arriscar e assumir riscos, a flexibilidade, e sobretudo a ideia de que a capacidade de se adaptar e reinventar é preferível à de construir uma carreira: "a passagem de um projeto para outro é a oportunidade de aumentar a própria empregabilidade" (BOLTANSKI; CHIAPELLO, op. cit.). Oriunda do discurso da nova gestão empresarial, a partir do Toyotismo, essa lógica se estende também para o âmbito das empresas, as quais se beneficiam do "espírito empreendedor" para o aumento da eficiência e da produtividade (LIMA, 2010).

No material do Pronatec Empreendedor destinado à formação dos estudantes, são destacados dois caminhos para se tornar um empreendedor de sucesso: ser um "colaborador empreendedor de sucesso" ou ser "dono do meu negócio - um empreendedor de sucesso". Para o primeiro caminho, o termo utilizado é o "intraempreendedorismo", o qual conduziria à formação de profissionais muito valorizados no mercado de trabalho:

sem medo de errar, o profissional mais procurado, disputado mesmo pelo mercado é aquele capaz de administrar os recursos e processos que estão em seu poder como se eles fossem seus próprios, com o chamado "espírito de dono". A lógica é bem simples (embora sua prática não seja necessariamente das mais fáceis): se o colaborador administra os recursos da empresa/instituição como se fossem seus, muito provavelmente desperdiçará menos materiais, faltará menos ao trabalho, buscará desenvolver novos caminhos de forma a superar os desafios e aperfeiçoar os processos internos (SEBRAE, 2013, p. 28).

A valorização do "intraempreendedorismo" na formação profissional, visa contribuir na formação de trabalhadores "engajados" que contribuam no aumento da produtividade do negócio. Para além dos conhecimentos técnicos, na nova gestão empresarial, em contraposição 
ao taylorismo, passam a ser valorizadas as características e os valores individuais que "justamente por serem mais humanos penetram com mais profundidade no íntimo das pessoas que - como se espera - devem 'doar-se'(...) ao trabalho” (BOLTANSKI; CHIAPELLO, 2009, p.132). A ideia de hierarquia tende a ser dissolvida a partir da valorização do "espírito de dono", sem, contudo, se dissolverem as diferenças salariais e de apropriação do valor produzido por meio do trabalho.

Sob a lógica da formação do "empreendedor de sucesso", reinterpreta-se, como aponta Lima (2010), o trabalho informal, "destacando seu potencial criador vinculado à predisposição individual ao risco e à inovação" (p. 161). Tal como o trabalho informal, que concorria para a diminuição do valor da força de trabalho, ao constituir um grupo de trabalhadores disponíveis à margem do mercado formal, o empreendedor, como um produto do capitalismo flexível, constitui fonte de "trabalho barato e não organizado", uma vez que no âmbito do empreendedorismo "a cultura compartilhada é do individualismo, quase do predador em busca da inovação permanente" (LIMA, 2010, p. 174-178).

Nesse sentido, tanto o intraempreendedorismo quanto o empreendedorismo são formas de socialização da força de trabalho frente às demandas do capital, que, no entanto, apresentamse como necessidades formativas do trabalhador, com vistas ao acesso e sobrevivência no mercado de trabalho. Compreende-se, nessa direção, com base na literatura sobre as relações entre o público e o privado na educação no contexto do capitalismo globalizado (PERONI, 2003; ADRIÃO, 2005; LAVAL, 2004; DALE, 1994), que as fronteiras entre estas duas esferas não estão restritas apenas a instituições e recursos, mas ocorrem também por meio de ideias e projetos que se orientam por diferentes concepções de sujeito e sociedade. Para além do repasse de recursos públicos às instituições de educação profissional privadas, o Pronatec abriu espaço também para que a concepção pedagógica do capital se direcionasse às instituições e ao projeto público de educação profissional, a qual revela mais da linguagem do mercado, que, propriamente, da linguagem pedagógica (TANGUY, 2016). Claramente identificada como estratégia de socialização da força de trabalho a partir das novas demandas do mercado de trabalho, e comprometida com a disseminação do empreendedorismo como ideologia, compreendida, na perspectiva gramsciana, como forma de pensar e agir no atual mercado de trabalho.

\subsection{O modus operandi do Pronatec Bolsa Formação}

A legislação que ampara o desenvolvimento do Pronatec Bolsa Formação é ampla, em virtude das diferentes instituições que atuam como ofertantes e demandantes dos cursos e das 
mudanças ocorridas ao longo de seu desenvolvimento. Fundamentada na Lei de sua criação, a Bolsa Formação é normatizada pelo Ministério da Educação, por meio de Portaria, e a sua execução financeira é regulamentada por meio de Resoluções do FNDE, de acordo com a natureza das instituições ofertantes.

Com base na última Portaria que normatiza a Bolsa Formação - Portaria MEC n. 817 de agosto de 2015 -, essa iniciativa se articula em torno dos cursos, do público a quem se destina e dos agentes envolvidos no planejamento e execução. Quanto aos cursos, esses são ofertados em duas modalidades:

I - Bolsa Formação Estudante:

a) cursos técnicos na forma concomitante, para estudantes em idade própria;

b) cursos técnicos na forma concomitante ou integrada, na modalidade Educação de Jovens e Adultos - EJA;

c) cursos técnicos na forma subsequente, para estudantes que concluíram o ensino médio; e

d) cursos de formação de professores em nível médio, na modalidade normal.

II - Bolsa Formação Trabalhador:

a) cursos de formação inicial e continuada ou qualificação profissional. (MEC, 2015)

Em relação ao público, os cursos se destinam, prioritariamente:

I - aos estudantes do ensino médio da rede pública, inclusive da EJA;

II - aos trabalhadores;

III - aos beneficiários titulares e dependentes dos programas federais de transferência de renda, entre outros que atenderem a critérios previstos no âmbito do Plano Brasil sem Miséria; e

IV - aos estudantes que tenham cursado o ensino médio completo em escola da rede pública ou em instituições privadas na condição de bolsista integral.

Será estimulada a participação de pessoas com deficiência, povos indígenas, comunidades quilombolas, adolescentes e jovens em cumprimento de medidas socioeducativas, mulheres responsáveis pela unidade familiar beneficiárias de programas federais de transferência de renda e de trabalhadores beneficiários do Programa Seguro-Desemprego. (MEC, 2015)

A Portaria define ainda que terão prioridade em cursos FIC os trabalhadores beneficiários do Seguro-Desemprego e em cursos FIC e técnicos concomitantes as pessoas com deficiência. A Lei do Pronatec, altera, inclusive, a regulamentação do Programa SeguroDesemprego (Lei no 7.998, de 11 de janeiro de 1990), incluindo a possibilidade da União condicionar o recebimento do seguro-desemprego à realização de matrícula em cursos de qualificação profissional com no mínimo 160 horas. Essa possibilidade foi regulamentada por meio do Decreto n. 7.721/2012, atribuindo àquele trabalhador que solicitar pela segunda vez o benefício do seguro-desemprego, no período de 10 anos, a necessidade de realização de matrícula em cursos FIC ofertado no âmbito do Pronatec Bolsa Formação, salvo em caso de inexistência de vaga ou da realização de outro curso, por parte do trabalhador, que atenda aos mesmos requisitos. A não realização do curso para o qual foi matriculado ou o não cumprimento 
de frequência mínima de $75 \%$ da carga horária implica no cancelamento do benefício e devolução de parcelas já recebidas pelo trabalhador. Esse fato reitera a lógica presente nas políticas de formação profissional que supõe uma relação direta entre a posse de uma qualificação e a ocupação de um posto de trabalho, conforme aponta Hirata (1999), e reforça no trabalhador a ideia de que ele é responsável pela sua condição de desemprego.

Em relação aos agentes da Bolsa Formação encontram-se como gestores no âmbito do Ministério da Educação a Secretaria de Educação Profissional e Tecnológica - SETEC/MEC e a Diretoria de Tecnologia da Informação - DTI/MEC, e como responsável pela normatização e execução financeira o Fundo Nacional de Desenvolvimento da Educação - FNDE, juntamente com as instituições demandantes e as instituições ofertantes dos cursos. Em relação a estes dois últimos agentes - demandantes e ofertantes - as instituições habilitadas precisam firmar termo de adesão ou cooperação com o Programa para poder atuar.

Poderão ser demandantes do Pronatec Bolsa Formação: a) os Ministérios e outros órgãos da Administração Pública Federal; b) as secretarias estaduais e distritais de educação e as Secretarias vinculadas ao MEC (MEC, 2015). Estas instituições têm como competência informar as demandas específicas de formação profissional no seu âmbito de atuação, a partir da colaboração de órgãos dos Estados, Distrito Federal, municípios e organizações da sociedade civil, e realizar a seleção e pré-matrícula dos candidatos nos cursos, de acordo com os requisitos legais, após a homologação da oferta pela SETEC.

A partir do ingresso desses diferentes órgãos demandantes, a Bolsa Formação desenvolveu 43 diferentes modalidades de demanda, que se diferenciam em razão do público a ser atendido e da origem da demanda, conforme Tabela 8. De acordo com relatório do Tribunal de Contas (TCU), até 2015, o demandante com o maior percentual de matrículas era o Ministério do Desenvolvimento Social, com 38\% das matrículas (TCU, 2016).

Tabela 8 - Relação de demandantes e modalidades de demanda do Pronatec Bolsa Formação

\begin{tabular}{|c|c|c|c|}
\hline Demandante & $\begin{array}{l}\text { Modalidade de } \\
\text { Demanda }\end{array}$ & Perfil de Público & $\begin{array}{l}\text { Unidade Demandante } \\
\text { Típica }\end{array}$ \\
\hline \multirow{2}{*}{$\begin{array}{l}\text { Secretarias de } \\
\text { Estado e do } \\
\text { Distrito Federal } \\
\text { de Educação }\end{array}$} & $\begin{array}{l}\text { Pronatec Jovem } \\
\text { Técnico } \\
\text { Concomitante }\end{array}$ & $\begin{array}{l}\text { Estudantes do ensino médio da } \\
\text { rede pública }\end{array}$ & \multirow{2}{*}{$\begin{array}{l}\text { Unidades de ensino da } \\
\text { educação básica, que tenham } \\
\text { ensino médio, e/ou secretaria } \\
\text { estadual e distrital de } \\
\text { educação. }\end{array}$} \\
\hline & $\begin{array}{l}\text { Pronatec Jovem } \\
\text { FIC }\end{array}$ & $\begin{array}{l}\text { do Ensino Médio da } \\
\text { a }\end{array}$ & \\
\hline \multirow{3}{*}{$\begin{array}{l}\text { Ministério do } \\
\text { Desenvolvimento } \\
\text { Social e Combate } \\
\text { à Fome }\end{array}$} & $\begin{array}{l}\text { Pronatec Brasil sem } \\
\text { Miséria }\end{array}$ & Cadastrados no CadÚnico & \multirow{3}{*}{$\begin{array}{l}\text { Centro de Referência de } \\
\text { Assistência Social - CRAS, } \\
\text { vinculados às prefeituras, } \\
\text { e/ou secretarias estaduais de } \\
\text { assistência social }\end{array}$} \\
\hline & $\begin{array}{l}\text { Pronatec Mulheres } \\
\text { Mil }\end{array}$ & cadastradas no & \\
\hline & $\begin{array}{l}\text { Pronatec Sistema } \\
\text { Socioeducativo } \\
\text { Aberto }\end{array}$ & $\begin{array}{l}\text { Jovens e Adolescentes em } \\
\text { cumprimento de medida } \\
\text { socioeducativa em meio aberto }\end{array}$ & \\
\hline
\end{tabular}




\begin{tabular}{|c|c|c|c|}
\hline & Pronatec Vira Vida & $\begin{array}{l}\text { Jovens em situação de } \\
\text { vulnerabiliade social que } \\
\text { participam do Projeto Vira Vida. }\end{array}$ & \\
\hline \multirow{5}{*}{$\begin{array}{l}\text { Ministério do } \\
\text { Trabalho e } \\
\text { Emprego }\end{array}$} & $\begin{array}{l}\text { Pronatec Seguro- } \\
\text { Desemprego }\end{array}$ & $\begin{array}{l}\text { Beneficiários do Seguro- } \\
\text { Desemprego }\end{array}$ & \multirow{5}{*}{$\begin{array}{l}\text { SINE e outras agências do } \\
\text { trabalhador }\end{array}$} \\
\hline & $\begin{array}{l}\text { Pronatec } \\
\text { Trabalhador }\end{array}$ & Trabalhadores & \\
\hline & Pronatec Aprendiz & $\begin{array}{l}\text { Participantes do Programa Jovem } \\
\text { Aprendiz }\end{array}$ & \\
\hline & Pronatec Certific & $\begin{array}{l}\text { Cidadãos interessados em realizar } \\
\text { processo de certificação de } \\
\text { saberes }\end{array}$ & \\
\hline & $\begin{array}{l}\text { Pronatec ProJovem } \\
\text { Trabalhador }\end{array}$ & $\begin{array}{l}\text { Jovens que participam do } \\
\text { ProJovem Trabalhador }\end{array}$ & \\
\hline \multirow{3}{*}{$\begin{array}{l}\text { Ministério do } \\
\text { Turismo }\end{array}$} & Pronatec Copa & $\begin{array}{l}\text { Trabalhadores que atuam ou } \\
\text { pretendem atuar nos setores de } \\
\text { turismo, hospitalidade ou lazer }\end{array}$ & $\begin{array}{l}\text { Secretarias estaduais e } \\
\text { municipais de turismo }\end{array}$ \\
\hline & $\begin{array}{l}\text { Pronatec Copa na } \\
\text { Empresa }\end{array}$ & $\begin{array}{l}\text { Trabalhadores que atuam nos } \\
\text { setores de turismo, hospitalidade } \\
\text { ou lazer }\end{array}$ & $\begin{array}{l}\text { Empresas do setor de } \\
\text { turismo, hospitalidade e } \\
\text { lazer }\end{array}$ \\
\hline & $\begin{array}{l}\text { Pronatec Copa } \\
\text { Social }\end{array}$ & $\begin{array}{l}\text { Jovens em situação de } \\
\text { vulnerabilidade egressos do } \\
\text { Projeto Vira Vida. }\end{array}$ & $\begin{array}{l}\text { Secretarias estaduais e } \\
\text { municipais de turismo }\end{array}$ \\
\hline \multirow{7}{*}{$\begin{array}{l}\text { Ministério da } \\
\text { Defesa }\end{array}$} & Pronatec Exército & $\begin{array}{l}\text { Praças do Exército em prestação } \\
\text { de Serviço Militar }\end{array}$ & Comando local do Exército \\
\hline & $\begin{array}{l}\text { Pronatec } \\
\text { Aeronáutica }\end{array}$ & $\begin{array}{l}\text { Praças da Aeronáutica em } \\
\text { prestação de Serviço Militar }\end{array}$ & \multirow{2}{*}{ Comando da Aeronáutica } \\
\hline & $\begin{array}{l}\text { Pronatec } \\
\text { Aeronáutica } \\
\text { Reserva }\end{array}$ & $\begin{array}{l}\text { Praças da Aeronáutica que deram } \\
\text { baixa do Serviço Militar, nos } \\
\text { últimos } 12 \text { meses. }\end{array}$ & \\
\hline & Pronatec Marinha & $\begin{array}{l}\text { Praças da Marinha em prestação } \\
\text { de Serviço Militar }\end{array}$ & \multirow[b]{2}{*}{ Comando da Marinha } \\
\hline & $\begin{array}{l}\text { Pronatec Marinha } \\
\text { Reserva }\end{array}$ & $\begin{array}{l}\text { Praças da Marinha que deram } \\
\text { baixa do Serviço Militar, nos } \\
\text { últimos } 12 \text { meses. }\end{array}$ & \\
\hline & $\begin{array}{l}\text { Pronatec Exército } \\
\text { Reserva }\end{array}$ & $\begin{array}{l}\text { Praças do Exército que deram } \\
\text { baixa do Serviço Militar, nos } \\
\text { últimos } 12 \text { meses, e Atiradores de } \\
\text { Tiro de Guerra }\end{array}$ & Organizações militares. \\
\hline & $\begin{array}{l}\text { Pronatec Marinha } \\
\text { Mercante }\end{array}$ & $\begin{array}{l}\text { Trabalhadores que atuam ou } \\
\text { pretendem atuar no setor } \\
\text { aquaviário. }\end{array}$ & $\begin{array}{l}\text { Órgãos de execução do } \\
\text { sistema de ensino } \\
\text { profissional marítimo }\end{array}$ \\
\hline $\begin{array}{l}\text { Ministério do } \\
\text { Desenvolvimento } \\
\text { Agrário }\end{array}$ & Pronatec Campo & $\begin{array}{l}\text { Público da agricultura familiar, } \\
\text { povos e comunidades tradicionais } \\
\text { e da Reforma Agrária }\end{array}$ & $\begin{array}{l}\text { EMATER, ATER, } \\
\text { SEAPROF, Sindicatos }\end{array}$ \\
\hline \multirow{3}{*}{$\begin{array}{l}\text { Secretaria de } \\
\text { Direitos Humanos }\end{array}$} & $\begin{array}{l}\text { Pronatec Sistema } \\
\text { Socioeducativo } \\
\text { Fechado }\end{array}$ & $\begin{array}{l}\text { Jovens e Adolescentes em } \\
\text { cumprimento de medida } \\
\text { socioeducativa em meio fechado }\end{array}$ & $\begin{array}{l}\text { Órgãos estaduais de } \\
\text { execução do sistema } \\
\text { socioeducativo }\end{array}$ \\
\hline & $\begin{array}{l}\text { Pronatec Viver sem } \\
\text { Limite }\end{array}$ & Pessoas com deficiência & \multirow{2}{*}{$\begin{array}{l}\text { Órgãos de gestão da política } \\
\text { da pessoa com deficiência; } \\
\text { entidades representativas da } \\
\text { sociedade civil vinculadas à } \\
\text { política da pessoa com } \\
\text { deficiência. }\end{array}$} \\
\hline & Pronatec Pop Rua & População em situação de rua & \\
\hline
\end{tabular}




\begin{tabular}{|c|c|c|c|}
\hline $\begin{array}{l}\text { Ministério do } \\
\text { Desenvolvimento, } \\
\text { Indústria e } \\
\text { Comércio } \\
\text { Exterior }\end{array}$ & $\begin{array}{l}\text { Pronatec Brasil } \\
\text { Maior }^{82}\end{array}$ & $\begin{array}{l}\text { Trabalhadores para os setores } \\
\text { relacionados ao Plano Brasil } \\
\text { Maior. }\end{array}$ & $\begin{array}{l}\text { Entidades representativas da } \\
\text { indústria }\end{array}$ \\
\hline $\begin{array}{l}\text { Ministério das } \\
\text { Comunicações }\end{array}$ & $\begin{array}{l}\text { Pronatec } \\
\text { Comunicações }\end{array}$ & $\begin{array}{l}\text { Trabalhadores que atuam ou } \\
\text { pretendem atuar nas áreas de } \\
\text { produção, programação e } \\
\text { distribuição de informações e } \\
\text { dados sobre plataformas de } \\
\text { radiodifusão ou } \\
\text { telecomunicações. }\end{array}$ & $\begin{array}{l}\text { Prefeituras participantes do } \\
\text { programa Cidades Digitais. } \\
\text { Associações e Federações de } \\
\text { empresas do setor. } \\
\text { Convenentes do programa } \\
\text { de Conteúdos Digitais } \\
\text { Criativos. }\end{array}$ \\
\hline \multirow[b]{2}{*}{$\begin{array}{l}\text { Ministério da } \\
\text { Justiça }\end{array}$} & $\begin{array}{l}\text { Pronatec Sistema } \\
\text { Prisional }\end{array}$ & $\begin{array}{l}\text { Privados de liberdade em regime } \\
\text { aberto e semi-aberto e egressos de } \\
\text { Estabelecimentos Penais. }\end{array}$ & \multirow{2}{*}{$\begin{array}{l}\text { Unidades prisionais } \\
\text { Secretarias estaduais de } \\
\text { administração prisional ou } \\
\text { órgãos congêneres. } \\
\text { Grupo de Monitoramento da } \\
\text { Execução Penal vinculado } \\
\text { ao Conselho Nacional de } \\
\text { Justiça }\end{array}$} \\
\hline & $\begin{array}{l}\text { Pronatec Sistema } \\
\text { Prisional em } \\
\text { Regime Fechado }\end{array}$ & $\begin{array}{l}\text { Cumpridores de penas Sistemas } \\
\text { Penitenciários em regime fechado }\end{array}$ & \\
\hline $\begin{array}{l}\text { Ministério da } \\
\text { Previdência } \\
\text { Social }\end{array}$ & $\begin{array}{l}\text { Pronatec } \\
\text { Reabilitação } \\
\text { Profissional }\end{array}$ & $\begin{array}{l}\text { Trabalhadores em processo de } \\
\text { reabilitação profissional }\end{array}$ & Postos do INSS \\
\hline $\begin{array}{l}\text { Ministério da } \\
\text { Cultura }\end{array}$ & Pronatec Cultura & $\begin{array}{l}\text { Trabalhadores para atender as } \\
\text { demandas do mercado cultural. }\end{array}$ & $\begin{array}{l}\text { Secretarias estaduais e } \\
\text { municipais de cultura }\end{array}$ \\
\hline $\begin{array}{l}\text { Ministério da } \\
\text { Pesca e } \\
\text { Aquicultura }\end{array}$ & $\begin{array}{l}\text { Pronatec Pesca e } \\
\text { Aquicultura }\end{array}$ & $\begin{array}{l}\text { Pescadores e aquicultores que } \\
\text { atuam ou pretendem atuar nos } \\
\text { setor pesqueiro e aquícola. }\end{array}$ & $\begin{array}{l}\text { Superintendências federais } \\
\text { da pesca e aquicultura }\end{array}$ \\
\hline \multirow{4}{*}{$\begin{array}{l}\text { Secretaria de } \\
\text { Educação } \\
\text { Continuada, } \\
\text { Alfabetização, } \\
\text { Diversidade e } \\
\text { Inclusão - } \\
\text { SECADI/MEC }\end{array}$} & $\begin{array}{l}\text { Pronatec Projovem } \\
\text { Urbano }\end{array}$ & $\begin{array}{l}\text { Jovens que participam do } \\
\text { Pronatec Projovem Urbano. }\end{array}$ & $\begin{array}{l}\text { Secretarias municipais e } \\
\text { estaduais de educação }\end{array}$ \\
\hline & $\begin{array}{l}\text { Pronatec EJA } \\
\text { Técnico Integrado }\end{array}$ & $\begin{array}{l}\text { Egressos do ensino fundamental, } \\
\text { inclusive na modalidade EJA e do } \\
\text { Pronatec Projovem Urbano, com } \\
\text { idade igual ou superior a } 18 \text { anos. }\end{array}$ & \multirow{3}{*}{$\begin{array}{l}\text { Secretarias municipais e } \\
\text { estaduais (órgãos gestores da } \\
\text { EJA e do ProJovem) }\end{array}$} \\
\hline & $\begin{array}{l}\text { Pronatec EJA } \\
\text { Técnico } \\
\text { Concomitante }\end{array}$ & $\begin{array}{l}\text { Egressos do ensino fundamental, } \\
\text { inclusive na modalidade EJA e do } \\
\text { Pronatec Projovem Urbano, com } \\
\text { idade igual ou superior a } 18 \text { anos. }\end{array}$ & \\
\hline & Pronatec EJA FIC & $\begin{array}{l}\text { Estudantes matriculados no } \\
\text { ensino fundamental EJA, com } \\
\text { idade igual ou superior a } 15 \text { anos, } \\
\text { e no ensino médio EJA, com } \\
\text { idade igual ou superior a } 18 \text { anos. }\end{array}$ & \\
\hline $\begin{array}{l}\text { Ministério da } \\
\text { Integração } \\
\text { Nacional }\end{array}$ & $\begin{array}{l}\text { Pronatec Defesa } \\
\text { Civil }\end{array}$ & $\begin{array}{l}\text { Pessoas que atuam, direta ou } \\
\text { indiretamente, em atividades } \\
\text { relacionadas à defesa civil. }\end{array}$ & $\begin{array}{l}\text { Coordenações locais de } \\
\text { defesa civil. }\end{array}$ \\
\hline $\begin{array}{l}\text { Secretaria } \\
\text { Nacional da } \\
\text { Juventude }\end{array}$ & $\begin{array}{l}\text { Pronatec Juventude } \\
\text { Viva }\end{array}$ & $\begin{array}{l}\text { Jovens em situação de } \\
\text { vulnerabilidade social }\end{array}$ & * Não Informado \\
\hline $\begin{array}{l}\text { Ministério da } \\
\text { Agricultura }\end{array}$ & Pronatec Agro & $\begin{array}{l}\text { Agricultores e suas famílias, } \\
\text { trabalhadores rurais, estudantes } \\
\text { do ensino médio, estudantes de } \\
\text { escolas técnicas e técnicos recém- } \\
\text { formados em agropecuária ou } \\
\text { agrícola. }\end{array}$ & * Não Informado \\
\hline
\end{tabular}

${ }^{82}$ O Plano Brasil Maior (PBM) foi desenvolvido no período de agosto de 2011 a 2014, o qual congregava e articulava as ações da política industrial do governo federal, tendo como foco no estímulo à inovação e à competitividade da indústria. 


\begin{tabular}{l|lll}
\hline $\begin{array}{l}\text { Secretaria da } \\
\text { Educação } \\
\text { Profissional e } \\
\text { Tecnológica e } \\
\text { Secretaria de } \\
\text { Ensino Superior }-\end{array}$ & $\begin{array}{lll}\text { Pronatec Serviços } \\
\text { MEC }\end{array}$ & $\begin{array}{l}\text { Servidores de instituições federais } \\
\text { de ensino. }\end{array}$ & $\begin{array}{l}\text { Instituições federais de } \\
\text { Ensino }\end{array}$ \\
\hline & Pronatec Bolsa & \\
Ministério do & Verde & $*$ Não Informado \\
\cline { 2 - 3 } Meio Ambiente & Pronatec Catadores & $*$ Não Informado \\
\cline { 2 - 3 } & $\begin{array}{l}\text { Pronatec Meio } \\
\text { Ambiente }\end{array}$ & $*$ Não Informado \\
\hline \hline
\end{tabular}

Fonte: elaborado pela autora com base em informações disponíveis no site: https://map.mec.gov.br

O processo de integração das demandas de diversas áreas sociais e econômicas no âmbito do Pronatec, demandava a articulação de vários órgãos e instituições e, inicialmente, apresentou resistências no âmbito dos Ministérios, conforme relata Marcelo Feres:

A questão é: como sincronizar essa grande oferta em torno do país? E aí uma série de dificuldades houve. Primeiro, que havia resistência dos parceiros, que nós chamávamos de demandantes, que são os parceiros Ministérios. Você imagina o Ministério do Trabalho perder o recurso que tinha? E recurso dentro da política pública te dá a capacidade de influenciar, você tem poder para influenciar na política pública; então, eles perderam, em grande medida, a capacidade de influência. O Ministério do Turismo, até então, ele tira do seu orçamento, recurso para poder induzir para onde deveria andar a política; perdeu essa capacidade, também. O mesmo valendo para outros Ministérios. Então, a gente tinha que compensar essa, digamos, resistência, de um trabalho integrado, no Governo Federal, em prol da Educação Profissional e da formação profissional - não da Educação Profissional, que era interesse do MEC - o que eles queriam era a formação profissional, porque uma parte desses Ministérios tinha a demanda por profissionais formados para estarem presentes lá no setor produtivo, ou social, porque também tivemos o Ministério de Desenvolvimento Agrário participando, com profissionais da Área de Agricultura, também participando. Então, ou seja, você tinha aí setores econômicos, mas também voltados para a Área Social, não é, quilombolas, pessoas com deficiência - que é o caso da Secretaria de Direitos Humanos, que também entrou forte no sentido de captar pessoas com deficiência, que pudessem integrar a Copa, que pudessem integrar aos Cursos do MDS. Então, a gente conseguiu criar um modelo, um único modelo - que eu entendo o Pronatec, nessa ótica, enquanto política pública - como um modelo que se fortalecia, na medida em que mais atores se aproximavam dele (Entrevista FERES, 2017).

Em razão da ausência de instrumentos e espaços capazes de apontar a real demanda de formação profissional, no primeiro ano de funcionamento do Programa, conforme aponta Almerico, foi identificada uma oferta excessiva de cursos na área de administração, como auxiliar administrativo, o que levou a SETEC a criar algumas limitações de oferta e aprimorar o processo de identificação das demandas.

Eu me lembro, que o que nos foi apresentado sobre o primeiro ano do Pronatec, foi um susto. O curso mais ofertado era o curso da Área de Administração, e quem mais 
dava Administração sabem quem era? O SENAI. Não era o SENAC, era o SENAI. Por que? O curso de "cuspe e giz", um curso que não custa... o custo é mínimo. Não é um Curso de Mecatrônica, não era o curso que a indústria precisa, Perfuratriz, Geologia, não eram os cursos intensivos em tecnologia que ele deveria dar, de produção industrial. Aí no segundo ano, não é, a Setec estabeleceu um limite para esse tipo de curso. $\mathrm{Na}$ Área de Gestão em Negócios, só poderia dar, o SENAI, se fosse Comércio Exterior, Logística; ou seja, ter a ver com a produção industrial; e também eles começaram a analisar esse excesso de curso nessa área, para fazer, e localizar qual era a demanda concreta (Entrevista LIMA, 2017).

Nesse sentido, diante das fragilidades na identificação das demandas e controle da oferta, sobressaiam-se os interesses no acesso aos fundos públicos, ao priorizar o atendimento de cursos com menor custo de execução. Por outro lado, a ausência de espaços para a análise dos levantamentos realizados pelos diferentes órgãos demandantes, conduziam à sobreposição de demandas, gerando números que não correspondiam à realidade, como relata Almerico Lima,

\begin{abstract}
Então, de repente, você descobria que um mesmo curso foi solicitado a duas entidades diferentes, num mesmo município, as salas vazias; podia ser uma sala só, eram duas... Lembro, por exemplo, que o Ministério das Telecomunicações fez uma solicitação de um curso na Área de Informática. Eu cruzei com a mesma demanda que tinha do Ministério do Desenvolvimento, Indústria e Comércio, e localizei que tinham, no Estado da Bahia, eu não me lembro qual era o número, mas vou dizer aqui só para ilustrar, tipo, 1.000 vagas, 600 eram no mesmo município. Inscreveram nos dois Ministérios, não é. Vem cá, você sabe que o Ministério do Comércio também pediu vagas nesses lugares? O quê que eu vou fazer? Somar ou diminuir? É 1.600 ou é 1.000 ? Sendo que aquelas 600 ali são, na verdade, concomitantes aos dois Ministérios (Entrevista LIMA, 2017).
\end{abstract}

A CGU também apontava, com base em auditoria do Programa iniciada em 2013, que os "processos de pactuação pelos demandantes e ofertantes, de homologação da pactuação pela SETEC e de oferta de vagas pelas redes de ensino não guardavam consonância entre si”, isso porque "enquanto ministérios/secretarias demandantes e redes de ensino ofertantes pactuavam número de vagas em cada curso, a SETEC convertia as vagas em horas-aula no momento da homologação" o que, somado ao fato de que as propostas de pactuação da oferta não eram integralmente homologadas, abria margem para que as "redes de ensino tivessem ampla margem de discricionariedade na conversão das horas-aula homologadas em cursos definidos na pactuação", voltando-se para cursos de menor custo, uma vez que prestam contas em horasaula realizadas e não por curso (CGU, 2018, p. 12).

Um exemplo, apresentado no Relatório, consiste na demanda levantada pelo Ministério do Turismo (MTUR) com vistas a qualificar profissionais nas cidades que receberiam jogos da Copa do Mundo, em 2014. O estudo e levantamento realizado apontou a necessidade de qualificação de 240 mil profissionais em cursos nos eixos de Turismo, Hospitalidade e Lazer e 
Desenvolvimento Educacional e Social (formação em idiomas), os quais foram demandados no âmbito do Pronatec Bolsa Formação. No entanto, ao cruzar as matrículas realizadas nessa modalidade à demanda informada pelo MTUR, o relatório aponta que a maior parte das pactuações e das ofertas foram realizadas em cursos do Eixo de Gestão e Negócios, conforme se observa na Tabela 9.

Tabela 9 - Matrículas x Pactuações no Pronatec Copa

\begin{tabular}{|c|c|c|c|c|c|}
\hline Eixo Tecnológico & Curso & Matrículas & Pactuações & $\begin{array}{l}\text { \% Matrículas/ } \\
\text { Pactuações }\end{array}$ & $\begin{array}{l}\text { \% Matrículas } \\
\text { por curso/Total } \\
\text { de Matrículas }\end{array}$ \\
\hline \multirow{4}{*}{ Gestão e Negócios } & $\begin{array}{l}\text { Auxiliar } \\
\text { Administrativo }\end{array}$ & 37.553 & 236.835 & $15,86 \%$ & $33,02 \%$ \\
\hline & Auxiliar de pessoal & 6.296 & 38.650 & $16,29 \%$ & $5,54 \%$ \\
\hline & Recepcionista & 7.175 & 37.316 & $19,23 \%$ & $6,31 \%$ \\
\hline & $\begin{array}{l}\text { Auxiliar de } \\
\text { Recursos Humanos }\end{array}$ & 3.818 & 22.708 & $16,82 \%$ & $3,36 \%$ \\
\hline \multirow[b]{2}{*}{$\begin{array}{l}\text { Desenvolvimento } \\
\text { Educacional e Social } \\
\text { - Idiomas }\end{array}$} & Inglês Básico & 8.432 & 54.746 & $15,40 \%$ & $7,41 \%$ \\
\hline & $\begin{array}{l}\text { Inglês aplicado a } \\
\text { Serviços Turísticos } \\
\text { - Básico }\end{array}$ & 4.178 & 13.415 & $31,14 \%$ & $3,67 \%$ \\
\hline \multirow{5}{*}{$\begin{array}{l}\text { Turismo, } \\
\text { Hospitalidade e } \\
\text { Lazer }\end{array}$} & $\begin{array}{l}\text { Recepcionista em } \\
\text { Meios de } \\
\text { Hospedagem } \\
\end{array}$ & 5.691 & 39.538 & $14,39 \%$ & $5,00 \%$ \\
\hline & $\begin{array}{l}\text { Camareira em } \\
\text { Meios de } \\
\text { Hospedagem }\end{array}$ & 5.025 & 39.994 & $13,58 \%$ & $4,42 \%$ \\
\hline & $\begin{array}{l}\text { Recepcionista de } \\
\text { Eventos }\end{array}$ & 3.861 & 26.970 & $14,32 \%$ & $3,39 \%$ \\
\hline & Outros & 31.713 & 231.651 & $13,69 \%$ & $27,88 \%$ \\
\hline & Totais & 113.743 & 738.823 & $15,40 \%$ & $100 \%$ \\
\hline
\end{tabular}

Fonte: Relatório CGU (2018).

Essas constatações levaram a SETEC, a partir de 2015, a realizar algumas alterações nesse processo. A elaboração do mapa de demanda passou a contar com duas etapas de análise pela SETEC: uma em relação ao levantamento da demanda, com vistas à melhor distribuição da oferta por município e também por demandante, e, outra, em relação à oferta pelas instituições, conforme se visualiza na Figura 3. Fruto da correlação de forças entre os Ministérios e da preocupação em abranger diferentes modalidades de oferta configuradas a partir do ingresso dos diferentes demandantes, o processo de levantamento da demanda passou a ter como ponto de partida a distribuição do atendimento das demandas dos diferentes Ministérios, constituindo-se o Mapa de Demanda Específica ou Mapa de Demandas Identificada. 
Figura 3 - Fluxo do Mapa de Demandas Específicas e pactuação da oferta de cursos no Pronatec Bolsa Formação

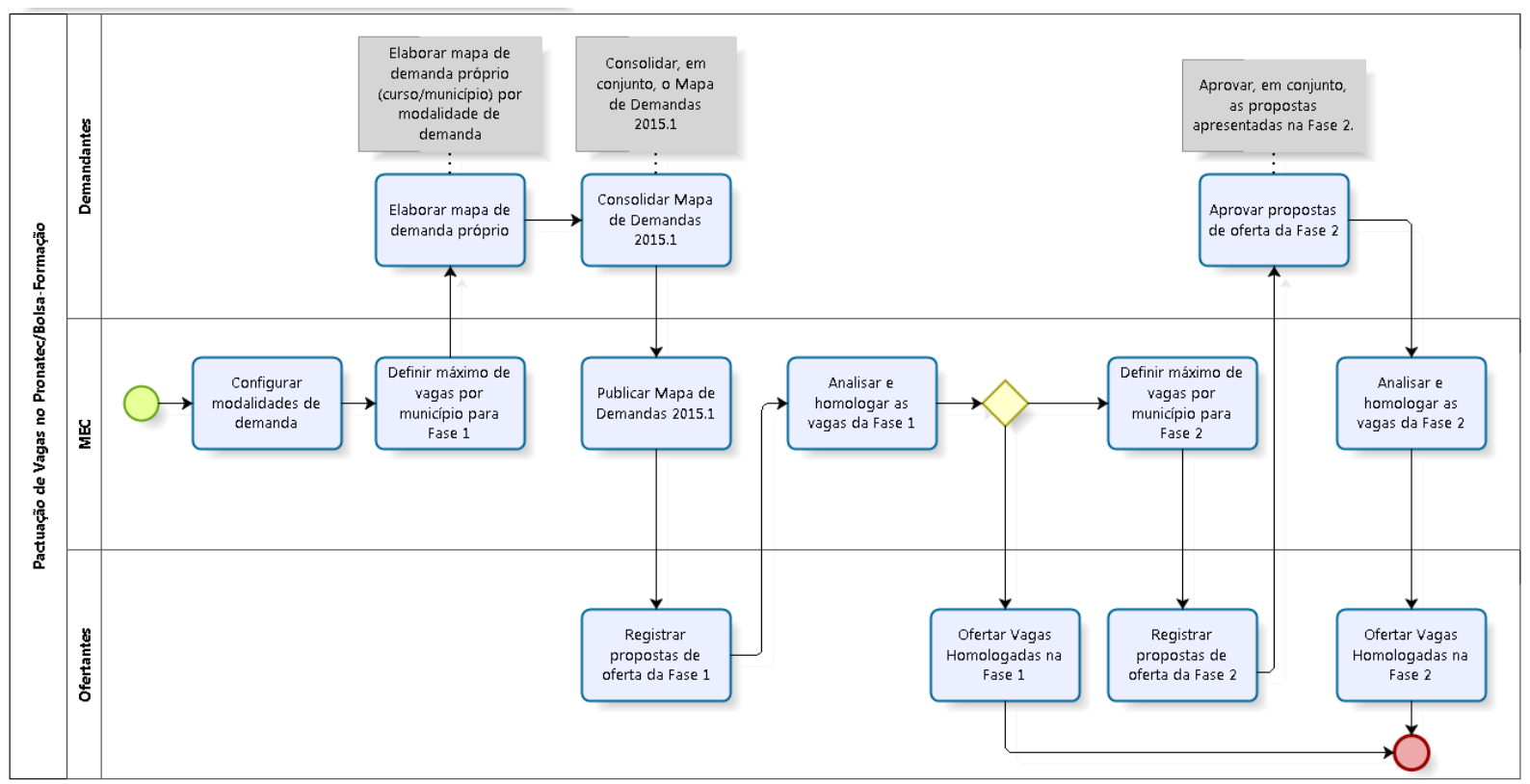

Fonte: Disponível no site https://map.mec.gov.br/

Em relação às instituições ofertantes, estão habilitadas, de acordo com a Lei do Pronatec, a firmar Termo de Adesão/Cooperação no programa: a) as instituições da Rede Federal de Educação Profissional, Científica e Tecnológica - Rede Federal de EPCT; b) as instituições públicas das redes estaduais, distrital e municipais; c) as Instituições de Ensino Superior - IES estaduais, distrital e municipais com cursos técnicos previamente autorizados pelos respectivos Conselhos de Educação; d) as instituições dos Serviço Nacional de Aprendizagem; e) as IES privadas de ensino superior e de educação profissional técnica de nível médio, devidamente habilitadas pelo MEC e; f) as fundações públicas, inclusive as públicas de direito privado, precipuamente dedicadas à educação profissional e tecnológica. Aos parceiros ofertantes instituições de ensino - cabe apresentar proposta de vagas para o atendimento das demandas apresentadas e realizar a oferta das vagas e cursos homologados pela SETEC, após o processo de pactuação. A interação e função dos agentes da Bolsa Formação pode ser expressa por meio da Figura 4.

Quanto ao tipo de curso que cada instituição pode ofertar, a Portaria n. 817/2015 define que as instituições públicas (federal, estadual, municipal ou distrital) e as instituições dos Serviços Nacionais de Aprendizagem (SNA) poderão ofertar cursos FIC e técnicos em todas as suas formas de oferta (concomitante, subsequente e integrada na modalidade EJA). As instituições privadas de ensino superior poderão ofertar apenas cursos técnicos subsequentes ao 
ensino médio, em áreas correlatas ${ }^{83}$ aos cursos de graduação que desenvolve, e as instituições privadas de ensino técnico de nível médio poderão ofertar cursos técnicos subsequentes, concomitantes ou integrados ao ensino médio na modalidade $\mathrm{EJA}^{84}$ - apenas na forma presencial, em ambas as instituições.

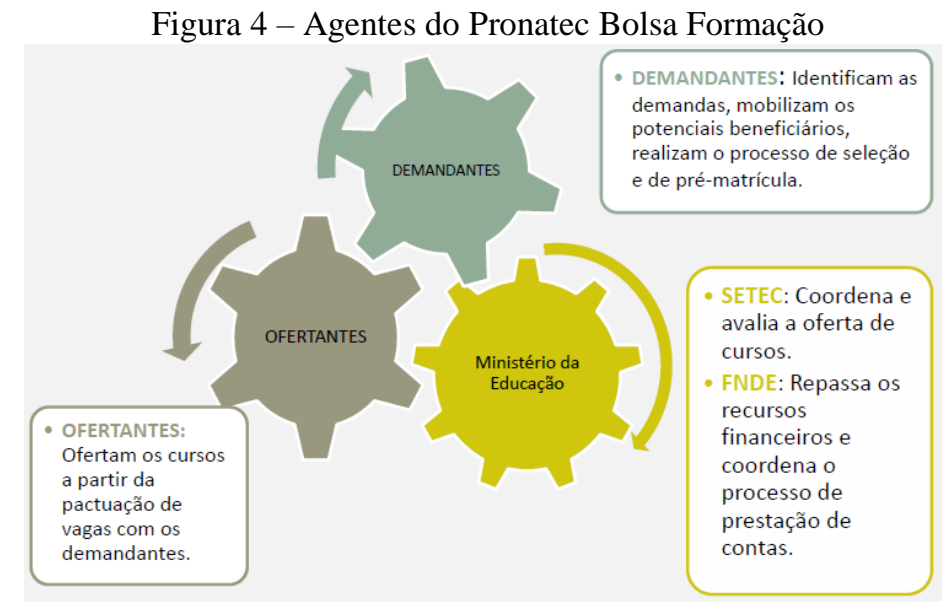

Fonte: SETEC (2013)

Os cursos técnicos subsequentes - acredita-se que em razão da pluralidade de instituições que o ofertam - seguem fluxo diferenciado de pactuação. Com base nas principais demandas identificadas, as instituições habilitadas apresentam suas propostas de vagas diretamente no SISTEC (Sistema Nacional de Informações da Educação Profissional e Tecnológica), as quais serão avaliadas pela SETEC a partir de critérios como: a distribuição regional das vagas, a distribuição das propostas por turno, ao valor de hora-aluno apresentado para cada oferta de curso; entre outros critérios definidos em edital.

O ingresso dos estudantes nos cursos pode ocorrer de duas formas: a partir de processo seletivo e pré-matrícula no SISTEC realizados pelas unidades demandantes e posterior matrícula junto à instituição ofertante - para cursos FICs, cursos técnicos concomitantes ou integrados na modalidade EJA; e por meio de editais do Sistema de Seleção Unificada da Educação Profissional e Tecnológica - SISUTEC, que utiliza como critério de seleção a nota

\footnotetext{
${ }^{83}$ A SETEC publicou, por meio da Portaria n. 20, de 27 de junho de 2013 (atualizada pela Portaria SETEC/MEC n. 01, de 29 de janeiro de 2014), uma tabela de correspondência entre cursos técnicos e cursos superiores, a fim de normatizar a autorização da oferta de cursos técnicos pelas instituições privadas de ensino superior. No processo de habilitação destas instituições para oferta de cursos no âmbito do Bolsa Formação será observada essa tabela de correspondência, juntamente com os seguintes requisitos: Conceito Preliminar de Curso (CPC) ou Conceito de Curso (CC) igual ou superior a três, no curso de graduação correlato ao curso técnico a ser ofertado; Índice Geral de Cursos (IGC) ou Conceito Institucional (CI) igual ou superior a três; inexistência de supervisão institucional ativa; e inexistência de penalidade institucional nos dois últimos anos nos cursos de graduação correlatos aos cursos técnicos a serem ofertado (Portaria MEC n. 817/2015).

${ }^{84}$ A Portaria n. 817/2015 expandiu a oferta de cursos técnicos concomitantes e técnicos integrados na modalidade EJA para as instituições privadas de ensino técnico de nível médio, com base no previsto no caput do artigo $6^{\circ}$ da Lei de criação do Pronatec.
} 
obtida no ENEM - para cursos técnicos subsequentes (Portaria MEC n. 817/2015). As vagas que não forem preenchidas de acordo com os procedimentos acima, ou aquelas abertas em decorrência de cancelamento de matrícula, de acordo com as regras previstas, poderão ser preenchidas por meio de sistema de inscrição on-line, cabendo ao candidato inscrever-se e comparecer à instituição de ensino com os documentos exigidos para a matrícula ${ }^{85}$.

De acordo com a natureza das instituições ofertantes há uma regulamentação específica para a transferência de recursos e execução da Bolsa Formação. As resoluções do FNDE que normatizam a questão orçamentária se dividem em quatro grupos de instituições: as instituições da Rede Federal de Educação Profissional e Tecnológica; as instituições das Redes Estaduais, Municipais e Distrital; as instituições dos Serviços Nacionais de Aprendizagem (SNA); e as instituições privadas de ensino superior e de ensino técnico de nível médio.

Como se pode observar no site da SETEC, foram realizadas várias alterações nas Resoluções do FNDE que regulamentam a execução financeira da Bolsa Formação. Nos três primeiros grupos de instituições - rede federal, redes estaduais, municipais e distrital e SNAs o repasse de recursos é realizado com base no valor hora-aluno definido em Resolução do FNDE. De acordo com a Resolução vigente para estas instituições, o valor da hora/aluno corresponde a R \$ 10,00 (dez reais) nos cursos presenciais, incluída a assistência estudantil ${ }^{86}$. Esse custo padrão foi definido com base na média dos custos aplicados pelo SENAI, SENAC e rede federal de EPT nos diferentes estados, não considerando as especificidades dos diferentes cursos, eixos tecnológicos, infraestrutura e material de consumo necessários, conforme aponta o Relatório da CGU (2013).

Em relação ao valor da hora-aula, a CGU se manifestou, novamente, no âmbito de relatório de auditoria realizada entre os anos de 2013 e 2017 nas instituições de ensino que ofertam o Pronatec. O valor da hora aula padronizado, segundo o levantamento realizado, estaria produzindo "dois riscos" ao atendimento dos objetivos do Programa: "a rede ofertante tende a não priorizar o atendimento às demandas dos Ministérios e Secretarias Estaduais e a ofertar cursos de menor custo e que exigem baixa qualificação dos professores" (CGU, 2018, p. 12). Esse fato poderia estar na base da explicação para o baixo número de matrículas no curso de Inglês aplicado a serviços turísticos comparado ao curso de Auxiliar Administrativo, ofertados no Pronatec Copa, como se observou na Tabela 9, de acordo com o Relatório da CGU:

\footnotetext{
${ }^{85}$ A inscrição on-line era realizada no seguinte endereço: http://spp.mec.gov.br/cadastro-online/meu-cadastro/. As vagas preenchidas desta forma desconsidera os públicos prioritários do Pronatec, tendo sido responsável até o ano de 2013 pelo total de $23,6 \%$ das matrículas.

${ }^{86}$ Para os cursos técnicos subsequente, pelo fato de não estar obrigado ao pagamento de assistência estudantil, o valor repassado é de $\mathrm{R} \$ 8,00$, conforme informação repassada pela Coordenação do Pronatec no IFFar.
} 
“em São Paulo, o SENAC cobra R\$ 5.606,00 no curso de 160 horas de Inglês Aplicado a Serviços Turísticos - Básico, valor oito vezes maior do que o cobrado no curso Auxiliar Administrativo, que é de R \$799,00". Dado que o valor da bolsa formação é fixo (R $\$ 10,00$ horas-aula por aluno), "é mais vantajoso economicamente a rede de ensino ofertar este último curso do que o de Inglês Aplicado a Serviços Turísticos - Básico" (CGU, 2018, p. 41). Essa situação aponta para o predomínio da lógica "ofertista", que "distancia a rede de ensino do compromisso de atender as necessidades por mão de obra qualificada dos demandantes" (CGU, 2018, p.12).

Além disso, a auditoria aponta que o valor de mercado cobrado pelas instituições estaria abaixo do valor repassado pela SETEC. Ao comparar os maiores valores cobrados no âmbito das instituições e do SNA nos estados de Paraná e São Paulo pelos cursos técnicos em Administração e em Segurança do Trabalho e o curso FIC em Auxiliar Administrativo, que foram os mais ofertados no âmbito dessas instituições até 2013, haveria um custo adicional de $\mathrm{R}$ \$ 163.752.950,00, isso já incluindo o valor de R 2,00 para assistência estudantil, conforme Tabela 10.

Tabela 10 - Diferença entre valor pago e valor praticado pelo mercado - Cursos FIC e Técnico

\begin{tabular}{|c|c|c|c|c|c|c|}
\hline \multirow{2}{*}{ Curso } & \multirow{2}{*}{ Matrículas } & \multirow{2}{*}{$\begin{array}{c}\text { C.H } \\
\text { (Horas) }\end{array}$} & \multirow{2}{*}{$\begin{array}{c}\begin{array}{c}\text { Pronatec Bolsa - } \\
\text { Formação }\end{array} \\
\text { Valor Transferido } \\
\text { (A) }\end{array}$} & \multicolumn{2}{|c|}{$\begin{array}{c}\text { Valor máximo praticado } \\
\text { nos SNA }\end{array}$} & \multirow{2}{*}{$\begin{array}{l}\text { Diferença } \\
(\mathbf{A}-\mathbf{B})\end{array}$} \\
\hline & & & & $\begin{array}{l}\text { Preço do } \\
\text { Curso }\end{array}$ & Gasto total (B) & \\
\hline $\begin{array}{l}\text { Auxiliar } \\
\text { Administrativo }\end{array}$ & 138.855 & 160 & $216.953 .600,00$ & $1.119,00$ & $155.378 .745,00$ & $61.574 .855,00$ \\
\hline $\begin{array}{l}\text { Técnicos em } \\
\text { Administração }\end{array}$ & 17.416 & 800 & $137.013 .600,00$ & $4.000,00$ & $69.664 .000,00$ & $67.349 .600,00$ \\
\hline $\begin{array}{l}\text { Técnicos em } \\
\text { Segurança do } \\
\text { Trabalho }\end{array}$ & 21.269 & 1.200 & $248.475 .600,00$ & $10.045,00$ & $213.647 .105,00$ & $34.828 .495,00$ \\
\hline TOTAL & 177.540 & & $602.442 .800,00$ & & 438.698.850,00 & $163.752 .950,00$ \\
\hline
\end{tabular}

Fonte: Relatório CGU (2018)

A assistência estudantil corresponde ao subsídio à alimentação e ao transporte, que poderá ser prestada diretamente ou na forma pecuniária. Nas Resoluções do Pronatec Bolsa Formação do ano de 2011, o valor da hora-aluno era de 8,50, tanto para o SNA quanto para a Rede Federal, e vinha acompanhado da recomendação de 0,50 (cinquenta centavos) para a assistência estudantil por hora aula. Porém, a partir de julho de 2012, o valor da hora-aluno passou a ser de 10,00 (para os três primeiros grupos de instituições da Figura 5) e as resoluções não fizeram mais menção a um valor específico para a assistência estudantil. De acordo com o Relatório do TCU (2015), vários ofertantes e os próprios gestores da SETEC utilizam como referência o valor de $\mathrm{R} \$ 2,00$ a hora/aula por estudante, para o custeio das despesas previstas, 
sendo que não há previsão de diferenciação desse valor de acordo com o custo do transporte e alimentação em cada município, ficando à cargo da autonomia de cada instituição. Conforme a Portaria MEC n. 817/2015, não fazem jus à assistência estudantil os estudantes de cursos subsequentes.

Figura 5 - Histórico das alterações nas Resoluções do FNDE no âmbito da Bolsa Formação

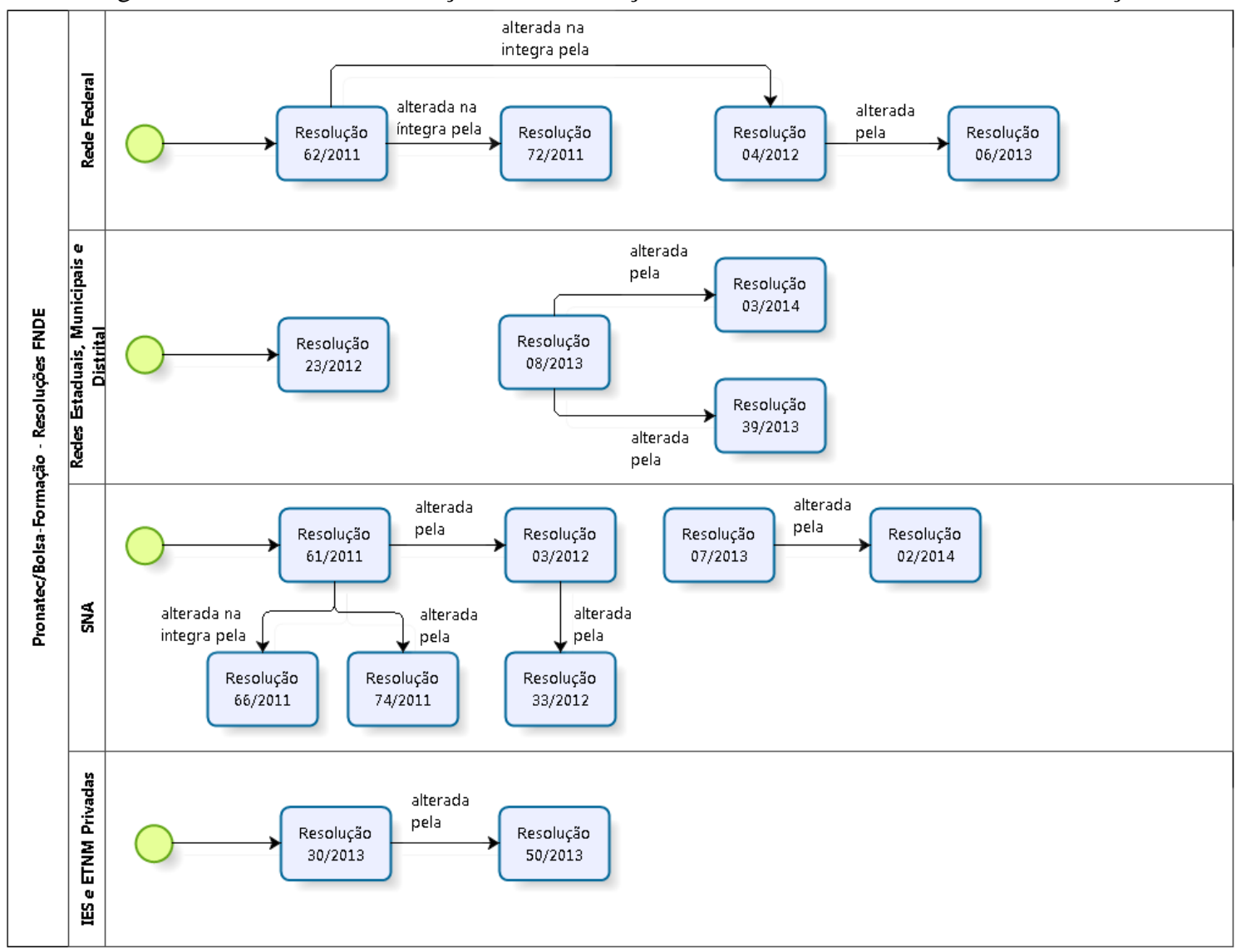

FONTE: Disponível no site https://map.mec.gov.br/

As instituições públicas ofertantes da Bolsa Formação poderão conceder bolsas aos profissionais envolvidos nas atividades correspondentes. No âmbito da Rede Federal essa prerrogativa foi normatizada em Resolução do FNDE, e quanto às instituições das redes estaduais, municipais ou distrital a regulamentação cabe ao seu órgão gestor. Já em relação às instituições do Sistema S, o pagamento dos profissionais envolvidos no Pronatec segue as normas de sua competência, não havendo um valor mínimo para a hora-aula ou demais funções.

De acordo com a Resolução FNDE n. 62/2011 e suas alterações, os profissionais que atuam na Bolsa Formação no âmbito das instituições da Rede Federal de EPT poderão receber os seguintes valores por hora de trabalho e atividade desempenhada: Coordenador-Geral $-\mathrm{R} \$$ 50,00 por hora; Coordenador-adjunto - R \$ 44,00 reais por hora; Supervisor de Curso - R \$ 36,00 reais por hora; Professor - $\mathrm{R} \$ 50,00$ reais por hora; Apoio às atividades acadêmicas e 
administrativas - $\mathrm{R} \$ 18,00$ reais por hora; Orientador - $\mathrm{R} \$ 36,00$ reais por hora. Em relação às duas primeiras funções, estas deverão ser desempenhadas por profissionais ativos ou inativos do quadro da instituição designados pelo gestor máximo, para as demais poderão ser selecionados profissionais tanto do quadro das instituições quanto externos, por meio de processo seletivo público. A carga horária semanal dos professores não poderá exceder a 16 horas, enquanto que para os demais profissionais poderá chegar a 20 horas, no máximo, sem sobrepor-se à carga horária das demais atividades desempenhadas.

O repasse dos recursos referentes aos cursos é realizado com base no número de matrículas reconfirmadas pelas instituições no SISTEC, observando os prazos: a) entre vinte e vinte e cinco por cento da integralização da carga-horária total de curso FIC; e b) entre vinte e vinte e cinco por cento da integralização da carga-horária dos quatro primeiros meses de curso técnico. Antes de atingir esses parâmetros de integralização, as instituições poderão substituir os alunos desistentes, de acordo com lista de espera ou outra forma de ingresso prevista. As desistências ocorridas após o prazo previsto para cálculo do repasse de recursos, não são descontadas, o que gerou fortes críticas ao Programa em virtude de financiar vagas que não estariam sendo ocupadas.

Com base nessa avaliação, apontada inclusive pelos relatórios do TCU e da CGU, a última Portaria que regulamenta a Bolsa Formação - Portaria MEC n. 817/2015 - introduziu como critério para o repasse de recursos o Índice Institucional de Conclusão (IC) que seria calculado semestralmente, a partir do primeiro semestre de 2016. As instituições que atingirem $85 \%$ de concluintes em seus cursos terão assegurado o financiamento da carga horária total dos cursos. Já para aquelas que não atingirem esse parâmetro, a diferença entre o IC obtido e o IC de referência (85\%) será convertida em horas-aluno a serem compensadas pela instituição de ensino, por meio de uma das seguintes formas: I - ofertar as horas-aluno devidas, gratuitamente, na pactuação de vagas seguinte à apuração do IC; ou II - devolver os valores referentes às horas-aluno devidas ao FNDE, quando da prestação de contas (parágrafo único, Artigo 90).

O financiamento das vagas ofertadas nas instituições privadas, diferentemente das demais instituições, é realizada por meio de bolsa de estudos integral, que corresponde ao pagamento da mensalidade do curso diretamente à mantenedora. $\mathrm{O}$ valor correspondente à horaaula nos cursos é definido mediante a proposição pelas instituições e análise e aprovação da SETEC. O estudante beneficiado com a bolsa de estudos integral é responsável por confirmar sua frequência mensal ao curso e autorizar o pagamento da mensalidade em favor da mantenedora, não fazendo jus à assistência estudantil. 
De acordo com Relatório da CGU os valores da hora-aula repassados às instituições privadas para a oferta da Bolsa Formação, a partir do estudo comparativo entre o valor cobrado pelas instituições aos estudantes e o valor pago pelo Programa no curso Técnico em Segurança do Trabalho, representou um custo de $\mathrm{R} \$ 1.264 .560,00$ a mais, em relação ao número de 958 matrículas. Enquanto as mesmas instituições cobraram o valor de $\mathrm{R} \$ 4,8$ (quatro reais e oitenta centavos) a hora-aula à comunidade, receberam o valor de $\mathrm{R} \$ 5,9$ (cinco reais e noventa centavos) para a oferta do mesmo curso por meio da Bolsa Formação (CGU, 2013).

Observa-se, também, que enquanto as instituições públicas, especialmente as da Rede Federal, possuem critérios específicos para o uso dos recursos - número e valor de horas para pagamento dos profissionais, assistência estudantil e materiais de custeio para oferta -, cabendo devolver o recurso não gasto com esses itens, as instituições privadas e do Sistema $\mathrm{S}$ conseguem utilizar todo o valor recebido, aplicando inclusive na expansão da sua rede física, após atendidas as condições de oferta dos cursos. Dessa forma, os recursos públicos do Pronatec Bolsa Formação contribuem para a expansão das instituições privadas de educação profissional, em detrimento das instituições públicas.

Em relação ao número de matrículas, tipo de cursos e participação das instituições ofertantes no âmbito da Bolsa Formação, considerando o período de 2011 a 2016, os dados do Sistec Nacional, obtidos por meio do e-SIC em agosto de 2017, mostram o seguinte cenário: foram realizadas 4.647.307 matrículas, sendo que 1.055.960 matrículas correspondem a cursos técnicos ${ }^{87}(22,7 \%)$ e 3.591 .347 a cursos FICs $(77,3 \%)$. A maioria das matrículas se concentram nos anos de 2013 e 2014, conforme o Gráfico 2.

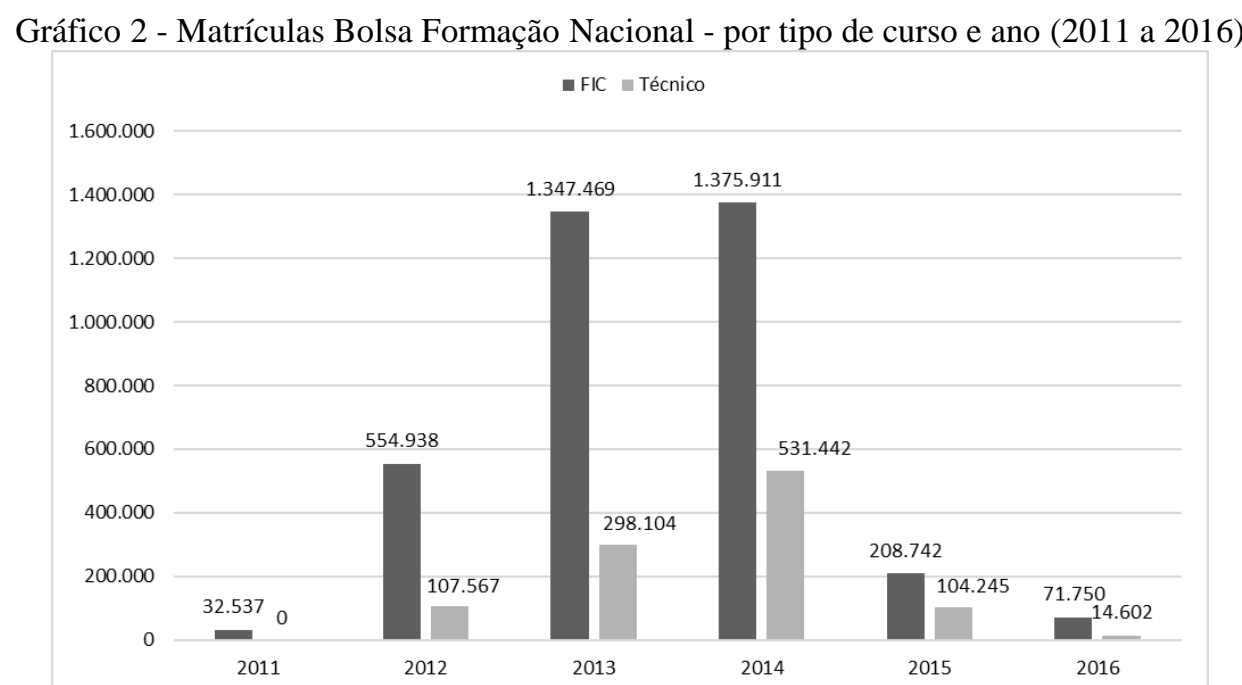

Fonte: elaborado pela autora com base nos dados do Sistec Nacional obtidos via e-Sic (2017).

\footnotetext{
${ }^{87}$ Os dados disponíveis não permitem diferenciar as formas de oferta de curso técnico - integrada, subsequente ou concomitante - e identificar as matrículas correspondentes à modalidade Pronatec EJA.
} 
Em relação às instituições ofertantes, conforme foi apontado, predominam as instituições do Sistema S (SENAI, SENAC, SENAR e SENAT). No total de matrículas o percentual ofertado por essas instituições chega a 67\%, e quando se consideram apenas as matrículas em cursos FIC, atingem 77\% do total. Já em relação aos cursos técnicos, a maioria das matrículas foram ofertadas pelas Instituições Privadas (54\%), mesmo tendo iniciado sua participação um ano e meio após as demais instituições - os cursos técnicos foram ofertados no âmbito da Bolsa Formação em 2012 e as IEs privadas iniciaram a oferta em agosto de 2013.

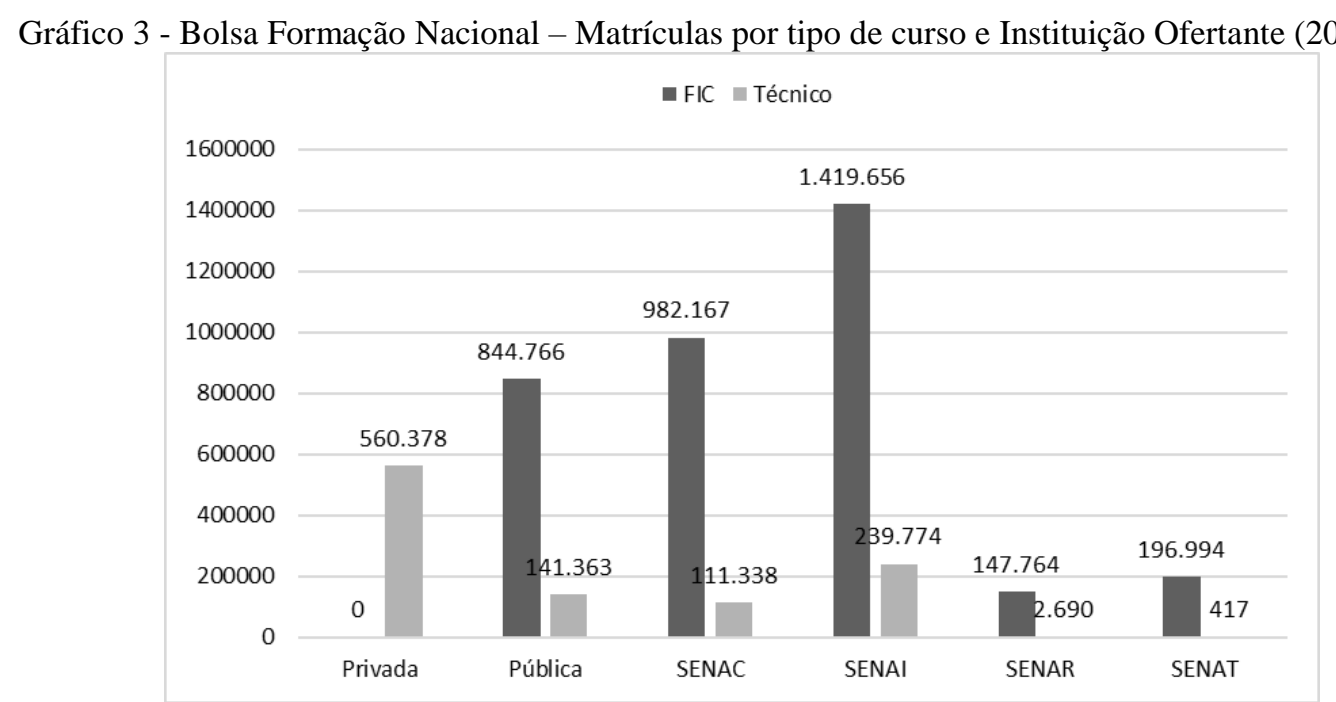

Fonte: elaborado pela autora com base nos dados do Sistec Nacional obtidos via e-Sic (2017).

Em relação ao percentual das matrículas realizadas em instituições públicas e privadas, observa-se que dentre as matrículas em cursos técnicos as instituições públicas ofertaram 13,4\% e em cursos FICs 23,5\%. Em relação às instituições privadas a proporção é de 86,6\% e 76,5\%, respectivamente. No total, apenas 21,2\% das matrículas da Bolsa Formação foram realizadas em instituições públicas, enquanto que as matrículas nas instituições privadas correspondem a $78,8 \%$.

Considerando as diferentes instituições habilitadas para a oferta da Bolsa Formação (Rede Federal, Rede Estadual, Rede Municipal, Instituições do Sistema S, Escolas Técnicas Privadas e Instituições de Ensino Superior Privadas), observa-se que, no conjunto, o SENAI ofertou o maior número de matrículas. Já entre as instituições públicas, a Rede Federal teve o número mais expressivo de matrículas, e entre as instituições privadas, as instituições de ensino superior ofertaram mais matrículas em relação às escolas técnicas privadas, conforme se observa no Gráfico 4: 
Gráfico 4 - Matrículas no Pronatec Bolsa Formação Nacional por natureza da Instituição Ofertante (2011-2016)

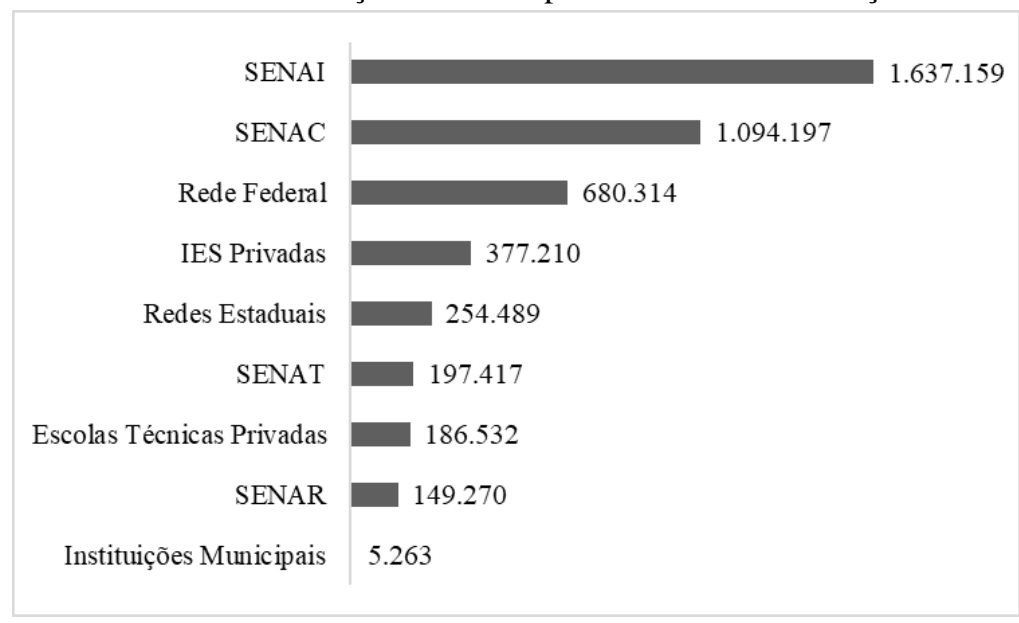

Fonte: Elaborado pela autora com base nos dados do SIMEC (2018).

Quanto aos recursos destinados ao Pronatec Bolsa Formação, em razão do montante de matrículas, as instituições do Sistema $\mathrm{S}$, no conjunto, foram as que mais receberam recursos $(60,8 \%)$. No total, foram repassados a essas instituições mais de 13 bilhões de reais, no período de 2011 a 2016. Na Tabela 11, pode-se visualizar o total de recursos recebidos pelas instituições ofertantes, por ano. No âmbito das instituições da Rede Federal não foi possível identificar o montante de recursos por ano, visto que o repasse é feito por meio de Termo de Execução Descentralizada, impossibilitando a realização de levantamento, tendo em vista o grande número de instituições e o fato de que esse documento apresenta apenas o valor orçamentário e não o valor, de fato, executado. Assim, o valor total destinado a essas instituições foi calculado com base na diferença entre o valor total destinado a essa ação e a soma dos valores destinados às demais instituições, que corresponde a $16,8 \%$ do orçamento destinado a essa iniciativa.

Tabela 11 - Recursos do Pronatec Bolsa Formação por Instituição Ofertantes - 2011 a 2016

\begin{tabular}{|c|c|c|c|c|c|c|}
\hline Ano & Sistema $\mathrm{S}$ & IEs Privadas & Rede Federal & Redes Estaduais & IEs Municipais & Total \\
\hline 2011 & $208.261 .704,50$ & & & & & $459.602 .953,70$ \\
\hline 2012 & $1.241 .426 .564,50$ & & & $92.648 .000,00$ & & $1.239 .515 .479,02$ \\
\hline 2013 & $2.065 .021 .070,00$ & $51.681 .163,63$ & & $228.482 .150,00$ & $14.681 .000,00$ & $2.753 .473 .655,76$ \\
\hline 2014 & $2.581 .208 .152,00$ & $644.920 .316,54$ & & $207.240 .495,61$ & $21.903 .577,33$ & $3.834 .858 .954,90$ \\
\hline 2015 & $1.321 .393 .229,20$ & $931.691 .313,70$ & & $64.545 .862,16$ & $16.704 .814,84$ & $3.513 .640 .048,27$ \\
\hline 2016 & 737.999.990,00 & $485.096 .160,40$ & & $209.869 .732,00$ & $20.005 .375,00$ & $1.595 .905 .753,28$ \\
\hline Total & $8.155 .310 .710,20$ & $2.113 .388 .954,27$ & $2.252 .216 .173,52$ & $802.786 .239,77$ & $73.294 .767,17$ & $13.396 .996 .844,93$ \\
\hline
\end{tabular}

Observando-se, separadamente, as instituições do Sistema S, o SENAI foi quem recebeu o maior volume de recursos, uma vez que realizou maior número de matrículas, seguido do SENAC, conforme demonstra a Tabela 12. 
Tabela 12 - Recursos do Pronatec Bolsa Formação por Instituição do Sistema S - 2011 a 2016

\begin{tabular}{lllll}
\hline \hline Ano & SENAI & SENAC & SENAR & SENAT \\
\hline 2011 & $125.517 .511,00$ & $82.744 .193,50$ & & \\
2012 & $807.426 .331,00$ & $383.179 .733,50$ & $38.290 .300,00$ & $12.530 .200,00$ \\
2013 & $1.161 .133 .060,00$ & $719.096 .760,00$ & $57.022 .190,00$ & $127.769 .060,00$ \\
2014 & $1.553 .903 .802,00$ & $836.137 .030,00$ & $70.213 .530,00$ & $120.953 .790,00$ \\
2015 & $823.000 .000,00$ & $430.000 .000,00$ & $38.393 .229,20$ & $30.000 .000,00$ \\
2016 & $540.606 .810,00$ & $149.393 .180,00$ & $45.000 .000,00$ & $3.000 .000,00$ \\
\hline Total & 5.011.587.514,00 & 2.600.550.897,00 & $248.919 .249,20$ & $294.253 .050,00$ \\
\hline \hline
\end{tabular}

Em relação ao perfil da oferta, o Eixo de Gestão e Negócios congregou o maior percentual, chegando a quase um quarto do total de matrículas. As instituições que mais ofertaram cursos nesse eixo foram aquelas pertencentes ao Sistema S. No âmbito desse Eixo, o curso de Assistente Administrativo foi o que teve a maior oferta: 345.060 matrículas, sendo que a instituição que mais ofertou matrículas nesse curso foi o SENAI, com 38,7\%, seguido do SENAC, com 35\% (Tabela 13).

Tabela 13 - Matrículas do Pronatec Bolsa Formação por Eixo Tecnológico e Instituição Ofertante - 2011 a 2016

\begin{tabular}{|c|c|c|c|c|}
\hline Eixo Tecnológico & Sistema $\mathbf{S}$ & Privadas & Públicas & Total \\
\hline Ambiente e Saúde & $8,1 \%$ & $\underline{35,2 \%}$ & $14,9 \%$ & $12,8 \%$ \\
\hline Controle e Processos Industriais & $15,4 \%$ & $8,3 \%$ & $3,6 \%$ & $12,0 \%$ \\
\hline Desenvolvimento Educacional e Social & $3,1 \%$ & $1,0 \%$ & $9,7 \%$ & $4,2 \%$ \\
\hline Gestão e Negócios & $\underline{26,8 \%}$ & $11,8 \%$ & $\underline{21,3 \%}$ & $\underline{23,8 \%}$ \\
\hline Informação e Comunicação & $10,9 \%$ & $18,5 \%$ & $13,9 \%$ & $12,5 \%$ \\
\hline Infraestrutura & $12,6 \%$ & $4,3 \%$ & $5,8 \%$ & $10,1 \%$ \\
\hline Militar & $0,0 \%$ & $0,0 \%$ & $0,0 \%$ & $0,0 \%$ \\
\hline Produção Alimentícia & $3,1 \%$ & $0,7 \%$ & $4,3 \%$ & $3,1 \%$ \\
\hline Produção Cultural e Design & $2,5 \%$ & $2,5 \%$ & $4,2 \%$ & $2,9 \%$ \\
\hline Produção Industrial & $6,3 \%$ & $2,9 \%$ & $2,0 \%$ & $5,0 \%$ \\
\hline Recursos Naturais & $4,0 \%$ & $1,1 \%$ & $10,6 \%$ & $5,0 \%$ \\
\hline Segurança & $2,0 \%$ & $9,2 \%$ & $1,5 \%$ & $2,8 \%$ \\
\hline Turismo, Hospitalidade e Lazer & $5,4 \%$ & $4,5 \%$ & $8,1 \%$ & $5,8 \%$ \\
\hline Total & $100 \%$ & $100 \%$ & $100 \%$ & $100 \%$ \\
\hline
\end{tabular}

O Eixo de Controle e Processos Industriais que abrange os cursos na área da indústria apresentou apenas $12 \%$ do total de matrículas, indicando que a demanda de formação de mão de obra com vistas no crescimento industrial parece ter sido tangenciada no âmbito da identificação das demandas ou do interesse em sua oferta, pelo fato de os cursos nessa área demandarem elevados custos em infraestrutura. No âmbito da modalidade Pronatec Brasil Maior, que estava ligada à demanda das indústrias, foram ofertadas apenas 55.123 matrículas, 
sendo que o único curso técnico ofertado foi o de "Design de Interiores", conforme dados obtidos via e-SIC. Assim, a demanda por formação técnica de mão de obra propalada pela CNI, parece não ter tido correspondência com as necessidades apontadas pelas empresas da área e/ou atendidas pelas instituições ofertantes.

No eixo de Recursos Naturais, as instituições públicas foram as que mais ofertaram cursos, o que indica a importância da interiorização dessas instituições de educação profissional para o desenvolvimento dos arranjos produtivos locais. Os cursos nessa área, demandam investimentos em equipamentos e áreas para cultivo de experimentos e criação de animais, os quais podem ser encontrados nos Campus de Institutos Federais que se localizam em regiões de produção agrícola.

Em relação ao público atendido, a maioria são mulheres $(59,2 \%)$ e jovens, com idades até 30 anos (27,3\%). Os homens estão mais concentrados nos eixos de Controle e Processos Industriais, Informação e Comunicação e Infraestrutura, enquanto que o maior percentual de mulheres se encontram nos Eixos de Ambiente e Saúde, Gestão e Negócios e Produção Industrial $^{88}$. Estes dados expressam a divisão sexual do trabalho, na qual as mulheres se concentram em áreas que se configuram como uma continuidade do trabalho doméstico, como a educação, a saúde, a alimentação, a produção de vestuário e o comércio, entre outros. Os homens, por sua vez estão concentrados em áreas em que a utilização de ferramentas pesadas e de tecnologias mais complexas são mais presentes (TABET, 1998). A única instituição em que a concentração de homens foi maior que a de mulheres é o SENAI, o que expressa sua marca histórica como espaço de formação de mão de obra masculina.

No âmbito dos cursos FIC, 19,8\% do público que realizou matrícula não possui ensino fundamental completo e 29,3\% não concluiu o ensino médio. Esses dados reforçam a importância da associação entre formação profissional e educação básica, com vistas na formação integral do trabalhador e demonstram que Programas como o Proeja precisam ser fortalecidos no âmbito da educação profissional.

\subsection{0 andamento das demais iniciativas que compõe o Pronatec no período de 2011 a 2016}

Como se viu, algumas ações criadas e em andamento desde os Governos Lula foram “abrigadas" no âmbito do Pronatec, passando a compor as matrículas ofertadas pelo Programa. Nesse tópico, tais ações serão contextualizadas, apontando-se os indicadores de matrículas e de

\footnotetext{
${ }^{88}$ Os cursos desse eixo se concentram nos serviços que podem ser produzidos em escala industrial, como: costura industrial, cozinha industrial e modelagem de roupas, por isso tem forte presença feminina.
} 
orçamento observadas no período de 2011 a 2016, com vistas a identificar possíveis impactos no seu desenvolvimento a partir da criação do Pronatec.

O Brasil Profissionalizado, criado por meio do Decreto n. 6.302, de 12 de dezembro de 2007, atua no repasse de recursos financeiros para os Estados, Distrito Federal e Municípios, que tenham assinado o Compromisso Todos pela Educação. O recurso, oriundo do Fundo Nacional de Desenvolvimento da Educação (FNDE), se destina à construção, reforma e modernização técnica e pedagógica de escolas técnicas, incluindo a formação e qualificação dos profissionais da educação, com vistas na oferta de cursos técnicos, especialmente de forma integrada ao ensino médio, incluindo a modalidade de educação de jovens e adultos (EJA).

Conforme dados orçamentários obtidos por meio de solicitação via e-SIC, os recursos destinados a essa ação tiveram grande redução a partir de 2012. Em relatório do TCU, a análise da execução financeira dessa iniciativa no âmbito do Pronatec foi de apenas $24 \%$ do valor empenhado, no período de 2011 a 2014. Em entrevista, Marcelo Feres justifica esses dados em virtude dos convênios para construção de escolas já em andamento com os Estados, nesse sentido, "não se tinha como passar mais recursos para os Estados. Se o Estado, ele pega 10 milhões de reais, para construir uma escola, ou duas escolas, ele não vai pegar mais 10, ou 20, ou 30 milhões de reais emprestado, porque ele está enrolado tentando fazer aquela escola" (Entrevista FERES, 2017). Na Tabela 14, pode-se observar o orçamento anual destinado a esse Programa no período de 2011 a 2016.

Tabela 14 - Orçamento destinado ao Programa Brasil Profissionalizado - 2011 a 2016

\begin{tabular}{ll}
\hline \hline Ano & Orçamento \\
\hline 2011 & $280.709 .934,70$ \\
2012 & $544.893 .966,81$ \\
2013 & $192.941 .086,41$ \\
2014 & $61.091 .621,26$ \\
2015 & $188.362 .425,70$ \\
2016 & $84.429 .892,69$ \\
\hline Total & $1.352 .428 .927,57$ \\
\hline
\end{tabular}

Fonte: Elaborada pela autora com base em dados obtidos via e-SIC (2017).

Conforme dados disponíveis no SIMEC, em relação ao número de matrículas nesta iniciativa, observa-se um crescimento no período de 2011 a 2014 e um decréscimo a partir de 2015. Conforme consta no relatório do TCU, "para efeito de contagem das matrículas do Programa Brasil Profissionalizado para o Pronatec, são consideradas todas as matrículas em EPT realizadas nas escolas que receberam recursos" (TCU, 2016, p. 20), conforme informou a SETEC. Nesse sentido, as matrículas registradas são oriundas tanto da "oferta de vagas 
proporcionadas pela criação ou reforma/ampliação de infraestrutura, financiada com recursos do programa, como nas ações de fomento realizadas em infraestrutura pré-existente que foram objeto de reforma ou onde houve repasse em ações relativas a recursos pedagógicos" (TCU, 2016, p. 20). Assim, pode-se apontar que a diminuição das matrículas compreendidas nessa iniciativa tem relação com a diminuição dos recursos repassados aos Estados, independente das razões para tal. No entanto, ao se considerar a oferta de cursos técnicos integrados no âmbito das redes estaduais, identifica-se um crescimento nesse mesmo período, que pode ser atribuído à ampliação do número de escolas proporcionada a partir do fomento destinado pelo Programa $^{89}$, somado aos esforços dos estados no fortalecimento do ensino médio integrado. No Gráfico 5, pode-se visualizar as matrículas contabilizadas no âmbito do Brasil Profissionalizado e o total de matrículas nos cursos técnicos integrados ofertado pelas redes estaduais, no período de 2011 a 2016.

Gráfico 5 - Matrículas no Brasil Profissionalizado e total de matrículas em cursos técnicos integrados nas redes estaduais (2011 a 2016)

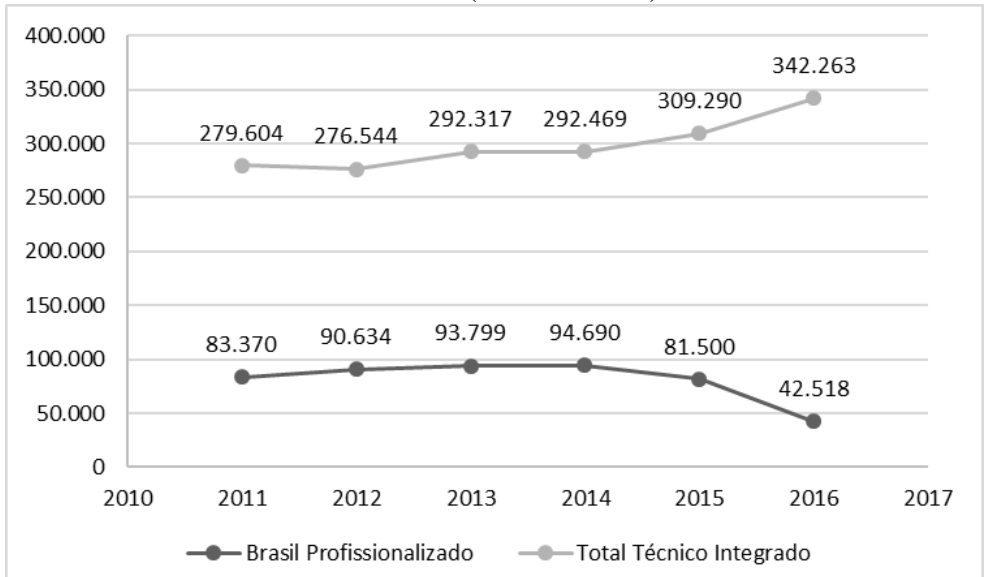

Fonte: elaborado pela autora com base nos dados disponíveis no SIMEC (2018) e Censo Escolar

A Rede e-Tec Brasil caracteriza-se pelo fomento da oferta gratuita de cursos de educação profissional e tecnológica e promoção da formação continuada dos profissionais que atuam na educação profissional e tecnológica, por meio da modalidade de ensino a distância. É constituída a partir da adesão de instituições da rede federal de educação profissional e tecnológica, de instituições do Sistema S que ofertam educação profissional e tecnológica e de instituições de educação profissional vinculadas aos sistemas estaduais de ensino.

89 Desde 2008, 236 escolas foram construídas, 442 ampliadas e 56 reformadas no âmbito do Brasil Profissionalizado (TCU, 2016). 
A Rede e-Tec é originária do Sistema Escola Técnica Aberta do Brasil - e-Tec Brasil, criado em dezembro de 2007, por meio do Decreto n. 6.301/2007. No contexto de criação do Pronatec, o Sistema e-Tec Brasil foi transformado em Rede e-Tec a partir do Decreto n. 7.589, de 26 de outubro de 2011. Esta mudança não foi apenas na nomenclatura, uma vez que representou a ampliação das instituições participantes, com a inclusão do Sistema $\mathrm{S}$ e da oferta de cursos abrangendo todas as formas previstas para a educação profissional e tecnológica, antes restrita a cursos técnicos de nível médio.

O financiamento dos cursos ofertados pelas instituições públicas até 2015 se dava por meio da assistência financeira da união mediante descentralização de recursos oriundos do FNDE $^{90}$ e do apoio aos estados e municípios na instalação e manutenção dos Polos de Apoio Presenciais. O repasse de recursos para a oferta de cursos de educação profissional a distância pelas instituições do Sistema $\mathrm{S}$ que aderiram à Rede e-Tec, foi normatizado pela Resolução FNDE n. 55/2013, por meio de recursos da iniciativa Bolsa Formação. De acordo com essa normativa, o financiamento se dá por meio do repasse do valor de $R \$ 4,50$ (quatro reais $\mathrm{e}$ cinquenta centavos) por hora-aluno, sem previsão de recurso para assistência estudantil, como ocorre nos cursos presenciais financiados pela Bolsa Formação.

No entanto, a partir de 2016, a iniciativa Bolsa Formação passou a financiar cursos a distância ofertados também por meio das instituições públicas que aderiram à Rede e-Tec Brasil, submetendo-se aos critérios de pactuação, matrículas e financiamento desta iniciativa, conforme normatiza a Portaria MEC n. 1.152, de 22 de dezembro de 2015. Essa mudança trouxe profundas alterações na forma de desenvolvimento e gestão desse Programa no âmbito das instituições públicas. Exemplifica-se aqui a realidade do Instituto Federal Farroupilha que faz parte do campo empírico da pesquisa e por fim se observa o impacto dessa mudança no número total de matrículas nesta iniciativa do Pronatec.

A partir do acompanhamento das ofertas de vagas no âmbito da Rede E-Tec no Instituto Federal Farroupilha, observa-se uma interrupção da oferta em 2016 e uma grande diminuição da oferta em 2017, em virtude das mudanças na forma de descentralização orçamentária e na forma de definição da oferta dos cursos, como ilustra o Gráfico 6.

A instituição iniciou sua trajetória no ensino a distância a partir de 2008, quando aderiu ao Programa e-Tec Brasil, recém-criado pelo Governo Federal, tendo realizado a primeira oferta de curso em 2009. Essa modalidade teve grande expansão a partir de 2011 quando a Pró-

\footnotetext{
${ }^{90}$ Para as instituições públicas federais era previsto o pagamento de bolsas para coordenadores, professores e tutores para o desenvolvimento das atividades de gestão, elaboração de materiais didáticos e atividades de ensino, com recursos oriundos do FNDE, conforme Resolução FNDE n. 36/2009, alterada pela Resolução n. 18/2010.
} 
Reitoria de Ensino passou a coordenar e incentivar o seu desenvolvimento institucional, culminando na criação da Diretoria de Educação a Distância, órgão ligado a esta Pró-Reitoria, e das Coordenações de Educação a Distância situadas nos campi, a partir de 2012.

Gráfico 6 - Vagas ofertadas pela Rede e-Tec no Instituto Federal Farroupilha - 2009 a 2017

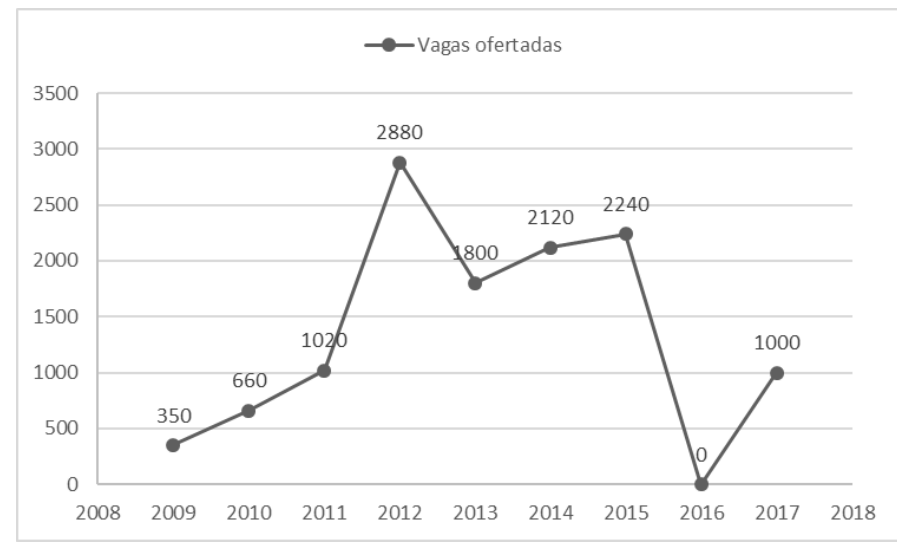

Fonte: elaborado pela autora com base nas informações disponíveis no Portal EaD do IFFar.

De acordo com a Diretora de Educação a Distância, a nova forma de financiamento da Rede e-Tec por meio da Bolsa Formação implicou na mudança em relação aos profissionais que atuam nos cursos, na forma de levantamento da demanda, além da impossibilidade da oferta em 2016, em decorrência da necessidade de adaptação dos processos, em nível institucional e também em nível governamental, aos novos parâmetros. A pactuação de novas ofertas de cursos técnicos a distância na Instituição, a partir dessa nova forma de financiamento e gestão, ocorreu apenas em 2017.

O quadro docente atuante nos cursos, até 2015, com base na Resolução do FNDE n. 18/2010, era composto por servidores docentes ou técnico-administrativos que possuíam formação na área do curso e formação em nível de licenciatura, os quais atendiam o convite do campus para atuar nessa modalidade de ensino. Já a partir do financiamento por meio da Bolsa Formação, o quadro docente passou a ser selecionado por meio de processos seletivos públicos, à semelhança dos cursos presenciais ofertados no âmbito do Pronatec Bolsa Formação, o que gera uma rotatividade maior e compromete a formação dos profissionais para atuação nessa modalidade de ensino. Nas palavras da Diretora:

Hoje não são somente colegas do Instituto Federal. Precisa-se ter um edital - para tutor sempre teve, coordenador de polo sempre teve - mas agora para todas as figuras, tirando coordenador da Rede e-Tec e coordenadores adjuntos da Rede e-Tec, todos tem que passar por processo seletivo público, incluindo os professores. E os recursos que vem hoje, praticamente eles apenas dão conta desse trabalho que, do meu ponto de vista, é um trabalho escravo, sem direitos. Qualquer bolsista não tem vínculo 
nenhum com a nossa instituição. Então tem uma rotatividade muito grande. O que acontecia antes, independente de serem colegas da instituição, mas era menor. Agora essa rotatividade é maior. Então, se capacita as pessoas, se fomenta a formação pedagógica, enfim, mas a rotatividade nessas funções é altíssima (Entrevista Diretora DEaD, IFFar, 2018).

De acordo com o novo Manual de Gestão da Rede e-Tec, o financiamento dos cursos corresponde ao valor de $\mathrm{R} \$ 4,50$ (quatro reais e cinquenta centavos) por hora/aluno, a ser utilizado pela instituição para despesas de custeio, capital e bolsa. Para pagamento das bolsas aos profissionais envolvidos, a SETEC definiu, por meio desse Manual, alguns parâmetros para o valor da hora trabalhada de acordo com o número de estudantes e/ou disciplina atendida, os quais configuram um teto máximo. Com vistas a agir de forma isonômica em relação ao pagamento dos profissionais que atuam nos cursos presenciais e a distância financiados pela Bolsa Formação, e ao mesmo tempo evitar concorrência por profissionais entre os Programas desenvolvidos na mesma instituição, segundo a Diretora, optou-se por igualar os valores de hora/aula dos professores já praticados nos cursos presenciais, assim como estabelecer equivalência na remuneração aos demais encargos envolvidos. Assim, a remuneração da hora/aula do professor formador, aquele responsável pela disciplina, é de $\mathrm{R} \$ 50,00$ equivalendo aos valores praticados pela Bolsa Formação e respeitando o parâmetro de até $\mathrm{R} \$ 100,00$ indicado pelo Manual da Rede e-Tec.

Em relação aos demais profissionais, a carga horária remunerada está diretamente relacionada ao número de estudantes em curso. Conforme os Editais publicados pela Instituição, a remuneração do Coordenador de Polo é de $\mathrm{R} \$ 36,00 /$ hora e do Professor mediador presencial ou a distância é de $\mathrm{R} \$ 25,00$, sendo o número de horas semanais definida em função do número de alunos atendidos, conforme as normas estabelecidas no Manual. Assim, de acordo com a confirmação mensal dos estudantes em curso, a remuneração desses profissionais poderá sofrer alterações caso o número de alunos gere impacto sobre o número de horas semanais a serem pagas, conforme se visualiza no Quadro 1.

Quadro 1 - Valores referência para pagamento de profissionais da Rede e-Tec

\begin{tabular}{|c|c|c|c|}
\hline FUNÇÃOO & QUANTIDADE & VALOR & CARGA HORÁRIA \\
\hline Coordenador Geral & *1 por Instituição & $\begin{array}{l}\text { Até } \\
\mathrm{R} \$ 50,00 / \mathrm{h}\end{array}$ & $\begin{array}{l}10 \mathrm{~h} / \text { semana (até } 1000 \text { matrículas) } \\
20 \mathrm{~h} / \text { semana (acima de } 1000 \text { matrículas) }\end{array}$ \\
\hline $\begin{array}{l}\text { Coordenador Geral } \\
\text { Adjunto }\end{array}$ & $\begin{array}{l}\text { *1 e-Tec por Câmpus/Escola Articulador } \\
\text { (min. } 5 \text { polos) } \\
\text { *1 e-Tec Profuncionário } \\
\text { *1e-Tec Idiomas } \\
\text { (Sob avaliação técnica e acadêmica da } \\
\text { Coordenação do e-Tec) }\end{array}$ & $\begin{array}{l}\text { Até } \\
\mathrm{R} \$ 44,00 / \mathrm{h}\end{array}$ & $\begin{array}{l}\text { 10h/semana (até } 1000 \text { matrículas) } \\
15 \mathrm{~h} / \text { semana (até } 1001 \text { e } 1500 \text { matrículas) } \\
20 \mathrm{~h} / \text { semana (acima de } 1500 \text { matrículas) }\end{array}$ \\
\hline Coordenador do Curso & $* 1$ por curso ofertado & $\begin{array}{l}\text { Até } \\
\mathrm{R} \$ 40,00 / \mathrm{h}\end{array}$ & $\begin{array}{l}10 \mathrm{~h} / \text { semana (até } 500 \text { matrículas) } \\
15 \mathrm{~h} / \text { semana (entre } 501 \text { e } 1000 \text { matrículas) } \\
20 \mathrm{~h} / \text { semana (acima de } 1000 \text { matrículas) }\end{array}$ \\
\hline Coordenador do Polo & $* 1$ por polo & $\begin{array}{l}\text { Até } \\
\mathrm{R} \$ 36,00 / \mathrm{h}\end{array}$ & $\begin{array}{l}10 \mathrm{~h} / \text { semana (até } 500 \text { matrículas) } \\
15 \mathrm{~h} / \text { semana (entre } 501 \text { e } 1000 \text { matrículas) }\end{array}$ \\
\hline
\end{tabular}




\begin{tabular}{|l|l|l|l|}
\hline & & & 20 h/semana (acima de 1000 mmatrículas) \\
\hline $\begin{array}{l}\text { Coordenador de } \\
\text { Professores Mediadores }\end{array}$ & $\begin{array}{l}* 1 \text { coordenador para cada 15 professores } \\
\text { mediadores (Sob avaliação técnica e } \\
\text { acadêmica da coordenação do e-Tec) }\end{array}$ & $\begin{array}{l}\text { Até } \\
\mathrm{R} \$ 30,00 / \mathrm{h}\end{array}$ & $20 \mathrm{~h} / \mathrm{semana}$ \\
\hline $\begin{array}{l}\text { Professor autor (por } \\
\text { disciplina) }\end{array}$ & $* 1$ por disciplina & $\begin{array}{l}\text { Até } \\
\mathrm{R} \$ 100,00 / \mathrm{h}\end{array}$ & Carga horária da disciplina \\
\hline Professor Formador & $* 1$ por disciplina & $\begin{array}{l}\text { Até } \\
\mathrm{R} \$ 100,00 / \mathrm{h}\end{array}$ & Carga horária da disciplina \\
\hline $\begin{array}{l}\text { Professor Mediador }(\mathrm{a} \\
\text { distância) }\end{array}$ & $* 1$ professor mediador a distãncia & $\begin{array}{l}\text { Até } \\
\mathrm{R} \$ 25,00 / \mathrm{h}\end{array}$ & $\begin{array}{l}15 \mathrm{~h} / \mathrm{semana} \text { (menos de } 20 \text { alunos }) \\
20 \mathrm{~h} / \mathrm{semana}(\mathrm{mais} \text { de } 20 \text { alunos) }\end{array}$ \\
\hline $\begin{array}{l}\text { Professor Mediador } \\
\text { (presencial) }\end{array}$ & $* 1$ professor mediador presencial & $\begin{array}{l}\text { Até } \\
\mathrm{R} \$ 25,00 / \mathrm{h}\end{array}$ & $\begin{array}{l}15 \mathrm{~h} / \mathrm{semana}(\mathrm{menos} \text { de } 20 \text { alunos }) \\
20 \mathrm{~h} / \mathrm{semana}(\mathrm{mais} \text { de } 20 \text { alunos) }\end{array}$ \\
\hline Equipe multidisciplinar & $\begin{array}{l}* \text { Conforme necessidade e disponibilidade } \\
\text { financeira }\end{array}$ & $\begin{array}{l}\text { Até } \\
\mathrm{R} \$ 36,00 / \mathrm{h}\end{array}$ & $20 \mathrm{~h} / \mathrm{semana}$ \\
\hline $\begin{array}{l}\text { Apoio } \\
\text { Administrativo/financeiro }\end{array}$ & $\begin{array}{l}\text { Conforme necessidade e disponibilidade } \\
\text { financeira }\end{array}$ & $\begin{array}{l}\text { Até } \\
\mathrm{R} \$ 18,00 / \mathrm{h}\end{array}$ & $20 \mathrm{~h} / \mathrm{semana}$ \\
\hline
\end{tabular}

Fonte: Manual de Gestão da Rede e-Tec e do Pró-Funcionário (SETEC, 2016).

Embora as normativas apontem para a possibilidade de utilização do recurso para custeio e capital, de acordo com a Diretora da EaD do IFFar, ao praticar esses valores de remuneração aos profissionais, o orçamento do curso é praticamente todo utilizado para esse fim. Além da variação na remuneração dos profissionais em virtude do número de estudantes, o orçamento da oferta de novos cursos também está atrelado ao número de alunos concluintes, conforme normatiza a Portaria n. 817/2015. Ao pactuar novos cursos, a instituição receberá o financiamento integral apenas se tiver obtido $85 \%$ de conclusão (relação entre o número de matriculados e o número de concluintes) nos cursos concluídos no semestre anterior. Caso o índice seja menor, essa diferença será convertida em carga horária que a instituição deverá custear nas próximas ofertas. A esse respeito a Diretora aponta preocupação:

Outra questão bem significativa dessa nova legislação é que o índice de conclusão de
curso dos alunos precisa ser de $85 \%$, ou seja, desconsidera a modalidade de educação
a distância em nível nacional em relação aos índices de conclusão de curso e até
mesmo a nível internacional, que é em torno de $50 \%$ o que literatura sempre aponta.
A educação a distância ainda é muito nova enquanto prática docente, enquanto prática
da instituição, precisamos aprender a fazer a modalidade. Qual o impacto que esse
índice de conclusão tem: ao passo que ocorrem evasões esse recurso pensado
inicialmente vai diminuindo... e onde que isso repercute? Na bolsa do colega que está
nos ajudando a fazer o pedagógico: do professor tutor, do professor, de todos; desse
colega que pode ser [servidor] do município, do Estado, trabalhar em empresas... (...)
Antes o Programa Rede e-Tec Brasil já deixava reservado o recurso, que era uma
bolsa com valor fixo, e agora esse valor pode mudar. O valor recebido pela instituição
praticamente só vai dar conta do pagamento desses atores para trabalhar na parte
pedagógica da educação a distância (Entrevista Diretora DEaD, IFFar, 2018).

Já em relação ao levantamento da demanda dos cursos, a instituição não tem mais autonomia para fazer o estudo junto às prefeituras. A demanda, que é identificada a partir da interlocução entre os Ministérios demandantes dos cursos e governos locais (município e estados), chega para a instituição, por meio do SISTEC, e esta deve informar se aceita ou não ofertar. Esta forma de levantamento e pactuação de cursos e vagas dá-se a partir da mesma 
metodologia praticada no âmbito da iniciativa Bolsa Formação. Sobre esta mudança na forma de definição dos cursos, a Diretora analisa que:

\begin{abstract}
Antes, digamos, a gente tinha mais autonomia e diálogo com as prefeituras, os municípios tinham mais tempo para fazer esse estudo de demanda, conversar mais com a comunidade, ver, regionalmente, quais são os seus enfrentamentos... E agora não. Já nos chega pronto via MEC, Ministério da Educação. (...) Nós perdemos bastante o diálogo com os municípios polos. (Diretora DEaD, IFFar, 2018)
\end{abstract}

Com base nessas mudanças na forma de fomento da Rede e-Tec da mesma forma que se observou a diminuição das matrículas no ensino a distância no Instituto Federal pesquisado, observa-se também um decréscimo em nível nacional. As matrículas em cursos a distância realizados por meio da Rede e-Tec nas redes estaduais e federal de ensino, a partir de 2016, passam a contar na iniciativa Bolsa Formação, assim como as matrículas realizadas pelas instituições do Sistema S a partir de 2015. Por meio dos extratos de Pactuação da BolsaFormação em 2016 foi possível identificar as vagas pactuadas por meio da Rede e-Tec, sendo que apenas as instituições públicas pactuaram a oferta de vagas e essas se deram em cursos técnicos (3.099 vagas nas redes estaduais e 21.821 na rede federal). No entanto, não foi possível identificar as matrículas realizadas pelas instituições do Sistema S no ano de 2015, pois os extratos de pactuação não apresentam as instituições ofertantes. Em 2016, das instituições do Sistema S apenas o SENAI pactuou oferta de cursos a distância no âmbito da Bolsa Formação, totalizando 430 vagas em cursos FIC.

A inclusão da oferta de cursos a distância no âmbito da Bolsa Formação, pode ser apontada como uma estratégia, diante das restrições no orçamento público decorrentes da crise econômica, para manter a oferta de cursos e atender as demandas dos Ministérios, porém, com um custo menor. Por outro lado, compromete o alcance das instituições federais de educação profissional no atendimento das demandas de sua região, visto que a Rede e-Tec atuava como um importante instrumento de interiorização da oferta de educação profissional.

Do total de matrículas realizadas nessa iniciativa, no período de 2011 a 2016, menos de $1 \%$ foram realizadas em cursos FIC $^{91}$ e estas se concentraram nos anos de 2015 e 2016 . As demais matrículas foram em cursos técnicos, conforme o Gráfico 7.

\footnotetext{
91 Estas matrículas correspondem aos cursos do Programa e-Tec Idiomas Sem Fronteiras, que a exemplo do Programa Inglês Sem Fronteiras destinados à estudantes do ensino superior, visava ofertar aos estudantes e profissionais que atuam na educação profissional a formação em línguas estrangeiras.
} 
Gráfico 7 - Matrículas Pronatec - Rede e-Tec Brasil (2011-2016)

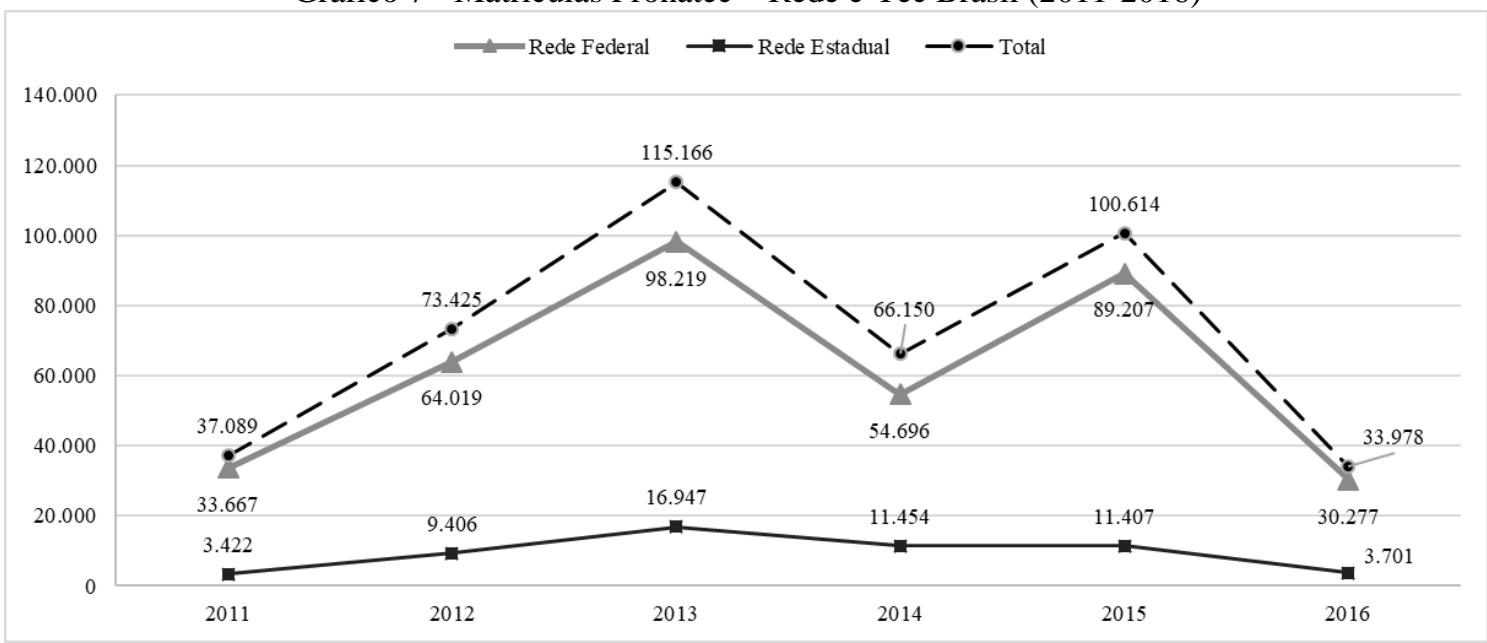

* Às matrículas no ano de 2016 disponíveis no SIMEC foram somadas as vagas pactuadas nesse ano por meio da Rede e-Tec no âmbito da Bolsa Formação.

Fonte: elaborado pela autora com base nos dados disponíveis no SIMEC e site da SETEC (mar. 2018)

Quanto aos recursos destinados a essa iniciativa, conforme os dados obtidos por meio de solicitação via e-SIC, há um crescimento a partir de 2012, conforme se observa na Tabela 15. No entanto, conforme aponta o relatório do TCU (2016), no período de 2011 a 2014, apenas $58 \%$ do orçamento destinado a essa ação foi executado. Assim, diante da redução do número de matrículas nessa iniciativa, pode-se questionar se o orçamento informado pela SETEC, via e-SIC foi de fato executado.

Tabela 15 - Orçamento destinado ao Programa Rede e-Tec Brasil - 2011 a 2016

\begin{tabular}{ll}
\hline \hline Ano & Orçamento \\
\hline 2011 & $121.752 .440,89$ \\
2012 & $129.787 .159,05$ \\
2013 & $143.468 .975,05$ \\
2014 & $161.559 .041,76$ \\
2015 & $157.706 .417,99$ \\
2016 & $151.922 .474,88$ \\
\hline Total & $866.196 .509,60$ \\
\hline \hline
\end{tabular}

Fonte: Elaborada pela autora com base em dados obtidos via e-SIC (2017).

\section{A Expansão da Rede Federal de Educação Profissional, Científica e Tecnológica}

também se encontra entre as iniciativas do Pronatec. Tendo sido iniciada em 2005, a partir da mudança na legislação que impedia o investimento direto da União na criação de novas escolas técnicas, como viu-se, o número de instituições cresceu mais de 500\% no período de 2003 a 2016, partindo de 140 unidades ao final de 2002, para 643 no mês de maio de 2016 (SETEC, 2016). A partir de 2011 até 2016 foram criadas mais 269 (duzentas e sessenta e nove) novas unidades. 
Nesse período, a SETEC expediu a Portaria n. 1291/2013 que normatiza as formas de expansão dos Institutos Federais, incluindo para além de Campus e Campus Avançando, já em vigor, a possibilidade de criação de Centros de Referência e Polos de Inovação. Nos Centros de Referência poderiam ser desenvolvidos programas e projetos de ensino, os quais foram utilizados em grande medida para o desenvolvimento de cursos do Pronatec Bolsa Formação, como se verá no Capítulo III. Segundo Marcelo Feres, a criação de Centros de Referência funcionava como “"unidades clandestinas', pois vários Centros de Referência eram Unidades que estavam sendo constituídas, que viriam a ser Campus, em algum momento, bastava ter recurso para poder contratar professor" (Entrevista FERES, 2017).

Em relação às matrículas dessa iniciativa contabilizadas no âmbito do Pronatec, que estão disponibilizadas no SIMEC, o relatório do TCU não aponta a metodologia para o cálculo. Assim, embora se observe um decréscimo nas matrículas informadas no âmbito da iniciativa Expansão da Rede Federal, nesse sistema, ao observarmos o total de matrículas e o número de ingressantes nas instituições da Rede Federal, no período de 2011 a 2016, identifica-se um crescimento da oferta, conforme aponta o Gráfico 8.

Gráfico 8 - Matrículas Expansão da Rede Federal (2011-2016)

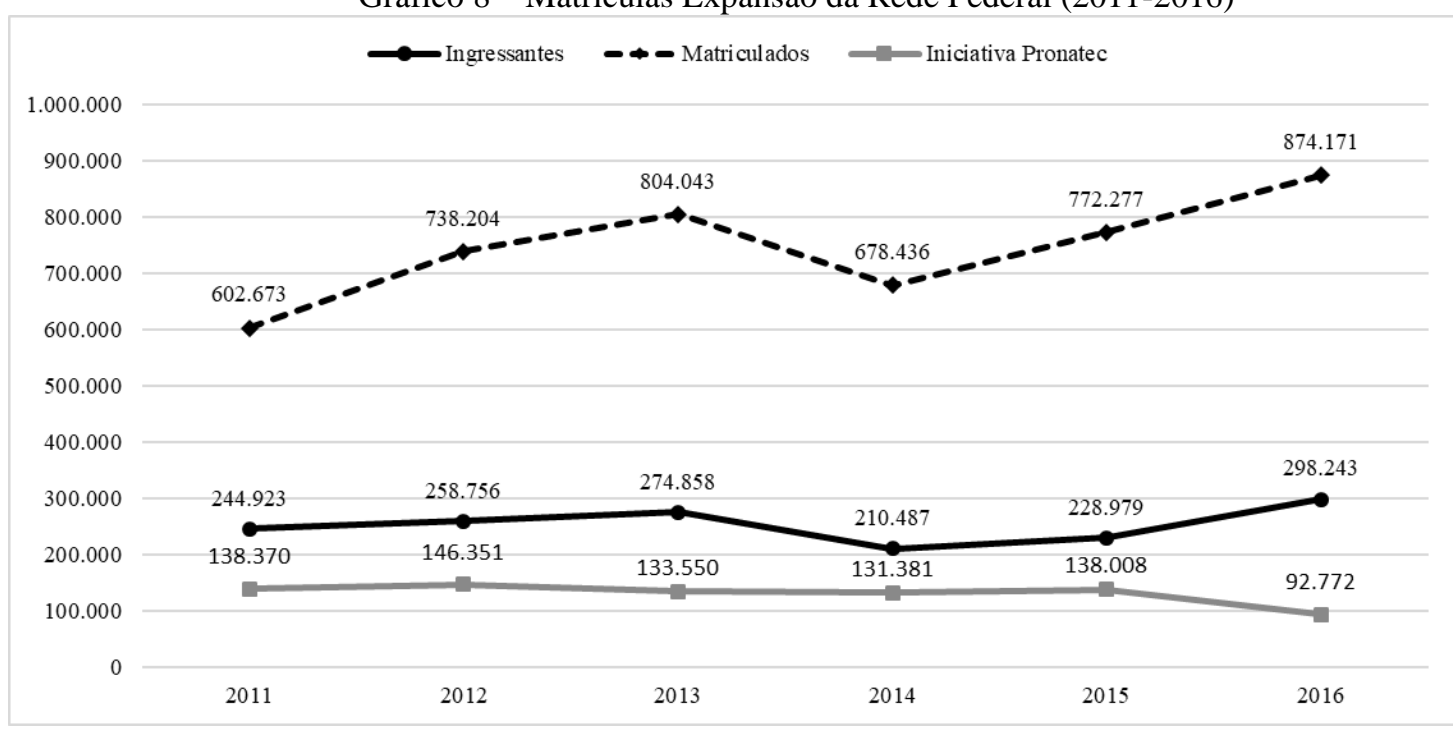

Fonte: elaborado pela autora com base nos dados dos Relatórios de Indicadores das Instituições Federais de Educação Profissional, Científica e Tecnológica de 2011 a 2016 (ingressantes e matriculados) e consulta ao SIMEC (Iniciativa Pronatec) (2018).

Ressalta-se que no total de matrículas informadas no SIMEC, 16,2\% foram realizadas em cursos FIC e 83,8\% em cursos técnicos. Já o total de matrículas e o total de ingressantes se referem ao conjunto dos cursos ofertados no âmbito dessas instituições.

Quanto aos recursos destinados à iniciativa Expansão da Rede Federal, as informações obtidas via e-SIC não foram conclusivas, uma vez que os dados repassados por meio de 
diferentes consultas diferem entre si. Assim, optou-se por apresentar os dados indicados no relatório do TCU, por sua confiabilidade, no entanto, compreendem apenas o período de 2011 a 2014. Nesse período, apenas $21 \%$ do orçamento previsto foi executado, conforme se observa na Tabela 16, o que corresponde a $15 \%$ do valor total destinado ao Pronatec no mesmo período.

Tabela 16 - Execução orçamentária e financeira da Expansão da Rede Federal, 2011 a 2014 (em milhões)

\begin{tabular}{lllllll}
\hline \hline $\begin{array}{l}\text { Expansão da } \\
\text { Rede Federal }\end{array}$ & Autorizado & Empenhado & Liquidado & Pago & $\begin{array}{l}\text { Execução } \\
\text { Orçamentária }\end{array}$ & $\begin{array}{l}\text { Execução } \\
\text { Financeira }\end{array}$ \\
\hline 2011 & 1.298 .179 & 1.131 .991 & 404.834 & 375.363 & $31 \%$ & $29 \%$ \\
2012 & 2.217 .633 & 1.534 .706 & 385.250 & 362.481 & $17 \%$ & $16 \%$ \\
2013 & 1.661 .412 & 1.350 .649 & 324.411 & 274.203 & $20 \%$ & $17 \%$ \\
2014 & 2.062 .544 & 1.182 .546 & 405.345 & 361.608 & $20 \%$ & $18 \%$ \\
\hline Total & $\mathbf{7 . 2 3 9 . 7 6 9}$ & $\mathbf{5 . 1 9 9 . 8 9 2}$ & $\mathbf{1 . 5 1 9 . 8 4 0}$ & $\mathbf{1 . 3 7 3 . 6 5 5}$ & $\mathbf{2 1 \%}$ & $\mathbf{1 9 \%}$ \\
\hline \hline
\end{tabular}

Fonte: Relatório TCU (2016).

O Acordo de Gratuidade com os Serviços Nacionais de Aprendizagem ${ }^{92}$ - SENAC e SENAI - teve início em 2008, o qual define, progressivamente, até o ano de 2014 que estas instituições devem aplicar 66,66\% da receita líquida obtida através da contribuição compulsória paga pelas empresas na oferta gratuita de cursos técnicos de nível médio e programas de formação inicial e continuada de trabalhadores. Apesar de realizarem um serviço público, uma vez que o valor pago pelas empresas deve ser destinado ao cidadão através de seus serviços/produtos, pela primeira vez definiu-se parâmetros para a oferta de vagas gratuitas, vinculando a obrigatoriedade de aplicação de um percentual desses recursos. Os dados de matrículas realizadas nessa iniciativa contabilizam, no período de 2011 a 2016, o total de 3.274.335, sendo que as matrículas em cursos técnicos representam apenas 8,9\% desse total. Tanto o SENAC, quanto o SENAI cumpriram até 2014 a aplicação de 2/3 de seus recursos em cursos de gratuidade, tendo investido nesse ano o total $72,4 \%$ e $68,3 \%$, respectivamente, de acordo com informações repassadas ao TCU (2015). No entanto, a Auditoria realizada pelo TCU, especificamente sobre o acordo de gratuidade, indica que "o modelo hoje utilizado não permite concluir, com razoável segurança, que as despesas apropriadas refletem as despesas reais com gratuidade" (TCU, 2017, p. 53). Assim, quase 10 anos após a realização do acordo, o objetivo da publicização do uso dos recursos parece ainda não ter sido atingido.

Quando se analisa a oferta de matrículas por ano, observa-se uma diminuição no número de matrículas nas duas instituições a partir de 2015, conforme o Gráfico 9.

\footnotetext{
92 O Acordo prevê também a destinação de um terço $(33,3 \%)$ das receitas do Serviço Social da Indústria - SESI e do Serviço Social do Comércio - SESC para a Educação. No entanto, as matrículas realizadas por estas instituições não estão inseridas no âmbito do Pronatec por não fazerem parte dos cursos previstos pelos Catálogos de Cursos FIC ou de Cursos Técnicos (TCU, 2015).
} 
Gráfico 9 - Matrículas no Acordo de Gratuidade no SENAC e SENAI (2011-2016)

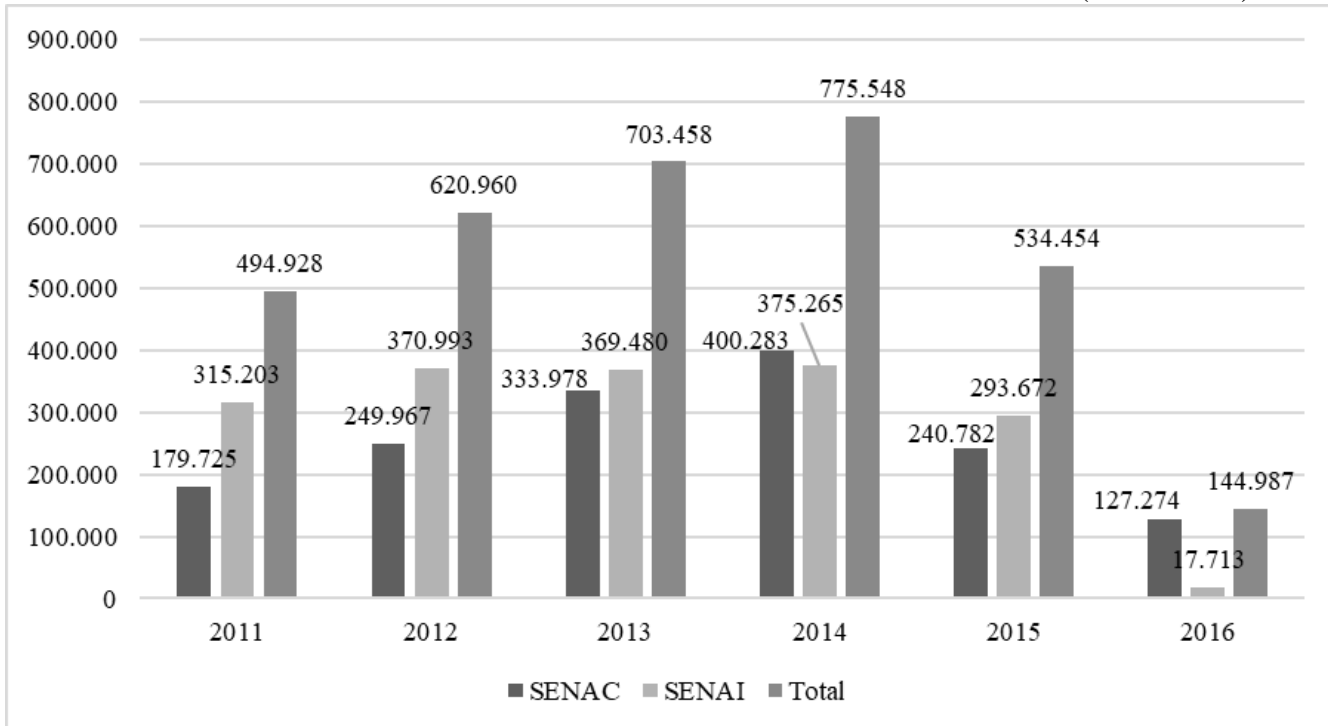

Fonte: elaborado pela autora com base nos dados disponíveis no SIMEC (2018) e obtidos via e-SIC (2018).

Nos relatórios de gestão da Instituição do Sistema $S$ que fez parte dessa pesquisa (Instituição SNA), verificou-se que os percentuais aplicados no período de 2014 a 2016 ultrapassaram o mínimo estabelecido. Em 2014 o percentual investido foi de 76,59\%, em 2015 foi $102,74 \%$ e em 2016, atingiu o percentual de $93,43 \%$. Já no ano de 2017 , esse percentual caiu para $65,61 \%$ o que configura o não atendimento do percentual definido no Acordo. No entanto, o Relatório justifica que o percentual faltante foi suprido pelo "Saldo Acumulado do Cumprimento do Programa de Gratuidade" nos anos anteriores (RELATÓRIO DE GESTÃO SNA, DIRETÓRIO REGIONAL DO RS, 2017³). Esse procedimento pode explicar a diminuição no número de matrículas em âmbito nacional a partir de 2015. Porém, é curioso o fato de o número de matrículas nessa ação ter diminuído de forma concomitante à diminuição dos recursos do Pronatec Bolsa Formação.

De acordo com apontamento da CGU, em 2013 "2143 alunos contabilizados em duplicidade no mesmo curso, mas em programas distintos, ou seja, contabilizados tanto como aluno do Pronatec Bolsa Formação, quanto como aluno do Acordo de gratuidade" (CGU, 2018, p. 13). Nesse sentido, levanta-se a hipótese de que as matrículas e a receita oriunda da Bolsa Formação possam ter tido papel importante na execução do Acordo de Gratuidade.

Fruto de muitas disputas no âmbito do Governo Federal, apesar de passada quase uma década, foi possível identificar a resignação destas instituições em relação à "ingerência" do governo sobre esse recurso. Nas palavras do Gestor do SNA - instituição do Sistema S que fez parte desta pesquisa - em entrevista realizada em fevereiro de 2016:

\footnotetext{
${ }^{93} \mathrm{O}$ documento se encontra nos arquivos da pesquisa.
} 
O Acordo de Gratuidade o que mudou é que antes desse acordo, o Sistema S, ele dizia aonde ele aplicava o recurso e quais os cursos que ele fazia. Ele tinha autonomia. Então, não deixou de ser uma ingerência do governo dizendo: oh, tu tens que aplicar este percentual em tais e tais cursos. Tem que se aplicar esse percentual em gratuidade. Isso limita. Quando tu tinhas a liberdade de usar esse dinheiro do compulsório, que é teu, é um dinheiro que tu recebes, que não é do governo, tu diz: olha vou fazer uma nova escola em tal lugar, aí tu tinha a condição de fazer isso. Agora não. Tu tens que fazer o curso, mesmo caindo aos pedaços o negócio lá... juntar esse recurso e aí fazer o investimento. Tu não tens a liberdade de usar o dinheiro como tu poderias usar. (Entrevista Gestor NEP SNA).

Ao mesmo tempo, apesar das "limitações" apontadas em relação ao Acordo de Gratuidade, a instituição destinou percentual acima do mínimo na realização de cursos gratuitos no período de 2014 a 2016, como se viu, e no mesmo período de vigência do Acordo ampliou suas unidades, passando de 38, em 2012, para 42 escolas, em 2018, além de ter reformado grande parte de suas instalações, como se verá no Capítulo IV.

Analisando-se as matrículas no conjunto das cinco (05) iniciativas abarcadas pelo Pronatec, para as quais se estimava a meta de oito milhões de matrículas até 2014, observa-se que ao final de 2016 o Programa havia atingido o total de 9.568 .519 matrículas, sendo quase metade dessa oferta foi realizada pela iniciativa Bolsa Formação, seguida do Acordo de Gratuidade, conforme se observa no Gráfico 10.

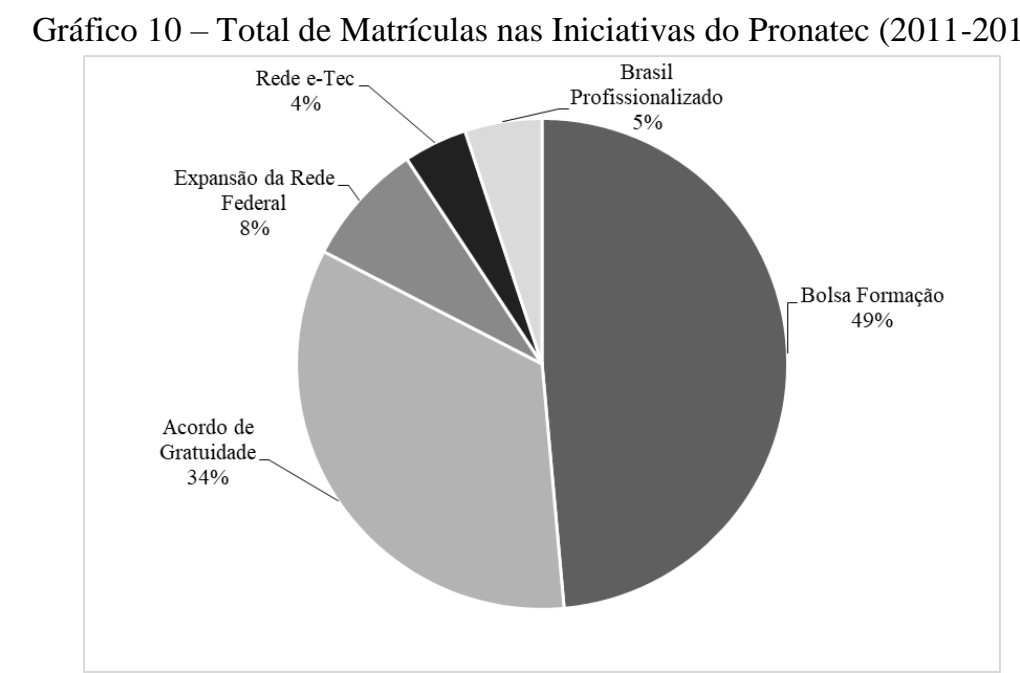

Fonte: elaborado pela autora com base nos dados disponíveis no SIMEC (2017).

Em relação aos recursos, não foi possível identificar o montante destinado a cada iniciativa nesse mesmo período de contabilização das matrículas. No entanto, se considerarmos o volume de recursos destinado entre 2011 e 2014, período em que foram ofertadas a maior parte das matrículas e de recursos, observa-se que a iniciativa Bolsa Formação recebeu 78\% do total dos recursos destinados ao conjunto das iniciativas do Programa, conforme Gráfico 11. 
Gráfico 11 - Orçamento destinado às Iniciativas do Pronatec (2011-2014)

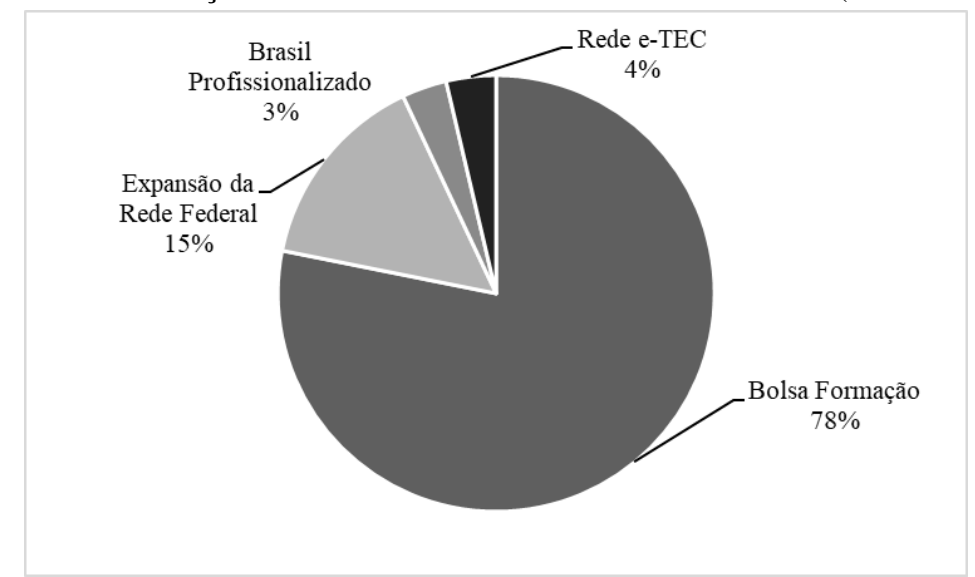

Fonte: Elaborado pela autora com base nos dados do Relatório TCU (2016)

Analisando-se os dados - de matrículas e de recursos - relativos ao conjunto de ações do Pronatec observa-se que as disputas que permearam a construção e desenvolvimento do Pronatec acabaram por fortalecer a oferta e a captação dos recursos públicos por meio de instituições privadas. Especialmente na rede estadual, onde se concentra a grande maioria dos estudantes de ensino médio público, observou-se a acentuada diminuição dos recursos investidos em infraestrutura, por meio do Brasil Profissionalizado, deslocando o investimento do governo federal para o financiamento de vagas no âmbito da Bolsa Formação. No âmbito da Rede Federal, em que pese o grande número de unidades de ensino criadas nesse período, a baixa execução orçamentária do orçamento previsto fez com que muitas "unidades clandestinas" - Centros de Referência - não pudessem se tornar unidades de ensino permanentes, conforme será observado no Capítulo III, e/ou comprometeu o avanço na consolidação de infraestrutura e corpo docente nas unidades já existentes. Como observado no Gráfico 1, a diminuição dos recursos no financiamento de vagas tem efeito imediato, enquanto o investimento em instituições permite sustentar a oferta de matrículas a longo prazo.

Nos próximos Capítulos, serão apresentadas as análises sobre o desenvolvimento do Pronatec Bolsa Formação em um Instituto Federal e em uma instituição do Sistema S, o que permitirá compreender de forma mais detalhada as condições de oferta e as disputas em nível local que perpassaram essa política. 
CApítulo III

O Desenvolvimento do Pronatec Bolsa FormaÇão em Um Instituto Federal de Educação, Ciência e Tecnologia

Os Institutos Federais de Educação, Ciência e Tecnologia são instituições de educação básica, profissional e superior, pluricurricular e multicampi, que integram a Rede Federal de Educação Profissional, Científica e Tecnológica ${ }^{94}$ do país - Rede Federal de EPCT. Criados em 29 de dezembro de 2008, pela Lei n ${ }^{\circ} 11.892$, a partir da transformação de Centros Federais de Educação Tecnológica e Escolas Técnicas Federais, atualmente, constituem 38 diferentes instituições que juntas possuem 589 campi e atendem 947.792 estudantes em seus diferentes níveis e modalidades de ensino, de acordo com as informações disponíveis na Plataforma Nilo Peçanha (2018). ${ }^{95}$

No Estado do Rio Grande do Sul situam-se três Institutos Federais - Instituto Federal Farroupilha, Instituto Federal do Rio Grande do Sul e Instituto Federal Sul-rio-grandense oriundos da transformação dos três Centros Federais de Educação Tecnológica existentes e duas escolas técnicas federais. Além dos Institutos Federais, que juntos somam 38 campi e 03 campi avançados, também compõem a Rede Federal de EPCT no estado, dois colégios técnicos vinculados à Universidade Federal de Santa Maria. Esse conjunto de instituições ofertou 10,1\% do total de matrículas realizadas no âmbito do Pronatec Bolsa Formação no Estado, no período de 2011 a 2016, o que corresponde a 33.210 matrículas. Desse total, 94,6\% foram realizadas em cursos FIC e 5,4\%, em cursos técnicos. Apesar da pequena participação da Rede Federal no conjunto da oferta realizada no Estado, observa-se grande diversidade de cursos e eixos ofertados: 24 cursos técnicos e 221 cursos FIC, totalizando 245 diferentes cursos que abrangem a maioria dos eixos tecnológicos, excetuando-se apenas o Eixo Militar (SISTEC NACIONAL, 2017).

Com vistas na compreensão da oferta e desenvolvimento dos cursos do Pronatec Bolsa Formação em instituição pública de ensino, realizou-se pesquisa no âmbito de um dos Institutos Federais, o Instituto Federal Farroupilha ${ }^{96}$, cujos resultados serão apresentados neste Capítulo. Inicia-se com a caracterização da instituição, a forma de gestão institucional do Pronatec Bolsa

\footnotetext{
94 Além dos Institutos Federais, também integram a Rede Federal de Educação Profissional, Científica e Tecnológica dois CEFETs, 23 escolas vinculadas a Universidades, o Colégio Pedro II e uma Universidade Tecnológica, que juntos somam 643 unidades de ensino, conforme informações disponíveis na Plataforma Nilo Peçanha (https://www.plataformanilopecanha.org/, acesso em 16/03/2018).

${ }^{95}$ Consulta realizada em 16/03/2018 no site da Plataforma: https://www.plataformanilopecanha.org/.

${ }^{96}$ Os critérios para seleção dessa instituição foram apresentados na introdução desta Tese.
} 
Formação e o perfil da oferta dos cursos. Em seguida, apresenta-se o processo e as condições de desenvolvimento dos cursos, a formação dispendida e os resultados obtidos em relação à conclusão das matrículas, a partir do aprofundamento da investigação em duas unidades de ensino da Instituição: um Campus e um Centro de Referência.

\subsection{Perfil da Instituição e do desenvolvimento do Pronatec Bolsa Formação}

O Instituto Federal Farroupilha possui 10 campi e um Campus Avançado, dos quais quatro estão presentes desde a sua criação e os demais foram criados ao longo de sua trajetória de expansão. O último campus que passou a integrar a instituição foi criado em 2014, a partir da transformação do Colégio Agrícola de Frederico Westphalen (CAFW) vinculado à Universidade Federal de Santa Maria em campus do Instituto. A instituição atua também em outras cidades do Estado, com oferta de cursos técnicos na modalidade de ensino a distância, por meio da sua adesão à Rede e-Tec.

A partir de 2014, a Portaria MEC 1.291/2013, que define novas normas e parâmetros para a expansão dos Institutos Federais, incluiu entre as possibilidades de expansão dos IFs a criação de Polos de Inovação e Centros de Referência. Com vistas a responder à demanda dos municípios que não possuíam campus da instituição, de acordo com a Gestora do IF, foram criados 09 (nove) Centros de Referência, nos quais, de acordo com a Portaria, podem ser desenvolvidos planos, programas e projetos voltados à Educação Profissional e Tecnológica. Nos Centros de Referência são/foram ofertados cursos técnicos e de formação inicial e continuada, principalmente por meio do Pronatec Bolsa Formação.

\section{Figura 6 - Mapa das unidades do IF Farroupilha}
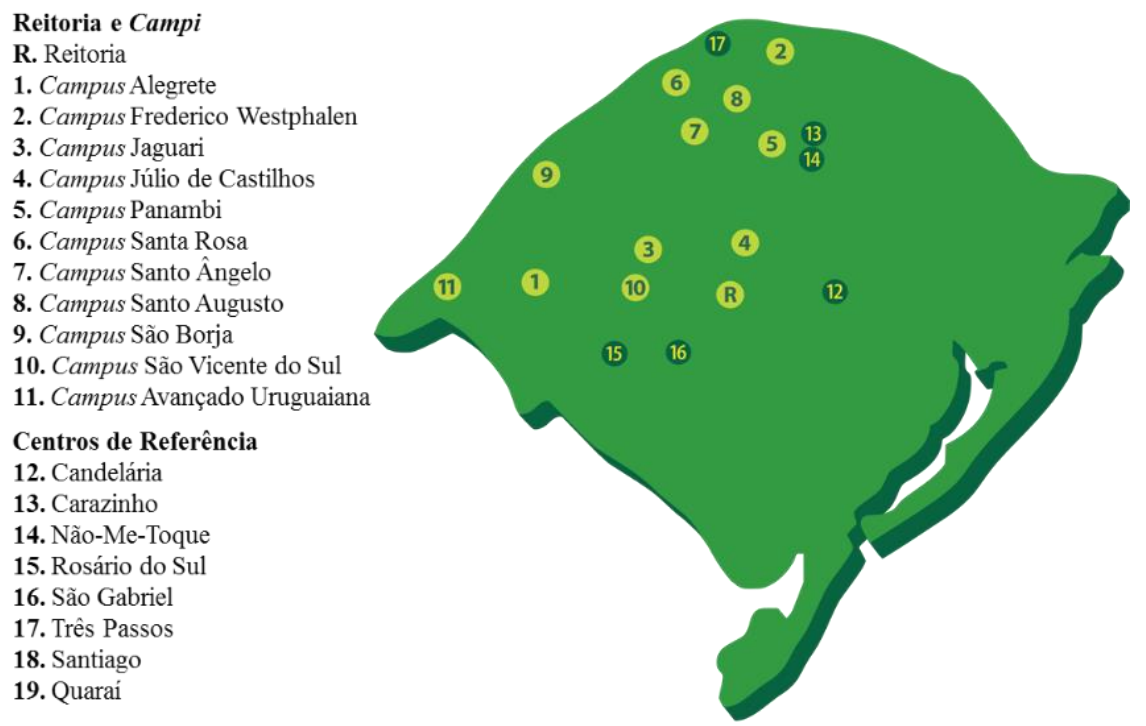

Fonte: Site do IFFar, 2016. 
A Reitoria - sede da administração central da instituição - está localizada na cidade de Santa Maria, onde não há campus do IFFar, de forma a facilitar geograficamente a comunicação e a interação entre as unidades de ensino. Na Figura 6, pode-se visualizar a localização geográfica das unidades de ensino da Instituição.

Atualmente, a Instituição oferta cursos de formação inicial e continuada, cursos técnicos de nível médio (integrados, concomitantes e subsequentes), inclusive na modalidade de educação de jovens e adultos integrada à educação profissional (Proeja), cursos superiores de licenciatura, bacharelado e tecnologia e cursos de pós-graduação, além de outros Programas fomentados pela Secretaria de Educação Profissional e Tecnológica (SETEC) e das atividades de pesquisa e extensão. No ano de 2017, a instituição possuía 13.278 (treze mil e duzentos e setenta e oito) estudantes, sendo que 55\% se encontravam em cursos técnicos - entre os quais $55 \%$ são cursos integrados ao ensino médio - e $37 \%$ em cursos de graduação, conforme o Gráfico 12. Apenas 10\% das matrículas (1.303) ocorriam por meio do ensino a distância e são realizadas em cursos técnicos na forma subsequente ao ensino médio. O corpo docente e técnico-administrativo, nesse ano, era composto por 674 e 679 profissionais, respectivamente.

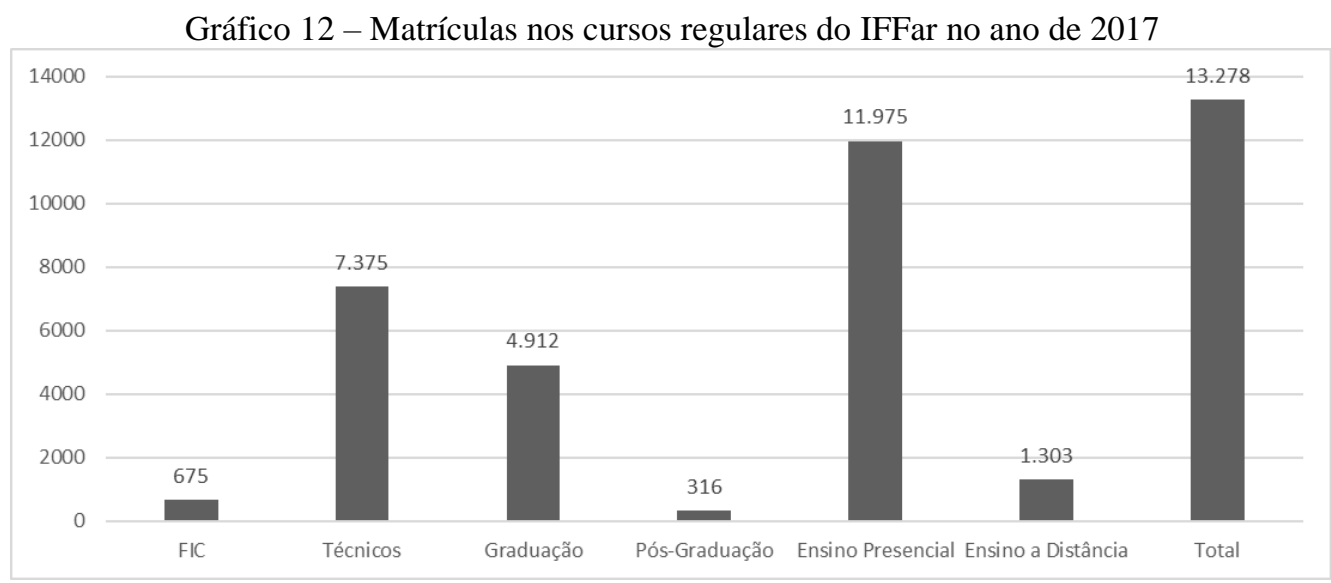

Fonte: Plataforma Nilo Peçanha (2018).

De acordo com seu Projeto Pedagógico, a "instituição compromete-se com uma formação humanística, integral, em que os conhecimentos partem da prática social e a ela retornam transformando-a". Nessa direção, destaca que o objetivo "não é formar um profissional para o mercado, mas sim um cidadão para o mundo do trabalho, que tanto poderia ser um técnico quanto um filósofo, um escritor ou tudo isso", com vistas a "superar o preconceito de classe de que um trabalhador não pode ser um intelectual, um artista" (PDI IFFar, 2014, p. 47-48). 
Com base nessa concepção, a instituição assume como proposta curricular o desenvolvimento do "currículo integrado", de forma a integrar formação geral (conhecimentos gerais) e formação profissional (conhecimentos específicos) sob "os eixos do trabalho, da ciência e da cultura" (PDI IFFar, 2014, p. 50). Como importante ferramenta metodológica para o desenvolvimento dessa concepção de currículo, a instituição desenvolve no âmbito de todos os cursos técnicos e de graduação ofertados a "Prática Profissional Integrada", que tem o propósito de "integrar os componentes curriculares formativos, ultrapassando a visão curricular como conjuntos isolados de conhecimentos e práticas desarticuladas e favorecer a integração entre teoria e prática, trabalho manual e intelectual, formação específica e formação básica ao longo do processo formativo", a partir do planejamento, estudo, pesquisas e práticas envolvendo os docentes e discentes dos cursos (PDI IFFar, 2014, p. 324).

De acordo com os objetivos da pesquisa, buscou-se compreender como se deu o processo de inserção da Instituição na oferta do Programa, a sua gestão, o público atendido e as características de seu desenvolvimento. Nessa direção, a análise desenvolveu-se a partir de três diferentes espaços: no âmbito da Reitoria, especialmente a Pró-Reitoria de Extensão, no âmbito de um Campus e no âmbito de um Centro de Referência. A investigação foi realizada por meio de entrevistas com gestores e professores, questionários destinados a estudantes e corpo docente, além da coleta e análise de documentos institucionais, projetos pedagógicos de cursos e indicadores de matrícula e perfil dos estudantes.

Com vistas na exposição dos resultados, serão apresentadas separadamente as análises em cada um desses espaços, as quais permitirão, ao final deste Capítulo, traçar uma visão geral do desenvolvimento do Programa no Instituto Federal Farroupilha.

\subsection{A Gestão Institucional do Pronatec Bolsa Formação}

A trajetória de implantação do Pronatec Bolsa Formação no IFFar foi marcada, inicialmente, por um processo de resistência motivado pela identificação de mudança de perspectiva quanto à expansão da educação profissional a partir desse Programa. Assim, a oferta de cursos iniciou de forma contida, tendo alavancado apenas dois anos após sua vigência.

Quanto ao seu desenvolvimento, as normas de operacionalização do Programa e o atraso no repasse dos recursos foram fatores que dificultaram o pleno desenvolvimento dos cursos. Nessa direção, observou-se que o modus operandi do Pronatec, que prevê bolsas para os profissionais envolvidos, os quais podem ser servidores da instituição ou profissionais externos, 
gerou uma estrutura paralela e diferenciada - de qualidade rebaixada, inclusive - em relação às atividades regulares de ensino, configurando uma "dualidade institucional".

Ao mesmo tempo, o Programa permitiu que a instituição ampliasse seu raio territorial de atuação, incorporando públicos que dificilmente chegariam aos seus cursos pelos meios convencionais, seja pela distância ou pelo imaginário social que a população, em especial a de baixa renda, tem acerca das instituições federais de ensino, motivado, em grande medida, pelo histórico elitista dessas instituições. A participação em cursos do Pronatec abriu oportunidade para vários estudantes continuarem seus estudos, ao "descortinarem" as diferentes possibilidades formativas ofertadas pela instituição. Nos tópicos a seguir, esses e outros elementos serão analisados de forma aprofundada.

\subsubsection{A Resistência em relação à concepção do Pronatec Bolsa Formação}

A partir das entrevistas realizadas com a Dirigente da Instituição e equipe gestora em nível de Reitoria, identificou-se uma resistência inicial em desenvolver o programa, em razão de que trazia uma concepção diferente daquela que orienta a oferta da educação profissional no âmbito dos Institutos Federais. De acordo com a Gestora, essa resistência ocorreu no âmbito das instituições da Rede Federal de EPT. O Programa indicava, na leitura de alguns gestores da Rede, uma mudança na lógica que orientava as políticas de educação profissional até então. Nas palavras da gestora:

(...) quando o Programa veio à tona constituiu-se um grupo na Rede Federal que colocou muitas críticas a esse programa, por uma lógica que eu vou tentar te explicar. Nós vínhamos lá desde 2004/2005 com toda uma mobilização do Governo Federal que conseguiu mudar a legislação que impedia a abertura de novas escolas técnicas, e com base nisso foi criado o programa de expansão da Rede Federal de Educação Profissional e Tecnológica, foi incluído no PPA [Plano Plurianual] do governo federal, teve aqueles projetos de lei que criaram cargos, que criaram funções... E aí a gente viveu aquele momento de expansão da rede. No nosso entendimento, o governo Dilma daria prosseguimento à expansão da rede; a prioridade do governo seria continuar aquele projeto que havia se iniciado lá no primeiro mandato do presidente Lula. E eu, inclusive, como não participei em nenhum momento, fui surpreendida quando nós vimos que o governo da Presidenta Dilma criava uma outra lógica para tratar a educação profissional. E aí a questão do Pronatec surge como prioridade do governo dela, né, e os institutos federais dentro desse programa, eles passavam a ser UM ente. Mas aquela lógica de ampliação da rede, de continuidade de investimentos prioritários na rede, ela se diluiu com o advento do Pronatec. (...) A partir do momento em que o programa foi lançado e eu lembro bem disso, porque daí sim eu já estava aqui [na Reitoria]. Logo que nós assumimos, nós fomos chamados a Brasília, e eu levei os cinco pró-reitores comigo, foi para apresentar a minha equipe e para atender a esse chamado. E aí nos foi colocado: agora com o Pronatec, esse ano vocês têm que, no mínimo, pactuar cinco mil matrículas - disse a Servidora que assumiu essa área. Aí, o Pró-reitor de Extensão, que era muito espirituoso, olhou para ela e disse assim: - Para toda a rede professora? E ela disse: - Não professor, só o seu Instituto! E 
realmente foi assim que eles trabalharam. Eles chamaram todos os institutos, né, no sentido de dar a cada um dos institutos metas a serem cumpridas. Que na verdade não foram né, porque houve o movimento muito forte de resistência nos institutos federais. Alguns institutos não apresentaram essa resistência. Aqui no Rio Grande do Sul, por exemplo, um dos institutos, desde que o programa iniciou, ele aderiu fortemente. Nós, não. Tanto que se tu olhares a evolução, nos dois primeiros anos a nossa inserção nesse programa foi muito pequena (Entrevista Gestora IFFar, 2016).

Nesse contexto, é possível compreender a evolução das matrículas no Programa no âmbito do Instituto Federal Farroupilha. Apesar de ter ofertado turmas desde o primeiro ano de sua vigência, a participação da instituição foi bem reduzida até o final de 2012, tendo sido ampliada em 2013 e 2014, como pode ser visualizado na Tabela 17.

Tabela 17 - Matrículas* por ano Pronatec Bolsa Formação - IFFar

\begin{tabular}{r|llllll}
\hline \hline Forma de oferta & $\mathbf{2 0 1 1}$ & $\mathbf{2 0 1 2}$ & $\mathbf{2 0 1 3}$ & $\mathbf{2 0 1 4}$ & $\mathbf{2 0 1 5}$ & $\mathbf{2 0 1 6}$ \\
\hline \hline Cursos técnicos & 0 & 0 & 338 & 583 & 382 & 0 \\
Cursos FIC & 85 & 389 & 2.349 & 2573 & 902 & 100 \\
Mulheres Mil (FIC) & 0 & 0 & 541 & 1.240 & 80 & 0 \\
\hline Total & 85 & 389 & 3.228 & 4.396 & 1.364 & 100 \\
\hline \hline
\end{tabular}

* Apenas matrículas novas a cada ano.

Fonte: SISTEC Institucional (2016).

Ao justificar a resistência ao Programa no âmbito da instituição, a gestora aponta três fatores:

Primeiro, essa mudança de foco do tratamento da educação profissional brasileira. Como eu te disse, a gente vinha naquele viés, de uma questão dos institutos organicamente estabelecidos, focados com 50\% das vagas para cursos técnicos, preferencialmente, integrados. E aí o Pronatec chega mais como um varejo - era essa palavra que eu usava, inclusive. Então essa falta de organicidade, de articulação com os ideais, as finalidades dos institutos era o viés de resistência. O outro é o fato de o programa a ser muito focado somente na profissionalização, no trabalho de questões relacionadas a qualificar profissionalmente sem preocupação com a elevação da escolaridade. Que é algo que no Instituto, e nos institutos, isso é muito forte. Então esse descolamento entre formação profissional e educação básica, elevação de escolaridade, era o outro elemento importantíssimo. Era não, é outro elemento importantíssimo, na questão dessa rejeição ao programa. E um outro elemento, que é inegável, é o fato de que quem sempre esteve muito mais na vitrine nesse programa e quem se valeu muito mais de recursos desse programa, não tem sido as redes públicas, e sim o Sistema S. Hoje se a gente vê os relatórios de execução e a maior parte de recursos do programa foi direcionado para o sistema $S$, que via de regra já recebe recursos que tem origem pública, mas os tratam com viés privado e que ainda passaram a ser beneficiário de um outro recurso que também é público. $\mathrm{E}$ aí, a gente via, e vê discrepâncias: nós por exemplo, os nossos professores do Pronatec, eles recebem o teto, eles recebiam 50 reais a hora aula. E no sistema $S, 17,19,20$ reais a hora-aula. E então basicamente essas três questões: a mudança no tratamento da educação profissional, o descolamento da elevação da escolaridade e mais essa coadjuvância para o sistema $\mathrm{S}$, na minha leitura, foram os três principais fatores de rejeição ao programa (Entrevista Gestora IFFar, 2016).

No âmbito da Pró-Reitoria de Ensino do IFFar, o Pronatec Bolsa Formação também foi recebido com certa resistência. Naquele mesmo período, os trabalhos da equipe estavam 
concentrados na construção coletiva de diretrizes institucionais para a organização didáticopedagógica dos cursos, a partir das recentes diretrizes curriculares nacionais para o ensino médio (2010) e para a educação profissional técnica de nível médio (2012). O debate tinha como horizonte a formação integrada e integral dos estudantes, associando os conhecimentos científicos básicos aos conhecimentos específicos dos eixos tecnológicos de cada curso técnico. O Pronatec Bolsa Formação, por priorizar a oferta de cursos de qualificação profissional e cursos técnicos concomitantes ou subsequentes ao ensino médio, vinha de encontro à prioridade da política de ensino profissional da instituição que é a oferta da formação profissional integrada à elevação da escolaridade, seja por meio do ensino regular ou pela modalidade de educação de jovens e adultos ${ }^{97}$. Essas circunstâncias, além da sobrecarga de trabalho da equipe, ajudam a compreender o pouco envolvimento da Pró-Reitoria de Ensino no desenvolvimento do Pronatec, conforme se evidencia no decorrer da análise.

\subsubsection{A expansão provisória a partir de Centros de Referência}

O aumento da oferta a partir de 2013 foi justificada em virtude da visualização do Programa como possibilidade de atendimento das demandas de municípios que se encontravam represadas frente à ausência de perspectivas para a criação de novos campi na instituição:

\footnotetext{
Depois, claro, como se percebeu que essa seria a prioridade do governo, e que isso poderia de alguma forma trazer uma maior capilaridade para o instituto, aí, sim, como política interna, nós começamos a enxergar a possibilidade, principalmente através de cursos técnicos, de nós chegarmos em cidades que vinham demandando o Instituto já há algum tempo, e que com a expansão suspensa, o Pronatec, especialmente a oferta de cursos técnicos, passava a ser um paliativo para atender, pelo menos minimamente, essas demandas. E foi aí que o nosso Instituto começou a entrar mais fortemente. Foi nesse contexto que criamos os Centros de Referência. Nós tínhamos uma demanda muito forte de municípios sempre aqui querendo um Campus do Instituto, um Campus do Instituto e a gente sempre deixando claro que não havia perspectiva de criação de novos Campus. Nesse contexto, bom, então, o Pronatec, apesar de ele não ter sido a política que nós gostaríamos que fosse, ele permite que o Instituto atenda algumas comunidades que, com a estrutura que nós temos, não estão atendidas. E foi isso que gerou a criação dos centros de referência. Teve aquela portaria, acho que n. 1291 do MEC, de dezembro de 2013, que traz a nova organização da rede, que fala em Campus, em Campus avançado, em Polo de inovação e traz o expediente dos Centros de Referência, que foi o que nos permitiu então criar os Centros, onde hoje a gente oferta cursos técnicos de nível médio e, claro, os cursos FICs também (Entrevista Gestora IFFar, 2016).
}

\footnotetext{
${ }^{97}$ O Instituto Federal Farroupilha apresenta-se, atualmente, como o segundo IF que oferta maior percentual de suas matrículas em cursos Proeja (6,6\%), conforme dados da Plataforma Nilo Peçanha (2018), embora não atinja o percentual de 10\% de matrículas, conforme o Decreto 5.840/2006.
} 
A criação dos Centros de Referência surgiu, nesse sentido, como uma forma de atender à demanda dos municípios, que reivindicavam a atuação da Instituição, por meio da criação de um Campus, o que não seria possível diante das perspectivas da expansão da Rede para o período. A implantação de Centro de Referência, diferentemente da criação de um Campus, não prevê estrutura física própria. São implantados, normalmente, com o apoio de prefeituras. Da mesma forma, não há previsão de vagas para o corpo docente e técnico. Para atender esses espaços, a instituição deve designar docentes e servidores que já atuam na Instituição. Tendo em vista o número limitado de servidores, a instituição destinou apenas um servidor para realizar as atividades de gestão de cada Centro $^{98}$.

Em relação à alocação de servidores nesses novos espaços, o Coordenador do FDE (Fórum dos Dirigentes de Ensino da Rede Federal de Educação Profissional e Tecnológica) aponta a contradição dessa estratégia de expansão dos IFs:

(...) se os Campus foram construídos com a projeção de um número $\mathrm{X}$ de docentes, um número $\mathrm{X}$ de técnicos-administrativos, para atingir $\mathrm{X}$ alunos em um determinado tempo, como que agora eu possibilito retirar servidores desses Campus - o que foi feito, literalmente -, e alocá-los para atuarem em Centros de Referência, sendo que se considerava aquele servidor essencial para atuação no Campus, o qual não é reposto por outro servidor? Então, quer dizer, se eu preciso de $\mathrm{X}$ servidores, para atingir $\mathrm{X}$ número de matrículas, em um determinado Campus, quando eu retiro um número de servidores desse Campus, para alocar em um Centro de Referência, por mais que gestado por aquele Campus, significa que eu deixo de atender aquele Campus, para atender, de uma outra forma, o mesmo objetivo, que não atingiu os mesmos resultados. Ou, significa admitir que aquele número de servidores não era o necessário para o Campus (Entrevista Coordenador FDE, 2018).

Nesse sentido, a expansão da rede federal a partir de Centros de Referência estaria impactando o próprio processo de consolidação das unidades já existentes. Além disso, não se configura uma ação permanente como são os campi, visto que a sua manutenção estaria basicamente atrelada aos recursos do Pronatec. No início de 2016, a Gestora apontava a preocupação com o futuro dos CRs frente ao término do Pronatec Bolsa Formação:

No momento em que nós não tivermos mais esse financiamento do Pronatec [Bolsa
Formação], dificilmente a gente consiga dar sustentabilidade para todos os centros
considerando a distância deles do local de lotação dos nossos professores. Então,
alguns deles que tem mais proximidade, a gente poderia sim dar continuidade, como
é o caso do [CR 4], por exemplo, onde inclusive nós fizemos lotação. Nós temos 3
professores lotados lá, por que nós temos um curso Binacional que corre paralelo às
ações do Pronatec. Alguns centros, talvez, a gente consiga, mas se nós perdermos

\footnotetext{
${ }^{98}$ De acordo com o Diretor de Implantação de Novas Unidades do Instituto, “o Centro de Referência precisa de um servidor do quadro permanente. Por que que precisa? Porque na verdade ele é um representante do Instituto naquela comunidade. Outra coisa, ali tem patrimônio, então precisa de alguém que seja servidor de carreira para ficar responsável por este patrimônio" (Entrevista Diretor DINU IFFar, 2018).
} 
completamente o financiamento do Pronatec inviabiliza a questão de pessoal. O restante, inclusive, nós temos feito destinação com recurso próprio, para aquisição de mobiliário, para algumas questões... Em alguns lugares a prefeitura nos dá o link de internet, em outros não, então nós bancamos. Serviço de limpeza, de vigilância, onde as prefeituras não dão, nós temos contratos próprios... Então, hoje, a gente já destina recursos orçamentários próprios para os Centros de Referência, mas o grande limitante está na remuneração dos professores externos, que isso para nós é um impeditivo. Nós não temos como legalmente dar prosseguimento a isso, se nós não tivermos a ferramenta ou do Pronatec, ou do E-tec que permitam o pagamento das bolsas (Entrevista Gestora IFFar, 2016).

Dentre os 09 (nove) Centros de Referência criados em 2014, apenas 06 (seis) continuavam em atividade em março de 2018. Inclusive o CR 4, citado na fala da gestora, encerrou suas atividades em 2017, tendo de remanejar os servidores para o campus mais próximo. Os Centros de Referência que se mantém em atividade estão desenvolvendo vagas remanescentes do Pronatec Bolsa Formação ou do Mediotec. Um deles, situado perto de um campus - cerca de $40 \mathrm{~km}$ - funciona como uma extensão deste, vislumbrando-se a sua continuidade futura. Os demais dependem de financiamento por meio de programas, visto que não possuem equipe docente e técnica, e a distância das unidades de lotação dos servidores não permite o seu atendimento diário.

De acordo com o Diretor de Implantação de Novas Unidades (DINU) do IFFar, os Centros de Referência foram "uma oportunidade, que na época o governo chegou ao entendimento, uma forma de abrir mais o 'leque' dos Institutos, porque realmente o orçamento da expansão tinha terminado" (Entrevista Diretor DINU IFFar, 2018). Em síntese, o Centro de Referência:

(...) é um convênio com a Prefeitura, onde são divididas as atribuições, são acordadas as atribuições de cada instituição - teve alguns em que entrou também o governo do Estado. Por exemplo, teve o Centro de Referência de Rosário do Sul que o estado entrou com a escola, com a sede, a prefeitura entrou com a manutenção, inclusive com internet, telefone e pessoal de limpeza e manutenção, e o Instituto entrou com os cursos (Entrevista Diretor DINU IFFar, 2018).

Enquanto os repasses orçamentários do Programa estavam ocorrendo, as atividades se desenvolviam de forma satisfatória, do ponto de vista da gestão, de acordo com o Diretor. Porém, quando "começou a diminuir os recursos, eles começaram a chegar de forma mais lenta, começou a ficar mais complicado, esse professor começou a se desmotivar. Tivemos situações até constrangedoras, de o professor não entregar a documentação [diário de classe] enquanto não recebesse, alguns pediram para sair...” (Entrevista Diretor DINU IFFar, 2018).

Com a diminuição do número de vagas do Programa e a mudança na equipe de gestão de alguns municípios, a partir das eleições municipais ocorridas em outubro de 2016, alguns 
Centros de Referência ficaram sem oferta de turmas, culminando no encerramento de suas atividades. A mudança de dirigente das prefeituras impactou no andamento dos CRs, pois "as equipes da Prefeitura elas meio que 'garimpavam' esses cursos. Nessa mudança de governos, além de diminuírem as vagas do Pronatec, essas novas equipes não souberam ou demoraram muito a achar esse caminho para irem buscar essas vagas" (Entrevista Diretor DINU IFFar, 2018), o que aponta para as fragilidades do processo de identificação das demandas de formação profissional no âmbito do Pronatec.

Com o fechamento de alguns CRs e a diminuição das vagas em outros, a Reitoria passou a receber demanda desses municípios para que o Instituto voltasse a atuar naquelas comunidades. Conforme relata o Diretor:

\begin{abstract}
Esse início de ano foi um "desfile" de prefeitos aqui na Reitoria, querendo levar o Instituto de volta, por que isso se tornou uma questão política no município, o pessoal começou a dizer: "olha só: a gestão nova entrou e já acabou com o Instituto, já mandou o Instituto embora". Então nós recebemos muitas visitas de prefeitos e secretários da educação pedindo ajuda nesse aspecto. Eles se mobilizaram, se juntaram, foram até o MEC [Ministério da Educação] e pediram para que fossem destinadas vagas para o Rio Grande do Sul. E surtiu algum efeito, apareceram vagas esse ano, mas não para todos os Centros (Entrevista Diretor DINU IFFar, 2018).
\end{abstract}

O processo de encerramento das atividades nos Centros de Referência, foi bastante difícil, segundo o Diretor, em virtude da expectativa da comunidade em relação à atuação do Instituto. Os Centros de Referência foram criados para serem "embriões de novos campi" e “essas comunidades eu acho, hoje, que elas têm uma certa decepção porque não chegou a se tornar um campus, né? A cidade se preparou para isso, acolheu, mas aí tu ficas vendo que não, que não vai avançar... Então fica um pouco de decepção" (Entrevista Diretor DINU IFFar, 2018).

Nessa direção, o coordenador do FDE, no período de 2014 a 2016, analisa que os Centros de Referência constituíram, em âmbito nacional, uma forma precária de expansão da rede, e que os atrasos financeiros do Programa trouxeram implicações negativas para a imagem das instituições junto à sociedade:

Uma forma muito precária, e muito equivocada de atender a expansão da rede (...). Inclusive, em alguns momentos, comprometeu a própria imagem da Rede, porque as pessoas envolvidas nisso, por exemplo, os estudantes, os professores do município, enfim a própria comunidade, eles não entendiam, e nem tinham o dever de entender, essa diferença entre o ofertante, o demandante e o órgão de fomento. Então, enquanto está lá o Instituto Federal ofertando um curso, no Centro de Referência, com o logo, a imagem do Instituto Federal, para essas pessoas, e não equivocadamente, a responsabilidade de fazer aquilo acontecer, de forma qualificada e satisfatória, era do Instituto Federal (Entrevista Coordenador FDE, 2018). 
Observa-se, com isso, a fragilidade da expansão do ensino dos IFs a partir de Centros de Referência. É um processo que depende dos vários agentes envolvidos, ficando totalmente suscetível às intempéries das mudanças no contexto político e econômico, tanto local, quanto nacional. Apesar de ser atendida durante um período de tempo, a comunidade se sente prejudicada, visto que se criou uma expectativa em relação à sua continuidade. O que revela, ao mesmo tempo, a importância da oferta de educação profissional pública nesses espaços. Conforme relato do Diretor DINU do IFFar, o Presidente da Associação de Pais do bairro onde se situava o Centro de Referência do Município de Rosário do Sul lamentou muito o encerramento das atividades, pois a população se sentia acolhida naquele espaço, visto que nas escolas do município, situadas no centro da cidade, há um conflito social entre os estudantes da periferia e dos bairros de classe média:

\begin{abstract}
"Professor, nós precisamos trazer o Instituto para cá. Os nossos filhos, eles são constrangidos de irem estudar na escola do centro". Porque tem duas escolas de ensino médio só, e as duas ficam no centro. Então há uma evasão muito grande dos meninos da periferia, porque eles vão para a mesma escola do pessoal da classe média, dos filhos da classe média. E muitos acabam desistindo, pelas próprias condições, de vestuário, discriminação... E o pessoal acaba desistindo e indo trabalhar, se tornando uma mão de obra barata. Para gente que iniciou lá, acompanhou as pessoas se envolverem, foi bem difícil essa questão... (Entrevista Diretor DINU IFFar, 2018).
\end{abstract}

Serão analisadas, mais detalhadamente, as condições de oferta do Pronatec Bolsa Formação em um Centro de Referência do Instituto Federal Farroupilha no item 3.3 deste Capítulo.

\title{
3.2.3 O corpo docente e a dualidade institucional
}

Como foi visto no Capítulo II, nas Instituições Federais, o corpo docente dos cursos desenvolvidos por meio do Pronatec Bolsa Formação é constituído a partir de processo seletivo. De acordo com a primeira CGBF (Coordenadora Geral da Bolsa Formação), no início, fazia-se um edital de processo seletivo específico para o público interno (docentes e técnicosadministrativos em educação) e apenas se sobrassem vagas era aberto novo edital de processo seletivo para selecionar profissionais externos à Instituição, com o objetivo de privilegiar a experiência e a afinidade com o projeto pedagógico institucional. No entanto, após orientação da Procuradoria Jurídica da Instituição, com vistas a assegurar o princípio de isonomia, passouse a realizar a seleção dos docentes a partir de Edital único, contemplando o público interno e externo. 
Os critérios de seleção observados nos Editais de processo seletivo correspondem à formação na área da disciplina (para cursos técnicos, no mínimo graduação, e para cursos FIC, no mínimo curso técnico ou comprovada formação e experiência profissional na área - como nos cursos de cabeleireiro e manicure e pedicure, por exemplo), titulação acadêmica, produção científica, experiência docente e profissional. Como critério de desempate, observa-se o intuito de priorizar os docentes da própria instituição ao se adotar critérios como: "maior tempo de efetivo exercício como docente no IF; e, maior número de Projetos de Extensão, devidamente registrados na PROEX, desenvolvidos ou em desenvolvimento" (Edital IFFar n. 76/2015

Assim, em 2012 e 2013, a participação dos servidores da própria instituição que atuavam no Programa era um pouco maior, em razão dos critérios seletivos e do fato de grande parte dos cursos terem sido ofertados nos próprios campi ou em outros locais na mesma cidade. No entanto, o aumento do número de cursos, contemplando áreas alheias à atuação do corpo docente institucional, a dificuldade de conciliar os horários das aulas no Programa com a carga horária regular de trabalho, a criação dos Centros de Referência em cidades distantes dos campi e a própria dificuldade de trabalhar com um público que está há muito tempo fora dos espaços escolares, o que exige maior dedicação dos professores, foram fatores identificados nas entrevistas, tanto com gestores quanto com professores, como responsáveis pela diminuição de professores internos no desenvolvimento do Programa nos anos seguintes.

Assim, com quase maioria dos docentes constituída por profissionais externos à instituição, aumentava a preocupação com o desenvolvimento pedagógico dos cursos e a necessidade de uma formação prévia desses profissionais com vistas a orientá-los no desenvolvimento da proposta pedagógica da instituição e dos objetivos do Programa no âmbito das suas atividades. Essa preocupação foi apontada pelos profissionais que atuaram/atuam na Coordenação Geral do Pronatec Bolsa Formação, os quais destacaram, ao mesmo tempo, as dificuldades na sua realização.

Apontou-se a dificuldade de viabilizar essa formação, uma vez que os profissionais são remunerados por hora/aula da disciplina para o qual foi selecionado, não sendo possível exigir dedicação para além desta carga horária. Outra dificuldade era a grande rotatividade dos professores, pois o corpo docente altera-se a cada novo edital de seleção. Soma-se a isso, também, o fato de o Programa ser coordenado pela PROEX, que não possuía entre seus servidores, desde o início, profissionais com formação na área pedagógica. Somente em março

\footnotetext{
${ }^{99} \mathrm{O}$ documento se encontra nos arquivos da pesquisa.
} 
de 2016, uma professora Pedagoga passou a integrar a equipe do Pronatec Bolsa Formação no âmbito da PROEX, com vistas a atender essa demanda.

Nos primeiros anos do Programa, conforme relata a CGBF 1, não ocorreu uma formação sistemática dos profissionais para atuação no Pronatec, em virtude da falta de profissionais da área e da impossibilidade de a Pró-Reitoria de Ensino assumir mais essa função:

\begin{abstract}
Uma coisa muito falha - eu acho que o programa vai acabar e vou ficar com essa mágoa, assim -é a gente nunca ter conseguido, por mais que se tenha pensado durante 3 anos consecutivos em fazer uma formação pedagógica para as pessoas que trabalham, para os professores... Mas a gente nunca teve, porque a gente nunca conseguiu ter um pedagogo aqui dentro. A gente nunca conseguiu ter um apoio suficiente. Também porque a Pró-Reitoria de ensino tem inúmeras demandas, não tem também como tirar o pessoal que está trabalhando lá, para trabalhar aqui. Não conseguimos atrair nenhuma pessoa para poder desenvolver, mesmo que fora do seu horário de trabalho, as atividades [pedagógicas] do Pronatec. Então a gente não conseguiu dar essa formação: uma formação para a equipe gestora e uma formação para os professores. A gente queria formar os agentes do Campus e eles formariam os professores. Cada leva nova de professores que recebem, eles formariam: como é que o instituto trabalha? Que documentos a gente utiliza? (Entrevista CGBF 1 IFFar, 2016)
\end{abstract}

No âmbito da Reitoria, a Pró-Reitoria de Ensino é o espaço onde se desenvolve, de forma prioritária, as questões relacionadas ao ensino, à aprendizagem e à formação docente. $\mathrm{O}$ fato de o Programa ser desenvolvido por outra Pró-Reitoria que não tem o ensino como área prioritária de atuação, acarreta esse tipo de dificuldade. Por outro lado, é realizado por equipes que recebem bolsa para desenvolver esse trabalho, o qual deve ser acrescido à carga horária de trabalho semanal, o que exime ou impede a participação dos demais profissionais. Essa mesma situação, observada pela coordenação geral do Programa, também ocorre no âmbito dos campi, em relação à atuação das equipes pedagógicas (profissionais ligados à Direção de Ensino), uma vez que a execução do Programa está ligada à Diretoria de Pesquisa, Extensão e Produção. De acordo com o CGBF 2, essas equipes não se envolvem no atendimento pedagógico dos estudantes do Pronatec, mesmo quando os cursos são desenvolvidos nas instalações dos campi:

Ela não se envolve. O problema de ter bolsa é isso... Essa deveria ser uma contrapartida do Campus. Mas é a mesma dificuldade que a gente tem com $\mathrm{EaD}$, com tudo que envolve bolsa, infelizmente tira do compromisso uma série de pessoas que não tem bolsa. Não deveria ser assim, mas infelizmente é. Na realidade isso deveria ser contrapartida do campus, né? (Entrevista CGBF 2 IFFar, 2016).

A constituição de uma equipe própria para o desenvolvimento do Programa nas instituições federais de ensino, a qual é selecionada por meio de processo seletivo próprio e remunerada para esse fim, cria uma estrutura à parte dos cursos regulares, não permitindo sua 
integração orgânica às atividades da instituição. Essa dualidade instituída com o Pronatec faz emergir situações, como a descrita por um dos CGBF, de que estudantes do Pronatec estariam sendo impedidos de frequentar a biblioteca em um dos campi em razão de não serem considerados alunos da unidade de ensino. Ocorrendo, nesse sentido, um estranhamento do trabalho desenvolvido pela própria instituição.

Essa mesma realidade é apontada em outras pesquisas que analisaram o Pronatec no âmbito das Instituições Federais de Ensino. Em pesquisa realizada no Instituto Federal do Rio de Janeiro, Ramos (2014) identificou que o Programa criou "uma estrutura paralela, com base em contratos de trabalho temporário e em uma organização pedagógica e administrativa improvisada" (p. 09). O próprio ex-Secretário de Educação Profissional, Eliezer Pacheco, faz uma avaliação sobre o Pronatec Bolsa Formação, apontando que,

ao ser receptor de tais iniciativas, os Institutos Federais acabaram por criar uma estrutura paralela de atendimento: os alunos normais e os do PRONATEC. Com o estímulo de uma bolsa, o Programa tem aderido a um grande número de interessados. A nosso ver, esse modelo tem sido um grande desafio para a Rede Federal. Na realidade está se convivendo com uma rede dentro de outra (PACHECO, 2015, p.62).

A gestora do IFFar também reconhece essa dificuldade de operacionalização do Programa, articulando os diferentes setores da instituição:

É, isso traz alguma dificuldade, sim. Começou pela extensão, porque o grande foco
inicial foi curso FIC, e os cursos FICs, dentro das dimensões da extensão que foram
criadas para a Rede Federal, são vistos como mais do que uma ação pedagógica, uma
ação de articulação entre a instituição e a sociedade, por isso estão na extensão. A
partir do momento em que os cursos técnicos começaram a ganhar corpo, o Programa
está dentro da Pró-Reitoria de Extensão, mas, evidentemente, a questão pedagógica
tem que estar contemplada e, infelizmente, apesar de a gente, enquanto professor, ter
muito forte o discurso da transdisciplinaridade, da articulação entre as áreas, na hora
de operacionalizar não é algo fácil. Então hoje, eu posso te dizer, que a articulação
entre a PROEX e a PROEN no que diz respeito aos cursos técnicos ela já melhorou
bastante, até porque todos os cursos técnicos passam por uma análise da Pró-reitoria
de Ensino. Mas, de qualquer forma, realmente não é uma engrenagem azeitada. Temos
alguns problemas, e inclusive, para minimizar um pouco isso, porque eu tenho uma
preocupação muito grande com a questão pedagógica, e principalmente com a questão
da formação dos professores externos, nós estamos trazendo para a PROEX um
professor pedagogo para assumir esse caráter mais pedagógico das atividades. Mas,
realmente, assim, é algo que a gente não conseguiu azeitar integralmente. É uma
política externa que acaba interferindo no funcionamento, nas dinâmicas internas da
instituição (Entrevista Gestora IFFar, 2016).

No âmbito do Fórum dos Dirigentes de Ensino da Rede Federal, as discussões relacionadas ao Pronatec também traziam à tona essa dualidade. De acordo com o Coordenador do FDE, as instituições apresentavam diferentes arranjos em relação à gestão do Pronatec Bolsa 
Formação: a grande maioria inseriu o desenvolvimento do Programa no âmbito da Pró-Reitoria de Extensão, algumas no âmbito da Pró-Reitoria de Ensino e outras, ainda, criaram uma “estrutura própria” para o Programa, ligada ao Gabinete da Reitoria.

Independente do lócus de sua execução, os pró-reitores de ensino da Rede manifestavam grande preocupação em relação à concepção de educação profissional promovida pelo Programa, segundo o Coordenador. Centrado na oferta de cursos de curta duração, embora contemplassem a formação de grande parcela de trabalhadores, o Programa não priorizava a oferta de uma formação integral, e sim uma "qualificação para o trabalho mais voltada para um mero mercado de trabalho, reprodução, atendimento dessa demanda mercadológica, ao invés daquela concepção de formação integral, omnilateral, politécnica, que se pretendia nos Institutos Federais" (Entrevista Coordenador FDE, 2018). Nessa direção, completa:

\begin{abstract}
então, todo aquele trabalho que vinha se fazendo na rede, em termos de discussão da formação integral, da integração Cultura, Ciência, Trabalho e Tecnologia, para não formar profissionais apenas para o mercado do trabalho, não apenas formar mão de obra qualificada para o mercado de trabalho, mas, também, profissionais qualificados para o mundo do trabalho, ficou comprometido com o Pronatec, porque gerou uma crise de identidade no âmbito da concepção de ensino dos próprios Institutos Federais (Entrevista Coordenador FDE, 2018).
\end{abstract}

Quando o Programa não era desenvolvido no âmbito da Pró-Reitoria de Ensino, por outro lado, muitos pró-reitores relatavam o sentimento de que se tornavam "apenas uma máquina para validar os projetos pedagógicos" (COORDENADOR FDE), comprometendo da mesma forma o espaço de debate sobre a concepção de ensino. De qualquer modo, pode-se apontar que o fato de haver uma forma de fomento e gestão paralela às atividades da instituição, independente do local onde é gestado, promovia essa dualidade.

No âmbito do IFFar, o Pró-Reitor de Ensino assinala que o desenvolvimento do Pronatec gerou esgotamentos institucionais, que comprometeram o desenvolvimento de um projeto de ensino institucional: "falo em projeto de ensino, não como Pró-Reitoria de Ensino, mas, integrando ensino, pesquisa e extensão em nível institucional, parece ter sido muito prejudicado" (Pró-Reitor de Ensino IFFar). Nessa direção, exemplifica alguns dos conflitos gerados pelo Programa em âmbito institucional, que impactaram no desenvolvimento das atividades institucionais:

Nas reuniões da Pró-Reitoria de Ensino com os Diretores de Ensino era sempre um muro de lamentações, justamente por esse motivo: qual era a dificuldade? Chegou um determinado momento em que era difícil convencer os colegas, como se convencidos fosse necessário, a fazer aquilo para o qual foram contratados em essência. Porque embora houvesse a previsão de que não entraria na carga horária regular, da jornada semanal, que receberiam por fora, portanto, deveriam fazer a mais, isso não acontecia. 
Porque muitos servidores, muitos docentes, se comprometiam com isso, e quando eram cobrados para fazer aquilo para o qual foram contratados, essencialmente, a fazer, atuar nos cursos regulares, fazer projeto de pesquisa, fazer projeto de extensão, participar das atividades regulares do Campus, reunião pedagógica, conselho de classe, formações, etc., eles alegavam que não podiam, porque estavam sobrecarregados, porque tinham que fazer Pronatec, como se a instituição estivesse obrigando-os a fazer isso. E aí, por um lado, os diretores de Ensino, com a Pró-Reitoria de Ensino, fazia essa briga, em nível institucional, para garantir o bom funcionamento das atividades regulares, pelo outro lado, ao invés de trabalharmos juntos, a PróReitoria de Extensão e outros setores, junto com os Diretores, Coordenadores de Extensão, e os que recebiam Bolsa do Pronatec, brigavam para que se diminuísse a carga horária desses servidores que atuavam no Pronatec, para poder atender o Pronatec, porque era prioridade do Governo. Então, nós brigávamos pela prioridade, sem saber qual era a prioridade. Na verdade, nós sabíamos qual era a prioridade. O que muitos de nós não queria ver, era que atender essa prioridade significava abrir mão de ficar recebendo Bolsa, penduricalho salarial, para atender aquilo para o qual fomos feitos. Então, pessoalmente, como Pró-Reitor, considerei isso traumático, desgastante, e hoje, depois aí de todo esse tempo, não observo resultados palpáveis, concretos, benéficos e duradouros daquilo que foi feito por meio do Pronatec, no âmbito do IFFar e das demais instituições (Pró-Reitor Ensino IFFar).

Esse depoimento revela as tensões geradas pelo Programa em âmbito institucional. As contradições que permeiam esta política se traduzem em disputas internas, que interferem não apenas na dinâmica de trabalho, mas no próprio projeto pedagógico institucional.

Em 2016, a PROEX do IFFar recebeu em sua equipe do Pronatec uma professora pedagoga, com a função de dar suporte ao desenvolvimento pedagógico do Programa, atuando no cargo de Coordenadora Ajunta da Bolsa Formação (CABF IFFar). Esta servidora realizou ao longo daquele ano uma formação com as equipes do Pronatec, especialmente nos Centros de Referência, com vistas a identificar as dificuldades e fomentar a formação pedagógica dos docentes. Porém, de acordo com a CABF IFFar, algumas dificuldades identificadas no processo de ensino e aprendizagem não puderam ser atendidas em razão da própria estrutura do Programa.

Em virtude do perfil do público atendido (estudantes de ensino médio, agricultores, mulheres em vulnerabilidade social, público beneficiário de políticas de redistribuição de renda, entre outros), os estudantes possuem dificuldades no acompanhamento das aulas, necessitando de um atendimento individualizado pelo professor para além do horário regular. No entanto, isso não ocorria, pois, o docente é pago apenas para desenvolver a carga horária da disciplina e, muitas vezes, mesmo que esse profissional tivesse interesse em atender o aluno para além das aulas regulares, a sua jornada de trabalho ou a distância entre a sua residência e o local das aulas inviabilizavam essa prática ${ }^{100}$. Conforme relata a CABF IFFar:

\footnotetext{
100 Grande parte dos docentes externos à instituição desenvolviam outro trabalho, além das aulas no Pronatec,
} chegando a jornadas semanais de até $56 \mathrm{~h}$, como veremos nas unidades de ensino pesquisadas. No Centro de 
a gente entende, a gente sabe quem é o aluno do Pronatec, mas quando nós selecionamos os professores, coordenadores, para atuar nesse programa, existem alguns empecilhos que não vão atender esse público, como, por exemplo: eu não tenho como pagar carga horária extra para esse professor trabalhar as dificuldades desse aluno. Eu não tenho. Então, se a disciplina é 40 horas, o professor só é pago por essas 40 horas, então, se o aluno precisar num contraturno, precisar num outro momento, precisar de um tempo a mais, que é o caso dos nossos alunos do Pronatec, do nosso público de alunos. A gente não tem como resolver, como organizar, e o programa cobra esse trabalho pedagógico. E como eu conto com a boa vontade dos professores para fazer o extra, ou a mais? (Entrevista CABF IFFar, 2017)

Com os atrasos nos repasses financeiros do Programa, o pagamento dos profissionais e da assistência estudantil para os alunos ocorria, muitas vezes, após decorridos vários meses da realização das aulas. Isso gerava ainda mais dificuldade no atendimento das necessidades de aprendizagem dos estudantes, pois, de um lado a instituição se sentia constrangida em cobrar essa dedicação para além da carga horária, frente à reclamação dos docentes em relação ao atraso na remuneração, e de outro, o não recebimento da bolsa por parte dos estudantes potencializava a evasão, o que tem implicações na carga horária dos profissionais encarregados da gestão pedagógica dos cursos, como no caso do Orientador - profissional que tem a responsabilidade de acompanhar o desenvolvimento pedagógico dos cursos, mediando as dificuldades dos professores e estudantes.

De acordo com a Resolução que normatiza o desenvolvimento do Pronatec Bolsa Formação no IFFar, a carga horária dos profissionais varia de acordo com o número de alunos atendidos - exceto o professor, o qual tem sua remuneração atrelada ao número de horas lecionadas. Todos os demais encargos podem ter carga horária que varia de 4 horas semanais, nas unidades com até 100 matrículas, chegando a 12 horas semanais, a partir de 500 matrículas. Em nível de Reitoria a carga horária remunerada desses profissionais corresponde às horas trabalhadas para além da carga horária semanal do cargo para o qual foi concursado ${ }^{101}$, obedecendo a um limite máximo. Pode-se observar essa relação nos quadros abaixo:

Quadro 2 - Remuneração dos Profissionais do Pronatec Bolsa Formação IFFar - Reitoria

\begin{tabular}{|l|l|l|}
\hline Encargo & Carga horária máxima semanal & Remuneração \\
\hline Coordenador Geral do Pronatec & $8 \mathrm{~h}$ & $\mathrm{R} \$ 50,00 /$ hora \\
\hline Coordenador Adjunto & $5 \mathrm{~h}$ & $\mathrm{R} \$ 44,00 / \mathrm{hora}$ \\
\hline Supervisor de Curso & $4 \mathrm{~h}$ & $\mathrm{R} \$ 36,00 / \mathrm{hora}$ \\
\hline Apoio às atividades acadêmicas e administrativas & $7,5 \mathrm{~h}$ & $\mathrm{R} \$ 18,00 / \mathrm{hora}$ \\
\hline
\end{tabular}

Fonte: Organizado pela autora com base na Resolução CONSUP IFFar n. 71/2016.

Referência analisado, a maioria dos professores não residia no município; assim, nos dias que iam para a instituição tinham sua jornada diária ou até semanal totalmente preenchidas com aulas.

${ }^{101}$ No IFFar, caso um servidor ocupante de cargo de gestão exerça algum encargo no Pronatec Bolsa Formação não será remunerado com bolsa, pois já estaria recebendo função gratificada (FG) ou cargo de direção (CD) para desempenho do trabalho. 
Quadro 3 - Remuneração dos Profissionais do Pronatec Bolsa Formação IFFar - Campus

\begin{tabular}{|l|l|l|l|l|l|l|}
\hline Encargo & $\begin{array}{l}\text { De } 80 \text { a } 100 \\
\text { matrículas }\end{array}$ & $\begin{array}{l}101 \text { a } 300 \\
\text { matrículas }\end{array}$ & $\begin{array}{l}301 \text { a } 400 \\
\text { matrículas }\end{array}$ & $\begin{array}{l}401 \text { a } 500 \\
\text { matrículas }\end{array}$ & $\begin{array}{l}\text { Acima de 500 } \\
\text { matrículas }\end{array}$ & Remuneração \\
\hline Coordenador Adjunto & $4 \mathrm{~h}$ & $7 \mathrm{~h}$ & $8 \mathrm{~h}$ & $10 \mathrm{~h}$ & $12 \mathrm{~h}$ & $\mathrm{R} \$ 44,00 / \mathrm{hora}$ \\
\hline Orientador & $4 \mathrm{~h}$ & $7 \mathrm{~h}$ & $8 \mathrm{~h}$ & $10 \mathrm{~h}$ & $12 \mathrm{~h}$ & $\mathrm{R} \$ 36,00 / \mathrm{hora}$ \\
\hline Supervisor de Curso & $4 \mathrm{~h}$ & $7 \mathrm{~h}$ & $8 \mathrm{~h}$ & $10 \mathrm{~h}$ & $12 \mathrm{~h}$ & $\mathrm{R} \$ 36,00 / \mathrm{hora}$ \\
\hline $\begin{array}{l}\text { Apoio às atividades } \\
\text { acadêmicas }\end{array}$ & $4 \mathrm{~h}$ & $7 \mathrm{~h}$ & $8 \mathrm{~h}$ & $10 \mathrm{~h}$ & $12 \mathrm{~h}$ & $\mathrm{R} \$ 18,00 / \mathrm{hora}$ \\
\hline $\begin{array}{l}\text { Apoio às atividades } \\
\text { administrativas }\end{array}$ & $4 \mathrm{~h}$ & $7 \mathrm{~h}$ & $8 \mathrm{~h}$ & $10 \mathrm{~h}$ & $12 \mathrm{~h}$ & $\mathrm{R} \$ 18,00 / \mathrm{hora}$ \\
\hline
\end{tabular}

Fonte: Organizado pela autora com base na Resolução CONSUP IFFar n. 71/2016.

Quadro 4 - Remuneração dos Profissionais do Pronatec Bolsa Formação IFFar - Centro de Referência

\begin{tabular}{|l|l|l|l|l|l|l|}
\hline Encargo & $\begin{array}{l}\text { De 80 a } 100 \\
\text { matrículas }\end{array}$ & $\begin{array}{l}101 \text { a } 300 \\
\text { matrículas }\end{array}$ & $\begin{array}{l}301 \text { a } 400 \\
\text { matrículas }\end{array}$ & $\begin{array}{l}401 \text { a 500 } \\
\text { matrículas }\end{array}$ & $\begin{array}{l}\text { Acima de 500 } \\
\text { matrículas }\end{array}$ & Remuneração \\
\hline Coordenador Adjunto & 9 & 12 & 12 & 12 & 12 & $\mathrm{R} \$ 44,00 /$ hora \\
\hline Orientador & 4 & 4 & 6 & 8 & 10 & $\mathrm{R} \$ 36,00 / \mathrm{hora}$ \\
\hline Supervisor de Curso & 4 & 4 & 6 & 8 & 10 & $\mathrm{R} \$ 36,00 / \mathrm{hora}$ \\
\hline $\begin{array}{l}\text { Apoio às atividades } \\
\text { acadêmicas e/ou } \\
\text { administrativas }\end{array}$ & 20 & 20 & 20 & 20 & 20 & $\mathrm{R} \$ 18,00 / \mathrm{hora}$ \\
\hline
\end{tabular}

Fonte: Organizado pela autora com base na Resolução CONSUP IFFar n. 71/2016.

Essa medida ${ }^{102}$, de acordo com a Pró-Reitoria de Extensão, visa equilibrar a gestão financeira do Programa - visto que o recurso disponível corresponde ao número de alunos e o valor da carga horária de cada profissional é definido por Resolução do FNDE - como também contemplar as diferentes necessidades de cada unidade. O CGBF 2 relata que o valor da carga horária paga ao professor ( $\mathrm{R} \$ 50,00$ a hora/aula) e da bolsa paga aos estudantes (entre $\mathrm{R} \$ 3,00$ a $\mathrm{R} \$ 3,75$ a hora aula) compromete grande parte do recurso ${ }^{103}$, implicando na necessidade dessa "flutuação" da carga horária dos demais profissionais, pois em alguns cursos que demandam um maior volume de material de consumo, como os da área de produção alimentícia, a instituição, por vezes, precisa complementar os recursos.

Por outro lado, nos cursos que não necessitam de muito material de consumo e quando são ofertados nos campi, grande parte dos recursos eram devolvidos em virtude das limitações no uso desse dinheiro pelas instituições federais, que se restringem à remuneração dos profissionais e material de consumo. Como relata a CGBF 1:

Para nós é uma burocracia imensa. Acho que em 2014, o número que a gente tinha pra receber conforme o número de matrículas eram 5 milhões e pouco. Nós matriculamos e chegamos a receber 3 milhões. Devolvi ainda 1 milhão e pouco. Não tinha no que gastar. Vou gastar com o que? Já paguei professor, já paguei aluno. Não tem com o que gastar. Até porque não posso ficar pagando coisas que não são

\footnotetext{
${ }^{102}$ Nas unidades de ensino que não atingirem o número mínimo de matrículas, o número de encargos poderá ser revisto e ajustado proporcionalmente ao quantitativo mínimo para abertura de turmas. Em caso de mais de 300 matrículas, poderá ser contratado um profissional adicional no cargo de Orientador (Resolução IF 71/2016).

103 Conforme as normas do Pronatec Bolsa Formação, as matrículas em cursos FIC e Técnico Concomitante equivalem à RS 10,00 a hora-aula, e nos cursos técnicos subsequentes, à R \$ 8,00.
} 
destinadas ao Programa. Agora claro que para os centros a gente gasta isso. Mas nos centros a gente contabiliza o que? Material de limpeza, muitas vezes a gente compra material de consumo, como alimento pra dar lanche aos alunos. Café, água, não tem Campus lá pra dar esse suporte...combustível, telefone, água, luz, quando a Prefeitura não dá contrapartida (Entrevista CGBF 1 IFFar, 2016).

Embora o Programa permitisse inserir novos estudantes em caso de desistência ocorrida dentro do prazo previsto para substituição, no IFFar essa prerrogativa foi pouco utilizada, uma vez que havia dificuldade em recuperar as aulas já realizadas em virtude, novamente, da forma de remuneração dos docentes. Assim, o orçamento repassado para o curso, após a confirmação das matrículas pelo SISTEC, já vinha com o desconto das vagas que ficaram ociosas.

Dentre os professores externos à instituição e atuantes no Programa, a maioria, de acordo com o relato da $\mathrm{CABF}$, possuía larga formação acadêmica, porém sem experiência docente, e boa parte também desenvolvia outro trabalho em paralelo às atividades no Pronatec, o que trazia, também, dificuldades para o desenvolvimento pedagógico dos cursos. É possível observar tais características na amostra de professores que responderam ao questionário da pesquisa, nas duas unidades investigadas, como veremos nos itens 3.2 e 3.3 deste Capítulo.

A partir dessa realidade, observa-se que as dificuldades em relação ao desenvolvimento pedagógico do Programa são intrínsecas à sua natureza, a seu próprio formato. As necessidades pedagógicas dos cursos que, no início, não foram atendidas em sua integralidade por falta de pessoal especializado, persistiram mesmo após ter sido suprida aquela carência, pois as condições de oferta não favoreciam o adequado desenvolvimento do trabalho pedagógico, de acordo com o projeto pedagógico institucional.

3.2.4 O desenvolvimento pedagógico e o currículo dos cursos: normativas didático-pedagógicas institucionais x normativas do Programa

Para além das dinâmicas internas, o Programa também interfere ou dificulta o atendimento às normativas didático-pedagógicas institucionais. Os projetos pedagógicos dos cursos (PPCs), quando já em andamento na Instituição, seguem o aprovado pelo Conselho Superior. Os novos são elaborados pelos docentes da área, de acordo com as Diretrizes Curriculares Institucionais ${ }^{104}$. No entanto, a previsão de estágio curricular obrigatório ou de

\footnotetext{
${ }^{104}$ Com base nas Diretrizes Curriculares Nacionais para a EPTNM, aprovadas pelo CNE em 2012 (Resolução n. 06/2012), o IFFar elaborou uma Resolução que normatiza a organização curricular dos cursos técnicos. A concepção que orienta os cursos é baseada na proposta de currículo integrado, que se assenta na integração entre os conhecimentos básicos e específicos ao longo do curso, tendo como eixos integradores o trabalho, a ciência e a cultura (PDI IFFar, 2014).
} 
trabalho de conclusão de curso (TCC) em alguns cursos técnicos teve de ser retirada, pois o Pronatec Bolsa Formação não prevê remuneração para o professor orientador de estágio ou orientador de $\mathrm{TCC}^{105}$.

Há dificuldades também no desenvolvimento das práticas profissionais integradas ${ }^{106}$ previstas nos currículos dos cursos técnicos, uma vez que o seu desenvolvimento demanda reunião entre os professores das disciplinas envolvidas e a compreensão dos objetivos desta metodologia. As práticas profissionais são previstas nos cursos como momentos de integração dos conhecimentos dos diferentes componentes curriculares e aproximação com realidade do mundo do trabalho na área de formação do curso, sob orientação dos professores. Tendo em vista a não previsão de estágio obrigatório, a prática profissional passa a ser um espaço privilegiado para a aproximação da realidade do trabalho.

A recuperação paralela da aprendizagem, prevista nas normas institucionais e na própria LDB, também não pode ser desenvolvida em razão da carga horária remunerada do professor, a qual se restringe à carga horária da(s) disciplina(s). A orientação, segundo a CABF é de que o professor consiga incluir na própria carga horária da disciplina momentos para a revisão e recuperação da aprendizagem dos conteúdos estudados. A reprovação dos estudantes em um ou mais componentes curriculares implica na impossibilidade de conclusão do curso, visto que dificilmente um mesmo curso é ofertado duas vezes no mesmo local e não há possibilidade de nova oferta de disciplinas, em virtude da não previsão de recurso para esses casos.

Nesse sentido, observa-se uma diferenciação tanto em relação ao corpo docente quanto ao currículo e à gestão pedagógica dos cursos, em razão das condições da oferta no âmbito da Bolsa Formação, reforçando a tese da dualidade de ensino em uma mesma instituição, ou de uma mesma rede, como se referiu Pacheco (2015).

Todos os estudantes de curso Pronatec recebiam um Kit com materiais escolares, como: pasta, caderno, estojo, lápis, borracha, canetas e uma camiseta com a logo do Programa e no caso do Pronatec Mulheres Mil, na camiseta constava a logo dos dois Programas - vide Figura x. Os materiais didáticos utilizados pelo professor no curso eram entregues aos estudantes, na forma de cópia impressa.

Os cursos que tinham como público os agricultores, embora o sistema de pactuação exigisse a informação de turno de oferta e carga horária diária, era necessário adaptar os

\footnotetext{
${ }^{105}$ Embora não tenham sido explicitadas as motivações da não remuneração desses componentes curriculares, acredita-se que, por demandarem mais de um professor por turma, tais componentes seriam muito onerosos.

${ }^{106}$ As práticas profissionais integradas são atividades previstas em todos os semestres dos cursos técnicos do IF. Essas atividades consistem no desenvolvimento de projetos, visitas técnicas, pesquisas, entre outros a partir do trabalho integrado em duas ou mais disciplinas, conforme Resolução n. 102/2012 do IF.
} 
horários à dinâmica de trabalho desses alunos. Conforme relata a CGBF 1, para o "agricultor não se consegue dar aula todos os dias da semana como é o ideal pelo programa. Tu vais dar aula para ele na sexta de noite e no sábado manhã e tarde”. Nesse sentido, a instituição buscava se adequar às necessidades do público atendido, tendo às vezes que "burlar" o sistema, como se referiu a CGBF 1 .

Figura 7 - Kit de material escolar entregue aos estudantes de curso Pronatec no IFFar

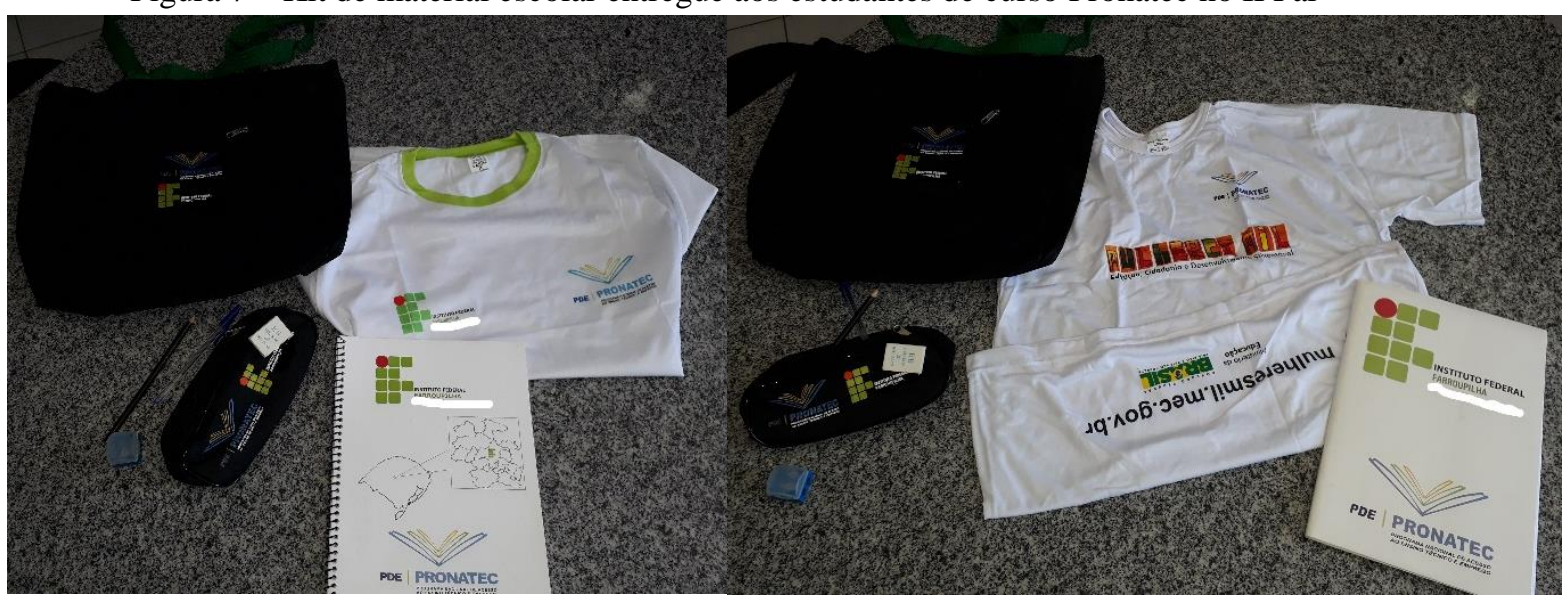

Fonte: Fotografia coletada pela pesquisadora durante trabalho de pesquisa no IFFar (2017).

Quanto aos conteúdos observados nos projetos pedagógicos de cursos, em razão do baixo nível de escolaridade do público atendido nos cursos FIC, a instituição incluiu em praticamente todos os cursos FICs disciplinas de português e matemática, por considerar que são conhecimentos essenciais para a aprendizagem no próprio curso e para a formação dos estudantes. No currículo dos cursos técnicos, entre as disciplinas que compõe o Núcleo Básico, também estão presentes disciplinas de Português Instrumental, língua estrangeira e matemática aplicada, dependendo da área de formação.

Nas duas unidades de ensino pesquisadas não foi localizado o Baú do Pronatec Empreendedor e os coordenadores e professores não tinham conhecimento dessa ação. Quando convidados para realizar o curso de Especialização em Educação Empreendedora, de acordo com as vagas disponibilizadas para a instituição no âmbito da ação Pronatec Empreendedor, nenhum docente manifestou interesse, de acordo com o CGBF 1. No entanto, a temática do empreendedorismo está presente em alguns cursos, tanto técnicos quanto FICs. Observa-se como conteúdo da disciplina de empreendedorismo os conhecimentos relacionados à elaboração e execução de um plano de negócio, a partir da área de formação do curso, que possibilitam aos egressos as ferramentas para a atuação como autônomos no mercado de trabalho. Apresentam-se alguns exemplos de ementas dessas disciplinas: 
Introdução ao Empreendedorismo (o empreendedor; ciclo de vida das pequenas empresas; ambiente empresarial; a prestação de serviços; aspectos legais). Plano de Negócios. Pessoa Física e Pessoa Jurídica. Sociedades Comerciais. Franquias. Cooperativas. Conceitos e Técnicas de Gestão. Tipos de Planejamento e Controle. Organização das Empresas (PPC Técnico em Informática subsequente, 2014).

Introdução aos aspectos importantes de empreendedorismo; Conceitos de administração, gestão e legalização de pequenos negócios e negócios coletivos; Elaboração do Plano de Negócio (PPC FIC Confeiteiro, 2014)

O Conceito de Empreendedorismo. Tipos de empreendedor. Constituição e organização da Prestação de Serviço. Por que planejar? Marketing e Empresas Prestadoras de serviços (PPC FIC Manicure e Pedicure, 2014).

Por outro lado, é possível identificar também conteúdos que buscam compreender criticamente o mundo do trabalho, incluindo temáticas que permitem situar o trabalhador nesse contexto, como indica a ementa da disciplina de Orientação e Integração Profissional, inserida no currículo dos cursos FIC do Programa Mulheres Mil:

Indivíduo e sociedade, direito e cidadania. As mudanças no mundo do trabalho. A
relação entre capital e trabalho. Formas de organização dos trabalhadores.
Comunicação no trabalho. Perfil profissional, currículo e entrevista. Legislação
trabalhista. Conceitos relativos aos princípios ambientais éticos. Sustentabilidade
ambiental e suas relações com os ambientes adequados à produção e manipulação de
alimentos. Segurança do trabalho (PPC FIC Costureiro, 2014).

Nos demais cursos FICs ofertados pelo Campus do IFFar encontra-se a disciplina de Ética e Orientação Profissional, com o objetivo de apresentar o Pronatec e a Instituição e abordar, ao mesmo tempo, aspectos do mundo do trabalho, conforme se observa na ementa dessa disciplina no curso de Salgadeiro:

Conhecendo o programa Pronatec e o Instituto Federal Farroupilha Campus xx. Atitude sustentável, ética e o mundo do trabalho. Cidadania no mundo do trabalho. Perspectivas profissionais - autoconhecimento e apresentação pessoal. Qualidade no atendimento. Motivação, Liderança e Resultados. Avaliação de Satisfação do Cliente (PPC FIC Salgadeiro, 2013).

Nesse sentido, observa-se que os currículos dos cursos contemplam tanto temáticas que vem ao encontro da formação do perfil de trabalhador requerido pelo mercado de trabalho, quanto aquelas relacionadas aos direitos dos trabalhadores, que permitem uma compreensão crítica das relações entre capital e trabalho.

3.2.5 O Programa Mulheres Mil e sua (des)caracterização no âmbito do Pronatec Bolsa Formação 
O fato de um Programa remunerar os profissionais que trabalham nos cursos e oferecer um valor mais expressivo de assistência estudantil, como no caso do Pronatec Bolsa Formação, gerou mal-estar em relação aos outros Programas que também eram desenvolvidos no âmbito da Rede Federal de EPT, como o Programa Mulheres Mil e o Proeja, uma vez que estavam perdendo espaço e recursos frente ao Pronatec. A partir da demanda das instituições e organizações, especialmente aquelas ligadas à EJA, como se viu no Capítulo II, em março de 2013, a SETEC emitiu a Portaria n. 168 que possibilita o desenvolvimento de programas de EPT no âmbito da Rede Federal por meio da Bolsa Formação Trabalhador.

Quanto ao Proeja, houve uma resistência inicial no âmbito do IFFar em razão da forma de contratação dos docentes, que poderia incluir profissionais com interesse exclusivamente na bolsa e sem o perfil necessário para os cursos nessa modalidade e, ao mesmo tempo, retirar a “institucionalidade” já construída, ao atrelar seu financiamento ao Programa. Ao longo de 2013, o grupo de coordenadores de cursos Proeja, juntamente com a Pró-Reitoria de Ensino, refletiu sobre as potencialidades que o recurso da Bolsa Formação traria para o desenvolvimento dos cursos, especialmente o valor maior da assistência estudantil para os estudantes ${ }^{107}$, chegando a pactuar a oferta de cursos no ano seguinte. Porém, a pactuação não foi aprovada pela SETEC.

Já em relação ao Mulheres Mil, por ser um Programa também situado no âmbito da PróReitoria de Extensão, a transição para o âmbito do Bolsa Formação ocorreu de forma mais natural. A sua oferta âmbito da Bolsa Formação, no entanto, implicou em mudança na metodologia de seu desenvolvimento, de acordo com a CGBF I, que também coordenava, institucionalmente, o Mulheres Mil naquele momento. Em virtude do pagamento de bolsas para os professores, houve uma modificação no perfil docente e na forma de gestão pedagógica dos cursos, conforme relata a seguir:

O envolvimento do servidor com o programa Mulheres Mil, ele é muito diferente. É
a mesma coisa da divisão entre dar aula para a graduação e dar aula para o PROEJA.
Quem dá aula para o PROEJA é quem gosta de dar aulas para o PROEJA. Era a mesma
coisa com o Mulheres Mil. Quem trabalhava com aquele público era porque gostava
de trabalhar. Se identificava com aquilo. E é uma metodologia demorada. Tu tinhas
que ter pelo menos 6 meses. (...) Antes, a gente construía o curso com elas. Por
exemplo, você ia lá numa comunidade de pescadores e reunia todas as pescadoras: "o
que vocês querem estudar?” A gente quer estudar isso e isso: é isso que nós vamos
estudar, então! Pelo Pronatec não, os cursos já são definidos, com a carga horária já
definida, com as atividades já definidas. E antes, no Mulheres Mil, não. O processo,
ele se dava desde ir lá na comunidade, agendar, marcar. Fazia uma, duas, três reuniões.
Você fazia o mapa da vida [das mulheres], fazia entrevistas... Ia psicólogo, assistente
social e até você começar a dar aula no curso, você se envolveu dois meses. A maioria

${ }^{107}$ No IFFar, os estudantes de cursos PROEJA tem preferência nos critérios de distribuição de bolsas de assistência estudantil, porém o valor mensal é três vezes menor do que o valor que a Bolsa Formação poderia oferecer. 
das vezes a gente ia nas comunidades e dava o curso lá, mas quando precisava de um laboratório, alguma coisa, elas vinham para o Instituto. Então a metodologia é diferente, não adianta... Agora no Pronatec não existe mais esse tempo. Todo esse processo que eu te falei ele não existe mais. O programa não prevê isso. Ele funciona conforme a carga horária paga pra funcionar o curso... Antes, por exemplo, nós tivemos uma turma de pescadoras em São Borja, na produção de alimentos, que a gente registrou o curso com 160 horas. Sabe quantas horas levou o curso? 240 horas. Porque vários assuntos foram inseridos ao longo das aulas, como sexualidade, por exemplo, que foi uma demanda delas. E a diferença que você via no processo! Elas entram no programa de um jeito e saem de outro. E hoje no Pronatec não é assim (Entrevista CGBF 1 IFFar).

Apesar de a Cartilha do "Pronatec Brasil sem Miséria Mulheres Mil” (BRASIL, 2014) contemplar a proposta pedagógica que embasa o Programa - "Acesso, Permanência e Êxito" -, com a previsão de metodologias que visam partir dos saberes e necessidades das mulheres para definir os conteúdos formativos, como o "mapa da vida", isso não ocorre integralmente, visto que o curso, e por consequência, é definido com base nas demandas socioeconômicas locais, antes mesmo de o grupo de mulheres ter sido selecionado. Embora o documento ressalte como de "extrema importância que os cursos, antes de serem negociados entre ofertantes e demandantes, estejam alinhados às demandas das realidades dessas mulheres e de seus saberes" (2014, p. 10), mais adiante contradiz essa premissa ao orientar as equipes das instituições ofertantes para que identifiquem as "vocações e interesses das participantes, para melhor direcioná-las aos cursos" (2014, p. 16), admitindo que a metodologia de pactuação dos cursos interfere nos pressupostos do Programa Mulheres Mil.

Essa Cartilha também menciona a equipe multidisciplinar da instituição ofertante, que seria formada por diferentes profissionais, como professores, psicólogo, dentista, médico, assistente social e pedagogo. No entanto, em virtude do pagamento de bolsas, apenas os professores e um Coordenador Adjunto do Pronatec Mulheres Mil puderam ser contratados, uma vez que o valor previsto para esses cursos seguiu o padrão definido em Resolução do FNDE para a Bolsa Formação (R\$ 10,00 por hora/aluno).

Além disso, o Catálogo de cursos FIC do Pronatec exige um mínimo de escolaridade prévia do candidato, o que exclui parcela de mulheres analfabetas que antes poderiam participar do Mulheres Mil, segundo a CGBF 1. Em paralelo à formação no Mulheres Mil, havia um encaminhamento destas mulheres para cursos de alfabetização na modalidade de educação de jovens e adultos na rede municipal de ensino, o que não impedia a participação no Programa.

Essa descaracterização do Programa ao ser financiado pela Bolsa Formação pode ser identificada nas unidades de ensino pesquisadas. No campus analisado, os cursos do Pronatec Mulheres Mil foram coordenados por uma servidora da instituição, que, embora não tenha 
atuado no desenvolvimento do Programa antes de sua inserção no Pronatec, conhecia os pressupostos do Programa, tendo feito o possível para minimizar os efeitos da metodologia da Bolsa Formação.

Todos os cursos ${ }^{108}$ desenvolvidos nessa modalidade tiveram sua carga horária acrescida de 40h, com vistas a inserir disciplinas que abarcassem as temáticas e metodologia do Programa. Tais disciplinas foram: Mapa da vida; Ética e Cidadania e Direitos da mulher; Relacionamento interpessoal e Seminários, com temas como: saúde da mulher, economia solidária e meio ambiente. A elaboração do mapa da vida seria o primeiro momento de trabalho com vistas a identificar saberes, dificuldades e perspectivas das mulheres e a partir daí orientar o trabalho a ser desenvolvido no curso. No entanto, essa atividade era desenvolvida de forma paralela a outras disciplinas ou até mesmo depois do início do curso, não cumprindo assim o objetivo de orientar professores e estudantes no processo formativo.

De acordo com a Coordenadora do Pronatec Mulheres Mil (CPMMIL Campus), os docentes que atuaram nos cursos participaram de formação sobre o Programa, com vistas à apresentar a proposta e o público que seria atendido: "explicando qual é o objetivo do programa, apresentando um pouquinho qual é o perfil, que público é esse que eles estão indo trabalhar, porque às vezes não é um público que sabe muito de matemática, por exemplo; já preparando e sensibilizando para quando forem atuar." (Entrevista CPMMIL Campus, 2016). A coordenadora, que estava sempre muito presente, tendo inclusive ministrado a disciplina Mapa da Vida em alguns cursos, aponta que, às vezes, as alunas "queriam que os professores continuassem, porque eles têm 8 horas aula e em 2 encontros já parte para outras [disciplinas], porque são pouquinhos encontros, é quebrado assim”. A partir disso, ela mesma conclui que uma implicação do financiamento via Pronatec foi "engessar um pouquinho isso, a questão da carga horária" (Entrevista CPMMIL Campus, 2016), o que ratifica a interferência da metodologia do Pronatec no atendimento das demandas do público alvo.

$\mathrm{O}$ atraso no pagamento das bolsas de assistência estudantil também comprometeu a frequência das mulheres, chegando a gerar algumas desistências, embora fossem alertadas da possibilidade de atraso desde o ingresso: "No primeiro dia de aula eu já avisava: gente, vocês podem ficar até 3 meses sem receber bolsa. Só que como elas tinham que pegar ônibus para vir para cá, elas não tinham dinheiro, porque às vezes elas não têm uma renda, isso nos chateava, de tanto atraso" (Entrevista CPMMIL Campus, 2016).

\footnotetext{
${ }^{108}$ O Campus desenvolveu os seguintes cursos FIC no Pronatec Mulheres Mil: Agricultor Orgânico, Ajudante de Padeiro, Auxiliar Administrativo, Auxiliar de Confeitaria, Auxiliar de Costura, Auxiliar de Cozinha, Cabeleireiro Assistente, Manicure e Pedicure, Manipulador de Alimentos e Viveirista de Plantas e Flores.
} 
O contato das alunas com o Campus permitiu o conhecimento de outras possibilidades formativas. Algumas continuaram seus estudos por meio dos cursos PROEJA ofertados pela instituição. Segundo a coordenadora do Pronatec MMIL, algumas mulheres ingressaram no PROEJA FIC em Assistente em Operações Administrativas que o campus oferta em parceria com o município, concluindo o ensino fundamental. Outras, que já tinham o ensino fundamental, cursaram o PROEJA Técnico em Comércio, sendo que uma delas continuou seus estudos no curso técnico em Alimentos, com vistas a obter a formação desejada: "como ela fez o Ajudante de Padeiro, o objetivo dela é trabalhar numa padaria, é ter o negócio dela. Então como não tinha o PROEJA Alimentos, ela foi para o PROEJA Comércio e agora está no Técnico em Alimentos, que é subsequente" (Entrevista CPMMIL Campus, 2016).

Já no Centro de Referência, apesar de também ter desenvolvido cursos no âmbito do Pronatec Mulheres Mil, não teve coordenação específica e os cursos seguiram a mesma orientação dos demais, diferenciando-se apenas no currículo. O coordenador do CR desse período não conhecia o Programa Mulheres Mil, mas, com base nos documentos do Programa e orientações da Pró-Reitoria de Extensão, identificou a necessidade de "adequar o curso FIC inserindo disciplinas da parte básica relacionadas às mulheres. Então entrava saúde da mulher, direito das mulheres, a questão de ética nas relações de trabalho, então entravam muitas disciplinas de formação humanística" (CCR 1). Nos projetos pedagógicos do curso, identificouse três disciplinas destinadas a estas temáticas - Direitos da Mulher; Identidade feminina e trajetória histórica; e Mulher e Saúde - as quais compunham o Núcleo de Cultura e Cidadania do currículo e fizeram parte da carga horária mínima de um dos cursos ofertados. A metodologia do Mapa da Vida não foi identificada no projeto pedagógicos desses cursos.

No entanto, essa proposta curricular diferenciada passou despercebida até mesmo pelos professores que atuaram no curso. Uma professora que atuou em disciplina de outro núcleo do curso, por exemplo, não percebeu que se tratava de um curso do Programa Mulheres Mil, pois no questionário aplicado aos docentes, ao indicar o tipo de curso que havia atuado, marcou a opção curso FIC e não curso FIC Mulheres Mil.

Observa-se que o índice de conclusão dos cursos do Pronatec Mulheres Mil é superior aos demais cursos FIC ofertados pelo Programa, tanto no campus, quanto no Centro de Referência. No campus, os cursos do Pronatec Mulheres Mil tiveram em média $79 \%$ de conclusão, enquanto nos demais o índice de concluintes foi de $68 \%$. No Centro de Referência, apesar de ter ocorrido apenas uma oferta de curso FIC para além da modalidade Pronatec Mulheres Mil, observa-se que o índice de conclusão nessa modalidade foi de 52,8\%, sendo que 
nenhum dos cursos teve índice menor de 45\%, enquanto no outro curso FIC concluíram apenas $30 \%$ dos estudantes matriculados.

Apesar das limitações geradas pela metodologia do Pronatec no âmbito do Programa Mulheres Mil, ressalta-se a importância desses espaços para a formação das mulheres, pois muitas estão há anos afastadas do ambiente escolar. Um ambiente formado por pares e o debate de temas relacionados à sua realidade tornam-se um elemento motivador para o interesse e conclusão do curso. O Pronatec potencializou o número de matrículas no Mulheres Mil, à medida que dispendeu mais recursos para o Programa e o inseriu em uma rede de demandantes e ofertantes que contribuiu para uma maior e mais rápida identificação de demanda. Tanto em nível nacional, quanto no âmbito do IFFar o número de matrículas cresceu muito a partir de 2014. Em 2013, em virtude da transição para a Bolsa Formação, observa-se a diminuição no número de matrículas nos planos nacional e local, como se pode observar na Tabela18, pois a oferta ocorreu apenas a partir do segundo semestre.

Tabela 18 - Matrículas Programa Mulheres Mil em nível nacional e do IFFar - 2011 a 2017

\begin{tabular}{lll}
\hline \hline Ano & Nacional & IFFar \\
\hline 2011 & 7.814 & 300 \\
2012 & 10.699 & 583 \\
2013 & 7.032 & 541 \\
2014 & 35.896 & 1.240 \\
2015 & 8.450 & 80 \\
2016 & 6.694 & 0 \\
2017 & 3.475 & 0 \\
\hline \hline
\end{tabular}

Fonte: elaborada pela autora com base em dados obtidos por meio do e-SIC e SISTEC institucional (2017).

No entanto, o fato de incluir o Programa Mulheres Mil no âmbito do Pronatec Bolsa Formação fez com que o primeiro "morresse" junto com o segundo, pois não encontrou mais espaço para o "caminho de volta", em virtude do corte no orçamento das instituições federais de ensino a partir de 2016. No IFFar, o Programa Mulheres Mil não teve mais oferta após 2015, pois não ocorreram novas pactuações de vagas no âmbito da Bolsa Formação. Conforme se referiu a CPMMIL do Campus, "o governo lançou muitas propostas, veio o Certific, Proeja Fic, Mulheres Mil, até que veio o Pronatec e 'sugou' todas essas outras propostas. Sumiram todas e ficou só o Pronatec". E, pode-se completar, quando “enxugaram” o Pronatec, por sua vez, foram com ele todos os outros programas.

Quanto ao Proeja, em nível institucional, parece que o fato de não ter sido desenvolvido por meio da Bolsa Formação contribuiu para a permanência de sua oferta. Observando-se os dados de matrícula a partir de 2012, o Proeja Técnico de nível médio manteve oferta regular até a conclusão do último ano letivo (2017). Já o Proeja FIC, que era integrado ao ensino 
fundamental, teve grande diminuição, pois era fomentado, em grande medida, por editais de financiamento da SETEC e pelo Certific, que perderam força a partir do Pronatec. Além disso, o Proeja de nível fundamental depende de parcerias com os municípios, o que complexifica o seu planejamento e execução. Na tabela 19 pode-se observar o quantitativo de matrículas do Proeja no IFFar, no período de 2012 a 2017.

Tabela 19 - Matrículas em cursos Proeja no IFFar - 2012 a 2017

\begin{tabular}{lll}
\hline \hline Ano & Proeja FIC & Proeja Técnico \\
\hline 2012 & 429 & 596 \\
2013 & 299 & 431 \\
2014 & 456 & 606 \\
2015 & 187 & 476 \\
2016 & 77 & 482 \\
2017 & 96 & 462 \\
\hline \hline
\end{tabular}

Fonte: elaborada pela autora com base nos dados do SISTEC institucional (2017).

Observando-se os dados de escolaridade do público atendido pelo Pronatec Bolsa Formação no IFFar, grande parcela (quase 17\%, o que equivale a 1.607 pessoas) não possui ensino fundamental completo (vide seção 3.2.7 deste Capítulo). Assim, pode-se apontar que o público atendido pelo Proeja FIC passou a ser atendido pelo Pronatec Bolsa Formação, porém sem a possibilidade de elevação da escolaridade, como se confirma na fala da Coordenadora do Pronatec Mulheres Mil do Campus: “o nosso público é muito mais carente do que a gente imagina, eles não têm o ensino fundamental completo... Uma pena que o Pronatec não tenha esse objetivo de elevar a escolaridade e sim só dar qualificação profissional. Seria muito interessante se tivesse também essa oportunidade”.

3.2.6 O processo de pactuação e o perfil dos cursos e do público atendido pelo IFFar no âmbito do Pronatec Bolsa Formação

O Rio Grande do Sul foi o primeiro Estado a instituir Comitês Gestores do Pronatec, em nível estadual, reunindo os órgãos demandantes e as instituições ofertantes, com vistas no levantamento e atendimentos destas demandas. Havia três Comitês Gestores do Pronatec: o Pronatec Técnico, o Pronatec FIC e o Pronatec Campo. Assim, com base nas demandas identificadas em cada área, junto aos órgãos demandantes municipais, a instituição procurava privilegiar a pactuação de cursos relacionados às áreas de atuação da instituição, com vistas na qualidade do trabalho e também no respeito às áreas de atuação das demais instituições ofertantes, de acordo com o CGBF 2. No entanto, nos municípios em que o Campus do IFFar 
era a principal instituição ofertante, observou-se que os cursos pactuados foram além das áreas de domínio da instituição, como no caso do Campus que fez parte da pesquisa.

Em muitos municípios em que o IFFar possui campus, essa era a única, ou a principal, instituição ofertante do Programa. Assim, além da oferta dos cursos, as coordenações locais cumpriam um importante papel de mobilização dos órgãos demandantes na elaboração do mapa de demanda. Conforme relata a CGBF 1: “em 2013 a gente foi em todos os Campi, mandamos um memorando chamando todos os responsáveis na Prefeitura pela Secretaria de Assistência Social, Secretaria da educação, Coordenadoria regional da educação, sindicatos, todos os segmentos que estivessem interessados em discutir a construção desse mapa de demanda" (Entrevista CGBF 1 IFFar, 2016).

Essa experiência nos Comitês Estaduais funcionou muito bem nos três primeiros anos do Programa, segundo os coordenadores, pois as demandas identificadas tiveram as turmas preenchidas. Porém, a partir de 2015, a gestão nacional do Pronatec instituiu a elaboração do "mapa de demandas específicas", conforme se viu no capítulo II, e o contato dos Ministérios com as respectivas unidades demandantes em nível municipal ou estadual foi realizado por email. Algumas unidades não responderam ou não receberam esse email, ficando "sem curso ou caíram uns cursos de 'paraquedas' (...) Por exemplo, a gente teve cursos que o Ministério da Defesa pediu para uma região onde tinha 5 pessoas para fazer um curso de 30 vagas. Não fecha o mínimo para abrir a turma" (Entrevista CGBF 2 IFFar, 2016).

De acordo com os coordenadores, a nova metodologia foi um "desastre", pois as vagas pareciam ter sido divididas por Ministério, e muitas vezes as prefeituras recebiam email de um Ministério "como o da Agricultura, ele tem aquele perfil de curso: 'ah, escolhe desse menu aqui qual você quer', e daí você acaba escolhendo... mas será que é realmente aquilo? Será que a gente não deveria conversar um pouco mais..." (Entrevista CGBF 2 IFFar, 2016). Ao mesmo tempo, muitos públicos alvo do Programa não eram informados: “por exemplo lá em São Borja o público pescador era um público necessitado. E a Prefeitura não indicou... O sistema abre muito rápido, as prefeituras não sabiam que tinha de ser cadastrado no sistema" (Entrevista CGBF 1 IFFar, 2016).

Observa-se, assim, que essa nova metodologia excluía os espaços de diálogo nos municípios, como também nos Estados. A divisão de vagas por Ministério parece ter sido uma estratégia muito mais para acomodar as disputas internas, como se viu no Capítulo II, do que para diversificar a oferta de cursos.

Com base em relatórios institucionais do SISTEC, encontrou-se a seguinte lista de cursos ofertados pelo IFFar: 
Tabela 20 - Cursos e matrículas do Pronatec Bolsa Formação no IFFar - 2011 a 2016

\begin{tabular}{|c|c|c|}
\hline Curso & Carga Horária & Matrículas \\
\hline Agricultor Familiar & 200 & 938 \\
\hline Operador de Computador & 160 & 555 \\
\hline Técnico em Informática & 1200 & 487 \\
\hline Assistente Administrativo & 160 & 472 \\
\hline Auxiliar de Confeitaria & 180 & 383 \\
\hline Operador de Máquinas e implementos agrícolas & 160 & 382 \\
\hline Vendedor & 160 & 332 \\
\hline Agricultor Orgânico & 160 & 275 \\
\hline Manicure e Pedicure & $160 / 200$ & 274 \\
\hline Padeiro & 300 & 231 \\
\hline Técnico em Informática para Internet & 1000 & 179 \\
\hline Cuidador de Idoso & 160 & 171 \\
\hline Jardineiro & 160 & 161 \\
\hline Assistente de Serviços em Comércio Exterior & 160 & 148 \\
\hline Salgadeiro & 160 & 142 \\
\hline Inglês básico & 160 & 127 \\
\hline Manipulador de Alimentos & 200 & 126 \\
\hline Espanhol Básico & 160 & 113 \\
\hline Auxiliar Administrativo & 160 & 112 \\
\hline Montador e Recuperador de Computadores & 160 & 102 \\
\hline Técnico em Logística & 800 & 102 \\
\hline LIBRAS básico & 160 & 96 \\
\hline Preparador de doces e conservas & 200 & 96 \\
\hline Introdução e Interpretação em LIBRAS & 160 & 95 \\
\hline Auxiliar de Cozinha & 200 & 89 \\
\hline Confeiteiro & 200 & 88 \\
\hline Inspetor de qualidade & 160 & 87 \\
\hline Bovinocultor de Leite & 200 & 85 \\
\hline Técnico em Administração & 1000 & 82 \\
\hline Auxiliar Pedagógico & 200 & 75 \\
\hline Promotor de Vendas & 200 & 73 \\
\hline Auxiliar de Agropecuária & 200 & 72 \\
\hline Técnico em Agropecuária & 1200 & 71 \\
\hline Cabeleireiro Assistente & 200 & 70 \\
\hline Fruticultor & 200 & 64 \\
\hline Horticultor orgânico & 160 & 64 \\
\hline Operador de Caixa & 160 & 64 \\
\hline Assistente de Recursos Humanos & 160 & 63 \\
\hline Masseiro & 160 & 61 \\
\hline Agente Comunitário de Saúde & 400 & 57 \\
\hline Programador Web & 200 & 56 \\
\hline Auxiliar de Padaria e Confeitaria & 200 & 54 \\
\hline Recepcionista & 160 & 50 \\
\hline Agente de Informações Turísticas & 200 & 49 \\
\hline Editor de Vídeo & 160 & 49 \\
\hline Agente de Inspeção de Qualidade & 160 & 46 \\
\hline Bovinocultor de Corte & 200 & 45 \\
\hline Carpinteiro de Obras & 200 & 44 \\
\hline Monitor de Recreação & 160 & 44 \\
\hline Eletricista instalador predial de baixa tensão & 200 & 41 \\
\hline Produtor de frutas, hortaliças e plantas aromáticas & 200 & 41 \\
\hline Operador de retroescavadeira & 160 & 40 \\
\hline Técnico em Agroindústria & 1200 & 39 \\
\hline Técnico em Agronegócio & 1200 & 38 \\
\hline Costureiro de Máquina Reta e Overloque & 160 & 37 \\
\hline Técnico em Aquicultura & 1000 & 36 \\
\hline
\end{tabular}




\begin{tabular}{|c|c|c|}
\hline Auxiliar de Biblioteca & 160 & 35 \\
\hline Balconista de Farmácia & 240 & 35 \\
\hline Desenhista da Construção Civil & 200 & 35 \\
\hline Técnico em Agricultura & 1200 & 35 \\
\hline Assistente de Vendas & 200 & 34 \\
\hline Auxiliar de Costura & 160 & 34 \\
\hline Produtor Agropecuário & 250 & 34 \\
\hline Técnico em Zootecnia & 1200 & 34 \\
\hline Pizzaiolo & 160 & 33 \\
\hline Desenhista de Móveis & 160 & 32 \\
\hline Inseminador Artificial de animais & 200 & 32 \\
\hline Técnico em Hospedagem & 800 & 31 \\
\hline Técnico em Nutrição e Dietética & 1200 & 31 \\
\hline Auxiliar de Pessoal & 160 & 30 \\
\hline Cozinheiro Industrial & 360 & 30 \\
\hline Moleiro & 160 & 30 \\
\hline Organizador de Eventos & 180 & 30 \\
\hline Técnico em Confeitaria & 800 & 30 \\
\hline Artesão de Bordado à mão & 160 & 28 \\
\hline Cuidador Infantil & 160 & 28 \\
\hline Padeiro e Confeiteiro & 200 & 27 \\
\hline Técnico em Secretaria Escolar & 1200 & 27 \\
\hline Ajudante de Padeiro & 180 & 26 \\
\hline Aplicador de Revestimento Cerâmico & 160 & 26 \\
\hline Assistente de Secretaria Escolar & 180 & 26 \\
\hline Merendeira & 160 & 26 \\
\hline Técnico em Paisagismo & 800 & 26 \\
\hline Vigilante & 200 & 26 \\
\hline Atendente de Lanchonete & 160 & 25 \\
\hline Inglês aplicado a serviços turísticos & 180 & 25 \\
\hline Mecânico de Máquinas Agrícolas & 160 & 25 \\
\hline Agente de Limpeza e Conservação & 160 & 24 \\
\hline Artesão de Pintura em Tecido & 160 & 24 \\
\hline Costureiro Industrial do Vestuário & 200 & 24 \\
\hline Monitor de Dependência Química & 240 & 24 \\
\hline Alemão Básico - A1 & 160 & 23 \\
\hline Cervejeiro & 200 & 23 \\
\hline LIBRAS Intermediário & 160 & 22 \\
\hline Garçom Básico & 200 & 21 \\
\hline Churrasqueiro & 160 & 20 \\
\hline Destilador de Bebidas & 160 & 20 \\
\hline Espanhol aplicado a serviços turísticos & 180 & 20 \\
\hline Espanhol intermediário & 160 & 20 \\
\hline Inglês Intermediário & 160 & 20 \\
\hline Instalador e recuperador de rede de computadores & 200 & 20 \\
\hline Operador de fresadora com comando numérico computadorizado & 200 & 20 \\
\hline Operador de processos químicos industriais & 200 & 20 \\
\hline Técnico em Manutenção e Suporte em Informática & 1000 & 20 \\
\hline Torneiro mecânico & 160 & 20 \\
\hline Pintor de Obras Imobiliárias & 180 & 20 \\
\hline Eletricista de linhas elétricas de baixa tensão & 300 & 19 \\
\hline Criador de animais de grande porte & 200 & 18 \\
\hline Marceneiro & 280 & 17 \\
\hline Operador de Sistemas de Irrigação & 160 & 17 \\
\hline Técnico em Estética & 1200 & 17 \\
\hline Fresador Mecânico & 200 & 16 \\
\hline Técnico em Alimentos & 1200 & 16 \\
\hline Agente de Desenvolvimento Cooperativista & 160 & 13 \\
\hline
\end{tabular}




\begin{tabular}{lll}
\hline Floricultor & 160 & 13 \\
\hline Reciclador & 200 & 12 \\
\hline Traçador de Caldeiraria & 160 & 12 \\
\hline \hline
\end{tabular}

Fonte: elaborada pela autora com base em dados do SISTEC institucional (2017).

Do total de 117 (cento e dezessete) diferentes cursos ofertados, 99 (noventa e nove) são de formação inicial e continuada e 18 (dezoito) são cursos técnicos. Entre os cursos com maior número de matrículas, encontram-se tanto cursos FIC (Agricultor Familiar e Operador de Computador), como também um curso técnico (Técnico em Informática). Na Tabela 21, podese visualizar a distribuição das matrículas nos eixos tecnológicos.

Tabela 21 - Matrículas por Eixo Tecnológico e tipo de curso Pronatec Bolsa Formação IFFar - 2011 a 2016

\begin{tabular}{llll}
\hline \multirow{2}{*}{\multicolumn{1}{c}{ Eixo Tecnológico }} & \multicolumn{3}{c}{ Tipo do Curso } \\
\cline { 2 - 3 } & FIC & Técnico & Total \\
\hline Ambiente e Saúde & $8,2 \%$ & $3,7 \%$ & $7,6 \%$ \\
Controle e Processos Industriais & $1,1 \%$ & & $1,0 \%$ \\
Desenvolvimento Educacional e Social & $8,5 \%$ & $2,1 \%$ & $7,7 \%$ \\
Gestão e Negócios & $18,7 \%$ & $14,1 \%$ & $18,1 \%$ \\
Informação e Comunicação & $9,6 \%$ & $\underline{52,7 \%}$ & $15,5 \%$ \\
Infraestrutura & $2,8 \%$ & & $2,4 \%$ \\
Produção Alimentícia & $16,7 \%$ & $3,5 \%$ & $14,9 \%$ \\
Produção Cultural e Design & $2,1 \%$ & $2,0 \%$ & $2,1 \%$ \\
Produção Industrial & $0,5 \%$ & & $0,5 \%$ \\
Recursos Naturais & $\underline{27,5 \%}$ & $19,4 \%$ & $\underline{26,4 \%}$ \\
Segurança & $0,3 \%$ & & $0,3 \%$ \\
Turismo, Hospitalidade e Lazer & $3,8 \%$ & $2,4 \%$ & $3,6 \%$ \\
\hline Total & $100,0 \%$ & $100,0 \%$ & $100,0 \%$ \\
\hline \hline Fonte: elaborada pela autora com base em dados do SISTEC institucional $(2017)$.
\end{tabular}

Esta distribuição das matrículas nos eixos é coerente com a atuação da instituição nos seus cursos regulares: em 2017, 25\% das matrículas se encontravam no eixo de Recursos Naturais e 20,5\% no eixo de Informação e Comunicação, por exemplo. Por estar situada em municípios e regiões do interior do Estado, em que a maior produção econômica se dá por meio da agricultura e da pecuária, predominam os cursos no eixo de Recursos Naturais. O único eixo que o IFFar ofertou cursos por meio do Programa e que não oferta em seus cursos regulares é o de Segurança, embora a oferta pelo Programa tenha sido bem reduzida, apenas $0,3 \%$ das matrículas.

Observa-se no total de matrículas que a maioria são mulheres $(66,5 \%)$, porém essa diferença se altera quando se compara o tipo de curso que as mulheres frequentam: $55 \%$ dos estudantes dos cursos técnicos são mulheres, enquanto nos cursos FIC o percentual sobe para $68,3 \%$. Já os homens estão mais concentrados em cursos Técnicos, $45 \%$, contra $31,7 \%$ nos cursos FICs. 
Gráfico 13 - Matrículas Bolsa Formação por sexo e tipo de curso no IFFar - 2011-2016

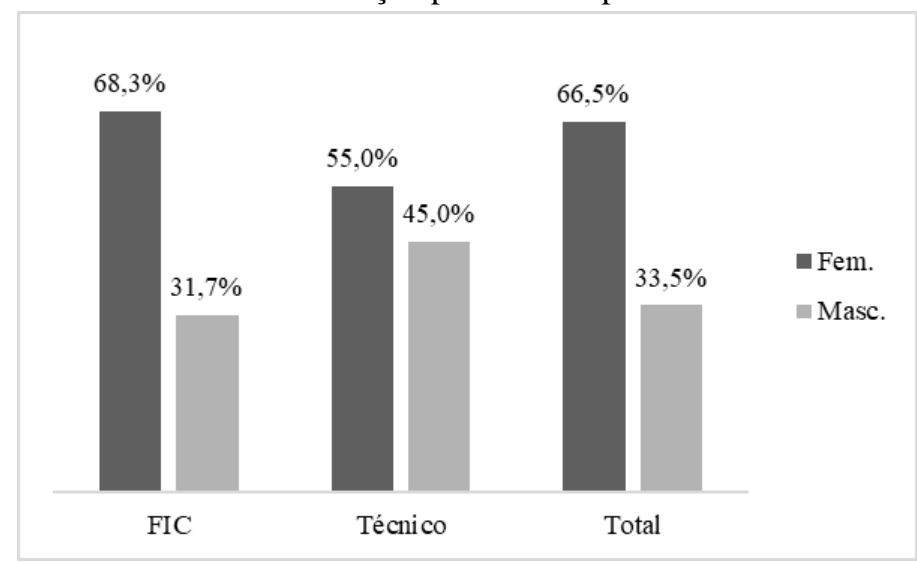

Fonte: elaborado pela autora com base nos dados disponíveis no SISTEC institucional (2017).

A predominância das mulheres nos cursos de qualificação profissional, como se observou também em relação às matrículas em nível nacional, pode ser compreendida no contexto da sua inserção no mercado de trabalho. Os dados da Pesquisa Nacional por Amostra de Domicílios (primeiro trimestre de $2016^{109}$ ) apontam a predominância das mulheres nos índices de desemprego no país - 66,1\% das pessoas desempregadas são mulheres - e, embora sendo mais numerosas no conjunto da população, correspondem a um percentual inferior ao dos homens entre a população empregada. De outro lado, pesquisas demonstram que os postos ocupados por mulheres no mercado de trabalho se concentram em áreas específicas, especialmente naquelas ligadas ao setor de serviços, configurando "guetos" de trabalhos femininos, caracterizados por baixa remuneração (MORAES, p. 255, 2013b).

Ao situar os Eixos Tecnológicos dos cursos em relação ao sexo, é possível observar essa realidade em relação às mulheres. Quase a metade dos estudantes do sexo masculino estão no eixo de Recursos Naturais, enquanto as mulheres se concentram nos eixos de Gestão e Negócios e Produção Alimentícia, que se caracterizam pela prestação de serviços e/ou ocupação de postos de trabalho no comércio.

Tabela 22 - Matrículas Pronatec Bolsa Formação por Sexo e Eixo Tecnológico no IFFar - 2011 a 2016

\begin{tabular}{lrrr}
\hline \multirow{2}{*}{ Eixo Tecnológico } & \multicolumn{2}{c}{ Sexo } & \multirow{2}{*}{ Total } \\
\cline { 2 - 3 } & \multicolumn{1}{c}{ Fem. } & Masc. & \\
\hline Ambiente e Saúde & $11,0 \%$ & $0,9 \%$ & $7,6 \%$ \\
Controle e Processos Industriais & $0,0 \%$ & $2,9 \%$ & $1,0 \%$ \\
Desenvolvimento Educacional e Social & $8,8 \%$ & $5,5 \%$ & $7,7 \%$ \\
Gestão e Negócios & $\underline{21,0 \%}$ & $12,3 \%$ & $18,1 \%$ \\
Informação e Comunicação & $12,4 \%$ & $\underline{21,6 \%}$ & $15,5 \%$ \\
Infraestrutura & $1,1 \%$ & $5,0 \%$ & $2,4 \%$
\end{tabular}

\footnotetext{
${ }^{109}$ Conforme notícia divulgada em: http://g1.globo.com/economia/noticia/2016/05/desemprego-sobe-em-todasgrandes-regioes-no-1-trimestre.html
} 


\begin{tabular}{lrrr} 
"Produção Alimentícia & $\underline{20,1 \%}$ & $4,6 \%$ & $14,9 \%$ \\
Produção Cultural e Design & $2,7 \%$ & $0,9 \%$ & $2,1 \%$ \\
Produção Industrial & $0,6 \%$ & $0,2 \%$ & $0,5 \%$ \\
Recursos Naturais & $17,8 \%$ & $\underline{43,4 \%}$ & $26,4 \%$ \\
Segurança & $0,2 \%$ & $0,5 \%$ & $0,3 \%$ \\
Turismo, Hospitalidade e Lazer & $4,3 \%$ & $2,2 \%$ & $3,6 \%$ \\
\hline Total & $100,0 \%$ & $100,0 \%$ & $100,0 \%$ \\
\hline \hline
\end{tabular}

Fonte: elaborada pela autora com base nos dados do SISTEC institucional (2017).

Em relação à escolaridade, a maioria já concluiu ou possui o ensino médio incompleto. Dentre as etapas de escolaridade, o percentual de mulheres que já concluiu o ensino médio é maior que o de homens, e essa diferença quase duplica quando se observa os dados em relação ao ensino superior completo, o que aponta para o fato de que as mulheres, embora mais escolarizadas, tem mais dificuldade de se inserir no mercado de trabalho (LAVINAS et al., 2016), impelindo-as a buscar novas qualificações.

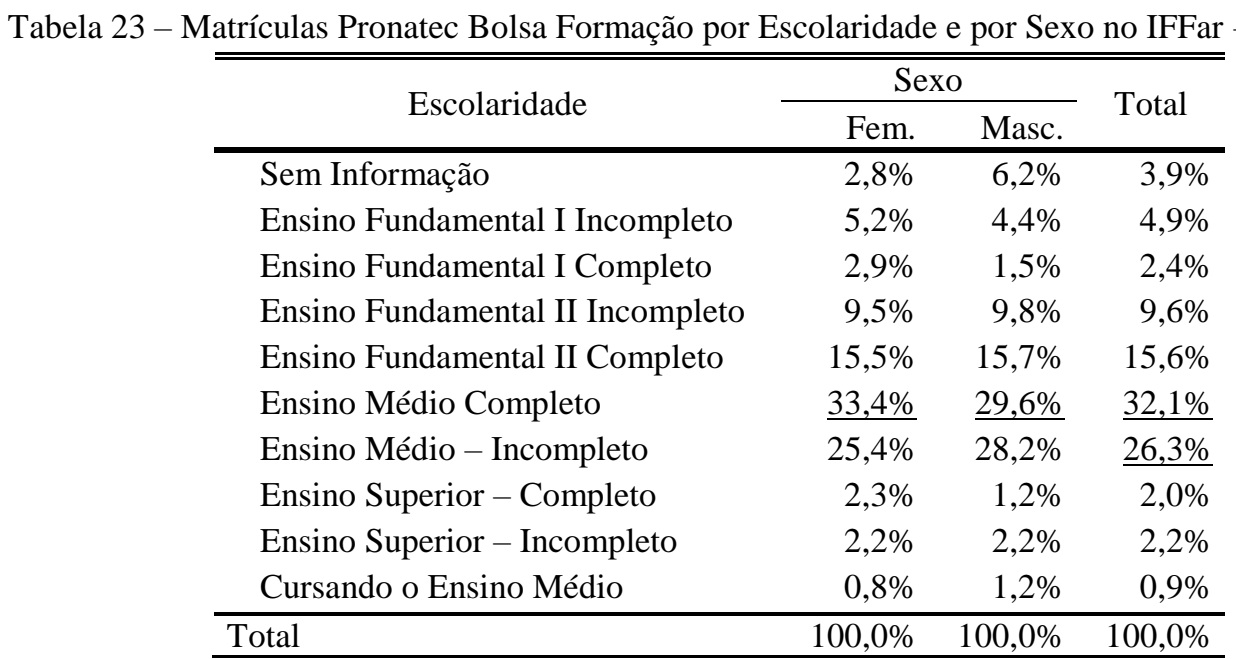

Fonte: elaborado pela autora com base nos dados do SISTEC (2017)

O público que acessou os cursos do Pronatec Bolsa Formação no IFFar é um público jovem, sendo mais de $56 \%$ com idades entre 14 e 30 anos. O percentual de homens com mais de 30 anos diminuiu bastante - apenas 31,8\% - enquanto que mais de $46 \%$ do público feminino está acima dessa faixa etária. Assim, além de serem maioria, as mulheres são mais velhas em relação ao público masculino que participou do Pronatec no IFFar.

Tabela 24 - Matrículas Pronatec Bolsa Formação por faixa etária e sexo - IFFar 2011 a 2016

\begin{tabular}{lrrr}
\hline \hline \multirow{2}{*}{ Faixa Etária } & \multicolumn{2}{c}{ Sexo } & \multirow{2}{*}{ Total } \\
\cline { 2 - 3 } & \multicolumn{1}{c}{ Fem. } & \multicolumn{1}{c}{ Masc. } & \\
\hline Sem Informação & $2,4 \%$ & $3,7 \%$ & $2,8 \%$ \\
14 a 18 anos & $\underline{19,6 \%}$ & $\underline{28,2 \%}$ & $\underline{22,5 \%}$ \\
19 a 21 anos & $9,9 \%$ & $12,8 \%$ & $10,9 \%$
\end{tabular}




\begin{tabular}{lrrr}
22 a 25 anos & $10,2 \%$ & $12,1 \%$ & $10,9 \%$ \\
26 a 30 anos & $11,7 \%$ & $11,5 \%$ & $11,7 \%$ \\
31 a 35 anos & $10,7 \%$ & $9,1 \%$ & $10,2 \%$ \\
36 a 40 anos & $10,4 \%$ & $7,4 \%$ & $9,4 \%$ \\
41 a 45 anos & $7,9 \%$ & $4,7 \%$ & $6,8 \%$ \\
46 a 50 anos & $7,5 \%$ & $4,3 \%$ & $6,4 \%$ \\
51 a 60 anos & $8,3 \%$ & $5,5 \%$ & $7,4 \%$ \\
61 a 70 anos & $1,2 \%$ & $0,8 \%$ & $1,0 \%$ \\
71 a 80 anos & $0,1 \%$ & & $0,1 \%$ \\
\hline Total & $100,0 \%$ & $100,0 \%$ & $100,0 \%$ \\
\hline \hline
\end{tabular}

Fonte: elaborada pela autora com base nos dados do SISTEC institucional (2017).

Quando se observa a faixa etária no âmbito dos Eixos Tecnológicos, é possível visualizar uma concentração de determinadas faixas etárias em algumas áreas. Os eixos de Produção Cultural e Design e Produção Industrial concentram um percentual maior de pessoas com mais de 50 anos, os quais ofertam a maior parte das matrículas em cursos de artesanato (bordado e pintura) e costura. Enquanto a faixa etária mais jovem é mais numerosa nos eixos de Desenvolvimento Educacional e Social - que ofertou $48 \%$ das matrículas em cursos de línguas estrangeiras -, Gestão e Negócios, Informação e Comunicação e Recursos Naturais.

Tabela 25 - Matrículas Pronatec Bolsa Formação por faixa etária e Eixo Tecnológico - IFFar 2011 a 2016

\begin{tabular}{|c|c|c|c|c|c|c|c|c|c|c|c|c|c|}
\hline \multirow{2}{*}{ Eixo Tecnológico } & \multicolumn{12}{|c|}{ Faixa Etária } & \multirow{2}{*}{ Total } \\
\hline & Inf. & 14 a 18 & 19 a 21 & 22 a 25 & 26 a 30 & 31 a 35 & 36 a 40 & 41 a 45 & 46 a 50 & 51 a 60 & 61 a 70 & 71 a 80 & \\
\hline Ambiente e Saúde & $2,4 \%$ & $\underline{13,5 \%}$ & $9,5 \%$ & $9,6 \%$ & $12,2 \%$ & $12,7 \%$ & $12,0 \%$ & $9,2 \%$ & $9,5 \%$ & $8,9 \%$ & $0,7 \%$ & & $100,0 \%$ \\
\hline Controle e Processos Industriais & & $1,1 \%$ & $10,8 \%$ & $\underline{26,9 \%}$ & $24,7 \%$ & $17,2 \%$ & $11,8 \%$ & $3,2 \%$ & $2,2 \%$ & $2,2 \%$ & & & $100,0 \%$ \\
\hline Desenvolvimento Educacional e Social & $0,3 \%$ & $\underline{41,4 \%}$ & $9,0 \%$ & $10,8 \%$ & $10,5 \%$ & $7,6 \%$ & $6,6 \%$ & $6,4 \%$ & $4,1 \%$ & $3,3 \%$ & & & $100,0 \%$ \\
\hline Gestão e Negócios & $6,0 \%$ & $\underline{22,7 \%}$ & $14,9 \%$ & $13,3 \%$ & $12,5 \%$ & $10,5 \%$ & $8,0 \%$ & $4,3 \%$ & $3,9 \%$ & $3,5 \%$ & $0,4 \%$ & & $100,0 \%$ \\
\hline Informação e Comunicação & $6,1 \%$ & $\underline{\mathbf{3 5}, 1 \%}$ & $11,8 \%$ & $11,6 \%$ & $11,4 \%$ & $6,9 \%$ & $5,5 \%$ & $4,6 \%$ & $3,5 \%$ & $2,8 \%$ & $0,4 \%$ & $0,1 \%$ & $100,0 \%$ \\
\hline Infraestrutura & & $12,2 \%$ & $13,1 \%$ & $12,2 \%$ & $10,5 \%$ & $\underline{16,2 \%}$ & $13,5 \%$ & $8,7 \%$ & $5,2 \%$ & $8,3 \%$ & & & $100,0 \%$ \\
\hline Produção Alimentícia & $1,1 \%$ & $6,6 \%$ & $6,2 \%$ & $8,1 \%$ & $10,9 \%$ & $13,3 \%$ & $14,9 \%$ & $11,0 \%$ & $11,4 \%$ & $14,1 \%$ & $2,3 \%$ & $0,1 \%$ & $100,0 \%$ \\
\hline Produção Cultural e Design & & $13,6 \%$ & $5,6 \%$ & $9,6 \%$ & $11,6 \%$ & $10,1 \%$ & $11,1 \%$ & $6,6 \%$ & $9,6 \%$ & $\underline{21,2 \%}$ & $1,0 \%$ & & $100,0 \%$ \\
\hline Produção Industrial & & & $11,4 \%$ & $11,4 \%$ & $13,6 \%$ & $11,4 \%$ & $15,9 \%$ & $13,6 \%$ & $2,3 \%$ & $\underline{20,5 \%}$ & & & $100,0 \%$ \\
\hline Recursos Naturais & $1,6 \%$ & $\underline{25,8 \%}$ & $11,9 \%$ & $9,5 \%$ & $11,3 \%$ & $8,7 \%$ & $8,7 \%$ & $6,2 \%$ & $6,7 \%$ & $7,9 \%$ & $1,6 \%$ & $0,2 \%$ & $100,0 \%$ \\
\hline Segurança & & & $7,7 \%$ & $19,2 \%$ & $\underline{23,1 \%}$ & $15,4 \%$ & $19,2 \%$ & $3,8 \%$ & $3,8 \%$ & $7,7 \%$ & & & $100,0 \%$ \\
\hline Turismo, Hospitalidade e Lazer & $0,3 \%$ & $9,4 \%$ & $6,7 \%$ & $\underline{15,2 \%}$ & $12,0 \%$ & $14,6 \%$ & $9,4 \%$ & $10,8 \%$ & $8,5 \%$ & $11,1 \%$ & $1,8 \%$ & $0,3 \%$ & $100,0 \%$ \\
\hline Total & $2,8 \%$ & $22,5 \%$ & $10,9 \%$ & $10,9 \%$ & $11,7 \%$ & $10,2 \%$ & $9,4 \%$ & $6,8 \%$ & $6,4 \%$ & $7,4 \%$ & $1,0 \%$ & $0,1 \%$ & $100,0 \%$ \\
\hline
\end{tabular}

Fonte: elaborada pela autora com base nos dados do SISTEC institucional (2017).

Com relação à cor da pele, a maior parte, tanto de homens quanto de mulheres, é da cor branca. Já o percentual de cor preta e parda é maior entre as mulheres, embora o percentual de homens que não informou a cor da pele seja bem significativo, podendo interferir nesse resultado. Observando-se esses dados em relação ao perfil da população do Estado, pode-se apontar que os percentuais de cor de pele observados no perfil dos estudantes vêm ao encontro do perfil populacional. 
Tabela 26 - Matrículas Pronatec Bolsa Formação por sexo e cor da pele - IFFar 2011 a 2016

\begin{tabular}{lrrr}
\hline \multirow{2}{*}{ Cor da Pele } & \multicolumn{2}{c}{ Sexo } & \multirow{2}{*}{ Total } \\
\cline { 2 - 3 } Amarela & \multicolumn{1}{c}{$\mathbf{F}$} & \multicolumn{1}{c}{$\mathbf{M}$} & \\
\hline Branca & $0,6 \%$ & $0,4 \%$ & $0,5 \%$ \\
Indígena & $01,6 \%$ & $\underline{52,1 \%}$ & $\underline{58,4 \%}$ \\
Não Informada & $24,6 \%$ & $0,3 \%$ & $0,2 \%$ \\
Parda & $9,6 \%$ & $6,6 \%$ & $8,6 \%$ \\
Preta & $3,5 \%$ & $2,4 \%$ & $3,1 \%$ \\
Total & $100,0 \%$ & $100,0 \%$ & $100,0 \%$ \\
Fonte: elaborada pela autora com base nos dados do SISTEC (2017).
\end{tabular}

Nos tópicos a seguir, 3.3 e 3.4, serão apresentados os resultados da pesquisa nas duas unidades de ensino do IFFar onde foi realizado estudo aprofundado sobre o desenvolvimento do Pronatec Bolsa Formação. Os dados observados nessas unidades ilustram os fatos identificados na análise geral na instituição e agregam novos elementos que corroboram na apreensão das particularidades no desenvolvimento do Programa.

\subsection{Unidade de desenvolvimento dos Cursos do Pronatec Bolsa Formação I - Centro de Referência do IFFar}

O Centro de Referência selecionado para o aprofundamento da pesquisa situa-se na região norte do Estado do Rio Grande do Sul, em município com quase 60 mil habitantes, de acordo com o último Censo (IBGE, 2010). A economia do município e região, historicamente, é dependente da agricultura, seja por meio da exploração de commodities como soja, trigo e milho e da produção pecuária, como também pelo desenvolvimento de grandes indústrias no ramo do agronegócio, como indústrias de peças e implementos agrícolas e de lacticínios, e empresas do setor de transportes, com vistas no transporte de maquinários e da produção agrícola. A exploração agropecuária é baseada em grandes propriedades, sendo que 172 propriedades rurais, o que equivale a 55\% do total, detêm $94,2 \%$ da área rural. Tal situação se expressa no baixo número de pessoas que vivem no campo - apenas $1,8 \%$ da população. A agricultura familiar é desenvolvida em 140 propriedades $-45 \%$ das propriedades rurais - e ocupa apenas $5,8 \%$ da área.

A grande concentração demográfica no meio urbano e a posição privilegiada do município em relação às principais rodovias, situado no maior entroncamento rodoviário do sul do país, tem alavancado o crescimento do comércio e serviços. Grande parte das transações comerciais são oriundas da indústria de peças e implementos agrícolas, que se destinam ao mercado interno e também a exportações. Com isso, quase 63\% do Produto Interno Bruto (PIB), 
em 2013, era resultante do setor de serviços e comércio. A indústria e agropecuária contribuíram com $15,4 \%$ e 7,2\% do PIB, respectivamente (IBGE, 2013).

De acordo com o último Censo, $74 \%$ da população economicamente ativa é constituída por empregados, recebendo em média 2,4 salários mínimos; 22,6\% trabalham por conta própria; e 3,4\% são empregadores. Desses trabalhadores, $72 \%$ são contribuintes de previdência social e a grande maioria mora no meio urbano - 97,6\%. Quanto ao tipo de ocupação, destacam-se o setor de serviços e comércio, as denominadas ocupações elementares e o setor de construção e de mecânica, com 19,75\%, 19,03\% e 17,35\%, respectivamente. Na Tabela 27 pode-se visualizar os demais grupos de ocupação e o respectivo percentual de trabalhadores.

Tabela 27 - População economicamente ativa por grupos de ocupação - Município Centro de Referência IFFar

\begin{tabular}{lr}
\multicolumn{1}{c|}{ Grupos de ocupação } & $\%$ \\
\hline Diretores e gerentes & 4,25 \\
Membros das forças armadas, policiais e bombeiros militares & 0,55 \\
Ocupações elementares* & $\underline{19,03}$ \\
Operadores de instalações e máquinas e montadores & 8,35 \\
Profissionais das ciências e intelectuais & 10,74 \\
Técnicos e profissionais de nível médio & 3,70 \\
Trabalhadores de apoio administrativo & 8,24 \\
Trabalhadores dos serviços, vendedores dos comércios e mercados & 19,75 \\
Trabalhadores qualificados da agropecuária, florestais, da caça e da pesca & 3,40 \\
Trabalhadores qualificados, operários e artesãos da construção, das artes mecânicas e outros ofícios & $\underline{17,35}$ \\
Ocupações mal definidas & 4,64 \\
\hline Total & 100,00 \\
\hline \hline
\end{tabular}

*Compreende os trabalhadores dos serviços domésticos e trabalhadores de limpeza em geral.

Fonte: Organizada pela autora com base nos dados do Censo Demográfico (IBGE, 2010).

O Índice de Desenvolvimento Humano (IDH) é de 0,766, o que situa o município na $28^{\mathrm{a}}$ posição entre os 497 municípios do Estado, e o índice Gini é de 0,517, indicando expressiva desigualdade na distribuição de renda. Em relação à escolaridade, em 2010, 4,1\% da população com 15 anos ou mais era analfabeta. Entre os habitantes com 25 anos ou mais, 57,28\% tinham o ensino fundamental completo, 39,40\% haviam completado o ensino médio e $11,15 \%$ possuíam o ensino superior completo (IBGE, 2010).

A educação básica é ofertada pelo sistema público municipal (27 escolas), estadual (16 escolas) e escolas privadas (11 escolas). Na área da educação profissional ${ }^{110}$, o município conta com unidades do Sistema S - SENAI, SENAC e SENAT - que ofertam cursos de qualificação profissional e cursos técnicos, uma Escola Estadual de Educação Profissional ${ }^{111}$ e outras duas

\footnotetext{
${ }^{110}$ No ano de 2014, as escolas privadas respondiam por 94 matrículas em cursos técnicos, enquanto as escolas estaduais ofertavam 261 matrículas (SIMEC, consulta em janeiro de 2018).

${ }^{111}$ Essa escola situa-se na zona rural a $8 \mathrm{KM}$ de distância da cidade e oferta o Curso Técnico em Agropecuária na forma integrada ao ensino médio e também na forma subsequente ao ensino médio. As instalações oferecem moradia aos estudantes que vem de outras cidades, funcionando em turno integral. $\mathrm{O}$ curso Técnico subsequente
} 
que ofertam cursos técnicos ${ }^{112}$, duas escolas privadas que ofertam cursos técnicos subsequentes, e até 2016 contava com um Centro Municipal de Educação Profissional que ofertava cursos de qualificação profissional. No que tange ao ensino superior, o município situa-se numa região onde, historicamente, predomina o ensino superior privado, sendo atendido por Campus de duas universidades privadas - Universidade de Passo Fundo (UPF) e Universidade Luterana do Brasil (ULBRA). Essa realidade mudou significativamente a partir de 2006, quando, por meio da expansão do ensino superior público promovido pelo governo federal, a Universidade Federal de Santa Maria expandiu sua atuação com a instalação de dois campi em cidades próximas - cerca de $90 \mathrm{~km}$. Com a criação dos Institutos Federais em 2008, a região também foi contemplada com campus do IFSul (Instituto Federal Sul-Riograndense) e, mais recentemente, em 2012, a região passou a contar com um campus da Universidade Federal da Fronteira Sul (UFFS), o qual oferta o curso superior de Medicina.

Essa expansão do ensino público federal na região e o decorrente desenvolvimento social e econômico, levou lideranças municipais a sinalizarem o interesse do município nessa direção. Assim, a criação do Centro de Referência do IFFar teve origem na demanda levantada e sistematizada pelo "Grupo de Trabalho Pró Vinda do Instituto Federal Farroupilha”, composto por gestores municipais e representantes da comunidade local e regional, que buscou o IFFar para solicitar a instalação de uma unidade de ensino naquele município. Não sendo possível a criação de um Campus em curto período de tempo, por depender da autorização do Ministério da Educação - e por serem as perspectivas da expansão pouco animadoras naquele momento a criação do Centro de Referência foi a forma encontrada, na perspectiva dos sujeitos entrevistados, para atender à demanda e ao mesmo tempo demonstrar a necessidade da implantação de um campus do Instituto Federal na cidade. No site da prefeitura municipal há várias notícias que registram as reuniões realizadas entre a gestão municipal (PDT 2013-2016) e o Instituto Federal Farroupilha, antes e depois da instalação do CR, estando o Prefeito e a Secretária Municipal de Educação à frente desse processo.

Criado no ano de 2014, o Centro de Referência do Instituto Federal Farroupilha iniciou suas atividades em outubro daquele mesmo ano. Os cursos do Pronatec Bolsa Formação foram desenvolvidos desde o início de suas atividades até final de 2017, quando as turmas em

oferta 50 vagas semestrais, cuja seleção para ingresso ocorre por meio de prova de conhecimento em português, matemática e conhecimentos gerais. Já o Técnico integrado oferta duas turmas anuais com 30 e 25 vagas, destinadas ao regime semi-interno e interno, respectivamente, e os estudantes são selecionados por meio de sorteio entre os inscritos (Fonte: site da escola).

${ }^{112}$ Essas escolas não são exclusivas de educação profissional. Uma delas oferta o Curso Técnico em Enfermagem na forma subsequente ao ensino Médio, e a outra oferta o Curso Normal (formação para o magistério na educação infantil e ensino fundamental I), na forma integrada ao Ensino Médio. 
andamento foram concluídas. Atualmente, o CR continua em atividade a partir do desenvolvimento de cursos técnicos na modalidade a distância, por meio do Pronatec MedioTec e da Rede e-Tec, sendo que o espaço também se constitui em um Polo de EaD da mesma instituição.

Como se viu em relação ao funcionamento dos Centros de Referência, há apenas um servidor público que desempenha as atividades de Coordenação Adjunta do Pronatec e Coordenação do Centro de Referência. Os demais profissionais que atuam/atuaram nos cursos são selecionados por meio de processo seletivo público. O Campus do IFFar mais próximo do CR situa-se a aproximadamente 100 quilômetros, assim a totalidade dos professores contratados para o desenvolvimento dos cursos do Pronatec Bolsa Formação são externos à instituição.

No período em que ocorreram as atividades de pesquisa no CR houve mudança na Coordenação, assim realizou-se entrevista com os dois servidores que atuaram nessa função. Os profissionais atuantes nos encargos pedagógicos do Programa (orientador, supervisor e apoio às atividades acadêmicas e administrativas) variaram bastante ${ }^{113}$, tendo sido possível entrevistar apenas uma professora que desempenha a função de "Apoio às atividades acadêmicas e administrativas". Além dessas entrevistas, compõem o corpus de análise do Pronatec Bolsa Formação nessa unidade as respostas de professores e estudantes aos questionários online ${ }^{114}$, entrevistas de aprofundamento com dois dos docentes ${ }^{115}$ que responderam ao questionário, projetos pedagógicos de curso e dados quantitativos sobre as matrículas.

Os cursos desenvolvidos nessa unidade atenderam a diferentes modalidades de demanda do Pronatec Bolsa Formação, como o Pronatec Campo, Pronatec Jovem, Pronatec Trabalhador

\footnotetext{
${ }^{113}$ Na primeira visita ao CR, em outubro de 2016, não foi possível conversar com a supervisora dos cursos técnicos, pois sua carga horária era de apenas 04 horas semanais e ela não estava trabalhando no dia da visita. Mesmo se estivesse, seria complicado realizar a entrevista pois iria comprometer seu curto tempo para o trabalho.

${ }^{114} \mathrm{O}$ questionário destinado aos docentes foi encaminhado para 28 contatos de email, informados pela coordenação do $\mathrm{CR}$, sendo que 2 contatos retornaram com a mensagem de email não encontrado e 15 responderam ao questionário, obtendo, assim, um retorno de $58 \%$ da amostra. Em relação aos estudantes, o CR não possuía uma lista de e-mails em virtude de que maior parte dos estudantes não possuía correio eletrônico, assim encaminhei o link do questionário para os docentes que estavam atuando nos cursos solicitando que fosse disponibilizado aos estudantes em algum momento de suas aulas. A partir desse procedimento, obtive o retorno de 16 estudantes, dos 24 estudantes em curso, o que corresponde a participação de $67 \%$ da amostra.

${ }^{115}$ De acordo com a manifestação de interesse dos docentes que responderam ao questionário online, realizamos entrevista com dois deles, um professor e uma professora, considerando a representatividade de gênero, faixa etária e experiência docente. O professor atuava no Curso Técnico em Informática para Internet, com graduação em Sistemas de Informação e formação pedagógica, Mestre em Informática e é docente concursado em campus de outro Instituto Federal. A professora atuava no Curso Técnico em Confeitaria, com graduação em Nutrição, Mestrado em Tecnologia de Alimentos, Doutoranda nessa mesma área e não possuía outro vínculo empregatício. Esses professores estão identificados no texto como Prof. Informática e Prof. Confeitaria, respectivamente.
} 
e Pronatec Mulheres Mil. Assim, foram desenvolvidos tanto cursos técnicos, na forma subsequente e concomitante, quanto cursos de formação inicial e continuada, os FICs, conforme se observa na Tabela 28.

Tabela 28 - Cursos Pronatec Bolsa Formação ofertados no CR do IFFar

\begin{tabular}{llll}
\hline \hline Curso & Tipo & C.H. & Início \\
\hline Técnico em Confeitaria & Técnico Concomitante & 800 & $23 / 11 / 2015$ \\
Técnico em Informática & Técnico Subsequente & 1.200 & $06 / 10 / 2014$ \\
Técnico em Informática para Internet & Técnico Concomitante & 1.000 & $23 / 11 / 2015$ \\
Técnico em Logística & Técnico Subsequente & 800 & $31 / 08 / 2015$ \\
Técnico em Secretaria Escolar & Técnico Concomitante & 1.200 & $23 / 11 / 2015$ \\
Confeiteiro & FIC Mulheres Mil & 200 & $16 / 11 / 2015$ \\
Costureiro de Máquina Reta e Overloque & FIC Mulheres Mil & 200 & $16 / 11 / 2015$ \\
Manicure e Pedicure & FIC Mulheres Mil & 200 & $22 / 10 / 2014$ \\
Manicure e Pedicure & FIC Mulheres Mil & 200 & $09 / 11 / 2015$ \\
Agricultor Orgânico & FIC & 160 & $31 / 10 / 2016$ \\
\hline \hline Fonte: elaborada pela autora com base nos dados do SISTEC Institucional (2016).
\end{tabular}

De acordo com o primeiro Coordenador do CR, esses cursos são oriundos da demanda levantada pela Secretaria de Assistência Social e de Educação, considerando dados socioeconômicos do município. Tendo em vista as diferentes instituições ofertantes do Programa na cidade, como o SENAI e o SENAC, a definição dos cursos a serem ofertados pelo IFFar observou, em grande medida, as instalações e recursos materiais disponíveis para a oferta, como os laboratórios já existentes no CMEP.

No período de 2011 a agosto de 2017, o Pronatec Bolsa Formação ofertou 8.469 matrículas no município, sendo a quase totalidade em cursos FIC, 98,7\%, e apenas 1,3\% em cursos técnicos. Dessas matrículas, o Centro de Referência do IFFar ofertou $100 \%$ das matrículas em cursos técnicos e 1,2\% em cursos FIC. O Sistema S desenvolveu 98,8\% das matrículas em cursos FIC, assim distribuídas entre as suas instituições: 82,7\% pelo SENAC; 13,3\% pelo SENAI e 2,8\% pelo SENAT. Na tabela 29 pode-se visualizar os cursos ofertados pelas diferentes instituições e a respectiva quantidade de matrículas.

Tabela 29 - Instituição Ofertante x Tipo de Curso no município do CR do IFFar

\begin{tabular}{|c|c|c|c|c|c|}
\hline \multirow{2}{*}{ Curso } & \multicolumn{4}{|c|}{ Instituição Ofertante } & \multirow{2}{*}{ Total } \\
\hline & CR IFFar & SENAC & SENAI & SENAT & \\
\hline Agente de Coleta e Entrega no Transporte de Pequenas Cargas & 0 & 0 & 0 & 23 & 23 \\
\hline Agente de Inclusão Digital em Centros Públicos de Acesso à Internet & 0 & 0 & 25 & 0 & 25 \\
\hline Agente de Recepção e Reservas em Meios de Hospedagem & 0 & 28 & 0 & 0 & 28 \\
\hline Agricultor Orgânico & 9 & 0 & 0 & 0 & 9 \\
\hline Almoxarife & 0 & 0 & 0 & 55 & 55 \\
\hline Apicultor* & 4 & 0 & 0 & 0 & 4 \\
\hline Arrumador e Conferente de Cargas & 0 & 0 & 0 & 32 & 32 \\
\hline Artesão de Pintura em Tecido & 0 & 20 & 0 & 0 & 20 \\
\hline Assistente Administrativo & 0 & 1178 & 43 & 21 & 1242 \\
\hline Assistente de Crédito e Cobrança & 0 & 27 & 0 & 0 & 27 \\
\hline Assistente de Recursos Humanos & 0 & 254 & 0 & 0 & 254 \\
\hline
\end{tabular}


Auxiliar Administrativo**

Auxiliar de Crédito e Cobrança

Auxiliar em Nutrição e Dietética

Balconista de Farmácia

Cabeleireiro

Camareira em Meios de Hospedagem

Comprador

Confeiteiro

Conformador de Peças em Metal

Contador de Histórias

Costureiro

Costureiro de Calçados

Costureiro de Máquina Reta e Overloque

Costureiro Industrial do Vestuário

Cuidador de Idoso

Cuidador Infantil

Desenhista de Moda

Desenhista Mecânico

Eletricista Industrial

Eletricista Instalador Predial de Baixa Tensão

Espanhol Básico

Fresador Mecânico

Garçom

Inglês Básico

Inspetor de Qualidade

Introdução à Interpretação em Língua Brasileira de Sinais (Libras)

Língua Brasileira de Sinais (Libras) - Básico

Manicure e Pedicure

Mecânico de Máquinas de Costura

Modelista

Modelista de Roupas

Montador e Reparador de Computadores

Operador de Computador

Operador de Empilhadeira

Operador de Máquinas de Marcenaria

Operador de Máquinas - Ferramentas Convencionais

Operador de Supermercados

Operador de Torno com Comando Numérico Computadorizado

Padeiro

Padeiro Confeiteiro

Programador Web

Promotor de Vendas

Recepcionista

Representante Comercial

Salgadeiro

Soldador de Estruturas e Tubulação no Processo MIG/MAG

Técnico em Confeitaria

Técnico em Informática

Técnico em Informática para Internet

Técnico em Logística

Técnico em Secretaria Escolar

Torneiro Mecânico
0

0

0

0

0

0

0

20

0

0

0

0

20

0

0

0

0

0

0

0

0

0

0

0

0

0

0

49

0

0

0

0

0

0

0

0

0

0

0

0

0
0

0

0

0

0

0

0

24

28

26

16

17

0

0

\begin{tabular}{llllll}
\hline Total & 213 & 6911 & 1113 & 232 & 8469 \\
\hline \hline
\end{tabular}

$\begin{array}{llll}461 & 0 & 0 & 461 \\ 17 & 0 & 0 & 17 \\ 29 & 0 & 0 & 29 \\ 182 & 0 & 0 & 182\end{array}$

$25 \quad 0 \quad 0 \quad 25$

$\begin{array}{llll}21 & 0 & 0 & 21\end{array}$

$\begin{array}{llll}17 & 0 & 0 & 17\end{array}$

$\begin{array}{llll}21 & 0 & 0 & 41\end{array}$

$0 \quad 16 \quad 0 \quad 16$

$\begin{array}{llll}18 & 0 & 0 & 18\end{array}$

$\begin{array}{llll}30 & 23 & 0 & 53\end{array}$

$\begin{array}{llll}0 & 22 & 0 & 22\end{array}$

$\begin{array}{llll}248 & 136 & 0 & 404\end{array}$

$\begin{array}{llll}0 & 22 & 0 & 22\end{array}$

$\begin{array}{llll}508 & 0 & 0 & 508\end{array}$

$\begin{array}{llll}352 & 0 & 0 & 352\end{array}$

$\begin{array}{llll}0 & 64 & 0 & 64\end{array}$

$\begin{array}{llll}0 & 62 & 0 & 62\end{array}$

$\begin{array}{llll}0 & 40 & 0 & 40\end{array}$

$\begin{array}{llll}0 & 101 & 0 & 101\end{array}$

$\begin{array}{llll}72 & 0 & 0 & 72\end{array}$

$\begin{array}{llll}0 & 18 & 0 & 18\end{array}$

$\begin{array}{llll}38 & 0 & 0 & 38\end{array}$

$\begin{array}{llll}758 & 40 & 0 & 798\end{array}$

$\begin{array}{llll}13 & 0 & 0 & 13\end{array}$

$\begin{array}{llll}0 & 0 & 17 & 17\end{array}$

$\begin{array}{llll}53 & 0 & 0 & 53\end{array}$

$\begin{array}{llll}78 & 0 & 0 & 127\end{array}$

$\begin{array}{llll}0 & 25 & 0 & 25\end{array}$

$\begin{array}{llll}30 & 24 & 0 & 54\end{array}$

$\begin{array}{llll}67 & 74 & 0 & 141\end{array}$

$\begin{array}{llll}31 & 0 & 0 & 31\end{array}$

$\begin{array}{llll}1017 & 18 & 0 & 1035\end{array}$

$\begin{array}{llll}0 & 0 & 47 & 47\end{array}$

$\begin{array}{llll}0 & 17 & 0 & 17\end{array}$

$\begin{array}{llll}0 & 20 & 0 & 20\end{array}$

$\begin{array}{llll}24 & 0 & 0 & 24\end{array}$

$\begin{array}{llll}0 & 63 & 0 & 63\end{array}$

$\begin{array}{llll}156 & 0 & 0 & 156\end{array}$

$\begin{array}{llll}75 & 0 & 0 & 75\end{array}$

$\begin{array}{llll}15 & 0 & 0 & 15\end{array}$

$\begin{array}{llll}83 & 0 & 0 & 83\end{array}$

$\begin{array}{llll}136 & 0 & 37 & 173\end{array}$

$\begin{array}{llll}43 & 0 & 0 & 43\end{array}$

$\begin{array}{llll}18 & 0 & 0 & 18\end{array}$

$\begin{array}{llll}0 & 113 & 0 & 113\end{array}$

$\begin{array}{llll}0 & 0 & 0 & 24\end{array}$

$\begin{array}{llll}0 & 0 & 0 & 28\end{array}$

$\begin{array}{llll}0 & 0 & 0 & 26\end{array}$

$\begin{array}{llll}0 & 0 & 0 & 16\end{array}$

$\begin{array}{llll}0 & 0 & 0 & 17\end{array}$

$\begin{array}{llll}0 & 147 & 0 & 147\end{array}$

\begin{tabular}{llll}
768 & 0 & 0 & 768 \\
\hline
\end{tabular}

* Esse curso não foi desenvolvido pelo CR, em razão de não ter atingido o número mínimo de matrículas.

** Antiga nomenclatura do curso de Assistente Administrativo

Fonte: elaborada pela pesquisadora com base em dados do SISTEC Nacional (2017). 
É interessante observar que, apesar das dificuldades de infraestrutura e pessoal, como se verá adiante, o Centro de Referência do IFFar é a única instituição a ofertar cursos técnicos pelo Pronatec Bolsa Formação. Considerando que quase $40 \%$ da população do município possui ensino médio completo (IBGE, 2010) e que, em 2014, mais de 2.000 estudantes se encontravam matriculados no ensino médio (INEP, 2015), o número de vagas ofertadas em cursos técnicos é muito pequeno frente ao potencial público para esses cursos.

Em relação aos Eixos Tecnológicos, observa-se que o eixo de Gestão e Negócios foi o que teve maior número de matrículas, 37,7\%. O SENAC e o SENAI, em coerência à sua área de atuação, ofertaram a maioria dos cursos nos eixos de Gestão e Negócios e Controle e Processos Industriais, respectivamente. Já o SENAT desenvolveu a maior número de matrículas em cursos do eixo de Gestão e Negócios, ficando em segundo lugar o atendimento da sua área de atuação, a Infraestrutura. É curioso, também, em relação ao SENAT, a oferta do Eixo de Desenvolvimento Educacional e Social, por meio do curso de "Introdução à Interpretação em Língua Brasileira de Sinais (Libras)”. O Centro de Referência do IFFar apresentou uma maior distribuição de matrículas nos eixos desenvolvidos, tendo ofertados os maiores percentuais nos eixos de Informação e Comunicação, Ambiente e Saúde e Produção Alimentícia.

\begin{tabular}{|c|c|c|c|c|c|}
\hline \multirow{2}{*}{ Eixo Tecnológico } & \multicolumn{4}{|c|}{ Instituição Ofertante } & \multirow[b]{2}{*}{ Total } \\
\hline & CR IFFar & SENAC & SENAI & SENAT & \\
\hline Ambiente e Saúde & $23,0 \%$ & $17,0 \%$ & & & $14,4 \%$ \\
\hline Controle e Processos Industriais & & & $\underline{43,8 \%}$ & & $6,0 \%$ \\
\hline Desenvolvimento Educacional e Social & $8,0 \%$ & $13,0 \%$ & $3,6 \%$ & $7,3 \%$ & $11,5 \%$ \\
\hline Gestão e Negócios & $7,5 \%$ & $43,7 \%$ & $3,9 \%$ & $\underline{48,7 \%}$ & $\underline{37,7 \%}$ \\
\hline Informação e Comunicação & $25,4 \%$ & $15,4 \%$ & $3,9 \%$ & & $13,7 \%$ \\
\hline Infraestrutura & & & $9,1 \%$ & $\underline{44,0 \%}$ & $2,4 \%$ \\
\hline Produção Alimentícia & $20,7 \%$ & $3,9 \%$ & & & $3,7 \%$ \\
\hline Produção Cultural e Design & & $0,7 \%$ & $7,8 \%$ & & $1,6 \%$ \\
\hline Produção Industrial & $9,4 \%$ & $5,0 \%$ & $28 \%$ & & $7,8 \%$ \\
\hline Recursos Naturais & $6,1 \%$ & & & & $0,2 \%$ \\
\hline Turismo, Hospitalidade e Lazer & & $1,3 \%$ & & & $1,0 \%$ \\
\hline Total & $100,0 \%$ & $100,0 \%$ & $100,0 \%$ & $100,0 \%$ & $100,0 \%$ \\
\hline
\end{tabular}

Fonte: tabela elaborada pela pesquisadora com base em dados do SISTEC Nacional, 2017.

Embora o município apresente uma economia baseada na agricultura, observa-se a quase ausência de formação nessa área, tendo sido ofertado um único curso, o de Agricultor Orgânico, pelo CR, o qual, em virtude de ter sido realizado na cidade, teve grande participação da população urbana com interesse na produção de hortas domésticas. Da mesma forma, o percentual de matrículas em cursos voltados ao desenvolvimento da indústria é muito pequeno, representando apenas 6\% do total (504 matrículas no eixo de Controle e Processos Industriais). 
De outro lado, o número de matrículas no curso de Assistente Administrativo, que demanda pouca infraestrutura e material para o seu desenvolvimento, é bastante elevado - 1703 matrículas, assim como no curso de Inglês Básico (798) e Operador de Computador (1035). Esse último, de acordo com a descrição do Catálogo de Cursos FIC ${ }^{116}$ poderia ser perfeitamente atendido por meio de treinamento em serviço.

3.3.1 A instabilidade nas condições de infraestrutura e manutenção do Centro de Referência a disputa de projetos e a (in)suficiência do Pacto Federativo

A infraestrutura para instalação e funcionamento do CR foi cedida pela prefeitura da cidade. Inicialmente, as atividades eram desenvolvidas no Centro Municipal de Educação Profissional (CMEP) do município, que possuía estrutura de laboratórios na área da gastronomia, corte e costura, beleza e estética, informática, entre outros, os quais forneceram as condições necessárias para a pactuação e desenvolvimento dos cursos. Porém, em virtude de as salas de aula serem pequenas e com a perspectiva de instalação futura de um Campus do Instituto Federal Farroupilha, a prefeitura cedeu também o prédio de uma escola municipal que apresentava melhores condições de infraestrutura para as aulas teóricas e localização ${ }^{117}$.

De acordo com o primeiro Coordenador ${ }^{118}$ (CCR 1), que é servidor TécnicoAdministrativo do IFFar e iniciou suas atividades junto ao CR em 31 de julho de 2014, inicialmente, o espaço era compartilhado com as turmas de educação básica, mas no ano seguinte a escola encerrou suas atividades e os estudantes foram encaminhados para outras instituições públicas de ensino da cidade. Esse fato gerou certa resistência na comunidade

\footnotetext{
${ }^{116}$ Esse curso habilita para "Utilizar sistemas operacionais, aplicativos e periféricos na organização de dados e sistemas computacionais" (Catálogo de Cursos FIC, $4^{\mathrm{a}}$ edição).

117 O prédio conta com cinco salas de aula, sendo que duas têm capacidade para 35 pessoas e três para 50, um refeitório, uma cozinha, uma sala de professores e direção, 2 laboratórios de informática (um de software e um de hardware), banheiros femininos e masculinos e amplo pátio com árvores frutíferas e paisagismo. Não há biblioteca, os poucos livros das áreas dos cursos o CCR1 conseguiu junto aos campi do IFFar e estão disponíveis em armários na sala da Direção, onde apenas os docentes tem acesso. Essa escola fica ao lado da Estação Rodoviária da cidade, o que facilita o deslocamento dos estudantes de cidades vizinhas. Na divisa com o terreno da escola também há uma grande área verde, que futuramente poderia abrigar a ampliação das instalações de um Campus. O município doou o terreno e a infraestrutura para o IFFar por meio de Lei Municipal para a instalação de um Campus da Instituição. Assim, enquanto o funcionamento da instituição for desenvolvido sob a forma de Centro de Referência, há a necessidade de renovação anual do direito de uso das instalações.

${ }^{118}$ Esse servidor é concursado no cargo de Assistente em Administração e possui formação em nível superior em Direito, ingressou no Instituto Federal em janeiro de 2010. Devido a sua experiência anterior no Pronatec Bolsa Formação - havia trabalhado com as atividades do Pronatec no seu campus de lotação, tanto como professor de curso, quanto como coordenador adjunto do Pronatec Bolsa Formação - e interesse em mudar de cidade, foi designado como Coordenador desse Centro de Referência.
} 
escolar, pois significava a extinção de uma escola municipal. Porém, a perspectiva de se consolidar naquele espaço uma instituição federal de ensino trazia, por outro lado, expectativas.

Assim, no período entre 2014 e o final de 2016 a prefeitura municipal ofereceu todo o subsídio para o funcionamento do CR, ao ceder os espaços físicos e realizar o serviço de manutenção e custeio das instalações, além de manter um Vigilante noturno e uma Servente (merendeira) à disposição do CR. Nesse período, as aulas práticas funcionavam nos laboratórios do CMEP e as aulas teóricas, na extinta escola municipal. Aos poucos, foram sendo criados laboratórios de informática também no espaço da escola, com algumas máquinas (quinze computadores) e aparelhos ar condicionado (quatro) adquiridos pelo próprio Instituto Federal e outros, incluindo também mobiliários, a partir de doação ou cessão obtida junto à Justiça Federal do município e região, visto que os recursos do Pronatec Bolsa Formação não podem ser utilizados para aquisição de material permanente.

Com a mudança na gestão municipal (MDB 2017-2020), a partir das eleições de 2016, o cenário de apoio da prefeitura mudou. O CR continua instalado no espaço da extinta escola, porém o prédio não conta mais com vigilante noturno, os serviços de manutenção ocorrem com atrasos e os laboratórios do CMEP foram desmontados em virtude do encerramento de suas atividades.

Na visita realizada em julho de 2017, a nova coordenadora ${ }^{119}$ do CR (CCR 2), que assumiu essa atividade em janeiro do mesmo ano, relata que o pátio com a grama recém cortada, estava sem jardinagem há mais de cinco meses ${ }^{120}$, embora tenha enviado vários ofícios solicitando esse serviço à prefeitura. Havia também algumas infiltrações no prédio que ainda não tinham sido reparadas, implicando em degradação do próprio patrimônio público do município. Alguns materiais, como lâmpadas e produtos de limpeza estavam sendo comprados com seus próprios recursos, pois não estavam mais sendo enviados pela prefeitura.

A situação mais difícil deu-se com o fechamento do $\mathrm{CMEP}^{121}$, onde ocorriam as aulas práticas do Curso Técnico em Confeitaria. A cozinha instalada nesse espaço contava com

\footnotetext{
${ }^{119}$ A nova Coordenadora do CR é professora da Instituição, formada em Letras Português e Espanhol e Mestra em Letras. Ingressou na Instituição em julho de 2010. Havia trabalhado como professora nos cursos do Pronatec no seu campus de lotação e com a saída do antigo coordenador foi contatada pela Reitoria, tendo em vista sua disponibilidade de atuar nessa cidade em virtude da proximidade de sua residência.

${ }^{120}$ A professora entrevistada ressalta que em dias de sol costuma levar os alunos para o pátio, visto que as aulas teóricas durante toda a tarde (em virtude de que não havia insumos para a prática desde o início da disciplina) são cansativas para os alunos, porém nem sempre as condições da grama permitiam: "por exemplo hoje, que você veio, a grama está bonita. Esses dias estava na cintura. Isso é responsabilidade da prefeitura" (Prof. Confeitaria). ${ }^{121} \mathrm{O}$ encerramento da oferta de qualificação profissional pela Prefeitura do município foi justificado, de acordo com a professora municipal que atuava no CMEP e que desempenha o cargo de Apoio acadêmico-administrativo no $\mathrm{CR}$, em razão da prioridade dos municípios, definida pela Constituição, na oferta das primeiras etapas da educação básica. $\mathrm{O}$ atendimento de outras etapas ou modalidades de educação pelos municípios pode ser realizado,
} 
equipamentos de uso profissional, como fogão, forno, batedeira, entre outros, os quais forneciam excelentes condições para o desenvolvimento das práticas de confeitaria.

Ao saber da previsão de encerramento das atividades do CMEP, a Coordenadora enviou ofício solicitando a preservação do espaço para conclusão das atividades do curso. No entanto, a solicitação não foi atendida e os materiais foram doados para uso nas cozinhas das escolas municipais. O CR conseguiu a doação de apenas um forno simples e um fogão, o que só foi possível em virtude de que a professora que atua no encargo de Apoio às atividades acadêmicas e administrativas no CR também atuava no CMEP e alertou a Coordenação do Centro sobre o que estava ocorrendo. Conforme relata a CCR 2:

\begin{abstract}
Na verdade, nós pedimos; eu pedi para a Secretária [de Educação] manter a cozinha para o Curso de Confeitaria, que nós precisávamos. Lá eles tinham forno industrial, fogão industrial, tudo industrial, era bem equipado. Mas ela faz de conta que não sabia, e distribuiu entre as escolas do município. Então, as [escolas] municipais estavam indo lá e pegando o que queriam e levavam para as suas escolas. A sorte é que a Ana ${ }^{122}$ era uma das que ficou por último lá no CMEP - foi a que fechou, apagou a luz, digamos assim, porque ela ficou acompanhando o fechamento, foi a última servidora do CMEP - ela conseguiu nos informar. Ela me disse: "Estão levando tudo, e nós vamos ficar sem nada aqui para o Curso da Confeitaria". Aí eu entrei com um pedido, novamente. Pedindo, então, que se eles não iriam manter a cozinha lá, que, pelo menos, nos passassem alguns equipamentos para a gente trabalhar aqui. Daí, de alguma forma, não sei quem autorizou - por que diz que a Secretária não foi, inclusive ela ficou indignada com quem fez a aprovação dessa liberação dos equipamentos - vieram alguns equipamentos para cá, mas não são muito bons, são o que sobrou, não é, do que tinha lá, o "piorzinho" que tinha ficado veio para cá. Então, nós não temos quase mais nada profissional, aqui tem um forno simples, o fogão é grande, profissional, mas, gás, a gente não tem. Tem um botijão e quando termina é uma briga para conseguir outro. Ficamos agora quase um mês sem gás, esperando. Então, os alunos, assim, agora vão enfrentar dificuldade... eles viram como que era o curso com uma estrutura boa (Entrevista CCR 2 IFFar, 2017).
\end{abstract}

Além de prejudicar as condições para a formação dos estudantes, esse fato gerou dificuldades também na contratação de docentes. De acordo com a professora entrevistada, que atuava no curso Técnico em Confeitaria, duas professoras, que também atuariam no curso, desistiram do trabalho após conhecerem os equipamentos disponíveis para as aulas práticas, durante a reunião de acolhida dos novos docentes. Essa desistência implica em chamar os demais classificados no Edital do processo seletivo ou então abrir novo processo seletivo, incidindo em atraso no andamento do curso.

desde que a sua prioridade esteja plenamente atendida, o que não estaria ocorrendo de acordo com a nova gestão municipal.

${ }^{122}$ Nome fictício da professora que desempenha o encargo de Apoio às atividades acadêmicas e administrativas no $\mathrm{CR}$. 
A Secretaria Municipal de Educação desconsiderou a contrapartida do município nas condições de funcionamento do Centro de Referência, ao desfazer-se dos equipamentos laboratório que estava sendo utilizado. A cooperação entre os entes federativos, apoiado na demanda local, que deu origem à instalação do CR e que tinha como perspectiva a futura instalação de um Campus do Instituto Federal, parece não ter sido assumida pela nova gestão.

Na visão da Coordenadora, não há interesse da Gestão municipal na consolidação do ensino público federal no município. Mas, há, por outro lado, uma forte defesa do sistema privado de educação profissional (Sistema S) e de ensino superior, que é tradicional na região, chegando a afirmar que:

Essa gestão, ela é uma gestão que defende o privado. O prefeito e a Secretária [de educação] eles defendem muito o Sistema S. Então, não sei o que eles acham, se acham que a gente vai competir com o Sistema S... Tem a ULBRA, a UPF, que têm muito apoio da prefeitura. O público aqui nunca se 'criou'. Teve a UERGS [Universidade Estadual do Rio Grande do Sul] no município e foi embora... Teve toda aquela disputa para receber uma extensão de Santa Maria [da UFSM], o município, na época, estava no páreo e perdeu (Entrevista CCR 2 IFFar, 2017).

Um fato que evidencia isso foi o não atendimento do Prefeito ao pedido de reunião com a Reitora do IFFar que esteve em atividade no CR, no início do ano letivo de 2017. No entanto, o Grupo de Trabalho constituído na gestão anterior que trabalhou no projeto voltado à implantação do Campus tem se mantido ativo e tenta convencer o prefeito da importância da instituição para o desenvolvimento da cidade e região. Conforme relato da Coordenadora:

\footnotetext{
A Reitora veio aqui numa reunião da Reitoria Itinerante, que ela faz em todos os Campus, para conversar com os prefeitos, com a comunidade acadêmica. O prefeito não recebeu a equipe da Reitoria. Então, ficou muito chato. Podia ter recebido, nem que fosse para ouvir. Mas nem isso. Ele não tem interesse nem em ouvir falar do Instituto. Mas até agora, essa semana, chegou uma senhora da Comissão [Grupo de Trabalho] aqui, estão tentando mudar o pensamento dele, não sei se vão conseguir, para agilizar, assim, o processo, refazer o processo, tentar movimentar aquele que está lá no MEC, para que as coisas comecem a andar novamente (Entrevista CCR 2 IFFar, 2017).
}

Com a mudança na gestão municipal, a pasta que atendia as necessidades de manutenção do Centro de Referência passou da Secretaria de Educação e Cultura para a Secretaria de Desenvolvimento e Mobilidade. Essa mudança, segundo a Coordenadora deu-se em virtude da postura da Secretária da Educação do período: "ela deixa bem claro que ela não tem interesse no Instituto e que não vai tirar nada da Secretaria dela para nós. E antes era a Secretaria dela que nos mantinha com os recursos do dia-a-dia. Daí foi trocado de Secretaria, foi para o Desenvolvimento" (Entrevista CCR 2 IFFar, 2017). 
No site da prefeitura, a partir de 2017, há apenas uma notícia relacionada à implantação de Campus do Instituto Federal, a qual registra reunião do Secretário de Desenvolvimento e Mobilidade do município com o Secretário Chefe da Casa Civil do governo do Estado Deputado Estadual natural do município - que teve entre os temas da pauta o pedido de apoio do governo estadual para a implantação de Campus do IFFar no município ${ }^{123}$.

Essa postura da Gestão Municipal encontra respaldo no seu próprio Plano de Governo, apresentado nas eleições, o qual não menciona o Centro de Referência entre os seus objetivos e metas. Ao tratar da meta de qualificação profissional, indica como estratégia a parceria com o Sistema S e o objetivo de criar uma escola aos moldes do SENAI, conforme extrato abaixo:

\section{3 - FORMAR E QUALIFICAR “MÃO DE OBRA” PROFISSIONAL \\ O nosso governo vai proporcionar pela FUNDETEC [Fundação Educacional e Tecnológica] de FORMA GRATUITA cursos de capacitação profissional em diversas áreas para atender a demanda de mão de obra do mercado. Faremos convênios com Sistema S - SENAI, SENAC, SENAR, SEST SENAT e o PRONATEC. A ideia é reformar o prédio do antigo SENAI e criar pela FUNDETEC o nosso SENAIZINHO (endereço) nas antigas instalações do SENAI, agora área do Município (grifos do original) (PLANO DE GOVERNO, 2016 ${ }^{124}$ ).}

Ao assumir a prefeitura, no entanto, a gestão eleita encaminhou projeto para extinção da FUNDETEC, com vistas no corte de gastos, e indicando que os serviços prestados por meio da Fundação serão doravante desenvolvidos por meio de parceria com o Sistema S: "A partir da extinção da FUNDETEC, a administração pretende contratar cursos gratuitos junto aos Sistema "S" dando prioridade aos membros de famílias cadastradas no Bolsa Família"125.

A negativa de apoio ao Centro de Referência do IFFar não significa, portanto, ausência de projeto da prefeitura para a educação profissional, mas divergências quanto ao tipo de educação profissional a ser ofertada. Identifica-se, nesse sentido, que a disputa por projetos de educação profissional que se observa nas políticas públicas federais de educação também está presente no nível local. Enquanto a gestão do Partido Democrático Trabalhista (PDT 20132016) trabalhava na ampliação das instituições e da oferta pública de formação profissional, embora mantendo diálogo e parceria também com o Sistema $S^{126}$, a Gestão do Movimento Democrático Brasileiro (MDB 2017-2020) prioriza a oferta e o desenvolvimento da educação profissional exclusivamente aos moldes do Sistema S. Soma-se a isso a mudança no governo

\footnotetext{
${ }^{123}$ Última consulta ao site do município foi realizada pela pesquisadora em 18 de maio de 2018 . A notícia destacada foi publicada em 27 de março de 2017, pela assessoria de comunicação da prefeitura.

$124 \mathrm{O}$ documento se encontra nos arquivos da pesquisa.

${ }^{125}$ Informação publicada no site da Prefeitura Municipal, em 25 de janeiro de 2017.

${ }^{126}$ Há uma notícia no site da Prefeitura, datada de junho de 2015, que registra o repasse de recursos da FUNDETEC para o SENAC com vistas na realização de cursos de qualificação profissional. Além disso, as instalações do CMEP também eram utilizadas para o desenvolvimento de cursos do Pronatec pelo SENAC.
} 
federal, após o Golpe de 2016, cujas ações colocam-se claramente contra a expansão das instituições públicas de educação profissional, a partir do contingenciamento do orçamento e indisposição para o diálogo, e o crescente avanço do setor privatista no âmbito federal.

Tais circunstâncias indicam que a parceria/cooperação entre os entes federativos, prerrogativa para a existência dos Centros de Referência, é um processo suscetível aos diferentes interesses e prioridades políticas locais de cada momento, configurando-se em uma prática quase que voluntária, sujeita ao arbítrio e à vontade política das partes envolvidas. Ao alterar a composição política na prefeitura, as condições que proporcionaram a criação e funcionamento do CR estão sendo alteradas, resultando em prejuízo para o bom funcionamento dos cursos e, consequentemente, para a formação dos estudantes.

Considerando que o apoio e o empenho da prefeitura são essenciais para a instalação de um Campus de Instituto Federal, a postura da atual gestão municipal indica que não haverá conjuntura política favorável nos próximos dois anos, pelo menos. Com base nessa realidade, pode-se apontar que a estratégia de criação de Centros de Referência como "embriões" de futuros campi parece não ter sido bem sucedida, representando uma expansão a partir de condições precárias e sem perspectivas de se consolidar enquanto instituição, o que poderá reforçar, nesse caso, o sentimento de que se tratou apenas do fechamento de uma instituição de ensino.

3.3.2 O desenvolvimento pedagógico dos cursos - (im)possibilidades frente ao atraso dos recursos

Em relação ao desenvolvimento pedagógico dos cursos, a principal limitação apontada pelos dois Coordenadores está relacionada à questão financeira do Programa. Tal questão diz respeito não apenas ao atraso no repasse dos recursos - embora seja apontado como o principal entrave - mas também à própria forma de contratação dos profissionais, que gera empecilhos ao trabalho pedagógico tanto dos docentes, quanto dos demais encargos.

O perfil do corpo docente, de acordo com o CCR 1, demanda um trabalho minucioso de acompanhamento e orientações de caráter administrativo-pedagógico (elaboração de planos de ensino, preenchimento de diário de classe, planejamento da prática profissional integrada, entre outros), visto que são profissionais que, na grande maioria, não possuem experiência no magistério e também não conhecem o fluxo acadêmico da instituição e do próprio Programa. De outro lado, devido ao número de alunos nos cursos, a carga horária dos profissionais da área pedagógica (supervisor e orientador) era insuficiente para atender a todas as necessidades e, ao 
mesmo tempo, as estratégias para a realização de seu trabalho encontravam-se limitadas, visto que o corpo docente permanecia no CR apenas nos horários das aulas. Assim, a maior parte das orientações tinha de ser repassada aos docentes por email, o que exigia desses profissionais a revisão de toda a documentação pedagógica a fim de verificar se as orientações haviam sido compreendidas e aplicadas corretamente. Conforme relata o Coordenador em relação ao corpo docente:

\begin{abstract}
Até alguns, para não dizer quase a maioria, entram no Pronatec para ter uma experiência docente para depois lograr êxito num concurso. Então boa parte dos professores já está no mestrado ou está entrando no doutorado, principalmente na área dos cursos técnicos, eles têm essa visão; alguns, outros não. Em razão de um nível alto de desemprego, eles optam por dar aula, fazer esses, como eles mesmos chamam, "bicos formais" e aí nós temos uma dificuldade grande, tanto naqueles que estão se preparando para uma carreira docente, tanto aqueles que são bacharéis de áreas técnicas que nunca entraram numa sala de aula, mas por questão de necessidade vem para o Pronatec. Então tem uns profissionais que tem dificuldade em transmitir conteúdo e conhecimento para os alunos e até para o preenchimento do caderno de chamada. Apesar de todas as orientações que a gente dá, encaminha os PPCs, faz o relatório das atividades que tem que fazer através da supervisão, encaminhamos tudo via e-mail, e mesmo assim têm dificuldade na execução. Lançamento de notas, chamadas, as frequências... A gente tem que fazer um acompanhamento diário... (Entrevista CCR 1 IFFar, 2016).
\end{abstract}

A partir de agosto de 2016, o CR passou a contar com apenas um profissional na coordenação pedagógica dos cursos, pois os encargos de supervisor e orientador foram suprimidos em virtude do baixo número de alunos. A professora - denominada aqui como Prof. Ana - atua no encargo de Apoio às Atividades Acadêmico-administrativas com carga horária de 20 horas e possui mais de 30 anos de experiência no Magistério, o que, juntamente com a jornada maior de trabalho, tem contribuído para um melhor acompanhamento das necessidades pedagógicas dos cursos. No entanto, o funcionamento do Programa, quanto à carga horária dos docentes e ao atraso no pagamento das bolsas, impõe alguns entraves.

De acordo com Ana, seu trabalho concentra grande tempo na "parte burocrática", incluindo "toda a parte de elaboração de calendário, os diários de classe, as efetividades, os pontos (...) toda a parte burocrática que envolve o trabalho pedagógico, na verdade. Eu acompanho mais a execução dessas tarefas, desses preenchimentos que eles têm que desenvolver" (Entrevista Prof. Ana CR IFFar, 2017). Em relação às dificuldades no desenvolvimento desse trabalho, Ana aponta as constantes mudanças no corpo docente e impossibilidade de realização de reuniões/encontros:

Eu não sei se é porque eu venho de uma escola que existia uma rotina, que se desenvolvia mais a longo prazo.... Eu tenho muita dificuldade, os nossos profissionais vêm e desenvolvem 20, 40 horas e se vão. Os Cursos do Pronatec são por disciplinas, 
e aí o profissional vem e desempenha aquelas 20 horas, ele não estabelece um vínculo, nem com a instituição, nem com os alunos. Essa dificuldade, a gente tem. E isso gera, também, uma demanda muito grande nas questões administrativas, de tempo, de gestão dessas questões administrativas, porque, às vezes, até o entendimento dessas rotinas se torna mais difíceis. Nós temos dificuldade de encontro com esses profissionais, de acompanhamento pedagógico efetivo, de planejamentos, Sabe? Os professores, muitos profissionais têm essa bagagem de escola, mas essa rotina nossa é diferenciada, sem contar esses profissionais que não têm nada dessa visão pedagógica, nada da questão didática (Entrevista Prof. Ana CR IFFar, 2017).

O perfil dos docentes pode ser melhor visualizado a partir do questionário que foi respondido pelos profissionais que atuaram no CR entre 2014 e julho de 2017. A amostra, que compreende 15, dos 28 docentes desse período, caracteriza-se por ser predominantemente feminina $-80 \%$ mulheres - e jovem $-60 \%$ com idades entre 20 e 35 anos. Todos são professores externos à instituição, sendo um deles professor concursado em Instituto Federal.

Em relação à formação, todos possuem ensino superior e a maioria cursou também pósgraduação. Quanto à graduação, 33\% é formado em curso de licenciatura; 33\% possui bacharelado e curso de formação pedagógica em nível de graduação; $27 \%$ possui apenas bacharelado; e $7 \%$ é formado em curso superior de tecnologia. Desse grupo, $77 \%$ possui pósgraduação concluída, sendo que $55,5 \%$ são mestres e $45,5 \%$ especialistas, e, ainda, dois são estudantes de doutorado.

Observa-se que o corpo docente, embora jovem, é bastante qualificado. Em relação à experiência no magistério, o percentual que já havia estado frente a uma sala de aula também é significativo: $47 \%$ tem experiência em cursos de educação profissional, $20 \%$ tem experiência no magistério da educação básica e 33\% exercia a docência pela primeira vez no Pronatec.

Todos os 15 docentes realizavam outra atividade além das aulas no Pronatec, sendo que quase a metade (47\%) trabalhava 40h semanais. Entre os que trabalhavam 40h semanais, 3 são professores da educação básica, o que pode representar uma jornada de até $56 \mathrm{~h}$ de atividade de ensino na semana, se for considerada a carga horária máxima semanal de aulas em cursos do Pronatec $^{127}$.

Tabela 31 - Corpo Docente do CR IFFar - Carga horária e atividade além do Pronatec

\begin{tabular}{lrrrr}
\hline \hline \multirow{2}{*}{ Tipo de Atividade } & \multicolumn{3}{c}{ Carga Horária } & \\
\cline { 2 - 4 } & 20h semanais & 30h semanais & 40h semanais & Total \\
\hline Autônomo e estudante de doutorado & 0 & 0 & 1 & 1 \\
Autônomo(a) & 0 & 1 & 0 & 1 \\
Estudante de Doutorado & 1 & 0 & 0 & 1 \\
Nutricionista clínica & 2 & 0 & 0 & 2 \\
Professor de educação básica & 1 & 0 & 3 & 4
\end{tabular}

${ }^{127}$ Conforme resolução do FNDE sobre a Bolsa Formação, a carga horária máxima do docente deverá ser de 16 horas semanais. 


\begin{tabular}{llllr} 
'Professor de educação profissional & 0 & 0 & 1 & 1 \\
Professor no ensino a distância & 1 & 0 & 0 & 1 \\
Trabalho na área de gestão/administração & 1 & 1 & 1 & 3 \\
Trabalho no comércio & 0 & 0 & 1 & 1 \\
\hline Total & 6 & 2 & 7 & 15 \\
\hline
\end{tabular}

Fonte: elaborada pela autora com base nas respostas do questionário aplicado aos docentes (2017).

Nesse contexto, apesar de os editais de seleção preverem, entre suas atribuições, a participação em reuniões promovidas pela coordenação, é possível compreender a dificuldade relatada pelo CCR 1 na realização de reuniões ou conversas com os docentes:

Eles têm aquela carga horária para executar, então eles sempre chegam na hora da aula e nós temos só a possibilidade de conversar com eles no intervalo. A gente oferece um café, eles vêm aqui, conversam e depois da aula, das cinco horas em diante, muitos já têm compromisso às seis, ou porque já tem que dar aula em outro lugar... (Entrevista CCR 1 IFFar, 2016).

Ao mesmo tempo, em decorrência dos atrasos no pagamento da bolsa ao docente, ocasionado pelo atraso na descentralização dos recursos do Programa pelo Governo Federal, a equipe do CR sente-se constrangida em cobrar dos docentes a presença para além da carga horária que é remunerada, pois receia que os professores desistam do trabalho:

Nós temos algumas limitações de exigências com eles né. Em função dos atrasos que ocorrem, a gente não tem questões morais de exigir, "olha né", apesar de o compromisso ser esse, fica com receio de perder o professor porque dá um trabalho enorme para conseguir outro e por causa que a seleção demora mais um mês para acontecer e aí não preenche as vagas... (Entrevista CCR 1 IFFar, 2016).

Em razão da não regularidade do pagamento e da própria fragilidade do regime de contratação dos docentes, ocorrem muitas interrupções de contrato durante o desenvolvimento das disciplinas. Conforme descreve o CCR 1, essas ocorrências têm sido constantes:

\footnotetext{
Nós tivemos mês retrasado, em agosto [de 2016], uma baixa de um profissional só largar quatro disciplinas em três turmas diferentes, tarde e noite. E aí domingo agora recebi pelo WhatsApp um professor dizendo que desistiu porque ele vai conseguir um outro trabalho. Então assim, essas interrupções não são programadas e não são previamente organizadas, são muito de improviso. Domingo te avisa que segundafeira não vai mais trabalhar e tu tem que avisar as turmas, tem que avisar a equipe, tem que ver os editais, quem que é o próximo, tentar contatar. Tu perdes, se tu tens [professor selecionado] no banco, pelo menos uma semana do teu cronograma. E aí começa o desânimo dos alunos: "o professor não vem mais, não vai ter aula, a gente não recebe" e todo dia é isso (Entrevista CCR 1 IFFar, 2016).
}

Essas situações geraram um grande atraso na conclusão dos cursos técnicos, visto que nem todas as disciplinas de cada semestre puderam ser desenvolvidas de forma concomitante, 
seja por desistência de docentes ou pelo fato de o orçamento não ter sido liberado para a contratação dos docentes. Para que os alunos não perdessem o contato com a instituição, o que poderia contribuir para o abandono, a coordenação fez o possível para que as atividades não parassem totalmente: “ele [o curso] fica pipocando. Então, a gente faz duas tardes, uma tarde, meia-tarde, e assim vai indo...” (Entrevista Prof. Ana CR IFFar, 2017).

Para suprir as lacunas de horário em razão da desistência de professores ${ }^{128}$, foram adiantadas disciplinas que já possuíam docente selecionado e/ou realizada a oferta de disciplinas de forma condensada. Esta última estratégia, além de visar o não abandono dos estudantes, também visava atender a necessidade dos docentes, pois muitos se deslocavam de outras cidades e isso reduziria o número de viagens, contribuindo para a não desistência por parte do professor. Uma disciplina de 60 horas/aula, por exemplo, poderia ser concluída em menos de 4 semanas, considerando a oferta de $4 \mathrm{~h} / \mathrm{a}$ por dia e o limite de $16 \mathrm{~h} / \mathrm{a}$ semanais para o professor.

A professora entrevistada, que atuou no curso Técnico em Confeitaria, desenvolvia suas disciplinas de forma condensada. Do ponto de vista pessoal, essa prática otimizava suas viagens, tanto em relação ao tempo de deslocamento, quanto aos recursos ${ }^{129}$, mas receava, ao mesmo tempo, a qualidade no aproveitamento dos estudos pelos alunos. Na sua avaliação,

Tem a parte boa e a parte ruim. Para mim, em especial, é interessante, porque eu não
sou daqui, então, é uma forma de ficar mais fácil, sem dúvida. É um pouco mais
complicado a parte de planejamento, porque você acabou hoje, depois na semana que
vem... não, é amanhã! Então, qualquer coisa que tem pendente, ou que já tem que
pensar, ou que tem que descongelar não sei o que... Eu estava no laboratório, antes:
meu Deus, como é que a gente vai fazer? Porque tem que descongelar, e daí no outro
dia eu tenho que estar com todo o material descongelado, e já pensando nisso e
naquilo. Tem tudo isso. Mas, para eles, creio que eles andaram bem desmotivados,
pelo fato de estarem um longo tempo sem aula, então, eles estão gostando. Eu acho
que tem a parte boa que faz uma sequência na cabeça e é mais fácil pelo curto período
para acompanhar. Mas, ao mesmo tempo, é pouco tempo fixando, reforçando, alguma
coisa. Então, eu não sei, porque, literalmente, sendo 04 horas, por dia, 40 horas a
disciplina, em 10 dias, acabou a disciplina! O tempo é reduzido. Então, tem isso que
eu não sei como que vai ser, não é? A princípio, parece, que o acompanhamento é
mais fácil. Mas e a fixação? Lembrar a aprendizagem a longo prazo? Eu não sei como
é que vai ser... (Entrevista Prof. Confeitaria CR IFFar, 2017).

${ }^{128}$ É importante ressaltar que a falta de professores não se dá pela ausência de candidatos no processo seletivo e sim após o contato com a instituição, seja pelo atraso no pagamento, pelas condições de trabalho ou mesmo por questões pessoais.

${ }^{129}$ A professora havia feito o cálculo de suas despesas em transporte, caso tivesse que ir todas as semanas ao CR durante o semestre, em relação ao valor da bolsa: "quando eu fiz os meus cálculos, se eu fosse toda semana e voltasse para Santa Maria, não fazendo condensado, a diferença, assim, era zero, não entrava nada quase, ficava elas por elas. Então, o fato de ter condensado, para mim, foi muito bom nesse sentido, porque senão ia ter apertado bastante. Sem contar que é longe, quatro horas de viagem, e a estrada é 'maravilhosa'..." (Entrevista Prof. Confeitaria CR IFFar, 2017). 
Por outro lado, a realização de disciplinas de forma condensada levou professores selecionados a desistirem do trabalho, em virtude de que isso reduziria o tempo de exercício da docência, prejudicando o comprovante de exercício do magistério que seria utilizado para prova de títulos em concurso público. A professora de Confeitaria, por exemplo, desenvolveu as suas três disciplinas ${ }^{130}$ (120 horas/aula) em 12 semanas de trabalho, o que equivale a 3 meses letivos.

$\mathrm{O}$ fato de algumas disciplinas terem sido adiantadas, em virtude da disponibilidade de docentes naquele momento, comprometeu, em alguns casos, a sequência do currículo. $\mathrm{O}$ Professor do Curso Técnico em Informática para a Internet, entrevistado, relata que ao iniciar suas atividades identificou que duas disciplinas que deveriam ter sido desenvolvidas em sequência estavam sendo ofertadas ao mesmo tempo, comprometendo o processo de ensino e aprendizagem: Eu iniciei, no meu cronograma, trabalhando com uma disciplina chamada Laboratório
de Banco de Dados, que é uma disciplina de $3^{\circ}$ Nível. E quando eu comecei a trabalhar
com os alunos, eles me falaram: "Mas, professor, o Professor Márcio [nome fictício]
está trabalhando com o Banco de Dados, também". E eu: "Como assim, trabalhando
com o Banco de Dados? Vocês não tiveram Banco de Dados ainda?" - "Não, estamos
tendo agora". Então, devido à história do curso, eles estavam tendo, simultaneamente,
uma disciplina de $2^{\circ}$ Nível, Banco de Dados, e uma de $3^{\circ}$ Nível, Laboratório de Banco
de Dados, e aquilo não ia dar certo. Daí nós conversamos bastante, eu, o Márcio e a
Coordenação, e fizemos um ajuste nos horários, para que ele pudesse concluir a
disciplina de Banco de Dados, e, posteriormente, eu iniciar com o Laboratório de
Banco de Dados, para ter uma sequência lógica (Entrevista Prof. Informática CR
IFFar, 2017).

Outra questão relatada pelos professores é a impossibilidade de contato com os docentes das disciplinas já lecionadas e mesmo daquelas que estão sendo ofertadas paralelamente. Em virtude de o contrato de trabalho ser por disciplina, dificilmente o professor mantém vínculo com o CR por mais de um semestre, e quando estão lecionando, os professores atuam em dias diferentes, o que impossibilita o encontro entre eles. "Eu não encontrei nenhum professor ainda do curso de Informática. O que é um pouco estranho, não é? Aqui, no meu campus, por exemplo, eu encontro com todos os colegas, a gente discute: "O aluno tal, tal perfil. Não veio na aula. Não veio na minha. Está faltando tal base" (Entrevista Prof. Informática CR IFFar, $2017)^{131}$.

Para o desenvolvimento das práticas pedagógicas integradas, que, como se viu no item 3.2 deste Capítulo, fazem parte do currículo dos cursos técnicos, os professores tentam

\footnotetext{
${ }^{130}$ Uma disciplina era do $2^{\circ}$ e duas eram do $3^{\circ}$ semestre do curso. Assim, além de condensadas, duas disciplinas foram adiantadas.

${ }^{131}$ Esse profissional é professor em um Campus de IF de cidade vizinha.
} 
encontrar alternativas para a realização do planejamento, em face da impossibilidade de encontros presenciais. No curso de Confeitaria, as professoras das disciplinas que iriam desenvolver a PPI têm realizado a maior parte do planejamento por meio de email e WhatsApp:

\begin{abstract}
Tendo em vista que ela vem só na quarta, e eu estou todos os outros dias, menos na quarta, a gente, atualmente, está combinando tudo via e-mail, Whats, enfim... Mas, a gente já combinou, para a semana que vem, tentar se reunir para fechar, porque, às vezes, tem detalhes que por esses meios a gente não consegue (Entrevista Prof. Confeitaria CR IFFar, 2017).
\end{abstract}

Em razão do atraso do cronograma dos cursos, muitos materiais perecíveis adquiridos para as aulas práticas ultrapassaram o prazo de validade, como no caso dos insumos para o curso técnico em Confeitaria. Esses produtos são comprados via licitação, o que, segundo a CCR 2, é um processo demorado e depende da previsão orçamentária do Pronatec para ser iniciado. Em razão disso, quando o ano letivo de 2017 iniciou não haviam insumos disponíveis para a realização das práticas. A professora do curso de Confeitaria relata que teve de atrasar o andamento da disciplina, em virtude da ausência dos materiais:

\begin{abstract}
(...) o material para a aula prática não chegou ainda, e, teoricamente, é muito mais a prática que nós temos que investir... Tanto que eu não planejava ter quase aula teórica, assim, apenas o básico, e no mais fazer tudo em aula prática, junto a teoria com a prática, que eu acho que eles aprendem muito mais, e ficam bem mais interessados. Mas é a situação que nós temos agora, então, estamos esperando. Eu preferi ir atrasando a disciplina, pedi até para postergar as aulas que eu daria nessa semana, porque senão a gente dava quase a metade da disciplina em teoria, e iria ficar só a metade para a prática, sendo que tem muita coisa prática. Então, a gente atrasou um pouco para poder fazer mais as práticas, propriamente, para poder chegar o material. Os alunos, eu acho que ficam bem chateados com isso, porque desde o começo eles falavam: "Ai, não tem material ainda? Ai, como sempre. Ai, não sei o que" ... (Entrevista Prof. Confeitaria CR IFFar, 2017).
\end{abstract}

Observa-se que as condições proporcionadas pelo Programa não possibilitam o pleno desenvolvimento da proposta pedagógica dos cursos, que seguem a política de ensino do IFFar. Embora o Programa não apresente, explicitamente, uma concepção pedagógica de educação profissional, delegando autonomia às instituições ofertantes, seu modus operandi não favorece o desenvolvimento de propostas pedagógicas que visam à integração curricular.

3.3.3 "Aprendemos melhor a história do Brasil do que na escola": índices de evasão e aproveitamento

A evasão nos cursos do Pronatec desenvolvidos pelo CR foi bastante acentuada, em especial nos cursos técnicos. Entre os motivos para a evasão, identificados por meio das 
entrevistas com a Coordenação do CR, encontram-se: o atraso no pagamento da assistência estudantil, a falta de professores e, em decorrência, o atraso do curso - nos cursos técnicos concomitantes os estudantes terminaram o ensino médio antes do técnico, assim, alguns ingressaram no ensino superior; alguns meninos com mais de 18 anos foram prestar serviço militar em outras cidades; e outros precisaram ingressar no mercado de trabalho, o que impossibilitou a continuidade do curso, visto que a oferta se dava à tarde -, a não identificação com o curso e o ingresso no mercado de trabalho. Na tabela 32 é possível visualizar o atraso na conclusão, especialmente nos cursos técnicos, e o percentual de concluintes dos cursos Pronatec Bolsa Formação desenvolvidos no CR.

Tabela 32 - Cursos Pronatec Bolsa Formação do CR IFFar - atraso e percentual de concluintes

\begin{tabular}{|c|c|c|c|c|c|c|c|c|}
\hline Curso & C.H. & Turno & Início & $\begin{array}{l}\text { Duração } \\
\text { Prevista }\end{array}$ & $\begin{array}{l}\text { Duração } \\
\text { total* }\end{array}$ & Ingres.** & Concl. & $\%$ \\
\hline $\begin{array}{l}\text { Técnico em Confeitaria - } \\
\text { Concomitante }\end{array}$ & 800 & Tarde & $23 / 11 / 2015$ & 3 semestres & 2 anos & 24 & 04 & 16,5 \\
\hline $\begin{array}{l}\text { Técnico em Informática - } \\
\text { Subsequente }\end{array}$ & 1.000 & Noite & $06 / 10 / 2014$ & 3 semestres & 2 anos & 28 & 08 & 28,5 \\
\hline $\begin{array}{l}\text { Técnico em Informática para } \\
\text { Internet - Concomitante }\end{array}$ & 1.000 & Tarde & $23 / 11 / 2015$ & 3 semestres & 2 anos & 26 & 04 & 15,5 \\
\hline $\begin{array}{l}\text { Técnico em Logística - } \\
\text { Subsequente }\end{array}$ & 800 & Noite & $31 / 08 / 2015$ & 3 semestres & $\begin{array}{l}2 \text { anos e } \\
4 \text { meses }\end{array}$ & 23 & 09 & 39 \\
\hline $\begin{array}{l}\text { Técnico em Secretaria Escolar - } \\
\text { Concomitante }\end{array}$ & 1.200 & Tarde & $23 / 11 / 2015$ & 4 semestres & 2 anos & 24 & 07 & 29 \\
\hline Confeiteiro - FIC MMil & 200 & Tarde & $16 / 11 / 2015$ & Não há previsão & 4 meses & 20 & 09 & 45 \\
\hline $\begin{array}{l}\text { Costureiro de Máquina e } \\
\text { Overloque - FIC MMil }\end{array}$ & 200 & Tarde & $16 / 11 / 2015$ & Não há previsão & 7 meses & 20 & 14 & 70 \\
\hline Manicure e Pedicure - FIC MMil & 200 & Tarde & $22 / 10 / 2014$ & Não há previsão & 3 meses & 29 & 15 & 52 \\
\hline Manicure e Pedicure - FIC MMil & 200 & Tarde & $09 / 11 / 2015$ & Não há previsão & 7 meses & 20 & 09 & 45 \\
\hline Agricultor Orgânico - FIC & 160 & Noite & $31 / 10 / 2016$ & Não há previsão & 5 meses & 30 & 09 & 30 \\
\hline \multicolumn{6}{|c|}{ Total } & 244 & 88 & 36 \\
\hline
\end{tabular}

* Calculada com base na data de início registrada no SISTEC e a data de conclusão informada pelo CR. No caso dos cursos FIC é possível que as aulas tenham iniciado após a data de registro no SISTEC.

** Nos cursos técnicos concomitantes e subsequentes o total de vagas ofertadas em cada turma era 30. Nos cursos FICs, apenas uma vaga ficou ociosa.

Fonte: elaborada pela autora com base em dados do SISTEC e coletados junto ao CR (2017).

O maior percentual de concluintes encontra-se nos cursos FIC, 47,5\%, enquanto que nos cursos técnicos apenas 25,6\% concluíram o curso com aproveitamento. Entre os cursos técnicos, o menor índice de conclusão se deu na forma concomitante $-20 \%$. Nestes cursos, além do atraso na sua conclusão em relação ao ensino médio, que contribuiu para a evasão, a dificuldade em conciliar os estudos em duas escolas e a própria dúvida dos estudantes em relação à profissão a seguir, foram elementos apontados pela CCR 2 como fatores de evasão.

Apesar do alto percentual de evasão, observou-se que a coordenação realizou verdadeiros "malabarismos" para tentar impedir um número ainda maior de abandono nos cursos. Em razão dos períodos em que os cursos não tiveram aula em todos os dias da semana, 
por falta de professor, uma aluna teve de interromper o contrato particular de transporte que utilizava para se deslocar de sua cidade até o CR, visto que estava pagando o serviço para cinco dias na semana e utilizando apenas um ou dois dias, e ao retomar o fluxo normal de aulas não conseguiu mais vaga no transporte para todos os dias da semana; outra conseguiu emprego como caixa de supermercado, com turno de trabalho que iniciava uma hora antes do término do turno de aulas do seu curso. Com vistas a impedir que estas estudantes não abandonassem o curso, a coordenação viabilizou junto aos professores outras formas de acompanhamento das aulas compreendendo atividades a distância nos horários ou dias em que não era possível a participação presencial das estudantes, sobrepondo o aproveitamento dos estudos (aprendizagem) à frequência. Conforme relata a CCR2: "E aí a gente tem que sugerir ao professor que não reprove por frequência, que deixe próximo a $75 \%$ de frequência, mas que não reprove. Sabe, até é chato falar isso, esse tipo de proposta, mas se tu não fizer, tu perde a maioria dos alunos" (Entrevista CCR 2 IFFar, 2017).

Nos períodos de atraso dos recursos, a própria coordenação, tanto o CCR 1 quanto a CCR 2, relataram utilizar de seus próprios recursos para viabilizar o transporte para a realização de visitas técnicas em empresas/instituições do município ou em municípios vizinhos. A alimentação dos estudantes no intervalo e até as passagens de ônibus urbano para o deslocamento dos alunos, várias vezes, foi bancada pela equipe da coordenação: “A gente comprava a passagem do nosso bolso e pagava, dava para eles, porque a gente via que não tinham condições mesmo. Então toda semana era trinta, quarenta reais em passagens que a gente dava para eles porque realmente não tinham condições” (Entrevista CCR 1 IFFar, 2016).

O perfil econômico dos estudantes do CR, a partir da amostra que respondeu ao questionário, revela que mais de $80 \%$ possuem renda familiar entre 1 e 2 salários mínimos, da qual dependem entre 3 e 5 pessoas. Isso demonstra a importância da assistência estudantil para a realização do curso e o impacto que os atrasos representaram nas condições para a sua continuidade.

Na visão de 16 estudantes em curso no primeiro semestre de 2017, que responderam ao questionário, a falta de professores, atraso no repasse da assistência estudantil e a insuficiência de aulas práticas foram aspectos negativos no desenvolvimento dos cursos. De acordo com um aluno do Curso Técnico em Logística, "a falta de professor foi o que impulsionou ainda mais a defasagem de alunos, pois houve épocas que ficamos semanas sem aulas e isso levou vários alunos a procurarem outras instituições para se profissionalizarem".

Ao mesmo tempo, entre os aspectos positivos dos cursos, os estudantes destacaram a atuação dos docentes, a contribuição do curso para a escolha profissional, o aprendizado 
adquirido e as novas amizades. Dois estudantes do curso Técnico em Secretaria Escolar destacaram, ainda, a contribuição do curso para a compreensão dos conteúdos do ensino médio: “Aprendemos melhor a história do Brasil do que na escola, sem contar que a qualificação de cada professor foi muito boa para as aulas, pois cada um contribuiu na formação dos alunos", e ainda, o curso "contribuiu muito na época da escola" (Estudantes CT em Secretaria Escolar, CR). Esses relatos apontam para a importância da integração entre os conhecimentos científicos e técnicos na formação em nível médio, que poderia ser melhor desenvolvido por meio de cursos técnicos integrados ao ensino médio, visto que a forma concomitante ao ensino médio, ofertada por duas instituições, dificulta o acompanhamento por parte dos estudantes, especialmente do aluno-trabalhador, além de não permitir a integração curricular.

\subsection{Unidade de desenvolvimento dos Cursos do Pronatec Bolsa Formação II - Campus do IFFar}

O Campus do IFFar onde foi realizada a investigação situa-se na região central do Estado, sendo um dos campi que fazem parte do Instituto desde a sua criação. O município em que está localizado possui pouco mais de 20 mil habitantes, dos quais 82,2\% vivem no meio urbano (IBGE, 2010).

A maior parte da economia local é oriunda da produção agropecuária e do setor de serviços e comércio, tendo contribuído com 34,7\% e 50,3\% do PIB, respectivamente, em 2013 (IBGE, 2013). O espaço rural, marcado historicamente pelas grandes propriedades de pecuária extensiva oriundas da ocupação portuguesa por meio de "sesmarias" (MOREIRA, 2008), sofreu modificações a partir dos anos 1980 com a criação de assentamentos de Reforma Agrária. A agricultura familiar, assim como a população no campo, foi ampliada significativamente a partir de três assentamentos de reforma agrária, que ocupam em torno de 5.500 hectares $-2,9 \%$ da área rural - e correspondem juntos a $29 \%$ da população rural do município. Esses assentamentos foram criados nos anos de 1989, 1996 e 1999, a partir da desapropriação de fazendas de criação de gado improdutivas (INCRA, 2017).

Embora seja significativo o número de produtores rurais que se enquadram na categoria de agricultura familiar, representando $65,4 \%$ dos produtores, acessam apenas $12,25 \%$ da área produtiva, o que indica ainda a predominância de grandes propriedades ${ }^{132}$ (IBGE, 2006). A agricultura familiar atua na produção de leite, fruticultura, horticultura, soja, milho, entre

${ }^{132}$ As propriedades de agricultura familiar possuem em média uma área de 28 hectares, enquanto a média nas grandes propriedades é de 378 hectares. 
outros, e também no beneficiamento de parte de seus produtos por meio de agroindústrias familiares. Grande parte desses produtos são comercializados no próprio município por meio de feiras, venda direta e/ou compras institucionais ${ }^{133}$. Já nas grandes propriedades, a produção se concentra no cultivo de soja, especialmente por meio da agricultura empresarial ${ }^{134}$, e gado de corte.

O Índice de Desenvolvimento Humano (IDH) do município é 0,716, ocupando a $238^{a}$ posição, entre os 497 municípios do Estado, e o índice Gini é 0,599, o que indica uma acentuada desigualdade social. De acordo com o último Censo, entre a população economicamente ativa, 59,5\% são empregados - recebem em média 2,2 salários mínimos - 38,8\% trabalham por conta própria e 1,7\% são empregadores. Dos trabalhadores, pouco mais da metade são contribuintes de previdência social $(51,8 \%)$ - entre os moradores do meio rural esse número cai para $34 \%$ e a grande maioria mora no meio urbano $-78 \%$.

Quanto ao tipo de ocupação, destacam-se as ocupações elementares, que abrigam aproximadamente um quarto dos trabalhadores, o setor da agropecuária, que abrange quase $20 \%$, e o setor do comércio, com 10,52\% da população ativa. Na tabela 33 pode-se visualizar os demais grupos de ocupação e o respectivo percentual de trabalhadores.

Em relação à escolaridade, em 2010, a taxa de analfabetismo correspondia a 5,7\% da população com 15 anos ou mais. Já entre população com 25 anos ou mais, 57,21\% não possuía instrução ou tinha o ensino fundamental incompleto, 16,44\% possuía o ensino fundamental completo ou ensino médio incompleto, $17,9 \%$ possuía o ensino médio completo ou ensino superior incompleto e $8,5 \%$ possuía ensino superior completo, segundo os dados do último Censo Demográfico (IBGE, 2010). Comparando a escolaridade da população ativa e inativa, observa-se que o percentual de pessoas economicamente ativas em cada faixa de escolaridade aumenta à medida que cresce o grau de escolaridade, o que indica que entre os $6,2 \%$ da população desempregada, em 2010, encontravam-se níveis de escolaridade mais baixos ou mesmo nenhuma instrução.

A educação básica é atendida por meio do sistema público municipal (05 escolas de ensino fundamental e 06 escolas de educação infantil) sistema público estadual (12 escolas de

\footnotetext{
${ }^{133}$ O campus do IFFar situado nesse município lançou Edital, em 2018, para aquisição de alimentos da agricultura familiar a serem servidos aos estudantes no refeitório da instituição por meio dos Programas PAA CI (Programa de Aquisição de Alimentos Compra Institucional) e PNAE (Programa Nacional de Alimentação Escolar). Com isso, $90 \%$ dos alimentos servidos aos estudantes são oriundos da agricultura familiar local.

${ }^{134}$ De acordo com Moreira (2008), nos grandes latifúndios há uma alternância entre a produção de gado de corte e a produção de soja. Administrados, geralmente, por herdeiros de grandes proprietários que não vivem no meio rural, a exploração da terra se dá por meio da criação de gado de corte no período do inverno e do arrendamento da terra para sojicultores, no período do verão.
} 
ensino fundamental e 02 escolas de ensino médio), do Campus do Instituto Federal Farroupilha, que oferta 03 cursos técnicos integrados ao ensino médio, sendo um deles na modalidade de educação de jovens e adultos, uma escola privada de ensino fundamental, uma escola privada de educação infantil e duas escolas filantrópicas, uma de educação infantil e outra de educação especial. A educação profissional é ofertada pelo Campus do IFFar e também por uma escola estadual de ensino médio, que oferta um curso técnico subsequente. Em relação ao ensino superior, além dos cursos ofertados pelo próprio IFFar, o município situa-se a $60 \mathrm{~km}$ da cidade de Santa Maria, que se constituiu em um polo universitário que congrega uma universidade federal (Universidade Federal de Santa Maria) e outras seis instituições de ensino superior privadas.

Tabela 33 - População economicamente ativa por grupos de ocupação - Município Campus do IFFar

\begin{tabular}{l|r}
\hline \hline \multicolumn{1}{c}{ Grupos de ocupação } & \multicolumn{1}{c}{$\%$} \\
\hline Diretores e gerentes & 2,26 \\
Membros das forças armadas, policiais e bombeiros militares & 0,41 \\
Ocupações elementares* & $\underline{24,08}$ \\
Operadores de instalações e máquinas e montadores & 6,72 \\
Profissionais das ciências e intelectuais & 7,72 \\
Técnicos e profissionais de nível médio & 4,80 \\
Trabalhadores de apoio administrativo & 4,86 \\
Trabalhadores dos serviços, vendedores dos comércios e mercados & $\underline{10,52}$ \\
Trabalhadores qualificados da agropecuária, florestais, da caça e da pesca & $\underline{19,82}$ \\
Trabalhadores qualificados, operários e artesãos da construção, das artes mecânicas e outros ofícios & 8,70 \\
Ocupações mal definidas & 10,10 \\
\hline Total & 100,00 \\
\hline \hline
\end{tabular}

* Compreende os trabalhadores dos serviços domésticos e trabalhadores de limpeza em geral.

Fonte: Organizada pela autora com base nos dados do Censo Demográfico (IBGE, 2010).

O Campus situado nesse município atende também estudantes oriundos de municípios vizinhos, os quais guardam semelhança em relação ao perfil socioeconômico. Outros dois municípios atendidos por meio dos cursos do Pronatec Bolsa Formação também possuem assentamentos rurais, criados entre os anos de 1988 a 2002. Um deles possui 08 assentamentos, abrigando 656 famílias em uma área de quase 12 mil hectares, e o outro abriga 637 famílias em 17 assentamentos que juntos perfazem o total 11 mil hectares, aproximadamente (INCRA, $2017)^{135}$. Estas pequenas propriedades rurais coexistem no âmbito de uma estrutura agrária marcada pelas grandes propriedades baseadas na monocultura.

Com base nessa realidade, observa-se que os eixos tecnológicos de atuação do Campus em seus cursos de educação profissional regulares vêm ao encontro dos arranjos produtivos

135 Na Tabela 34, que apresenta os cursos do Pronatec Bolsa Formação, esses municípios correspondem aos munícipios 2 e município 1 , respectivamente. 
locais. O Campus oferta três cursos técnicos integrados ao ensino médio, Técnico em Agropecuária, Técnico em Informática e Técnico em Comércio, sendo esse último na modalidade Proeja, dois cursos técnicos subsequentes, Técnico em Agropecuária e Técnico em Alimentos, e um curso Proeja FIC em Assistente em Operações Administrativas integrado ao ensino fundamental, o qual é desenvolvido em parceria com o sistema municipal de ensino. Entre os quatro eixos ofertados, a maior parte das matrículas são desenvolvidas em cursos do eixo de Recursos Naturais (45,5\%), seguido pelo eixo de Gestão e Negócios (32,75\%). Os eixos de Informação e Comunicação e Produção Alimentícia ofertam 14,4\% e 7,35\% das matrículas, respectivamente (Plataforma Nilo Peçanha, 2018). Quanto ao ensino superior, de forma a verticalizar a formação nos eixos tecnológicos, o Campus oferta dois cursos de bacharelado (Administração e Sistemas de Informação), dois cursos de Tecnologia (Gestão do Agronegócio e Produção de Grãos) e dois cursos de Licenciatura (Matemática e Ciências Biológicas).

A equipe que coordenou o desenvolvimento do Pronatec BF no Campus foi formada pelos encargos: Coordenador Adjunto, Orientador de curso, Supervisor de curso (no caso dos cursos técnicos), Coordenador Adjunto do Pronatec Mulheres Mil e Apoio às atividades acadêmico-administrativas, todos desempenhados por profissionais internos. Observou-se que a Direção de Ensino oferecia todo o suporte para o desenvolvimento do Programa, sendo que a Diretora no período de realização da pesquisa havia atuado na coordenação do Pronatec Mulheres Mil e acompanhava de forma muito próxima o curso em andamento no período em que se realizou a pesquisa de campo, o qual era desenvolvido no presídio.

A Coordenação Adjunta do Programa mudou no final de 2015, assim realizou-se entrevista com os dois docentes que atuaram na função ${ }^{136}$. Além desses, entrevistou-se dois supervisores de curso, a coordenadora do Pronatec Mulheres Mil, a qual atuou também no acompanhamento pedagógico dos cursos realizados no Presídio, e quatro docentes que manifestaram disponibilidade por meio do questionário online. Não foram realizadas entrevistas com os profissionais que atuaram na função de apoio pedagógico e orientador de curso, que exerciam funções mais burocráticas relacionadas ao controle de pagamento e documentação pedagógica, pois considerou-se que as entrevistas com os coordenadores haviam atendido as principais questões da pesquisa. Também compõem o corpus de análise do desenvolvimento do Pronatec Bolsa Formação no âmbito deste campus as respostas de professores e estudantes ao questionário online, projetos pedagógicos de curso e indicadores de matrículas e de cursos ofertados.

\footnotetext{
${ }^{136} \mathrm{Na}$ troca de Coordenador, por um período de alguns meses, a Coordenadora do Pronatec Mulheres Mil acumulou as duas funções.
} 
3.4.1 O desenvolvimento pedagógico dos cursos Pronatec Bolsa Formação no Campus do IFFar

Os cursos do Pronatec Bolsa Formação desenvolvidos nesse Campus ocorreram entre o segundo semestre de 2012 e o início de 2017, atingindo seu ápice nos anos de 2013 e 2014 quando foram realizadas $90 \%$ das matrículas ${ }^{137}$. Além do município em que está situado, onde foram ofertadas quase $60 \%$ das matrículas, o Campus desenvolveu cursos também em outros 03 municípios vizinhos e em um quilombo situado a uma distância de $120 \mathrm{~km}$. Ao todo, foram realizadas 1.538 matrículas em 41 cursos FIC, que representaram 94\% da oferta, e em 03 cursos técnicos na forma concomitante. A maior parte da oferta compreende os eixos já ofertados pelo Campus, 57,8\%, sobressaindo-se o eixo de Recursos Naturais com 31,7\% das matrículas. Somado a isso, foram desenvolvidos cursos em outros 08 eixos, de acordo com as demandas locais e regionais.

Entre as modalidades de demanda do Pronatec Bolsa Formação, a maior parte das matrículas atenderam o Pronatec Brasil sem Miséria (47,85\%), seguida do Pronatec Campo $(20,70 \%)$ e Pronatec Mulheres Mil (12,15\%). Em menor número, também foram atendidas as modalidades: Pronatec Jovem, por meio dos cursos técnicos concomitantes, Pronatec Jovem FIC, por meio de cursos de línguas, Pronatec Sistema Prisional e Pronatec Pró-Funcionário, esse último com apenas um curso. Do total de vagas ofertadas, 89,7\% foram ocupadas. $\mathrm{Na}$ Tabela 34 encontram-se os cursos ofertados, com a respectiva carga horária, eixo tecnológico, matrículas, local de oferta e modalidade.

Tabela 34 - Cursos e locais de oferta do Pronatec Bolsa Formação desenvolvidos pelo Campus do IFFar

\begin{tabular}{|c|c|c|c|c|c|}
\hline Eixo Tecnológico & Curso & $\overline{\mathrm{CH}}$ & Vagas & Matr. & Local \\
\hline $\begin{array}{l}\text { Ambiente e Saúde - } \\
8,75 \%\end{array}$ & $\begin{array}{l}\text { Cabeleireiro Assistente* } \\
\text { Aconselhador em Dependência Química** } \\
\text { Cabeleireiro Assistente** } \\
\text { Manicure e Pedicure** } \\
\text { Manicure e Pedicure* }\end{array}$ & $\begin{array}{l}240 \\
240 \\
200 \\
160 \\
200\end{array}$ & $\begin{array}{l}15 \\
20 \\
40 \\
40 \\
20\end{array}$ & $\begin{array}{l}15 \\
20 \\
40 \\
39 \\
20\end{array}$ & $\begin{array}{l}\text { Município Sede } \\
\text { Município } 1 \\
\text { Município } 1 \\
\text { Município } 1 \\
\text { Município Sede }\end{array}$ \\
\hline $\begin{array}{l}\text { Controle e } \\
\text { Processos } \\
\text { Industriais - 2,55\% }\end{array}$ & $\begin{array}{l}\text { Eletricista Instalador Predial de Baixa } \\
\text { Tensão** } \\
\text { Eletricista Instalador Predial de Baixa } \\
\text { Tensão*** } \\
\end{array}$ & $\begin{array}{l}200 \\
200\end{array}$ & $\begin{array}{l}20 \\
20\end{array}$ & $\begin{array}{l}19 \\
20\end{array}$ & $\begin{array}{l}\text { Município Sede } \\
\text { Município Sede }\end{array}$ \\
\hline $\begin{array}{l}\text { Desenvolvimento } \\
\text { Educacional e } \\
\text { Social }-7,7 \%\end{array}$ & $\begin{array}{l}\text { Cuidador de Idoso } * * \\
\text { Cuidador Infantil } * * \\
\text { Espanhol } * * * * \\
\text { Libras } * * * *\end{array}$ & $\begin{array}{l}160 \\
160 \\
160 \\
160\end{array}$ & $\begin{array}{l}25 \\
25 \\
30 \\
40\end{array}$ & $\begin{array}{l}23 \\
25 \\
30 \\
40\end{array}$ & $\begin{array}{l}\text { Município Sede } \\
\text { Município Sede } \\
\text { Município Sede } \\
\text { Município Sede }\end{array}$ \\
\hline $\begin{array}{l}\text { Gestão e Negócios } \\
-13,9 \%\end{array}$ & $\begin{array}{l}\text { Assistente de Venda** } \\
\text { Auxiliar Administrativo** } \\
\text { Auxiliar Administrativo***** } \\
\text { Auxiliar Administrativo** }\end{array}$ & $\begin{array}{l}200 \\
160 \\
160 \\
160\end{array}$ & $\begin{array}{l}30 \\
80 \\
20 \\
30\end{array}$ & $\begin{array}{l}30 \\
77 \\
20 \\
29\end{array}$ & $\begin{array}{l}\text { Município Sede } \\
\text { Município Sede } \\
\text { Município Sede } \\
\text { Município } 1\end{array}$ \\
\hline
\end{tabular}

${ }^{137} \mathrm{O}$ total de matrículas desse período está assim distribuído: 74 matrículas em 2012; 544 em 2013; 820 em 2014 ; 80 em 2015; e 20 em 2016. 


\begin{tabular}{|c|c|c|c|c|c|}
\hline & $\begin{array}{l}\text { Auxiliar Administrativo* } \\
\text { Operador de Caixa** }\end{array}$ & $\begin{array}{l}200 \\
160 \\
\end{array}$ & $\begin{array}{l}35 \\
30 \\
\end{array}$ & $\begin{array}{l}29 \\
28 \\
\end{array}$ & $\begin{array}{l}\text { Município Sede } \\
\text { Município Sede }\end{array}$ \\
\hline $\begin{array}{l}\text { Informação e } \\
\text { Comunicação - } \\
1,9 \%\end{array}$ & Montador e Reparador de Computadores** & 160 & 30 & 30 & Município Sede \\
\hline $\begin{array}{l}\text { Infraestrutura - } \\
2,5 \%\end{array}$ & $\begin{array}{l}\text { Agente de Limpeza e Conservação** } \\
\text { Pintor de obras Imobiliárias*** }\end{array}$ & $\begin{array}{l}160 \\
180\end{array}$ & $\begin{array}{l}30 \\
20\end{array}$ & $\begin{array}{l}23 \\
20\end{array}$ & $\begin{array}{l}\text { Município Sede } \\
\text { Município Sede }\end{array}$ \\
\hline $\begin{array}{l}\text { Produção } \\
\text { Alimentícia - } \\
10,3 \%\end{array}$ & $\begin{array}{l}\text { Ajudante de Padeiro* } \\
\text { Auxiliar de Confeitaria* } \\
\text { Cozinheiro Industrial** } \\
\text { Manipulador de Alimentos* } \\
\text { Masseiro** } \\
\text { Moleiro** } \\
\text { Padeiro** } \\
\text { Padeiro** }\end{array}$ & $\begin{array}{l}220 \\
220 \\
360 \\
200 \\
160 \\
160 \\
200 \\
200\end{array}$ & $\begin{array}{l}25 \\
25 \\
25 \\
35 \\
20 \\
25 \\
20 \\
20 \\
\end{array}$ & $\begin{array}{l}13 \\
21 \\
24 \\
18 \\
20 \\
22 \\
20 \\
20\end{array}$ & $\begin{array}{l}\text { Município Sede } \\
\text { Município Sede } \\
\text { Município } 1 \\
\text { Município Sede } \\
\text { Município } 1 \\
\text { Município Sede } \\
\text { Município } 1 \\
\text { Município Sede }\end{array}$ \\
\hline $\begin{array}{l}\text { Produção Cultural } \\
\text { e Design - } 4,95 \%\end{array}$ & $\begin{array}{l}\text { Artesão de Pintura em Tecido** } \\
\text { Auxiliar de Costura** } \\
\text { Auxiliar de Costura* } \\
\text { Técnico em Paisagismo****** }\end{array}$ & $\begin{array}{l}160 \\
160 \\
200 \\
800\end{array}$ & $\begin{array}{l}25 \\
15 \\
15 \\
35 \\
\end{array}$ & $\begin{array}{l}22 \\
14 \\
15 \\
25\end{array}$ & \begin{tabular}{|l|} 
Município 1 \\
Município Sede \\
Município Sede \\
Município 3 \\
\end{tabular} \\
\hline $\begin{array}{l}\text { Produção Industrial } \\
-1,8 \%\end{array}$ & $\begin{array}{l}\text { Costureiro** } \\
\text { Marceneiro** }\end{array}$ & $\begin{array}{l}160 \\
280\end{array}$ & & $\begin{array}{l}15 \\
13\end{array}$ & $\begin{array}{l}\text { Município Sede } \\
\text { Município Sede }\end{array}$ \\
\hline $\begin{array}{l}\text { Recursos Naturais - } \\
31,7 \%\end{array}$ & 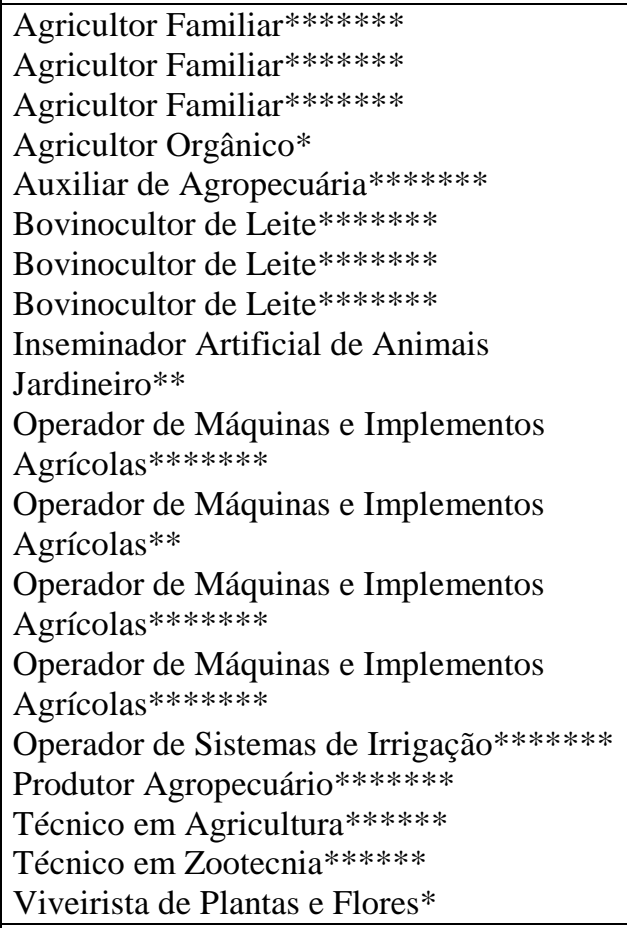 & $\begin{array}{l}200 \\
200 \\
200 \\
200 \\
200 \\
200 \\
200 \\
200 \\
200 \\
160 \\
160 \\
160 \\
160 \\
160 \\
160 \\
250 \\
1200 \\
1200 \\
200 \\
\end{array}$ & $\begin{array}{l}40 \\
35 \\
60 \\
30 \\
25 \\
25 \\
20 \\
30 \\
30 \\
25 \\
25 \\
\\
25 \\
\\
30 \\
\\
25 \\
\\
20 \\
30 \\
35 \\
35 \\
35 \\
\end{array}$ & $\begin{array}{l}38 \\
21 \\
51 \\
19 \\
25 \\
25 \\
18 \\
20 \\
28 \\
23 \\
25 \\
\\
24 \\
\\
24 \\
\\
22 \\
\\
17 \\
25 \\
35 \\
33 \\
13 \\
\end{array}$ & $\begin{array}{l}\text { Município 2 } \\
\text { Quilombo } \\
\text { Município Sede } \\
\text { Município Sede } \\
\text { Município 1 } \\
\text { Município 1 } \\
\text { Município 2 } \\
\text { Município Sede } \\
\text { Município 1 } \\
\text { Município 1 } \\
\text { Município 2 } \\
\text { Município Sede } \\
\text { Município Sede } \\
\text { Município 1 } \\
\\
\text { Município Sede } \\
\text { Município 1 } \\
\text { Município 1 } \\
\text { Município Sede } \\
\text { Município Sede }\end{array}$ \\
\hline Segurança - 1,55\% & Vigilante** & 160 & 25 & 24 & Município Sede \\
\hline $\begin{array}{l}\text { Turismo, } \\
\text { Hospitalidade e } \\
\text { Lazer }-12,3 \%\end{array}$ & $\begin{array}{l}\text { Atendente de Lanchonete** } \\
\text { Auxiliar de Cozinha** } \\
\text { Auxiliar de Cozinha** } \\
\text { Auxiliar de Cozinha* } \\
\text { Pizzaiolo** } \\
\text { Salgadeiro** }\end{array}$ & $\begin{array}{l}160 \\
200 \\
200 \\
240 \\
160 \\
160\end{array}$ & $\begin{array}{l}25 \\
30 \\
30 \\
25 \\
30 \\
55\end{array}$ & $\begin{array}{l}25 \\
29 \\
28 \\
24 \\
29 \\
54\end{array}$ & $\begin{array}{l}\text { Município 1 } \\
\text { Município } 1 \\
\text { Município Sede } \\
\text { Município Sede } \\
\text { Município Sede } \\
\text { Município 1 }\end{array}$ \\
\hline $\begin{array}{l}\text { Modalidade do } \\
\text { Pronatec }\end{array}$ & \multirow{2}{*}{\multicolumn{2}{|c|}{$\begin{array}{l}\text { *Pronatec Mulheres Mil } \\
\text { **Pronatec Brasil sem Miséria } \\
* * * \text { Pronatec Sistema Prisional Regime Fechado } \\
\text { ****Pronatec Jovem FIC } \\
\text { *****Pronatec Pró-Funcionário } \\
\text { ******Pronatec Jovem Concomitante } \\
* * * * * * * \text { Pronatec Campo }\end{array}$}} & \begin{tabular}{|l|}
260 \\
825 \\
40 \\
70 \\
20 \\
105 \\
395 \\
\end{tabular} & $\begin{array}{l}187 \\
789 \\
40 \\
70 \\
20 \\
93 \\
339 \\
\end{array}$ & \\
\hline Total & & & 1.715 & 1.538 & \\
\hline
\end{tabular}

Fonte: Organizada pela autora com base nas informações coletadas no Campus do IFFar. 
Cabe ressaltar que no conjunto dos municípios atendidos pelo Campus, o IFFar foi responsável por 65,6\% das matrículas da Bolsa Formação, visto que o Sistema $S$ não possui unidades físicas nesses municípios. O SENAC e o SENAI, por meio de suas unidades móveis ou balcões vinculados às unidades físicas mais próximas, atenderam $23 \%$ e 11,35\% das matrículas, respectivamente, apenas em cursos FIC ${ }^{138}$. Ambos desenvolveram a maior parte das matrículas no eixo de gestão e negócios - o curso mais ofertado por estas instituições foi o de Auxiliar Administrativo -, sendo que o SENAI desenvolveu também grande número no eixo de infraestrutura com cursos na área da construção civil. Nenhum dos dois ofertou cursos na área de recursos naturais, a qual compreende grande parte da atividade produtiva da região.

Tabela 35 - Eixos Tecnológicos atendidos pelo Sistema S nos municípios atendidos pelo Campus do IFFar*

\begin{tabular}{l|ll}
\hline \hline Eixo Tecnológico & SENAC & SENAI \\
\hline Ambiente e Saúde & $19,1 \%$ & $0 \%$ \\
Desenvolvimento Educacional e Social & $6,5 \%$ & $7,15 \%$ \\
Gestão e Negócios & $\underline{58,6 \%}$ & $\underline{42,9 \%}$ \\
Informação e Comunicação & $9,6 \%$ & $12 \%$ \\
Produção Alimentícia & $2,5 \%$ & $7,15 \%$ \\
Infraestrutura & $0 \%$ & $30,8 \%$ \\
Turismo, Hospitalidade e Lazer & $3,7 \%$ & $0 \%$ \\
\hline \hline
\end{tabular}

* Os cursos foram ofertados majoritariamente nos anos de 2013 e 2014, período com os maiores orçamentos do Programa. Apenas 2 cursos foram ofertados pelo SENAC em 2015.

Fonte: elaborada pela autora de acordo com os dados disponíveis no SIMEC (2018).

\section{De acordo com o primeiro Coordenador Adjunto da Bolsa Formação do Campus (CABF} 1 Campus IFFar) ${ }^{139}$, foi a instituição que, ao receber a solicitação da Reitoria para desenvolver o Programa, buscou as lideranças locais para identificar as demandas de curso e avaliar as possibilidades de atendimento pelo Campus.

Em 2012, a Reitoria acho que sofreu pressão e trouxe essa proposta para as direções dos Campus e aí a Direção nos convidou a participar do Programa: organizar, montar os cursos, as propostas, levantar as demandas... A primeira tarefa, qual foi: a gente, como não era do local, não sabia quais eram as demandas. Esse foi o maior dos desafios nossos, não sabíamos como o programa funcionava. Então, chamamos as lideranças. A gente começou pelas associações comerciais, pelos sindicatos, pelos CRAS, as próprias prefeituras, os prefeitos, e chamamos para uma reunião, para definir quais eram as prioridades de cada região e elencar os principais cursos, a partir das demandas de trabalho e falta de profissionais qualificados naquela área e eles que conheciam a região, ficava mais fácil. E aí foram feitos os mapas de demandas, foram

\footnotetext{
${ }^{138}$ Entre os municípios atendidos pelo IFFar, o Sistema S não atuou no município 2. O município 4 não foi incluído, pois fica distante dos demais e o Campus do IFFar desenvolveu apenas um curso naquele local.

${ }^{139}$ No período de 2012 a 2015, o coordenador adjunto do Pronatec foi um professor de física, com Mestrado em Educação, que atuava na Coordenação de Extensão do Campus. No período seguinte, assumiu a Coordenação uma professora de Agronomia, com mestrado e doutorado na área que havia atuado como Supervisora em dois dos cursos técnicos desenvolvidos por meio do Pronatec. Com vistas na compreensão do desenvolvimento do Pronatec Bolsa Formação no campus, realizou-se entrevista com os dois coordenadores, os quais serão identificados no texto como CABF 1 Campus e CABF 2 Campus, respectivamente.
} 
elencadas a relação de cursos e de vagas, inclusive. Então esse foi o primeiro passo, e aí a gente viu, em conversa interna, quais eram os cursos que nós tínhamos condições de ofertar. Primeiro o que era a demanda da região, aí elencamos se não me falhe a memória, 4 cursos, e dos 4 conseguimos implementar 3, com projeto, todo o levantamento, aí teve início em outubro (Entrevista CABF 1 Campus IFFar, 2016).

Esses três primeiros cursos - Bovinocultor de Leite, Operador de Máquinas e Implementos Agrícolas e Auxiliar Administrativo - foram desenvolvidos nas instalações do campus, mas grande parte dos estudantes se deslocavam de município vizinho, cerca de $40 \mathrm{~km}$ de distância ${ }^{140}$. O fato de se desenvolver no próprio campus favoreceu uma participação maior dos docentes da instituição (embora a maioria fosse de externos); houve, porém, grande evasão dos estudantes - mais de $60 \%$. Muitos moravam na zona rural e as chuvas que ocorreram no período do curso trouxeram dificuldades no deslocamento, pois as estradas de terra não ofereciam condições para a circulação do ônibus.

Nos anos seguintes, a partir do melhor conhecimento do público a ser atendido, os cursos passaram a ser ofertados nos locais da demanda. Assim, em vez de os estudantes se deslocarem, os professores passaram a ir até os municípios/comunidades. Os órgãos demandantes também já estavam mais familiarizados com o Programa e as demandas cresceram bastante, incluindo áreas que não eram do perfil de atuação da instituição, de acordo com o Coordenador. Esses dois elementos, associados ao fato de que no primeiro ano o pagamento dos docentes não era feito por meio de bolsa, que é isenta de imposto de renda, e a necessidade de compensação da carga horária para além da rotina semanal de trabalho, fez com que aumentasse a participação de profissionais externos entre o corpo docente dos cursos - em 2012,61\% dos docentes eram externos e esse número passou para $78 \%$, em $2013^{141}$.

Um fator que ajuda a compreender a baixa atuação dos docentes da instituição no desenvolvimento do Programa é a alta carga horária de atividades já desenvolvida. Nesse Campus, em 2014, a relação de professor por aluno era de $22^{142}$, sendo que os indicadores de gestão da Rede Federal de Educação Profissional, assim como o Plano Nacional de Educação, recomendam como parâmetro de qualidade a relação de 20 alunos por professor. Na entrevista com um professor do Campus que lecionou em cursos do Pronatec, a carga horária foi o fator apontado como impeditivo para uma maior participação dos docentes: “todos nós temos carga horária quase no limite, (...) por mais que nós quiséssemos trabalhar, não tinha perna para tanto.

\footnotetext{
${ }^{140}$ De acordo com o CABF 1, a assistência estudantil paga aos estudantes que precisavam se deslocar de municípios vizinhos tinha o valor ampliado, em função do custo do transporte. No geral, o valor da assistência estudantil era de $\mathrm{R} \$ 3,00$ a hora/aula.

${ }^{141}$ Consulta realizada nos arquivos de seleção e pagamento de docentes dessa unidade nos anos de 2012 e 2013.

142 Dados coletados no Sistema Integrado de Gestão de Pessoas do IFFar, por meio do site: https://sig.iffarroupilha.edu.br/sigrh/public/home.jsf.
} 
Eu, pessoalmente, gostaria de ter trabalhado muito mais, também, como docente, mas não tinha como. Por isso, que, mesmo nessa área [recursos naturais], um grande número de professor foi externo" (Entrevista Prof. Campus IFFar, 2017).

Por outro lado, seria contraditório que o próprio corpo docente tivesse capacidade para atender todos os cursos do Programa na sua área de atuação, recebendo remuneração específica para isso, o que viria a indicar que o Campus não atende adequadamente as demandas locais e teria como incluí-las nas suas atividades regulares. Como pode ser identificado na Tabela 36, o crescimento de matrículas no Programa não impactou um decréscimo nas matrículas dos cursos regulares, o que reafirma o pressuposto de que a força de trabalho docente estava comprometida com esses cursos, além das atividades de pesquisa e extensão.

Tabela 36 - Matrículas regulares e Matrículas Pronatec - Campus IFFar (2012 a 2016)

\begin{tabular}{l|l|l}
\hline \hline Ano* & Matrículas Regulares & Matrículas Pronatec \\
\hline 2012 & 1.226 & 74 \\
2013 & 1.180 & 544 \\
2014 & 1.436 & 820 \\
2015 & 1.157 & 80 \\
2016 & 1.344 & 20 \\
\hline \hline
\end{tabular}

* Alguns cursos têm ingresso e/ou conclusão na metade do ano letivo, por isso observa-se diminuição no número de matrículas a cada dois anos, dependendo do período de levantamento dos dados.

Fonte: elaborada pela autora com base nos dados coletados no Campus do IFFar.

Em relação à atuação do corpo docente do IFFar nos cursos do Pronatec, o professor entrevistado destaca a complexidade do trabalho junto ao público do Programa, o que também contribuiu para a baixa participação do corpo docente, tendo em vista a obrigatoriedade de ser realizado além da carga horária regular:

(...) tínhamos, num mesmo dia, e não é exagero; num mesmo dia, eu dei aula para o FIC, com pessoas analfabetas, ou semialfabetizado - analfabeto é meio estranho dizer isso - e, ao mesmo tempo, tinha aula na Pós-Graduação. Então, imagina tu chegar numa sala, com as pessoas que trabalharam o dia inteiro, pessoas cansadas, pessoas que deixam os filhos em casa, e quando não podiam deixar os filhos em casa, levavam os filhos junto, tínhamos criança na sala de aula, e a gente tinha que adaptar a metodologia, a forma de trabalho. Uma coisa que para mim foi diferente, que eu tive que praticar muito, foi escrever no quadro. O Data Show, com slide pronto, era muito difícil de prender a atenção, porque quando tu jogavas todo o texto no quadro, eles entravam em desespero: "Tem que copiar? Tem que copiar? Tem que copiar?". Eu disse: "Não. Calma, eu vou dar tempo". E aí o quê que acontece? Uma ou duas pessoas não sabiam copiar, e aí ficava constrangido; eles ficavam meio constrangidos. Então, tu tinhas que desenhar, fazer a palavra, escrever; tu tinhas que ter um ritmo de aula totalmente diferente. Aí tu chegas numa outra turma, de noite, onde tu levas um artigo científico para a gente debater a ideia. Então, tu imaginas o desafio que é trabalhar com tudo isso (Entrevista Prof. Campus IFFar, 2017).

Diferentemente do Centro de Referência, no Campus não houve problema de desistência de docentes, embora também tenha ocorrido atraso no pagamento das bolsas. De acordo com 
os docentes externos que responderam ao questionário ${ }^{143}$ (21 profissionais), observa-se que aqueles que não desenvolviam nenhuma atividade ou desenvolviam atividades de trabalho compatível com aulas no Pronatec, constituíam mais da metade desse grupo: 03 não desenvolviam nenhuma atividade, 05 apenas trabalhos eventuais e 06 eram estudantes de PósGraduação. Os profissionais que desenvolviam outra atividade indicaram cargas horárias compatíveis com a atuação no Programa, e apenas 01 trabalhava 60 horas semanais ${ }^{144}$.

A proximidade do Campus com a Universidade Federal de Santa Maria possibilitou a participação de profissionais com uma formação qualificada e que visavam desenvolver experiência docente, o que pode ser identificado pela titulação informada pelos docentes externos - $67 \%$ possui pós-graduação stricto sensu, $24 \%$ pós-graduação lato sensu e apenas 9\% possui somente graduação - e pelo fato de mais da metade não possuir experiência docente. Por outro lado, 66,7\% desses profissionais haviam realizado curso de Formação Pedagógica ${ }^{145}$ após a conclusão dos cursos de bacharelado ou tecnologia, o que indica terem formação para o desempenho da docência e confirma a pretensão de desenvolver carreira nessa profissão.

Conforme destaca o CABF 1, em relação à atuação dos profissionais externos ao IFFar, eram "profissionais com comprometimento assim de aulas práticas, de atividades, espetacular! Às vezes bem mais comprometidos que o pessoal do próprio Instituto. Então acho que não deveu em nada, essa parte de qualificação [formação dos profissionais], por ser pessoal externo ou do próprio Instituto" (Entrevista CABF 1 Campus IFFar, 2016). Além de buscarem experiência profissional, esses profissionais tinham expectativa também de prestar concurso no próprio Instituto, “e aí ele dá tudo o que tem, ele se empenha bastante, visualizando talvez essa possibilidade", conclui o Coordenador. Essa perspectiva pode ser observada nas entrevistas com duas professoras externas, as quais buscavam desenvolver experiência pois tinham o desejo de seguir carreira na docência: "durante a Graduação sempre tive vontade de ser professora; sempre essa parte, a temática da escola, sempre me instigou bastante. E aí eu li o

\footnotetext{
${ }^{143} \mathrm{O}$ questionário foi enviado para 66 endereços de email, coletados junto ao Campus, dos quais 03 retornaram com a mensagem de email não encontrado e 34 responderam ao questionário. Assim, foi obtido um retorno de $54 \%$ dos docentes contatados, desse total 21 eram professores externos, 08 eram docentes do campus e 05 técnicosadministrativos na instituição.

144 Esse profissional atuava em escola pública estadual e indicou como motivação para dar aulas no Pronatec a necessidade de dinheiro. Nesse período, o governo estadual do RS (Governo José Ivo Sartori - PMDB 2014-2018) vinha realizando a maior parte dos pagamentos dos docentes de forma parcelada e atrasado o pagamento do $13^{\circ}$, o que ajuda a compreender essa necessidade de dinheiro por parte do docente, além dos baixos salários pagos pelo governo estadual, acarretando essa altíssima carga horária de trabalho.

145 Por serem instituições de educação básica, os Institutos Federais exigem em seus concursos para docente a formação em nível de licenciatura ou formação pedagógica equivalente. Assim, várias instituições de ensino superior passaram a ofertar cursos especiais de graduação em formação de professores para atuar na educação profissional. A UFSM oferta o Programa Especial de Graduação de Formação de Professores para a educação profissional desde 2009, onde grande parte desses profissionais realizaram essa formação.
} 
edital [da seleção de professores para o Pronatec] e disse: vou tentar!” (Entrevista Prof. Externa 1, 2017); "o meu objetivo era pegar essa experiência de sala de aula, de contato com os alunos, eu sempre gostei de dar aula e queria seguir essa carreira acadêmica" (Entrevista Prof. Externa 2, 2017).

Além dos profissionais externos e docentes do Campus, atuaram também como professores alguns técnicos-administrativos em educação (TAE) da instituição. Em entrevista com um desses profissionais, que atuou em curso na área de informática, pode-se identificar como motivação para a atuação a oportunidade de ampliar o currículo, com vistas em processos seletivos para ingresso na pós-graduação. Especialmente na área de informática, as unidades de ensino tiveram dificuldade para contratar profissionais, por isso os técnicos-administrativos com formação nesta área foram chamados para atender essa demanda. Conforme relatou o profissional entrevistado, dar aula foi um grande desafio, especialmente, porque para "nós que trabalhamos sentados o dia inteiro, com o fone de ouvido, quieto, a gente não está acostumando com isso" (Entrevista Prof. TAE, 2017).

A diversidade de perfis docentes nos cursos levou um estudante a afirmar, por meio do questionário, que "qualquer um dá aula no Pronatec" (Estudante, curso Auxiliar Administrativo). Outros dois estudantes destacaram como pontos negativos, em relação ao corpo docente, o fato de que "alguns professores não tinham prática em dar aula" e que "algumas disciplinas foram muito fracas" (Estudantes, curso Jardineiro e Auxiliar Administrativo, respectivamente).

Nas entrevistas realizadas com quatro docentes que atuaram nos cursos - duas professoras externas, um professor do Campus e um Técnico-Administrativo -, foi unânime a percepção da ausência de espaços de diálogo entre o corpo docente dos cursos nos quais atuaram. Embora afirmem ter recebido orientações quanto às questões práticas do desenvolvimento das aulas, o projeto pedagógico do curso, ementa da disciplina, diário de classe, entre outros, e o suporte da Coordenação quando precisassem, os docentes apontaram que se sentiram isolados no desenvolvimento de suas atividades. A única experiência de planejamento conjunto foi relatada pelo docente interno que conseguiu desenvolver algumas atividades junto aos seus colegas do campus que atuaram no mesmo curso. No geral, cada professor atuava em um dia diferente, o que impossibilitava o encontro entre eles: "eu trabalhava, por exemplo, na quinta, de tarde, as 04 aulas. Na quarta, tinha um outro professor que trabalhava as 04 aulas. Então, ficou aquela classe com a pedagogia das caixinhas. Essa é a minha gaveta, essa é a tua e aquela é a tua” (Entrevista Prof. Campus IFFar, 2017). 
Assim, como se viu em relação ao Centro de Referência, a contratação de docentes por disciplina não permitia a criação de espaços para trocas de experiência e planejamento coletivo. Já quando havia um grupo de docentes internos atuando no mesmo curso, embora também fossem remunerados pela carga horária da disciplina, era possível desenvolver um planejamento integrado em virtude da convivência no Campus. Conforme relata o Professor entrevistado, que também atuou como Supervisor no curso Técnico em Paisagismo, nesse curso havia outros 05 professores do Campus, o que permitiu o planejamento de um projeto que foi desenvolvido ao longo do curso:

Então, o quê que nós combinamos? De, mais ou menos, trabalhar dentro de um projeto. Então, tínhamos uma estufa montada lá, nós montamos, com material, recurso do programa, compramos todo o material. Como era um curso que poderia ser feito bastante prática, foi feito muita prática. Então, a gente combinava, tentava organizar uma linha de trabalho que pudesse aproveitar aquele recurso, tanto de irrigação, quanto de solo, quanto de prática... Então, foi, em termos de experiência, foi a melhor por trabalhar em equipe, conseguir trabalhar em cima de um pensamento. Então, quando a gente, quando a equipe de professores conversou, a organização funcionou muito melhor, bem melhor. (...) Mas isso foi possível por sermos professores internos, por trabalharmos juntos (Entrevista Prof. Campus IFFar, 2017).

No entanto, esse planejamento ficou restrito a esse grupo de docentes, pois uma das professoras externas entrevistadas, que também atuou no curso Técnico em Paisagismo, relata que sentiu falta de um contato com outros docentes no intuito de realizar um planejamento conjunto e até mesmo para verificar se suas aulas estavam de acordo com o que a Instituição esperava. Nas suas palavras: "como era uma tarde inteira para cada professor, eu acabei conhecendo os professores só no dia da formatura mesmo. E uma das professoras, a gente trocou e-mail para fazer um trabalho em conjunto, e depois em função da formatura, para ajudar a organizar alguma coisa para os alunos" (Entrevista Prof. Externa 1, 2017).

Com isso, pode-se evidenciar a diferença no trabalho pedagógico realizado por professores externos em relação àquele do corpo docente da instituição. E isso não se dá em razão de qualificação ou competência distintas, mas pelo fato de a metodologia do Programa não favorecer essa integração. Como destaca o professor do Campus, o contato com os docentes externos não ocorria, não pelo fato de que "a pessoa era difícil. Era a questão da logística, da distância". Nesse sentido, refletindo a partir das suas experiências no Programa, apresenta como sugestão a contratação dos professores não por disciplina, mas por equipes encarregadas de desenvolver todo o curso:

Eu acho que se tivesse que voltar de novo; se tivéssemos que organizar o Pronatec de novo, eu acho que esse seria o grande diferencial: tu não ter professor, ter uma equipe. 
E uma equipe, de preferência, que seja selecionada no edital. Se tu conseguisse selecionar uma equipe com quatros ou cinco professores, eu acredito que a expectativa de tu ter sucesso é muito maior, pela experiência do Paisagismo (Entrevista Prof. Campus IFFar, 2017).

Essa proposta vem ao encontro do trabalho que é desenvolvido no próprio Campus em que cada curso possui seu corpo docente, que se reúne e discute as questões relativas ao trabalho pedagógico, tanto em conversas informais, quanto nas reuniões ordinárias, o que possibilita um planejamento integrado no desenvolvimento do currículo, tanto no sentido horizontal, entre as disciplinas do semestre, quanto no sentido vertical, entre os semestres do curso. Com base na sugestão do professor, percebe-se que essa integração não ocorre nos cursos desenvolvidos por meio do Pronatec, confirmando a existência de condições diferenciadas no desenvolvimento dos cursos do Programa, em relação aos cursos regulares. Porém, a contratação de docentes na forma de equipes só traria os resultados esperados no caso de os profissionais serem docentes da própria instituição ou terem toda a carga horária de trabalho no curso - aula + planejamento coletivo - remuneradas, no caso de professores externos.

Embora o Campus não tenha tido atraso nos seus cursos em virtude de desistência de professores, como se observou no $\mathrm{CR}$, alguns cursos tiveram seus cronogramas de início prorrogados em razão do atraso na liberação dos recursos, o que trouxe implicações especialmente para os cursos técnicos concomitantes, que precisariam acompanhar o calendário das escolas de ensino médio onde foram desenvolvidos. Os cursos técnicos, por exemplo, que tinham previsão para começar em abril, dois começaram apenas em agosto e um começou em junho, o que ocasionou desistência de alguns estudantes. No curso Técnico em Paisagismo, onde se desenvolveu a experiência de trabalho pedagógico integrado, o número de concluintes foi bem pequeno em relação ao número de matrículas, pois muitos alunos desistiram do curso antes mesmo de começarem as aulas, em razão do atraso no seu início.

O atraso na liberação dos recursos comprometeu também a frequência dos estudantes. A maior parte dos cursos FIC foram desenvolvidos na Modalidade Pronatec Brasil sem Miséria, que visa atender a população de baixa renda inscrita no Cadastro Único dos programas sociais do governo. Assim, o atraso no pagamento da assistência estudantil comprometia as condições para o transporte e alimentação dos alunos e inclusive o interesse na sua continuidade, pois para muitos a bolsa era também um atrativo, sendo uma forma de complementação ou, até mesmo, de obtenção de renda. A reclamação dos estudantes em relação ao atraso na bolsa gerou reclamação dos professores, que se sentiam frustrados pelo fato de, na sua visão, os alunos estarem demonstrando mais interesse pela bolsa do que pelas aulas: "eu estava dando aula, 
explicando e falando, falando, quando um aluno levanta a mão e me pergunta: 'Professor, a nossa bolsa vai entrar quando?' Eu achei que ele ia perguntar alguma coisa da aula. Aí eu já fiquei bem chateado, eu não acredito nisso!” (Entrevista Prof. TAE, 2017). Por outro lado, alguns professores encaravam essa situação sob outra ótica: "nós tínhamos um cuidado para, exatamente, evitar de dizer que os alunos estavam lá pela Bolsa, embora a gente sabia que estavam. Mas, se foi o jeito de prender eles, que bom que funcionou!" (Entrevista Prof. Campus IFFar, 2017).

Não foi possível realizar o levantamento do perfil socioeconômico dos estudantes, pois um número muito pequeno respondeu ao questionário online (apenas 16) ${ }^{146}$. Porém, por meio das entrevistas, tanto os coordenadores, quanto os professores relataram se tratar de um público de baixa renda e que dificilmente a instituição teria condições de atendê-los não fosse a possibilidade de desenvolver cursos fora da sede, por meio do Pronatec. Grande parte passou a conhecer a instituição a partir do Pronatec e, especialmente, entre os estudantes que tiveram a oportunidade de participar de aulas nas dependências da instituição, alguns continuaram seus estudos por meio de cursos regulares, como se viu em relação ao Pronatec Mulheres Mil. Como destaca um professor do Campus, que atuou em um dos cursos técnicos, "o Curso permitiu que os alunos conhecessem a infraestrutura do Campus e, como resultado, vários deles hoje são alunos de cursos superiores da Instituição" (Questionário Prof. Campus IFFar.). Assim, a preocupação com o atraso da bolsa revela a importância desse recurso na vida daquelas pessoas. Uma das professoras externas destaca, em relação à reclamação dos estudantes frente ao atraso na bolsa: "uma das alunas estava grávida, e ela, se não me engano, já tinha três filhos, então, querendo ou não, a bolsa eram as fraldas do nenê, as mamadeiras das crianças - às vezes ela ia na aula com essas crianças. (...) Alguns iam a pé para as aulas para poder usar o dinheiro em outras coisas" (Entrevista Prof. Externa 2, 2017).

Observando o relatório de matrículas, pode-se identificar que um número significativo de pessoas fez mais de um curso no Programa, todos concluídos com êxito: 101 fizeram dois cursos, 11 fizeram 03 cursos e $01 \mathrm{fez} 04$ cursos. O número de pessoas que se inscreveu em mais de um curso e abandonou ou não frequentou a primeira semana de aulas, foi de apenas 32. A partir desses dados, não se confirma a visão de que os alunos estavam interessados apenas na bolsa, pois grande parte daqueles que fizeram mais de um curso concluíram-no com êxito. Ao

\footnotetext{
146 Quando foi realizada a pesquisa nesse Campus, segundo semestre de 2016 e primeiro de 2017, estava em andamento apenas um dos cursos, por isso o questionário aos estudantes foi enviado por email, porém muitos emails haviam sido criados para a matrícula nos cursos e os estudantes não tem acesso à internet ou não costumam usar essa ferramenta.
} 
mesmo tempo, tendo em vista a condição socioeconômica do público atendido pelo Programa, pode-se apontar que a assistência estudantil foi essencial para a permanência e conclusão dos cursos, embora fosse utilizada para outras necessidades que não àquelas previstas pela política.

Em razão das particularidades do Pronatec Campo e Pronatec Sistema Prisional, o desenvolvimento dos cursos nessas modalidades será analisado de forma separada nas duas próximas seções deste Capítulo.

3.4.2 Pronatec Campo: entre o desenvolvimento da agricultura familiar e a formação de mão de obra para as grandes propriedades

A modalidade Pronatec Campo surgiu como "braço" da Política Nacional de Educação do Campo (PRONACAMPO), lançado em março de 2012, a partir do Decreto $\mathrm{n}^{\mathbf{0}} 7.352$, de novembro de 2010, que dispõe sobre a política de educação do campo e do Programa Nacional de Educação na Reforma Agrária - Pronera. Entre as diferentes ações previstas pelo Pronacampo, descriminadas na Portaria n. 86, de fevereiro de 2013, o fomento à educação profissional e tecnológica passou a ser executada por meio do Pronatec Bolsa Formação, tendo em vista que esse programa articulou todas as iniciativas de formação profissional promovidas pelo governo federal.

Com o objetivo de fortalecer a "agricultura familiar e o desenvolvimento rural sustentável em bases territoriais e agroecológicas", o Pronatec Campo se destina à formação profissional, por meio de cursos técnicos e FICs, da diversidade interna agricultura familiar, comunidades tradicionais do campo e assalariados rurais: agricultores familiares, assentados e acampados da reforma agrária, assalariados rurais, indígenas, quilombolas e demais povos e comunidades tradicionais do campo (Cartilha Pronatec Campo, s/d). O Ministério do Desenvolvimento Agrário - e a partir do Golpe de 2016, a Secretaria Especial da Agricultura Familiar e do Desenvolvimento Agrário - é o demandante dessa ação, responsável pelo levantamento da demanda junto aos municípios por meio dos sindicatos dos trabalhadores rurais, da Emater e das prefeituras. As instituições ofertantes são as mesmas autorizadas para desenvolver os cursos do Pronatec Bolsa Formação, quais sejam: instituições da rede federal de EPT, rede estadual, instituições privadas e instituições do Sistema S.

O Campus do IFFar desenvolveu vários cursos na modalidade Pronatec Campo. As demandas desses cursos surgiram a partir de reuniões com o sindicato de trabalhadores rurais, Emater, Secretarias de Assistência Social e Secretarias Municipais de Agricultura dos 
municípios atendidos. No total, foram realizadas 339 matrículas em 07 diferentes cursos, conforme a Tabela 37.

Tabela 37 - Cursos da modalidade Pronatec Campo desenvolvidos pelo Campus do IFFar

\begin{tabular}{l|l|l|l}
\hline \hline Curso & Matrículas & Local Execução & Município \\
\hline Agricultor Familiar & 21 & Quilombo & Município 4 \\
Agricultor Familiar & 18 & Escola Estadual & Município 2 \\
Agricultor Familiar & 26 & Distrito Rural & Município Sede \\
Agricultor Familiar & 25 & Assentamento & Município Sede \\
Agricultor Familiar & 20 & Vila São José & Município 2 \\
Auxiliar de Agropecuária & 25 & Escola Estadual & Município 1 \\
Bovinocultor de Leite & 20 & Campus do IFFar & Município Sede \\
Bovinocultor de Leite & 18 & Escola Municipal & Município 2 \\
Bovinocultor de Leite & 25 & Escola Estadual & Município 1 \\
Inseminador Artificial de Animais & 28 & Escola Estadual & Município 1 \\
Operador de Máquinas e Implementos Agrícolas & 24 & Escola Estadual & Município Sede \\
Operador de Máquinas e Implementos Agrícolas & 22 & Escola Estadual & Município 1 \\
Operador de Máquinas e Implementos Agrícolas & 25 & Assentamento & Município 2 \\
Operador de Sistemas de Irrigação & 17 & Campus do IFFar & Município Sede \\
Produtor Agropecuário & 25 & Escola Estadual & Município 1 \\
\hline \hline
\end{tabular}

Fonte: elaborada pela autora com base nos dados coletados no Campus do IFFar (2017).

A maioria dos cursos, como pode-se visualizar na Tabela 37, atende o público alvo agricultores familiares, assentados rurais e comunidade quilombola - assim como o objetivo da formação, de acordo com a política do Pronacampo, como os cursos de Agricultor Familiar e Bovinocultor de leite, por exemplo, que são atividades desenvolvidas nas pequenas propriedades de agricultura familiar. Os cursos de Produtor Agropecuário e Auxiliar de Agropecuária, por exemplo, possuem um currículo que contempla o desenvolvimento de diversas atividades agropecuárias, como olericultura, fruticultura, produção animal e produção vegetal, e temas como meio ambiente e sustentabilidade, associativismo e cooperativismo rural, que contribuem na diversificação da produção e ampliação das possibilidades de renda nas pequenas propriedades.

Por outro lado, observa-se a oferta de dois cursos - operador de máquinas e implementos agrícolas e operador de sistemas de irrigação - que compreendem uma formação que visa à especialização em uma determinada atividade, a qual é importante para propriedades que utilizam equipamentos de alta tecnologia. De acordo com o CABF 1 Campus, no município 1, por exemplo, "em um levantamento rápido que eles fizeram, tinha mais de 100 vagas de postos de trabalho para operador de máquinas, por conta da agricultura forte e ausência de pessoas qualificadas para manejar essas máquinas mais modernas, que demandam maior 
conhecimento", o que indica claramente o objetivo de formar mão de obra para atuar nas grandes propriedades.

De acordo com o Técnico da Emater do município sede do IFFar, as demandas de cursos com o objetivo de qualificar mão de obra para o uso de tecnologias no campo partia da Secretaria Municipal de Agricultura ${ }^{147}$. No entanto, na sua visão, o que ocorria não era falta de mão de obra, pois muitos trabalhadores qualificados saem do município para buscar empregos em fazendas no Mato Grosso do Sul em razão de melhores salários e do fato de ter trabalho o ano todo. Na região, além de os grandes produtores rurais quererem economizar com a força de trabalho, os empregos são sazonais, não possibilitando que os trabalhadores obtenham a renda necessária para a sobrevivência nos períodos sem trabalho. Nesse sentido, a qualificação da população rural é muito interessante para os grandes produtores do agronegócio, visto que são pessoas já habituadas à "lida" no campo e irão realizar o trabalho como um "bico" nos períodos de colheita, dispensando inclusive a assinatura da carteira de trabalho, pois poderia comprometer sua condição de agricultor familiar no acesso às políticas públicas de financiamento na área, como o Pronaf (Programa Nacional de Apoio à Agricultura Familiar). Essa situação pode explicar os baixos índices de contribuição previdenciária junto aos trabalhadores no campo, como se viu no início desta seção.

Uma das turmas do curso de Operador de Máquinas e Implementos Agrícolas foi realizada em um dos assentamentos situados no município 1. De acordo com o CABF 1 Campus, a formação era voltada para o trabalho nas próprias comunidades, que por ser um assentamento antigo possui propriedades com maquinários, e também para atuação em grandes propriedades. No entanto, ao observar o currículo do curso (Quadro 5), identifica-se uma formação voltada para a "agricultura de precisão", que compreende o uso de equipamentos de alta tecnologia, justificando, assim, a formação de profissionais capazes de regular e operar tais tecnologias. Embora importante também nas pequenas propriedades, pois visa obter maior produtividade do solo, a agricultura de precisão requer um investimento técnico-científico, de análise das condições do solo, e tecnológico, o que demanda um investimento financeiro que não seria viável em pequenas áreas produtivas.

Da mesma forma, no curso de Operador de Sistemas de Irrigação - embora as técnicas de irrigação também se apliquem e sejam importantes para as pequenas propriedades - o currículo do curso compreende desde técnicas que demandam equipamentos simples até sistemas de irrigação autopropelido e com pivô central, os quais se destinam e são viáveis

\footnotetext{
${ }^{147}$ Destaca-se que a gestão municipal desse período era do PSDB (Partido da Social Democracia Brasileira).
} 
apenas em grandes propriedades, tendo em vista o seu custo. É possível visualizar tais objetivos no projeto pedagógico do curso, quando se observa os equipamentos necessários para as aulas práticas: "para a realização das aulas práticas serão necessários, entre outros equipamentos, cano de PVC de diferentes diâmetros, acessórios (curva, registros, luvas, reduções etc..), aspersores de diferentes portes, mangueiras gotejadoras, sistema de irrigação autopropelido e sistema de irrigação pivô central.” (PPC Operador de Sistemas de Irrigação, IFFar, 2014).

Quadro 5 - Currículo do curso de Operador de Máquinas e Implementos Agrícolas - Campus IFFar

\begin{tabular}{|c|c|}
\hline \multicolumn{2}{|l|}{ ORGANIZAÇÃO CURRICULAR } \\
\hline Disciplina/módulo & Carga Horária (h) \\
\hline Leitura e Produção de Texto & 12 \\
\hline Matemática básica & 12 \\
\hline Noções básicas sobre procedimentos de segurança & 16 \\
\hline Agricultura de precisão & 20 \\
\hline Regulagem de semeadoras & 20 \\
\hline Regulagem de pulverizadores & 16 \\
\hline Operação de tratores agrícolas & 20 \\
\hline Operação de colheitadeiras agrícolas & 24 \\
\hline Operação de pulverizadores agrícolas & 12 \\
\hline Ética e Orientação Profissional & 08 \\
\hline Total & 160 \\
\hline
\end{tabular}

Fonte: Projeto Pedagógico do Curso de Operador de Máquinas e Implementos Agrícolas, IFFar (2014).

Nessa direção, observa-se que no âmbito do Pronacampo, por meio da ação Pronatec Campo, conviveram diferentes perspectivas de qualificação profissional: uma voltada ao fortalecimento da agricultura familiar e outra voltada à formação de mão de obra do campo para atuação na agricultura empresarial, que é uma característica dessa região. Essas contradições expressam as disputas por projetos de agricultura e de desenvolvimento do campo e revelam que a lógica do Pronatec Campo permitia essa convivência, por não estar acompanhado de um debate sobre sua finalidade e concepção, seguindo apenas a lógica "demandante e ofertante" que instrumentaliza o desenvolvimento do Programa. Ou, como se verá a seguir, pelo fato de a própria elaboração da política do Pronacampo ter sido atravessada por essas disputas, como resultado da correlação de forças naquele momento.

O Pronacampo foi recebido com muitas críticas por organizações e movimentos da educação do campo, especialmente quanto à forma de desenvolvimento da ação que visa à qualificação profissional. A CONTAG (Confederação Nacional dos Trabalhadores na Agricultura $)^{148}$ encaminhou ao MEC um documento intitulado "Posicionamento Político da

\footnotetext{
${ }^{148}$ Desde 2016 a CONTAG teve uma mudança na sua nomenclatura com vistas a se adequar às demandas jurídicas no campo do sindicalismo rural. Atualmente, chama-se Confederação Nacional dos Trabalhadores Rurais Agricultores e Agricultoras familiares, mantendo a sigla CONTAG. Para maiores detalhes ver Picolotto (2017; 2018).
} 
CONTAG contra a participação do SENAR enquanto entidade participante da execução das ações do PRONACAMPO para os trabalhadores rurais", no qual manifesta a contradição dessa política, que objetiva o desenvolvimento da agricultura familiar, ao incluir o SENAR - entidade vinculada e representante da agricultura patronal (Confederação Nacional da Agricultura CNA) - enquanto executor de cursos de qualificação profissional aos trabalhadores rurais, por meio da ação Pronatec campo. Conforme sintetiza o documento:

\begin{abstract}
A inserção do SENAR, pelo Ministério da Educação, como executor de políticas, programas e ações da educação do campo, é uma tentativa de negar ou omitir as contradições que envolvem esta luta. Não é possível que o mesmo projeto que serve ao agronegócio, que expulsa os trabalhadores do campo ou que os torna meramente técnicos para o exercício de uma função pontual na produção (na condição de empregado), conviva, de forma naturalizada, com a perspectiva defendida pelos movimentos que lutam pela permanência de homens e mulheres do campo, na produção familiar, na produção de saberes e conhecimentos e que reafirmam o campo como lugar de vida, de cultura, de valores e de produção (CONTAG, 2012).
\end{abstract}

Na mesma direção, o Fórum Nacional de Educação do Campo (FONEC), com base nas análises produzidas no Seminário Nacional, realizado em Brasília nos dias 15 a 17 de agosto de 2012, lançou o documento "Manifesto à sociedade Brasileira", que aponta as contradições nos rumos da política de educação do campo a partir do Pronacampo. O Manifesto recupera o histórico de lutas e conquistas dos movimentos do campo na construção de políticas de “educação do campo", a partir da segunda metade da década de 1990, como contraponto à "educação rural" ${ }^{149}$, e indica que o Pronacampo, embora responda a algumas reivindicações dos movimentos pela educação do campo, reedita os princípios da "educação rural" ao se associar às entidades representativas do agronegócio. Entre os pontos criticados no Programa, está a ação Pronatec Campo:

\footnotetext{
Não reconhecemos a proposta do PRONATEC Campo elaborada pelo SENAR/CNA, pelo projeto de campo que representa e porque como política o PRONATEC ignora as experiências de Educação Profissional realizadas por instituições como SERTA, MOC, ITERRA, Escolas Famílias Agrícola - EFA's, Casas Familiares Rurais - CFR's e pelo próprio PRONERA em parceria com os Institutos Federais, entre outras (FONEC, 2012a, p. 3).
}

\footnotetext{
${ }^{149} \mathrm{O}$ conceito de educação rural denomina, nesse contexto, o projeto de educação instituído pelo Estado Brasileiro que se vincula a um "projeto de sociedade e agricultura subordinado aos interesses do capital, que submeteu e pretende continuar submetendo a educação escolar ao objetivo de preparar mão de obra minimamente qualificada e barata, sem perspectiva de um projeto de educação que contribua à emancipação dos camponeses" (FONEC, 2012a, p. 1-2). Assim, o termo "educação do campo" visa demarcar sua diferença em termos de nomenclatura e sobretudo de concepção em relação ao anterior.
} 
Como resultado dos debates do mesmo Seminário, um grupo de educadores membros do FONEC sistematizou um material denominado "Notas para análise do momento atual da Educação do Campo", o qual apresenta uma análise coletiva mais aprofundada da política de educação do campo nesse período. A análise identifica um novo ciclo econômico no espaço rural, em que o capitalismo financeiro incide sobre a agricultura promovendo uma articulação entre o setor agrícola, industrial, bancário e o aparato estatal, que gera implicações sobre as políticas públicas nesse campo. Diferentemente do ciclo em que se deu a construção do projeto de "educação do campo", final dos anos 1990, marcado pela "crise do latifúndio e da emergência do agronegócio e dos movimentos sociais de luta pela terra e pela reforma agrária", em que as políticas de "educação rural” se resumiam "ao transporte escolar para os 'resíduos' da população do meio rural" (FONEC, 2012b, p. 04), o ciclo atual identifica na educação um importante papel "para a ampliação e manutenção do agronegócio" (p. 08). Como se viu no contexto dos municípios atendidos pelo IFFar, a agricultura empresarial necessita de mão de obra abundante e de preferência recrutando, quando necessitar, os trabalhadores na agricultura familiar com vistas a diminuir os custos da produção.

Nesse contexto, que foi exposto de forma muito resumida apenas com o objetivo de situar o caráter das disputas, os avanços nas políticas de educação do campo que expressam o projeto concebido pela e para a classe trabalhadora do campo são objetos de disputa na segunda década dos anos $2000^{150}$, especialmente em razão dos fundos públicos destinados a essas políticas. Contraditoriamente, o Pronacampo nasce, como se viu, do Decreto 7.352/2010 que representou um dos mais importantes marcos da Educação do Campo, pois alçou-a à "condição potencial de política de estado" (FONEC, 2012b, p. 14). No entanto, seu processo de elaboração, apesar de ter contado com a presença de movimentos e organizações sociais, foi atravessada por interesses antagônicos, fruto de discussões internas ao governo, "contendo elementos da pressão das lutas dos trabalhadores" (p. 17).

No Estado do Rio Grande do Sul, formou-se o Comitê Pronatec Campo com a participação da FETAG (Federação dos Trabalhadores na Agricultura), FETRAF (Federação

\footnotetext{
${ }^{150}$ Dentre as conquistas da Educação do Campo, destacam-se os aparatos legais: "Diretrizes Operacionais para Educação Básica nas Escolas do Campo: Resolução CNE/CEB n 1/2002 e Resolução CNE/CEB n 2/2008. Parecer CNE/CEB n 1/2006 que reconhece os Dias Letivos da Alternância; Resolução CNE/CEB nº 4/2010 que reconhece a Educação do Campo como modalidade específica e define a identidade da escola do campo; Decreto $\mathrm{n}^{\circ}$ 7.352, de 4 de novembro de 2010, que dispõe sobre a Política Nacional de Educação do Campo e sobre o Programa Nacional de Educação na Reforma Agrária (Pronera)" e os Programas: "Programa Nacional de Educação na Reforma Agrária (Pronera), este em alguma medida elemento da própria constituição histórica da Educação do Campo, o Programa Saberes da Terra e o Programa de Apoio às Licenciaturas em Educação do Campo (Procampo); O Programa de Iniciação à Docência - PIBID Diversidade/CAPES, entre outros" (FONEC, 2012b, p. 13-15).
} 
dos Trabalhadores na Agricultura Familiar) e Superintendência Estadual do MDA, que intermediou o levantamento das demandas de qualificação profissional junto aos municípios. Conforme os dados de oferta do Pronatec Campo, no RS foram realizadas 2.652 matrículas na modalidade Pronatec Campo, nos anos de 2013, 2014 e 2015 (SISTEC Nacional, 2018). Apenas 20 matrículas foram realizadas pelo SENAC (no curso de Costureiro de Máquina Reta e Overloque) e todas as demais foram realizadas em Institutos Federais. Na tabela 38 pode-se observar os cursos ofertados e o respectivo número de matrículas.

Tabela 38 - Cursos ofertados na modalidade Pronatec Campo no RS - 2013 a 2015

\begin{tabular}{|c|c|}
\hline Curso & Matrículas \\
\hline Agricultor Familiar & 602 \\
\hline Auxiliar de Agropecuária & 275 \\
\hline Operador de Máquinas e Implementos Agrícolas & 214 \\
\hline Bovinocultor de Leite & 160 \\
\hline Agricultor Orgânico & 153 \\
\hline Agente de Desenvolvimento Cooperativista & 126 \\
\hline Editor de Vídeo & 98 \\
\hline Produtor de Frutas, Hortaliças e Plantas Aromáticas Processadas por Secagem e Desidratação & 90 \\
\hline Operador de Sistemas de Irrigação & 84 \\
\hline Costureiro Industrial do Vestuário & 70 \\
\hline Cervejeiro & 62 \\
\hline Floricultor & 60 \\
\hline Agente de Informações Turísticas & 58 \\
\hline Mecânico de Máquinas Agrícolas & 51 \\
\hline Produtor Agropecuário & 47 \\
\hline Padeiro & 44 \\
\hline Horticultor Orgânico & 39 \\
\hline Fruticultor & 27 \\
\hline Preparador de Doces e Conservas & 27 \\
\hline Preparador de Pescado & 27 \\
\hline Domador de Cavalos & 26 \\
\hline Inseminador Artificial de Animais & 26 \\
\hline Editor de Projeto Visual Gráfico & 25 \\
\hline Modelista de Roupas & 25 \\
\hline Produtor de Embutidos e Defumados & 24 \\
\hline Agricultor Agroflorestal & 22 \\
\hline Piscicultor & 22 \\
\hline Açougueiro & 21 \\
\hline Costureiro de Máquina Reta e Overloque & 20 \\
\hline Auxiliar de Cozinha & 19 \\
\hline Apicultor & 18 \\
\hline Agente de Projetos Sociais & 15 \\
\hline Bovinocultor de Corte & 12 \\
\hline Condutor de Turismo em Unidades de Conservação Ambiental Local & 12 \\
\hline Destilador de Bebidas & 11 \\
\hline Operador de Computador & 11 \\
\hline Ovinocultor & 11 \\
\hline Costureiro de Calçados & 6 \\
\hline Artesão de Artigos Indígenas & 5 \\
\hline Operador e Mantenedor de Embarcações de Pesca Artesanal & 3 \\
\hline Jardineiro & 2 \\
\hline Montador e Reparador de Computadores & 2 \\
\hline
\end{tabular}

Fonte: elaborada pela autora com base em dados do SISTEC Nacional (2018). 
Não se observa, portanto, a participação do SENAR no desenvolvimento dessa modalidade do Pronatec no RS. Em todo o país, de um universo de 46.409 matrículas desenvolvidas no âmbito do Pronatec Campo, 8.824 matrículas foram ofertadas pelo SENAR (SISTEC Nacional, 2018). Talvez pelas críticas e mobilizações dos Comitês Pronatec Campo nos Estados, a participação do SENAR tenha sido minimizada nessa modalidade. No entanto, essa instituição formadora, que representa o projeto do agronegócio, teve expressiva participação no Pronatec Bolsa Formação, tendo atuado em outras modalidades, especialmente no Pronatec Brasil sem Miséria que atendia o público beneficiários dos programas sociais, totalizando mais de 150 mil matrículas, no período de 2011 a 2016, sendo mais de $70 \%$ dessas matrículas realizadas no eixo de Recursos Naturais ${ }^{151}$ (SISTEC NACIONAL, 2017).

Em todos os cursos desenvolvidos pelo SENAR o empreendedorismo faz parte do currículo, tendo sido apresentado ao público como: "Pronatec do SENAR tem algo a mais". Sob a justificativa de que "atualmente não basta apenas plantar e colher. É preciso conhecer as técnicas básicas de administração, as máquinas e equipamentos, enfim, de todos os recursos usados para produzir mais e melhor", a instituição inseriu o módulo "Empreender no Campo", por meio do qual "ensina a analisar, avaliar, tomar as melhores decisões, colocando a técnica e a criatividade a serviço da produtividade e da lucratividade" (Site SENAR), o que revela claramente a lógica de conceber a propriedade rural estritamente como um "negócio". Os cursos ofertados pelo SENAR no âmbito do Pronatec seguem um o "Portfólio de Cursos FIC do SENAR", o que contradiz o princípio de que a demanda a ser atendida deve partir dos arranjos produtivos locais, porém favorece a instituição ofertante à medida em que pode planejar previamente a sua oferta, otimizando os custos com material didático, por exemplo. ${ }^{152}$

Com base nesses dados e na realidade analisada no âmbito do Campus do IFFar, embora tenha sido ofertado quase que em sua totalidade pelos Institutos Federais, o Pronatec Campo não deixou de ser atravessado pelos interesses alheios à agricultura familiar e à política de educação do campo, uma vez que essas instituições também se constituem em espaços de disputas, em que a formação voltada a diferentes projetos de sociedade e de agricultura convivem e são levados para o âmbito do Programa. O terceiro curso com maior número de

\footnotetext{
${ }^{151}$ Santos (2016) destaca em sua pesquisa que enquanto os IF's alegavam não ter condições financeiras pelo Pronatec Bolsa Formação para se deslocar até as comunidades do campo, a coordenadora do Pronatec no SENAR afirmava não ter sala de aula fixa; o SENAR vai onde a comunidade está.

${ }^{152}$ A maior parte dos cursos são do eixo de Recursos Naturais, incluindo desde Agricultor familiar e Agricultor orgânico a Operador de Tratores e Operador de Sistemas de Irrigação. Curiosamente, também fazem parte do Portfólio cursos de Assistente administrativo, Operador de computador e Costureiro. O documento pode ser consultado no site: http://www.senar.org.br
} 
matrículas, como pode ser observar na Tabela 38, foi o de "Operador de Máquinas e Implementos Agrícolas", o que expressa uma formação que atende, sobretudo, ao agronegócio.

Esses diferentes projetos de formação para o campo também podem ser identificados no âmbito dos cursos regulares da instituição. Em relação aos cursos do eixo de Recursos Naturais, observa-se que a nível técnico as áreas de formação ofertadas - Agropecuária e Alimentos atendem a demandas tanto da agricultura familiar, quanto das grandes propriedades, sendo possível identificar no currículo a presença de conteúdos da agricultura familiar, movimentos sociais do campo, entre outros. Já em relação ao ensino superior, a formação em Gestão em Agronegócio e Produção de Grãos se vinculam diretamente a atividades produtivas desenvolvidas em grande escala, atendendo às demandas, especialmente, da agricultura empresarial desenvolvida na região. As disciplinas com conteúdos voltados à agricultura familiar, como Agroecologia, aparecem no currículo apenas sob a forma de atividades eletivas.

Nesse sentido, como analisa o FONEC, o Pronatec Campo configura-se como uma "política falaz da conciliação" que prega haver espaço para todos: "para as grandes propriedades que serão responsáveis pelas monoculturas de exportação e para os pequenos agricultores que devem produzir sua subsistência e buscar competência para vender excedentes [inclusive de força de trabalho] no mercado, todos, afinal, integrados ao 'agronegócio"” (FONEC, 2012b, p. 19).

Outro impacto na política de educação do campo gerado pelo Pronatec - talvez o mais regressivo, pois atinge o núcleo dessa política - foi a redução do orçamento do Pronera (Programa Nacional de Educação na Reforma Agrária). Esse Programa, criado em 1998, como resultado da organização e mobilização pela reforma agrária que incluiu na sua pauta a necessidade de um projeto de educação que acompanhe e promova a emancipação da população do campo, foi o espaço em que se forjou o projeto de "educação do campo", por meio tanto da escolarização dos trabalhadores com base nesses princípios, como também da formação de camponeses-educadores, com vistas a multiplicar essa formação ${ }^{153}$. Com o advento do Pronatec Campo, o orçamento do Pronera passou por grande contingenciamento, como apontam as pesquisas de Santos (2016) e Kuhn (2015), passando de R\$70.800.000,00, em 2010, para menos de R \$30.000.000,00, em 2014. Essa redução pode ser compreendida a partir da lógica que orientou a construção do Pronatec: reunir no âmbito do Ministério da Educação as ofertas de qualificação profissional, o que promoveu um deslocamento dos recursos no mesmo sentido.

\footnotetext{
${ }^{153}$ Para um maior aprofundamento sobre o Pronera e seu percurso histórico, ver Santos (2016).
} 
Conforme relata Santos (2016), coordenadora do Pronera no período de advento do Pronatec Campo, demandas de incremento do orçamento do programa levadas ao governo federal foram respondidas pela própria Presidenta Dilma nos seguintes termos: "o programa de formação profissional do Governo é o Pronatec. E teria repetido que a ordem do Governo era 'Pronatec! Pronatec! Pronatec!'” (p. 113). Apesar dos esforços por meio do Grupo de Trabalho Pronatec, constituído no âmbito do MDA, o qual também era permeado por "conflitos internos de concepção", em "como fazer limonada deste limão" (SANTOS, 2016, p. 115), na análise de Santos, somam-se às críticas já destacadas, o fato de o Pronatec Campo promover uma formação restrita a cursos de curta duração ${ }^{154}$, sem associação com a elevação da escolaridade, “o que para os camponeses significa manter sua perene condição de classe iletrada, disponível somente e nada mais que para o "trabalho no cabo da enxada"” (SANTOS, 2016, p. 121).

\subsubsection{Pronatec Sistema Prisional: "agora posso dizer que sou um Pintor profissional"}

A partir de demanda do Presídio Estadual masculino situado no município sede do Campus do IFFar, a instituição desenvolveu dois cursos FIC na modalidade Pronatec Sistema Prisional em Regime Fechado. Os cursos de qualificação demandados foram "Eletricista Instalador Predial de Baixa Tensão" e "Pintor de Obras Imobiliárias". As aulas foram realizadas nas instalações do presídio e das 20 matrículas realizadas em cada um dos cursos, apenas 10 não concluíram, pois passaram para o regime semiaberto ou foram liberados.

Tendo em vista a baixa escolaridade dos presidiários, o currículo dos cursos incluiu português e matemática, com vistas a fornecer os conceitos básicos necessários ao acompanhamento dos cursos. Segundo a Diretora de Ensino "quando a gente foi ter uma conversa com os apenados, explicar quais eram as disciplinas, quais eram os objetivos do programa, uns queriam desistir porque tinha matemática e português". De acordo com o questionário da pesquisa respondido pelos formados no curso de Pintor (15), mais da metade (09) não tem o ensino fundamental concluído e um terço não tinha sequer a primeira etapa do ensino fundamental concluída, o que vem ao encontro do perfil da população carcerária no Estado do RS - 61,5\% não possui o ensino fundamental completo. Nesse sentido, a Diretora de Ensino do Campus lamentou o fato de o Programa não priorizar a elevação da escolaridade e

\footnotetext{
${ }^{154}$ Do total de 46.409 matrículas do Pronatec Campo, apenas 36 foram desenvolvidas em cursos técnicos $(02$ no curso Técnico em Segurança do Trabalho, em Minas Gerais, e 34 no curso Técnico em Agropecuária, em Santa Catarina).
} 
ao mesmo tempo as dificuldades de realizar parcerias com a rede municipal ou estadual para oferta de curso na modalidade Proeja, integrado ao ensino fundamental.

Com base no relato da CABF 2, da Diretora de Ensino e de uma das professoras externas que atuou no curso ${ }^{155}$, pode-se evidenciar que o desenvolvimento dos cursos no espaço do presídio não formou apenas os presidiários, possibilitou também melhorias físicas no espaço do presídio - na parte prática do curso de Pintor todas as celas e corredor do presídio foram pintados - e desencadeou uma mudança, inclusive, nos protocolos de segurança adotados.

De acordo com a professora que atuou no curso de Pintor de Obras Imobiliárias, "não foi apenas um curso de pintor, a meu ver", pois ao longo das aulas, especialmente durante o trabalho de pintura das aulas práticas, vários assuntos eram abordados "eles tinham uma carência muito grande de serem ouvidos" (Entrevista Prof. Externa 1, 2017). Tendo em vista a rigidez disciplinar do espaço carcerário, os apenados ficavam surpresos, positivamente, com a postura dos professores chegando a afirmar "Ah, a gente gosta de ti, gosta das suas aulas, porque tu trata a gente olhando nos olhos, tu trata a gente de igual para igual" (Entrevista Prof. Externa 1, 2017).

Ao final de cada um dos cursos foi realizada uma cerimônia de formatura, que o Campus sugeriu que fosse num espaço que permitisse a participação das famílias dos formandos, assim como ocorria nos demais cursos do Programa. Com a concordância da Direção do presídio, a formatura ocorreu em um auditório no centro da cidade. O deslocamento dos formandos seguiu os protocolos de segurança do sistema carcerário, sendo que as algemas só foram retiradas segundos antes de cada formando subir ao palco. O barulho produzido pela abertura dos braceletes, tão comum no ambiente carcerário, soou pela primeira vez num ambiente em que apenas discursos e aplausos eram esperados, gerando constrangimento na plateia e também entre os formandos. Conforme o relata a Diretora de Ensino,

\footnotetext{
eles entraram algemados, mas entraram por um lado, não teve acesso às pessoas, eles só abriram as algemas na hora de eles entrarem para sentarem nas cadeiras de onde eles ficariam para receber o certificado. Só que a gente ouviu o "estalinho". Quando chamava fulano, "estalinho" da algema, ciclano, "estalinho" da algema... Não precisava, deviam ter tirado essa algema antes. Na hora abria. Eles não sabiam nem onde colocar as mãos. Porque como eles ficam sempre presos, sempre com a posição nas costas com as algemas, eles não sabiam se botavam as mãos na frente, se botavam atrás. Eles entravam com a cabeça lá no chão... (Entrevista Diretora de Ensino Campus IFFar, 2016).
}

\footnotetext{
155 Todos os docentes dos cursos foram externos, mesmo nas disciplinas de português e matemática em que há professores no Campus.
} 
Essa situação repercutiu entre os presos e alguns que participaram dessa cerimônia e também estavam realizando o segundo curso afirmavam não querer participar de nova formatura em razão da conduta dos agentes penitenciários naquela ocasião. Conforme relata a Professora, os alunos argumentavam: "se for como foi a outra, a gente não quer; chegar com a gente lá, de cabeça baixa, dobravam a gente, algemado para trás. Não precisava isso. Se a gente fez o curso, se a gente se comportou o curso inteiro, se querem nos oferecer uma formatura, então, que nos tratem bem” (Entrevista Prof. Externa 1, 2017). A partir dessa contestação, embora os alunos tenham sido conduzidos da mesma forma que na ocasião anterior, as algemas foram retiradas em local um pouco mais afastado, de forma que o barulho não fosse ouvido do auditório, e os formandos caminharam de cabeça erguida para o palco de onde se levantavam para buscar o certificado quando chamados, sob os "cuidados" de vários agentes armados posicionados no fundo do palco.

Essa mesma professora que atuou no curso de Pintor, também havia atuado no curso Técnico em Paisagismo ofertado pelo Campus, o qual foi desenvolvido no espaço de uma escola estadual. Ao comparar as duas experiências, a professora aponta: "Eu me senti muito à vontade lá dentro do presídio para dar aula. Eu te digo que eu me sentia mais à vontade para dar aula no presídio do que lá na escola, porque a equipe lá do presídio foi muito mais envolvida, prestativa" (Entrevista Prof. Externa 1, 2017).

Ao serem questionados sobre os pontos positivos ou negativos do curso e a contribuição para a sua vida, todos os formados no curso de Pintor destacaram apenas pontos positivos. A partir de uma grafia que evidencia a pouca "destreza" com lápis e caneta, ressaltam que o curso trouxe novos conhecimentos, que representa uma nova oportunidade na vida e a expectativa de conseguir um emprego digno: "agora posso dizer que sou um Pintor profissional", confirmando o papel da educação dentro da prisão, que é “o de ajudar o ser humano privado da liberdade a desenvolver habilidades e capacidades para estar em melhores condições de disputar as oportunidades socialmente criadas" (SILVA; MOREIRA, 2011, p. 92).

No Estado do Rio Grande do Sul foram desenvolvidas apenas 849 matrículas no Pronatec Sistema Prisional Regime Fechado e 11 matrículas na modalidade Pronatec Sistema Prisional, que contempla os presidiários em regime semiaberto, no período de 2013 a 2016, conforme os dados de matrícula nessa modalidade (SISTEC NACIONAL, 2018). Em todo o país, as matrículas nessa modalidade totalizam 35.991, nesse mesmo período, o que representa apenas $0,77 \%$ do total da oferta do Pronatec Bolsa Formação. Considerando que a população carcerária no Estado chega a 40 mil pessoas (SUSEPE, 2018), em todo o país ultrapassa os 700 
mil (AGÊNCIA BRASIL, 2017), esse número ainda é muito pequeno e revela as dificuldades de inserção da educação formal nesses espaços.

\subsection{4 Índices de evasão e aproveitamento dos cursos}

No geral, o índice de conclusão dos cursos do Pronatec nesse Campus foi de 67,16\%. Em relação ao tipo de curso, técnico ou FIC, observa-se que nos cursos técnicos o percentual de concluintes foi bem inferior: $32,25 \%$ no técnico e $69,4 \%$ no FIC. De acordo com os percentuais observados na Rede Federal de EPT, em 2017, a evasão nos cursos FIC ofertados pelo Pronatec no Campus do IFFar está abaixo da média nacional, que é de 39,9\%. Já em relação aos cursos técnicos, a média de evasão nacional é bem menor que o observado no âmbito do Pronatec: $22,4 \%$.

A segunda Coordenadora Adjunta do Pronatec BF do Campus, que atuou também como Supervisora em dois dos cursos técnicos - Técnico em Agricultura e Técnico em Zootecnia -, destacou que o curso desenvolvido no Município 1 teve uma grande evasão já no primeiro semestre. De 35 matrículas, 23 comparecem e apenas 11 estudantes continuaram no segundo semestre do curso, em virtude do atraso no início do curso e também à dificuldade de transporte. $\mathrm{Na}$ pactuação do curso, a Coordenadoria Regional de Educação do Estado havia se comprometido a disponibilizar um ônibus para o transporte dos estudantes no turno da tarde, porém “o ônibus de contrapartida da coordenadoria que viria e a prefeitura entrava com motorista, combustível e fazia o transporte, nunca apareceu. A maioria dos estudantes do curso Técnico em Agricultura eram moradores do campo, filhos de famílias assentadas rurais, que cursavam o ensino médio pela manhã e fariam o curso técnico a tarde" (Entrevista CABF 1 Campus IFFar, 2016). Assim, apenas os estudantes que moravam mais perto da escola, ou que conseguiam carona no transporte escolar que passava próximo às suas residências, conseguiram se manter no curso. $\mathrm{O}$ atraso no pagamento das bolsas, também motivou desistências, segundo a Supervisora.

As aulas práticas desse curso ocorriam aos sábados, quando os estudantes eram trazidos de Kombi, pela própria Supervisora, para as dependências do Campus. Nesses momentos eram realizadas as práticas profissionais integradas, reunindo tanto professores internos, quanto externos. As aulas em um ambiente com boas condições de infraestrutura geravam uma maior motivação nos estudantes, segundo a supervisora - a qual também relata ter sentido impacto, no sentido inverso, ao atuar no espaço da escola estadual, em razão das má condições de 
conservação da infraestrutura: “eu nunca atuei no Estado, daí eu vi todo o paralelo e o abismo que tem".

O curso técnico que teve o maior número de concluintes foi o de Zootecnia, realizado no município sede do Campus. Grande parte do corpo docente desse curso foi formado por professores do próprio Campus e, pela proximidade física, as aulas práticas eram todas desenvolvidas nas instalações da instituição, que conta com laboratórios, animais e equipamentos nessa área. O último semestre do curso foi desenvolvido em turno integral nas instalações do campus, pois os estudantes já haviam concluído o ensino médio e essa medida visava, também, evitar novas evasões. Segundo a CABF2, os alunos "tinham o direito ao lanche da manhã, ao almoço e ao lanche da tarde. Então, era mais fácil para eles, porque aqui tinha toda a estrutura das aulas práticas" (Entrevista CABF 2 Campus IFFar, 2017). Esse contato mais próximo com o Campus possibilitou a esses estudantes um maior conhecimento da instituição e muitos deles continuaram seus estudos em cursos superiores ofertados no campus.

Em relação aos demais cursos, observa-se que a maior evasão ocorreu em alguns cursos do Pronatec Campo, principalmente em virtude das chuvas que dificultava a locomoção no meio rural, e nos cursos do Pronatec Brasil sem Miséria, motivada pelo atraso nas bolsas que comprometia as condições para a permanência do curso. O curso de Auxiliar Administrativo ofertado no âmbito do Pró-Funcionário, que tem como público servidores públicos federais, também teve baixo percentual de conclusão, em razão de ter sido ofertado no final do segundo semestre do ano, momento em que os servidores se encontravam com grande demanda de trabalho em razão do término de ano letivo. Das modalidades Pronatec desenvolvidas, os melhores índices de conclusão foram obtidos no Pronatec Mulheres Mil. Na tabela 39 é possível verificar os índices de conclusão por curso e por modalidade do Pronatec.

Tabela 39 - Índice de conclusão dos cursos Pronatec Bolsa Formação no Campus do IFFar

\begin{tabular}{l|l|l|l|l|l}
\hline \hline Curso & Turno & Matrículas & Concluintes & Índ. Concl. & Modalidade Pronatec \\
\hline Auxiliar Administrativo & Noite & 20 & 8 & $40 \%$ & Pró-Funcionário-40\% \\
\hline Aconselhador em Dependência Química & Noite & 20 & 15 & $75 \%$ & $56,50 \%$ \\
Agente de Limpeza e Conservação & Noite & 23 & 13 & $86,40 \%$ \\
Artesão de Pintura em Tecido & Noite & 22 & 19 & $63,30 \%$ \\
Assistente de Venda & Noite & 30 & 19 & $48 \%$ \\
Atendente de Lanchonete & Tarde & 25 & 12 & $53,30 \%$ \\
Auxiliar administrativo & Noite & 30 & 16 & $89,30 \%$ \\
Auxiliar Administrativo & Noite & 28 & 25 & $75,90 \%$ \\
Auxiliar Administrativo & Noite & 29 & 22 & $68,40 \%$ \\
Auxiliar Administrativo & Noite & 19 & 13 & Pronatec Brasil Sem \\
Auxiliar de Costura & Noite & 14 & 13 & $92,80 \%$ \\
Auxiliar de Cozinha & Noite & 28 & 18 & $64,30 \%$ \\
Auxiliar de Cozinha & Noite & 29 & 25 & $86,20 \%$ \\
Cabeleireiro Assistente & Noite & 20 & 14 & $70 \%$ \\
Cabeleireiro Assistente & Noite & 20 & 20 & $100 \%$
\end{tabular}




\begin{tabular}{|c|c|c|c|c|c|}
\hline Costureiro & Noite & 15 & 14 & $93,30 \%$ & \\
\hline Cozinheiro Industrial & Noite & 24 & 18 & $75 \%$ & \\
\hline Cuidador de Idoso & Noite & 23 & 19 & $82,60 \%$ & \\
\hline Cuidador Infantil & Noite & 25 & 21 & $84 \%$ & \\
\hline Eletricista Instalador Predial de Baixa Tensão & Noite & 19 & 8 & $42,10 \%$ & \\
\hline Jardineiro & Noite & 23 & 14 & $60,90 \%$ & \\
\hline Manicure e Pedicure & Noite & 20 & 18 & $90 \%$ & \\
\hline Manicure e Pedicure & Noite & 19 & 18 & $94,70 \%$ & \\
\hline Marceneiro & Noite & 13 & 5 & $38,50 \%$ & \\
\hline Masseiro & Tarde & 20 & 20 & $100 \%$ & \\
\hline Moleiro & Noite & 22 & 17 & $77,30 \%$ & \\
\hline Montador e Reparador de Computadores & Noite & 30 & 24 & $80 \%$ & \\
\hline Operador de Caixa & Noite & 28 & 13 & $46,50 \%$ & \\
\hline Operador de Máquinas e Implementos Agrícolas & Noite & 24 & 6 & $25 \%$ & \\
\hline Padeiro & Tarde & 20 & 15 & $75 \%$ & \\
\hline Padeiro & Tarde & 20 & 14 & $70 \%$ & \\
\hline Pizzaiolo & Noite & 29 & 20 & $69 \%$ & \\
\hline Salgadeiro & Noite & 25 & 25 & $100 \%$ & \\
\hline Salgadeiro & Noite & 29 & 19 & $65,50 \%$ & \\
\hline Vigilante & Noite & 24 & 11 & $45,80 \%$ & \\
\hline Agricultor Familiar & Noite & 21 & 18 & $85,70 \%$ & \multirow{15}{*}{$\begin{array}{l}\text { Pronatec Campo - } \\
64,3 \%\end{array}$} \\
\hline Agricultor Familiar & Noite & 18 & 5 & $57,70 \%$ & \\
\hline Agricultor Familiar & Noite & 26 & 18 & $69,20 \%$ & \\
\hline Agricultor Familiar & Noite & 25 & 23 & $92 \%$ & \\
\hline Agricultor Familiar & Noite & 20 & 15 & $75 \%$ & \\
\hline Auxiliar de Agropecuária & Noite & 25 & 16 & $64 \%$ & \\
\hline Bovinocultor de Leite & Noite & 20 & 4 & $20 \%$ & \\
\hline Bovinocultor de Leite & Manhã & 18 & 10 & $55,50 \%$ & \\
\hline Bovinocultor de Leite & Tarde & 25 & 14 & $56 \%$ & \\
\hline Inseminador Artificial de Animais & Noite & 28 & 16 & $57,10 \%$ & \\
\hline Operador de Máquinas e Implementos Agrícolas & Noite & 24 & 8 & $33,30 \%$ & \\
\hline Operador de Máquinas e Implementos Agrícolas & Noite & 22 & 20 & $90,90 \%$ & \\
\hline Operador de Máquinas e Implementos Agrícolas & Noite & 25 & 24 & $96 \%$ & \\
\hline Operador de Sistemas de Irrigação & Tarde & 17 & 7 & $41,20 \%$ & \\
\hline Produtor Agropecuário & Noite & 25 & 20 & $80 \%$ & \\
\hline Espanhol & Tarde & 30 & 15 & $50 \%$ & \multirow{2}{*}{\begin{tabular}{|l} 
Pronatec Jovem FIC - \\
$51,4 \%$
\end{tabular}} \\
\hline LIBRAS & Tarde & 40 & 21 & $52,5 \%$ & \\
\hline Técnico em Agricultura & Tarde & 35 & 6 & $17,1 \%$ & \multirow{3}{*}{$\begin{array}{l}\text { Pronatec Jovem Técnico } \\
-32,25 \%\end{array}$} \\
\hline Técnico em Paisagismo & Tarde & 25 & 9 & $36 \%$ & \\
\hline Técnico em Zootecnia & Tarde & 33 & 15 & $45,5 \%$ & \\
\hline Agricultor Orgânico & Tarde & 19 & 13 & $68,40 \%$ & \multirow{10}{*}{$\begin{array}{l}\text { Pronatec Mulheres Mil } \\
-79,15 \%\end{array}$} \\
\hline Ajudante de Padeiro & Tarde & 13 & 10 & $77 \%$ & \\
\hline Auxiliar Administrativo & Noite & 29 & 29 & $100 \%$ & \\
\hline Auxiliar de Confeitaria & Tarde & 21 & 11 & $52,40 \%$ & \\
\hline Auxiliar de Costura & Noite & 15 & 14 & $93,30 \%$ & \\
\hline Auxiliar de Cozinha & Tarde & 24 & 20 & $83,30 \%$ & \\
\hline Cabeleireiro Assistente & Noite & 15 & 13 & $86,70 \%$ & \\
\hline Manicure e Pedicure & Manhã & 20 & 17 & $85 \%$ & \\
\hline Manipulador de Alimentos & Tarde & 18 & 13 & $72,20 \%$ & \\
\hline Viveirista de Plantas e Flores & Noite & 13 & 8 & $61,50 \%$ & \\
\hline Eletricista Instalador Predial de Baixa Tensão & Tarde & 20 & 15 & $75 \%$ & Pronatec Sistema \\
\hline Pintor de Obras Imobiliárias & Tarde & 20 & 15 & $75 \%$ & Prisional $-75 \%$ \\
\hline Total & & 1.538 & 1.033 & $67.16 \%$ & \\
\hline
\end{tabular}

Fonte: elaborada pela autora com base nos dados coletados no Campus do IFFar.

Em relação ao turno de oferta, observa-se que quase $70 \%$ das matrículas foram realizadas no turno da noite, com vistas a melhor atender as necessidades do público. Nesse turno o índice de conclusão chega a 70,8\%. O turno da tarde foi o que apresentou o menor 
número de concluintes, $57,64 \%$, em virtude da grande evasão ocorrida nos cursos técnicos, que foram ofertados nesse turno. Pela manhã, foram ofertados apenas dois cursos, obtendo no total $71 \%$ de concluintes. 


\section{CAPítulo IV \\ O desenvolvimento do Pronatec Bolsa FormaÇão EM UMA INSTITUIÇÃO DO SISTEMA S}

Os Serviços Nacionais de Aprendizagem (SNA), que compõem o conjunto das instituições do Sistema S, destinam-se à formação profissional dos trabalhadores em suas áreas de atuação - indústria, comércio, transporte, cooperativas e rural. Criadas pelo Estado - SENAI e SENAC na década de 1940 e SENAT, SENAR e SESCOOP na década de 1990 - estas instituições são mantidas por meio de contribuições compulsórias das empresas de cada setor, que são recolhidas pela Receita Federal e repassadas aos seus órgãos gestores. Nesse sentido, são consideradas entes paraestatais, pois não se integram à administração pública, embora sejam mantidas com recursos públicos, oriundos de tributos criados pelo Estado para serem aplicados em favor da sociedade, mas que não fazem parte do orçamento da União.

Com uma trajetória de mais de 70 anos, como o SENAI e SENAC, e um orçamento na casa dos bilhões ${ }^{156}$, estas instituições atingiram uma grande capilaridade ${ }^{157}$ no território nacional por meio de suas escolas, as quais tem sido mobilizadas por diferentes governos na implementação de programas de qualificação profissional, como se observou na década de 1990, com o PLANFOR, e, no último período, em relação ao Pronatec.

Participaram do Pronatec Bolsa Formação, tanto em âmbito nacional, quanto estadual, como se viu, as seguintes instituições do Sistema S: SENAI, SENAC, SENAT e SENAR. Juntas, ofertaram 66,7 \% das matrículas em âmbito nacional e 81,9\%, no Estado do Rio Grande do Sul, o que corresponde a 3.100 .800 e 269.447 matrículas, respectivamente, no período de 2011 a 2016 - em âmbito estadual, 91,8\% das matrículas foram realizadas em cursos FIC e $8,2 \%$ em cursos técnicos. Com vistas a compreender o desenvolvimento do Programa no seio destas instituições, foi selecionada uma delas - que será nominada aqui como "instituição SNA" ou apenas "SNA" - com base no critério de maior número de oferta de cursos, tanto FIC, quanto técnico e da autorização da instituição para a realização da pesquisa.

Nesse Capítulo, apresentam-se os dados e resultados da pesquisa realizada no SNA situado no Rio Grande do Sul, cotejando-os em relação à realidade observada no Instituto

\footnotetext{
${ }^{156}$ No ano de 2016, o SENAC recebeu 2,57 bilhões via contribuição compulsória e o SENAI, 1,52 bilhões (fonte: Receita Federal). Além disso, as instituições de ensino do Sistema S também obtêm receita por meio da venda de seus cursos para o mercado ou para governos.

157 O SENAC possui 600 unidades escolares, empresas pedagógicas e unidades móveis que atendem 2.200 municípios. Enquanto o SENAI, em 2015, contava com 518 unidades fixas e 504 unidades móveis em 2,7 mil municípios brasileiros (Fonte: site do SENAC e site da CNI).
} 
Federal. Inicia-se com a caracterização da instituição, a forma de gestão institucional do Programa e o perfil da oferta dos cursos. Em seguida, apresenta-se o processo e as condições do desenvolvimento dos cursos do Pronatec Bolsa Formação, buscando compreender os sentidos construídos no âmbito da instituição em relação ao Programa, a formação dispendida e os resultados obtidos em relação à conclusão das matrículas, a partir do aprofundamento da investigação em duas unidades de ensino da Instituição: uma situada em Porto Alegre e outra na cidade de Uruguaiana, as quais serão identificadas no texto como "Escola A" e "Escola B" do SNA, respectivamente.

\subsection{Perfil da Instituição e do desenvolvimento do Pronatec Bolsa Formação}

O SNA que fez parte da pesquisa possui mais de 70 anos de existência, tendo sido instalado no Estado do Rio Grande do Sul no mesmo ano de sua criação pelo Governo Vargas. A instituição atua em todas as regiões do Estado a partir de 42 escolas de educação profissional e 20 balcões, que são extensões de algumas escolas, e duas Faculdades. Também atua por meio do ensino à distância, tendo como polos de apoio presencial as próprias unidade de ensino. A administração central da Instituição no Estado, o chamado Diretório Regional, situa-se em Porto Alegre, onde é realizada a gestão institucional da educação profissional no âmbito do Núcleo de Educação Profissional (NEP), que foi o primeiro espaço de interlocução da pesquisa.

O Projeto Político Pedagógico da instituição, reelaborado em 2014, aponta a adoção do “modelo de educação para a competência". Nesse modelo, o currículo passa a ser organizado a partir das competências necessárias ao perfil profissional que se pretende desenvolver. Os conhecimentos, as habilidades, atitudes e valores passam a ser "os recursos ou subsídios necessários ao desenvolvimento da competência”, conclui (SNA, 2014, p. $24^{158}$ ).

Com base nessa proposta pedagógica, o processo de criação do projeto pedagógico de novos cursos ou de reformulação daqueles vigentes segue metodologia com participação direta da comunidade empresarial na definição das competências necessárias ao egresso. Tais competências são a base da organização do currículo, conforme explica o Gestor que atua no Núcleo de Educação Profissional (NEP), do Diretório Regional ${ }^{159}$ do SNA:

O nosso novo modelo pedagógico, que é muito bom - eu considero muito bom e inteligente - ele discute com a comunidade empresarial, com aquele segmento empresarial o perfil daquele profissional. Olha vamos fazer um curso de

\footnotetext{
${ }^{158} \mathrm{O}$ documento se encontra nos arquivos da pesquisa.

${ }^{159}$ O Diretório Regional do SNA, situado em Porto Alegre, é responsável pela gestão administrativo-pedagógica das unidades de ensino situadas no Rio Grande do Sul.
} 
Instrumentador Cirúrgico, por exemplo. Bom, o que faz o Instrumentador Cirúrgico? Quais são as competências? Todo o nosso currículo é por competências, a formação é por competências hoje. Então nós reunimos todos aqueles empresários do setor, lideranças do setor, profissionais do setor, e nós discutimos em dois dias - fazemos uma reunião de dois dias, eles almoçam no hotel conosco - qual o perfil, quais as competências com a visão de futuro hoje. E daqui a três anos com a evolução do setor, o que nós precisamos colocar como perfil na vida desses profissionais? Definido esse perfil a gente parte para a discussão da montagem do currículo, aí nós chamamos os professores que são observadores do fórum, eles participam como observadores, mas não interferem. Colhem aquele material, trabalham aquelas competências e definem quantos módulos vai ter, quais as competências, o projeto integrador, o sistema de avaliação por competências... Isso para os cursos técnicos e também para alguns cursos de qualificação também fazemos, aqueles com duração de 400 horas ou mais. Os mais rápidos não precisamos fazer isso, só a comissão técnica se reúne e dá conta. E aí devolvemos para o fórum: “é isso? Isso!” Validado, a gente então coloca o curso. (...) Então isso é muito bom, porque aí o mercado está recebendo aquilo que ele espera receber. "Olha, nós precisamos é de profissionais formados com essas competências" E a gente depois vai complementando. (Entrevista GESTOR NEP SNA).

\section{No âmbito do Pronatec Bolsa Formação, o SNA foi a instituição que mais ofertou vagas}

no Estado do Rio Grande do Sul, até o ano de 2016. Na Tabela 40 pode-se visualizar os dados da oferta a cada ano, de acordo com o tipo de curso. Do total de matrículas, 86,5\% foram realizadas em cursos FIC e 13,5\% em cursos técnicos, sendo que parte destes foi realizada na modalidade a distância ${ }^{160}$.

Tabela 40 - Matrículas no Pronatec Bolsa Formação - SNA (2011-2016*)

\begin{tabular}{l|lllllll}
\hline \hline Curso/Ano & $\mathbf{2 0 1 1}$ & $\mathbf{2 0 1 2}$ & $\mathbf{2 0 1 3}$ & $\mathbf{2 0 1 4}$ & $\mathbf{2 0 1 5}$ & $\mathbf{2 0 1 6}^{\mathbf{1 6 1}}$ & Total \\
\hline FIC & 3.397 & 24.698 & 60.074 & 54.065 & 5.075 & 16 & 147.325 \\
\hline Técnico & & 1.636 & 3.660 & 6.984 & 801 & & 13.081 \\
\hline Técnico EAD & \multicolumn{7}{c}{} \\
\hline Total & 3.397 & 26.334 & 63.734 & 61.049 & 7.803 & 16 & 162.333 \\
\hline * Apenas matrículas novas a cada ano. \\
Fonte: elaborada pela autora com base nos dados do SISTEC Nacional (2017).
\end{tabular}

De acordo com o Gestor do NEP, a participação do SNA como instituição ofertante deuse desde o início do Pronatec, na condição de "principais parceiros do governo federal", juntamente com as demais instituições do Sistema S, na implementação da política. Conforme destaca,

Este programa, ele foi concebido pelo Governo Federal, pelo MEC, e buscaram o Sistema $\mathrm{S}$ como o principal parceiro. Porque este programa exige uma boa capilaridade no país todo, uma boa estrutura de escolas, um bom conteúdo programático, uma boa proposta curricular, instalações de equipamentos, de laboratórios e também de docentes, de multiplicadores, de expertises... O governo

${ }^{160}$ Conforme viu-se no Capítulo II, desde 2013 a oferta de cursos na modalidade a distância pelo Sistema S, a partir da adesão à Rede e-Tec, foi normatizada no âmbito da Bolsa Formação, com o repasse do valor de R $\$ 4,50$ (quatro reais e cinquenta centavos) o valor da hora/aluno, sem previsão de assistência estudantil.

${ }^{161}$ A partir do segundo semestre de 2015, o SNA passou a sofrer com atrasos no repasse dos recursos do Programa pelo governo federal. Assim, neste ano os cursos em andamento tiveram continuidade, e apenas 16 novas matrículas foram pactuadas, conforme consta nos relatórios de matrículas do SISTEC Nacional obtidos via e-Sic. 
elaborou este programa, mas ele não tinha essa condição. Só as escolas técnicas e em número pequeno para atender esse programa no país inteiro, e algumas com dificuldades, inclusive de execução, algumas escolas estavam realmente bastante ruins, escolas estaduais. Contou também com os Institutos Federais como parceiros, mas também são em pequeno número. E o sistema $\mathrm{S}$ tem uma grande capilaridade, atende o país inteiro, está em todos os lugares e se não está fisicamente ele tem condições de rapidamente colocar uma extensão e levar suas unidades móveis, seus recursos móveis para implantar outros em outros locais, assim, estruturas, polos para atendimento desta população. Por essa razão o Sistema $\mathrm{S}$ foi estratégico e fundamental para que este programa pudesse ser implementado, iniciado (Entrevista GESTOR NEP SNA).

Com vistas nessa parceria, a Lei do Pronatec vinculou as instituições dos Serviços Nacionais de Aprendizagem (SNA) ao sistema federal de ensino, como se viu no Capítulo II, possibilitando-lhes autonomia para a criação de cursos e programas de educação profissional e tecnológica. Esse fato é destacado pelo Gestor como um dos benefícios do Programa à instituição:

\begin{abstract}
Um grande benefício, que eu acho que ele trouxe, notadamente para o Sistema S, foi vincular, não subordinar, mas de o vincular ao sistema federal de educação. Todos os nossos planos de curso antes, os cursos técnicos, precisavam ser submetidos ao Conselho Estadual de Educação e à Secretaria Estadual de Educação. Por vezes nós tínhamos cursos assim que ficavam um ano, um ano e meio esperando autorização para começar. $\mathrm{O}$ empresário não podia esperar um ano e meio para ter uma autorização. Tens autorização depois leva mais um ano e meio para formar mais estágio, até o mercado receber esse aluno formado era uma eternidade... Então o processo era lento, burocrático, não por desinteresse do Estado, mas por pouco pessoal. É um sistema mais burocrático, mais lento e até que viesse uma visita aqui do Governo do Estado para verificar as instalações e autorizar a realização do curso levava muito tempo. E agora não, esses cursos agora são submetidos ao Conselho Regional da Instituição ao nosso Conselho Regional, como funciona nas Instituições Federais. E, é claro, dentro das normas, atendendo às exigências do MEC, com instalações de biblioteca com padrões de qualidade, acessibilidade, docentes formados, formação pedagógicas, formação técnica, estrutura toda de suporte acadêmico dentro da escola, conselhos exigidos, secretário escolar, pedagogos, orientadores educacionais, toda a estrutura. Isso o programa trouxe de bom agilizar, modernizar, qualificar. Nos permitiu isso, nos deu, assim, agilidade (Entrevista GESTOR NEP SNA).
\end{abstract}

Em relação à aplicação dos recursos provenientes da Bolsa Formação, a instituição paga a assistência estudantil no valor de $\mathrm{R}$ \$2,00 (dois reais) a hora-aula por estudante e o restante faz parte da receita da instituição utilizada para o pagamento das despesas da oferta. Não há diferença entre a venda de cursos para o governo, no caso do Pronatec, e a venda de cursos para empresas, ressalta o Gestor:

Como se eu vendesse o curso, por exemplo, para a Gerdau; fazer um curso em combo para a Gerdau: é 10 reais a hora/aula. O curso é tantas horas/aula, etc, por tanto tempo: sai x o custo aluno e o todo completo sai 6 mil reais, por exemplo, para tantas pessoas. Então tem um valor hora/aula negociado com o governo federal de 10 reais, incluindo assistência estudantil. Alguns cursos até nem pagam isso, porque tem alguns cursos 
que são bem mais caros. No Instituto Federal é diferente, os professores recebem para dar aula e recebem também o salário, me parece, porque é além da carga horária. Aqui não recebem nada além. Esses 10 reais vêm para dentro da receita global da instituição, como qualquer outro curso. Que é mais ou menos o preço de mercado (Entrevista GESTOR NEP SNA).

No entanto, os valores pagos pelo Pronatec são bem superiores aos praticados no mercado, pela própria instituição. Na escola A, por exemplo, entre os cursos técnicos ofertados o maior valor cobrado pela hora/aluno é de $\mathrm{R} \$ 6,24$ e, na Escola B, o valor da hora/aluno no curso Técnico em Enfermagem, um dos cursos técnicos mais caros, é de R\$ 5,55. Assim, observa-se que a participação no Programa era muito vantajosa para a instituição, tanto em relação ao valor pago quanto em relação à garantia de pagamento, tendo impulsionado a oferta de grande número de matrículas. Conforme aponta o próprio Gestor do SNA "Enquanto o governo estava pagando com regularidade, era um parceiro confiável. Isso reduziu a inadimplência, que muitas vezes a gente tem com as pessoas que nos procuram e fazem cursos de mercado conosco, que às vezes atrasam, desistem, não pagam...” (Entrevista GESTOR NEP SNA).

Além disso, após decorrido o prazo para confirmação dos estudantes nos cursos, os casos de abandono não impactavam no orçamento, visto que o valor já havia sido repassado à instituição. Essa característica do Programa foi salientada de forma positiva pelo Gestor do NEP e pelo Diretor da Escola A, conforme os depoimentos a seguir:

A gente tinha um acordo: olha a turma é pra 20 alunos, então nós temos docentes para 20 alunos, o custo docente é $\mathrm{x}$, o custo aluno hora/aula é y, né. Bom, mas se o índice de evasão é muito grande, nesse grupo é muito grande (...) é superior aos nossos cursos regulares. Então nós temos que garantir, até mesmo porque se ficam três ou quatro na turma eles tem que ir até o final. Uma coisa é ratear o curso de um docente, o material, energia, instalações que ficam ali cativos para aquilo aí, reservadas para vinte alunos outra é ficar para quatro ou cinco alunos. Então se continuava recebendo por esse aluno mesmo se ele tivesse desistido, ido embora, eles continuavam pagando pelos vinte alunos (Entrevista GESTOR NEP SNA).

O que, digamos assim, deu certo no programa, é que o início da turma, levando-se em consideração aquele tempo para substituição de alunos, depois que a turma estava montada, independente da desistência, ele continuou sendo pago pelo valor inicial. Isso foi importante, aliás, foi fundamental, se não fosse isso, o curso se tornava inviável. Em alguns lugares houve, digamos assim, uma demanda inicial de 30, 35 vagas, e a turma terminou com 06. Não teria condições de manter. Então, isso foi importante, essa questão da pactuação (Entrevista Diretor Escola A SNA).

Em 2015, a SETEC alterou esta norma, incluindo, a partir de 2016, como fator no repasse dos recursos o percentual de conclusão dos cursos do exercício anterior, como se viu no Capítulo II. Apesar da grande diminuição do orçamento do Pronatec Bolsa Formação 
naquele ano, curiosamente, pela primeira vez a oferta pública de matrículas no Programa foi maior que a do Sistema S. Das 86.352 (oitenta e seis mil trezentas e cinquenta e duas) matrículas desenvolvidas nesse ano, 71,2\% foi desenvolvida pela rede pública (rede federal e rede estadual) e apenas $28,8 \%$ pelas instituições do Sistema $\mathrm{S}$.

Nesse sentido, a Diretora da Escola B destaca que o Programa deixou uma boa "herança" para a instituição:

\begin{abstract}
Eu acho que a principal vantagem foi o que o Pronatec deixou, a herança do Pronatec, principalmente, na parte de estruturas. As Unidades cresceram muito. E a gente sabe que esse período bom do Pronatec, de recursos, foi o que ajudou o SNA a poder construir, reformar as Unidades. Aqui a escola foi reformada, assim como quase todas as Unidades do Estado, ou foram construídas escolas novas, ou foram reformadas as escolas. Então, eu acho que o Pronatec, assim, ele deixou bons frutos, não é: os Laboratórios de Beleza, os Laboratórios de Enfermagem, esses laboratórios todos, que eram tão necessários para o Pronatec, hoje a gente consegue vender cursos neles, e eles são muito bem equipados. Então, eu acho que foi um ótimo período. Eu gosto muito de lembrar do período do Pronatec (Entrevista Diretora Escola B SNA).
\end{abstract}

A partir de 2015, quando os recursos do Programa passaram a diminuir, as instituições privadas e inclusive as do Sistema S reclamavam da falta de continuidade do Programa visto que haviam se preparado para atender um número $\mathrm{x}$ de matrículas e com os cortes no orçamento esse número diminuiu muito ou era inexistente, em algumas instituições. Porém, grande parte da estrutura preparada para atender esses alunos havia sido construída/adquirida com recursos do próprio Programa. Assim, a dificuldade que se apresentava a essas instituições era o desafio de voltar "vender seus cursos", após um período em que a população estava acostumada a realizar os mesmos cursos de forma gratuita e a instituição a receber o pagamento em dia e em valores superestimados.

Nessa direção, as falas do Gestor NEP e do Prof. 01, Escola B, ilustram essa situação:

Isso desafia as nossas unidades a reverterem aquilo que faziam com o Pronatec, com aquela receita, a fazer mercado, vendendo os cursos. E é difícil, tu hás de convir conosco, que é difícil. Num momento em que a população está recebendo tudo de graça, tem o acordo de gratuidade uma parte, pelo Pronatec outra parte. A população já está acostumada a receber tudo, aí tu vais vender aqueles mesmos cursos? (Entrevista GESTOR NEP SNA).

O SNA acabou sendo uma empresa que as pessoas achavam que era pública, que estava aqui para fazer assistencialismo só. Em 2015, que já tinha terminado, praticamente, foi muito ruim a questão de venda de curso pago, porque até tu desmistificar não só para as pessoas, mas a sociedade inteira, dizendo que: "Ó, nós oferecemos cursos pagos". Aí vem e diz: "Ah, por quê que eu vou pagar, se tinha curso gratuito aqui?” (Entrevista Prof. 01, Escola B SNA). 
No entanto, passado essa fase, no ano de 2017, na avaliação da Diretora da Escola B o Programa contribuiu para a retomada da venda de cursos, pois as pessoas passaram a conhecer a instituição:

\begin{abstract}
Eu acho que ele trouxe, assim, como desafio a questão de que o SNA se transformou: era uma escola, uma instituição forte, que trabalhava já com vendas de curso e com cursos gratuitos, aprendizagem, e o Pronatec, ele foi tão grande, que ele acabou nos tirando um pouco desse caminho da venda. A maioria das Unidades tinha mais turmas de Pronatec, do que turmas de Mercado, que nós chamamos, que são turmas vendidas. Então, precisou, num determinado momento, quando a gente identificou, como gestores, que o Pronatec estava diminuindo, e que corria o risco de acabar, chegou aquele clique, assim, da virada: bom, a partir de agora a gente não pode mais depender financeiramente, do Pronatec, só do Pronatec, e o que nós vamos fazer para que o SNA volte a ser visto pelas pessoas como uma instituição que não oferta só cursos gratuitos? Porque, num determinado momento, algumas Unidades ofertavam tantos cursos gratuitos, que ninguém lembrava mais que o SNA podia vender um curso. Então, as pessoas, até hoje, ligam perguntando: "Que cursos gratuitos vocês têm? Que Cursos do Pronatec vocês têm?" Mas, acho que nosso Diretor Regional ele tem uma questão de gestão tão forte, que ele conseguiu decidir na hora certa o momento de dar essa virada: "Bom, a partir de agora, nós vendemos. Quem tem Pronatec, continua ofertando, mas eu preciso de estratégia de vendas e de recolocação da imagem do SNA, como uma instituição que vende". Então, assim, eu sou fã dele, porque outras instituições não conseguiram fazer isso, dar essa virada, de não ser vista como uma escola de cursos gratuitos. O SNA conseguiu, nós realmente vendemos muito bem hoje, mais do que vendíamos antes do Pronatec, até porque tem uma questão do quanto as pessoas passaram a conhecer o SNA, a qualidade dos cursos do SNA. Então, eu acho que esse foi o principal desafio, que foi a virada, de sair da imagem de uma instituição que ofertava só cursos gratuitos, e que as pessoas entendessem o funcionamento do SNA (Entrevista Diretora Escola B SNA, grifos nossos).
\end{abstract}

Obviamente, a partir da venda de cursos direto no mercado não é possível atingir os mesmos valores em termos de orçamento, pois o atendimento ao programa ultrapassou a própria capacidade física das escolas, como se verá em relação às duas unidades de ensino pesquisadas. Como destaca a Diretora da Escola B, "no último ano de Pronatec a Unidade chegou a receber 7 milhões. E esse ano a gente tem uma meta de venda de 1 milhão e 700 mil” e isso já ocuparia toda a capacidade da escola no turno da noite, o qual concentra a maior demanda.

Com isso observa-se que as escolas do SNA atendiam quase que exclusivamente apenas as demandas de curso pelo Pronatec, ao contrário das instituições públicas federais que tinham de conciliar as demandas do Programa com o atendimento de seus cursos regulares. Essa especificidade culminou nas grandes diferenças no número de matrículas no Pronatec Bolsa Formação entre as instituições. Além disso, a grande oferta de cursos gratuitos e o pagamento regular da assistência estudantil contribuiu para a construção de uma boa imagem da instituição 
junto à comunidade ${ }^{162}$, diferentemente das unidades do IF, onde tanto docentes quanto estudantes foram atingidos pelo atraso no repasse dos recursos pelo governo federal.

Quanto à forma de recebimento destes recursos, segundo o Gestor, o repasse era feito pelo MEC ao Diretório Nacional do SNA de forma antecipada, de acordo com a previsão de matrículas. O Diretório Nacional, por sua vez, repassava os valores aos Diretórios Regionais com base nos relatórios de produção, que é medida pela carga horária de aulas e número de matrículas desenvolvidos no Programa. Desse valor de R\$10,00 a hora aula, R \$ 2,00 são destinados à assistência estudantil e o restante entra na "receita" da instituição para cobrir os custos da realização dos cursos, que pode ir desde o pagamento do professor à manutenção e construção de novos prédios. Nas palavras do Gestor:

Esse dinheiro é assim: a produção que é feita no Pronatec vai para o controle de produção no relatório que vai para o DN, que é o Departamento Nacional: olha, o Rio Grande do Sul fez tantas mil horas em carga horária efetiva, que eles chamam, e tantas mil matrículas. O recurso chega através do Nacional, que estava recebendo antecipadamente do MEC por previsão de matrículas que seriam realizadas. Aí o DN repassava o custo ao departamento regional do Rio Grande do Sul, para pagar a produção que ele fez no Pronatec, a 10 reais a hora aula, com assistência estudantil e de alimentação, em torno de R\$ 2 reais. Então o líquido ficava em torno de 8 reais. Mas tu terias que tirar dentro desses 8 reais todo o teu custo: custo do docente, do material didático, luz, água, equipamentos, material de consumo, etc. Isso tu tira e fica um saldo, um certo lucro. Bom, isso fica com a instituição e vem para a receita geral da instituição. Dessa receita geral tu tem tanto para gastar nos serviços educacionais, então isso pode ser do Pronatec, oriundo da venda de cursos incompany das empresas, oriundo das vendas de cursos geral (Entrevista GESTOR NEP SNA, grifos nossos).

Com base nesse relato, observam-se algumas diferenças em relação ao desenvolvimento do Programa no âmbito dos Institutos Federais e, especificamente, do IFFar: os recursos para o SNA eram repassados de forma adiantada, o valor dispensando para a assistência estudantil é menor, não há um valor fixo para o pagamento dos profissionais envolvidos e não há restrições no uso do recurso, tendo sido utilizado inclusive em reformas e construções de novas escolas, como se observou na fala da Diretora da Escola B. Os atrasos do governo no repasse do orçamento tiveram início no segundo semestre de 2015, enquanto no IFFar os atrasos foram sentidos ainda no segundo semestre de 2014.

O corpo docente da instituição é contratado sob o regime de horista, ou seja, pela carga horária de aulas realizadas ou atividade de coordenação. A remuneração segue a tabela da instituição, que varia de acordo com o nível de curso de educação profissional - Aprendizagem,

\footnotetext{
${ }^{162}$ Por meio do questionário respondido pelos discentes das escolas A e B do SNA, num total de 34, apenas três (03) apontaram pontos negativos em relação aos cursos: não ter opção de troca de horário; sala de aula pequena; e pouco espaço físico para os intervalos. As duas últimas observações eram decorrentes do grande número de alunos atendidos pelas escolas e a primeira era uma limitação do SISTEC, que não permitia troca de turno em um mesmo curso no âmbito do Programa.
} 
FIC ou Técnico - em que atua e a formação acadêmica. A titulação máxima considerada para remuneração dos professores - que são contratados como Orientador de Educação Profissional (OEP) - é Mestrado e a mínima Ensino Médio. No Quadro 6, pode-se visualizar essa estrutura remuneratória:

\begin{tabular}{|c|c|c|c|c|c|c|c|}
\hline ATUAÇĀO & \multicolumn{2}{|c|}{ CARGO } & \multicolumn{5}{|c|}{ Valor da horalaula } \\
\hline \multirow[b]{2}{*}{ Aprendizagem } & \multirow{2}{*}{ OEP A } & Valor & $\frac{\text { Médio }}{12,38}$ & $\frac{\text { Técnico }}{1324}$ & $\frac{\text { Superior }}{14,17}$ & $\begin{array}{c}\text { Especializacäo } \\
15,15\end{array}$ & $\frac{\text { Mestrado }}{16,22}$ \\
\hline & & $Q t$ & 7 & 1 & 42 & 39 & 6 \\
\hline \multirow{2}{*}{ Formação inicial e continuada (FIC) } & \multirow{2}{*}{ OEP B } & Valor & 16,10 & 17,23 & 18,43 & 19,71 & 21,11 \\
\hline & & $Q t$ & 59 & 11 & 71 & 80 & 25 \\
\hline \multirow{2}{*}{ Técnico e FIC } & \multirow{2}{*}{ OEP C } & Valor & 22,54 & 24,13 & 25,80 & 27,60 & 29,54 \\
\hline & & $Q t$ & 48 & 11 & 136 & 240 & 60 \\
\hline
\end{tabular}

Fonte: Estrutura Remuneratória de cargos e funções, em maio de 2018 (arquivos da pesquisa).

Pode-se observar que o valor da hora/aula é bem inferior ao pago pelas instituições públicas (R\$ 50,00 a hora/aula). O menor valor da hora aula corresponde a 32,2\% e o maior não atinge $60 \%$ do valor pago pelas instituições públicas federais no âmbito do Programa. Esse fato gerou indignação por parte de alguns professores que atuaram no Pronatec em instituições do Sistema $S$, conforme noticiado pela mídia ${ }^{163}$, e resultou, inclusive, em ações jurídicas junto a instâncias competentes ${ }^{164}$.

Havia também a contratação de professores como "pessoa física ou pessoa jurídica", os quais são contratados para uma carga horária e período de trabalho específico, não gerando vínculo empregatício com a instituição. Conforme exemplifica a Diretora da Escola B "quando é um curso, dois, a gente consegue contratar a pessoa como pessoa física ou pessoa jurídica, dependendo de como ela trabalhe. Então, em um curso de 60 horas, eu faço um contrato com o pagamento de 60 horas, e não tem vínculo empregatício com o SNA". Já "quando é um curso que a gente vê uma demanda maior, por exemplo, aqui que tinham os Técnicos em Enfermagem: aí a gente precisa fazer todo o processo seletivo e a pessoa entra no quadro, e ela fica trabalhando como colaboradora do SNA" (Entrevista Diretora Escola B SNA).

De acordo com o Diretor da Escola B, o custo total da hora de trabalho docente para a instituição chega a 1,8 vezes o valor recebido pelo profissional. Assim, o docente que recebe o maior valor $(\mathrm{R} \$ 29,54)$ custaria para a instituição o valor de $\mathrm{R} \$ 53,20$. Porém, observou-se por meio das entrevistas e questionários aplicados aos docentes, que havia uma divisão entre o

\footnotetext{
163 No Distrito Federal, profissionais que atuaram em cursos do Pronatec ofertados pelo SENAC argumentavam que: "O Senac paga R $\$ 28,26$, mas eu soube que o valor pago pelo MEC é de R \$ 50 para todas as instituições" (Jornal Correio Brasiliense, em 08/04/2014).

164 No site www.jusbrasil.com.br foi possível localizar dois processos (Processo No RO-000202641.2014.5.19.0061 e Processo No RTOrd-0001435-45.2015.5.19.0061) que tem como objeto a complementação dos valores da hora aula pagos por instituições do Sistema $S$ em cursos do Pronatec, em relação ao valor de $R \$$ 50,00. As apreciações apresentam decisões contraditórias, ora dando ganho de causa ao autor, ora à instituição.
} 
corpo docente dos cursos FIC e cursos Técnicos, em virtude do custo da hora aula. Do total de 26 docentes que responderam ao questionário, 07 atuaram apenas em cursos FIC, o que corresponde a contrato como OEP B, 10 atuaram exclusivamente em cursos técnicos e 08 atuaram em ambos os cursos. Tendo em vista que grande parte dos cursos realizados por meio do Pronatec Bolsa Formação foram cursos FICs, aliado à possibilidade de contrato temporário de trabalho, a maior parte dos docentes atingiria um custo bem menor que o exemplificado pelo Diretor $^{165}$.

Observa-se que são desenvolvidas, no âmbito do Pronatec Bolsa Formação, relações precárias de trabalho, tanto nas instituições públicas federais quanto nesse caso. Os contratos de trabalho temporários, além de eximir os direitos trabalhistas, também fragilizam a constituição de coletivos de trabalhadores que poderiam atuar tanto na qualificação do trabalho desenvolvido - neste caso das condições pedagógicas de desenvolvimento do próprio Programa - quanto nas próprias condições de trabalho, configurando a "quase uberização" do trabalho docente (VENCO, 2018). Este fenômeno, caracterizado pelas relações instáveis e sem nenhum direito trabalhista realizadas por meio do aplicativo de transporte UBER, configura uma "tentativa de introjetar em cada trabalhador/a o sentimento de ser um empresário de si: deixar o carro agradável ao passageiro, oferecer balas, revistas; e, no caso dos professores 'não criar caso com a escola', mostrar-se sempre disponível para qualquer aula para ser chamado sempre" (VENCO, 2018, p. 102).

Essa diferença no pagamento se reflete também na titulação dos professores. Dos 26 docentes que atuaram no Pronatec no âmbito das Escolas A e B pesquisadas, que responderam ao questionário, apenas 02 possuem Mestrado, 15 possuem Especialização, 08 apenas graduação e 01 é formado em curso Técnico. Por outro lado, a grande maioria desses profissionais (22) tinham experiência na docência em educação profissional, embora somente 08 possuíam formação pedagógica. Esses dados vêm ao encontro do perfil da instituição, que prioriza profissionais com experiência profissional e conhecimento do mercado de trabalho à formação acadêmica. Conforme aponta o Prof. 01, da Escola B, a instituição costuma manter entre seu quadro docentes alguns profissionais do mercado de trabalho considerados "medalhões": "Ah, era dono de uma empresa, que era o gerente não sei de onde. Que era para dar impacto: Ó, o gerente de fulano não sei de onde, dá aula no SNA".

Conforme os dados disponíveis nos Relatórios de Gestão do SNA, em todo o Estado, nos períodos de maior número de matrículas no Programa o número de colaboradores

165 Pode-se observar no Quadro 6, que, em 2018, após o período do Pronatec, a maior quantidade de docentes se encontra nas faixas de menor remuneração. 
aumentou, conforme a Tabela $41^{166}$. No entanto, nas duas escolas pesquisadas havia apenas uma Pedagoga atuando na parte pedagógica, as quais desempenhavam a mesma carga horária, independente do acréscimo no número de alunos e docentes ${ }^{167}$. A carga horária dos docentes entrevistados chegava a 180 horas mensais, no período de oferta de cursos pelo Pronatec, o que equivale a uma média de 09 horas diárias, sendo que o limite de contratação era de 10 horas diárias. De acordo com o Prof. 1 da Escola B, havia pouca rotatividade dos professores que atuavam no Pronatec, pois se priorizava professores que "tivessem disponibilidade total de horário, era meia-dúzia de professores que tinham disponibilidade só à noite”. Assim, a alta carga horária "compensava" o baixo valor da hora/aula. Esse fato, associado à oferta de várias turmas por curso, contribuía para um melhor aproveitamento do corpo docente e das instalações físicas e materiais disponíveis.

\begin{tabular}{c|c} 
Tabela $41-$ Número de colaboradores no SNA - 2012 a 2017 \\
\hline \hline Ano & N. colaboradores \\
\hline 2012 & 1.849 \\
2013 & 2.424 \\
2014 & 2.801 \\
2015 & 2.390 \\
2016 & 2.155 \\
2017 & 1.948 \\
\hline
\end{tabular}

Fonte: elaborada pela autora com base nos Relatórios de Gestão do SNA (arquivos da pesquisa).

Para orientar a gestão do Pronatec no âmbito dos Diretórios Regionais da Instituição, o Departamento Nacional elaborou um Documento que apresenta as diretrizes operacionais para a execução do Programa, desde a pactuação da oferta até os procedimentos para o repasse dos recursos aos departamentos regionais de acordo com relatório de produção, que ocorrem mensalmente. $\mathrm{O}$ valor de $\mathrm{R} \$ 2,00$ (dois reais) para a assistência estudantil é definido nesse documento, sendo válido para todos os Departamentos Regionais do SNA.

Não se observa nessa instituição uma flexibilidade em relação à distância para locomoção dos estudantes, como se observou no IFFar. No SNA, todos os estudantes recebem o mesmo valor, independente do custo do transporte e da alimentação em cada cidade. Os estudantes da Escola A, situada na capital do Estado, que tem uma das cestas básicas mais caras do país, reclamavam do valor da assistência estudantil, pois não possibilitava comprar o lanche na cantina da própria escola. Frente a esta demanda, a orientação da Direção era de que "com

\footnotetext{
166 Nesses dados estão incluídos os colaboradores de todas as unidades do SNA, inclusive as Faculdades e equipe técnica do Diretório Regional, sendo que as Faculdades não atuaram no Programa.

${ }^{167}$ De acordo com um dos professores entrevistados, após a aposentadoria da Pedagoga que atuava na escola B, em 2012, vários pedagogos passaram pelo cargo, onde permaneciam por alguns meses e saiam alegando a grande quantidade de trabalho.
} 
aquele valor comprassem alguma fruta no mercado, trouxessem uma fruta", ao mesmo tempo em que reconhece "Mas aí tu vê alguém tomando um refrigerante, tu vê alguém comendo um pastel, você vai querer fazer exatamente isso...” (Entrevista Diretor Escola A SNA). Segundo o Diretor, esse era o valor pactuado no "contrato" com o Pronatec e não tinha como ser alterado pela escola. No entanto, as resoluções do FNDE que regulamentam o repasse de recursos para o Sistema S não definem um valor mínimo para a assistência estudantil, ficando a cargo das instituições.

No início do Programa, as escolas faziam o repasse do valor da assistência estudantil na forma de passagens e vale alimentação. Porém, em virtude das dificuldades de controle da entrega e inclusive de necessidade de pessoal para realizar esse trabalho - era necessário ir até as empresas de transporte para carregar o cartão magnético para o transporte público ou comprar as "fichas" de passagem - o repasse passou a ser realizado por meio de depósito bancário.

Na cidade de Uruguaiana, onde fica a Escola B, às vezes, as empresas de transporte não tinham, no dia da compra, o número de fichas de passagem necessárias, em razão do grande número de alunos, o que implicava em atraso na entrega das passagens aos estudantes. Havia uma preocupação também em relação à segurança no transporte destes valores, embora não fossem em espécie, conforme relata o Diretor da Escola A:

(...) nós íamos buscar o cartão, o Tri, não é, que é da passagem. Então, houve ocasião em que tivemos que buscar 120 mil reais em cartões. Então, a gente ficava, assim: poxa vida, vamos ter que trazer com carro-forte para cá, porque aquilo ali é dinheiro. Embora não fosse em espécie, mas vale dinheiro. Então, a gente brincava: ó, vamos ter que vim acompanhado por um batedor (Entrevista Diretor Escola A SNA).

Assim, com a possibilidade de depósito bancário, a instituição não teve mais esse problema, além de gerar economia em força trabalho. Nas palavras de um dos professores entrevistados: "No Financeiro eram duas pessoas, tinha que pagar o serviço para fazer isso, também. Então, ficou bem mais fácil, assim, com o dinheiro. Não fazia diferença, para nós não tinha desconto..." (Entrevista Prof. 01, Escola B SNA).

4.1.1 O desenvolvimento pedagógico e o currículo dos cursos: ênfase no empreendedorismo e na psicologia organizacional

O desenvolvimento pedagógico dos cursos ofertados pelo Pronatec no âmbito das escolas do SNA, não se diferenciava dos demais, uma vez que estes seguiam o mesmo Projeto Pedagógico, inclusive com estágios e Trabalho de Conclusão de Curso, quando previsto. Não 
se observou incompatibilidade entre as normas institucionais e as do Programa, visto que, diferentemente do que se observou no IFFar, os cursos ofertados pelo Pronatec no SNA seguiam a mesma dinâmica de gestão dos demais. A autonomia de gestão dos recursos financeiros e da contratação de docentes foi o grande diferencial nesta instituição para o desenvolvimento pedagógico dos cursos de acordo com a sua proposta pedagógica. Afinal, a única diferença, conforme se referiu o gestor do NEP, é que em vez de a instituição vender seus cursos no mercado, estava vendendo para o governo.

O grande volume de matrículas nos cursos, também favorecia a recuperação da aprendizagem, uma vez que no caso de reprovações ou necessidade de recuperação de aulas, os estudantes tinham a possibilidade de frequentar outras turmas em andamento - o que não se observou no IFFar, o qual atendia uma maior diversidade de cursos, considerando o número de matrículas. Além disso, havia a possibilidade de atendimento de estudantes com dificuldade de aprendizagem em horário específico antes das aulas, conforme relata a Pedagoga da Escola A:

\begin{abstract}
As recuperações acontecem em aula ou em outras turmas que estão em andamento. Eu tenho alguns estudantes que tem muito mais dificuldade e que não conseguem, em função às vezes da idade ou em função da complexidade, de chegar ao modulo três que é a área de programação, então eles tem muita dificuldade na lógica, na matemática e pra que eles consigam se apropriar a gente oportuniza que eles frequentem uma outra turma num contra turno, por exemplo, para que eles consigam acompanhar, desde que eles tenham disponibilidade. Se não existe essa disponibilidade a gente desloca um professor na disponibilidade do estudante para que ele consiga realizar essas recuperações e apropriar esse conhecimento (Entrevista Pedagoga, Escola A SNA).
\end{abstract}

A frequência, às vezes, também era recuperada junto com a recuperação dos conteúdos, de acordo com a Profa. 02:

\begin{abstract}
Acontecia, assim, de faltas: era 05 dias na semana de curso, aparecia em 02. Chamava para conversar... Então, nós tínhamos aquele mínimo, que tinha que ter de frequência, e muitos, às vezes, não atingiam. Aí antes de fechar aquele acompanhamento curricular e de iniciar outro, fazíamos recuperações. Muitas vezes, fazia agendamento: "Ó, o curso começa à 19h, tem condições de vir às $18 \mathrm{~h} ?$ ?" - "Tenho". Então, nós fazíamos 03 dias, na semana, das $18 \mathrm{~h}$ às $19 \mathrm{~h}$, a recuperação, e a partir das $19 \mathrm{~h}$, aula (Entrevista Profa. 02, Escola B SNA).
\end{abstract}

Além das pedagogas que davam suporte ao professor nas questões pedagógicas, os cursos técnicos, nas duas escolas pesquisadas, também contavam com coordenadores, os quais atendiam também os cursos FIC da mesma área, que auxiliavam no contato com os estudantes que estavam faltando às aulas e atendiam questões de aprendizagem e de indisciplina encaminhadas pelos professores em sala de aula. De acordo com a Pedagoga da Escola B, a 
atuação dos coordenadores contribuía muito no atendimento das demandas dos estudantes, em virtude do grande número.

Para o acompanhamento das aulas, os estudantes recebiam o material didático do curso, de acordo com o previsto nos projetos pedagógicos (muitas vezes eram cópias disponibilizadas pelo professor, de acordo com o seu planejamento) e uma pasta com material escolar, como lápis, caneta e caderno. Os cursos que demandavam materiais para aulas práticas, como o curso de Modelista de Roupas, na escola B, estes eram comprados pela instituição e disponibilizados aos estudantes.

No entanto, apesar dessa diferença no acompanhamento e recuperação dos estudantes, relatadas nas entrevistas, observa-se que em relação ao percentual de concluintes não há grande diferença entre o IFFar e o SNA. Em ambas as instituições, com base nas unidades de ensino pesquisadas, o percentual de concluintes nos cursos técnicos foi baixo, como se verá até o final deste Capítulo.

Todos os projetos pedagógicos de cursos (PPCs) de Formação Inicial e Continuada ofertados no âmbito do Pronatec pelo SNA, que são padronizados no Estado, possuíam um módulo inicial de 20 horas intitulado "Integração e Orientação Profissional”, que abrange temas como: Princípios de Saúde e Segurança no Trabalho; Princípios de Educação Ambiental; O Mundo do Trabalho: cenário e perspectivas; e Cidadania. Em alguns PPCs há também, no âmbito deste módulo, uma introdução à temática do curso. Esse espaço/tempo do currículo destina-se, segundo as Pedagogas entrevistadas em cada unidade, a acolher o aluno no curso e apresentar noções sobre o mercado de trabalho na área, além de princípios de cidadania e de educação ambiental.

É no âmbito deste módulo que os estudantes têm o primeiro contato com a temática do empreendedorismo, quando são apresentadas as características do mundo do trabalho atual. Alguns cursos apresentam uma disciplina específica de empreendedorismo, além de fazer parte do calendário das escolas a Feira de Profissões, momento para o qual os estudantes são estimulados a desenvolver e apresentar ideias empreendedoras. Estas práticas estão ancoradas na concepção de educação expressa nos Projetos Pedagógicos de Curso, a qual sentencia que a educação deve contribuir "para a autoformação da pessoa, ensinando a viver no sentido de se tornar cidadão e promovendo a formação de profissionais competentes, empreendedores, inovadores, de modo a possibilitar sua inserção e permanência no mundo do trabalho" (PPC Enfermagem, 2012, p. $\left.17^{168}\right)$.

\footnotetext{
168 O documento se encontra nos arquivos da pesquisa. Essa concepção está expressa em todos os Projetos Pedagógicos de Curso.
} 
As escolas receberam o Baú do Empreendedorismo, que fazia parte da ação Pronatec Empreendedor do SEBRAE, e os livros se encontravam disponíveis na biblioteca, para uso de professores e alunos. O empreendedorismo já fazia parte dos cursos da instituição, mas no Pronatec passou a se dar mais ênfase em função do perfil do programa e do público, segundo a Pedagoga da Escola A.

De acordo com o relato da Diretora da Escola B, que havia atuado em outra escola do SNA antes de assumir esse cargo, "no Pronatec Empreendedor, vinha o material do SEBRAE, muito legal, para a gente trabalhar com os alunos, Pen Drive, livros; e nós trabalhávamos em alguns cursos, eu sempre fui muito fã do Pronatec Empreendedor" (Entrevista Diretora Escola B SNA). Nessa escola, inclusive, houve um projeto, desenvolvido no curso Técnico em Meio Ambiente, que foi premiado em uma das edições do Concurso Pronatec Empreendedor, e vários professores realizaram os cursos de formação continuada em educação empreendedora.

Outro componente que se observa nos cursos FIC, especialmente naqueles voltados para trabalhos que envolvem relacionamento interpessoal ${ }^{169}$, são os conhecimentos no campo da psicologia organizacional, algumas vezes apresentado sob o nome de "relações interpessoais". De acordo com os conhecimentos, habilidades, valores e atitudes previstos nestes componentes, pode-se identificar claramente o intuito de socializar os futuros trabalhadores no "espírito" requerido pelas empresas, encorajando-os a 'pensar 'pró-ativamente' e a encontrar soluções antes que os problemas aconteçam” (ALVES, 2011, p. 111). Uma vez que as competências previstas para os cursos são definidas a partir de "mesa redonda" com os empresários da área, como se viu, o currículo nada mais faz que "ensinar o espírito da empresa na escola", parafraseando o título do livro de Lucie Tanguy (2016). No Quadro 7 pode-se visualizar um exemplo do componente de Psicologia Organizacional.

Estes componentes curriculares, assim como o módulo inicial sobre as características do "mundo do trabalho", podem ser compreendidos como espaços de socialização dos estudantes com vistas em um mercado de trabalho que não tem como interesse "apenas o 'fazer' e o 'saber' dos trabalhadores, mas a sua disposição intelectual-afetiva” (ALVES, 2011, p. 111). Essa perspectiva formativa pode ser identificada nas respostas dos estudantes, por meio do questionário, em relação à contribuição do curso nas suas vidas, quando enfatizam valores/atitudes como "saber ser uma pessoa diante dos outros", "ter atitude", "ter responsabilidade".

\footnotetext{
${ }^{169}$ Cursos FIC na área de informática, como editor de vídeo e montador e reparador de computadores, não apresentam esse componente curricular.
} 
Quadro 7 - Componente curricular de Psicologia Organizacional - Curso Balconista de Farmácia (SNA)

\begin{tabular}{|c|c|c|}
\hline \multicolumn{3}{|c|}{$\begin{array}{l}\text { PSICOLOGIA ORGANIZACIONAL - } 16 \mathrm{~h} \\
\text { Competência: Relacionar-se com a equipe de trabalho com confiabilidade, respeitando as } \\
\text { diferenças individuais, assim como evidenciar uma atitude cooperativa e comprometida, aplicando } \\
\text { princípios éticos nas relações de trabalho. }\end{array}$} \\
\hline Conhecimentos & Habilidades & Valores/Atitudes \\
\hline $\begin{array}{l}\text { - Relações } \\
\text { humanas no } \\
\text { trabalho; } \\
\text { - Liderança; } \\
\text { - Trabalho em } \\
\text { equipe; } \\
\text { - Comunicação } \\
\text { verbal e não-verbal; } \\
\text { - Habilidades } \\
\text { comunicativas; } \\
\text { - Técnicas } \\
\text { desinibição. }\end{array}$ & 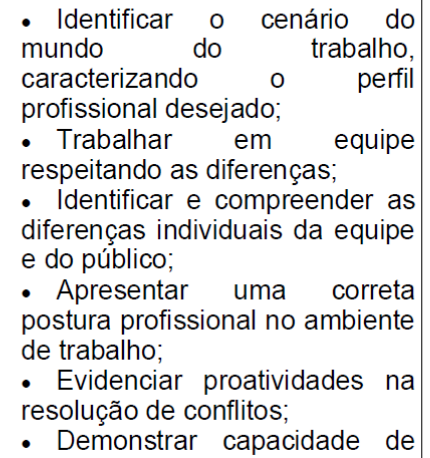 & $\begin{array}{l}\text { - Visão sistêmica; } \\
\text { - Confiabilidade; } \\
\text { - Comprometimento; } \\
\text { - Planejamento } \\
\text { sistemático; } \\
\text { - Versatilidade; } \\
\text { - Capacidade de decisão; } \\
\text { - Proatividade; } \\
\text { - Gerenciamento } \\
\text { conflitos; } \\
\text { - Trabalho em equipe com } \\
\text { criatividade e flexibilidade; } \\
\text { - Respeito às diferenças; } \\
\text { - Clareza na comunicação } \\
\text { oral e escrita. }\end{array}$ \\
\hline
\end{tabular}

Fonte: Projeto Pedagógico do curso de Balconista em Farmácia (arquivos da pesquisa).

Diferentemente do IFFar, os projetos pedagógicos dos cursos FIC no SNA não apresentam componentes de matemática e português com vistas a suprir o baixo nível de escolaridade dos estudantes dos cursos FIC. A baixa escolaridade também estava presente nos cursos FIC da Escola B, por exemplo, e a dificuldade dos estudantes com os conteúdos de matemática nos cursos da área de Gestão e Negócios comprometia o acompanhamento das aulas, conforme relata o Prof. 01:

Nos Cursos FICs tinha pessoas que vinham sem saber escrever, pessoas analfabetas, praticamente, assim. Não, não digo, praticamente, digo, literalmente, eram analfabetas. Eu trabalhava matemática. Então, no início, eu comecei dar um componente de Matemática aqui, outro ali, outro ali; daqui a pouco, eu estava trabalhando só matemática; todos os turnos, só matemática. Era uma aula que eu já tinha pronta, que matemática não muda, então, para mim era mais fácil. Cada vez, vinha pessoas com um pior nível de conhecimento, pior, pior, pior. E assim, eu conseguia enxergar bem quando a pessoa não sabia, porque ela ficava quieta; simplesmente, não falava nada. Eu explicava o exercício, perguntava se tinham entendido, e todo mundo dizia que tinha entendido. Passava o exercício, aí de 30, 15 faziam, 05 sabiam, mas não queriam fazer,10 não sabiam nada, e uma pessoa não sabia ler... Então, teve uns casos assim que a pessoa, talvez, até quisesse, sabe, quisesse realmente crescer, mas, primeiro, ela tinha que voltar para a escola, porque era muita insuficiência de aprendizado, não sabia nada, nada, nada, nada (Entrevista Prof. 01, Escola B SNA).

Em algumas situações, como relata a escola a Profa. 01, da Escola A, era necessário retomar alguns conteúdos básicos de matemática nos cursos FIC da área de informática, pois o "Excel, ele exige que você saiba noções básicas de matemática, então eu tinha que passar isso para eles, para depois entrar no Excel” (Entrevista Profa. 01, Escola A SNA). Embora esses conteúdos não estivessem previstos no curso "a gente começou a fazer pela dificuldade que a gente tinha de ensinar essa ferramenta" (Entrevista Profa. 01, Escola A SNA). O mesmo ocorria 
em relação aos conhecimentos de português: "a gente tinha alunos com muita dificuldade para escrever, com muitos erros de português" (Entrevista Profa. 01, Escola A SNA). Essa situação também era observada nos cursos técnicos em Informática nessa mesma escola, como relata o Prof. 02:

\begin{abstract}
Bah, eu falava: "Vocês já aprenderam isso, já viram matrizes?" - "Não". "Têm certeza que não viram matrizes?" "Vocês já viram isso aqui?" - "Não." - "Isso aqui é base do Ensino Fundamental, vocês viram?". Eu vi que eles tinham uma base Matemática bem fraca. Aí quando chegava na aula de formação de cálculo, eles se perdiam bastante, não é. Então, a desistência, era na parte de programação, quando chegava na parte mais aprofundada da Informática, eles tinham uma desistência bem enorme, bem enorme mesmo. (...) Mesmo retomando o conteúdo da Matemática. Então, na noite, os mais velhos que faziam o Pronatec, a maioria desistiu, a maioria, boa parte desistiu, um ou dois que conseguiu ficar até o final ali. Dos mais velhos, eu digo, que estão com uns 40 anos, que queriam Informática, acabaram desistindo. E o mesmo problema, a Matemática que pesava bastante, quando chegava na parte de Programação ali, eles não entendiam mais nada (Entrevista Prof. 02, Escola B SNA).
\end{abstract}

Essas dificuldades dos estudantes em relação aos conhecimentos básicos, embora fossem atendidas por alguns professores, não estavam previstos nos currículos dos cursos, os quais tinham sido elaborados para outro perfil de público, que não era o mesmo do Pronatec. Assim, no SNA, observa-se um currículo mais preocupado com o atendimento das demandas do mundo do trabalho, do ponto de vista dos empregadores, em detrimento das necessidades formativas dos estudantes. Também não foi identificado no âmbito do currículo, conteúdos que remetam a questões do ponto de vista do trabalhador, como os direitos dos trabalhadores.

4.1.2 O processo de pactuação e o perfil dos cursos e do público atendido pelo SNA no âmbito do Pronatec Bolsa Formação

Em relação à pactuação dos cursos, o Gestor do NEP apontou como problema a falta de diálogo com os empresários, aqueles que seriam os "tomadores" dos profissionais egressos dos cursos. Observa-se nesse discurso que a principal preocupação está no atendimento às demandas do mercado, ao perfil exigido pelos empregadores.

Eu acho que ele começou com alguns equívocos como por exemplo: não discutir com as comunidades, com as instituições locais, com os empresários, com aqueles que seriam os "tomadores" destes profissionais para trabalhar no mercado de trabalho, discutir com eles as reais necessidades de perfis profissionais para determinadas regiões. Houve um levantamento do MEC sob o qual a gente não teve nenhuma ingerência, das entidades formadoras e muito pouco os empresários tiveram condições de definir: "olha, é esse o perfil que nós queremos e em tal lugar". Olharam pela RAIS [Relação Anual de Informações Sociais], pelas empresas, pela concentração de estudantes, de população economicamente ativa e tal. Com adesão das prefeituras e 
adesão do governo do estado, que foram lá para aderir a um programa já concebido, e já definiram aonde os cursos aconteceriam, quais os cursos e em que quantidade (Entrevista GESTOR NEP SNA).

O Gestor do SNA, na mesma direção do IFFar, também destaca como positivo os Comitês Gestores desenvolvidos em nível estadual, que permitiram a participação das instituições ofertantes no processo de pactuação dos cursos, e aponta a instituição como proponente destes espaços:

\begin{abstract}
Aos poucos a gente foi criando o grupo de interlocução, para que todo mundo tivesse conhecimento das ofertas e pudesse definir, então nós fazíamos arranjos aqui, regionais. Foi aqui que iniciou a ideia dos comitês gestores, aqui no RS. Nós que propusemos, junto com os Institutos Federais, outros "Ss" - que pouco participaram, os que mais participaram foram o SENAC e SENAI - e o Governo do Estado, Secretaria de Educação, Secretaria de Trabalho, Secretaria de Cultura, criar comitês para tratar daqueles cursos vocacionados para aqueles segmentos. Funcionou muito bem, até que o governo mudou... Nós fazíamos a negociação, encaminhávamos essas propostas para o governo federal, para o MEC, o MEC homologava aquilo, autorizava e então nós fazíamos as inscrições, as matrículas e realizávamos os cursos (Entrevista Gestor NEP SNA).
\end{abstract}

A mudança no processo de pactuação, apontada pelo Gestor do SNA, se refere à inserção do modelo do "mapa de demandas específicas", conforme se viu no Capítulo II. Embora esse modelo tenha apresentado falhas, especialmente nos canais de diálogo entre os ministérios e os órgãos municipais das diferentes áreas sociais e econômicas, conforme indicado pelos coordenadores do Pronatec no IFFar, visava reduzir a interferência da lógica "ofertista" no atendimento das demandas, uma vez que a pactuação da oferta ocorria somente após a análise da demanda pela SETEC.

Entre os cursos ofertados pela instituição em todo o Estado, tiveram ofertas mais expressivas os cursos de Assistente Administrativo, com 21.267 matrículas, Inglês Básico, com 15.871, e Operador de Computador, com 13.419, conforme Tabela 42. Observa-se que alguns cursos apresentaram cargas horárias diferenciadas em cada oferta. Até agosto de 2015 era possível desenvolver cursos FIC com carga horária de até 50\% a mais do mínimo previsto no Guia Pronatec de cursos FIC. Após essa data, a nova Portaria que regulamenta a Bolsa Formação - n. 817/2015 - extinguiu o financiamento de carga superior à mínima, o que pode ter levado a instituição a adequar os projetos dos cursos a este critério. Do total de 128 cursos, 110 são de formação inicial e continuada e 18 são cursos técnicos de nível médio. 
Tabela 42 - Cursos ofertados pelo SNA no Pronatec Bolsa Formação - 2011 a 2016

\begin{tabular}{|c|c|c|}
\hline Curso & Carga Horária & Matrículas \\
\hline Auxiliar Administrativo/Assistente Administrativo & 180 & $20.699 / 568$ \\
\hline Inglês Básico & 160 & 15.871 \\
\hline Operador de Computador & $160 / 180 / 200$ & 13.419 \\
\hline Vendedor & 180 & 8.554 \\
\hline Manicure e Pedicure & 180 & 7.082 \\
\hline Cuidador de Idoso & 180 & 5.965 \\
\hline Recepcionista & $160 / 180$ & 5.698 \\
\hline Auxiliar de Recursos Humanos & 180 & 5.497 \\
\hline Montador e Reparador de Computadores & 200 & 3.985 \\
\hline Balconista de Farmácia & 260 & 3.931 \\
\hline Operador de Supermercados & $200 / 180 / 160$ & 3.748 \\
\hline Operador de Caixa & $180 / 160$ & 3.317 \\
\hline Técnico em Informática & $1000 / 1200$ & 3.265 \\
\hline Espanhol Básico & 160 & 3.168 \\
\hline Auxiliar de Cozinha & 220 & 2.718 \\
\hline Costureiro & $188 / 168$ & 2.705 \\
\hline Promotor de Vendas & 200 & 2.531 \\
\hline Cabeleireiro & 420 & 2.520 \\
\hline Organizador de Eventos & 180 & 2.463 \\
\hline Montagem e Manutenção de Computadores & $180 / 200$ & 2.438 \\
\hline Auxiliar de Crédito e Cobrança & 180 & 2.407 \\
\hline Técnico em Segurança do Trabalho & 1200 & 2.325 \\
\hline Cuidador Infantil & 180 & 2.232 \\
\hline Garçom & $220 / 244 / 250$ & 1.963 \\
\hline Camareira em meios de Hospedagem & $160 / 180 / 200$ & 1.908 \\
\hline Técnico em Administração & 800 & 1.827 \\
\hline Inglês intermediário & 160 & 1.784 \\
\hline Auxiliar Financeiro & 180 & 1.527 \\
\hline Técnico em Logística & 800 & 1.519 \\
\hline Recepcionista de Eventos & $160 / 180 / 200 / 220$ & 1.517 \\
\hline Padeiro & 300 & 1.363 \\
\hline Atendente de Nutrição & 260 & 1.338 \\
\hline Recepcionista em Meios de Hospedagem & $160 / 180 / 200$ & 1.330 \\
\hline Padeiro Confeiteiro & 300 & 1.269 \\
\hline Maquiador & 180 & 1.151 \\
\hline Modelista & 230 & 1.059 \\
\hline Monitor de Recreação & $160 / 180$ & 899 \\
\hline Salgadeiro & $175 / 200$ & 888 \\
\hline Representante Comercial & 180 & 847 \\
\hline Almoxarife & 180 & 755 \\
\hline Porteiro e Viga & 180 & 736 \\
\hline LIBRAS Básico & 160 & 701 \\
\hline Técnico em Enfermagem & 1600 & 664 \\
\hline Desenhista de Produtos Gráficos Web & 240 & 638 \\
\hline Padeiro e Confeiteiro & $230 / 250$ & 616 \\
\hline
\end{tabular}


Cabeleireiro Assistente

220

573

Confeiteiro

300

536

Programador Web

$250 / 260$

489

Depilador

180

435

Auxiliar de Serviços em Comércio Exterior

Artesão de Pintura em Tecido

$192 / 172 \quad 434$

Frentista

$180 / 160 \quad 416$

Editor de Projeto Visual Gráfico

180

Desenvolvedor de Jogos eletrônicos

$200 / 236 \quad 387$

Inglês aplicado a serviços turísticos

$260 \quad 385$

Recepcionista em serviços de saúde

$180 \quad 372$

Espanhol Intermediário

Operador de Telemarketing

$260 \quad 368$

Técnico em Enfermagem

160

Trabalhador Doméstico

$180 \quad 326$

Trabalhador Doméstico

Atendente de Lanchonete

$\begin{array}{ll}1800 & 322 \\ 200 & 322\end{array}$

Técnico em Comércio Exterior

$180 \quad 315$

Editor de Vídeo

800

Desenhista de Moda

$200 \quad 290$

Técnico em Meio Ambiente

Massagista

Assistente de Produção Cultural
Bartender

Comprador

Instalador e reparador de redes de computadores 200

Garçom Básico 220

Agente de inclusão digital em centros públicos de acesso à internet

Francês Básico

Agente de Inspeção de Qualidade

Técnico em Informática para Internet

220

$800 \quad 278$

$360 \quad 271$

$180 \quad 262$

$180 / 224 \quad 239$

$180 \quad 223$

$200 \quad 221$

$220 \quad 209$

$240 \quad 206$

$162 \quad 197$

180

Agente de Limpeza e Conservação

$1000 \quad 183$

Agente de Informações Turísticas

$160 \quad 172$

Higienista de serviços de saúde

\begin{tabular}{lll}
\hline Espanhol aplicado a serviços turísticos & 180 & 157 \\
\hline Artesão de Bordado a mão & 180 & 150 \\
\hline Programador de Sistemas & $250 / 300$ & 131 \\
\hline Técnico em Guia de Turismo & 800 & 123 \\
\hline Técnicos em Redes de Computadores & 1000 & 119 \\
\hline Churrasqueiro & 200 & 104 \\
\hline Programador de Dispositivos Móveis & 200 & 101 \\
\hline Recreador-Monitor & 180 & 96 \\
\hline Técnico em Marketing & 800 & 92 \\
\hline Sommelier & 200 & 92 \\
\hline Açougueiro & 200 & 91 \\
\hline Editor Gráfico & 236 & 90 \\
\hline Técnico em Multimídia & 800 & 87 \\
\hline Contador de Histórias & 180 & 86
\end{tabular}

Contador de Histórias

\begin{tabular}{ll}
220 & 167 \\
240 & 161 \\
180 & 157 \\
180 & 150 \\
$250 / 300$ & 131 \\
800 & 123 \\
1000 & 119 \\
200 & 104 \\
200 & 101 \\
180 & 96 \\
800 & 92 \\
200 & 92 \\
200 & 91 \\
236 & 90 \\
\hline 800 & 87 \\
180 & 86 \\
\hline
\end{tabular}




\begin{tabular}{|c|c|c|}
\hline Assistente de Recursos Humanos & 180 & 86 \\
\hline Administrador de Banco de Dados & $280 / 250$ & 83 \\
\hline Técnico em Recursos Humanos & 800 & 78 \\
\hline Jardineiro & 180 & 77 \\
\hline Cadista para a construção civil & 240 & 72 \\
\hline Web Designer & 240 & 71 \\
\hline Técnico em Programação de Jogos Digitais & 1000 & 70 \\
\hline Pizzaiolo & 180 & 69 \\
\hline Agente de Desenvolvimento Socioambiental & 180 & 65 \\
\hline Auxiliar de Nutrição e Dietética & 260 & 58 \\
\hline Técnico em Comunicação Visual & 800 & 57 \\
\hline Despachante Aduaneiro & 180 & 55 \\
\hline Assistente de vendas & 220 & 48 \\
\hline Auxiliar de Faturamento & 180 & 45 \\
\hline Agente Cultural & 180 & 45 \\
\hline Auxiliar Pessoal & 180 & 43 \\
\hline Fotógrafo & 236 & 42 \\
\hline Cerimonialista & 200 & 41 \\
\hline Assistente de Serviços em Comércio Exterior & 192 & 40 \\
\hline Auxiliar de Tesouraria & 180 & 39 \\
\hline Confeccionador de Bijouterias & 180 & 39 \\
\hline Agente comunitário de saúde & 400 & 38 \\
\hline LIBRAS Intermediário & 180 & 38 \\
\hline Sushiman & 160 & 38 \\
\hline Assistente de Crédito e Cobrança & 180 & 37 \\
\hline Vitrinista & 180 & 37 \\
\hline Alemão Básico - A1 & 162 & 36 \\
\hline Técnico em Óptica & 1200 & 27 \\
\hline Shiatsuterapeuta & 240 & 25 \\
\hline Técnico em Estética & 1200 & 20 \\
\hline Assistente Financeiro & 180 & 20 \\
\hline Barbeiro & 180 & 18 \\
\hline Introdução à interpretação em LIBRAS & 180 & 15 \\
\hline Auxiliar em Administração de Redes & 216 & 15 \\
\hline Auxiliar de Transporte, Movimentação e Distribuição & 160 & 9 \\
\hline Técnico em Podologia & 1200 & 8 \\
\hline
\end{tabular}

Fonte: elaborada pela autora com base em dados do SISTEC institucional (2016).

O eixo com maior oferta de matrículas, tanto de cursos técnicos, quanto de FIC, foi o de Gestão e Negócios, com mais de um terço. O menor número de matrículas é observado no eixo de Infraestrutura, com 1\% e apenas cursos FIC. Em relação à oferta realizada pelo IFFar, apesar de o número de vagas no SNA ter sido quase 17 vezes maior, esse último apresentou um menor número de eixos atendidos - apenas 10 eixos, contra 12 no IFFar - e não há grande diferença 
em relação ao número de cursos ofertados - 128 no SNA e 117 no IFFar, sendo que ambas as instituições ofertaram 18 diferentes cursos técnicos.

Tabela 43 - Matrículas por Eixo Tecnológico e Tipo de Curso - Pronatec Bolsa Formação SNA - (2011 a 2016)

\begin{tabular}{llll}
\hline \multirow{2}{*}{ Eixo Tecnológico } & \multicolumn{2}{c}{ Tipo de Curso } & \multirow{2}{*}{ Total } \\
\cline { 2 - 3 } & FIC & Técnico & \\
\hline Ambiente e Saúde & $16,8 \%$ & $17,1 \%$ & $16,9 \%$ \\
Desenvolvimento Educacional e Social & $14,3 \%$ & & $13,0 \%$ \\
Gestão e Negócios & $\underline{37,4 \%}$ & $\underline{31,7 \%}$ & $\underline{36,9 \%}$ \\
Informação e Comunicação & $14,3 \%$ & $27,8 \%$ & $15,6 \%$ \\
Infraestrutura & $1,1 \%$ & & $1,0 \%$ \\
Produção Alimentícia & $3,0 \%$ & & $2,7 \%$ \\
Produção Cultural e Design & $1,6 \%$ & $0,6 \%$ & $1,5 \%$ \\
Produção Industrial & $2,1 \%$ & & $1,9 \%$ \\
Segurança & & $20,4 \%$ & $1,9 \%$ \\
Turismo, Hospitalidade e Lazer & $9,3 \%$ & $2,4 \%$ & $8,7 \%$ \\
\hline Total & $100,0 \%$ & $100,0 \%$ & $100,0 \%$ \\
\hline \hline
\end{tabular}

Fonte: Elaborada pela autora com base nos dados do SISTEC Nacional (2017).

Em relação ao sexo, os dados apontam situação similar à realidade dos cursos ofertados pelo IFFar: predominância do sexo feminino no total dos cursos $(73,7 \%)$, sendo que a diferença entre os sexos aumenta em favor das mulheres nos cursos FIC $(74,8 \%)$ e diminui nos cursos Técnicos (63,3\%). O sexo masculino, apesar de minoria no total dos cursos $(26,3 \%)$, tem seu percentual ampliado para 36,7\% quando se observa a relação de sexo nos cursos técnicos (vide Gráfico 14). Assim, observa-se também no perfil do público atendido pelo SNA que são as mulheres que mais procuram pelos cursos, em razão da sua própria condição de inserção no mercado de trabalho, como se viu no Capítulo III.

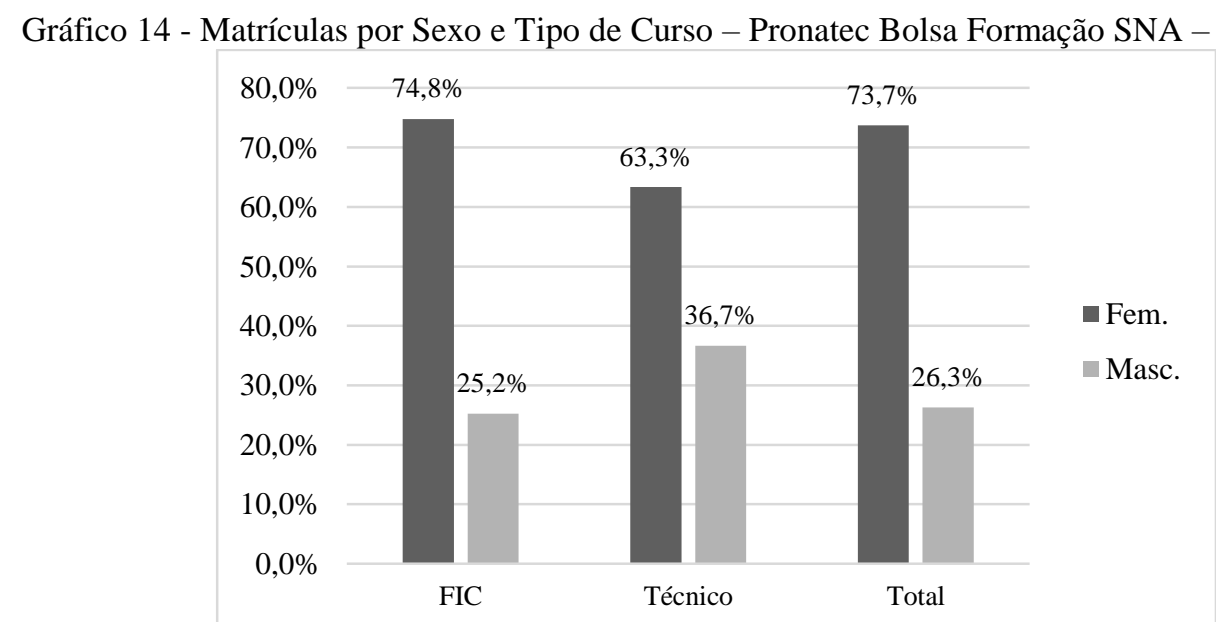

Fonte: Elaborado pela autora com base nos dados do SISTEC Nacional (2017). 
Quanto aos eixos tecnológicos, o maior percentual tanto do sexo feminino quanto masculino se encontra em Gestão e Negócios, em virtude do expressivo número de matrículas neste Eixo. Observa-se, no entanto, uma maior discrepância na relação de sexos nos eixos de Ambiente e Saúde, no qual o sexo feminino é preponderante, e Informação e Comunicação, onde predomina o sexo masculino. Assim como se viu em relação ao IFFar, estas diferenças na concentração dos sexos nos eixos tecnológicos expressam a divisão sexual do trabalho. Nesse caso, pode-se observar que a área da informática, espaço privilegiado da tecnologia como ferramenta e produto do trabalho, predominam os homens, enquanto na área da saúde, onde o cuidado - tarefa atribuída histórica e culturalmente às mulheres - é a principal atividade, as mulheres estão mais presentes, indicando que a divisão sexual do trabalho também corresponde à uma divisão no uso das ferramentas/tecnologias, conforme analisa Tabet (1998).

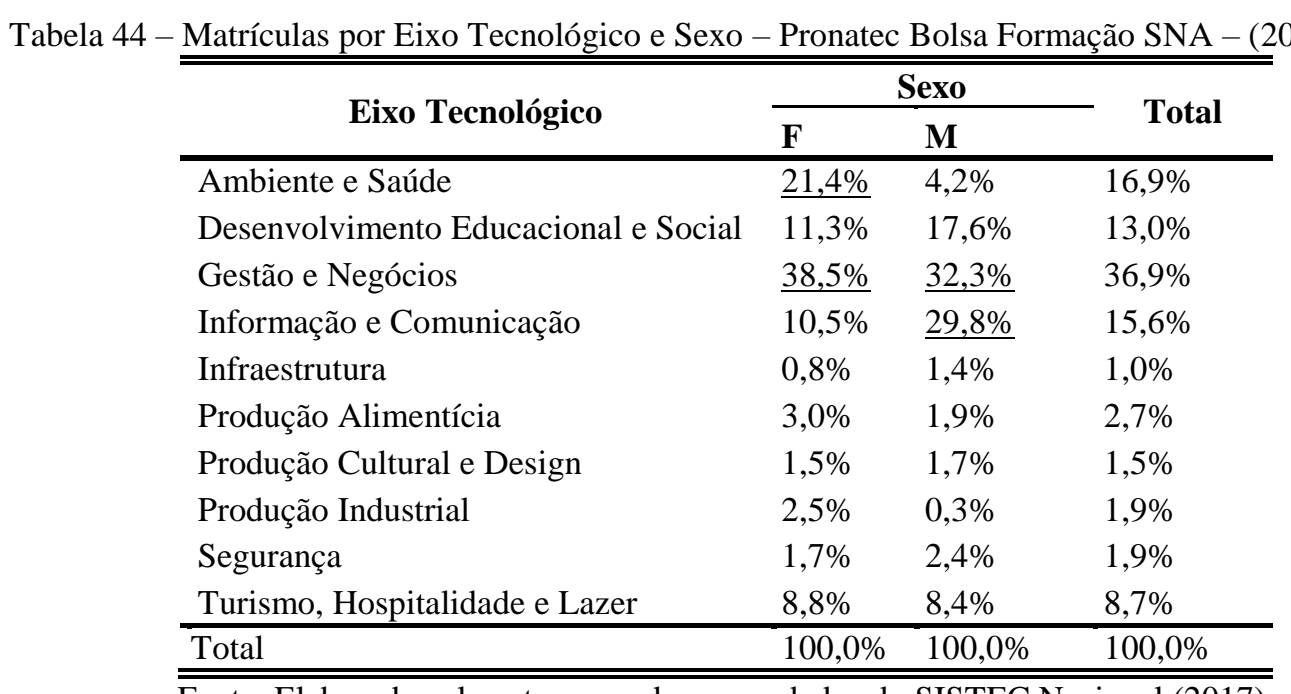

$\overline{\text { Fonte: Elaborada pela autora com base nos dados do SISTEC Nacional (2017). }}$

Quanto à escolaridade, o maior percentual tanto do sexo feminino quanto do masculino possui ensino médio completo, 40,6\% e 35,3\%, respectivamente. No caso dos homens, esse mesmo percentual é observado na categoria ensino médio incompleto, na qual, desconfia-se, estão inseridos parte dos estudantes que estão cursando o ensino médio, visto que o percentual nessa categoria é muito pequeno frente ao número de estudantes que realizaram cursos técnicos concomitantes - uma vez que para cursar o técnico concomitante o estudante deveria estar matriculado no ensino médio em escola pública. Chama a atenção o número de pessoas com ensino superior (completo ou cursando) que realizaram cursos do Pronatec Bolsa Formação no SNA (7.319), sendo que a maioria são mulheres (5.124). No Tabela 45, pode-se visualizar esses dados. 
Tabela 45 - Matrículas por Escolaridade e Sexo - Pronatec Bolsa Formação SNA - (2011 a 2016)

\begin{tabular}{llll}
\hline \hline \multirow{2}{*}{ Escolaridade } & \multicolumn{2}{c}{ Sexo } & \multirow{2}{*}{ Total } \\
\cline { 2 - 3 } & $\mathbf{F}$ & $\mathbf{M}$ & \\
\hline Cursando o Ensino Médio & $2,4 \%$ & $2,9 \%$ & $2,5 \%$ \\
Ensino Fundamental I completo & $1,0 \%$ & $0,6 \%$ & $0,9 \%$ \\
Ensino Fundamental I incompleto & $6,9 \%$ & $5,7 \%$ & $6,6 \%$ \\
Ensino Fundamental II completo & $11,1 \%$ & $9,0 \%$ & $10,6 \%$ \\
Ensino Fundamental II incompleto & $1,3 \%$ & $1,4 \%$ & $1,4 \%$ \\
Ensino Médio completo & $\underline{40,6 \%}$ & $\underline{35,3 \%}$ & $\underline{39,2 \%}$ \\
Ensino Médio incompleto & $29,8 \%$ & $\underline{35,3 \%}$ & $31,2 \%$ \\
Ensino Superior completo & $1,9 \%$ & $2,0 \%$ & $2,0 \%$ \\
Ensino Superior incompleto & $2,3 \%$ & $3,4 \%$ & $2,6 \%$ \\
Não há informação & $2,6 \%$ & $4,5 \%$ & $3,1 \%$ \\
\hline Total & $100,0 \%$ & $100,0 \%$ & $100,0 \%$ \\
\hline \hline
\end{tabular}

Com relação ao sexo e à cor da pele, a maior parte tanto de homens, quanto de mulheres são da cor branca. Nas demais categorias de cor da pele não há diferença significativa entre os sexos. Tendo em vista que o SNA possui escolas em 34 municípios e também atuou em municípios vizinhos por meio de seus balcões e cursos a distância, observa-se que estes percentuais estão em acordo com os dados do IBGE (2010) em relação à cor da pele da população deste Estado: $83,20 \%$ da população se declara de cor branca; 5,56\% de cor preta; $10,56 \%$ de cor parda; $0,33 \%$ de cor amarela; e $0,30 \%$ indígena.

\begin{tabular}{|c|c|c|c|}
\hline \multirow{2}{*}{ Cor da Pele } & \multicolumn{2}{|c|}{ Sexo } & \multirow{2}{*}{ Total } \\
\hline & $\mathrm{F}$ & M & \\
\hline Amarela & $0,5 \%$ & $0,5 \%$ & $0,5 \%$ \\
\hline Branca & $\underline{53,8 \%}$ & $\underline{52,4 \%}$ & $\underline{53,4 \%}$ \\
\hline Indígena & $0,2 \%$ & $0,2 \%$ & $0,2 \%$ \\
\hline Não há informação & $33,2 \%$ & $34,8 \%$ & $33,6 \%$ \\
\hline Parda & $6,7 \%$ & $6,8 \%$ & $6,7 \%$ \\
\hline Preta & $5,7 \%$ & $5,2 \%$ & $5,5 \%$ \\
\hline Total & $100,0 \%$ & $100,0 \%$ & $100,0 \%$ \\
\hline
\end{tabular}

Fonte: Elaborada pela autora com base nos dados do SISTEC Nacional (2017)

Os dados relativos à faixa etária dos estudantes não puderem ser utilizados, pois mais da metade dos registros $(60,4 \%)$ não possuía esta informação, o que inviabiliza a análise estatística.

Nos tópicos a seguir, 4.2 e 4.3, será apresentado o estudo de aprofundamento nas duas unidades de ensino do SNA onde foi realizada a pesquisa. Busca-se relacionar a oferta com o contexto socioeconômico local e analisar o desenvolvimento dos cursos, assim como os indicadores de conclusão. 


\subsection{Desenvolvimento do Pronatec Bolsa Formação na Escola A do SNA}

A Escola A, situada em um bairro central da capital do Estado, Porto Alegre, é especializada na oferta de formação profissional na área de Tecnologia da Informação. Assim, a oferta de cursos pelo Pronatec concentrou-se principalmente no Eixo Tecnológico de Informação e Comunicação, incluindo cursos de outros eixos que tem a informática como conhecimento e ferramenta de trabalho, totalizando 5.549 matrículas no período de 2011 a 2015. As únicas exceções, foram os cursos FIC de idiomas (inglês) e Vendedor e o curso Técnico em Administração, como se verá a seguir.

Porto Alegre foi o município com maior percentual de matrículas na Bolsa Formação no Estado, tendo desenvolvido 13\% do total de matrículas (43.093 matrículas), por meio de instituições da Rede Federal (pública), Instituições privadas e Instituições do Sistema $\mathrm{S}$ (SENAI, SENAC, SENAT e SENAR). Esse número de matrículas foi desenvolvido por meio de 179 cursos, sendo 35 cursos técnicos e 144 cursos FICs, que corresponderam a 26,8\% e $73,2 \%$ da oferta, respectivamente. O SNA ofertou 53,30\% desse total (22.973 matrículas) por meio de 07 unidades de ensino - 89,8\% das matrículas foram em cursos FICs e apenas 10,2\% em cursos técnicos.

Conforme se observa na Tabela 47, no total, os Eixos de Informação e Comunicação e Gestão e Negócios concentram as maiores ofertas, o que é observado também no total de matrículas realizadas pelas instituições do Sistema S. Nas instituições públicas, por outro lado, se observa uma maior oferta de matrículas nos Eixos de Desenvolvimento Educacional e Social e Turismo Hospitalidade e Lazer, e nas instituições privadas, além de Informação e Comunicação, o segundo Eixo com maior oferta é o de Ambiente e Saúde.

Tabela 47 - IE Ofertante x Eixo Tecnológico Matrículas Pronatec Bolsa Formação em Porto Alegre (2011 a 2016)

\begin{tabular}{lllll}
\hline \hline \multirow{2}{*}{ Eixos Tecnológicos } & \multicolumn{3}{c}{ IE Ofertante } & \multirow{2}{*}{ Total } \\
\cline { 2 - 5 } & Sistema S & Privada & Pública & \\
\hline Ambiente e Saúde & 3078 & $\underline{1987}$ & 421 & 5486 \\
Controle e Processos Industriais & 2711 & 104 & 0 & 2815 \\
Desenvolvimento Educacional e Social & 5464 & 0 & $\underline{1088}$ & 6552 \\
Gestão e Negócios & $\underline{6838}$ & 862 & 748 & $\underline{8448}$ \\
Informação e Comunicação & $\underline{\mathbf{5 6 8 1}}$ & $\underline{3206}$ & 638 & $\underline{9525}$ \\
Infraestrutura & 2286 & 210 & 32 & 2528 \\
Produção Alimentícia & 530 & 0 & 0 & 530 \\
Produção Cultural e Design & 1039 & 167 & 38 & 1244 \\
Produção Industrial & 540 & 64 & 18 & 622 \\
Recursos Naturais & 61 & 0 & 43 & 104 \\
Segurança & 351 & 570 & 0 & 921 \\
Turismo, Hospitalidade e Lazer & 3272 & 86 & $\underline{959}$ & 4317 \\
\hline Total & $\mathbf{3 1 8 5 1}$ & $\mathbf{7 2 5 6}$ & $\mathbf{3 9 8 5}$ & $\mathbf{4 3 0 9 2}$ \\
\hline \hline Fonte: elaborada pela autora com base nos dados do SISTEC Nacional (2017).
\end{tabular}

Fonte: elaborada pela autora com base nos dados do SISTEC Nacional (2017). 
Os cursos mais ofertados pelas diferentes instituições foram: Inglês Básico (3.838 matrículas) e Assistente Administrativo (3.295 matrículas), pelo Sistema S; Técnico em Informática (2.452 matrículas) e Técnico em Enfermagem (918 matrículas), pelas instituições privadas; e Inglês Básico (297 matrículas) e Espanhol Básico (276 matrículas), pelas instituições públicas. O grande número de matrículas em cursos FIC idiomas pode ser compreendido como decorrência do atendimento da modalidade Pronatec Copa, visto que Porto Alegre foi sede de jogos da Copa do mundo de 2014.

Por se tratar de uma cidade com quase 1,5 milhões de pessoas, em que $80 \%$ do PIB é composto pelo setor de serviços e comércio (IBGE, 2010), a demanda de mão de obra é bastante elevada, especialmente, nestas áreas. Assim, os cursos atendidos pela Escola A no âmbito do Pronatec Bolsa Formação, na área de tecnologia da informação, atendem parte das demandas desse contexto.

Foram desenvolvidas 5.549 matrículas em 29 diferentes cursos, assim distribuídas entre os tipos de curso: 4.383 matrículas em cursos FIC e 1.116 matrículas em cursos técnicos, sendo 714 matrículas em cursos técnicos concomitantes e 452 em técnicos subsequentes. Entre os turnos ofertados, observa-se que o turno da tarde concentrou o maior número de matrículas, $38,2 \%$, que é justamente o turno que a escola tem mais dificuldade de fechar turmas de Mercado. Conforme aponta do Diretor: “o turno que nós menos temos alunos é o turno da tarde", ao se referir ao período posterior à oferta do Pronatec (Diretor Escola A SNA). Tendo em vista que a escola continuava realizando turmas de mercado, a oferta de cursos pelo Pronatec ocorria de acordo com a sua capacidade ociosa, em detrimento do melhor atendimento ao público alvo. Na Tabela 48, pode-se visualizar os cursos, turno de oferta e quantidade de matrículas realizadas na Escola A do SNA.

Tabela 48 - Matrículas Pronatec Bolsa Formação realizadas pela Escola A do SNA (2011 a 2015)

\begin{tabular}{lllll}
\hline \multirow{2}{*}{\multicolumn{1}{c}{ Curso }} & \multicolumn{3}{c}{ Turno } & \multirow{2}{*}{ Total } \\
\cline { 2 - 4 } & Manhã & Noite & Tarde & 20 \\
\hline Administrador de Banco de Dados & 0 & 20 & 0 & 20 \\
Auxiliar em Administração de Redes & 0 & 8 & 7 & 15 \\
Cadista para a Construção Civil & 17 & 0 & 36 & 53 \\
Desenhista de Produtos Gráficos Web & 0 & 20 & 103 & 123 \\
Desenvolvedor de Jogos Eletrônicos & 43 & 41 & 39 & 123 \\
Editor de Projeto Visual Gráfico & 0 & 54 & 75 & 129 \\
Editor de Vídeo & 73 & 13 & 62 & 148 \\
Editor Gráfico & 34 & 19 & 18 & 71 \\
Espanhol Básico & 0 & 20 & 19 & 39 \\
Fotógrafo & 18 & 0 & 0 & 18 \\
Inglês Aplicado a Serviços Turísticos & 36 & 0 & 0 & 36 \\
Inglês Básico & 175 & 241 & 163 & 579
\end{tabular}




\begin{tabular}{lllll} 
Inglês Intermediário & 43 & 31 & 44 & 118 \\
Instalador e Reparador de Redes de Computadores & 0 & 0 & 18 & 18 \\
Monitor de Recreação & 21 & 0 & 0 & 21 \\
Montador e Reparador de Computadores & 306 & 307 & 298 & 911 \\
Montagem e Manutenção de Computadores & 182 & 191 & 168 & 541 \\
Operador de Computador & 230 & 420 & 544 & 1194 \\
Programador de Dispositivos Móveis & 0 & 19 & 20 & 39 \\
Programador de Sistemas & 0 & 32 & 30 & 62 \\
Programador Web & 38 & 17 & 11 & 66 \\
Técnico em Administração & 0 & 33 & 40 & 73 \\
Técnico em Informática & 215 & 180 & 299 & 694 \\
Técnico em Informática para Internet & 29 & 36 & 35 & 100 \\
Técnico em Logística & 63 & 33 & 12 & 108 \\
Técnico em Programação de Jogos Digitais & 71 & 0 & 0 & 71 \\
Técnico em Redes de Computadores & 40 & 40 & 40 & 120 \\
Vendedor & 0 & 0 & 18 & 18 \\
Web Designer & 20 & 0 & 21 & 41 \\
\hline Total & $\mathbf{1 6 5 4}$ & $\mathbf{1 7 7 5}$ & $\mathbf{2 1 2 0}$ & $\mathbf{5 5 4 9}$ \\
\hline \hline
\end{tabular}

Fonte: elaborada pela autora com base nos dados do SISTEC Nacional obtidos via e-SIC (2018)

Como se observa, o curso mais ofertado pela Escola A foi o de "Operador de Computador", com 1.194 matrículas, seguido por "Montador e Reparador de Computadores", com 911 matrículas. O total de matrículas foi distribuído da seguinte forma entre os anos de oferta do Programa: 81 matrículas em 2011; 1.159 em 2012; 2.628 em 2013; 1.191 em 2014 e 490 em 2015.

De acordo com o Diretor da Escola, a participação como instituição ofertante no Pronatec Bolsa Formação "foi uma experiência muito boa, porque nós tivemos a oportunidade de utilizar $100 \%$ da capacidade instalada e, mais ainda, tivemos que locar um novo espaço, para poder atender a demanda de turmas" (Entrevista Diretor Escola A SNA). Em 2012, a escola ofertava apenas o curso Técnico em Informática e com o Pronatec chegou a ofertar cinco diferentes cursos técnicos que hoje fazem parte "da carta de oferta da instituição", contribuindo na construção de uma nova identidade para a escola: "eu posso dizer que com a vinda do Pronatec, embora pela gratuidade, nós também criamos uma identidade de uma escola que tem muitos cursos técnicos" (Entrevista Diretor Escola A SNA). Para atender um maior número de cursos de forma paralela, a escola organizou turmas alternando os dias na semana, conforme relata o Diretor: "num dado momento, até foi importante por uma questão de visão de mercado, chegamos a fazer turmas: segundas, quartas e sextas; terças, quintas e sábados; para poder atender essa demanda" (Entrevista Diretor, Escola A SNA, grifos nossos).

O novo espaço locado ficava em um colégio particular da cidade, próximo à escola, com salas de aula, laboratórios de informática e biblioteca. Os laboratórios, segundo o Diretor, eram 
"um pouquinho até mais evoluídos que os daqui" e "até com espaço maior do que temos aqui" - a maioria dos laboratórios da escola contava com até 15 máquinas. A equipe administrativa e pedagógica se revezava nos dias da semana para atender os dois espaços, assim como os docentes, segundo o Diretor. Nesse período, o número de colaboradores da escola passou de 60 para 100, incluindo a parte administrativa, técnico-pedagógica e de docentes.

De acordo com a Professora entrevistada, quando a escola atingiu a capacidade máxima, os cursos de Mercado passaram a ser desenvolvidos no espaço alugado: "tinha os cursos técnicos Pronatec e os que não eram Pronatec, os de Mercado, que a gente tinha muitas turmas. Aí o Pronatec ficou aqui e o de Mercado saiu daqui” (Entrevista Prof. 01, Escola A SNA), foi para o espaço alugado. O prédio da Escola A é um espaço praticamente sem pátio (o espaço na frente do prédio é usado como estacionamento), sem área verde e com pouco espaço para socialização dos estudantes no horário de intervalo - um estudante inclusive aponta no questionário que "o prédio não foi feito de uma forma que te deixe confortável na hora do intervalo". Observa-se, assim, que a escola priorizou atender os estudantes de cursos de Mercado, que são mais exigentes, no espaço que oferecia melhores condições de infraestrutura, assim como se verá na Escola B.

O processo de pactuação foi realizado a partir do Diretório Regional do SNA, em Porto Alegre, o qual pactuava os cursos junto aos Comitês estaduais do Pronatec e encaminhava a demanda às suas escolas na cidade. Assim, à Escola A cabia a divulgação dos cursos juntos às escolas estaduais, no caso dos cursos técnicos concomitantes, e à comunidade local. De acordo com a Pedagoga da Escola, a instituição teve dificuldades em acessar as escolas de ensino médio para divulgar os cursos - os professores alegavam atrapalhar as aulas - e quando conseguiam conversar com os estudantes, estes ficavam receosos quanto à gratuidade do curso, pois muitas instituições iam até as escolas públicas divulgar seus cursos, alegando que eram gratuitos, mas no final tinham de adquirir algum material didático. O fato de o SNA, tradicionalmente, cobrar pelos seus cursos também contribuía nesse imaginário dos estudantes. Esta escola, inclusive, não oferta cursos gratuitos, no âmbito do Acordo de Gratuidade, uma vez que as demais escolas do SNA da cidade já estariam atendendo o percentual exigido ${ }^{170}$. Nessa mesma direção, relata a Profa. 01: "tinha curso que a gente tinha, assim, que ir à caça das pessoas para se matricularem. Cursos bons, cursos caros, em que eram abertas as inscrições e a coisa não acontecia" (Entrevista Profa. 01, Escola A SNA).

${ }^{170} \mathrm{O}$ atendimento do percentual definido no Acordo de Gratuidade é realizado no âmbito do Diretório Regional do SNA no Estado. Assim, nem todas as escolas ofertam cursos gratuitos no âmbito do acordo, uma vez já atingido o percentual. 
Em relação ao perfil dos estudantes, os professores entrevistados relatam que, no geral, eram pessoas de baixo nível socioeconômico. O pagamento da assistência estudantil foi apontado pelos docentes como fator que contribuiu para a permanência dos estudantes: "a gente sabia que tinha pessoas que vinham só pelo lanchinho, porque quase não tinham o que comer em casa. (...) O mercado aqui da frente aceitava o vale-refeição que era dado, então eles pagavam aqui, para poder ir comer" (Entrevista Prof. 01, Escola A SNA).

Diferentemente da visão dos docentes Escola B, como se verá a seguir, estes professores reconheciam a importância da gratuidade e da assistência estudantil, destacando o caráter social do Programa. Como relata o Prof. 02, "a maioria das pessoas que fazem o Pronatec é de classe baixa. A maioria são de vilas de Porto Alegre, da Restinga, da Vila Nova, do que a gente chama de periferia e eles tiveram a oportunidade de fazer o curso, que se fosse pago, não iam conseguir" (Entrevista Prof. 02, Escola A SNA).

Ao mesmo tempo, o baixo valor destinado às passagens impossibilitava o deslocamento daqueles que precisavam pegar mais de um ônibus: "Tem Restinga, que é um bairro longe que aí precisava 02 ônibus para vir para o Centro, então, às vezes, não tinham condições e acabavam desistindo também" (Entrevista Prof. 02, Escola A SNA). Ocorriam também algumas situações em que as passagens, repassadas via cartão de ônibus ou em dinheiro, eram utilizadas para outras necessidades, o que levava alguns estudantes a faltarem parte das aulas: "eles recebiam as passagens, só que eles gastavam as passagens no seu dia-a-dia, e faltava a passagem para vir para o curso; então, eu me lembro de alguns casos de que eles paravam de vir por falta de dinheiro para o transporte" (Entrevista Profa. 01, Escola A SNA).

De acordo com os estudantes que responderam ao questionário da pesquisa (31 estudantes de cursos técnicos em andamento no período da pesquisa), quase $90 \%$ possuíam renda mensal inferior a um salário mínimo per capita. Assim, diferentemente das cidades do interior, nas quais as distâncias são menores e permitem o deslocamento a pé, os estudantes de Porto Alegre que fizessem uso do recurso da assistência estudantil para outra necessidade comprometiam a sua continuidade do curso. Além disso, aqueles que não tinham condições de complementar os gastos com passagem, no caso de ultrapassar o valor recebido, também tinham dificuldades em se manter no curso.

Entre as modalidades do Pronatec atendidas pela escola, embora não tenha sido possível obter o relatório das pactuações de curso, pode-se identificar por meio das entrevistas que nos cursos FICs grande parte do público era encaminhado pelas agências do SINE (Sistema Nacional de Emprego), incluindo trabalhadores em seguro desemprego, que compreendia a modalidade Pronatec Trabalhador, e no caso dos cursos FIC idiomas, eram jovens e estudantes. 
Os cursos técnicos ofertados na modalidade concomitante tinham como público alvo os estudantes de escola pública de ensino médio, e aqueles na modalidade subsequente, os egressos do ensino médio que haviam realizado o ENEM.

Uma característica dessa unidade de ensino, além do grande número de matrículas desenvolvidas pelo Pronatec, foi a oferta também significativa de cursos de mercado. Conforme se observa na Tabela 49, com exceção do ano de 2012, nos demais anos de oferta do Pronatec o número de estudantes em cursos de mercado manteve-se praticamente estável, ocorrendo um decréscimo a partir de 2015, quando a crise econômica atinge as empresas, o orçamento do governo e das famílias. Em 2016, a Escola não realizou novas matrículas no Pronatec, e assim, contrariando a visão de que a gratuidade dificultava a venda de cursos, observa-se nessa escola que ambas as formas de venda - para o governo e para o mercado - foram desenvolvidas de forma concomitante. Grande parte das turmas de mercado, segundo a Pedagoga da escola, eram oriundas da venda de cursos in company a empresas.

Tabela 49 - Matrículas em cursos de Mercado - Escola A SNA (2011 a 2016)

\begin{tabular}{lr}
\hline \hline Ano & Mercado* \\
\hline 2011 & 3.547 \\
2012 & 2.895 \\
2013 & 2.316 \\
2014 & 2.025 \\
2015 & 2.012 \\
2016 & 1.326 \\
\hline \hline
\end{tabular}

* Os números correspondem ao total de estudantes em curso em cada ano.

Fonte: elaborada pela autora com base nas informações obtidas na pesquisa de campo.

No tópico a seguir, serão analisados os índices de conclusão dos cursos do Pronatec Bolsa Formação nesta unidade de ensino do SNA.

\subsection{1 Índice de conclusão de cursos na Escola A do SNA}

Os percentuais de conclusão dos cursos, observados nesta unidade de ensino do SNA, no geral, são inferiores àqueles observados no Campus do IFFar e na Escola B do SNA. Apesar de contar com um corpo docente fixo, que possibilitava diversas formas de recuperação da aprendizagem, e não ter sofrido os entraves do atraso no repasse de recursos, os índices de conclusão observados, especialmente nos cursos técnicos, é baixo: $35,85 \%$ entre os cursos técnicos e 45,46\% entre os cursos FIC. 
Tabela 50 - Status de Matrícula dos Cursos Pronatec Bolsa Formação - Escola A SNA

\begin{tabular}{|c|c|c|c|c|c|c|c|c|c|}
\hline Curso & 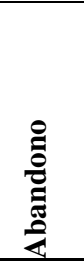 & 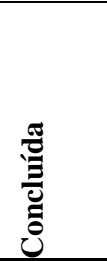 & 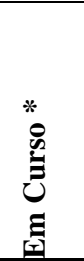 & 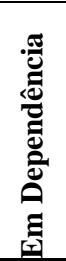 & 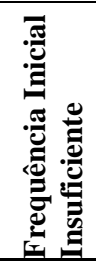 & 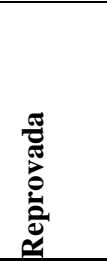 & 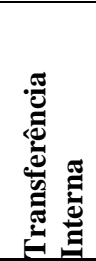 & 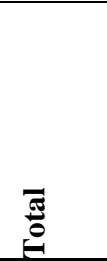 & 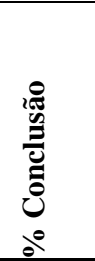 \\
\hline$\overline{\text { Administrador de Banco de Dados }}$ & 16 & 3 & 1 & 0 & 0 & 0 & 0 & 20 & 15,78 \\
\hline Auxiliar em Administração de Redes & 7 & 5 & 0 & 0 & 0 & 3 & 0 & 15 & 33,33 \\
\hline Cadista para a Construção Civil & 0 & 26 & 0 & 0 & 4 & 23 & 0 & 53 & 49,05 \\
\hline Desenhista de Produtos Gráficos Web & 7 & 48 & 0 & 0 & 20 & 48 & 0 & 123 & 39,02 \\
\hline Desenvolvedor de Jogos Eletrônicos & 19 & 32 & 0 & 0 & 17 & 55 & 0 & 123 & 26,01 \\
\hline Editor de Projeto Visual Gráfico & 4 & 73 & 1 & 0 & 15 & 36 & 0 & 129 & 57,03 \\
\hline Editor de Vídeo & 12 & 80 & 0 & 0 & 10 & 46 & 0 & 148 & 54,05 \\
\hline Editor Gráfico & 17 & 23 & 1 & 0 & 0 & 30 & 0 & 71 & 32,85 \\
\hline Espanhol Básico & 0 & 33 & 0 & 0 & 5 & 1 & 0 & 39 & 84,61 \\
\hline Fotógrafo & 2 & 7 & 0 & 0 & 0 & 9 & 0 & 18 & 38,88 \\
\hline Inglês Aplicado a Serviços Turísticos & 0 & 13 & 0 & 0 & 0 & 23 & 0 & 36 & 36,11 \\
\hline Inglês Básico & 61 & 238 & 0 & 0 & 74 & 206 & 0 & 579 & 41,1 \\
\hline Inglês Intermediário & 34 & 41 & 0 & 0 & 14 & 29 & 0 & 118 & 34,74 \\
\hline $\begin{array}{l}\text { Instalador e Reparador de Redes de } \\
\text { Computadores }\end{array}$ & 0 & 8 & 0 & 0 & 0 & 10 & 0 & 18 & 44,44 \\
\hline Monitor de Recreação & 0 & 12 & 0 & 0 & 2 & 7 & 0 & 21 & 57,14 \\
\hline Montador e Reparador de Computadores & 72 & 473 & 1 & 0 & 113 & 252 & 0 & 911 & 51,97 \\
\hline Montagem e Manutenção de Computadores & 57 & 254 & 0 & 0 & 2 & 228 & 0 & 541 & 46,95 \\
\hline Operador de Computador & 101 & 564 & 0 & 0 & 149 & 380 & 0 & 1194 & 47,23 \\
\hline Programador de Dispositivos Móveis & 5 & 4 & 0 & 0 & 0 & 30 & 0 & 39 & 10,25 \\
\hline Programador de Sistemas & 22 & 17 & 0 & 0 & 1 & 22 & 0 & 62 & 27,41 \\
\hline Programador Web & 13 & 14 & 0 & 0 & 5 & 34 & 0 & 66 & 21,21 \\
\hline Vendedor & 0 & 13 & 0 & 0 & 0 & 5 & 0 & 18 & 72,22 \\
\hline Web Designer & 5 & 10 & 0 & 0 & 0 & 25 & 1 & 41 & 24,39 \\
\hline Total FIC & 454 & 1991 & 4 & $\mathbf{0}$ & 431 & 1502 & 1 & 4383 & 45,46 \\
\hline Técnico em Administração & 6 & 42 & 0 & 0 & 15 & 10 & 0 & 73 & 57,53 \\
\hline Técnico em Informática & 116 & 102 & 79 & 29 & 17 & 2 & 5 & 350 & 37,63 \\
\hline Técnico em Informática para Internet & 43 & 31 & 0 & 11 & 0 & 0 & 15 & 100 & 31 \\
\hline Técnico em Programação de Jogos Digitais & 0 & 0 & 68 & 0 & 0 & 0 & 3 & 71 & 0 \\
\hline Técnico em Redes de Computadores & 60 & 34 & 0 & 18 & 0 & 0 & 8 & 120 & 28,33 \\
\hline Total Técnico Concomitante & 225 & 209 & 147 & 58 & 32 & 12 & 31 & 714 & 36,86 \\
\hline Técnico em Informática & 196 & 100 & 1 & 12 & 35 & 0 & 0 & 344 & 29,06 \\
\hline Técnico em Logística & 31 & 56 & 0 & 16 & 5 & 0 & 0 & 108 & 51,85 \\
\hline Total Técnico Subsequente & 227 & 156 & 1 & 28 & 40 & $\mathbf{0}$ & $\mathbf{0}$ & 452 & $\mathbf{3 4 , 5 8}$ \\
\hline Total Cursos Técnicos & 452 & 365 & 148 & 86 & 72 & 12 & 31 & 1.166 & 35,85 \\
\hline Total todos os Cursos & 906 & 2.356 & 152 & 86 & 503 & 1.514 & 32 & 5.549 & 43,65 \\
\hline
\end{tabular}

O curso técnico em Programação de Jogos Digitais, de acordo com entrevista com o Prof. 02, foi ofertado na modalidade a distância e teve apenas um estudante formado, embora as matrículas realizadas nesse curso ainda constem como "em curso". Os cursos técnicos na modalidade a distância, são desenvolvidos pela unidade de EAD do SNA, situada em Porto Alegre, e cabe aos polos, neste caso as escolas, realizarem o acompanhamento dos estudantes no ambiente virtual de aprendizagem e os encontros presenciais mensais. No âmbito da Bolsa 
Formação, os cursos ofertados na modalidade a distância recebem o valor de $\mathrm{R} \$$ 4,50 a hora/aluno e não preveem assistência estudantil, conforme se viu no Capítulo II.

O SISTEC permite o registro de vários "status de matrícula", de acordo com a ocorrência que a gerou. A situação de "frequência inicial insuficiente" significa que o estudante não atingiu o percentual mínimo de frequência no período inicial do curso ${ }^{171}$ e por algum motivo não foi substituído. Embora o sistema possibilite o registro desta forma, na prática configura um abandono. É curioso o número de estudantes em "dependência”, que se aplica aos casos em que o estudante avançou no curso, mas precisa refazer um módulo ou disciplina em virtude de reprovação. No entanto, no período de realização da última visita às unidades de ensino, tanto na Escola A quanto na Escola B, a informação era de que não havia mais nenhuma turma ou estudante do Pronatec em curso. Assim, esse registro configura, na verdade, casos de reprovação no âmbito do Pronatec, pois a única possibilidade de retomar o curso seria por meio do pagamento da mensalidade correspondente ao módulo ou disciplina em que foi reprovado. Os casos de transferência interna, configuram troca de curso, porém não é possível inferir se ocorreu entre diferentes cursos ofertados no âmbito da Bolsa Formação, para um curso pago ou para o Programa institucional de gratuidade.

Em relação aos turnos de desenvolvimento dos cursos, observa-se que os turnos da tarde e da noite apresentaram os melhores índices de conclusão nas diferentes formas de oferta. No caso dos cursos técnicos concomitantes, observa-se uma grande diferença no percentual de concluintes nos diferentes turnos, indicando que o turno da tarde melhor atenderia esse público, assim como o turno da noite parece ter melhor favorecido o público dos cursos subsequentes. Em relação aos cursos FICs não se observa diferença expressiva no percentual de concluintes nos diferentes turnos.

Tabela 51 - Índice de conclusão dos cursos por turno de oferta - Escola A SNA

\begin{tabular}{lrrr}
\hline \hline Tipo de Curso & Manhã & Tarde & Noite \\
\hline FIC & $41,99 \%$ & $\underline{47,84 \%}$ & $45,66 \%$ \\
Técnico Concomitante & $29,41 \%$ & $\underline{42,08 \%}$ & $32,14 \%$ \\
Técnico Subsequente & $36,68 \%$ & $28,12 \%$ & $\underline{37,66 \%}$ \\
Todos os cursos & $40,54 \%$ & $\underline{45,84 \%}$ & $43,68 \%$ \\
\hline \hline
\end{tabular}

Fonte: elaborada pela autora com base nos dados do SISTEC Nacional obtidos via e-Sic (2018)

\footnotetext{
${ }^{171}$ De acordo com o Manual de Gestão do Pronatec Bolsa Formação, configuram situação de "frequência inicial insuficiente", passível de cancelamento e substituição de matrícula os seguintes casos: "I. não frequentou os cinco primeiros dias consecutivos de aula. II. teve frequência menor que $50 \%$ ao completar: $20 \%$ da $\mathrm{CH}$ total de um curso FIC $20 \%$ da $\mathrm{CH}$ integralizada nos 4 primeiros meses de um curso técnico. III. não teve frequência maior que $50 \%$ nos 10 primeiros dias de aula".
} 
Em relação ao abandono, a pedagoga apontou como principal motivo a inserção profissional dos estudantes. No entanto, no turno da noite o percentual de abandono também foi alto, o que indica que este não pode ser considerado o único motivo para evasão. Por meio da entrevista com professores, como se viu, a dificuldade dos estudantes em acompanharem os cursos - a grande maioria na área de informática, que exige conhecimentos lógicos da área da matemática -, impulsionou grande número de desistentes.

\subsection{Desenvolvimento do Pronatec Bolsa Formação na Escola B do SNA}

A escola B do SNA é localizada na cidade de Uruguaiana, maior cidade da região Oeste do Rio Grande do Sul, situada na fronteira pluvial com a Argentina e fronteira seca com o Uruguai. A população do município, em 2010, era de 125.435 habitantes, sendo que $6 \%$ reside no meio rural (IBGE, 2010). Essa região do Estado é caracterizada por municípios com grandes áreas territoriais e pela baixa densidade geográfica (apenas 11 habitantes por $\mathrm{km}^{2}$ ), sendo que, na última década (2000-2010), dez dos treze municípios situados nessa região, tiveram taxas negativas de crescimento populacional, entre eles Uruguaiana (FEE, 2015).

A economia do município é baseada na produção agropecuária ${ }^{172}$, desenvolvida especialmente por meio das atividades de pecuária extensiva e da produção de arroz, que configuram um espaço rural baseado em grandes propriedades: mais de $98 \%$ da área rural corresponde a propriedades com média de 700 hectares (69\% das propriedades rurais). A agricultura familiar é desenvolvida em menos de $2 \%$ da área produtiva, por propriedades que possuem em média 28 hectares (31\% das propriedades rurais).

O Produto Interno Bruto do Município, em 2010, era composto, principalmente, pelo setor de comércio e serviços (67\%), agropecuária (15,6\%) e indústria (8,6\%) (FEE, 2017b). Entre estes setores, a indústria foi a que teve o menor crescimento no período de 2010 a 2015 , diminuindo em $1,1 \%$ sua participação no PIB, enquanto a agropecuária aumentou sua participação em $0,65 \%$. Em decorrência da produção de arroz, o município e região conta com grandes indústrias de beneficiamento do grão, que abastecem tanto o comércio interno, quanto o externo. Apesar de figurar entre os trinta municípios gaúchos com maior PIB (ocupa a 27 posição), Uruguaiana apresenta uma grande desigualdade na distribuição de renda, sendo o $6^{\circ}$ município no Estado com maior número de habitantes vivendo em situação de extrema pobreza - 3.806 pessoas com renda per capita mensal de até R\$ 70,00, (MARTINS; WINK JUNIOR,

172 Em 2015, o Valor Adicionado Bruto oriundo da Agropecuária foi o segundo maior do Estado, com R\$ 426.654.000,00 (FEE, 2017a). 
2013). Além disso, a taxa de desemprego era de 8,48\% - bem acima da média do Estado que era de $4,77 \%$ - e mais de um terço da população $(35,6 \%)$ vivia com até meio salário mínimo per capita, em 2010 (IBGE, 2010).

Um dos fatores que pode ter contribuído para essa concentração de pobreza foi a diminuição ou retirada da mão de obra no campo. Historicamente a "economia estancieira" (grandes fazendas) se valia da mão de obra de famílias que moravam em suas propriedades, as quais produziam sua subsistência por meio da troca de sua força de trabalho por alimentação e moradia, sem qualquer direito trabalhista e, em alguns casos, análoga ao trabalho escravo (PICCIN, 2012). O Estatuto do Trabalhador Rural, que regulamenta o trabalho assalariado no campo, apesar de ter sido aprovado ainda na década de 1960, passou a ter efeitos somente na década de 1990, quando "o risco representado por ações judiciais faz a legislação trabalhista bater à porta do mundo estancieiro" (PICCIN, p. 02, 2013). De acordo com Piccin (2012), o abalo nas relações de "confiança" ocasionado pelas crescentes ações judiciais determinou a expulsão ${ }^{173}$ destas famílias do território das estâncias, sendo que muitas delas passaram a se instalar nas periferias das cidades ou nos "corredores" das fazendas ${ }^{174}$. Ao mesmo tempo, essa situação impulsionou a modernização dos processos de trabalho no campo, visto que a mão de obra antes obtida com baixo ou nenhum custo monetário passou a exigir remuneração, o que, somada à baixa nos preços do gado, no final dos anos de 1980, passou a demandar menor número de trabalhadores. Os trabalhadores excedentes, majoritariamente com baixo nível de escolaridade, passaram a figurar nos índices de pobreza e desemprego.

Essa situação remete ao caráter produtivo do atraso, conforme analisa Francisco de Oliveira (2013), em que a pobreza é produtiva à medida em que rebaixa o valor do trabalho. "Existe a sensação intuitiva, mas falsa, de que o atraso segura, suga para baixo o setor moderno", quando, na realidade, "o limbo funciona como a atmosfera da qual o moderno retira o ar que respira - ou melhor, a mão de obra que o alimenta", conforme sintetiza Singer (2018, p. 22), apoiando-se na tese de Oliveira. Não por acaso, a cidade de Uruguaiana figura em

\footnotetext{
173 Conforme dados dos Censos de 1991 e 2000, nessa década, a população do campo em Uruguaiana diminuiu $23,5 \%$, o que corresponde a 2.093 pessoas. Já na primeira década dos anos 2000, o número de habitantes no meio rural se manteve praticamente o mesmo.

${ }^{174}$ Conforme a pesquisa de Piccin (2012), parte dessas famílias "passaram a engrossar a categoria dos chamados moradores de corredor, quando a casa era instalada entre a cerca das grandes propriedades e as estradas, ou as periferias das cidades" (p. 41). Vivendo de pequenas hortas e até de furtos de animais das estâncias (sendo muitas vezes consentido pelos estancieiros), os "moradores de corredor" representam o acesso à mão de obra pelas estâncias, quando necessário. Essa "submissão" aos donos de terra pode ser compreendida pelo histórico das famílias, que são, muitas vezes, descendente de mais de uma geração de trabalhadores no campo, sendo muito difícil visualizar outras perspectivas de vida.
} 
segundo lugar no Estado no ranking do VAB (Valor Adicionado Bruto) da Agropecuária (ATLAS, 2015).

Entre a população economicamente ativa, 28,45\% trabalham por conta própria, 2,4\% são empregadores e 69,15\% são empregados - recebendo em média 2,2 salários mínimos -, dos quais mais de $25 \%$ não possui carteira assinada. De acordo com os grupos de ocupação do IBGE, conforme a Tabela 52, destacam-se as ocupações elementares $(20,47 \%)$ e os trabalhadores de serviços e comércio (17,56\%). Contam, também, com número expressivo de trabalhadores ocupações como as de "operadores de instalações e máquinas e montadores", com 10,7\%, que abrangem trabalhadores dos diferentes ramos industriais, e os "trabalhadores qualificados, operários e artesãos da construção, das artes mecânicas e outros ofícios”, com 11,88\% da população economicamente ativa. Apesar da grande participação da agropecuária no PIB do município, observa-se que o percentual de trabalhadores nessa área é pouco expressivo, resultado dos processos de expulsão das famílias que viviam no campo e da mecanização da produção. A maior contribuição dessas atividades na produção de postos de trabalho, atualmente, se dá no setor secundário, por meio do beneficiamento do arroz e de frigoríficos.

Tabela 52 - População economicamente ativa por grupos de ocupação Município de Uruguaiana Escola B SNA

\begin{tabular}{l|l}
\multicolumn{1}{c|}{ Grupos de ocupação } & $\%$ \\
\hline \hline Diretores e gerentes & 3,88 \\
Membros das forças armadas, policiais e bombeiros militares & 2,62 \\
Ocupações elementares* & $\underline{20,47}$ \\
Operadores de instalações e máquinas e montadores & $\underline{10,07}$ \\
Profissionais das ciências e intelectuais & 9,05 \\
Técnicos e profissionais de nível médio & 5,94 \\
Trabalhadores de apoio administrativo & 6,54 \\
Trabalhadores dos serviços, vendedores dos comércios e mercados & $\underline{17,56}$ \\
Trabalhadores qualificados da agropecuária, florestais, da caça e da pesca & 3,97 \\
Trabalhadores qualificados, operários e artesãos da construção, das artes mecânicas e outros ofícios & $\underline{11,88}$ \\
Ocupações mal definidas & 8,01 \\
\hline Total & 100,00 \\
\hline \hline
\end{tabular}

*Compreende os trabalhadores dos serviços domésticos e trabalhadores de limpeza em geral.

Fonte: Organizada pela autora com base nos dados do Censo Demográfico (IBGE, 2010).

Em relação ao perfil educacional da população de Uruguaiana, em 2010, 4,07\% da população com 15 anos ou mais era analfabeta ${ }^{175}$. Entre a população de 25 anos ou mais, $42,8 \%$ não possuía instrução ou tinha o ensino fundamental incompleto; $19,1 \%$ apresentava o ensino

\footnotetext{
${ }^{175}$ De acordo com a pesquisa de Piccin (2012) grande parte dos trabalhadores nas estâncias (fazendas) da região da fronteira oeste são analfabetos. Parte destes trabalhadores foram os que permaneceram no trabalho no campo, já parte daqueles com alguma escolaridade lograram postos de trabalho na indústria ou em frigoríficos na cidade.
} 
fundamental completo e ensino médio incompleto, $27 \%$ tinha o ensino médio completo e ensino superior incompleto e 10,8\% possuía o ensino superior completo (IBGE, 2010).

A educação básica é atendida pelos sistemas municipal (31 escolas, sendo 24 no meio urbano e 7 no meio rural), estadual (31 escolas, sendo 25 no meio urbano e 6 no meio rural), privado (20 escolas) - entre elas escolas tradicionais católicas onde estudam os filhos dos arrozeiros e fazendeiros de gado - e por um Campus Avançado de Instituto Federal, que oferta o ensino médio integrado ao ensino técnico. $\mathrm{Na}$ área de educação profissional, o município conta com uma escola estadual que oferta curso técnico em Comércio Exterior, uma escola agrícola municipal que oferta o curso técnico de Agropecuária, um Campus Avançado de Instituto Federal que oferta cursos na área de Informática, e as instituições do Sistema $\mathrm{S}$ (SENAI, SENAC, SENAT e SENAR ${ }^{176}$ ), que ofertam cursos de qualificação profissional e cursos técnicos. Em dezembro de 2012 havia sido inaugurada pela gestão municipal a Universidade do Trabalho (UNITRA) com vistas à oferta de qualificação profissional, visto que algumas empresas estavam trazendo trabalhadores de outras cidades em razão da ausência de mão de obra no município, segundo o Prefeito da época ${ }^{177}$. No entanto, com a oferta de cursos gratuitos pelo Pronatec Bolsa Formação, a nova gestão municipal encerrou suas atividades em 2014, pois as demandas locais seriam atendidas por meio do Programa. No ensino superior, predominavam até o início dos anos 2000 as instituições privadas, como a PUC (Pontifícia Universidade Católica) e instituições de ensino a distância ${ }^{178}$. Em 2008, o governo federal criou a Universidade Federal do Pampa, com vistas a promover o desenvolvimento da região do "Pampa Gaúcho" (fronteira sul e oeste), considerado atrasado, instalando um Campus em Uruguaiana, além de outras nove cidades da mesma região ${ }^{179}$.

A escola do SNA está presente na cidade desde a segunda metade da década de 1950, atuando nas áreas de Gestão, Comércio, Informática e Saúde. No total de matrículas do Pronatec Bolsa Formação desenvolvidas no município, esta escola ofertou $62 \%$. O restante foi

\footnotetext{
176 Destas instituições apenas o SENAR não ofertou cursos no âmbito do Pronatec Bolsa Formação.

177 Os cursos ofertados pela UNITRA, em 2013, eram na área de: costura industrial, modelismo, mecânica de automóveis e motocicletas, eletromecânica e construção civil. Segundo noticiado pelo jornal da cidade "A costura industrial já emprega mais de 800 pessoas na cidade e está em evolução. Hoje falta mais de 200 profissionais nessa área". Ao se observar a oferta de cursos pelo Pronatec na cidade, na área de costura foram realizadas apenas 131 matrículas nessa área (85 matrículas no curso de Costureiro de Máquina Reta e Overloque, 23 no curso de Costureiro Industrial do Vestuário e 23 no curso de Confeccionador de Lingerie e Moda Praia).

178 A elite agrária da região sempre priorizou enviar seus filhos para fazer faculdade nas universidades federais de Santa Maria e de Porto Alegre, instituições de maior prestígio social.

${ }^{179}$ Com a chegada da Universidade Federal, o Campus da PUC, que já vinha com poucos estudantes, encerrou suas atividades (aprovou sua extinção em 2009 e encerrou suas atividades em 2013). Assim, o Campus Uruguaiana da Unipampa foi instalado nas dependências da PUC. De acordo com relatos de estudantes da UNIPAMPA, a instituição não teve uma boa recepção na elite agrária da região.
} 
desenvolvido por outras duas escolas do Sistema S, $20 \%$ e $17 \%$, respectivamente, e $1 \%$ pelo Campus Avançado de um Instituto Federal ${ }^{180}$. Apenas $15 \%$ do total de matrículas foram realizadas em cursos técnicos, os quais foram ofertados pela Escola B (14\%) e pelo IF (1\%). No total, a escola B ofertou 43 diferentes cursos, sendo 06 cursos técnicos e 37 cursos de formação inicial e continuada, que correspondem a $22,6 \%$ e $77,4 \%$, respectivamente, das matrículas.

Conforme se observa na Tabela 53, o curso com maior número de matrículas foi “Operador de Computadores”, com 759 matrículas, seguido por “Operador de Supermercados”, com 677 matrículas, e "Montador e Reparador de Computadores”, com 633 matrículas - sendo que estes dois últimos foram ofertados exclusivamente pela Escola B do SNA. Assim como se viu no município do Centro de Referência do IFFar, houve grande número de matrículas nos cursos de Operador de Computadores ofertados por instituições do Sistema S, formação que não se constitui em uma ocupação em si, mas em conhecimento necessário para desempenhar diversas atividades que envolvam o uso de computador, o qual poderia ser atendido por meio de treinamento em serviço. Chama a atenção, também, o grande número de matrículas no curso de Operador de Supermercados, sendo que na cidade há apenas 10 supermercados (de acordo com o guia comercial).

Tabela 53 - Cursos Pronatec Bolsa Formação por Instituição Ofertante - Município de Uruguaiana (2011 a 2016)

\begin{tabular}{llllll}
\hline \hline Curso & IF & Escola B & Sistema $\mathbf{S}^{\mathbf{1}}$ & Sistema $\mathbf{S}^{\mathbf{2}}$ & Total \\
\hline Operador de Computador & 0 & $\mathbf{4 5 0}$ & 307 & 0 & 757 \\
Operador de Supermercados & 0 & $\mathbf{6 7 7}$ & 0 & 0 & 677 \\
Montador e Reparador de Computadores & 0 & $\mathbf{6 3 3}$ & 0 & 0 & 633 \\
Assistente de Recursos Humanos & 0 & $\mathbf{1 0 9}$ & 0 & 391 & 500 \\
Eletricista Instalador Predial de Baixa Tensão & 0 & $\mathbf{0}$ & 293 & 96 & 389 \\
Técnico em Logística & 0 & $\mathbf{3 6 3}$ & 0 & 0 & 363 \\
Vendedor & 0 & $\mathbf{3 5 9}$ & 0 & 0 & 359 \\
Técnico em Informática & 86 & $\mathbf{2 5 7}$ & 0 & 0 & 343 \\
Mecânico de Motores a Diesel & 0 & $\mathbf{0}$ & 0 & 292 & 292 \\
Técnico em Segurança do Trabalho & 0 & $\mathbf{2 9 2}$ & 0 & 0 & 292 \\
Cuidador de Idoso & 0 & $\mathbf{2 6 6}$ & 0 & 0 & 266 \\
Operador de Retroescavadeira & 0 & $\mathbf{0}$ & 0 & 267 & 267 \\
Inglês Básico & 0 & $\mathbf{1 4 8}$ & 94 & 0 & 242 \\
Assistente Administrativo & 0 & $\mathbf{1 8 4}$ & 24 & 22 & 230 \\
Operador de Caixa & 0 & $\mathbf{2 1 7}$ & 0 & 0 & 217 \\
Técnico em Enfermagem & 0 & $\mathbf{2 1 8}$ & 0 & 0 & 218 \\
Torneiro Mecânico & 0 & $\mathbf{0}$ & 197 & 0 & 197 \\
Modelista de Roupas & 0 & $\mathbf{1 0 9}$ & 79 & 0 & 188 \\
Frentista & 0 & $\mathbf{3 1}$ & 0 & 146 & 177 \\
Aplicador de Revestimento Cerâmico & 0 & $\mathbf{0}$ & 172 & 0 & 172
\end{tabular}

${ }^{180}$ Este Campus Avançado iniciou suas atividades em outubro de 2013, com cursos pelo Pronatec. Somente em agosto de 2014 ofertou seus primeiros cursos próprios. Assim, compreende-se que a pequena oferta de matrículas no programa deu-se pelo fato de estar em processo de implantação. 
Balconista de Farmácia

Técnico em Administração

$0 \quad 152$

Organizador de Eventos

Técnico em Comércio Exterior

Agente de Recepção e Reservas em Meios de

Hospedagem

Assistente de Despachante Aduaneiro

Espanhol Básico

Pedreiro de Alvenaria Estrutural

Operador de Empilhadeira

Auxiliar Administrativo

Assistente Financeiro

Costureiro de Máquina Reta e Overloque

Eletricista Industrial

Cuidador Infantil

Garçom

Pintor de Obras Imobiliárias

Recepcionista de Eventos

Eletricista de Automóveis

Desenhista de Produtos Gráficos Web

Marceneiro

Monitor de Recreação

Encanador Instalador Predial

Recepcionista em Serviços de Saúde

Promotor de Vendas

Artesão em Bordado à Mão

Higienista de Serviços de Saúde

Camareira em Meios de Hospedagem

Mecânico de Refrigeração e Climatização

Residencial

Representante Comercial

Assistente de Crédito e Cobrança

Operador de Equipamento de Guindar

Libras - Básico

Inglês Aplicado a Serviços Turísticos

Reformador de Móveis

Instalador e Reparador de Redes de Computadores

Motorista de Transporte de Passageiros

Auxiliar de Cozinha

Espanhol Aplicado a Serviços Turísticos

Eletricista de Rede de Distribuição de Energia

Elétrica

Recreador

Francês Básico

Motorista de Transporte de Produtos Perigosos

Confeccionador de Lingerie e Moda Praia

Costureiro Industrial do Vestuário

Lapidador de Gemas

Ajustador Mecânico

Mecânico de Freios, Suspensão e Direção de

Veículos Leves

Agente de Observação de Segurança

Pedreiro de Alvenaria

Agente de Informações Turísticas

Assistente de Serviços em Comércio Exterior

$\begin{array}{lllll}0 & \mathbf{2 0} & 0 & 0 & 20\end{array}$




\begin{tabular}{llllll} 
Técnico em Informática para Internet & 13 & $\mathbf{0}$ & 0 & 0 & 13 \\
\hline Total & 99 & $\mathbf{6 1 9 4}$ & 1989 & 1688 & 9970 \\
\hline \hline
\end{tabular}

Fonte: elaborada pela autora com base nos dados do SISTEC Nacional, 2017.

Em relação aos eixos tecnológicos, observa-se que predominam os eixos de Gestão e Negócios e Informação e Comunicação (Tabela 54). Embora a indústria tenha um percentual importante no PIB e na geração de postos de trabalho, o percentual de vagas nessa área é muito pequeno $(7,4 \%)$. Já a agricultura e a pecuária, que correspondem aos cursos do eixo de Recursos Naturais, não foram contempladas. Um fator que pode contribuir para a compreensão desta ausência é o receio dos estancieiros de que a qualificação formal dos assalariados rurais estimule o abandono dos postos de trabalho (PICCIN, 2012) ${ }^{181}$, além da distância entre as estâncias e a cidade, em razão da vasta área rural do município, uma vez que todos os cursos realizados pela Escola B ocorreram na zona urbana. Esse fator pode ser reforçado pela ausência do SENAR, instituição especializada na qualificação de trabalhadores do campo, na oferta de cursos pelo Pronatec, confirmando o não interesse do patronato rural na formação de seus assalariados e até mesmo da mão de obra excedente. Com isso, pode-se apontar que a dinâmica de mapeamento da demanda de cursos pelo Programa é conduzida pela relação de forças dos setores/grupos dominantes em cada território, não promovendo espaços de disputa ${ }^{182}$.

A Escola B tem uma atuação mais voltada para os eixos de Gestão e Negócios, Informação e Comunicação e Ambiente e Saúde em seus cursos regulares e são nestes mesmos eixos em que se observa o maior número de matrículas pelo Pronatec, o que pode indicar que a carta de cursos da instituição balizou a pactuação dos cursos no âmbito do Programa. Os cursos ofertados em outros eixos que demandavam laboratórios e equipamentos, como Auxiliar de Cozinha e Modelista de Roupas, foram desenvolvidos em parceria com empresas e instituições da cidade, as quais forneceram os espaços e equipamentos para as aulas práticas. O curso na área de cozinha, por exemplo, teve as aulas práticas desenvolvidas em um restaurante da cidade, onde

\footnotetext{
${ }^{181}$ Conforme pesquisa de campo realizada em estâncias da mesma região (Piccin, 2012), depoimento de um dos donos de Terra revela esse "receio" dos estancieiros: "Eu tenho oito funcionários. Mas está ficando só os analfabetos lá fora; ninguém mais quer ficar lá. O Marfrigui [frigorífico] tomou muita mão de obra. Lá adiante, não sei o que vai acontecer. O meu esquilador é analfabeto, o aramador também. Dei curso de inseminação para dois dos meus, e essa família já esquilava para o meu pai e agora vem inseminando; esquilam para mim e para o Pedro. Muitos não querem capacitar seus empregados de medo de perdê-los. Eu te dou vários casos de gente que deu curso de inseminador e o cara deixa o emprego e sai inseminando para fora, abre negócio" (p. 417).

${ }^{182}$ Infelizmente, não foi possível entrevistar a Diretora da Escola B que atuou no período do Pronatec, visto que foi demitida, para compreender melhor o processo de pactuação dos cursos nesta instituição. No entanto, a nova Diretora, que havia atuado como Diretora em outra escola do SNA em cidade próxima a Uruguaiana, relata que Secretarias da Prefeitura Municipal e as associações comerciais faziam contato com a instituição para saber da possibilidade de atender os cursos que almejavam e que grande parte da oferta era recebida por meio do Diretório Regional: "Olha, a partir de tanto, daqui a 03 meses, são esses os cursos que vocês vão precisar ofertar" (Diretora Escola B).
} 
atuava o professor do curso. Já o curso de modelista de roupas teve as máquinas emprestadas pela UNITRA, escola de educação profissional do município.

Tabela 54 - Cursos Pronatec Bolsa Formação por Eixo Tecnológico - Município de Uruguaiana (2011 a 2016)

\begin{tabular}{|c|c|c|c|c|c|}
\hline & IF & Escola B & Sistema S & Sistema S & Total \\
\hline Ambiente e Saúde & & $13,4 \%$ & & & $8,3 \%$ \\
\hline Controle e Processos Industriais & & & $19,3 \%$ & $20,9 \%$ & $7,4 \%$ \\
\hline Desenvolvimento Educacional e Social & & $3,9 \%$ & $7,1 \%$ & $2,5 \%$ & $4,3 \%$ \\
\hline Gestão e Negócios & & $\underline{41,7 \%}$ & $1,2 \%$ & $\underline{30,5 \%}$ & $\underline{31,3 \%}$ \\
\hline Informação e Comunicação & $100,0 \%$ & $\overline{\mathbf{2 3 , 0 \%}}$ & $\underline{25,1 \%}$ & & $\overline{20,3 \%}$ \\
\hline Infraestrutura & & $\overline{\mathbf{0 , 5 \%}}$ & $\overline{27,9 \%}$ & $44,9 \%$ & $\overline{13,5 \%}$ \\
\hline Produção Cultural e Design & & & $2,7 \%$ & & $0,5 \%$ \\
\hline Produção Industrial & & $1,8 \%$ & $16,8 \%$ & & $4,4 \%$ \\
\hline Segurança & & $4,7 \%$ & & $1,2 \%$ & $3,1 \%$ \\
\hline Turismo, Hospitalidade e Lazer & & $11,1 \%$ & & & $6,9 \%$ \\
\hline Total & $100,0 \%$ & $100,0 \%$ & $100,0 \%$ & $100,0 \%$ & $100,0 \%$ \\
\hline
\end{tabular}

Fonte: elaborada pela autora com base nos dados do SISTEC Nacional, 2017.

Não foi possível identificar por meio dos relatórios de cursos disponibilizados pela instituição quais foram as modalidades do Pronatec atendidas. Entretanto, nas entrevistas, identificou-se que o público principal era encaminhado pelo Centro de Assistência Social (CRAS), que corresponde à modalidade Pronatec Brasil sem Miséria; os estudantes do ensino médio, por meio do Pronatec Jovem Técnico ${ }^{183}$; algumas pessoas que recebiam seguro desemprego, e adolescentes em medida socioeducativa na FASE (Fundação de Atendimento Socioeducativo do RS). Alguns cursos técnicos também foram desenvolvidos na forma subsequente, e a seleção dos estudantes se dava por meio do SISUTEC, contemplando pessoas com ensino médio completo que haviam realizado o último ENEM.

Para atender a demanda de cursos pelo Pronatec, a Escola chegou a ter em torno de 50 docentes - sendo que, em 2017, após o Programa, contava com 23 professores - e precisou alugar um espaço em prédio próximo à instituição, pois todas as salas de aula já estavam sendo ocupadas nos três turnos: "teve um ano que nós atendemos 6.000 alunos, o que, para nós, é absurdamente grande. Hoje, a gente deve estar com 1.000 alunos" (Entrevista Prof. 01, Escola B SNA). Neste espaço alugado foram organizadas 06 salas de aula, as quais eram ocupadas também nos três turnos, um auditório, banheiros e sala de professores. Como não havia biblioteca e nem laboratórios, eram desenvolvidos somente cursos FIC, para os quais não tem a exigência legal de biblioteca, de acordo com as normas da instituição, e aulas teóricas. De acordo com o Prof. 01, "Lá, normalmente, ficavam os cursos que não teriam práticas,

\footnotetext{
${ }^{183}$ Os cursos técnicos concomitantes foram desenvolvidos na forma presencial e também a distância. Nesta última modalidade foram ofertados, no ano de 2015, três cursos: duas turmas de Técnico em Informática (40 matrículas); três turmas de Técnico em Logística (88 matrículas) e duas turmas de Técnico em Segurança do Trabalho (54 matrículas), totalizando 180 matrículas.
} 
justamente para não vir para cá. Cursos, basicamente, da área de Gestão” (Entrevista Prof. 01, Escola B SNA).

Embora em menor quantidade, a instituição continuava atendendo turmas de mercado (cursos pagos), os quais se desenvolviam nas instalações da escola, pois segundo o Prof. 01, os estudantes de cursos pagos pressionavam por melhores condições de infraestrutura: "É, cursos pagos, lá [no espaço alugado], dificilmente tinha alguma coisa. Uma vez, teve um curso lá, e ficou 02 semanas, e mandaram para cá", por que tinha a "pressão de quem pagava; tu sentia a pressão deles, que eles não queriam estudar lá, porque sabiam que lá era calor no verão e era frio no inverno, que era longe de todo mundo, aqui sempre tinha lugares para comer, e tal, e lá não tinha ninguém" (Entrevista Prof. 01, Escola B SNA). Assim, embora grande parte dos docentes e gestores afirmassem o tempo todo que não havia diferença entre os cursos pagos e aqueles ofertados pelo Pronatec (eram os mesmos professores, mesmos planos de curso, entre outros), evidencia-se, nessa situação, que a instituição privilegiava o atendimento das reivindicações dos estudantes de cursos pagos.

O curso de Enfermagem, que é considerado o "carro-chefe" da escola, também tinha turmas de mercado em andamento, sendo que $90 \%$ destas se desenvolviam no período noturno, que é o turno que apresenta mais facilidade para preencher as turmas pagas. Já as turmas desse curso pelo Pronatec ocorriam no turno diurno (manhã ou tarde). Assim, a pessoa que trabalha durante o dia não teria condições de fazer o curso gratuito, apenas o pago. Cabe ressaltar, que o levantamento das demandas de curso não tinha como critério o turno a ser ofertado, essa era uma prerrogativa da instituição, a qual, obviamente, buscava atender de forma a não interferir na sua dinâmica de venda de cursos, assim como também se observou na Escola A. Na tabela 55, pode-se verificar que os turnos manhã e tarde concentraram a maior parte das matrículas em cursos pelo Programa, evidenciando que a oferta do Programa era realizada de forma a ocupar a capacidade ociosa da instituição, sem comprometer a venda de cursos de mercado.

Tabela 55 - Turno dos cursos Ofertados pela Escola B do SNA pelo Pronatec Bolsa Formação (2011 a 2016)

\begin{tabular}{lllll}
\hline \multirow{2}{*}{ Curso } & \multicolumn{3}{c}{ Turno } \\
\cline { 2 - 4 } & Manhã & Tarde & Noite & Total \\
\hline Agente de Informações Turísticas & 0 & 0 & 20 & 20 \\
Agente de Recepção e Reservas em Meios de Hospedagem & 95 & 33 & 0 & 128 \\
Assistente Administrativo & 52 & 112 & 20 & 184 \\
Assistente de Crédito e Cobrança & 0 & 29 & 21 & 50 \\
Assistente de Despachante Aduaneiro & 0 & 0 & 27 & 27 \\
Assistente de Recursos Humanos & 26 & 28 & 55 & 109 \\
Assistente de Serviços em Comércio Exterior & 0 & 0 & 20 & 20 \\
Assistente Financeiro & 0 & 40 & 54 & 94 \\
Auxiliar Administrativo & 0 & 50 & 50 & 100
\end{tabular}




\begin{tabular}{|c|c|c|c|c|}
\hline Auxiliar de Cozinha & 20 & 18 & 0 & 38 \\
\hline Balconista de Farmácia & 96 & 31 & 25 & 152 \\
\hline Camareira em Meios de Hospedagem & 0 & 24 & 28 & 52 \\
\hline Cuidador de Idoso & 191 & 74 & 0 & 265 \\
\hline Cuidador Infantil & 55 & 26 & 0 & 81 \\
\hline Desenhista de Produtos Gráficos Web & 50 & 0 & 13 & 63 \\
\hline Espanhol Aplicado a Serviços Turísticos & 8 & 12 & 14 & 34 \\
\hline Espanhol Básico & 16 & 30 & 20 & 66 \\
\hline Francês Básico & 13 & 15 & 0 & 28 \\
\hline Frentista & 0 & 0 & 31 & 31 \\
\hline Garçom & 20 & 56 & 0 & 76 \\
\hline Higienista de Serviços de Saúde & 0 & 0 & 53 & 53 \\
\hline Inglês Aplicado a Serviços Turísticos & 28 & 0 & 13 & 41 \\
\hline Inglês Básico & 69 & 64 & 15 & 148 \\
\hline Instalador e Reparador de Redes de Computadores & 19 & 0 & 0 & 19 \\
\hline Modelista de Roupas & 110 & 0 & 0 & 110 \\
\hline Monitor de Recreação & 60 & 0 & 0 & 60 \\
\hline Montador e Reparador de Computadores & 572 & 60 & 0 & 632 \\
\hline Operador de Caixa & 78 & 139 & 0 & 217 \\
\hline Operador de Computador & 269 & 159 & 23 & 451 \\
\hline Operador de Supermercados & 163 & 143 & 371 & 677 \\
\hline Organizador de Eventos & 66 & 70 & 0 & 136 \\
\hline Promotor de Vendas & 28 & 0 & 28 & 56 \\
\hline Recepcionista de Eventos & 31 & 42 & 0 & 73 \\
\hline Recepcionista em Serviços de Saúde & 30 & 0 & 28 & 58 \\
\hline Recreador & 30 & 0 & 0 & 30 \\
\hline Representante Comercial & 0 & 29 & 22 & 51 \\
\hline Técnico em Administração & 0 & 142 & 0 & 142 \\
\hline Técnico em Comércio Exterior & 0 & 0 & 138 & 138 \\
\hline Técnico em Enfermagem & 136 & 87 & 0 & 223 \\
\hline Técnico em Informática & 49 & 172 & 37 & 258 \\
\hline Técnico em Logística & 59 & 90 & 214 & 363 \\
\hline Técnico em Segurança do Trabalho & 135 & 85 & 72 & 292 \\
\hline Vendedor & 85 & 230 & 44 & 359 \\
\hline Total & 2659 & 2090 & 1456 & $6205^{*}$ \\
\hline
\end{tabular}

* Observa-se uma pequena variação no número de matrículas entre o relatório obtido em 2017 e o obtido em 2018, por meio do e-Sic, porém não compromete os resultados.

Fonte: Elaborada pela autora com base nos dados do SISTEC Nacional (2018).

Todos os docentes entrevistados relataram como dificuldade do Programa o interesse de muitos estudantes apenas pela assistência estudantil, o que lhes gerava certo incômodo. Segundo alegavam, havia mais interesse dos alunos pelo valor recebido, que pelos estudos:

Quantas vezes nós questionamos eles: por quê que eles estavam aqui? Se a passagem e o vale-alimentação era o meio ou era o fim, para eles? Porque parecia para nós que era o fim, que eles estavam aqui só por causa da questão da passagem. E alguns, depois dessas conversas, acabaram desistindo. Vieram aqui, inclusive, para pedir desculpa, que eles estavam aqui só pela passagem mesmo. Poucos casos vieram pedir desculpa, vieram cancelar, muitos acabavam não vindo mais (Entrevista Prof. 1, escola B SNA) (grifos nossos). 
Nós escutávamos muito, assim, as pessoas, não é, Neila, chegar e falar, assim, ó: “Ah, eu estou aqui, porque eu recebo a ajuda”. Então, nós enfrentamos muito, assim, as pessoas estarem no Pronatec porque elas queriam aquele curso de graça, que pagava elas para fazer. Então, as pessoas iam, se inscreviam no curso, e o que eles menos queriam era aprender, o que eles mais queriam era estar ali para receber (Entrevista Profa. 02, Escola B SNA).

Eu ouvi de um aluno, um dia, que ele só vinha na aula por conta do vale-transporte e do vale-alimentação. Eu digo: "Poxa, cara, beleza. Nós estamos numa oportunidade de fazer algo diferente na tua vida, que tu tens de mudar a tua vida realmente, e tu está pensando só no valor financeiro, que tu estás recebendo, no final do mês ali". Entende? Isso, para mim, como cidadão, era frustrante. Poxa, não é esse tipo de coisa que a gente gostaria de desenvolver nas pessoas (Entrevista Prof. 03, Escola B SNA).

No período em que a assistência estudantil era repassada na forma de passagens de ônibus e vale alimentação, grande parte dos estudantes vendia suas passagens para utilizar o dinheiro em outras necessidades. $\mathrm{O}$ vale alimentação era utilizado, em grande medida, para a comprar alimentação para toda a casa e não apenas para o lanche nos intervalos das aulas - para fazer o "rancho", como se diz popularmente no Rio Grande do Sul. Essa prática foi facilitada no momento em que a escola passou a repassar o valor da assistência estudantil na forma pecuniária, uma vez que o dinheiro passou a ser utilizado diretamente para esses fins. Destacase, abaixo, trechos das entrevistas com docentes que ilustram essa situação:

Aqui na frente tinha um comércio de passagens e de vale-alimentação, por causa do Terminal. Então, eles aprendiam Economia, porque no dia que recebiam o preço baixava, a cotação da passagem baixava, daí passava uma semana, duas, aí o preço da passagem subia, eles recebiam mais; então, eles aprendiam a segurar a passagem, assim, para vender depois, e tal (...) porque têm umas pessoas que vendem passagem mais barata no Terminal. E aí quando tinha o Pronatec, o pessoal ia levar todas as passagens que ganhavam aqui, para essas pessoas. Aí, em vez deles pagarem $\mathrm{R} \$ 1,50$, eles pagavam $R \$ 1,00$. Pagavam $R \$ 1,00$ na passagem para o cara que vinha aqui, esse cara ia, de a pé, para casa, e embolsava o dinheiro.

E assim com o vale-alimentação, também. O vale-alimentação era aceito por poucas empresas na cidade. Eu sei que aqui atrás tinha uma padaria e tinha um mercado na cidade que aceitava; então, todo mundo descobriu que aceitava na padaria aqui, e era uma fila, absurdamente, grande. As pessoas faziam "rancho" na padaria, elas iam ali de final de semana e compravam. Aí a padaria começou a colocar mais coisa, começou a colocar carne, começou a colocar a parte de limpeza, ketchup, maionese, erva-mate, todas essas coisas assim, e a pessoa saía dali com um "rancho". Então, assim, a padaria, de um ano para o outro, eles ficaram muito ricos por causa disso, sabe. E era uma fila enorme que tinha, aí pediam para aumentar o tempo do intervalo para poderem comer, sabe. As pessoas saíam correndo, para ir na padaria.

Depois eles passaram a receber no banco, aí acabou com o comércio ilegal de passagens aqui, e a questão da alimentação, não é. E todo mundo vinha a pé, ou vinha de bicicleta, vinha de qualquer jeito, menos de ônibus, eles economizavam o máximo. Tinha uma mulher, ela chegava aqui com um cheiro bem forte de suor, sabe, no inverno, de manhã. E aí as colegas: "Ó, fulana, o quê que houve? Não deu tempo de tomar banho?" Brincando, não é. E ela, assim: "Não, eu saí de casa 06h30, de a pé, para chegar aqui dez para as oito". E aí: "Ah, mas por quê? Por que tu não vai de passe? Por que não vai de ônibus? - "Isso aqui é o dinheiro que eu estou comprando comida para a minha casa" (Entrevista Prof. 01, Escola B SNA). 
(...) as pessoas recebiam aquela ajuda de custo, que, na realidade, a ajuda de custo era para o vale-transporte e para o lanche, diários, mas nós sabíamos que a maioria deles não utilizava aquilo ali, para isso (Entrevista Prof. 02, Escola B SNA).

$*$

Às vezes, nós perguntávamos: "Fulana, por que tu não vieste ontem?" E ela...e elas nos diziam, assim: "Ai, professora, não tinha dinheiro para vir". Eu digo: "Como tu não tinhas dinheiro para vir?" - "Ah, mas é que eu precisei, gastei em outra coisa" (Entrevista Prof. 04, Escola B SNA).

Considerando o índice de pobreza do município, pode-se compreender que o interesse pelo valor da assistência estudantil tinha como base a necessidade de complementação de renda para a subsistência das famílias. Ao mesmo tempo, a mulher que chegava "cheirando a suor" pela manhã, pois utilizava o dinheiro para comprar comida, concluiu o curso com êxito. Assim, a intencionalidade da política, que destinava a assistência estudantil para o deslocamento e a alimentação durante as aulas, nem sempre era o que correspondia à necessidade concreta dos sujeitos atendidos, mas, ao mesmo tempo, era um fator de condição para a permanência dos estudantes nos cursos. Conforme destacou um dos professores: "quando era o Programa de Gratuidade as turmas não fechavam, eram cursos muito bons, eram Cursos Técnicos, e as turmas não fechavam", denotando assim a importância da assistência estudantil nesse contexto.

No total, 932 (novecentos e trinta e duas) pessoas fizeram mais de um curso pelo Programa, alguns fizeram até 6 cursos diferentes. Desse total, o número de pessoas que não concluiu nenhum dos cursos iniciados foi de apenas 96 (noventa e seis). Embora, para muitos, o interesse inicial possa ter sido o valor da assistência estudantil, conforme apontavam os docentes, o acesso a este recurso possibilitava, ao mesmo tempo, o acesso à formação profissional.

Essa crítica dos docentes em relação à assistência estudantil, que gerou constrangimento aos estudantes, a ponto de alguns pedirem desculpas, expressa um certo "choque" entre a cultura institucional e a realidade existente. Acostumados a atender um público que trabalha durante o dia e, com certo sacrifício, consegue pagar o curso que frequenta a noite, não era admissível que aqueles estudantes que já frequentavam um curso gratuito ainda tivessem interesse no dinheiro aportado pelo Programa. A cultura do esforço e do mérito individual conflitava com o direito e as condições de acesso proporcionadas pelo Programa.

No caso dos cursos concomitantes, outra questão levantada pelos docentes era a não identificação dos estudantes com o curso. A Coordenadoria Estadual de Educação, responsável pela demanda dos cursos, realizava sorteio das vagas entre os estudantes interessados. Ocorria que muitas vezes o interesse dos estudantes era maior por alguns cursos, e aqueles não 
contemplados com vagas na sua primeira opção de curso eram inseridos em outros, conforme o sorteio:

Quando eles vinham pelo sorteio, muitos diziam, assim: "Não, isso aí eu fiz uma vez, inscrição lá na $10^{\mathrm{a}}$ Coordenadoria de Educação, e agora me sortearam. Mas, assim, professor, eu me inscrevi para Informática na $3^{\text {a }}$, ou $4^{\text {a }}$ opção; e aí fui sorteado para Informática, eu queria fazer Administração, eu queria fazer Comércio Exterior" (Entrevista Prof. 03, Escola B SNA).

A falta de motivação pelo curso, somada às dificuldades de frequentar duas escolas no mesmo dia, assim como se observou no IFFar, levaram muitos estudantes a abandonar o curso técnico, conforme relatam os professores:

E eles estudavam numa escola normal, também; enfim, achavam muito complicado conciliar as duas coisas, ter que vim no Curso Técnico, de manhã; e, à tarde, ir para a escola; ou vim no Curso, à tarde; e manhã, ir para a escola (Entrevista Prof. 03, Escola B SNA).

Os Técnicos, eles começavam muito bem, e, de repente, começava a esvaziar, aí tu: "O quê que houve?” - “Ah, porque eu vou mudar de endereço". "Ah, porque estou muito cansado, eu chego muito cansado, eu vou priorizar o Ensino Médio". Isso, eu te digo, porque eu telefonava para todo mundo, para todo mundo. Então, tinha uma evasão bem efetiva (Entrevista Prof. 04, Escola B SNA).

Durante o período de desenvolvimento dos cursos pelo Pronatec, a escola passou por uma reforma, que visava melhorar as condições da infraestrutura e também ampliar o número de salas de aula e laboratórios. Um dos professores relata que as condições da escola eram bem precárias antes da reforma: "era bem diferente aqui a escola, era bem caindo aos pedaços, antes da reforma; as portas, as chaves não funcionavam direito, você podia empurrar um pouquinho forte, que ela abria; o prédio era amarelo, então, refletia o sol, parecia que estava mais calor ainda" (Entrevista Prof. 01, Escola B SNA). A reforma, que durou dois anos, 2012 a 2014, ocorreu paralelamente às aulas - apenas durante uma semana as aulas pararam, quando o piso dos corredores foi substituído - o que trouxe alguns transtornos aos professores e estudantes:

E assim, nossa, ficou muito ruim, porque tu estavas dando aula, e tu estava vendo a mesa encher de pó; estava limpa, mas quando chegava no intervalo, tu não enxergavas mais a mesa de tanto pó. (...) e os alunos, nós temos os indicadores deles, de avaliação, toda semana tinha reclamação de limpeza, reclamação que não conseguia prestar atenção na aula (...), principalmente os cursos pagos (Entrevista Prof. 01, Escola B SNA).

Nesse sentido, se observa que o aporte de recursos pelo Pronatec proporcionou a melhoria das condições de infraestrutura da escola, que se reverteu em benefício para o desenvolvimento dos cursos do Programa apenas no último ano de oferta. Talvez, se a escola estivesse desenvolvendo apenas cursos de mercado, a reforma não teria sido conduzida da 
mesma forma, visto que estes estudantes eram os que mais reclamavam, rebaixando os indicadores de satisfação do cliente, nas avaliações.

\subsection{1 Índice de conclusão de cursos na Escola B do SNA}

Esta unidade de ensino apresentou os melhores índices de conclusão de cursos técnicos, porém ainda não atinge a metade dos estudantes matriculados: 45,98\%. Os cursos FICs apresentaram bons índices de conclusão, chegando a 67,50\%.

Não foi possível obter os dados de conclusão nos cursos técnicos concomitantes na modalidade EAD (190 matrículas) e em três turmas de cursos FIC (50 matrículas) e 20 matrículas em cursos técnicos presenciais, os quais se encontravam com matrícula "em curso" no relatório do SISTEC Nacional, obtido via e-Sic, e a instituição não disponibilizou estes dados, apesar de várias solicitações. No entanto, a Pedagoga da Escola, em entrevista, informou que "o EAD não foi uma experiência muito legal no Pronatec", pois a evasão nos cursos em andamento era muito grande: "numa turma de 90 alunos [do curso técnico em Logística] a gente tem 2 ou 3, vindo ainda. Segurança do Trabalho eram 60, se a gente tiver uns 05 ou 06, também é muito. E o Técnico em Informática, que eram 40, porque é 20 e 20, por causa do laboratório. Também, deve ter uns 02 ou 03 alunos" (Entrevista Pedagoga, Escola B SNA). Embora estivessem todos os dias à disposição desses estudantes, muito poucos vinham tirar dúvidas ou solicitar ajuda no uso do ambiente virtual - cabe lembrar que na modalidade de ensino a distância não está prevista a assistência estudantil, como se viu no capítulo II. Entre os motivos para o abandono, segundo a Pedagoga, estava o nível de dificuldade dos cursos.

Entre os cursos técnicos concomitantes, apesar do desinteresse apontado pelos professores, observou-se um maior percentual geral de conclusão $(48,57 \%)$, em relação aos subsequentes. Na Tabela 56, pode-se visualizar o percentual de concluintes em cada curso, assim como no total e em cada tipo de curso e modalidade. Conforme já apontado em relação ao "status de matrícula", no item 4.2.1 deste Capítulo, apesar de constarem várias formas de registro, na prática, os estudantes que receberão diploma, no caso de curso técnico, ou certificação, no caso de curso FIC, no âmbito do Programa são apenas aqueles com status de matrícula "concluída". 


\begin{tabular}{|c|c|c|c|c|c|c|c|c|}
\hline Nome do Curso & 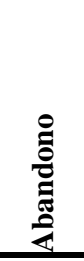 & 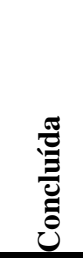 & 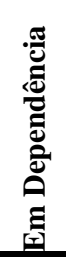 & 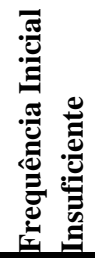 & 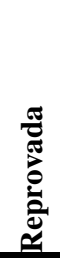 & 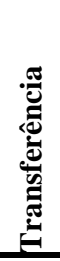 & 跑 & 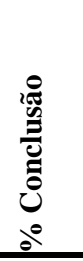 \\
\hline Agente de Informações Turísticas & 15 & 5 & & 0 & 0 & 0 & 20 & 25,00 \\
\hline Agente de Recepção e Reservas em Meios de Hospedagem & 33 & 61 & & 14 & 0 & 0 & 108 & 56,48 \\
\hline Assistente Administrativo & 46 & 132 & & 6 & 0 & 0 & 184 & 71,74 \\
\hline Assistente de Crédito e Cobrança & 4 & 46 & & 0 & 0 & 0 & 50 & 92,00 \\
\hline Assistente de Despachante Aduaneiro & 4 & 22 & & 1 & 0 & 0 & 27 & 81,48 \\
\hline Assistente de Recursos Humanos & 26 & 82 & & 1 & 0 & 0 & 109 & 75,23 \\
\hline Assistente de Serviços em Comércio Exterior & 5 & 15 & & 0 & 0 & 0 & 20 & 75,00 \\
\hline Assistente Financeiro & 11 & 76 & & 6 & 1 & 0 & 94 & 80,85 \\
\hline Auxiliar Administrativo & 14 & 75 & & 0 & 11 & 0 & 100 & 75,00 \\
\hline Auxiliar de Cozinha & 0 & 36 & & 2 & 0 & 0 & 38 & 94,74 \\
\hline Balconista de Farmácia & 33 & 103 & & 15 & 1 & 0 & 152 & 67,76 \\
\hline Camareira em Meios de Hospedagem & 13 & 35 & & 4 & 0 & 0 & 52 & 67,31 \\
\hline Cuidador de Idoso & 51 & 188 & & 9 & 17 & 0 & 265 & 70,94 \\
\hline Cuidador Infantil & 13 & 65 & & 3 & 0 & 0 & 81 & 80,25 \\
\hline Desenhista de Produtos Gráficos Web & 22 & 31 & & 8 & 2 & 0 & 63 & 49,21 \\
\hline Espanhol Aplicado a Serviços Turísticos & 15 & 19 & & 0 & 0 & 0 & 34 & 55,88 \\
\hline Espanhol Básico & 15 & 35 & & 0 & 4 & 0 & 54 & 64,81 \\
\hline Francês Básico & 8 & 19 & & 1 & 0 & 0 & 28 & 67,86 \\
\hline Frentista & 2 & 25 & & 4 & 0 & 0 & 31 & 80,65 \\
\hline Garçom & 14 & 37 & & 15 & 0 & 0 & 66 & 56,06 \\
\hline Higienista de Serviços de Saúde & 12 & 38 & & 3 & 0 & 0 & 53 & 71,70 \\
\hline Inglês Aplicado a Serviços Turísticos & 8 & 32 & & 1 & 0 & 0 & 41 & 78,05 \\
\hline Inglês Básico & 35 & 107 & & 6 & 0 & 0 & 148 & 72,30 \\
\hline Instalador e Reparador de Redes de Computadores & 10 & 4 & & 0 & 5 & 0 & 19 & 21,05 \\
\hline Modelista de Roupas & 23 & 79 & & 8 & 0 & 0 & 110 & 71,82 \\
\hline Monitor de Recreação & 17 & 42 & & 1 & 0 & 0 & 60 & 70,00 \\
\hline Montador e Reparador de Computadores & 243 & 324 & & 23 & 41 & 1 & 632 & 51,27 \\
\hline Operador de Caixa & 63 & 150 & & 3 & 0 & 0 & 216 & 69,44 \\
\hline Operador de Computador & 116 & 299 & & 33 & 2 & 0 & 450 & 66,44 \\
\hline Operador de Supermercados & 189 & 469 & & 18 & 1 & 0 & 677 & 69,28 \\
\hline Organizador de Eventos & 34 & 98 & & 4 & 0 & 0 & 136 & 72,06 \\
\hline Promotor de Vendas & 18 & 37 & & 1 & 0 & 0 & 56 & 66,07 \\
\hline Recepcionista de Eventos & 15 & 57 & & 1 & 0 & 0 & 73 & 78,08 \\
\hline Recepcionista em Serviços de Saúde & 14 & 41 & & 3 & 0 & 0 & 58 & 70,69 \\
\hline Recreador & 5 & 24 & & 1 & 0 & 0 & 30 & 80,00 \\
\hline Representante Comercial & 6 & 44 & & 1 & 0 & 0 & 51 & 86,27 \\
\hline Vendedor & 91 & 238 & & 10 & 1 & 0 & 340 & 70,00 \\
\hline Total Cursos FIC & 1243 & 3190 & & 206 & 86 & 1 & 4726 & 67,50 \\
\hline Técnico em Administração & 26 & 94 & 0 & 20 & 2 & & 142 & 66,20 \\
\hline Técnico em Comércio Exterior & 32 & 84 & 0 & 21 & 1 & & 138 & 60,87 \\
\hline Técnico em Enfermagem & 63 & 47 & 5 & 0 & 0 & & 115 & 40,87 \\
\hline Técnico em Informática & 87 & 52 & 10 & 32 & 1 & & 182 & 28,57 \\
\hline Técnico em Logística & 64 & 81 & 19 & 0 & 0 & & 164 & 49,39 \\
\hline Técnico em Segurança do Trabalho & 21 & 34 & 11 & 0 & 0 & & 66 & 51,52 \\
\hline Total Técnico Concomitante & 293 & 392 & 45 & 73 & 4 & & 807 & 48,57 \\
\hline Técnico em Enfermagem & 48 & 53 & 3 & 1 & & & 105 & $\overline{50,48}$ \\
\hline Técnico em Informática & 10 & 12 & 7 & 0 & & & 29 & 41,38 \\
\hline Técnico em Logística & 45 & 38 & 16 & 7 & & & 106 & 35,85 \\
\hline Técnico em Segurança do Trabalho & 45 & 60 & 46 & 9 & & & 160 & 37,50 \\
\hline Total Técnico Subsequente & 148 & 163 & 72 & 17 & & & 400 & 40,75 \\
\hline
\end{tabular}




\begin{tabular}{lllllllll}
\hline Total Cursos Técnicos & 441 & 555 & 117 & 90 & 4 & 0 & 1207 & 45,98 \\
\hline Total todos os cursos & 1684 & 3745 & 117 & 296 & 90 & 1 & 5933 & 63,12 \\
\hline \hline
\end{tabular}

Fonte: elaborada pela autora com base no relatório do SISTEC Nacional obtido via e-Sic (2018).

Na análise do índice de conclusão por turno de oferta, observa-se que os turnos da tarde e da noite apresentaram os melhores índices de conclusão nas diferentes formas de oferta. No turno da manhã, que concentrou a maior parte das matrículas $(42,85 \%)$, observam-se os menores índices de conclusão em todos os tipos de curso, conforme ilustrado na Tabela 57.

Tabela 57 - Índice de conclusão dos cursos por turno de oferta - Escola A SNA

\begin{tabular}{llll}
\hline \hline Tipo de Curso & Manhã & Tarde & Noite \\
\hline FIC & $62,2 \%$ & $\underline{72,4 \%}$ & $72,1 \%$ \\
Técnico Concomitante & $35,9 \%$ & $49,4 \%$ & $\underline{53,4 \%}$ \\
Técnico Subsequente & $43,7 \%$ & $\underline{51 \%}$ & $31 \%$ \\
Todos os cursos & $59,6 \%$ & $\underline{66,8 \%}$ & $64,2 \%$ \\
\hline \hline
\end{tabular}

Fonte: elaborada pela autora com base nos dados do SISTEC Nacional obtidos via e-Sic (2018).

Apesar de gestores e alguns professores apontarem nas entrevistas que um grande número de estudantes abandonou os cursos em virtude de ter conseguido emprego, o que explicaria, então, o baixo nível de concluintes nos cursos técnicos subsequentes noturnos? Embora fosse necessário um estudo mais aprofundado sobre os motivos para a evasão, que não foi possível em virtude da ausência de canais de contato com os estudantes e de mecanismos de registro dos motivos para o abandono no âmbito do Programa, pode-se apontar que, diferentemente do IFFar no qual as condições para permanência foram comprometidas pelo atraso no repasse dos recursos, no SNA as condições financeiras para execução da oferta não constituíram condicionantes para a evasão. Assim, os motivos estariam situados mais na relação entre as condições administrativo-pedagógicas e o público atendido. 


\section{CONSIDERAÇões FinAIS}

Esta tese é produto de uma pesquisa que visou compreender o processo de construção do Pronatec e o desenvolvimento da iniciativa Bolsa Formação no âmbito de duas instituições com natureza jurídica e propostas pedagógicas diferenciadas - uma pública, pertencente à Rede Federal de EPCT (Instituto Federal) e outra privada, integrante do Sistema S (Instituição SNA). Optou-se pela realização de estudos de caso em instituições situadas no âmbito do Rio Grande do Sul, que se encontra entre os três estados com maior oferta de matrículas no âmbito do Programa. Tendo em vista que o Pronatec foi proposto como um programa "guarda-chuva" das políticas de educação profissional no país, objetivou-se também identificar e analisar as possíveis implicações do grande volume de matrículas e recursos destinados à iniciativa Bolsa Formação no âmbito das demais ações.

A partir da adoção de um método de investigação que visou compreender o objeto de estudo como parte e produto de uma totalidade social, a análise integrou elementos históricos da formação social e econômica do país na apreensão dos projetos de formação da classe trabalhadora que se expressaram/expressam nas políticas públicas de formação profissional. Parafraseando Caio Prado Jr, quando diz que "todo povo tem na sua evolução, vista à distância, um certo sentido" (2011, p. 15), foi possível também identificar o "sentido" ou os "sentidos" que a educação profissional assumiu, no Brasil, ao longo de sua trajetória. Historicamente, a formação para o trabalho foi uma tarefa protagonizada pelo setor empresarial. A maior intervenção do Estado nessa área, ao longo do século XX, foi na direção de implementar em nível nacional o projeto de formação profissional da burguesia brasileira, ao criar e delegar para a iniciativa privada as instituições que constituem o atual Sistema "S". Esse mesmo projeto orientou a oferta da educação profissional por meio dos sistemas públicos de ensino, ocorrendo de forma dissociada e paralela à educação básica, ou quando associada, como a partir da profissionalização compulsória do ensino de $2^{\circ}$ grau no período ditatorial, representou uma regressão da função de socialização do conhecimento nessa etapa formativa, em virtude da não valorização do conhecimento na formação do trabalhador. Nos anos 1990, a partir da reestruturação produtiva com base no modelo de produção flexível, a política de educação profissional foi direcionada à socialização dos trabalhadores nos valores regressivos do capitalismo neoliberal, que reduz o acesso ao conhecimento técnico e científico na direção do desenvolvimento de competências que conduziriam ao aumento da produtividade por meio da "captura da subjetividade" do trabalhador (ALVES, 2012). É somente com o fortalecimento 
das organizações e movimentos sociais de trabalhadores, no processo de redemocratização do país, que um projeto de formação dirigido às necessidades da classe trabalhadora ganha força e encontra espaço, duas décadas depois, no âmbito do governo do Partido dos Trabalhadores, não sem contradições e disputas. Nesse sentido, o "desvio de rota" na orientação políticopedagógica da educação profissional nos governos do Partido dos trabalhadores, a partir do Pronatec, pode ser compreendido não apenas como produto do atual momento histórico, mas como parte de um processo de longa duração no país, no qual a disputa por projetos de formação da classe trabalhadora situa-se no âmbito das disputas entre capital e trabalho e expressa, portanto, diferentes projetos de sociedade.

A análise do processo de construção e desenvolvimento do Pronatec permitiu explicitar o quadro contraditório de lutas que levaram a mudanças de concepção e propostas no campo da educação profissional, na primeira década dos anos 2000. Os avanços nesse campo, conforme os identificamos - integração entre educação básica e educação profissional, criação dos Institutos Federais de Educação, Ciência e Tecnologia, desenvolvimento de programas voltados à educação de jovens e adultos integrando escolaridade básica e formação profissional - foram forjados em meio a disputas pela hegemonia na política educacional, o que imprimiu a necessidade de atender a demandas das diferentes frações de classe que compunham a base do governo, e, ao mesmo tempo, realizar concessões ao projeto oposto, voltado aos interesses pragmáticos "do mercado", alicerçado nos pressupostos marginalistas da Teoria do Capital Humano, e de cunho majoritariamente privatizante.

Análises produzidas sobre os governos do PT (SINGER, 2012, 2015, 2018; ALVES, 2014; BOITO JR, 2012), evidenciam que a governabilidade se amparava na coalizão entre frações da burguesia e da classe trabalhadora. O fenômeno político do "lulismo" (SINGER, 2012) atuava na arbitragem da correlação de forças entre as classes, conciliando o atendimento das demandas de parcela da classe trabalhadora no âmbito da conservação das condições para a reprodução do capital. Assim, as políticas de inclusão social, de distribuição de renda e de investimentos públicos na economia eram operadas nos limites de um projeto econômico "neodesenvolvimentista" (ALVES, 2014), representando a modernização possível dentro da ordem sistêmica. As políticas e ações desenvolvidas nesse período expressavam, portanto, as contradições dos diferentes interesses em jogo.

Com base na análise da correlação de forças produzida no processo de construção e desenvolvimento do Pronatec Bolsa Formação foi possível apreender um conjunto de elementos que concorreram para a configuração das características e indicadores de cursos e matrículas no âmbito do Programa. Do ponto de vista econômico, a política de desenvolvimento industrial 
adotada pelo governo Dilma, nomeada pela economista Laura Carvalho (2018) como "Agenda Fiesp", que se amparava na "coalização entre os industriais e os trabalhadores" (SINGER, 2018, p. 39), somada ao discurso do "apagão de mão de obra", teria produzido efeitos na correlação de forças no âmbito da construção das políticas de educação profissional, ampliando os espaços de interlocução das instituições do Sistema S no âmbito do governo. O que as levou a conquistar bons termos nas condições para participação como parceiras no desenvolvimento do Pronatec Bolsa Formação, a exemplo da sua inserção no sistema federal de ensino, outorgando-lhes autonomia na abertura de unidades de ensino e na criação de cursos, e na recepção dos recursos por meio de repasse direto em vez de convênio. A concepção pedagógica que informou a oferta de cursos pelo Programa expressou, por sua vez, o predomínio de orientações de ensino e aprendizagem próprias a essas instituições, e a minimização/neutralização do projeto educacional nessa área construído ao longo dos governos do PT.

Considerando o histórico das políticas de educação profissional desenvolvidas no período dos governos Lula, observou-se que, pela primeira vez, as matrículas públicas ultrapassaram as matrículas privadas no âmbito dos cursos técnicos de nível médio. Esse crescimento se apresentava como resultado dos investimentos em instituições e programas de educação profissional das redes federal e estadual de ensino, com a criação dos Institutos Federais, dos Programas Brasil Profissionalizado, Proeja, entre outros. A concepção pedagógica que orienta essas políticas, forjada em meio ao acúmulo de experiências de organizações da classe trabalhadora e proposições teóricas do campo acadêmico, defende a integração entre a educação básica/científica e a educação profissional/técnica como projeto emancipatório de formação dos trabalhadores, e situa a esfera das instituições públicas como espaço privilegiado para essa formação.

Nessa direção, aponta-se que as instituições do Sistema S, historicamente hegemônicas no campo da formação profissional, perderam força na disputa pela direção da formação da classe trabalhadora e, consequentemente, pelo acesso aos recursos públicos destinados a essa modalidade de ensino. Do ponto de vista financeiro, as contribuições compulsórias, a sua principal fonte de receita, tiveram seu uso limitado por meio do Acordo de Gratuidade, o que as impelia a ampliar suas receitas por meio da venda de cursos. Nesse contexto, o Pronatec Bolsa Formação apresentava-se como alternativa, por meio do repasse de recursos pelo governo, visto como um parceiro confiável e rentável, uma vez que durante um bom período esses recursos eram recebidos de forma regular e em valores acima dos praticados no mercado pelas próprias instituições - o que despertou o interesse das demais instituições privadas de ensino, as quais, após muita pressão, passaram a ofertar cursos pelo programa a partir de 2013. 
Do ponto de vista da SETEC, a proposta de uma política de educação profissional nos moldes do Prouni, conforme anunciada pela Presidente Dilma, como estratégia de atendimento rápido à demanda por formação de mão de obra, deveria integrar as diversas iniciativas de qualificação profissional operadas por diferentes esferas do governo, reivindicação antiga de alguns setores. Assim, foram reunidas no âmbito do Pronatec as demandas de formação profissional originárias de diferentes setores sociais e econômicos, indicadas pelos órgãos demandantes ligados aos Ministérios e Secretarias do governo, a serem atendidas pelo conjunto de instituições autorizadas à realização da oferta.

Em que pese o caráter progressista dessa iniciativa e da perspectiva de que, ao trazer as ações de qualificação profissional destinadas aos trabalhadores para a esfera educativa (Ministério da Educação), o conteúdo da formação viesse a congregar tanto as demandas do mercado de trabalho como as necessidades dos trabalhadores enquanto cidadãos, propiciando a elevação da escolaridade, por exemplo, observou-se que a centralidade da disputa pelos recursos frustrou tal expectativa e, ao mesmo tempo, descaracterizou a concepção pedagógica de alguns programas de formação profissional de trabalhadores. De acordo com os dados levantados no Instituto Federal em estudo, pode-se indicar que o Pronatec Campo, que propunha ofertar cursos de educação profissional com vistas a fortalecer a agricultura familiar, de acordo com a Política Nacional de Educação do Campo, foi atropelado por outros projetos de agricultura tornando-se, também, um espaço para a formação de mão de obra para o agronegócio. Programas criados no âmbito da luta dos movimentos sociais pela educação do campo, como o Pronera, tiveram seus orçamentos esvaziados, uma vez que o Pronatec passou a ser o principal - e único - espaço de fomento da formação profissional para trabalhadores, jovens e adultos.

Esse mesmo deslocamento pode ser observado no desenvolvimento do Programa Mulheres Mil ao ter sua oferta inserida no Pronatec Bolsa Formação, como foi visto no Instituto Federal Farroupilha. Já em relação ao Proeja, que também passou a ser ofertado pela iniciativa Bolsa Formação, não foi possível observar, na instituição investigada, os impactos no desenvolvimento pedagógico dos cursos ofertados. No entanto, identificou-se que os seus indicadores de matrículas diminuíram em âmbito nacional após a vigência do Pronatec e que a execução orçamentária destinada a ações pedagógicas e fomento da oferta foi represada pela SETEC em virtude dos esforços da equipe para fazer rodar a iniciativa Bolsa Formação. A inserção da oferta do Proeja por meio dos recursos do Pronatec apresentou leve impacto no crescimento das matrículas, indicando que a oferta de formação profissional integrada à elevação da escolaridade não encontrou terreno fértil no âmbito desse programa. Assim, os 
propósitos e especificidades político-pedagógicas de diferentes Programas de educação profissional se esvaziaram quando inseridos no modus operandi da Bolsa Formação.

Os grandes esforços da SETEC no acompanhamento e execução do Pronatec Bolsa Formação, em virtude das metas audaciosas e do pioneirismo dessa política, do ponto de vista da integração de programas e órgãos do governo federal, parece ter diminuído o ritmo de fortalecimento das demais iniciativas, como o Brasil Profissionalizado e a Expansão da Rede Federal. Embora o número de instituições e matrículas tenha continuado em crescimento, relatórios de órgãos de controle (TCU e CGU) indicam baixos percentuais na execução do orçamento previsto.

A análise do desenvolvimento do Pronatec Bolsa Formação no âmbito das instituições pesquisadas - instituição do Sistema S (SNA) e de um Instituto Federal - possibilitou apreender as especificidades da oferta, do público atendido, do conteúdo da formação e dos índices de conclusão. No âmbito do Instituto Federal Farroupilha, assim como apontam outras pesquisas no âmbito das instituições da rede federal de EPCT, o desenvolvimento do Pronatec Bolsa Formação constituiu uma estrutura administrativo-pedagógica à parte daquela destinada aos cursos regulares, uma vez que a oferta é desenvolvida por meio de equipe constituída por profissionais internos e/ou externos e remunerada por meio de bolsa. No caso dos profissionais internos, deveriam realizar as atividades no âmbito do Programa para além da carga horária regular de trabalho.

A pouca expressividade da oferta do Pronatec Bolsa Formação nas instituições públicas pode ser compreendida, também, como expressão da resistência à concepção veiculada pelo Pronatec Bolsa Formação, como se observou no IFFar, e ainda pelo fato de a força de trabalho de seus servidores já estar em grande medida comprometida com o desenvolvimento de suas ofertas regulares. Embora houvesse a possibilidade de contratação de professores externos, a gestão dos cursos era desenvolvida no âmbito da instituição envolvendo um número muito limitado de servidores, como se observou no Campus e no Centro de Referência do IFFar onde foi realizado o estudo.

Em relação ao público e cursos atendidos, observou-se que o IFFar desenvolveu uma maior diversidade de eixos tecnológicos e atendeu públicos de diferentes idades e condições sociais, incluindo a população do campo e pessoas privadas de liberdade. Grande parte dos cursos foi realizada fora das instalações da instituição, no caso do campus, de forma a melhor atender o público alvo dos cursos. O contato dos estudantes com a instituição permitiu vislumbrar novas possibilidades formativas, possibilitando que alguns continuassem seus estudos em nível técnico ou superior. Nesse sentido, o Pronatec Bolsa Formação cumpriu 
importante papel de aproximação entre instituição e comunidade local e regional, impulsionado pelas condições fornecidas pela assistência estudantil fomentada pelo programa.

A principal dificuldade no desenvolvimento dos cursos, no âmbito do IFFar, foi decorrente do atraso no repasse dos recursos, o que gerou a desistência tanto de estudantes quanto de professores em função do não recebimento regular da bolsa. A forma de contratação e remuneração dos docentes também trazia dificuldades para o desenvolvimento pedagógico dos cursos, uma vez que remuneração se restringia à carga horária da disciplina, não possibilitando as condições para o atendimento das dificuldades individuais dos estudantes, a participação em reuniões pedagógicas e o desenvolvimento da proposta curricular da instituição - como o desenvolvimento de projetos interdisciplinares no âmbito da prática profissional integrada, prevista no currículo dos cursos técnicos. O fato de grande parte dos professores externos desenvolverem outras atividades para além das aulas no Programa e os recorrentes atrasos no pagamento trouxeram constrangimentos à instituição para demandar a presença do professor fora de sua carga horária remunerada, pois corria o risco de perder o profissional, o que acarretaria em mais prejuízos para o andamento do curso.

Já em relação à instituição do Sistema $\mathrm{S}$, o estudo evidenciou que a grande oferta de matrículas foi impulsionada pela ocupação da capacidade ociosa das escolas nos turnos em que a oferta de turmas de mercado não se consolida - o que indica a presença de critérios orientados pela lógica do "negócio". Nessa instituição, ao contrário do IFFar, eram os alunos que iam até a instituição e nos horários disponíveis. No caso do curso Técnico em Enfermagem, ofertado na Escola B do SNA, por exemplo, a oferta de turmas pelo Pronatec ocorria apenas no período diurno, enquanto as turmas de mercado eram ofertadas à noite, período em que havia grande procura. Além de ocupar 100\% da capacidade de suas instalações, a instituição ainda alugava outros espaços de forma a ampliar o número de matrículas, os quais nem sempre apresentavam as mesmas condições de infraestrutura.

Quanto ao uso dos recursos, as normas para sua utilização se diferenciam de acordo com a natureza da instituição. Na instituição do Sistema $\mathrm{S}$, o saldo gerado, após o pagamento da assistência estudantil e das despesas da oferta dos cursos, era utilizado da mesma maneira que outra receita qualquer, enquanto que no Instituto Federal o recurso só poderia ser utilizado nas atividades de custeio da oferta, como material didático, remuneração dos profissionais e assistência estudantil, cabendo devolução, ao governo, do valor excedente. Nesse sentido, os recursos provenientes do Pronatec Bolsa Formação tiveram importante papel na expansão e qualificação da rede física das escolas do SNA, conforme observado e apontado nas entrevistas. Outra diferença em relação aos recursos foi a de haver atraso no repasse à instituição SNA 
apenas no segundo semestre de 2015, enquanto que, no Instituto Federal, os recursos começaram a atrasar ainda em 2014.

O desenvolvimento pedagógico dos cursos do Pronatec, no âmbito do SNA, seguia a mesma lógica dos demais cursos, assim como a constituição de seu corpo docente e as condições para a recuperação da aprendizagem. A concepção pedagógica orientada pela pedagogia das competências não encontrava obstáculo para o seu desenvolvimento no âmbito do Programa, diferentemente do que se observou em relação ao currículo integrado frente às condições de oferta no IFFar. A remuneração docente praticada na instituição, bem abaixo do valor da hora aula estabelecida pelo Programa no âmbito das instituições federais, permitia a contratação de profissionais com carga horária integral, incluindo carga horária para recuperação da aprendizagem dos estudantes.

No entanto, os índices de conclusão dos cursos observados no âmbito das unidades de ensino pesquisadas não apresentam grandes diferenças. Apesar de todas as dificuldades identificadas no âmbito do Instituto Federal, o maior percentual de conclusão dos cursos FIC é observado no Campus do IFFar. Assim, pode-se apontar que a eficiência das instituições do Sistema S na oferta de cursos do Programa não se traduziu nos índices de conclusão, conforme se visualiza na Tabela 58.

Tabela 58 - Percentual de conclusão dos cursos nas unidades de ensino pesquisadas

\begin{tabular}{|l|l|l|l|l|}
\hline Tipo de curso & Campus IFFar & CR IFFar & Escola A SNA & Escola B SNA \\
\hline FIC & $69,4 \%$ & $47,5 \%$ & $45 \%$ & $67,50 \%$ \\
\hline Técnico Concomitante & $32,25 \%$ & $20 \%$ & $36,86 \%$ & $48,57 \%$ \\
\hline Técnico Subsequente & - & 33,33 & $34,58 \%$ & $40,75 \%$ \\
\hline Técnicos geral & $32,25 \%$ & $26,5 \%$ & $35,85 \%$ & $45,98 \%$ \\
\hline Todos os cursos & $67,16 \%$ & $36 \%$ & $43,65 \%$ & $63,12 \%$ \\
\hline
\end{tabular}

Fonte: elaborada pela autora com base nos dados coletados pela pesquisa.

Um dos fatores que concorrem para um melhor aproveitamento no âmbito do IF são os conteúdos da formação. Com vistas no perfil do público atendido nos cursos FIC - baixa escolaridade - a instituição inseriu, em praticamente todos os cursos, os conteúdos de português e matemática. Já na instituição do SNA, predominam os conteúdos voltados ao desenvolvimento de habilidades e competências requeridas pelo mercado de trabalho, como os conhecimentos da psicologia organizacional, em detrimento dos conhecimentos básicos, o que contribuiu para a evasão. Foi o que ocorreu na Escola A, por exemplo, que desenvolveu a maioria dos cursos na área da informática, os quais demandam conhecimentos lógicomatemáticos. Além disso, o reduzido valor destinado à assistência estudantil e as críticas dos 
professores ao interesse demonstrado pelos estudantes nos recursos propiciados pela bolsa, também contribuíram, muito provavelmente, para o abandono dos cursos.

Ainda em relação ao conteúdo da formação, o Programa desenvolveu, em nível nacional, a ação Pronatec Empreendedor, realizada por meio de parceria do SEBRAE com o Ministério da Educação, que se encarregou de disseminar a cultura do empreendedorismo por meio da inserção deste tema como conteúdo obrigatório em alguns cursos de formação profissional, e de formação destinada aos professores. O empreendedorismo expressa o "novo espírito do capitalismo" (BOLTANSKI; CHIAPELLO, 2009, p. 126), lógica permeou a concepção pedagógica do Programa, independente da instituição ofertante. A educação empreendedora visa socializar a força de trabalho nos valores e atitudes requeridas pelas empresas, submetendo a formação profissional unicamente às necessidades do empregador.

No currículo dos cursos do Instituto Federal Farroupilha, observou-se um contraponto a essa formação para o mercado a partir da inserção de conteúdos voltados à análise crítica do mundo do trabalho, à contextualização das relações entre capital e trabalho e dos direitos dos trabalhadores. Já em relação à instituição do Sistema S, o empreendedorismo faz parte da concepção pedagógica e é desenvolvido por meio de diferentes práticas, não havendo conteúdo do ponto de vista do trabalhador. O que confirma a tese de que, na disputa pela hegemonia, a luta democrática no campo da formação profissional encontra espaço mais favorável nas instituições públicas.

Considerando que mais de dois terços das matrículas foram desenvolvidas no âmbito das instituições do Sistema S, pode-se apontar que o Pronatec Bolsa Formação exerceu importante papel na socialização da ideologia do capital entre as classes trabalhadoras. Para além do conhecimento técnico, a produção capitalista se utiliza de estratégias de cooptação da subjetividade do trabalhador com vistas no aumento da produtividade (ALVES, 2012). Assim, o protagonismo, a criatividade, o espírito de dono, a flexibilidade são valores e atitudes importantes no mundo do trabalho, atualmente. Conforme aponta Tanguy, nesse contexto, "a formação aparece, se não a solução, ao menos como instrumento de modernização das empresas, da competitividade da economia, da adaptação ao mercado de trabalho e também de conversão de espíritos" (TANGUY, 2016, p. 197).

Embora não tenha sido possível aprofundar a análise sobre o processo de pactuação dos cursos ofertados pelas instituições pesquisadas - ficando em aberto para pesquisas futuras -, o último relatório da CGU (2018) evidencia a preponderância da lógica econômica do custo/benefício como critério de escolha dos cursos a serem desenvolvidos. Isso poderia explicar o grande número de matrículas no curso de Assistente Administrativo (345.060 em 
todo o país), o qual, por demandar menor custo de execução, representaria maiores margens de lucro. No âmbito dos municípios pesquisados, também é possível identificar o número excessivo de matrículas em alguns cursos, como "Operador de Supermercados" em Uruguaiana, frente à "demanda potencial" do mercado de trabalho, e a ausência de formação em áreas centrais da economia local, como a agricultura e a pecuária.

Esses fatos apontam para a importância de se constituir um espaço destinado à análise das demandas do trabalho e da formação. Embora se reconheça o esforço coletivo no âmbito do governo na elaboração de mapas de demandas que orientassem a oferta em nível nacional, as fragilidades nos mecanismos de interlocução a nível local e os interesses meramente financeiros de parte das instituições ofertantes, acabaram distorcendo os propósitos do Programa, como se observou em relação ao distanciamento entre as demandas e a execução da formação no âmbito do Pronatec Copa, por exemplo. Da mesma forma que os incentivos fiscais destinados às empresas, nesse período, se traduziram mais como forma de compensação das margens de lucro do que como investimento no processo de produção, não tendo produzido os efeitos econômicos esperados pelo governo Dilma (CARVALHO, 2018), a captação dos recursos do Programa pelas instituições privadas parece ter sido orientado muito mais pela lógica de um mercado de formação do que pelo atendimento às necessidades concretas de formação de mão de obra para o país. No geral, predominaram os cursos de curta duração na área de gestão e negócios, que correspondem a postos de trabalho de baixa complexidade e demandam baixo custo de formação - sendo que algumas formações poderiam ser perfeitamente desenvolvidas no próprio ambiente de trabalho. Nesse aspecto, é necessário um estudo mais aprofundado sobre a relação entre a formação ofertada por meio do Pronatec e os postos de trabalho criados nesse período, apresentando-se como parte de um programa mais amplo de pesquisas futuras sobre o Pronatec.

No contexto francês ${ }^{184}$, apesar das ofensivas regressivas da lógica neoliberal, a existência de instituições públicas incumbidas do levantamento de informações sobre o movimento da economia, as mudanças no emprego e no perfil ocupacional permite um melhor direcionamento das políticas na área. O Céreq (Centre d'études et de Recherches sur les Qualifications) constitui-se em um Centro Nacional de estudos e pesquisas que tem como tema

\footnotetext{
${ }^{184}$ Durante o período de doutorado, realizei estágio de pesquisa junto ao Laboratório CERTOP (Centre d'Études et de Recherches Travail, Organisations et Pouvoir), da Université Toulouse Jean-Jaurès, na França, sob a supervisão da Professora Prisca Kergoat. Essa vivência me permitiu o contato com os estudos produzidos pelo Ceréq, que, a partir de uma rede de pesquisadores, analisam criticamente as mudanças no mundo do trabalho, possibilitando às políticas do campo educacional não apenas a reprodução das relações observadas no mercado, mas também o desenvolvimento de formas de resistência à lógica regressiva dos valores que o orientam.
} 
principal de investigação a relação entre formação e emprego, a par de outras temáticas, como a transição entre escola e emprego, a evolução das profissões e das qualificações e certificação e formação ao longo da vida, atuando na produção de pesquisas que podem subsidiar as políticas públicas na área e os agentes econômicos e sociais. Criado em 1970, o Céreq é uma instituição autônoma, ligada ao Ministério de Educação Nacional, Ministério do Trabalho e Emprego e Diálogo Social, que conta com 14 unidades associadas em todo o território francês.

No Brasil, apesar do reconhecimento da importância desse espaço e das tentativas de instituição de Observatórios do Trabalho, por exemplo, o desenvolvimento "de pesquisas e de novas metodologias na construção de indicadores sobre as situações de emprego/desemprego, o movimento das ocupações e os conteúdos das qualificações” (MORAES, 2013, p. 08) continua uma tarefa por fazer. Para além da realização de pesquisas isoladas, é urgente, em um país de dimensões continentais como o Brasil, a consolidação de instituições, com gestão pública, que atuem como "observatórios permanentes de situações de trabalho e da formação" (MORAES, 2013, p. 08), de forma que políticas da natureza do Pronatec não continuem sendo apropriadas e/ou orientadas apenas pelos interesses empresariais.

Com base na interpretação das informações coletadas, pode-se indicar que o Pronatec é resultado de uma intensa disputa política sobre a concepção de formação da classe trabalhadora e pela apropriação dos fundos públicos da educação profissional; um desvio de rota nas políticas de educação profissional construídas a partir das propostas dos movimentos sociais e de coletivos de educadores democráticos ligados à classe trabalhadora, durante a primeira década dos anos 2000, que significou a legitimação do projeto formativo do mercado, de acordo com as premissas da atual fase do capitalismo, no âmbito das políticas públicas da área. É possível afirmar que a nova forma de indução da educação profissional, por meio da oferta de vagas gratuitas em instituições públicas e privadas, a partir do Pronatec Bolsa Formação, é parte das medidas desenvolvidas pelos governos petistas, os quais podem ser caracterizados, com base nas premissas gramscianas, como expressão da "revolução passiva à brasileira": parte "conservação" e parte "inovação". "Um processo de atualização gradual do capitalismo por meio de reformas promovidas diretamente pelo Estado", no qual ocorre a incorporação de “aspirações das classes subalternas” (BIANCHI; BRAGA, 2015). No campo educacional, apesar de incorporar elementos das lutas dos trabalhadores, o protagonismo das instituições privadas e a fragilidade dos mecanismos para identificação das reais demandas formativas conduziu ao desenvolvimento de formas de oferta desintegradas da educação básica, à fragilização das instituições, políticas e ações orientadas pela concepção progressista de 
educação profissional e à recuperação da hegemonia do projeto educacional da burguesia na socialização da classe trabalhadora no novo espírito do capitalismo. 


\section{REFERÊNCIAS}

ADRIÃO, T. Educação e Produtividade: a reforma do ensino paulista e a desobrigação do Estado. São Paulo: Xamã, 2005.

AGÊNCIA BRASIL. Com 726 mil presos, Brasil tem terceira maior população carcerária do mundo. Publicado em 08/12/2017. Disponível em: http://agenciabrasil.ebc.com.br/geral/noticia/2017-12/populacao-carceraria-do-brasil-sobe-de622202-para-726712-pessoas. Acesso em: 20 setembro 2018.

AGÊNCIA BRASIL. Pronatec é a maior reforma da educação profissional já feita no Brasil, diz presidenta. 24/10/2011. Disponível em: http://memoria.ebc.com.br/agenciabrasil/noticia/2011-10-24/pronatec-e-maior-reforma-daeducacao-profissional-ja-feita-no-brasil-diz-presidenta Acesso em: 09 de maio 2016.

ALVES, Giovanni. Trabalho e Neodesenvolvimentismo: choque de capitalismo e nova degradação do trabalho no Brasil. Bauru, SP: Canal 6, 2014. (Projeto Editorial Praxis)

ALVES, Giovanni. Trabalho e Subjetividade: o espírito do toyotismo na era do capitalismo manipulatório. São Paulo: Boitempo, 2011.

ANPED. Moção no 6 - Sobre o PRONATEC (GT 05, 09, 11 e 19). Rio de Janeiro: 2011.

ANTUNES, Ricardo. Os sentidos do Trabalho. São Paulo: Boitempo, 2005.

ARAÚJO, José Prata. Um retrato do Brasil: balanço do governo Lula. São Paulo: Editora Fundação Perseu Abramo, 2006. (Coleção Brasil urgente)

ARELARO, L. Reforma do Ensino Médio: o que querem os golpistas. Revista Retratos da Escola, Brasília, v. 11, n. 20, p. 11-17, jan./jun. 2017.

ARELARO, Lisete R. G. Resistência e Submissão: a reforma educacional na década de 1990. In: KRAWCZYK, N.; CAMPOS, M. M.; HADDAD, S. O Cenário Educacional LatinoAmericano no Limiar do Século XXI: reformas em debate. Campinas, SP: Autores Associados, 2000. (Coleção Educação Contemporânea)

ATLAS SOCIOECONÔMICO RIO GRANDE DO SUL. VAB da Agropecuária - O RS contribui com $12 \%$ do VAB agropecuário ocupando o primeiro lugar entre os estados brasileiros. 2015. Disponível em: https://atlassocioeconomico.rs.gov.br/vab-da-agropecuaria Acesso em: 14 mar. 2018.

AZEVEDO, Luiz A.; SHIROMA, Eneida O.; COAN, Marival. As Políticas Públicas para a Educação Profissional e Tecnológica: sucessivas reformas para atender a quem? Boletim Técnico SENAC: a Reforma da Educação Profissional. Rio de Janeiro, v. 38, nº 2, maio/agosto, 2012.

BARRADAS, Anésia Maria da Silva. "Fábrica PIPMO" - Uma discussão sobre política de treinamento de Mão-de-obra no período 1963-1982. Dissertação de Mestrado. Rio de Janeiro: 
FGV - Instituto de Estudos Avançados em Educação/Depto de Administração de Sistemas Educacionais, 1986.

BATISTA, Eraldo Leme. Trabalho e Educação Profissional das décadas de 1930 e 1940 no Brasil: análise do pensamento e das ações da burguesia industrial a partir do IDORT. Campinas, SP: Editores Associados, 2015.

BIANCHI, Álvaro. O laboratório de Gramsci: Filosofia, História e Política. São Paulo: Alameda, 2008.

BIANCHI, Álvaro; BRAGA, Ruy. Hegemonia e crise: noções básicas para entender a situação brasileira. Blog Junho, São Paulo, 28 de junho de 2015. Disponível em: http://blogjunho.com.br/hegemonia-e-crise-nocoes-basicas-para-entender-a-situacaobrasileira/ Acesso em: 10 abril 2018.

BIANCHI, Álvaro. Revolução passiva e crise de hegemonia no Brasil contemporâneo. Revista Outubro, n. 28, abril de 2017.

BLOG DO PLANALTO. Governo lança Programa Nacional de Acesso ao Ensino Técnico e ao Emprego. Vídeo. 28/04/2011. Disponível em: http://blog.planalto.gov.br/ao-vivogoverno-lanca-programa-nacional-de-acesso-ao-ensino-tecnico-e-ao-emprego/ Acesso em: 07 abr. 2016.

BLOG DO PLANALTO. Pronatec já ultrapassou 5,8 milhões de matrículas. 27 de fevereiro de 2014. Disponível em: http://blog.planalto.gov.br/pronatec-ja-ultrapassou-58-milhoes-dematriculas-veja-os-numeros/ Acesso em: 20 julho 2015.

BOITO JR, Armando. O lulismo é um tipo de bonapartismo? Uma crítica às teses de André Singer. Crítica Marxista, Campinas, n.37, p.171-181, 2013.

BOITO JR. Armando. Governos Lula: a nova burguesia nacional no poder. BOITO Jr, Armando; GALVÃO, Andréia (org.). Política e Classes no Brasil dos anos 2000. São Paulo: Alameda, 2012.

BOITO JR., Armando. Os atores e o enredo da crise política. In: JINKINGS, Ivana; DORIA, Kim; CLETO, Murilo (Orgs.). Por que gritamos golpe? Para entender o impeachment e a crise política no Brasil. São Paulo: Boitempo, 2016.

BOLTANSKI, Luc; CHIAPELLO, Éve. O novo espírito do capitalismo. São Paulo: Editora WMF Martins Fontes, 2009.

BRAGA, Rui. Movimentos sociais na Era Lula: hegemonia às avessas, pequena política ou revolução passiva à brasileira? Blog Filosofia, Cultura, Política e Marxismo. Publicado em 08 de julho de 2010. Disponível em:

http://agarrandooconceito.blogspot.com/2010/07/movimentos-sociais-na-era-lula.html Acesso em: 09 abril 2018.

BRASIL. Decreto 7.566, de 23 de setembro em 1909. Disponível em: http://portal.mec.gov.br/setec/arquivos/pdf3/decreto_7566_1909.pdf. Acesso em: 20 setembro 2018. 
BRASIL. Decreto n. 6.301, de 12 de dezembro de 2007. Institui o Sistema Escola Técnica Aberta do Brasil - e-Tec Brasil. Disponível em:

http://www.planalto.gov.br/ccivil_03/_Ato2007-2010/2007/Decreto/D6301.htm Acesso em: 08 março 2016.

BRASIL. Decreto n. 6.302, de 12 de dezembro de 2007. Institui o Programa Brasil Profissionalizado. Disponível em: http://www.planalto.gov.br/ccivil_03/_Ato20072010/2007/Decreto/D6302.htm. Acesso em: 11 março 2016.

BRASIL. Decreto n. 6.633, de 05 de novembro de 2008. Altera e acresce dispositivos ao Regulamento do Serviço Nacional de Aprendizagem Comercial - SENAC, aprovado pelo Decreto $\mathrm{n}^{\mathrm{O}}$ 61.843, de 5 de dezembro de 1967. Disponível em:

http://www.planalto.gov.br/ccivil_03/_Ato2007-2010/2008/Decreto/D6633.htm. Acesso em: 20 março 2016.

BRASIL. Decreto n. 6.635, de 05 de novembro de 2008. Altera e acresce dispositivos ao Regimento do Serviço Nacional de Aprendizagem Industrial - SENAI, aprovado pelo Decreto no 494, de 10 de janeiro de 1962. Disponível em:

http://www.planalto.gov.br/ccivil_03/_Ato2007-2010/2008/Decreto/D6635.htm. Acesso em: 20 março 2016.

BRASIL. Decreto n. 7.589, de 26 de outubro de 2011. Institui a Rede e-Tec Brasil. Disponível em: http://www.planalto.gov.br/ccivil_03/_Ato20112014/2011/Decreto/D7589.htm Acesso em: 08 março 2016.

BRASIL. Decreto $\mathbf{n}^{\circ} \mathbf{2 . 2 0 8}$, de 17 de abril de 1997. Regulamenta o $\S 2^{\circ}$ do art. 36 e os arts. 39 a 42 da Lei ${ }^{\circ}$ 9.394, de 20 de dezembro de 1996, que estabelece as diretrizes e bases da educação nacional. Diário Oficial da União, Brasília, DF, 18 de abr. 1997.

BRASIL. Decreto $\mathbf{n}^{\mathbf{0}}$ 5.154, de 23 de Julho de 2004. Regulamenta o $\S 2^{\circ}$ do art. 36 e os arts. 39 a 41 da Lei $n^{\circ}$ 9.394, de 20 de dezembro de 1996, que estabelece as diretrizes e bases da educação nacional, e dá outras providências. Diário Oficial da União, 26 jul. 2004.

BRASIL. Decreto no 5.478, de 24 de junho de 2005. Disponível em: http://www.planalto.gov.br/ccivil_03/_ato2004-2006/2005/Decreto/D5478.htm. Acesso em: 20 setembro 2018.

BRASIL. Decreto $\mathbf{n}^{\mathbf{0}} \mathbf{5 . 8 4 0}$, de 13 de julho de 2006. Disponível em: http://www.planalto.gov.br/ccivil_03/_ato2004-2006/2006/decreto/D5840.htm. Acesso em: 20 setembro 2018.

BRASIL. Lei 12.816, de 05 de junho de 2013. Altera as Leis $\mathrm{n}^{\text {os }} 12.513$, de 26 de outubro de 2011, para ampliar o rol de beneficiários e ofertantes da Bolsa Formação Estudante, no âmbito PRONATEC e dá outras providências. Disponível em: http://www.planalto.gov.br/ccivil_03/_Ato2011-2014/2013/Lei/L12816.htm. Acesso em: 20 setembro 2018. 
BRASIL. Lei 13.415, de 15 de fevereiro de 2017. Disponível em: http://www.planalto.gov.br/ccivil_03/_Ato2015-2018/2017/Lei/L13415.htm. Acesso em: 20 setembro 2018.

BRASIL. Lei n. 11.195, de 18 de novembro de 2005. Dá nova redação ao § 5o do art. 3o da Lei no 8.948, de 8 de dezembro de 1994. Disponível em:

http://www.planalto.gov.br/ccivil_03/_Ato2004-2006/2005/Lei/L11195.htm. Acesso em: 23 jan 2017.

BRASIL. Lei n. 13.005, de 25 de junho de 2014. Aprova o Plano Nacional de Educação - PNE e dá outras providências.

BRASIL. Lei n⿳ 11.892, de 29 de dezembro de 2008. Institui a Rede Federal de Educação Profissional, Científica e Tecnológica, cria os Institutos Federais de Educação, Ciência e Tecnologia, e dá outras providências. Disponível em:

http://www.planalto.gov.br/ccivil_03/_ato2007-2010/2008/lei/111892.htm. Acesso em: 20 setembro 2018.

BRASIL. Lei $\mathbf{n}^{\mathbf{0}}$ 12.513, de 26 de outubro de 2011. Institui o Programa Nacional de Acesso ao Ensino Técnico e Emprego (Pronatec). Diário Oficial da União, Brasília, DF, 27 de out. 2011.

BRASIL. Lei no 10.260, de 12 de julho de 2001. Dispõe sobre o Fundo de Financiamento ao estudante do Ensino Superior e dá outras providências. Disponível em:

http://www.planalto.gov.br/ccivil_03/leis/LEIS_2001/L10260.htm. Acesso em: 20 setembro 2018.

BRASIL. Pronatec Brasil Sem Miséria Mulheres Mil. Brasília, MEC/MDS, 2014 (Cartilha). BRASIL. Pronatec Campo. Brasília, MEC/MDA, s/d. (Cartilha).

CARVALHO, Laura. Valsa Brasileira: do boom ao caos econômico. São Paulo: Todavia, 2018.

CARVALHO, Marcelo Augusto Monteiro de. Nilo Peçanha e o sistema federal de Escolas de Aprendizes Artífices (1909 a 1930). Tese (Doutorado em História Econômica) Faculdade de Filosofia, Letras e Ciências Humanas, Universidade de São Paulo. 304 f. São Paulo, 2017. CASTIONI, Remi. Planos, Projetos e Programas de educação profissional: agora é a vez do Pronatec. Sociais e Humanas, Santa Maria, v. 26, n. 01, jan/abr 2013.

CASTRO, Claudio de M. Desenvolvimento econômico, educação e educabilidade. $2^{\mathrm{a}}$ ed. Rio de Janeiro: Tempo Brasileiro, 1976.

CGU (Controladoria Geral da União). Relatório de Auditoria Anual de Contas da Secretaria de Educação Profissional e Tecnológica. Brasília, DF: 2013.

CGU (Controladoria Geral da União). Relatório de avaliação da execução de programa de governo no 79 - apoio à formação profissional, científica e tecnológica. Brasília, DF: 2018.

CIAVATTA, Maria. O ensino integrado, a politecnia e a educação omnilateral. Por que lutamos? Trabalho \& Educação, Belo Horizonte, v.23, n.1, p. 187-205, jan-abr, 2014. 
CIAVATTA, Maria; RAMOS, Marise. A "era das diretrizes": a disputa pelo projeto de educação dos mais pobres. Revista Brasileira de Educação, v. 17 n. 49 jan.-abr. 2012. CNE, Concelho Nacional de Educação. Resolução n⿳0 6, de 20, de setembro de 2012. Define Diretrizes Curriculares Nacionais para a Educação Profissional Técnica de Nível Médio. Disponível em: http://portal.mec.gov.br/. Acesso em: 20 setembro 2018.

CNI, Confederação Nacional da Indústria. BNDES empresta R\$ 1,5 bilhão para SENAI ampliar formação profissional e serviços de inovação. Notícias, 01 de março de 2012. Disponível em: http://www.portaldaindustria.com.br Acesso em: 18 outubro 2017.

CNI, Confederação Nacional da Indústria. Pronatec atenuará falta de trabalhador qualificado, avalia CNI. 29/04/2011. Disponível em: www.senaimt.com.br/site/mostra.php?noticia=5971 Acesso em: 21 mar. 2016.

CNTE, Confederação Nacional dos Trabalhadores em Educação. Os riscos do Pronatec para a educação técnica profissional. Revista Retratos da Escola, Brasília, v. 5, n. 8, p. 179-184, jan./jun. 2011.

CONTAG. Confederação Nacional dos Trabalhadores na Agricultura. Posicionamento Político da CONTAG contra a participação do SENAR enquanto entidade participante da execução das ações do PRONACAMPO para os trabalhadores rurais. Brasília: [s.n], 2012.

CORREIO BRASILIENSE. O Senac paga $\mathbf{R} \$ 28,26$, mas eu soube que o valor pago pelo MEC é de R\$ 50 para todas as instituições. Publicado em 08/04/2014. Disponível em: https://www.correiobraziliense.com.br/app/noticia/euestudante/professor/2014/04/08/professor_interna,422076/instrutores-do-senac-querem-serenquadrados-como-professores.shtml. Acesso em: 20 setembro 2018.

COSTA, Fernanda Cosme da. O Programa Nacional de Acesso ao Ensino Técnico e Emprego (Pronatec) e a educação escolar da classe trabalhadora. $141 \mathrm{f}$. Dissertação (Mestrado em Educação Profissional em Saúde), Programa de Pós-Graduação em Educação Profissional em Saúde, Escola Politécnica São Joaquim Venâncio, Rio de Janeiro, 2015.

COUTINHO, Carlos Nelson. A Época Neoliberal: revolução passiva ou contra-reforma? Novos Rumos, v. 49, n. 01, p. 117-126, Jan.-Jun., 2012.

CUNHA, Luiz Antônio. O ensino de ofícios nos primórdios da industrialização. $2^{\text {a }}$ Edição. São Paulo: Editora UNESP; Brasília, DF: FLACSO, 2005.

DAGNINO, E. Construção democrática, neoliberalismo e participação: os dilemas da confluência perversa. Revista Política \& Sociedade, Florianópolis, v. 1, n. 5, p. 137-161, 2004.

DALE, Roger. A promoção do mercado educacional e a polarização da educação. Educação, Sociedade \& Culturas, $n^{\circ}$ 2, 295d. 109-139, 1994.

DEDECA, Claudio Salvadori. Emprego e qualificação no Brasil dos 90. In: OLIVEIRA, Marco A. Reforma do Estado e políticas de emprego no Brasil. Campinas: Unicamp, Instituto de Economia, 1998. 
DUBAR, Claude. A sociologia do trabalho frente à qualificação e à competência. In: Educação e sociedade. Campinas, v.19, n.64, sept.,1999.

EDUCAÇÃO e SOCIEDADE. Editorial. Educ. Soc., Campinas, v. 34, n. 123, p. 335-342, abr.-jun. 2013.

EPSJV, Escola Politécnica São Joaquim Venâncio. Pronatec é aprovado sem modificações no Senado. Outubro de 2011. Disponível em: http://www.epsjv.fiocruz.br/printpdf/5005 Acesso em: 21 mar. 2016.

FASOLO, Camila Porto; CASTIONI, Remi. Educação profissional no PNE 2014-2024: contexto de aprovação e monitoramento da meta 11. Linhas Críticas, Brasília, DF, v.22, n.49, p. 577-597, 2017.

FEE, Fundação de Economia e Estatística. Perfil Socioeconômico: Corede Fronteira Oeste. Porto Alegre, 2015. Disponível em: https://www.fee.rs.gov.br/perfilsocioeconomico/coredes/detalhe/?corede=Fronteira+Oeste Acesso em: 14 de ago. 2017. FEE, Fundação de Economia e Estatística. PIB dos municípios do RS em 2015. Publicado em 14/12/2017. Disponível em: https://www.fee.rs.gov.br/indicadores/pib-rs/municipal/destaques/ Acesso em: 14 de ago. 2017a.

FEE, Fundação de Economia e Estatística. PIB Municipal - Série Histórica. Publicado em 14/12/2017. Disponível em: https://www.fee.rs.gov.br/indicadores/pib-rs/municipal/seriehistorica/ Acesso em: 14 de ago. 2017b.

FIESP. Federação das Indústrias do Estado de São Paulo. Produtividade do trabalho na Indústria de Transformação: Maio de 2012. Disponível

em: http://az545403.vo.msecnd.net/uploads/2012/07/Produtividade_Apresenta\%C3\%A7\%C3 \%A3o_16_07_20121.pdf Acesso em: 10 mai. 2016.

FILGUEIRAS, Luiz. O neoliberalismo no Brasil: estrutura, dinâmica e ajuste do modelo econômico. In: BASUALDO, E. M.; ARCEO, E. Neoliberalismo y sectores dominantes: tendencias globales y experiências nacionais: Buenos Aires: CLACSO Libros, 2006.

FNDE, Fundo Nacional de Desenvolvimento da Educação. Resolução/CD/FNDE no 2, de 6 de março de 2014. Disponível em: https://www.fnde.gov.br/fndelegis Acesso em: 01 junho 2016.

FNDE, Fundo Nacional de Desenvolvimento da Educação. Resolução/CD/FNDE no 3, de 6 de março de 2014. Disponível em: https://www.fnde.gov.br/fndelegis Acesso em: 01 junho 2016.

FNDE, Fundo Nacional de Desenvolvimento da Educação. Resolução/CD/FNDE $\mathbf{n}^{\mathbf{0}}$ 62, de 11 de novembro de 2011. Disponível em: https://www.fnde.gov.br/fndelegis Acesso em: 01 junho 2016.

FONEC, Fórum Nacional de Educação do Campo. Manifesto à Sociedade Brasileira. Brasília, 2012a. 
FONEC, Fórum Nacional de Educação do Campo. Notas para análise do momento atual da educação do campo. In: SEMINÁRIO NACIONAL, 2012, Brasília. Anais... Brasília, 2012b.

FONEC, Fórum Nacional de Educação do Campo. Relatório Síntese das Conclusões e Proposições. Oficina de Planejamento. Brasília, 13 a 14 de junho de 2013.

FORUM EJA/ES, Fórum de Educação de Jovens e Adultos do Espírito Santo. Manifesto do Fórum de Educação de Jovens e Adultos do Espírito Santo em defesa do Proeja. 2013. Disponível em: http://xa.yimg.com/kq/groups/25553747/428558451/name/Manifesto+F\% C3\%B3rum+EJA+em+defesa+do+Proeja.pdf Acesso em: 19 mar. 2016.

FRANZOI, Naira Lisboa. et al. Ensino médio e educação profissional - Tensões e possibilidades: o que há de atual nas políticas de educação profissional? Anais VI Escola de Inverno - Educação e Políticas Públicas: Encontros e Desencontros, FACED/UFRGS, 2008.

FRANZOI, Naira Lisboa; SILVA, Carla Odete B, COSTA, Rita de Cássia Dias. PROEJA e PRONATEC: ciclo de políticas, políticas recicladas. Políticas Educativas, Porto Alegre, v. 6, n.2, p. 84-100, 2013.

FREITAS, Luiz Carlos de. Três Teses Sobre as Reformas Empresariais da Educação: perdendo a ingenuidade. Cad. Cedes, Campinas, v. 36, n. 99, p. 137-153, maio-ago. 2016.

FRIGOTTO, Gaudêncio. A produtividade da escola improdutiva: um (re)exame das relações entre educação e estrutura econômico-social capitalista. $9^{a}$ ed. São Paulo: Cortez, 2010.

FRIGOTTO, Gaudêncio. A Relação da Educação Profissional e Tecnológica com a universalização da Educação Básica. Revista Educação e Sociedade, Campinas, vol. 28, n. 100 - Especial, p. 1129-1152, out. 2007.

FRIGOTTO, Gaudêncio. Ensino Médio e técnico profissional: disputa de concepções e precariedade. Le Monde Diplomatique Brasil, edição 68, Mar. 2013. Disponível em: https://www.diplomatique.org.br/artigo.php?id=1384 Acesso em: março de 2014.

FRIGOTTO, Gaudêncio. Entrevista. In: CIAVATTA, Maria (org.). Gaudêncio Frigotto um intelectual crítico nos pequenos e grandes embates. Belo Horizonte: Autêntica, 2012. (Coleção Perfis da Educação)

FRIGOTTO, Gaudêncio. Fundamentos Científicos e Técnicos da Relação Trabalho e Educação no Brasil de Hoje. In: LIMA, J. C. F.; NEVES, L. M. W. Fundamentos da Educação Escolar no Brasil Contemporâneo. Rio de Janeiro: Editora Fiocruz/EPSJV, 2006.

FRIGOTTO, Gaudêncio; CIAVATTA, Maria; RAMOS, Marise. A Gênese do Decreto 5.154/2004: um debate no contexto controverso da democracia restrita. In: FRIGOTTO, G; CIAVATTA, M; RAMOS, M. Ensino médio integrado: concepções e contradições. São Paulo: Cortez, 2005.

GRABOWSKI, Gabriel. Financiamento da Educação Profissional no Brasil: contradições e desafios. Tese (Doutorado em Educação) Programa de Pós-Graduação em Educação da Universidade Federal do Rio Grande do Sul, UFRGS, 2010. 
GRAMSCI, A. Cadernos do Cárcere. V. 2. Os intelectuais. O princípio educativo. Jornalismo. $7^{\text {a }}$ ed. Rio de Janeiro: Civilização Brasileira, 2014.

GRAMSCI, Antonio. Cadernos do Cárcere. V. 3. Maquiavel e Notas Sobre o Estado e a Política. $3^{\mathrm{a}}$ ed. Rio de Janeiro: Civilização Brasileira, 2007.

GUIMARÃES, Ailton Vitor. Editorial. Revista Trabalho \& Educação, Belo Horizonte, v.26, n.1, p. 9-13, jan-abr, 2017.

GUIOT, A. P. Um "moderno Príncipe" para a burguesia brasileira: o PSDB (1988-2002). 202f. Dissertação (Mestrado em Educação), Programa de Pós-Graduação em Educação da Universidade Federal Fluminense, Rio de Janeiro, 2006.

HARVEY, David. Condição Pós-Moderna: uma pesquisa sobre as origens da mudança cultura. 17a 298d. São Paulo: Edições Loyola, 2008.

HIRATA, Helena. Apresentação. In: MORAES, C.S.V. e FERRETTI, C. (coord.). Diagnóstico da formação profissional. Ramo metalúrgico. São Paulo, CNM-CUT/Rede Unitrabalho, 1999. HOBSBAWM, Eric J. A Era dos Extremos: o breve século XX 1914-1991. $2^{a}$ edição, 39ª reedição. São Paulo: Cia. Das Letras, 1995.

IBGE, Instituto Brasileiro de Geografia e Estatística. Censo Agropecuário, 2006. Disponível em: https://sidra.ibge.gov.br Acesso em: abril 2017.

IBGE, Instituto Brasileiro de Geografia e Estatística. Censo Demográfico, 2010. Disponível em: https://cidades.ibge.gov.br/ Acesso em: março 2017.

IBGE, Instituto Brasileiro de Geografia e Estatística. Produto Interno Bruto dos Municípios, 2013. Disponível em: https://cidades.ibge.gov.br/ Acesso em: maio 2018.

IF FARROUPILHA. Plano de Desenvolvimento Institucional (PDI) 2014-2018. Disponível em: http://w2.iffarroupilha.edu.br/site/midias/arquivos/20148309056884pdi_14_18pdf.pdf Acesso em: 14 maio 2016.

IF FARROUPILHA. Resolução CONSUP IFFar n. 71, de 14 de dezembro de 2016. Disponível em: https://www.iffarroupilha.edu.br/documentos-ead/item/3806resolu\%C3\%A7\%C3\%B5es. Acesso em: 20 setembro 2018.

IF FARROUPILHA. Resolução CONSUP n. 102, de 12 de Dezembro de 2012.

INCRA, Instituto Nacional de Colonização e Reforma Agrária. Informações gerais sobre os assentamentos da Reforma Agrária. Data de atualização: 31/12/2017. Disponível em: http://painel.incra.gov.br/sistemas/index.php Acesso em: 10 março 2018.

INEP, Instituto Nacional de Estudos e Pesquisas Educacionais Anísio Teixeira. Censo Escolar. Disponível em: http://inep.gov.br/censo-escolar Acesso em: março. 2018.

IPEA, Instituto de Pesquisa Econômica Aplicada. A Década Inclusiva (2001-2011): Desigualdade, Pobreza e Políticas de Renda. Comunicados do Ipea, nº 155, Brasília, Setembro, 2012. 
IPEA, Instituto de Pesquisa Econômica Aplicada. Sistema "S" - Com mais de 60 anos, é hora de reformar. Por Edla Lula. Desafios do Desenvolvimento. Ano 5, Edição 44 - 08/06/2008.

IPEA, Instituto de Pesquisa Econômica Aplicada. Um retrato de duas décadas do mercado de trabalho brasileiro utilizando o Pnad. Comunicados do Ipea, nº 160, Brasília, Outubro, 2013.

KERGOAT, Prisca. Les formations par apprentissage dans les grandes entreprises. Sarrebruck: Editions Universitaires Européennes, 2010.

KONDER, L. A questão da ideologia. São Paulo: Companhia das Letras, 2001.

KOSIK, Karel. Dialética do concreto. Rio de Janeiro: Paz e Terra, 1969.

KUENZER, Acácia. A Educação Profissional nos anos 2000: a dimensão subordinada das políticas de inclusão. Revista Educação e Sociedade, Campinas, vol. 27 n.96, p. 877-910, out. 2006.

KUHN, Ednizia Ribeiro Araujo. Análise da Política de Educação do Campo no Brasil: meandros do Pronera e do Pronacampo. Tese (Doutorado) Programa de Pós-Graduação em Geografia, Universidade Federal da Bahia. Bahia, 2015.

LAVAL, Christian. A escola não é uma empresa: o neoliberalismo em ataque ao ensino público. Trad. Maria Luiza M. de Carvalho e Silva. Londrina: Editora Plana, 2004.

LAVINAS, Lena; CORDILHA, Ana Carolina; CRUZ, Gabriela Freitas da. Assimetrias de gênero no mercado de trabalho no Brasil: rumos da formalização. In: ABREU, Alice Rangel de Paiva; HIRATA, Helena; LOMBARDI, Maria Rosa. Gênero e Trabalho no Brasil e na França: perspectivas interseccionais. São Paulo, Boitempo: 2016.

LIMA FILHO, Domingos Leite. Expansão da educação superior e da educação profissional no Brasil: tensões e perspectivas. Revista Educação em Questão Natal, v. 51, n. 37, p. 195223, jan./abr. 2015.

LIMA, Antonio Almerico Biondi. As mutações do campo qualificação: trabalho, educação e sujeitos coletivos no Brasil contemporâneo. Tese (Doutorado em Educação), Programa de PósGraduação em Educação da Universidade Federal da Bahia (UFBA). 375 f. Salvador, 2006.

LIMA, Jacob Carlos. Participação, empreendedorismo e autogestão: uma nova cultura do trabalho? In: Sociologias. Porto Alegre, ano 12, nº 25, set./dez., 2010.

LIMA, Marcelo. Perspectivas e riscos da educação profissional do governo Dilma: educação profissional local e antecipação ao Programa Nacional de Acesso à Escola Técnica (Pronatec). In: 34 ${ }^{\text {a }}$ Reunião Nacional da Anped. Anais Educação e Justiça Social. Natal, 2011. v. 1. p. 116.

LIMA, Marcelo. A educação profissional no governo Dilma: Pronatec, PNE e DCNEMs. Revista Brasileira de Política e Administração da Educação, v. 28, n. 2, p. 495-513, mai/ago. 2012. 
LIMA, Marcelo; PACHECO, Zilka Sulamita Teixeira de Aguilar; FERREIRA, Ana Paula Ribeiro; MACIEL, Samanta Lopes. O Público e o Privado na Educação Profissional: um estudo sobre a execução do Pronatec na Rede Federal e no SENAI. RBPAE, v. 32, n. 3, p. 871 - 885 set./dez. 2016.

LIMA, Marcelo. Trabalho e educação no Brasil: da formação do mercado ao mercado da formação. Curitiba: CRV, 2016.

MACHADO, Lucília Regina de Souza. Organização da Educação Profissional e Tecnológica por Eixos Tecnológicos. Linhas Críticas, Brasília, DF, v. 16, n. 30, p. 89-108, jan./jun. 2010. MACHADO, Maria M. GARCIA, Lênin T. Passado e presente na formação de jovens e adultos trabalhadores. Revista Brasileira de Educação de Jovens e Adultos, v. 1, n. 1, 2013.

MALDANER, Jair José. O papel da formação docente na efetividade das políticas públicas de EPT no Brasil - período 2003-2015 - Implicações políticas e pedagógicas na atuação de professores. Tese (Doutorado em Educação) Programa de Pós-Graduação em Educação da Faculdade de Educação da Universidade de Brasília (UnB). 207 f. Brasília, DF: 2016.

MANFREDI, Silvia M. Educação Profissional no Brasil. São Paulo: Cortez, 2002.

Mantega, Guido. O primeiro ano da nova matriz econômica. Valor Econômico, 19 dez. 2012. MARTINS, Clitia Helena Backx; WINK JUNIOR, Marcos Vinício. Pobreza extrema em municípios do Rio Grande do Sul: evidências da multidimensionalidade. Série Textos para Discussão FEE nº 114. Porto Alegre, 2013.

MARTINS, José de Souza. Prefácio à quinta Edição. In: FERNANDES, Florestan. A Revolução Burguesa no Brasil. Ensaio de Interpretação Sociológica. $5^{\text {a }}$ edição. São Paulo: Globo, 2006.

MARX, Karl. O capital: crítica da economia política. Livro Primeiro: o processo de produção do capital, v. 1. $32^{\mathrm{a}}$ ed. Tradução de Reginaldo Sant'Anna. Rio de Janeiro: Civilização Brasileira, 2014.

MAZZEO, Antonio. C. Estado e Burguesia no Brasil: origens da autocracia burguesa. $3^{\text {a }}$ edição. São Paulo: Boitempo, 2015.

MEC, Ministério da Educação. Centenário da Rede Federal de Educação Profissional e Tecnológica. 2009. Disponível em:

http://portal.mec.gov.br/setec/arquivos/centenario/historico_educacao_profissional.pdf Acesso em: 20 abr. 2016.

MEC, Ministério da Educação. O PRONATEC como política estruturante da Educação Profissional Brasileira. 2012. Disponível em: http://docplayer.com.br/17367612-O-pronateccomo-politica-estruturante-da-educacao-profissional-brasileira.html. Acesso em: 20 setembro 2018.

MEC, Ministério da Educação. Portaria MEC n. 1.291, de 30 de dezembro de 2013.

Disponível em: http://portal.mec.gov.br/ Acesso em: 20 março 2016. 
MEC, Ministério da Educação. Portaria MEC no 168, de 07 de março de 2013. Disponível em: http://portal.mec.gov.br/ Acesso em: 20 março 2016.

MEC, Ministério da Educação. Portaria MEC n 899, de 20 de setembro de 2013. Disponível em: http://portal.mec.gov.br/ Acesso em: 20 março 2016.

MEC, Ministério da Educação. Portaria n. 817, de 13 de agosto de 2015. Disponível em: http://pronatec.mec.gov.br/images/stories/pdf/portaria_mec_817_13082015.pdf. Acesso em: 05 abril 2016.

MEC, Ministério da Educação. PRONATEC: um caminho de oportunidades pela Educação Profissional e Tecnológica. Março de 2016. Disponível em:

http://portal.mec.gov.br/index.php?option=com_docman\&view=download\&alias=36561pronatec-2016-apresentacao-pdf\&category_slug=marco-2016-pdf\&Itemid=30192_Acesso em: 04 abril 2016.

MEC, Ministério da Educação. Referenciais Curriculares Nacionais da Educação Profissional de Nível Técnico (RCNEPT). Brasília, 2000.

MEC, Ministério da Educação; SEBRAE, Serviço Brasileiro de Apoio às Micro e Pequenas Empresas. Acordo de Cooperação Técnica, $n^{\circ}$ 50, de 28 de maio de 2013. Disponível em: http://pronatecempreendedor.sebrae.com.br/ Acesso em: 28 maio 2016.

MORAES, C. S. V. Trajetórias de vida, trabalho e educação/formação profissional de trabalhadoras militantes sindicais brasileiras e francesas: uma perspectiva comparada. MORAES, C. S. V. (org.). Educação de trabalhadores por trabalhadores: educação de jovens e adultos e formação profissional. São Paulo: Editora Sociologia e Política, 2013 b.

MORAES, C.S.V. A socialização da força de trabalho: instrução popular e qualificação profissional no Estado de São Paulo (1873-1934). Bragança Paulista, SP: Edusf, 2003.

MORAES, Carmen S. V. Educação de Jovens e Adultos Trabalhadores de Qualidade: Regime de Colaboração e Sistema Nacional de Educação. Educação e Sociedade, Campinas, v. 34, n. 124, jul./set. 2013a.

MORAES, Carmen S. V. Instrução Popular e Ensino Profissional: uma perspectiva histórica. In: VIDA, D. G.; HILSDORF, M. L. S. Tópicas em História da Educação. São Paulo: EDUSP, 2001.

MORAES, Carmen S. V. Trabalho e educação como pauta do GT Trabalho e Educação da ANPED. Algumas considerações sobre o campo de pesquisa. Trabalho Necessário, v. 13, n. $20,2015$.

MORAES, Carmen S. V; NETO, Sebastião L. Educação, Formação Profissional e Certificação de Conhecimentos: considerações sobre uma política pública de certificação profissional. Revista Educação e Sociedade, Campinas, vol. 26, n. 93, p. 1435-1469, Set./Dez. 2005.

MORAES, Carmen Sylvia Vidigal. A relação Educação e Trabalho e seus desafios teóricos. In: XXIX Congreso Alas Chile: Crisis y Emergencias Sociales en América Latina, 2013, Santiago do Chile. Acta Cientifica. Santiago do Chile: FACSO; SocioRed; ALAS, 2013. 
MORAES, Gustavo Henrique. Identidade de Escola Técnica vs. Vontade de Universidade: a formação da identidade dos Institutos Federais. Tese (Doutorado em Educação) Programa de Pós-Graduação em Educação da Faculdade de Educação da Universidade de Brasília (UnB). 388 f. Brasília, DF: 2016.

MOREIRA, Vinicius Silva. Territorialidades Rurais em Júlio de Castilhos - RS: da pecuária extensiva à agricultura familiar. Dissertação (Mestrado em Geografia e Geociências) Programa de Pós-Graduação em Geografia e Geociências, Universidade Federal de Santa Maria. Santa Maria, 2008.

MOTTA, V. C. da; FRIGOTTO, G. Por que a urgência da reforma do ensino médio? Medida Provisória no 746/2016 (Lei n ${ }^{\circ}$ 13.415/2017). Educação e Sociedade, Campinas, v. 38, nº. 139, p.355-372, abr.-jun., 2017.

MOURA, Dante Henrique. Ensino Médio e Educação Profissional no Brasil nos anos 2000: movimentos contraditórios. In: MOURA, Dante Henrique (org.). Produção do Conhecimento, Políticas Públicas e Formação Docentes em Educação Profissional. Campinas, SP: Mercado de Letras, 2013.

MOURA, Dante Henrique. Programa Nacional de Integração da Educação Profissional com a Educação Básica na Modalidade de Educação de Jovens e Adultos ? PROEJA: entre potencialidades e entraves diante de projetos societários em disputa. In: Cristina Azevedo Gomes; Maria Figueiredo; Henrique Ramalho; João Rocha. (Org.). Livro de Atas do XIII Congresso da SPCE. Fronteiras, diálogos e transições na educação. 1ed.Lisboa: SPCE, 2016, v. 1, p. 381-392.

NASCIMENTO, Paulo A. Meyer M. Há escassez generalizada de profissionais de carreiras técnico-científicas no Brasil? Uma análise a partir de dados do CAGED. Boletim Mercado de trabalho: conjuntura e análise, Instituto de Pesquisa Econômica Aplicada, Ministério do Trabalho e Emprego. Ano 16, n. 49. Brasília: Ipea, MTE, 2011.

NAVILLE, Pierre. Essai sur la qualification du travail. Paris : Éditions Syllepse, 2012.

O GLOBO. Contra o apagão de mão de obra. 23/04/2011. Disponível em:

http://www2.senado.leg.br/bdsf/item/id/426263 Acesso em: 09 maio 2016.

OFFE, Claus. Problemas estruturais do Estado capitalista. Rio de Janeiro: Tempo Brasileiro, 1984.

OLIVEIRA, Dalila Andrade. Política Educacional. IN: OLIVEIRA, Dalila Andrade, et al. Dicionário: trabalho, profissão e condição docente. Belo Horizonte: UFMG, Faculdade de Educação, 2010.

OLIVEIRA, Francisco. A hegemonia às avessas. OLIVEIRA, Francisco de; BRAGA, Ruy; RIZEK, Sibele. Hegemonia às avessas. São Paulo: Boitempo, 2010.

OLIVEIRA, Franscisco. Crítica à razão dualista: o ornitorrinco. São Paulo: Boitempo, 2013. 
OLIVEIRA, Ramon de. A (Des)Qualificação da Educação Profissional Brasileira. São Paulo: Cortez, 2003. (Coleção questões da nossa época)

OLIVEIRA, Ramon de. Agências Multilaterais e a educação profissional brasileira. Campinas, SP: Editora Alínea, 2006.

OLIVEIRA, Ramon de. Empregabilidade. In: FUNDAÇÃO OSWALDO CRUZ. ESCOLA POLITÉCNICA DE SAÚDE JOAQUIM VENÂNCIO. Dicionário da Educação

Profissional em Saúde. Rio de Janeiro: FIOCRUZ, 2009.

PACHECO, Eliezer. Fundamentos político-pedagógicos dos institutos federais: diretrizes para uma educação profissional e tecnológica transformadora. Natal: IFRN, 2015.

PALÁCIO DO PLANALTO. Pronunciamento à nação da Presidenta da República, Dilma Rousseff, em cadeia nacional de rádio e TV. Brasília-DF, 10 de fevereiro de 2011. Disponível em: http://www2.planalto.gov.br/acompanhe-o-planalto/discursos/discursos-dapresidenta/pronunciamento-a-nacao-da-presidenta-da-republica-dilma-rousseff-em-cadeianacional-de-radio-e-tv Acesso em: 16 fev. 2016.

PDI, Projeto de Desenvolvimento Institucional do Instituto Federal Farroupilha (2014 2018). Santa Maria, 2014. Disponível em:

http://w2.iffarroupilha.edu.br/site/midias/arquivos/2015324151055989pdi_14_18pdf.pdf Acesso em: 09 junho 2017.

PEREIRA, Luiz. Trabalho e Desenvolvimento no Brasil. São Paulo: Edipe Artes Gráficas, 1965.

PERONI, Vera. M. V. Política educacional e papel do Estado. São Paulo: Xamã, 2003.

PESAVENTO, Sandra J. A Burguesia Gaúcha: dominação do capital e disciplina do trabalho (RS: 1889-1930). Porto Alegre: Mercado Aberto, 1988.

PICCIN, Marcos Botton. A mudança da morfologia social do patronato rural no espaço estancieiro do Rio Grande do Sul. Anais do $37^{\circ}$ Encontro Anual da ANPOCS. Águas de Lindoia, São Paulo, 2013.

PICCIN, Marcos Botton. Os senhores da terra e da guerra no Rio Grande do Sul: um estudo sobre as estratégias de reprodução social do patronato rural estancieiro. Tese (Doutorado em Ciências Sociais) Instituto de Filosofia e Ciências Humanas, Universidade Estadual de Campinas. 458 f. Campinas, 2012.

PICOLOTTO, Everton Lazzaretti. Pluralidade sindical no campo? Agricultores familiares e assalariados rurais em um cenário de disputas. In: $55^{\circ}$ Congresso da Sociedade Brasileira de Economia, Administração e Sociologia e Rural (SOBER), 2017, Santa Maria. Anais do 55 Congresso da Sociedade Brasileira de Economia, Administração e Sociologia e Rural (SOBER). Santa Maria: Sober/UFSM, 2017.

PICOLOTTO, Everton Lazzaretti. Pluralismo, neocorporativismo e o sindicalismo dos agricultores familiares no Brasil. Soc. estado, Brasília, v. 33, n. 1, abr. 2018. Disponível em 
<http://www.scielo.br/scielo.php?script=sci_arttext\&pid=S0102-

69922018000100085\&lng=pt\&nrm=iso> Acesso em: 06 jul. 2018.

PINTO, José Marcelino de Rezende. Uma análise da destinação dos recursos públicos, direta ou indiretamente, ao setor privado de ensino no Brasil. Revista Educação e Sociedade, Campinas, v. 37, nº. 134, p.133-152, jan./mar., 2016.

PRADO JR, Caio. Formação do Brasil Contemporâneo: colônia. São Paulo: Companhia das Letras, 2011.

RAMOS, Leandro da Fonseca. O Pronatec como Política Social de Estado: historicidade e contradição na construção de uma política para Educação Profissional. 118 f. Dissertação (Mestrado em Educação Profissional em Saúde), Programa de Pós-Graduação em Educação Profissional em Saúde, Escola Politécnica São Joaquim Venâncio, Rio de Janeiro, 2014a.

RAMOS, Marise. Educação Profissional: história e legislação. Curitiba: Instituto Federal do Paraná, 2011.

RAMOS, Marise. Pedagogia das Competências. In: PEREIRA, Isabel Brasil; LIMA, Júlio Cesar França. Dicionário da Educação Profissional em Saúde. 2. 304ed. ver. ampl. - Rio de Janeiro: EPSJV, 2008.

RAMOS, Marise. Pedagogia das Competências: autonomia ou adaptação? 4. Edição. São Paulo: Cortez, 2011.

RAMOS, Marise. Trabalho, Educação e Correntes Pedagógicas no Brasil: um estudo a partir da formação dos trabalhadores técnicos em saúde. Rio de Janeiro: EPSJV, UFRJ, 2010.

RAMOS, Moacyr Salles. Limites e Possibilidades do PRONATEC como ação governamental de ampliação da Educação Profissional no Brasil: uma análise a partir da experiência do IFRJ. Dissertação (Mestrado em Educação), Programa de Pós-graduação em Educação, Contextos Contemporâneos e Demandas Populares, UFRRJ, 204f, Nova Iguaçu, 2014b.

REIS, Cinval Filho dos. Educação profissional em debate: da crise financeira mundial de 2008 ao arranjo institucional do Pronatec. Tese (Doutorado em Educação), Programa de PósGraduação em Educação, Universidade Federal de Uberlândia (UFU), 193f, Uberlândia, 2017.

RODRIGUES, Romir de Oliveira. No caminho do curupira: o Programa Nacional de Acesso ao Ensino Técnico e Emprego - Pronatec - e as relações público-privadas. Tese (Doutorado em Educação), Programa de Pós-Graduação em Educação, Universidade Federal do Rio Grande do Sul (UFRGS), 322f, Porto Alegre, 2017.

ROMANELLI, Otaíza Oliveira. História da educação no Brasil. Rio de Janeiro: Vozes, 2006.

RUMMERT, Sônia; GASPAR, Leandro da Silva. Projovem Urbano: proposta ambiciosa e "pequena política" no vácuo de um Sistema Nacional de Educação. Revista Trabalho, Política e Sociedade, Vol. II, nº 03, p. 397-424, jul.-dez., 2017. 
SALDANHA, Leticia de Luca Wollmann. O PRONATEC e a relação Ensino Médio e Educação Profissional. In: IX Seminário de Pesquisa em Educação da Região Sul ANPED SUL, 2012, Caxias do Sul. A Pós-Graduação e suas interlocuções com a Educação Básica, 2012. v. 1. p. 1-13.

SALDANHA, Leticia de Luca Wollmann. O PRONATEC e a proclamada política de democratização da educação profissional técnica de nível médio: acesso, abandono e permanência a partir de um estudo de caso. Tese (Doutorado em Educação), Programa de Pós-Graduação em Educação da Universidade Federal do Paraná (UFPR). 282f. Curitiba, PR, 2016.

SALLUM JR., Brasilio. Metamorfoses do Estado Brasileiro no final do Século XX. Revista Brasileira de Ciências Sociais, v. 18, nº 52, p. 35-53, 2003.

SAMPAIO JR., Plínio de Arruda. Desenvolvimentismo e neodesenvolvimentismo: tragédia e farsa. Serviço Social \& Sociedade, São Paulo, n. 112, p. 672-688, dez. 2012.

SANTIAGO, Ariane De Cássia Q. A qualificação profissional pelo Programa Nacional de Acesso ao Ensino Técnico e Emprego: um debate necessário. 90 f. Dissertação (Mestrado em Educação), Programa de Pós-Graduação em Educação, Universidade Federal da Bahia, 2015.

SANTOS, Clarice Aparecida dos. Pronera, educação técnico-profissional e reforma agrária popular: um estudo na perspectiva do projeto formativo vinculado aos processos produtivos dos camponeses. Tese (Doutorado) Programa de Pós-Graduação em Políticas Públicas e Formação Humana, Universidade do Estado do Rio de Janeiro. Rio de Janeiro, 2016.

SANTOS, Simone Valdete. O Ser e o Estar de Luto na Luta: Educação Profissional em Tempos de Desordem - Ações e Resultados do PLANFOR / Qualificar na cidade de Pelotas/RS (2000-2002). Porto Alegre: UFRGS, Tese de Doutorado - PPGEdu, Faced, UFRGS, Porto Alegre, 2003.

SAVIANI, Dermeval. A Nova Lei da Educação: trajetória, limites e perspectivas. $9^{\text {a }} 305$ d. Campinas, SP: Autores Associados, 2004. (Coleção educação contemporânea).

SAVIANI, Dermeval. O Choque Teórico da Politecnia. Revista Trabalho, Educação e Saúde. V. 01, n. 01, p. 131, 152, mar./2003.

SCHULTZ, Theodore. Capital Humano. Rio de Janeiro: Zahar, 1973.

SEBRAE. Caderno de Apresentação, Pronatec Empreendedor. Brasília/DF: 2013

SENAR, Serviço Nacional de Aprendizagem Rural. Empreender no campo: manual do facilitador. CNA/SENAR, 2012.

SENAC. Senac e Pronatec, a transformação do Brasil via educação profissional. Revista Correio do Senac. Rio de Janeiro, ano 61, nº 709, jan./fev 2012. 
SERAFIM, Maurício Custódio. Sobre esta Igreja edificarei minha empresa: organizações religiosas e empreendedorismo. (Tese de Doutorado) Programa de Pós-Graduação em Administração de Empresas, Fundação Getúlio Vargas. 257 f. São Paulo, 2008.

SETEC, Secretaria de Educação Profissional e Tecnológica. Dúvidas Pronatec [mensagem pessoal] Mensagem recebida por <neila@usp.br> em 24 jun. 2016a.

SETEC, Secretaria de Educação Profissional e Tecnológica. Nota Informativa - n. 10/2013. Disponível em: https://map.mec.gov.br/ Acesso em: 10 junho 2016.

SETEC, Secretaria de Educação Profissional e Tecnológica. Nota Informativa - n. 20/2013. Disponível em: https://map.mec.gov.br/ Acesso em: 10 junho 2016.

SETEC, Secretaria de Educação Profissional e Tecnológica. Nota Informativa - n. 122/2015. Disponível em: https://map.mec.gov.br/ Acesso em: 10 junho 2016.

SETEC, Secretaria de Educação Profissional e Tecnológica. Pronatec 2011-2013. Apresentação de Power-Point. Brasília, 25 de Novembro de 2013. Disponível em: https://map.mec.gov.br/. Acesso em: 07 abril 2016.

SILVA JÚNIOR, João dos Reis; LUCENA, Carlos; FERREIRA, Luciana Rodrigues. As relações entre o ensino médio e a educação superior no Brasil: profissionalização e privatização. Revista Educação e Sociedade [online]. 2011, vol.32, n.116, p.839-856.

SILVA, Danilma de M. Desvelando o PRONATEC: uma avaliação política do Programa. 174 f. Dissertação (Mestrado em Educação), Programa de Pós-Graduação em Educação - PPGE, Universidade Federal do Rio Grande do Norte, 2015.

SILVA, Luiz Antônio Machado da. Mercado de trabalho, ontem e hoje: informalidade e empregabilidade como categorias de entendimento. In: SANTANA, Marco A.; RAMALHO, José R. (org.). Além da fabrica: trabalhadores, sindicatos e nova questão social. São Paulo: Boitempo, 2003.

SILVA, Roberto da; MOREIRA, Fábio Aparecido. O projeto político-pedagógico para a educação em prisões. Em Aberto, Brasília, v. 24, n. 86, p. 89-103, nov. 2011.

SINGER, André. Cutucando onças com varas curtas - O ensaio desenvolvimentista no primeiro mandato de Dilma Rousseff (2011-2014). Novos estudos, CEBRAP, São Paulo, n. $102,2015$.

SINGER, André. O Lulismo em crise: um quebra-cabeça do período Dilma (2011-2016). São Paulo: Companhia das Letras, 2018.

SINGER, André. Os sentidos do Lulismo: reforma gradual e pacto conservador. São Paulo: Companhia das Letras, 2012.

SINGER, André. Raízes Sociais e Ideológicas do Lulismo. Novos estudos, CEBRAP, São Paulo, n. 85, 2009. 
SKAF, Paulo; HENRIQUE, Artur; SILVA, Paulo Pereira. Um acordo pela indústria brasileira. Jornal Folha de São Paulo, Tendências/Debates, 26 de maio de 2011. Disponível em: https://www1.folha.uol.com.br/fsp/opiniao/fz2605201107.htm Acesso em: 08 out. 2017.

SOUZA, Jessé. A radiografia do Golpe: entenda como e por que você foi enganado. Rio de Janeiro: LeYa, 2016.

SUSEPE, Serviços Penitenciários da Secretaria de Segurança Pública do Rio Grande do Sul. População prisional. Disponível em: http://www.susepe.rs.gov.br/capa.php. Acesso em: 20 setembro 2018.

TABET, Paola. La construction sociale d l'inegalités des sexes: des outils et des corps. Paris, L'Harmattan, 1998.

TANGUY, Lucie. Competências e Integração social na empresa. In: ROPÉ, Françoise; TANGUY, Lucie (Orgs.). Saberes e Competências: o uso de tais noções na escola e na empresa. Campinas, SP: Papirus, 1997.

TANGUY, Lucie. Enseigner l'esprit d'entreprise à l'école. Paris : La Dispute, 2016.

TANGUY, Lucie. La Formation, une activité sociale em voie de définition ? In: COSTER, M. D. et al Traité de Sociologie du Travail. De Boeck Supérieur « Overtures Sociologiques », $2^{\mathrm{a}}$ edição, 1998.

TAVARES, Maria da Conceição; Serra, José. Além da estagnação. In: TAVARES, Maria da Conceição. Da substituição de importações ao capitalismo financeiro. Rio de Janeiro: Zahar, 1972.

TCU, Tribunal de Contas da União. Auditoria Acordo de Gratuidade. Processo TC 010.803/2016-5, Data da Sessão: 24/5/2017.

TCU, Tribunal de Contas da União. Auditoria Operacional Bolsa Formação. Processo TC 019.154/2015-1. Data da Sessão: 30/11/2016.

TCU, Tribunal de Contas da União. Relatório de levantamento do Programa Nacional de Acesso ao Ensino Técnico e Emprego - Pronatec. Secretaria de Controle Externo da Educação, da Cultura e do Desporto - SecexEducação. Brasília, DF: 2015.

TOLEDO, Flaviana Alves; RUMMERT, Sonia Maria. O PNQ e a política de qualificação profissional de trabalhadores a partir dos anos 1990. Trabalho Necessário, ano 07, número 09, 2009.

VENCO, Selma. Situação de Quasi-Uberização dos Docentes Paulistas? Revista da ABET, v. 17, n. 1, Jan-Jun., 2018.

WEINSTEIN, Bárbara. (Re)Formação da Classe Trabalhadora no Brasil (1920-1964). Tradução Luciano Vieira Machado. São Paulo: Cortez; CDAPH-IFAN - Universidade São Francisco, 2000. 
WESTIN, Ricardo. Dilma e Serra têm concepções opostas sobre ensino técnico. Folha de São Paulo, São Paulo, 11 out. 2010. Caderno Poder. Disponível em: <http://www1.folha.uol.com.br/poder/2010/10/812788-dilma-e-serra-tem-concepcoesopostas-sobre-ensino-tecnico.shtml>. Acesso em 10 março 2014.

\section{Sistemas de Consulta de Matrículas da EPT e de recursos orçamentários do Pronatec:}

E-SIC, Sistema Eletrônico do Serviço de Informação ao Cidadão. Consulta ao Orçamento Bolsa Formação. Protocolos:23480023388201713 e 23480003378201761. 2017.

SISTEC Nacional. Relação de cursos do Pronatec Campo. Informação obtida via E-SIC, Sistema Eletrônico do Serviço de Informação ao Cidadão. Protocolo: 23480014439201805. 09/07/2018.

SISTEC Nacional. Relação de cursos do Pronatec Sistema Prisional. Informação obtida via ESIC, Sistema Eletrônico do Serviço de Informação ao Cidadão. Protocolo:

23480015924201898. 09/08/2018.

PLATAFORMA NILO PEÇANHA. PNP 2018, v. 2 - Ano Base 2017. Matrículas no IFFar no ano de 2017. Disponível em: https://www.plataformanilopecanha.org/. Acesso em: 20 março 2018 .

SISTEC INSTITUCIONAL, Sistema Nacional de Informações da Educação Profissional e Tecnológica, disponível no endereço: http://sistec.mec.gov.br/. Os dados citados foram disponibilizados pelas instituições pesquisadas, no período de janeiro a março de 2016.

SISTEC NACIONAL, Sistema Nacional de Informações da Educação Profissional e Tecnológica. Perfil dos estudantes do Pronatec Bolsa Formação. Informação solicitada via Lei de Acesso à Informação. Protocolo: 23480016367201741. 2017.

SIMEC (Sistema Integrado de Monitoramento Execução e Controle do Ministério da Educação) Consulta Indicador 2782. 2015. Disponível no endereço: http://painel.mec.gov.br/. Acesso em: março 2015.

SIMEC (Sistema Integrado de Monitoramento Execução e Controle do Ministério da Educação) Consulta Indicador 2782. Disponível no endereço: http://painel.mec.gov.br/ . Acesso em: fevereiro 2018.

Portal do FNDE, consulta ao SIGEF. Disponível no site: https://www.fnde.gov.br/sigefweb/index.php/liberacoes. Os dados citados foram extraídos por meio da consulta por Programa - PRONATEC TD e PRONATEC MANTENEDORAS - nos anos de 2011 a 2016, realizada no mês de abril de 2018. 